\title{
Prawo rzymskie w orzecznictwie Izby Lordów w latach 1876-2009
}


盗 


\section{Łukasz Jan Korporowicz}

\section{Prawo rzymskie w orzecznictwie Izby Lordów w latach 1876-2009}

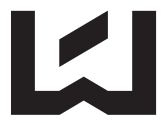


Łukasz Jan Korporowicz - Uniwersytet Łódzki, Wydział Prawa i Administracji Katedra Prawa Rzymskiego, 90-232 Łódź, ul. Kopcińskiego 8/12

\author{
RECENZENT \\ Marzena Dyjakowska \\ REDAKTOR INICJUJĄCY \\ Monika Borowczyk \\ REDAKTOR WYDAWNICTWA UŁ \\ Danuta Bak \\ SKŁAD I ŁAMANIE \\ AGENT PR \\ PROJEKT OKŁADKI \\ Łukasz Orzechowski
}

Na okładce wykorzystano ilustrację ze strony: https://commons.wikimedia.org/wiki/File:Microcosm_of_London_Plate_052_-_House_of_Lords_ (tone).jpg

(C) Copyright by Łukasz Jan Korporowicz, Łódź 2016

(c) Copyright for this edition by Uniwersytet Łódzki, Łódź 2016

Wydane przez Wydawnictwo Uniwersytetu Łódzkiego

Wydanie I. W.07224.15.0.M

Ark. wyd. 16,5; ark. druk. 21,0

ISBN 978-83-8088-237-9

e-ISBN 978-83-8088-238-6

https://doi.org/ 10.18778/8088-237-9

Wydawnictwo Uniwersytetu Łódzkiego

90-131 Łódź, ul. Lindleya 8

www.wydawnictwo.uni.lodz.pl

e-mail: ksiegarnia@uni.lodz.pl

tel. (42) 6655863 


\section{SPIS TREŚCI}

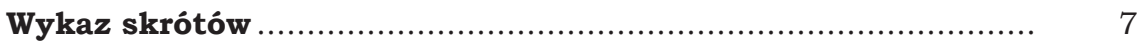

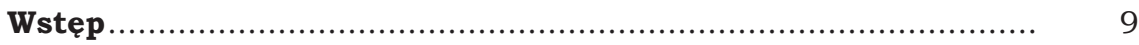

Rozdzial 1. PRAWO RZYMSKIE W ANGLII I SZKOCJI

DO KOŃCA XIX WIEKU ..................................................... 15

1.1. Najstarsze dzieje prawa rzymskiego w Brytanii ................. 15

1.2. Prawo rzymskie w okresie narodzin common law ................ $\quad 20$

1.3. Prawo rzymskie w średniowiecznej Szkocji ........................ 36

1.4. Prawo rzymskie w Anglii nowożytnej (do połowy XVIII w.) ..... 40

1.5. Recepcja prawa rzymskiego w Szkocji (XVI-XVIII w.)............ 55

1.6. Prawo rzymskie w Anglii w drugiej połowie XVIII i w XIX w... 64

Rozdzial 2. UPRAWNIENIA SĄDOWNICZE IZBY LORDÓW........... 79

2.1. Działalność sądownicza Izby Lordów przed 1873 rokiem....... 79

2.2. Judicature Acts 1873-1875 i Appellate Jurisdiction Act 1876. 97

2.3. Działalność sądownicza Izby Lordów w latach 1876-2009 .... 101

2.4. Reforma konstytucyjna i powołanie Sądu Najwyższego ......... 113

Rozdzial 3. PRAWO RZYMSKIE JAKO AUTORYTET I ŹRÓDEO UZUPEENIENIA LUK PRAWNYCH ................................... 119

3.1. Powoływanie prawa rzymskiego bez skutku dla rozstrzygnięcia sprawy .................................................................... 119

3.2. Pośrednie wykorzystanie autorytetu prawa rzymskiego......... 139

3.3. Powołanie prawa rzymskiego w celach prawnoporównawczych 142

3.4. Odrzucenie autorytetu prawa rzymskiego .......................... 154

3.5. Argument ,już w prawie rzymskim" ............................... 162

3.6. Prawo rzymskie jako źródło uzupełnienia luk prawnych ....... 164 


\section{Rozdzial 4. PRAWO RZYMSKIE JAKO ELEMENT ANGIELSKIEJ LINII ORZECZNICZEJ.}

4.1. Rzymskie zasady prawne dotyczące nabycia własności

4.2. Prawo rzymskie w sprawach dotyczacych frustration of contract

4.3. Prawo rzymskie $\mathrm{w}$ orzeczeniach $\mathrm{z}$ zakresu unjust enrichment.

4.4. Volenti non fit iniuria

4.5. Rzymskie domicilium i angielski domicile

4.6. Inne przypadki odwołania się do tradycji orzeczniczej....

Rozdzial 5. RECEPCJA PRAWA RZYMSKIEGO A SCOTS LAW..

5.1. Łacińskie reguły prawne jako przykład pośredniej recepcji prawa rzymskiego

5.2. Pośrednie wykorzystanie prawa rzymskiego poprzez prawo szkockie

5.3. Bezpośrednie wykorzystanie prawa rzymskiego w orzeczeniach pochodzacych $z$ apelacji szkockiej

5.4. Recepcja rzymskich rozwiązań dotyczacych odpowiedzialności deliktowej

Zakończenie

Wykaz orzeczeń.

Wykaz źródel 


\section{WYKAZ SKRÓTÓw}

\begin{tabular}{|c|c|}
\hline AJLH & - American Journal of Legal History, Philadelphia, PA \\
\hline CLJ & - Cambridge Law Journal, Cambridge \\
\hline DNB & $\begin{array}{l}\text { - Dictionary of National Biography, London 1885-1900, } \\
\text { Supplements 1901-1986 }\end{array}$ \\
\hline EHR & - English Historical Review, Oxford \\
\hline ELR & - Edinburgh Law Review, Edinburgh \\
\hline HLR & - Harvard Law Review, Boston \\
\hline HPLS & $\begin{array}{l}\text { - K. Reid, R. Zimmermann (eds.), A History of Private Law in } \\
\text { Scotland, vol. 1-2, Oxford } 2000\end{array}$ \\
\hline HUC & $\begin{array}{l}\text { - A History of the University of Cambridge, vol. 1-4, } \\
\text { Cambridge 1989-2004 }\end{array}$ \\
\hline HUO & $\begin{array}{l}\text { - The History of the University of Oxford, vol. 1-8, Oxford } \\
\text { 1984-2000 }\end{array}$ \\
\hline JLH & - Journal of Legal History, Cambridge \\
\hline JR & - Juridical Review, Edinburgh \\
\hline Jud.HL. & $\begin{array}{l}\text { - L. Blom-Cooper, B. Dickson, G. Drewry (eds.), The Judicial } \\
\text { House of Lords 1876-2009, Oxford } 2009\end{array}$ \\
\hline L.C. & - Lord Chancellor \\
\hline LHR & - Law and History Review, Cambridge \\
\hline LQR & - Law Quarterly Review, London \\
\hline MLR & - Modern Law Review, London \\
\hline M.R. & - Master of the Rolls \\
\hline OHLE & $\begin{array}{l}\text { - J.H. Baker, Oxford History of the Law of England, Oxford- } \\
\text { New York } 2003\end{array}$ \\
\hline SPE & - Studia Prawno-Ekonomiczne, Łódź \\
\hline SS & - Selden Society, London 1887 \\
\hline SS. Sup.Ser. & - Selden Society Supplement Series, London 1965 \\
\hline TLR & - Tulane Law Review, New Orleans, LA \\
\hline TR & - Tijdschrift voor Rechtsgeschiedenis, Leiden \\
\hline ZP UKSW & - Zeszyty Prawnicze UKSW, Warszawa \\
\hline
\end{tabular}





\section{WSTĘP}

Różnice występujące $\mathrm{w}$ sposobie prowadzenia refleksji nad prawem od dawna fascynowały prawników common law oraz prawników kontynentalnych. Stopień tego zainteresowania bywał zmienny w różnych epokach historycznych. Ostatnio dostrzec można jednak wyraźną skłonność do podejmowania badań prawnoporównawczych, które za cel obrały sobie ocenę stopnia podobieństwa obu tradycji prawnych. Do niedawna zasadnicza różnica, jakiej dopatrywano się zestawiając rozwiązania prawne znane w Anglii i na kontynencie europejskim, był brak recepcji prawa rzymskiego za kanałem La Manche.

Współcześnie trudno jest już obronić powyższe twierdzenie. Obecność prawa rzymskiego, jak i jego znaczenie w systemie prawnym Anglii, nie sa kwestionowane, choć nadal podnoszone sa watpliwości co do bezpośredniego wpływu rzymskiej tradycji prawnej na rozwiazania znane klasycznemu common law. Odmiennie oceniać należy jednak rozwój innych systemów prawnych obowiązujących w Anglii przez stulecia, takich jak prawo kościelne, handlowe czy uniwersyteckie. W wymienionych przypadkach prawo rzymskie stanowiło istotny jakościowo składnik. Było fundamentem, na którym kształtowała się linia orzecznicza sądów, zaś orzekajaccymi w nich, jak i występującymi przed nimi, byli prawnicy-romaniści zwani w Anglii civilians.

Wraz ze zniesieniem średniowiecznego systemu sądownictwa angielskiego w wieku XIX dotychczasowy rozdział na sądy common law i sądy, w których wykorzystywano prawo rzymskie, został zniesiony, a kompetencje jednych i drugich powierzono nowym, jednolitym strukturalnie sadom. W takiej 
sytuacji można domniemywać, iż reforma angielskiej judykatury spowodowała zlanie się obu tradycji prawnych, przez co we współczesnym prawie angielskim powinno być możliwe odnalezienie instytucji, które swymi korzeniami nawiązują do prawa rzymskiego.

Niezależnie od jego wykorzystania przez sąy specjalne, także w historii common law wskazać można okresy, gdy ius Romanum bezpośrednio na nie oddziaływało (przede wszystkim XII-XIII wiek). Nie odmawiajacc zatem prawu angielskiemu samodzielnej tożsamości, nie sposób nie dostrzec piętna, jakie rzymskie rozwiązania prawne odcisnęły na common law.

Co ważne, wskazane wpływy rozciagnięte były w czasie i $z$ różnym natężeniem trwały od wieku XII aż do przełomu XVIII i XIX stulecia. Z tego względu należy pamiętać, iż oddziałująca na angielskich prawników i sędziów tradycja romanistyczna również ewoluowała - początkowo było to prawo rzymskie epoki glosatorów i komentatorów, następnie prawo kanoniczne, prawnicza myśl humanistyczna, czy wreszcie szkoła prawa natury, a nawet Pandektystyka.

Obok prawa angielskiego, na Wyspach Brytyjskich powstał inny system prawny - Scots law, którego rozwój aż do XVIII wieku pod wieloma względami był niezależny od rozwoju prawa angielskiego. Na skutek okoliczności natury politycznej, na prawo szkockie, począwszy od XV wieku, bardzo silnie oddziaływała kontynentalna tradycja prawa, przede wszystkim tradycja prawa rzymsko-holenderskiego. W ten sposób w Szkocji pojawiła się grupa dobrze wykształconych prawników, którzy rozpoczęli studia nad rodzimym prawem uwzględniając wzorce zaczerpnięte $z$ badań romanistycznych. Dzięki tym zabiegom prawo szkockie poddane zostało procesowi romanizacji. Szkockich prawników piszacych w tym okresie i wykorzystujących wzorzec justyniańskich Instytucji zaczęto nazywać instytucjonalistami. Samodzielny byt prawa szkockiego - pod wieloma względami aktualny także i dziś - został częściowo zaburzony po zawarciu między Anglia i Szkocją unii realnej, która połaczyła oba królestwa. Od tego momentu tzw. Scots law poddane zostało licznym wpływom 
angielskim, które m.in. objawiły się w utrwaleniu doktryny precedensu.

Mając na uwadze ocenę znaczenia i autorytetu prawa rzymskiego we współczesnej Anglii i Szkocji, niezbędnie należy rozpoczać badania od reform, do których doszło w latach 1873-1876. W tym okresie powołano nowa strukture sądownictwa, odchodząc jednocześnie od wcześniejszych, średniowiecznych rozwiązań. Na czele nowej struktury postawiono Izbę Lordów, której przypisano funkcję najwyższego sądu Zjednoczonego Królestwa. Wcześniej występowała ona wprawdzie w podobnej roli, jednak dopiero od roku 1876 uznać ja można za organ realizujący w pełni zadania najwyższego organu sądowego w państwie.

Znaczenie, jakie przypisano Izbie Lordów w strukturze sądownictwa Wielkiej Brytanii, uzasadnia podjęcie szczegółowych badań, których celem miałoby być ukazanie stopnia wykorzystania prawa rzymskiego przez orzekajacych w imieniu Izby tzw. lordów prawa (law lords). Ocena ich dorobku orzeczniczego wydaje się być ponadto uzasadniona faktem niedawnego odjęcia funkcji sądowniczych Izbie i przeniesieniu ich na nowo powołany Sąd Najwyższy Zjednoczonego Królestwa, który rozpoczął swoją działalność $z$ dniem 1 października 2009 roku. Jak dotąd brak w literaturze przedmiotu kompleksowej oceny tego dorobku.

W niniejszym opracowaniu zostanie podjęta próba ustalenia zakresu i celów wykorzystania prawa rzymskiego w trakcie postępowań - zarówno przez law lords, jak i pełnomocników stron. Analiza będzie miała za zadanie dostarczenie materiału do udzielenia odpowiedzi na pytania: kto przywoływał ius Romanum najczęściej, jakie źródła prawa zostały w tym celu wykorzystane oraz prace których autorów były najchętniej cytowane, wreszcie, czy dokonanie stosownych odwołań wpływało na ostateczny kształt ferowanych w sprawach wyroków?

Ze względu na specyfikę badań wypada odnieść się do przyjętej w pracy metody ich prowadzenia. Odpowiada ona raczej metodologii stosowanej w badaniach nad dziejami praw 
wchodzacych do rodziny common law, aniżeli typowej metodologii historyczno-prawnej stosowanej w romanistyce. Takie stanowisko uzasadnia temat prowadzonej analizy. Trzeba jednak równocześnie zaznaczyć, iż mimo że materiałem źródłowym, na którym oparte zostały prowadzone badania, były orzeczenia wydane przez Izbę Lordów w latach 1876-2009, to jednak ich analiza dokonana została pod katem występowania w ich treści bezpośrednich odwołań do prawa rzymskiego, bądź terminów, które w sposób uprawdopodobniony zdradzaja rzymskie pochodzenie. Tak zgromadzony materiał bazowy poddany został następnie ocenie $z$ perspektywy jakości poczynionych przez sędziów bądź zastępców procesowych odwołań, jak również (gdy dało się to jednoznacznie stwierdzić) ich wpływu na ostatecznie sformułowaną w wyroku zasadę prawa. Stąd w pracy niniejszej trudno szukać szczegółowych rozważań dotyczacych konkretnych kazusów. Wprawdzie dla prawidłowego zrozumienia okoliczności powołania się przez prawników na rzymskie rozwiazania prawne znalazły się w pracy krótkie opisy stanów faktycznych, to jednak podporządkowane zostały one nadrzędnemu celowi pracy, jakim było ustalenie zakresu rzymskich odwołań.

Wyjaśnienie należy się także w odniesieniu do rozumienia w niniejszej pracy terminu „prawo rzymskie”. Pojęcie to traktowane jest bowiem szerzej aniżeli w pracach ściśle dogmatycznych, a nawet w pracach poświęconych recepcji konkretnych instytucji prawa rzymskiego w epoce średniowiecza, czy nowożytnej. Na gruncie niniejszej monografii pojęcie „prawo rzymskie" nawiąuje do znaczenia, jakie przypisane mu zostało przez włoskiego romanistę Riccardo Orestano, który posłużył się terminem romanesimo. W tym ujęciu prawo rzymskie to nie konkretny system prawny, ani nawet system podlegający pewnym zmianom ewolucyjnym, lecz wieloznaczeniowy i wielopoziomowy fenomen kulturowy, do którego na przestrzeni wieków odnosiło się wiele osób. Ich cele potrafiły się diametralnie różnić, podobnie jak sposób ich oceny prawa rzymskiego. Dzięki temu prawo rzymskie mogło być raz przedmiotem ataku konserwatywnych prawników com- 
mon law, kiedy indziej budulcem wypełniajacym niedostatki angielskiego systemu prawnego, czy wreszcie źródłem naukowej argumentacji wykorzystanej przez szkockich instytucjonalistów, bądź chwalących się swoją erudycją lordów prawa ${ }^{1}$.

$* * *$

Powstanie pracy takich rozmiarów jak przedkładana monografia nie byłoby możliwe bez udziału i pomocy licznego grona osób przychylnych autorowi. W sposób szczególny wyrazy podziękowania autor winien skierować ku prof. dr hab. Annie Pikulskiej-Radomskiej, promotorowi rozprawy doktorskiej stanowiacej podstawe niniejszej monografii, oraz recenzentom w przewodzie doktorskim - prof. dr hab. Annie Tarwackiej (UKSW) oraz dr hab. Maciejowi Jońcy (KUL). Podziękowania należą się również pani prof. dr hab. Marzenie Dyjakowskiej (KUL), pełniącej funkcje recenzenta wydawniczego niniejszej monografii.

Autor zobowiązany jest również wyrazić swoją wdzięczność koleżance i kolegom $z$ Katedry Prawa Rzymskiego UŁ, którzy zawsze gotowi byli służyć swoja rada. Za pomoc w zebraniu materiału badawczego oraz cenne uwagi dotyczace historii i praktyki prawa angielskiego podziękowania należą się: Victorowi Tunkelowi (Selden Society), profesorom University College London - Andrew Lewisowi i Paulowi Mitchellowi oraz prof. Thomasowi Glynowi Watkinowi z Cardiff Law School. Przy przygotowywaniu finalnej wersji ksiażki nieoceniona pomoc świadczył autorowi również Jan Halberda (UJ), który obficie dzielił się swoją własna wiedza na temat historii prawa angielskiego.

Oddzielne, choć spóźnione, podziękowania należą się także nieżyjącemu już dziś sędziemu Sądu Najwyższego Zjedno-

${ }^{1}$ Cytaty z rzymskich i łacińskich źródeł pochodzące od sędziów zostały zachowane $\mathrm{w}$ oryginalnym kształcie, tak jak odnotowane zostały w law reports. 
czonego Królestwa, Lordowi Rodger'owi of Earlsferry ${ }^{2}$, który zwrócił uwagę autora na potencjał kryjacy się w orzecznictwie Izby Lordów.

$\mathrm{Na}$ koniec, za wsparcie i stworzenie warunków do pracy, szczególną wdzięczność autor pragnie wyrazić swoim rodzicom oraz żonie, którym dedykuje niniejszą książkę.

${ }^{2}$ Nie wszystkie tytuły lordowskie użyte w pracy sa odmieniane. Jest to następstwo ich pochodzenia. W pracy przyjęto, iż te pochodzace od nazwisk lordów podlegają odmianie (Lord [jaki] - np. Lord Hoffmann, Lord Hope), tytuły pochodzace od konkretnych lokalizacji pozostawiono natomiast w postaci nieodmiennej (Lord [czego] - np. Lord Mansfield, Lord Macclesfield). 
Rozdział 1

\section{PRAWO RZYMSKIE W ANGLII I SZKOCJI DO KOŃCA XIX WIEKU}

\subsection{Najstarsze dzieje prawa rzymskiego w Brytanii}

Podręczniki historii prawa angielskiego, podobnie jak i szkockiego, datuja początki rozwoju obu systemów prawnych mniej więcej na połowę XI wieku ${ }^{3}$. W Anglii momentem przełomowym dla wszystkich badan historycznych jest rok 1066, gdy anglosaskich władców Wyspy zastapili Normanowie na czele $z$ Williamem Zdobywca. Zmiany, do jakich doszło w następstwie tych wydarzen, doprowadziły do wykształcenia się w Anglii nowego systemu prawnego, który w przyszłości dał poczatek common law.

$Z$ punktu widzenia dziejów prawa rzymskiego, wieki XI i XII również okazały się być kluczowe dla jego późniejszych losów. Odkrycie justyniańskich tekstów dokonane w Italii doprowadziło do nagłego rozkwitu studiów nad prawem przede

${ }^{3}$ Spośród trzech używanych współcześnie podręczników historii prawa angielskiego, jeden w ogóle nie poświęca miejsca okresowi przed rokiem 1066 (S.F.C. Milsom, Historical Foundations of the Common Law, ed. 2, Oxford 1981), dwa pozostałe zaś - po jednym krótkim rozdziale (T.F.T. Plucknett, A Concise History of the Common Law, ed. 5, BostonLondon 1956, s. 6-10 oraz J.H. Baker, An Introduction to English Legal History, ed. 4, Oxford 2002, s. 1-11). Dla historii prawa szkockiego zob. J.W. Cairns, Historical Introduction, [w:] HPLS, vol. 1, Oxford 2000, s. 15. 
wszystkim w północnowłoskich uczelniach ${ }^{4}$. Stamtąd wiedza o prawie rzymskim, jak również metody jego badania, poczęły rozprzestrzeniać się na obszar całej Europy. Podobnie jednak jak nadużyciem jest stawianie wyraźnej cezury między prawem anglosaskim a prawem powstajaccym w Anglii po 1066 roku, tak samo nieuprawnione jest twierdzenie, iż odkrycie Digestów zapoczątkowało studia nad prawem w okresie średniowiecza. Prawo rzymskie istniało w świadomości średniowiecznych prawników od samego początku trwania tego okresu historycznego ${ }^{5}$. Wydaje się wprawdzie, iż owi mediewistyczni juryści bardzo często nie umieli dostrzec rzymskich korzeni tekstów, na których pracowali, a nawet nie rozumieli w pełni czytanych przez siebie treści, to jednak fakt obecności chociażby encyklopedycznego dzieła Izydora z Sewilli Etymologiarum sive Originum - którego rozdział piaty dotyczy zwulgaryzowanego prawa rzymskiego, jest najlepszym dowodem ciagłości myśli prawnej starożytnych.

Prawo rzymskie pojawiło się na Wyspach Brytyjskich już w I w., gdy stały się one w roku 43 częścią Cesarstwa Rzymskiego. W przekonaniu wielu historyków Brytania była prowincją drugorzędna. Pozostając na uboczu, szarpana wewnętrznymi, jak i granicznymi konfliktami zbrojnymi, nie miała stanowić silnego ośrodka cywilizacji rzymskiej. Coraz częściej jednak taki obraz Brytanii poddawany jest rewizji. Interpretacja licznych znalezisk archeologicznych udowadnia bowiem wysoki standard życia społecznego i kulturalnego mieszkańców prowincji. Tym samym dzieje rzymskiej Brytanii zaczynaja powoli jawić się w znacznie jaśniejszych barwach niż na podstawie dotychczasowych badań. Brytania przestaje być zmilitaryzowana nadgraniczna prowincja, a coraz częściej staje się ważnym obszarem oddziaływania rzymskiej kultury. Taki „unowocześniony” obraz starożytnych Wysp Brytyjskich zdają się potwierdzać również znaleziska prawniczych źródeł

${ }^{4}$ P. Stein, Roman Law in European History, Cambridge 1999, s. 43-45.

${ }^{5}$ Ibidem, s. 38-43. 
epigraficznych ${ }^{6}$. Ich liczba nie jest wprawdzie duża, jednak już teraz wystarczająca, aby móc powiedzieć, że rzymskie ustawodawstwo nie stanowiło w Brytanii „martwej litery prawa”. Obok niewielkiej grupy tekstów prawnych zachowanych w Kodeksie Teodozjańskim ${ }^{7}$ oraz Digestach ${ }^{8}$, najważniejszymi dziś źródłami zaświadczającymi o rozbudowanej praktyce prawa prowincjonalnego są coraz liczniej odnajdywane źródła dokumentowe.

Dzięki tej ostatniej grupie możliwa jest rekonstrukcja niektórych przynajmniej relacji życia codziennego rzymskiej Brytanii. $Z$ jednej strony woskowe tabliczki dostarczaja przykładów dokonywania czynności prawnych - zawierania umów, sporządzania testamentów, $z$ drugiej natomiast pozwalaja obserwować działalność sądów prowincjonalnych.

Wraz z wycofaniem się Rzymian z Brytanii w początkach $\mathrm{V}$ w., instytucje prawa rzymskiego zaczęły stopniowo zanikać, lecz ich oddziaływanie można dostrzec $\mathrm{w}$ prawach zwyczajowych lokalnej społeczności rzymsko-celtyckiej. Ustępując pod naporem anglosaskim, ludy te coraz bardziej kierowały się ku zachodowi Wyspy. To właśnie w prawach póżniejszych

${ }^{6} \mathrm{Na}$ temat obecności prawa rzymskiego w rzymskiej Brytanii por. E. Birley, Law in Roman Britain, [w:] Aufstieg und Niedergang der römischen Welt, II.13, Berlin-New York 1980, s. 609-625; D.A. Thomas, Origins of the Common Law. Part 1: The Disappearance of Roman Law from Dark Age Britain, Brigham Young University Law Review 1984, s. 563-598; Ł.J. Korporowicz, Działalność 'legati iuridici' w rzymskiej Brytanii, SPE 82 (2010), s. 69-80; idem, Nieskuteczność prowincjonalnego wymiaru sprawiedliwości na przykładzie rzymskiej Brytanii, [w:] K. Amielańczyk, A. Dębiński, D. Słapek, Ochrona bezpieczeństwa i porzadku publicznego $w$ prawie rzymskim, Lublin 2010, s. 129-137; idem, Roman Law in Roman Britain. An Introductory Survey, JLH 33/2 (2012), s. 133-150; idem, Buying a Slave in Roman Britain. The Evidence from the Tabulae, Revue Internationale des Droits de l'Antiquite 58 (2011), s. 211-224 oraz idem, Roman Tax Law in Roman Britain, Revue Internationale des Droits de l'Antiquite 61 (2014), s. 229-251.

${ }^{7}$ C.Th. 9, 36, 1; C.Th. 11, 7, 2.

${ }^{8}$ D. $12,1,40$; D. 28,3 , 6. 7; D. $28,6,2$, 4; D. 29, 1, 34, pr.; D. 36, 1 , 48; D. 49, 15, 6. 
średniowiecznych Walijczyków odnaleźć można stosunkowo dużo zachowanych śladów rzymskich rozwiąań prawnych ${ }^{9}$.

Nowo przybyłe na Wyspy ludy germańskie posługiwały się własnymi prawami zwyczajowymi. Wraz jednak $z$ dotarciem pod koniec VI w. misjonarzy z Rzymu, kolejni władcy królestw anglosaskich zaczęli przyjmować chrześcijaństwo, a wraz $z$ nim także jego kulturę prawna, mocno osadzoną na dorobku tradycji romanistycznej ${ }^{10}$.

Obecność prawa rzymskiego na Wyspach Brytyjskich w okresie między przyjęciem chrztu przez króla Kentu Ethelberhta (ok. 600 roku) a podbojem normańskim nie budzi wątpliwości. Jej intensywność podlegała jednak zmianom. Często przywoływanym dowodem przemawiajacym za znajomościa prawa Rzymian przez Anglosasów ma być fragment pochodzacy $z$ dzieła napisanego na przełomie VII i VIII w. przez św. Bedę Czcigodnego, w którym mnich stwierdził, iż prawa króla Æthelberhta zostały sporządzone iuxta exempla Romanorum ${ }^{11}$. Sformułowanie to nie oznacza wprawdzie, iż konkretne regulacje prawne zostały recypowane wprost $z$ prawa rzymskiego, lecz wskazuje, że idea spisania prawa wprowadziła królestwo Æthelberhta do grona rozwiniętych królestw wczesnośredniowiecznego barbaricum ${ }^{12}$.

${ }^{9} \mathrm{O}$ procesie kontynuacji rzymskich wzorców prawnych i ich przechowaniu w tradycji walijskiej zob. np. T.G. Watkin, The Death and Later Life of Legal Symbols. Welsh Legal Symbols after the Union with England, [w:] R. Schulze (Hrsg.), Symbolische Kommunikation vor Gericht in der Frühen Neuzeit, Berlin 2006, s. 214-215 oraz idem, Saints, Seaways and Dispute Settlements, [w:] W.M. Gordon, T.D. Fergus (eds.), Legal History in the Making. Proceedings of the Ninth British Legal History Conference Glasgow 1989, London 1991, s. 5-8.

${ }^{10}$ Szeroko na temat prawa rzymskiego w anglosaskiej Anglii zob. J.F. Winkler, Roman Law in Anglo-Saxon England, JLH 13/2 (1992), s. $101-127$.

${ }^{11}$ Beda, Historia ecclesiastica gentis Anglorum, 2, 5.

12 Por. także P. Wormald, The First Code of English Law, Canterbury 2005, s. 16-17; B. Griffith, Early English Law. An Introduction, Norfolk 2006, s. 32 . 
Nauka nie dysponuje dziś jednoznacznymi przekazami odnośnie do praktyki prawa okresu anglosaskiego i ewentualnego wykorzystania w niej prawa rzymskiego. $Z$ pewnościa wpływ poszczególnych instytucji prawa rzymskiego na germańskie zwyczaje był ograniczony, lecz trudno dziś zgodzić się z opiniami dawniejszych autorów, którzy bądź w ogóle odmawiali prawu rzymskiemu bycia źródłem inspirującym rozwój praw anglosaskich, bądź dostrzegali tylko pojedyncze przypadki takiego wpływu. Dotychczasowe badania pozwalają wskazać kilka obszarów oddziaływania prawa rzymskiego na prawo anglosaskie. Percy H. Winfield, opierając się raczej na domysłach niż na szczegółowych badaniach naukowych, wskazał jednak już w latach dwudziestych ubiegłego wieku trzy sfery działania ius Romanum we wczesnym średniowieczu - prawo własności ${ }^{13}$, prawo spadkowe oraz prawo procesowe ${ }^{14}$. W większości przypadków poszczególne zapożyczenia kreowane były przez ośrodki władzy i nie były zwiazane $z$ praktyka sadów jako taką. Być może wyjątek stanowia tu wyroki sadowe ferowane przez monarchów wspieranych przez duchowieństwo oraz doradców świeckich w trakcie obrad zgromadzeń możnowładców (witengamot) ${ }^{15}$. Istotny wydaje się być tu szczególnie wpływ duchowieństwa na kształ-

${ }^{13}$ Zasadnicza dyskusja (w tym też związana $\mathrm{z}$ rzymskimi korzeniami) dotyczyła instytucji bookland i folkland, czyli dwóch form władztwa nad nieruchomościami, jakie znane były rozwiniętemu prawu anglosaskiemu. Trwa ona $z$ przerwami od końca lat 90. XIX stulecia. Zestawienie argumentów przedstawia A.G. Kennedy, Disputes about bocland: the forum for their adjudication, Anglo-Saxon England 14 (1985), s. 175-196.

${ }^{14}$ P.H. Winfield, The Chief Sources of English Legal History, Cambridge, MA, 1925, s. 55 (reprint z 2000). Por. także komentarz do opinii P.H. Winfielda: E.D. Re, The Roman Contribution to the Common Law, Fordham Law Review 29 (1961), s. 457-458. Pierwszym autorem, który podjał się systematyki oddziaływań prawa rzymskiego na prawo anglosaskie, był wprawdzie H.C. Coote w swojej pracy zatytułowanej A Neglected Fact in English History, London 1864, ale jego sugestie poddane zostały już wkrótce krytyce m.in. przez T.E. Scruttona, The Influence of the Roman Law on the Law of England, Cambridge 1885, s. 13.

${ }^{15}$ W. Senior, Roman Law in England before Vacarius, LQR 46 (1930), s. 196. 
towanie się anglosaskiej procedury sądowej. John F. Winkler wskazuje, iż Anglosasi, za przykładem Rzymian, zezwalali, aby protokoły sądowe (placita) sporządzała strona wygrana ${ }^{16}$.

\subsection{Prawo rzymskie w okresie narodzin common law}

Upadek państwa anglosaskiego nastąpił w roku 1066 wraz ze zwycięstwem Williama Zdobywcy pod Hastings ${ }^{17}$. Wydarzenie to otworzyło nowy etap w dziejach Anglii, zakończony ostatecznie powstaniem tamtejszej państwowości w oparciu o kontynentalne wzorce przywiezione $z$ Normandii. Efektem tych przemian było wykształcenie się zrębów państwa, które dało początek współcześnie istniejącemu Zjednoczonemu Królestwu Wielkiej Brytanii i Irlandii Północnej. W sferze prawa wydarzenia roku 1066 nie przyniosły natychmiastowych zmian. Pośrednio jednak zapoczątkowały przeobrażenia, które sto lat później doprowadzić miały do powstania common law-endemicznego tworu wyspiarskiej tradycji prawnej ${ }^{18}$.

William, pragnąc potwierdzić swoje prawa do korony i okiełznać buntujących się poddanych, ogłosił kontynuację obowiazywania dotychczasowych zwyczajów anglosaskich. Normańskie prawo zwyczajowe nie miało być recypowane w Anglii ${ }^{19}$. Dzięki tej decyzji król potwierdził swoje pokojo-

${ }^{16}$ J.F. Winkler, Roman..., s. 108.

${ }^{17} \mathrm{~W}$ pracy imię monarchy podawane jest $\mathrm{w}$ formie angielskojęzycznej. Posługiwanie się $\mathrm{w}$ polskiej historiografii imieniem Wilhelm związane jest $z$ przejęciem tej maniery od naukowców niemieckich.

${ }^{18} \mathrm{Na}$ temat okresu kształtowania się common law zob. J.H. Baker, An Introduction..., s. 12-33.

${ }^{19}$ Prawo normańskie było prawem zwyczajowym, na które prawo rzymskie wywarło niewielki wpływ. Tym samym nie mogło ono stanowić „pomostu” na drodze recepcji rzymskich instytucji prawnych w Anglii, por. T.F.T. Plucknett, The Relations Between Roman Law and English Common Law Down to the Sixteenth Century: A General Survey, University of Toronto Law Journal 3 (1939-1940), s. 28-29. Dopiero z czasem prawo 
we zamiary. Jednak mimo wcześniejszych zapowiedzi system prawa anglosaskiego coraz mniej odpowiadał potrzebom zmieniających się czasów i wymagał gruntownej reformy ${ }^{20}$. Administrację państwową, a także plany jej unowocześnienia, król powierzył swojemu zaufanemu współpracownikowi - Lanfrancowi, którego w roku 1070 ustanowił arcybiskupem Canterbury. Duchowny nie tylko był znawca teologii, lecz również prawa ${ }^{21}$. Wprawdzie nie można dziś wskazać bezpośredniego udziału Lanfranca w procesie recypowania prawa rzymskiego, to jednak potwierdzony historycznie jest jego udział w kształtowaniu się nowego modelu prawa angielskiego, które za sprawa znającego prawo kleru ulegało coraz większym wpływom kontynentalnym ${ }^{22}$.

Jednym $z$ najważniejszych przedsięwzięć prawnych okazało się przetłumaczenie na łacinę anglosaskich zbiorów prawa. Władzę w królestwie w imieniu króla sprawowali jego zaufani współpracownicy pochodzacy z Normandii, nie zaś

rzymskie zaczęło oddziaływać na system prawny Normandii, por. E. Caillemer, Le droit civil dans les provinces Anglo-Normandes au XIIe siècle, Mémoires de l'Académie des Science de Caen 1883, s. 157-226. Warto zauważyć jeszcze, iż prawo normańskie, także współcześnie, stanowi część brytyjskiego systemu prawnego. Jest ono stosowane na tzw. Channel Islands. Najwyższym sądem apelacyjnym jest dla nich Tajna Rada Królewska (Privy Council). W roku 2001 orzekajacc w sprawie Snell v. Beadle [2001] 2 A.C. 304, zmuszona została ona do jednoczesnego zastosowania reguł normańskiego zwyczaju oraz prawa rzymskiego, zob. więcej W.J. Zwalve, 'Snell v. Beadle' - The Privy Council on Roman Law, Norman Customary and the 'Ius Commune', [w:] L. de Ligt, 'Viva Vox Iuris Romani'. Essays in Honour of Johannes Emil Spruit, Amsterdam 2002, s. 379-386.

20 J.L. Barton, Roman Law in England, Mediolani 1971, s. 6.

${ }^{21}$ Starsza literatura uznawała go za znawcę prawa rzymskiego. Nowsze badania wykluczaja jednak tę hipotezę. Wskazuje się wszakże, iż Lanfranc zajmował się w młodości prawem lombardzkim, a ponadto $z$ racji pełnionej funkcji zobowiazany był znać prawo kanoniczne. Więcej por. R.V. Turner, Roman Law in England Before the Time of Bracton, Journal of British Studies 15 (1975), s. 3, a także W. Senior, Roman..., s. 199.

${ }^{22}$ Więcej na temat Lanfranca i jego prawniczej działalności w Anglii zob. Ch.P. Sherman, The Romanization of English Law, Yale Law Journal 23 (1914), s. 321; E.D. Re, The Roman..., s. 462-464. 
lokalni możnowładcy. Trudności związane ze sprawnym zarządzaniem państwem musiały być na tyle dokuczliwe, iż sami urzędnicy podjęli starania o tłumaczenie praw anglosaskich $^{23}$. Nigdy nie udało się jednak sporządzić jednolitego tłumaczenia mającego aprobatę królewska, zaś jakość tłumaczeń prywatnych była dosyć niska.

W tym samym mniej więcej czasie, gdy w Anglii kształtowało się nowe królestwo anglonormańskie, w Bolonii zainicjowane zostały studia nad prawem rzymskim oparte na dokonanym niedawno odkryciu tekstu Digestów justynianskich. Efektem rozpoczętych wówczas badań było pojawienie się w stosunkowo krótkim czasie grona wykształconych prawników, którzy przynajmniej początkowo łączyli wiedzę o prawie rzymskim $z$ wiedza o prawie kanonicznym ${ }^{24}$. Wielu $z$ nich przybyło także do Anglii. Prócz wskazanego powyżej Lanfranca, na Wyspy dotarła także duża grupa wychowanków włoskich szkół prawniczych, których wiedza zaczęła być wykorzystywana w sposób praktyczny. Wielu kanonistów i cywilistów służyło bowiem angielskim monarchom rada, a $z$ czasem zaczęło pełnić urzędy dworskie, w tym królewskich sędziów ${ }^{25}$. Podatny grunt dla rozwoju wiedzy, jaka przywozili ze soba przybysze $z$ kontynentu, zapewniali kolejni arcybiskupi Canterbury. Do tego grona zaliczyć należy przede wszystkim bezpośredniego następcę Lanfranca - Anzelma,

${ }^{23}$ Por. T.E. Scrutton, The Influence..., s. 59-60. W nowszej literaturze: P. Wormald, 'Quadripartitus', [w:] G. Garnett, J. Hudson (eds.), Law and Government in Medieval England and Normandy. Essays in honour of Sir James Holt, Cambridge 1994, s. 111-172.

${ }^{24} \mathrm{Na}$ temat przenikania się nauki prawa rzymskiego i prawa kanonicznego w XII w. w Italii zob. A. Dębiński, Kościół i prawo rzymskie, Lublin 2007, s. 65-94.

${ }^{25}$ Ich zestawienie podaje E. Rathbone, Roman Law in the Anglo-Norman Realm, Studia Gratiana 11 (1967), s. 259-261. Por. także F. De Zulueta, William of Drogheda, [w:] Mélanges de droit romain dédiés a Georges Cornil, vol. 2, Grand-Paris 1926, s. 641-657. William Senior w swych krótkich rozprawach wspomina także o wizytach znanych prawników na Wyspach, por. W. Senior, Peter della Vigna, LQR 48 (1932), s. 324-327; idem, Accursius and his son Franciscus, LQR 51 (1935), s. 513-516. 
który uchodzi współcześnie za jednego $z$ najwybitniejszych teologów XI w., oraz działających w wieku XII arcybiskupów Theobalda i Thomasa Becketa ${ }^{26}$. To dzięki ich wstawiennictwu włoskie uczelnie zaczęły się stosunkowo szybko zapełniać studentami przybyłymi $z$ Anglii.

Jednak dla dziejów prawa rzymskiego w Anglii szczególnie ważna postacią w tym okresie okazał się być Vacarius Włoch przybyły w roku 1143 na zaproszenie wspomnianego już arcybiskupa Theobalda.

Urodził się między 1115 a 1120 rokiem we Włoszech. Ukończył wszechnicę bolońską i w tym samym czasie przyjął święcenia kapłańskie. Niewiele później przybył do Anglii, gdzie stał się bliskim współpracownikiem arcybiskupa Theobalda. Zajmował się zarówno praktyka, jak i nauczaniem prawa. Pod koniec lat pięćdziesiątych XII w. rozpoczął służbę u boku arcybiskupa Yorku, Rogera. Przez stulecia utrzymywano, iż Vacarius był pierwszym nauczycielem prawa rzymskiego na Uniwersytecie Oxfordzkim ${ }^{27}$. Dziś hipoteza ta nie znajduje już tak szerokiego poparcia w literaturze jak niegdyś, lecz nie ulega watpliwości, iż przynajmniej w pewnym okresie swego życia Vacarius nauczał prawa ${ }^{28}$. Być może czynił to $\mathrm{w}$ szkołach przykatedralnych, najpierw w Canterbury, a następnie w Yorku. Zdaniem P. Steina, Vacarius mógł nauczać prawa rzymskiego także w Lincoln, w tamtejszej szkole przykatedralnej ${ }^{29}$. Dydaktyczna działalność Vacariusa potwierdzona jest przede wszystkim dzięki jego dwóm dzie-

${ }^{26}$ E.D. Re, The Roman..., s. 465.

${ }^{27}$ Por. T.E. Scrutton, The Influence..., s. 68.

${ }^{28}$ Nową hipotezę przedstawił L.E. Boyle, według którego Vacarius przebywał w Oxfordzie okazjonalnie, przybywając wraz $z$ arcybiskupem Rodgerem na posiedzenia sądów kościelnych, jakie w drugiej połowie XII w. odbywały się tam regularnie. Być może w czasie tych wizyt także wykładał prawo. Mógł wówczas zostać również poproszony o opracowania Liber Pauperum. Zdaniem L.E. Boyle'a przemawia za tym fakt, iż Oxford jest jedynym znanym miejscem, w którym podręcznik Vacariusa był używany, zob. więcej L.E. Boyle, The Beginnings of Legal Studies at Oxford, Viator 13 (1983), s. $120-126$.

${ }^{29}$ P. Stein, Roman Law in European..., s. 56. 
łom o charakterze podręcznikowym ${ }^{30}$. Pierwszym $z$ nich jest Liber Pauperum, wyciag $z$ Digestów i Kodeksu opracowany $z$ myśla o angielskich studentach, dla których zdobycie kopii justyniańskich tekstów nastręczać musiało znaczne trudności, przede wszystkim finansowe ${ }^{31}$. Druga zachowana praca Vacariusa jest Lectura Institutionum - wykład Instytucji Justyniana $^{32}$. Najprawdopodobniej prawnik pozostał w Anglii do końca swojego życia, gdzie zmarł około roku 1200.

Nawet jeśli Vacarius nie nauczał w Oxfordzie, to jednak studia nad prawem rzymskim i kanonicznym na tej właśnie uczelni musiały rozpocząć się jeszcze za jego życia ${ }^{33}$. Pod koniec lat czterdziestych XII w. król Stefan wydał dokument zakazujący nauczania prawa rzymskiego w Anglii ${ }^{34}$. Dekret został jednak wkrótce zniesiony. Spowodowało to znaczny

${ }^{30}$ Vacarius jest także autorem innych prac - prawniczej rozprawy Summa de Matrimonio (F.W. Maitland, Magistri Vacari Summa de Matrimonio, LQR 13 (1897), s. 133-143, 270-287) oraz prac o charakterze teologicznym: De assumpto homine i Liber contra multiplices et varios errors, por. F. de Zulueta, P. Stein, The Teaching of Roman Law in England around 1200 , SS Sup.Ser. 8, London 1990, s. xxiv-xxv.

${ }^{31}$ Tekst $z$ thumaczeniem: F. de Zulueta, The Liber Pauperum of Vacarius, SS 44, London 1927.

${ }^{32}$ Tekst $\mathrm{z}$ thumaczeniem: F. de Zulueta, P. Stein, The Teaching of Roman Law in England around 1200, SS Sup.Ser. 8, London 1990.

${ }^{33}$ Nauczanie prawa kanonicznego w sformalizowanej formie w Oxfordzie można datować na rok 1195. Pierwsi wykładowcy pojawili się w mieście już około 1190 roku. Najprawdopodobniej wykładali oni zarówno prawo rzymskie, jak i kanoniczne, zob. L.E. Boyle, The Beginnings..., s. 113. Prawo było zresztą w tym okresie nauczane także w szkołach przykatedralnych w Exeter, Northampton, Lincoln, St Albans, Londynie i w Yorku, zob. R.V. Turner, Roman Law..., s. 11; F. van Liere, The Study of Canon Law and the Eclipse of the Lincoln Schools, 1175-1225, [w:] M. Feingold (ed.), History of Universities, Oxford 2003, s. 1-10.

${ }^{34} \mathrm{~W}$ literaturze wskazuje się różne przyczyny wprowadzenia zakazu. Za jeden $z$ prawdopodobnych powodów uznaje się konflikt króla i arcybiskupa Theobalda, opiekuna Vacariusa. Według innych teorii przyczyna miałaby być zbyt duża liczba odwołań do prawa kanonicznego wykorzystywana przez Vacariusa w trakcie jego wykładu, por. T.E. Scrutton, The Influence..., s. 69; E.D. Re, The Roman..., s. 466. Jako że zakaz wydany został przez władcę Anglii, nie należy go raczej łączyć z zakazami studiowania 
wzrost liczby chętnych zainteresowanych studiowaniem ius Romanum. Głównym źródłem ich wiedzy stały się zaś prace autorstwa Vacariusa. O ich popularności w Oxfordzie świadczy fakt, iż adeptów nauki prawa rzymskiego na tej właśnie uczelni zaczęto określać mianem pauperistae ${ }^{35}$.

Poziom i charakter nauczania prawa rzymskiego i kanonicznego na angielskich uczelniach w okresie średniowiecza trudno jednoznacznie ocenić. Rozwój obu „uczonych praw” najpierw we włoskich, a następnie w innych kontynentalnych uniwersytetach, szybko wywarł także wpływ na nauczanie utriusque iuris w Anglii. Zarówno w Oxfordzie, jak i w Cambridge funkcjonowały dwa niezależne „wydziały prawa”. Zdaniem R.H. Helmholza wykład prawa rzymskiego stanowił zazwyczaj wstęp do dalszej nauki prawa kanonicznego, a co za tym idzie, liczba studentów prawa rzymskiego na obu uczelniach była regularnie większa niż studentów prawa kanonicznego ${ }^{36}$. Z czasem proporcje te zaczęły się zmieniać i pod koniec średniowiecza w Cambridge stosunek studentów kanonistyki do tzw. cywilistów wynosił już dwa do jednego. Warto jednak zauważyć, iż słuchacze obu prawniczych fakultetów stanowili wówczas jedną trzecią wszystkich studentów uniwersytetu ${ }^{37}$.

prawa rzymskiego wydawanymi począwszy od 1163 roku przez papieży. Na ten temat zob. A. Dębiński, Kościół..., s. 94-110.

${ }^{35}$ P. Stein, Vacarius and the Civil Law, [w:] idem, The Character and Influence of the Roman Law. Historical Essays, London-Ronceverte 1988, s. 170 .

${ }^{36}$ D.R. Leader, HUC, vol. 1, Cambridge 1988, s. 192; R.H. Helmholz, The Canon Law and Ecclesiastical Jurisdiction from 597 to 1640s, OHLE, vol. 1, Oxford-New York 2004, s. 188.

${ }^{37}$ D.R. Leader, HUC, vol. 1, s. 195. Wielu studentów prawa przybywających do Cambridge wybierało jako swój college Trinity Hall, który powstał specjalnie $z$ myśla o adeptach utriusque iuris. O dziejach Trinity Hall i kształceniu prawników por. J. Langbein, Trinity Hall and the Relations of European and English Law from the Fourteenth to the Twenty-First Century, [w:] H. Felter (ed.), Trinity Hall Cambridge. The Milestones Lectures. In celebration of 650 years of education and learning, Cambridge 2001, s. 75-86. 
Oprócz tradycyjnych wykładów, w ramach których dokonywano egzegezy źródeł, zachowane dokumenty pozwalaja stwierdzić, iż studenci obu praw uczestniczyli także w tzw. repetitiones oraz disputationes i quaestiones ${ }^{38}$. Zajecia te miały charakter praktyczny. Ich celem było rozwiazywanie przedstawionych przez wykładowców kazusów prawnych w oparciu o prawo rzymskie i kanoniczne. Większość materiałów wykorzystywanych w czasie studiów prawniczych pochodziła $z$ kontynentu. W niewielkim tylko stopniu korzystano $z$ prac autorów angielskich ${ }^{39}$. Co więcej, brak reformy programu kształcenia spowodował, iż pod koniec średniowiecza, a nawet i w wiekach późniejszych, adeptów nauki prawa nie nauczano prawa obowiazujacego ${ }^{40}$. Pod koniec XIV w. uzyskanie tytułu bakałarza prawa kanonicznego w Cambridge wymagało odbycia trzyletniego kursu prawa rzymskiego - jeśli kandydat posiadał wcześniejszy tytuł regent of arts, albo pięcioletniego - gdy takiego tytułu nie posiadał. Następnie kandydat zobowiązany był przez kolejne pięć lat studiować Decretum Gracjana oraz Dekretały Grzegorza IX. W przypadku duchownych, którym na mocy bulli papieskiej Super specula Honoriusza III z 1219 r. zabroniono studiowania prawa rzymskiego, wymagane było uzyskanie wcześniejszej dyspensy zwalniającej ich z obowiązku odbycia pierwszej, romanistycznej, części studiów ${ }^{41}$. Stopień doktora obojga praw uzyskiwało się dopiero po odbyciu co najmniej dwudziestoletnich studiów ${ }^{42}$.

${ }^{38}$ R.H. Helmholz, The Canon Law..., s. 192.

${ }^{39}$ D.R. Leader, HUC, vol. 1, s. 200. Dorothy M. Owen zwraca uwage, iż prace angielskich autorów nie były wprawdzie wykorzystywane bezpośrednio w czasie wykładów, jednak wielu studentów podejmowało samodzielne próby ich studiowania, por. D.M. Owen, The Medieval Canon Law. Teaching, Literature and Transmission, Cambridge 1990, s. 2.

${ }^{40}$ R.H. Helmholz, University Education and English Ecclesiastical Lawyers 1400-1650, Ecclesiastical Law Journal 13 (2011), s. 136.

${ }^{41}$ D.R. Leader, HUC, vol. 1, s. 194. Na temat bulli Super specula zob. A. Dębiński, Kościół..., s. 97-98.

${ }^{42}$ R.H. Helmholz, The Canon Law..., s. 189. Na temat wymagan stawianych kandydatom ubiegającym się o stopień doktora obojga prawa zob. D.R. Leader, HUC, vol. 1..., s. 194. 
Wiedza, jaką absolwenci prawa $z$ Oxfordu i Cambridge wynosili po ukończeniu nauki, nie umożliwiała im wszakże występowania przed sądami królewskimi. Znawcy prawa rzymskiego stawali się jednak cennym nabytkiem dla administracji państwowej. Ich wiedza była chętnie wykorzystywana dla celów handlowych. Rozwój handlu europejskiego, poczynając od schyłku średniowiecza, wymusił na angielskich kupcach posługiwanie się instytucjami prawnymi, których geneza tkwiła $\mathrm{w}$ prawie rzymskim ${ }^{43}$. Znajomość prawa kanonicznego $z$ kolei, co oczywiste, była niezbędna przesłanką umożliwiająca występowanie przed sądami kościelnymi. Te zreszta zajmowały istotna pozycję $\mathrm{w}$ angielskiej strukturze sądownictwa, gdyż bardzo długo przysługiwała im jurysdykcja w zakresie prawa spadkowego i małżeńskiego, w sprawach o zniesławienie (defamation) oraz wówczas, gdy strony do zawieranej przez siebie umowy dołączyły klauzulę pledge of faith, czyli obwarowywały ja przyrzeczeniem wykonania złożonym na Boga ${ }^{44}$.

W tym samym czasie prawnicy występujący w sądach królewskich odbierali praktyczne wykształcenie w istniejacych od co najmniej XIII wieku Inns of Court. Zastępowały one akademicki model kształcenia, oferujac przyszłym prawnikom wykształcenie na zasadach zbliżonych do organizacji cechowych. Studenci „terminowali” u swoich patronów obserwując ich pracę - przede wszystkim prowadzone postępowania sądo$w^{45}$. Ten sposób kształcenia prawników wyraźnie przyczynił się do ugruntowania w Anglii proceduralnej perspektywy pa-

${ }^{43}$ D.M. Oven, The Medieval..., s. 2-3.

${ }^{44}$ Ł.J. Korporowicz, Pacta sunt servanda $w$ prawie kanonicznym, [w:] E. Kozerska, P. Sadowski, A. Szymański (red.), Pacta sunt servanda - nierealny projekt czy gwarancja ładu społecznego i prawnego?, Kraków 2015, s. $117-119$.

${ }^{45}$ Nie oznaczało to wszakże, iż akademickie metody nauczania nie były w Inns of Court znane. Członkowie palestry wygłaszali dla młodych prawników wykłady, często także stosowano ćwiczenia w postaci disputationes. Sporadycznie zdarzało się, że w czasie owych wykładów odwoływano się do prawa rzymskiego, zob. wieccej J.H. Baker, Roman Law at the Third University of England, Current Legal Problems 55 (2002), s. 123-150. 
trzenia na prawo, nieobcej rzymskim jurystom. Rzutowało to na kształtujące się wówczas fachowe piśmiennictwo.

Angielska literatura prawnicza okresu średniowiecza to przede wszystkim tzw. literatura traktatów. Najstarszy był traktat określany dziś mianem Glanvill - od imienia jego domniemanego autora, królewskiego justycjariusza Ranulfa de Glanvilla $^{46}$. Dzieło zatytułowane Tractatus de Legibus et Consuetudinibus Regni Angliae tempore Regis Henrici Secundi ukończone zostało pod koniec panowania Henryka II - ojca common law - około 1187-1189 roku. Stanowiło ono katalog rytów procesowych (writs) ${ }^{47}$ wykorzystywanych w sądach królewskich ${ }^{48}$. Celem opracowania było zatem przedstawienie prawa angielskiego $z$ perspektywy stosowanej procedury, która miała rodzimy charakter. W ten sposób prawo rzymskie nie mogło stanowić podstawy rozważań prowadzonych przez autora traktatu. Nie oznacza to jednak, iż pewnych jego wpływów dostrzec nie można. Rzymskie odwołania najłatwiej zauważyć we wstępie do dzieła, które rozpoczyna się od słów

${ }^{46}$ Przed opublikowaniem Glanvilla podejmowane były wprawdzie próby opracowania prostych „podręczników” prawa, lecz ich wartość i znaczenie dla późniejszego prawa angielskiego trudno porównywać $z$ omawianym traktatem. Zdaniem J.L. Bartona wcześniejsze próby miały na celu opisanie prawa stosowanego w sadach lokalnych, podczas gdy Glanvill przedstawiał prawo obowiazujace w całym królestwie. Por. więcej T.F.T. Plucknett, Early English Legal Literature, Cambridge 1958, s. 24-30; J.L. Barton, Roman..., s. 7-8. Co do autorstwa traktatu F.W. Maitland i F. Pollock zaproponowali, iż autorem Glanvilla mógł być sekretarz królewskiego justycjariusza, który następnie sam sprawował to stanowisko, Hubert Walter (F.W. Maitland, F. Pollock, History of English Law Before the Time of Edward I, vol. 1, Cambridge 1898, s. 164). Zdaniem innych autorstwo traktatu można przypisać Geoffrey'owi Fitz Peterowi (T.F.T. Plucknett, Early English..., s. 30) bąź Godfrey'owi de Lucy (R.V. Turner, Who was the Author of 'Glanvill'? Reflections on the Education of Henry II's Common Lawyers, LHR 8 (1990), s. 97-127).

${ }^{47}$ Określenie „ryty procesowe” jest tradycyjnie używane w polskiej literaturze historyczno-prawnej na określenie writs, por. ostatnio obszernie na ich temat J. Halberda, Historia zobowiazań quasi-kontraktowych w common law, Kraków 2012, s. 93-110.

48 J.H. Baker, An Introduction..., s. 175-176. 
„Regiam potestatem”, wzorowanych na pierwszych słowach („Imperatoriam majestatem”) justyniańskiej konstytucji Proemium wyjaśniającej przyczyny sporządzenia Instytucji ${ }^{49}$. Zdaniem J.L. Bartona, wpływ nauki prawa rzymskiego dostrzec można także w wykorzystaniu przez autora traktatu metody dialektycznej, której potwierdzeniem maja być licznie stosowane podziały omawianej materii. Podziały te dotycza przede wszystkim rodzajów skarg - cywilne i karne, ich zastosowania w sądach królewskich bądź lokalnych sądach szeryfów oraz rozdziału skarg na dotyczacce własności i posiadania ${ }^{50}$.

Ponadto, bezpośrednie zastosowanie rzymskich konstrukcji prawnych możliwe jest do zaobserwowania w dziesiątej księdze traktatu zatytułowanej Placitum de debitis laicorum. Autor wskazuje w niej, iż wierzyciel może domagać się swojej wierzytelności od dłużnika przed sądem, o ile dług powstal „ex causa mutui aut ex causa venditionis aut ex commodato aut ex locato aut ex depositio aut ex alia iusta debendi causa". Wprawdzie interpretacja znaczenia poszczególnych umów jest daleka od rzymskiej ${ }^{51}$, to jednak zastosowanie powyżej wskazanych pojęć sugeruje co najmniej przeciętną znajomość prawa rzymskiego przez autora traktatu. Nie należy temu się zresztą dziwić, skoro powstać miał on w późnych latach osiemdziesiatych XII w., w okresie gdy od co najmniej czterdziestu lat Vacarius przebywał i nauczał w Anglii, zaś w Oxfordzie zaczynał powstawać fakultet prawniczy ${ }^{52}$.

${ }^{49}$ T.E. Scrutton, The Influence..., s. 74; T.F.T. Plucknett, Early English..., s. 32.

50 J.L. Barton, Roman..., s. 9. Zob. także T.F.T. Plucknett, Early English..., s. 23. Na temat własności zob. także dyskusję przytoczona przez R.V. Turnera, Roman Law..., s. 15-18.

${ }^{51}$ Mutuum opisane u Glanvilla okazuje się być trzema bądź nawet czterema oddzielnym kontraktami, commodatum najprawdopodobniej nie istniało w prawie angielskim, zaś sprzedaż nie miała charakteru konsensualnego, zob. J.L. Barton, Roman..., s. 11 oraz T.E. Scrutton, The Influence..., s. $75-76$.

52 Trudno przypuszczać, aby autor Glanvilla był znawca prawa rzymskiego, który odebrał gruntowne wykształcenie w tym zakresie (por. T.F.T. Plucknett, The Relation..., s. 33), lecz pewne wiadomości na 
Glanvill, choć do dziś stanowi ważny pomnik angielskiej myśli prawniczej, szybko utracił swoje znaczenie praktyczne. Przyczyny tego stanu rzeczy sa dwojakie. Po pierwsze szybki rozwój prawa angielskiego doprowadził do zdezaktualizowania się dzieła, a po drugie zostało ono zastapione już w latach pięćdziesiatych XIII w. przez traktat autorstwa Henry'ego de Bractona (Brattona) ${ }^{53}$.

Problem wpływu prawa rzymskiego na pracę Bractona był $\mathrm{w}$ literaturze przedmiotu szeroko dyskutowany ${ }^{54}$. $Z$ pewnościa wiedza trzynastowiecznego prawnika znacznie przewyższała tę, która posiadał jeszcze pod koniec XII w. autor Glanvilla. Prawo rzymskie posłużyło Bractonowi przede wszystkim jako model do rozważań nad prawem angielskim. W tym celu zastosował on nieco zmodyfikowana, gajańska systematyke

jego temat $\mathrm{z}$ cała pewnościa posiadał i oczekiwał ich od swoich czytelników (por. T.F.T. Plucknett, A Concise History..., s. 298; R.V. Turner, Who was..., s. 106). Za przesadzony uznać należy jednak poglad J.L. Bartona, który uważał, iż autor Glanvilla traktował prawo rzymskie jako subsydiarne źródło prawa angielskiego, zob. J.L. Barton, Roman..., s. 12.

${ }^{53}$ J.H. Baker, An Introduction..., s. 176. Autorstwo Henry'ego de Bractona jest podobnie jak Glanvilla kwestionowane, lecz nie $\mathrm{z}$ taka zaciekłością. Por. w szczególności dyskusję J.L. Bartona i P. Branda: J.L. Barton, The Mystery of Bracton, JLH 14.3 (1993), s. 1-142; P. Brand, The Age of Bracton, [w:] J. Hudson (ed.), The History of English Law. Centenary Essays on 'Pollock and Maitland', Oxford 1996, s. 65-89; J.L. Barton, The Authorship of Bracton, JLH 30/2 (2009), s. 117-174; P. Brand, The Date and Authorship of Bracton, JLH 31/3 (2010), s. 217-244.

${ }^{54}$ Wśród najważniejszych prac dotyczacych tego zagadnienia wymienić należy: C. Güterbock, Bracton and His Relation to the Roman Law, trans. B. Coxe, Philadelphia 1866; T.E. Scrutton, The Influence..., s. 78121; F.W. Maitland, Selected Passages from the Works of Bracton and Azo, SS 8, 1894, London 1895; G.E. Woodbine, The Roman Element in Bracton's De Adquirendo rerum dominio, Yale Law Journal 31/8 (1922), s. 827-847; H. Kantorowicz, Bractonian Problems, Glasgow 1941; H.G. Richardson, Bracton. The Problem of His Text, SS Sup.Ser. 2, London 1965, s. 79-151; M. Franklin, Bracton, Para-Bracton(s) and the Vicarage of the Roman Law, TLR 42 (1968), s. 455-518; J.L. Barton, Bracton as a Civilian, TLR 42 (1968), s. 555-583; D.J. Seipp, Bracton, the Year Books, and the "Transformation of Elementary Legal Ideas" in the Early Common Law, LHR 7 (1989), s. $179-183$. 
prawa. Traktat podzielony został na dwie części, pierwszą materialną oraz druga - proceduralną. Część pierwsza, zawarta w trzech księgach, odpowiadała rzymskiej systematyce personae - res-actiones ${ }^{55}$. Druga natomiast, zawierajaca tylko jedną księgę, poświęcona została przede wszystkim zagadnieniom prawa karnego i procedury sadowej ${ }^{56}$.

Źródłem zapożyczeń z prawa rzymskiego wykorzystanych przez H. Bractona w jego dziele była Summa Azona. Stanowiła ona główne źródło wiedzy angielskiego prawnika o prawie rzymskim $^{57}$. Wiele fragmentów traktatu jest dosłownymi zapożyczeniami $z$ pracy glosatora. Boloński wzorzec nie został jednak wykorzystany w sposób czysto odtwórczy. Tam, gdzie rzymskie rozwiązania nie odpowiadały angielskim stosunkom społecznym i prawnym, zostały przez autora traktatu pominięte lub odpowiednio zmodyfikowane ${ }^{58}$.

Największe bogactwo rzymskich przejątków dostrzec można w księdze drugiej traktatu ${ }^{59}$. Omówione zostały tam m.in. zagadnienia dotyczące nabycia własności za pośrednictwem

${ }^{55}$ Księga pierwsza zatytułowana została De rerum divisione, w rzeczywistości zawiera ona ogólną charakterystykę prawa (rozdziały 1-5) oraz zagadnienia prawa osobowego (rozdziały 6-11). Dopiero ostatni rozdział odnosi się do podziałów rzeczy. Księga druga zatytułowana została De adquirendo rerum dominio. Trzecia $z$ kolei De actionibus w swej zdecydowanej części zawiera informacje dotyczące zobowiązań. Ostatnia część traktatu (De Corona) poświęcona jest prawu karnemu. Ta nieścisłość nazewnictwa i treści nie odbiega jednak od rzymskiego wzorca, którym dla prawników średniowiecznych były Instytucje Justyniana. Ich czwarta księga zawierała bowiem w tytułach 1-5 wiadomości z zakresu prawa zobowiazaniowego, w tytułach 6-17 procedury sądowej, zaś tytuł 18 poświęcony został prawu karnemu.

${ }^{56}$ T.E. Scrutton, The Influence..., s. 80.

${ }^{57}$ Ibidem, s. 81; J.L. Barton, Roman..., s. 15. Obszerna analizę i porównanie passusów pochodzących $z$ prac Bractona i Azona przeprowadził F.W. Maitland, Selected..., passim. Por. także źródła wskazane przez H.G. Richardsona, Bracton. The Problem..., s. 79-151; T.F.T. Plucknett, Early English..., s. 53.

${ }_{58}$ T.E. Scrutton, The Influence..., s. 82.

${ }^{59}$ Zdaniem G.E. Woodbine'a ta część traktatu wskazuje na tendencję H. Bractona do zestawiania i porównywania odpowiadajacych sobie rozwiązań rzymskich i angielskich; por. G.E. Woodbine, The Roman..., s. 847. 
occupatio, alluvio, accessio, specificatio oraz confusio. Wśród metod nabycia własności wymieniona została również donatio. Przedmiotem dalszych rozważań stały się także usucapio, służebności oraz posiadanie ${ }^{60}$.

Liczne wpływy prawa rzymskiego zaobserwować można także przy opisie actiones. Podobnie jak wcześniej u Glanvilla, tak również w dziele $\mathrm{H}$. Bractona zastosowany został podział na skargi cywilne i karne, a ponadto, za wzorem Azona, skargi cywilne podzielone zostały na rzeczowe, osobowe i mieszane ${ }^{61}$.

Wprawdzie wiele $z$ opisanych przez H. Bractona zagadnień zdradza czysto angielska proweniencję, lecz do ich objaśnienia wykorzystana została rzymska terminologia prawnicza. Często zdarza się także, iż angielskie instytucje prawne zostały wtłoczone w rzymskie schematy konstrukcyjne ${ }^{62}$. Zdaniem części autorów, tego rodzaju charakter De Legibus et Consuetudinibus świadczyć musi o tym, że jego autor był wykształconym cywilistą, który dopiero $z$ czasem zajął się praktyką common law. Stosowne wykształcenie powinien zatem odebrać w Oxfordzie. Teza ta ma jednak także przeciwników, którzy twierdza, iż znajomość prawa rzymskiego przez H. Bractona nie jest wystarczająca, aby móc przypisać mu posiadanie bakalaureatu $z$ prawa rzymskiego ${ }^{63}$. Możliwe jest jednak, że poznał

${ }^{60}$ Zagadnienie posiadania we wczesnym common law i jego rzymskich korzeni budzi kontrowersje w nauce. Wprawdzie angielskie posiadanie różni się od rzymskiego, to jednak, jak zauważa T.E. Scrutton, Bracton skonstruowal je w swoim traktacie bezpośrednio opierając się na rzymskich źródłach (por. T.E. Scrutton, The Influence..., s. 89-90). Na temat relacji własności i posiadania we wczesnym common law por. ostatnio D.J. Seipp, The Concept of Property in the Early Common Law, LHR 12 (1994), s. 2991; J.C. Tate, Ownership and Possession in the Early Common Law, AJLH 48 (2006), s. 280-313.

${ }^{61}$ T.E. Scrutton, The Influence..., s. 104. Zob. także D.J. Seipp, Roman Legal Categories in the Early Common Law, [w:] T.G. Watkin (ed.), Legal Record and Historical Reality. Proceedings of the Eighth British Legal History Conference, Cardiff 1987, London-Ronceverte 1989, s. 13, 17-22.

${ }^{62}$ T.E. Scrutton, The Influence..., s. 88. Por. także J.L. Barton, Roman..., s. $15,18-19$.

${ }^{63}$ Por. T.F.T. Plucknett, Early English..., s. 48, 61. 
on prawo rzymskie uczęszczając do jednej z przykatedralnych szkół bądź przebywając przez pewien czas w Oxfordzie ${ }^{64}$. Pozostawiając na uboczu kwestię wykształcenia, we współczesnej literaturze panuje zgodne przeświadczenie, iż tekst traktatu jest najważniejszym przykładem obecności prawa rzymskiego w średniowiecznej Anglii65. Pamiętać trzeba ponadto, że przywołanie rzymskich instytucji prawnych nie świadczy jedynie o znajomości zagadnienia przez autora, lecz również przez czytelników, do których praca była adresowana ${ }^{66}$.

Traktat H. Bractona, nigdy nie dokończony, był ostatnim wielkim dziełem średniowiecznej angielskiej literatury prawniczej. Nowe dzieła o podobnych rozmiarach i tematyce opracowane zostały dopiero kilkaset lat później. Wydawane były wprawdzie sporadycznie mniejsze prace, lecz w znacznej części stanowiły one streszczenie De Legibus et Consuetudinibus ${ }^{67}$.

${ }^{64}$ Przypadki rezygnacji ze studiów na rzecz praktyki prawa nie były czymś wyjątkowym, por. D.R. Leader, HUC, vol. 1, s. 195-196. W czasie takich studiów w Oxfordzie Bracton mógł poznać Williama Droghedę i pod jego wpływem zainteresować się prawem rzymskim i kanonicznym. Na temat wpływów prac W. Droghedy na pracę Bractona zob. H.G. Richardson, Azo, Drogheda and Bracton, EHR 59 (1944), s. 22-47; T.F.T. Plucknett, Early English..., s. 75-76.

${ }^{65} \mathrm{P}$. Stein, na podstawie badań przeprowadzonych wcześniej przez S.E. Thorne'a, uważa, że jedna trzecia dzieła Bractona stanowi bezpośrednie wykorzystanie passusów pochodzacych z Digestów oraz Kodeksu Justyniana, zob. P. Stein, Roman Law and English Jurisprudence. Yesterday and Today, [w:] idem, The Character..., s. 152.

${ }^{66}$ Por. podobnie J.L. Barton, Roman..., s. 25-26. Inaczej D.J. Seipp, Roman Law Categories..., s. 14. Na temat znajomości prawa rzymskiego u schyłku XII w. zob. E. Rathbone, Roman Law..., s. 263. Warto zwrócić dodatkowo uwage na rozważania R.H. Helmholza, który udowadnia, iż część postanowień Wielkiej Kraty Swobód (1215) została zaczerpnięta z prawa rzymskiego oraz kanonicznego, zob. R.H. Helmholz, Continental Law and Common Law: Historical Strangers or Companions?, Duke Law Journal 1990, s. 1209-1214.

${ }^{67}$ Do tej grupy należały m.in. pochodzące $z$ końca XIII w. prace Fleta i Britton. Pierwsza praca zawiera pewne odwołania do prawa rzymskiego, zarówno zaczerpnięte wprost $z \mathrm{H}$. Bractona, jak i część dodanych przez samego autora streszczenia (T.E. Scrutton, The Influence..., s. 123; więcej na temat Fleta wraz ze współczesnym tłumaczeniem zob. H.G. Richardson, 
Koniec XIII i początek XIV wieku (okres rządów Edwarda I, 1272-1307) jest zreszta kluczowy dla dalszych losów prawa angielskiego. W tym bowiem czasie nastapiło apogeum studiów nad prawem rzymskim i kanonicznym w średniowiecznej Anglii. Jednocześnie rządy Edwarda I (nazywanego bardzo często angielskim Justynianem ${ }^{68}$ ) zamykaja okres intensywnego rozwoju wczesnego common law ${ }^{69}$.

Zanik traktatów nie spowodował wszakże zaniku twórczości prawników w ogólności. W okresie od końca XIII wieku dostrzec można bowiem szybki rozwój nowej formy literackiej, niezmiernie ważnej dla angielskiego systemu prawnego - tzw. law reports ${ }^{70}$. Sprawozdania te stanowiły próbę usystematy-

G.O. Sayles, Fleta. Prologue, Books 1 and 2, SS 72 (1953), London 1955; H.G. Richardson, G.O. Sayles, Fleta, Book 3 and 4, SS 89 (1972), London 1972; G.O. Sayles, Fleta. Book 5 and 6, SS 99 (1983), London 1984). Druga praca, sporządzona w języku francuskim, powstała przede wszystkim jako aktualne spojrzenie na prawo angielskie. Różni się znacznie od oryginału i jedynie w niewielkim stopniu zawiera odwołania do rzymskiej tradycji prawnej (T.E. Scrutton, The Influence..., s. 124). Ponadto podobny charakter miała praca Gilberta de Thorntona pełniącego funkcję Chief Justice of King's Bench, por. T.F.T. Plucknett, The Harvard Manuscript of Thornton's Summa, HLR 51 (1938), s. 1038-1056; S.E. Thorne, Gilbert de Thornton's Summa de Legibus, University of Toronto Law Journal 7 (1947), s. 1-26. Na temat innych traktatów zob. T.J. McSweeney, Creating a Literature for the King's Courts in the Later Thirteenth Century: Hengham Magna, Fet Asaver, and Bracton, JLH 37/1 (2016), s. 41-71.

${ }^{68}$ Przydomek ten spopularyzował E. Jenks, nadając swojej książce tytul Edward Plantagenet (Edward I). The English Justinian or Making of the Common Law, London 1901. Zob. także Ch.P. Sherman, The Romanization..., s. 327.

${ }^{69}$ Cytujacc T.F.T. Plucknetta, prawo angielskie stało się prawem wyspiarskim („the law became insular"), T.F.T. Plucknett, The Relations..., s. 40.

${ }^{70}$ Początki sporządzania sprawozdań sądowych sięgają wprawdzie już połowy XII w., jednak faktycznego znaczenia nabrały one dopiero pod koniec XIII w. Więcej na ich temat zob. P. Brand, The Beginning of the Law Reporting, [w:] Ch. Stebbings (ed.), Law Reporting in Britain. Proceedings of the Eleventh British Legal History Conference, London-Rio Grande, $\mathrm{OH}$ 1995, s. 1-14 oraz ostatnio T. McSweeney, English Judges and Roman Jurists: The Civilian Learning behind England's First Case Law, Temple Law Review 84 (2012), s. 829-836. 
zowania wyroków wydawanych przez różne sądy królewskie z uwzględnieniem argumentów stron, rodzajów wytaczanych przez nie skarg, a na końcu wyroku i jego uzasadnienia. Wprawdzie poziom tych sprawozdań nie był wysoki, a wiele istotnych dla oceny sprawy faktów było przez prawników tworzacych sprawozdania pomijanych, to jednak $z$ biegiem czasu stały się one podstawowa forma przekazywania wiedzy na temat reguł rządzacych angielskim systemem prawnym (poczatkowo przybierały one formę tzw. yearbooks podejmujacych przede wszystkim kwestie procesowe, dopiero $z$ czasem pojawiły się właściwe law reports, które dotyczyły już prawa materialnego). Jako że w treści law reports wskazywano podstawy prawnej argumentacji przygotowywanej przez strony i ratio decidendi wydawanych wyroków, służyć mogą one także do określenia poziomu wiedzy na temat prawa rzymskiego w społeczeństwie angielskim epoki schyłku średniowiecza.

Problematykę wpływu prawa rzymskiego na orzecznictwo angielskich sądów wieków średnich podjął w swych badaniach D.J. Seipp ${ }^{71}$. Amerykański historyk prawa objął swoja analiza orzeczenia powstałe w latach 1300-1600. Po dokonaniu wstępnej selekcji, D.J. Seipp wybrał takie orzeczenia, które zawierały bezpośrednie odwołania do źródeł prawa rzymskiego i kanonicznego oraz do literatury poświęconej tym prawom. Łącznie udało mu się zlokalizować około 200 przypadków odwołania się do tradycji cywilistycznej i kanonistycznej. Częstotliwość dokonywanych powołań rosła, tak aby osiagnaćc liczbę kilku w każdym kolejnym roku (początkowo badacz odnajdywał kilka odwołań na okres dekady). W efekcie tych badań udało się ustalić, iż prawo rzymskie najczęściej powoływane było w sądach czy to common law czy kościelnych w sprawach: uznania dzieci pozamałżeńskich, $z$ zakresu prawa małżeńskiego, obsadzania probostw oraz kwestii związanych $z$ prawem spadkowym. Wydaje się

${ }^{71}$ Zob. D.J. Seipp, The Reception of Canon and Civil Law in the Common Law Courts before 1600, Oxford Journal of Legal Studies 13 (1993), s. 388-420. 
jednak, iż w praktyce większość spraw, które zostały zakwalifikowane przez D.J. Seippa do jednej z czterech powyższych kategorii, w rzeczywistości dotyczyła problematyki nabywania rzeczy.

\subsection{Prawo rzymskie w średniowiecznej Szkocji}

Początki rozwoju państwa i prawa szkockiego ${ }^{72}$ przypadaja - podobnie zreszta jak prawa angielskiego - na okres XI i XII stulecia. W roku 1034 pierwsze próby zjednoczenia terytoriów północnych podjęte zostały przez lokalnego władcę Duncana I, którego dzieło kontynuowane było następnie - od roku 1058 - przez jego syna Malcolma III. Proces zjednoczeniowy trwał $z$ przerwami przez kolejne dwa stulecia, zanim został ostatecznie zakończony ${ }^{73}$.

Konsolidacji państwa towarzyszyła także konsolidacja szkockiego systemu prawnego. Był to jednak proces skomplikowany i pod wieloma względami trudniejszy, aniżeli miało to miejsce w tym samym okresie w Anglii. Bezsprzecznie ujednolicenie prawa było kluczowym celem działań podejmowanych przez szkockich monarchów. Jednakże ich wysiłki konfrontowane były $z$ różniącymi się od siebie zwyczajami ludów zamieszkujących terytorium Szkocji. W omawianym czasie możliwe jest bowiem wskazanie kilku źródeł tożsamości prawnej jej mieszkańców. Część z nich posługiwała się prawem zwyczajowym, które wyewoluowało $z$ dawnych zwyczajów starożytnych Celtów. Prócz tego przybycie w VI wieku irlandzkich misjonarzy doprowadziło do przeszczepienia na grunt szkocki niektórych przynajmniej zwyczajów irlandz-

${ }^{72} \mathrm{~W}$ polskiej literaturze na temat historii prawa szkockiego zob. A. Stępkowski, Kształtowanie się szkockiego systemu prawa prywatnego do końca XVIII wieku, Studia Iuridica 40 (2002), s. 209-230; idem, Ksztattowanie się mieszanego systemu szkockiego prawa prywatnego $w$ XIX $i$ XX wieku, ZP UKSW 2/1 (2002), s. 57-92.

${ }^{73}$ Więcej o poczatkach monarchii szkockiej zob. S. Zabieglik, Historia Szkocji, Gdańsk 2000, s. 35-45. 
kich, wzbogaconych już zresztą elementami tradycji chrześcijańskiej ${ }^{74}$. Wreszcie południowa Szkocja, zachowując bliskie kontakty $z$ królestwami anglosaskimi, podatna była także na ich wpływy, co również znalazło swe odbicie w zwyczajach prawnych.

Wpływ obcych systemów prawnych na prawo stosowane w Szkocji nie był zreszta w wiekach XII i XIII zjawiskiem minionym. W znaczący sposób był on również kontynuowany ze względu na kontakty gospodarcze i polityczne, jakie w owym czasie łączyły królestwa Szkocji i Anglii. Główna zaś ich przyczyna były związki personalne, jakie łączyły oba dwory. $Z$ jednej bowiem strony potomkowie Duncana I składali hołd władcom angielskim ${ }^{75}, \mathrm{z}$ drugiej zaś dwory połączone zostały związkami małżeńskimi ${ }^{76}$. O sile tych relacji i ich przełożeniu na system prawny Szkocji świadczyć może fakt, iż charakteryzujacy owe prawo Lord Cooper określił je mianem prawa szkocko-normańskiego (Scoto-Norman law) ${ }^{77}$.

Mimo powyższych uwag, trzeba zauważyć, iż prawo rzymskie w Szkocji w omawianym okresie nie oddziaływało na tamtejsze prawodawstwo $\mathrm{w}$ tak znaczacym stopniu jak w Anglii. To raczej prawo angielskie, ze względu na stosunki osobiste łączące oba dwory, wpływało na rozwój prawa szkockiego $^{78}$. Warto także zauważyć, iż Szkocja, nieposiadająca jeszcze zcentralizowanej struktury sądownictwa powszechne-

${ }^{74}$ O chrystianizacji Szkocji zob. ibidem, s. 26-35.

${ }^{75}$ P. Stein, Roman Law in Scotland, Mediolani 1968, s. 4.

${ }^{76}$ J.W. Cairns, Historical Introduction..., s. 19-20.

${ }^{77}$ Lord Cooper, The Dark Age of Scottish Legal History 1350-1650, Glasgow 1952, s. 15.

${ }^{78}$ Przykładem wpływów prawa angielskiego na prawo szkockie jest zbiór zwany Regiam Maiestatem, który wzorowany był na Glanvillu. Niemniej jego część została także oparta na wzorach rzymsko-kanonicznych, zob. P. Stein, The source of Romano-canonical part of Regiam Maiestatem, Scottish Historical Review 48 (1969), s. 107-123. Zdaniem W.D.H. Sellera intensywność wpływów angielskich na prawo szkockie była w tym okresie tak duża, iż należy mówić o recepcji prawa angielskiego w Szkocji w XIII w., zob. W.D.H. Seller, Scots Law: Mixed from the Very Beginning? A Tale of Two Receptions, ELR 4 (2000), s. 6. 
go, obficie czerpała $z$ pracy sądów kościelnych, powierzając im rozstrzyganie dużej grupy spraw, które w innych krajach starano się zachować do wyłącznej kontroli państwa ${ }^{79}$.

Zdaniem Williama M. Gordona znajomość instytucji prawa rzymskiego przez szkockich prawników ograniczała się jedynie do tych, które zostały recypowane przez Kościół i stały się częścią prawa kanonicznego ${ }^{80}$. Pogląd ten musi być jednak uznany za zbyt skrajny. Chociaż nie ulega wattpliwości, iż źródłem zapożyczeń było istotnie prawo kanoniczne, to jednak szkoccy prawnicy, studiujac na uczelniach kontynentalnych, umieli dostrzec oryginalne źródło pochodzenia stosowanych przez nich reguł prawa. Nigdy przecież wiedza o romanistycznej proweniencji norm kanonicznych nie była ukrywana ${ }^{81}$.

Owo nakierowanie prawników szkockich działających w XIII i XIV wieku na prawo kanoniczne nie powinno zresztą dziwić, było ono bowiem ściśle związane $z$ przemianami, jakie zachodziły w tym okresie na europejskich uniwersytetach. Pod wpływem coraz prężniej rozwijających się struktur kościelnych doszło do zintensyfikowania studiów nad prawem kanonicznym, co przełożyło się następnie także na liczbę studiujących je słuchaczy średniowiecznych wszechnic. Prawidłowość tę dostrzec można zarówno na uczelniach angielskich, do których początkowo większość chcących studiować Szkotów wyjeżdżała, jak i później, gdy na skutek konfliktu politycznego z Anglią, Szkoci zaczęli wybierać uniwersytety francuskie, przede wszystkim w Paryżu, Avignonie oraz w Orleanie ${ }^{82}$. Kres tych peregrynacji naukowych nasta-

${ }^{79}$ Lord Cooper, The Dark..., s. 28.

${ }^{80}$ W.M. Gordon, Roman Law in Scotland, [w:] R. Evans-Jones (ed.), The Civil Law Tradition in Scotland, Edinburgh 1995, s. 17.

${ }^{81}$ Por. Lord Cooper, The Dark..., s. 21-22.

${ }^{82}$ W.M. Gordon, Roman Law in Scotland..., s. 19-20. Na temat najważniejszej z tych szkół - szkoły orleańskiej - zob. P. Stein, Roman Law in European..., s. 67-68. Dobór uniwersytetów francuskich jako miejsca odbywania studiów przez Szkotów nie powinien zresztą dziwić ze względu na sytuację polityczną na linii Szkocja-Anglia. Więcej na temat tego konfliktu, jak również sojuszu Szkotów z Francuzami, zob. S. Zabieglik, Historia..., s. 50-60. 
pił dopiero w XV w., gdy założone zostały pierwsze szkockie uczelnie - w roku $1413 \mathrm{w}$ St Andrews, następnie w roku $1451 \mathrm{w}$ Glasgow i ok. roku $1495 \mathrm{w}$ Aberdeen. Istotny wydaje się być wszakże fakt, że na wszystkich podjęto w pierwszej kolejności studium obojga praw ${ }^{83}$.

W początkowym okresie działalności sądów szkockich trudno jest ocenić stopień wykorzystania rzymskich rozwiązań prawnych w ferowanych przez ich sędziów wyrokach. Brak zachowanych sprawozdań sądowych nie pozwala dokonać nawet przybliżonej rekonstrukcji stosowanych wówczas norm prawnych ${ }^{84}$. Próby takie podejmowane mogą być dopiero dla okresu późniejszego (XIV w.). Zachowany materiał pozwala sądzić, iż ówczesny system sądownictwa w znacznej mierze opierał się na doświadczeniu prawniczym duchownych, którzy wykorzystywali swoja znajomość prawa kanonicznego, a pośrednio także rzymskiego ${ }^{85}$, przy wydawaniu wyroków w sprawach tak kościelnych, jak i świeckich. Najstarsze zachowane dowody twórczego wykorzystania argumentacji romanistycznej odnotować można w tym właśnie okresie ${ }^{86}$. Trzon owej recepcji stanowiły jednak przede wszystkim unormowania o charakterze technicznoprawnym ${ }^{87}$, podczas gdy konstrukcje materialnoprawne, jeśli wdrażane były do systemu prawa szkockiego, to raczej w drodze królewskiego ustawodawstwa, które począwszy od drugiej połowy XV w. wyraźnie zdradzało wplywy prawa rzymskiego ${ }^{88}$.

${ }^{83}$ W.M. Gordon, Roman Law in Scotland..., s. 21

${ }^{84}$ P. Stein, Roman Law in Scotland..., s. 22-23. Na temat braku materiału źródłowego do badania dziejów prawa szkockiego zob. Lord Cooper, The Dark..., s. 6-8.

${ }^{85}$ Sędziowie sądów kościelnych uprawnieni byli do subsydiarnego wykorzystywania prawa rzymskiego w swych orzeczeniach począwszy od dekretału Intelleximus wydanego przez papieża Lucjusza III, zob. szerzej. A. Dębiński, Kościót..., s. 87-92.

${ }^{86}$ W.M. Gordon, Roman Law in Scotland..., s. 18-19.

${ }^{87}$ Odmiennie P. Stein, Roman Law in Scotland..., s. 25.

${ }^{88}$ W.M. Gordon, Roman Law in Scotland..., s. 22-23. 


\subsection{Prawo rzymskie w Anglii nowożytnej (do połowy XVIII w.)}

W okresie, który dzielił rządy Edwarda I i Henryka VIII, ius Romanum nie stanowiło przedmiotu szerszego zainteresowania angielskich prawników. Tak prawo rzymskie, jak i prawo kanoniczne, nauczane były wprawdzie na angielskich uniwersytetach, lecz coraz wyraźniej program studiów stawał się anachroniczny w stosunku do zmieniającej się sytuacji polityczno-prawnej. W tym kontekście wyjątkowo prezentuja się prace Johna Fortescue, żyjącego w XIV w., który w swych traktatach naukowych, w tym w najsłynniejszym: De laudibus legum Angliae ${ }^{89}$, wskazywał m.in. na podobieństwa łaczące i różnice dzielące prawo rzymskie i prawo angielskie ${ }^{90}$. Traktat zaplanowany był jako podręcznik przeznaczony dla księcia Edwarda - syna Henryka VI Lancastera.

Dopiero objęcie rządów przez Henryka VIII w roku 1509 zapoczatkowało liczne zmiany w kulturze Wysp Brytyjskich, w tym także w kulturze prawnej. Należy zauważyć, iż autorytarne dążenia króla - wzorowane na postawie władców kontynentalnych - spowodowały jego zainteresowanie możliwościa posłużenia się prawem rzymskim w celu uargumentowania zasadności stawianych przez niego żądań i rozrastającej się władzy. Komentujaccy te działania F.W. Maitland posuną się wręcz do stwierdzenia, iż za czasów Henryka VIII common law było poważnie zagrożone wpływami rozwijającego się prawa rzymskiego ${ }^{91}$. Opinię tę krytycznie ocenili wprawdzie późniejsi autorzy, w tym W.S. Holdsworth ${ }^{92}$, a za nim

${ }^{89} \mathrm{~J}$. Fortescue, De laudibus legum Angliae. The Translation into English and The Original Latin Text with Notes, ed. A. Amos, Cambridge 1825.

${ }^{90}$ Zob. np. C.A.J. Skeel, The Influence of the Writtings of Sir John Fortescue, Transactions of the Royal Historical Society (Third Series) 10 (1916), s. 77-114. Por. także T.E. Scrutton, The Influence..., s. 73.

${ }^{91}$ F.W. Maitland, English Law and the Renaissance, Cambridge 1901, passim, a w szczeg. s. 17, 20-22.

92 W.S. Holdsworth, The Reception of Roman Law in the Sixteenth Century, 1, LQR 27 (1911), s. 397-398; idem, The Reception of Roman Law in the Sixteenth Century, 4, LQR 28 (1912), s. 247-248, 254. 
T.F.T. Plucknett ${ }^{93}$, lecz obaj przyznali równocześnie, iż panowanie Henryka VIII przyniosło kres zwierzchnictwu common law nad innymi systemami prawnymi, które w tym czasie istniały już w angielskim porządku prawnym.

Najbardziej widocznym przejawem poparcia, jakim cieszyło się prawo rzymskie na dworze angielskiego monarchy, było utworzenie około 1540 roku dwóch królewskich katedr prawa rzymskiego w Oxfordzie i Cambridge. Ich ustanowienie bezpośrednio wiązało się $z$ zakazem nauczania prawa kanonicznego, co $z$ kolei stanowiło następstwo zerwania kontaktów z papiestwem i ogłoszenia powstania Kościoła Anglikańskiego ${ }^{94}$. Obie Katedry powierzone zostały wybitnym znawcom prawa rzymskiego tamtego okresu: w Oxfordzie - Johnowi Story'emu ${ }^{95}$, zaś w Cambridge - Thomasowi Smithowi ${ }^{96}$.

93 T.F.T. Plucknett, A Concise History..., s. 299; idem, The Relations..., s. 46-47. Por. także J.H. Baker, English Law and the Renaissance, CLJ 44 (1985), s. 50-51, 56, 59.

${ }^{94}$ J.L. Barton, The Faculty of Law, [w:] HUO, vol. 3, Oxford 1986, s. 257262; R.H. Helmholz, The Canon Law..., s. 243. Mimo to R.H. Helmholz sugeruje, iż formalnie wykłady zostały usunięte $z$ programu nauczania, jednak do pewnego stopnia prawo kanoniczne było na angielskich uczelniach nauczane jeszcze kilkadziesiąt lat, por. R.H. Helmholz, Roman Canon Law in Reformation England, Cambridge 1990, s. 153.

${ }^{95} \mathrm{John}$ Story był wychowankiem wszechnicy oxfordzkiej, w 1538 roku uzyskał doktorat obojga praw i od tego samego roku wykładał prawo rzymskie. Ze względu na głoszone przez siebie poglądy, jako członek Izby Gmin, kilkukrotnie był osadzany w więzieniach oraz dwukrotnie udawał się na wygnanie do Louvain. W czasie jednego wygnania został wysłannikiem króla hiszpańskiego. $Z$ tego względu w roku 1571 uznano go winnym zdrady, powieszono, a jego ciało poćwiartowano. W roku 1886 papież Leon XIII ogłosił Johna Story'ego błogosławionym, więcej por. J.L. Barton, The Faculty..., s. 285-286.

${ }^{96}$ Thomas Smith nie był $z$ wykształcenia prawnikiem. Jego pierwotnym obszarem zainteresowania była greka, na temat której opublikował kilka prac. Dzięki poparciu królewskiego lekarza uhonorowany został stanowiskiem królewskiego profesora prawa rzymskiego. Nie posiadając jednak jakiejkolwiek wiedzy na jego temat, zdecydował się opuścić Anglię i przez dwa lata studiował prawo rzymskie w Paryżu i Padwie. Więcej 
Początkowo nakazana metoda nauczania nie różniła się od stosowanej przed 1540 rokiem. Profesor miał prowadzić swój wykład w oparciu o Digestum vetus oraz Kodeks, zaś pozostałe części justyniańskiej kodyfikacji miały być wykładane przez bakałarzy ubiegajacych się o uzyskanie tytułu doktora. Wedle regulacji wprowadzonych za rządów Edwarda VI wykładowca miał sam dokonać wyboru wykładanej materii spośród zagadnień zawartych w Digestach i Kodeksie, zaś reforma studiów dokonana za rząów Elżbiety I dała profesorom pełna swobodę w zakresie przedmiotu wykładu, wskazywała wszakże, iż wykład prowadzony musi być przez cztery dni w tygodniu ${ }^{97}$.

W kolejnych dziesięcioleciach nauczanie prawa rzymskiego spotkało się $z$ atakami, które po raz pierwszy dały się zauważyć za rządów Jakuba I. Dążenia absolutystyczne króla uzasadnione były (przynajmniej w opinii wielu obserwatorów ówczesnego życia politycznego) przez największe autorytety środowiska cywilistów ${ }^{98}$. W Oxfordzie w latach trzydziestych XVII w. dało się zaobserwować odrodzenie autorytetu studiów prawniczych, lecz wybuch angielskiej wojny domowej ponownie zagroził dalszemu ich istnieniu. Pełne odrodzenie studiów nad prawem rzymskim w Oxfordzie datować można dopiero na czasy Restauracji Stuartów ${ }^{99}$.

Początek XVII w. był wprawdzie okresem silnych ataków skierowanych przeciwko prawu rzymskiemu, ale jednocześnie był to też okres, gdy na obu angielskich uczelniach przedmiot ten wykładany był przez wielkie postacie ówczesnej nauki. Królewskim profesorem prawa rzymskiego w Oxfordzie w latach 1587-1608 był Włoch Alberico Gentili, który dziś znany jest przede wszystkim jako jeden ze współtwórców teo-

por. P. Stein, Sir Thomas Smith: Renaissance Civilian, [w:] idem, The Character..., s. 186-196.

${ }^{97}$ J.L. Barton, The Faculty..., s. 263.

${ }^{98} \mathrm{Na}$ temat związków cywilistów i polityki w pierwszej połowie XVII w. zob. B.P. Levack, The Civil Lawyers in England 1603-1641. A Political Study, Oxford 1973, s. 86-121.

${ }^{99}$ B.P. Levack, Law, [w:] HUO, vol. 4, Oxford 1997, s. 559-561. 
rii prawa międzynarodowego ${ }^{100}$. Jego następcą był John Budden (profesor w latach 1611-1620) ${ }^{101}$, jego uczniami zaś bylikolejny królewski profesor Richard Zouche (profesor w latach 1620-1661) ${ }^{102}$ oraz Arthur Duck ${ }^{103}$. W Cambridge $z$ kolei w latach 1594-1611 królewska katedrę zajmował John Cowell ${ }^{104}$. W przeciwieństwie do wcześniejszej epoki, począwszy od wieku XV opracowania naukowe dotyczące utriusque iuris były w Anglii stosunkowo łatwo dostępne. Popularność prawa kanonicznego, którą dało się zaobserwować jeszcze u schyłku średniowiecza, spowodowała początkowe zwiększenie zasobów uniwersyteckich, jak i prywatnych bibliotek o prace z zakresu kanonistyki ${ }^{105}$. Z czasem jednak ta swoista moda zaczęła przemijać, co było prawdopodobnie związane $z$ reformacja, a popularnościa zaczęły cieszyć się prace poświęcone prawu rzymskiemu. Dla przykładu, w bibliotece oxfordzkiego All Souls College na przełomie XV i XVI w. znajdowało się jedynie kilka kopii Corpus Iuris Civilis oraz klasyczne opracowa-

${ }^{100}$ Ostatnio w polskiej literaturze ukazała się krótka wzmianka na temat A. Gentili'ego wraz $z$ tłumaczeniem fragmentu jednego $z$ jego dzieł De armis Romanis, zob. I. Precz, Iustitia Romanorum in Foederibus, Studia Prawnicze KUL 49 (2012), s. 129-137.

${ }^{101}$ S. Lee, Budden, John, [w:] DNB, vol. 3, s. 221-222.

102 R. Helmholz, Richard Zouche (1590-1661), Ecclesiastical Law Journal 15 (2013), s. 204-207.

${ }^{103} \mathrm{Na}$ temat A. Ducka, jego poglądów na prawo rzymskie oraz na temat jego dzieła De Usu Authoritate Iuris Civilis Romanorum in Dominiis Principium Christianorum zob. J. Sondel, Artur Duck - niedoceniony poprzednik Savigny'ego i jego poglady na role prawa rzymskiego $w$ Polsce, Zeszyty Naukowe Uniwersytetu Jagiellońskiego DCXXV, Prace Prawnicze 97 (1982), s. 69-86; Ł. Marzec, Artur Duck, De Usu et Authoritate Iuris Civilis Romanorum - podrzędna rozprawa czy dzieło światowej romanistyki?, ZP UKSW 6/1 (2006), s. 145-157; idem, Prawo rzymskie $w$ dawnej Anglii $w$ świetle pogladów Artura Ducka (wybrane zagadnienia), ZP UKSW 6/2 (2006), s. 117-136; idem, Wizja powszechnego prawa europejskiego według Arthura Ducka, Studia Prawnoustrojowe 7 (2007), s. 255-261.

${ }^{104}$ J. Simon, Dr. Cowell, CLJ 26 (1968), s. 260-272.

${ }^{105}$ A. Wijffels, The civil law, [w:] L. Hellinga, J.B. Trapp (eds.), The Cambridge History of the Book in Britain. Volume III, 1400-1557, Cambridge 1999, s. 402-404. 
nia monograficzne autorów włoskich i francuskich. Dopiero połowa XVI wieku przyniosła wzrost liczby prac cywilistycznych ${ }^{106}$. Na podstawie katalogów pochodzacych $\mathrm{z}$ biblioteki uniwersyteckiej w Cambridge wiadomo z kolei, iż w latach trzydziestych XVII wieku uniwersytet posiadał łącznie 769 tomów ksiąg kanonistycznych i cywilistycznych ${ }^{107}$.

Począwszy od połowy wieku XVII prestiż królewskich katedr znacznie osłabł, przede wszystkim ze względu na silne upolitycznienie procesu doboru profesorów. Zdaniem H.G. Hanbury'ego, w Oxfordzie od czasów Richarda Zouche'a, który opuścił katedrę w 1661 roku, aż do roku 1767, gdy na stanowisko profesora mianowano Roberta Vansittarta, wszyscy królewscy wykładowcy prezentowali niski poziom merytoryczny ${ }^{108}$.

Podobnie jak w epoce średniowiecza, także w czasach nowożytnych absolwenci uniwersyteccy wykształceni w prawie rzymskim nie występowali przed sądami królewskimi ${ }^{109}$. Spośród prawników, których można nazwać uniwersyteckimi,

106 Ibidem, s. 404.

${ }^{107}$ A. Wijffels, Law Books at Cambridge, 1500-1640, [w:] P. Birks (ed.), The Life of the Law. Proceedings of the Tenth British Legal History Conference, Oxford 1991, London-Ohio 1993, s. 61. Książki kolekcjonowane były także w prywatnych bibliotekach. Przykładem takiej kolekcji, składającej się zarówno $z$ prac dotyczacych prawa rzymskiego, jak i kanonicznego, sa książki Thomasa Legge'a - cywilisty angielskiego działającego w Cambridge w drugiej połowie XVI w., przekazane po jego śmierci do biblioteki Gonville and Caius College w Cambridge (P. Stein, Thomas Legge, a Sixteenth Century English Civilian and his Books, [w:] idem, The Character..., s. 197-208, w szczeg. 205-208). Por. również zestawienie kilkudziesięciu prac cytowanych przez A. Ducka w jednym $z$ rozdziałów jego dzieła, przedstawione przez Ł. Marca w artykule Artur Duck, De Usu Authoritate Iuris Civilis Romanorum in Regno Galliarum. Przegląd bazy bibliograficznej, ZP UKSW 8/1 (2008), s. 141-150.

${ }^{108}$ H.G. Hanbury, The Vinerian Chair and Legal Education, Oxford 1958, s. 10.

109 Niektórzy autorzy wskazuja jednak, iż młodym prawnikom wprost sugerowano, ażeby własne studia nad prawem rozpoczynali od lektury Instytucji Justyniana, zob. D. Ibbetson, Common Law and 'Ius Commune', SS Lecture, London 2001, s. 11-12. 
rekrutowała się jednak inna grupa znawców prawa, zwana popularnie cywilistami (civilians). Występowali oni przed licznymi rodzajami sądów, które znajdowały się poza struktura sądownictwa westminsterskiego (królewskiego). Do tej kategorii należały przede wszystkim sądy kościelne, a także Sąd Admiralicji, Sąd Lorda Konstabla, czy wreszcie sądy uniwersyteckie.

Rozwój oddzielnej korporacji cywilistów (College of Advocates) był procesem długotrwałym, zintensyfikowanym po wydarzeniach okresu reformacji ${ }^{110}$. Zakaz prowadzenia wykładów prawa kanonicznego wyniósł prawo rzymskie do rangi jedynego nauczanego na Wyspach prawa pisanego. Mimo to sądy kościelne oraz inne, w których wykorzystywana była procedura sądowa oparta na wzorcach rzymsko-kanonicznych, nadal istniały i zyskiwały coraz większe znaczenie. Prawnicy common law zupełnie nie znali praktyki tych sądów, dzięki czemu cywiliści mogli zyskać prawdziwy monopol. $Z$ ich grona wywodzili się nie tylko praktycy, którzy reprezentowali strony przed sądami, lecz również sędziowie, którzy ferowali wyroki. Ponadto wymóg uzyskania tytułu doktora prawa znacznie ograniczył liczbę potencjalnych członków powstałego w tym czasie Kolegium Adwokatów (nazywanego zreszta Doctors' Commons). W pierwszej połowie XVII w., zdaniem D.R. Coquillette'a, w Anglii praktykowało jedynie dwustu cywilistów. W tym samym czasie liczba prawników common law była około dziesięciokrotnie większa ${ }^{111}$.

Co ciekawe, to prace cywilistów były pierwszymi, po długim okresie pustki literackiej, próbami przedstawienia angielskiego porządku prawnego. Wpisując się w tradycję szkoły bartolistów, angielscy cywiliści starali się tak opisać istniejace instytucje prawa angielskiego, aby obraz ten odpowiadał potrzebom istniejącego już wówczas ius commune.

${ }^{110}$ Na temat powstania College of Advocates zob. G.D. Squibb, Doctors' Commons. A History of the College of Advocates and Doctors of Law, Oxford 1977, s. 2-8.

${ }^{111}$ D.R. Coquillette, Legal Ideology and Incorporation 1. The English Civilian Writers, 1523-1607, Boston University Law Review 61 (1981), s. 21. 
Ich pisma w wyraźny sposób kształtowały kulturę prawna szesnasto- i siedemnastowiecznej Angliii ${ }^{112}$. Najbardziej wyrazistymi przykładami tego rodzaju działań były opublikowane w latach 1523-1532 w Londynie Dialogues between a Doctor of Divinity and a Student of the Common Law autorstwa Christophera St Germana ${ }^{113}$, wydana w roku 1602 praca Williama Fulbecke'a A Parallele or Conference of the Civil Law, the Canon Law, and the Common Law of this Realme of England ${ }^{114}$ oraz pierwszy w dziejach prawa angielskiego słownik terminów prawniczych autorstwa królewskiego profesora prawa rzymskiego $z$ Cambridge, Johna Cowella, zatytułowany The Interpreter, or Booke Containing the Signification of Words ${ }^{115}$.

Mimo zaangażowania cywilistów w działalność uniwersytecka, administracyjną czy dyplomatyczną, głównym polem ich aktywności zawsze pozostawało sądownictwo. Najważniejsze $z$ nich było sądownictwo kościelne. Początki działalności consistory courts sięgają połowy XIII wieku. Już wtedy ustrój kościelnych trybunałów, jak również stosowana w nich procedura, wyraźnie różniły się od tej stosowanej w sądach królewskich ${ }^{116}$.

112 Ibidem, s. 35.

${ }^{113}$ Ibidem, s. 39-49. Zob. także wstęp i komentarz do Doctor and Student autorstwa T.F.T. Plucknetta i J.L. Bartona, St. German's Doctor and Student, SS 91, London 1974, s. xi-lxxvi.

${ }^{114}$ D.R. Coquillette, Legal Ideology 1..., s. 63-70. Wart wspomnienia jest także działający na przełomie XVII i XVIII w. doktor prawa cywilnego Thomas Wood. Był on nauczycielem akademickim, nigdy nie przynależącym do College of Advocates. Posiadał rozległa wiedzę tak w zakresie prawa rzymskiego, jak i common law. Dał temu wyraz pisząc dwa podręczniki poświęcone obu zagadnieniom - New Institute of the Imperial Civil Law, wydane w 1704 r. oraz An Institute of the Laws of England, wydane w roku 1720; więcej na jego temat i na temat jego prac R.B. Robinson, The Two Institutes of Thomas Wood: A Study in Eighteenth Century Legal Scholarship, AJLH 35 (1991), s. 432-458.

115 J. Simon, Dr. Cowell..., s. 268-270.

${ }^{116}$ R.H. Helmholz, The Canon Law..., s. 311. Przyjmuje się, że od schyłku XIII stulecia angielskie sady kościelne sprawowały jurysdykcję w sprawach: małżeńskich, dzieci pochodzących z nieprawego łoża, dziedziczenia tzw. personal property, dotyczacych grzechów śmiertelnych (zdrada, cudzołóstwo, obżarstwo), dóbr ziemskich należących do instytucji kościel- 
Wykorzystanie procedury rzymsko-kanonicznej w angielskich sądach kościelnych stanowiło naturalne następstwo łączności wszystkich sądów kościelnych w całym chrześcijańskim świecie. Wprawdzie, jak zauważa R.H. Helmholz, procedura stosowana w poszczególnych sądach do pewnego stopnia się różniła, co stanowić miało rezultat dopuszczenia tzw. stylus curiae, to jednak podstawowe zasady postępowania były identyczne we wszystkich sądach kościelnych ${ }^{117}$. Prócz procedury, także w warstwie materialnej prawo rzymskie przenikało do sądów kościelnych, $z$ różnym jednak skutkiem i z różnym nasileniem. W Anglii łatwo dostrzegalna była konkurencja wpływów romanistycznych i czysto angielskich. Spowodowane było to bardzo częstym uzurpowaniem przez sądy kościelne uprawnień do orzekania w sprawach, w których właściwymi były sądy królewskie, pomimo iż już od schyłku średniowiecza wprowadzane były stosowne zakazy zabraniajace podobnych praktyk, zaś niezadowolonym $z$ doboru sadu pozwanym przysługiwał writ of prohibition ${ }^{118}$.

Zerwanie więzi z Rzymem nie doprowadziło ostatecznie do przeniesienia rozległej jurysdykcji kościelnej na sądy królewskie. Monarcha stał się wprawdzie głowa nowo powstałej wspólnoty religijnej, jednak jej ramy administracyjne pozostały w zasadzie niezmienione. Angielskie sądy kościelne, zachowujac swoje liczne kompetencje, wymagały zachowania profesjonalnej administracji, która mogłaby je obsługiwać. Prawnicy common law nie mogli jednak temu zadaniu podo-

nych, laesio fidei, zniesławienia i deliktu laying violent hand on a clerk, por. J.H. Baker, An Introduction..., s. 129.

${ }^{117}$ R.H. Helmholz, The Canon Law..., s. 313. Warto zauważyć jednak, iż zdaniem D. Ibbetsona praktyka sądowa była głównym czynnikiem osłabiajacym jednolitość ius commune. Praktyka powoływania się na precedensy, a nie na literaturę naukowa lub regulacje prawne o charakterze powszechnym, była charakterystyczna dla wielu europejskich judykatur epoki późnego średniowiecza i czasów nowożytnych. Zob. D. Ibbetson, Common Law..., s. 6-9.

118 Por. Ch. Donahue Jr., 'Ius Commune', Canon Law, and Common Law in England, TLR 66 (1992), s. 1775-1776; J.H. Baker, An Introduction..., s. 128-129, 133. 
łać ${ }^{119}$. Naturalne wydało się zatem, iż pustkę tę należy zapełnić cywilistami, którzy w przeciwieństwie do prawników common law rozumieli zasady procedury rzymsko-kanonicznej.

Bardzo długo, bo aż do XIX w., w sferze jurysdykcji kościelnej pozostawały sprawy małżeńskie oraz spadkowe. Ponadto sądy te decydować mogły także w innych, nieco mniej istotnych sprawach dotyczących szeroko rozumianego prawa osobowego, np. dotyczacych zniesławienia ${ }^{120}$ czy w sprawach dotyczacych opieki ${ }^{121}$.

Mimo poważania, jakim cieszyły się sądy kościelne, zdecydowanie bardziej cywilistyczny w swym charakterze był Sąd Admiralicji ${ }^{122}$. Jego powstanie, podobnie zreszta jak Sądu Wysokiego Lorda Konstabla i Hrabiego Marszałka, o którym będzie mowa dalej, związane było $z$ faktem, iż sądy common law zobowiazane były do powołania ławy przysięgłych $z$ terenu wystapienia zdarzenia, którego skutki stanowiły przedmiot postępowania. Wówczas gdy okoliczności stanowiące podstawę wytoczenia powództwa miały miejsce poza obszarem Królestwa, ława przysięgłych nie mogła się zebrać. Początkowo jedynym dopuszczalnym rozwiąaniem było rozpoznawanie spraw przed samym królem i jego Radą. Autorytet monarchy niwelował potrzebę wzywania ławy przysięłych. W ten sposób doszło $z$ czasem do powstania dwóch trybunałów reali-

${ }^{119}$ Oznaki tego chaosu można zaobserwować na podstawie danych dotyczacych liczby rozpatrywanych przez poszczególne sądy diecezjalne spraw w latach bezpośrednio następujacych po dokonaniu aktu secesji od Kościoła rzymskiego. Chaos ten był jednak krótkotrwały i już trzydzieści czterdzieści lat później liczba spraw oscylowała na podobnym poziomie jak przed reformacją, aby następnie zaczać się zwiększać, por. R.B. Outhwaite, The Rise and Fall of the English Ecclesiastical Courts, 1500-1860, Cambridge 2006, s. 17-18.

${ }^{120} \mathrm{Na}$ ten temat zob. R.H. Helmholz, Canon Law and English Common Law, SS Lecture, London 1983, s. 9-11.

${ }^{121}$ R.H. Helmholz, The Roman Law of Guardianship in England, 13001600, TLR 52 (1978), s. 223-257.

${ }^{122}$ Por. Ch. Donahue Jr, 'Ius Commune'..., s. 1773. W polskiej literaturze na temat tego sadu zob. Ł. Marzec, Kilka uwag o sadownictwie admiralicji $w$ Anglii, ZP UKSW 4/ 1 (2004), s. 75-89. 
zujących uprawnienia monarchy ${ }^{123}$ - Sadu Admiralicji (The Court of the Lord High Admiral) oraz Sadu Wysokiego Lorda Konstabla i Hrabiego Marszałka (The Court of the Lord High Constable and Earl Marshal of England ${ }^{124}$.

Poczatki sądownictwa admiralicji sięgają swymi korzeniami XIV wieku ${ }^{125}$. Podstawa angielskiej jurysdykcji morskiej uczyniony został powstały w XIII w. zbiór zwany Rolls of Oléron (Rôles d'Oléron) ${ }^{126}$. Był to zbiór zawierający spisane zwyczaje morskie, z których część swymi korzeniami może sięgać rzymskiego prawa morskiego ${ }^{127}$. Także późniejsza praktyka sądów orzekających na podstawie Rolls of Oléron zadecydowała o wykorzystaniu rzymskiej tradycji prawnej ${ }^{128}$. Rozwój prawa morskiego spowodował opracowanie w XV w. angielskiej wersji olerońskiego zbioru, który od tej pory określany był mianem Black Book of the Admiralty ${ }^{129}$.

${ }^{123}$ Niewykluczone jednak, że początkowo starano się w niektórych przynajmniej sprawach zwoływać ławę przysięgłych, por. więcej Ch.S. Cumming, The English High Court of Admiralty, Tulane Maritime Law Review 17 (1993), s. 229.

${ }^{124}$ J.H. Baker, An Introduction..., s. 122.

${ }^{125} \mathrm{Na}$ temat regulacji dotyczących jurysdykcji w sprawach morskich zawartych w Domesday Book zob. T.E. Scrutton, The Influence..., s. 170.

${ }^{126} \mathrm{Na}$ przykład Pilk $v$. Venere (1350) SS 46 (1929), s. XCV. Zbiór obowiązywał także w sądach szkockich, np. Nicolsoun $v$. Watsoun (1560), Stair Society 2 (1937), s. 164. Więcej na temat Rolls of Oléron i jego zastosowania przez sadownictwo angielskie zob. T.J. Runyan, The Rolls of Oleron and the Admiralty Court in Fourteenth Century England, AJLH 19 (1975), s. 96-97; Ł. Marzec, Kilka uwag o sadownictwie..., s. 78-79; J.W. Shephard, The Rôles d'Oléron: A 'lex mercatoria' of the Sea?, [w:] V. Piergiovanni (ed.), From lex mercatoria to commericial law, Berlin 2005, s. 207-217.

${ }^{127}$ Rzymskie prawo morskie w znacznym stopniu zawdzięczało swój rozwój wcześniejszym regulacjom prawnym znanym w poleis greckich, przede wszystkim prawu rodyjskiemu, dzięki któremu do prawa rzymskiego recypowana została instytucja zrzutu morskiego, zob. więcej S. Płodzień, 'Lex Rhodia de Iactu'. Studium historycznoprawne z zakresu rzymskiego prawa handlowomorskiego, Lublin 2010, s. 29-61.

${ }_{128}$ T.E. Scrutton, The Influence..., s. 173.

${ }^{129}$ Ostatnia edycja Black Book of the Admiralty pochodzi z drugiej połowy XIX w.: The Black Book of the Admiralty with the Appendix, ed. T. Twiss, vol. 1-4, London 1871-1876. 
Wykorzystanie prawa rzymskiego przez sądownictwo admiralicji stanowiło wyraz wielowiekowej tradycji. Dzięki zastosowaniu procedury rzymsko-kanonicznej, cywilistyczny charakter sadu nie został ograniczony. Nie spowodował tego ani wpływ lokalnych zwyczajów, ani pojawienie się nowej linii orzeczniczej - z czasem ważniejszego punktu odniesienia niż zasady zawarte w Czarnej Księdze.

Admiralicja stanowiła najważniejsza chyba ostoję cywilistów w Wielkiej Brytanii okresu nowożytnego. Wynikało to wprost $z$ praktycznego charakteru sadu. Rozkwit handlu dalekomorskiego, stanowiący następstwo objęcia przez Wielka Brytanię morskiej dominacji po roku 1588 (zniszczenie Wielkiej Armady), wyprowadził ją na pozycję samodzielnego lidera gospodarczego ówczesnego świata. Brytyjskich kupców można było spotkać we wszystkich zakątkach świata. Wzrost liczby spraw rozpatrywanych przez Sad Admiralicji był zatem nieunikniony. Jednocześnie elitarność Doctors' Commons zapewniała tej niewielkiej korporacji ciagłe zatrudnienie.

Pochodna działań sądownictwa admiralicji stał się rozwój angielskiego prawa handlowego (merchant law). Jego cechą charakterystyczna była przynależność do kontynentalnej tradycji lex mercatoria, nie zaś oparcie się na wzorcach common law ${ }^{130}$. Kontynentalne oddziaływanie na strukturę angielskiego prawa handlowego związane było przede wszystkim $z$ tym, iż wraz ze swoim rozwojem, jeszcze w epoce średniowiecza, stanowiło ono w zasadzie konglomerat norm prawnych o charakterze starożytnego ius gentium, czy do pewnego stopnia współczesnego prawa prywatnego międzynarodowego ${ }^{131}$. Reguły prawa handlowego w swym oryginalnym kształcie stanowiły zatem wspólny dorobek całej cywilizacji średniowiecznej i wczesnonowożytnej. De-

130 Ł.J. Korporowicz, Spółka akcyjna w prawie angielskim - rozwój konstrukcji, [w:] K. Brzeziński, Prywatnoprawne aspekty działalności gospodarczej $w$ prawie polskim i europejskim, Kraków 2011, s. 99, 100-101.

${ }^{131}$ Por. W.S. Holdsworth, The Development of the Law of Merchants and its Court, [w:] Selected Essays in Anglo-American Legal History, vol. 1, Boston, 1907, s. 293. 
cyzje zapadajace w sadach prawa handlowego działajacych w różnych krajach mogły się od siebie różnić, jednak było to następstwo dopuszczalności specyficznego stylus curiae, analogicznego do istniejącego niegdyś w sądach kościelnych. Proces właczenia prawa handlowego w sferę działalności sąów common law następował stopniowo począwszy od XVI wieku ${ }^{132}$. Ostatecznie zakończył się w XVIII w., m.in. na skutek działalności Lorda Mansfield ${ }^{133}$.

Drugim z sądów na wskroś cywilistycznych był Sąd Rycerski, oficjalnie nazywany Sądem Wysokiego Lorda Konstabla i Hrabiego Marszałka ${ }^{134}$. W zakresie jurysdykcji tego trybunału znajdowało się poczatkowo szereg spraw wojskowych (zdrada, jeńcy wojenni itp.), jak również sprawy z zakresu heraldyki. $Z$ czasem, na skutek ingerencji monarchów, to ostatnie zagadnienie zaczęło coraz wyraźniej dominować ${ }^{135}$. Wykorzystanie prawa rzymskiego w Sądzie Rycerskim, podobnie jak w Sądzie Admiralicji, dotyczyło przede wszystkim sfery procesowej.

Co ciekawe, mimo zniesienia innych sądów specjalnych, Sąd Rycerski oficjalnie nigdy nie został usunięty ze struktur angielskiego wymiaru sprawiedliwości. Funkcjonuje on, przynajmniej formalnie, nadal. Po raz ostatni jego posiedzenie, po niemalże dwustu dwudziestu latach przerwy, odbyło

${ }^{132}$ Ibidem, s. 327.

133 Zob. m.in. J.H. Baker, The Law Merchant and the Common Law Before 1700, CLJ 38 (1979), s. 297. O znaczeniu Lorda Mansfield dla kształtowania się angielskiego prawa handlowego świadczy fakt, iż jemu współcześni określali go jako founder of the commercial law of this country. Po raz pierwszy nazwał go w ten sposób sędzia Francis Buller w orzeczeniu w sprawie Lickbarrow v. Mason (1787) 2 T.R. 63; 100 Eng. Rep. 35.

${ }^{134}$ Najobszerniejsza jak dotychczas praca poświęcona temu sądowi jest praca G.D. Squibba, The High Court of Chivalry. A Study of the Civil Law in England, Oxford 1959.

${ }^{135}$ J.H. Baker, An Introduction..., s. 122-123. Zdaniem G.D. Squibba zasadnicza funkcją Sadu Rycerskiego, w początkowym okresie jego istnienia, było rozpatrywanie wszelkich spraw, które dotyczyły wojska, a nie mogły być rozpatrywane przez sady common law, por. G.D. Squibb, The High Court..., s. xxvi, 138-161. 
się w roku 1954, gdy orzekał w sprawie Manchester Corporation $v$. Manchester Palace of Varietes Ltd. ${ }^{136}$

Trzecim ważnym rodzajem sądów, w których prawo rzymskie było wykorzystywane jako podstawa orzekania, były sądy uniwersyteckie ${ }^{137}$. Ich ustanowienie datować należy już na okres średniowiecza, kiedy angielscy monarchowie przyznawali uniwersytetom w Oxfordzie i w Cambridge przywileje sadowe zezwalajace na samodzielne rozpatrywanie wszystkich spraw dotyczacych członków społeczności akademickiej, bez odwoływania się do sądownictwa powszechnego. Ostateczne uznanie wcześniejszych przywilejów nastąpiło w drodze ustawy wydanej przez parlament w roku $1571^{138}$.

Wedle tych postanowień sady uniwersyteckie miały prawo orzekać we wszystkich prawie sprawach (jurysdykcję ograniczono jedynie w przypadku niektórych spraw karnych), które dotyczyły samego Uniwersytetu, jak i miasta i jego przedmieść ${ }^{139}$. Co ciekawe, jurysdykcja sądów uniwersyteckich rozciagnięta została także na duchownych ${ }^{140}$. W Cambridge istniały dwa sady - jeden do spraw karnych (Vice-Chancellor's Court), drugi do spraw cywilnych (Commissary's Court). W podobny sposób zorganizowane było sądownictwo uniwersyteckie w Oxfordzie ${ }^{141}$. Sądy działające przy obu angielskich

${ }^{136}$ Manchester Corporation v. Manchester Palace of Varieties Ltd. [1955], 2 W.L.R. 440; na temat tej sprawy zob. G.D. Squibb, The High Court..., s. 123-127.

${ }^{137}$ Praktyka taka znana był w wielu innych krajach. W Polsce podobne przywileje posiadali akademicy i żacy Akademii Krakowskiej, zob. J. Sondel, Sadownictwo nad scholarami Akademii Krakowskiej, [w:] D. Janicka, R. Łaszewska (red.), Historia Integra. Ksiega pamiatkowa ofiarowana Prof. Stanisławowi Salmonowiczowi $w$ siedemdziesięciolecie urodzin, Torun 2001, s. 255, 258, 259-261.

${ }_{138}$ A. Shepard, Legal Learning and the Cambridge University Courts, c. 1560-1640, JLH 19/1 (1998), s. 63-64.

${ }^{139}$ R. O'Day, The Professions in Early Modern England, 1450-1800. Servants of the Commonwealth, Harlow 2000, s. 159.

${ }^{140}$ A.B. Cobban, The Medieval Universities. Their Development and Organization, London-Chatham 1975, s. 104.

${ }^{141} \mathrm{Na}$ jego temat zob. w szczególności M.B. Hackett, The University as a Corporate Body, [w:] HUO, vol. 1, Oxford 1984, s. 76-81; M. Underwood, 
uczelniach odgrywały bardzo ważną rolę w kształtowaniu doświadczenia zawodowego przyszłych cywilistów. Wielokrotnie od występowania przed nimi swoje kariery prawnicze rozpoczynali późniejsi znani adwokaci i sędziowie sądów kościelnych, admiralicji, a nawet Sądu Kanclerskiego ${ }^{142}$.

Warto odnotować, iż znaczna część praktycznych informacji dotyczących działalności sądów, w których stosowane było prawo rzymskie, zachowana została w pismach (często niepublikowanych) angielskich cywilistów. Szczególnie pomocne przy analizie ich funkcjonowania sa tzw. Notebooks prywatne zbiory orzecznictwa będace krótkimi opisami spraw sądowych sporządzonymi przez prawników obserwujących toczace się postępowania ${ }^{143}$.

Omawiając wpływ prawa rzymskiego na prawo angielskie, w szczególności jego sądownictwo, nie można zapomnieć o specyficznym dla tradycji angielskiej systemie equity i kierującym nim od czasów średniowiecza Sądzie Kanclerskim.

Wraz z końcem panowania Edwarda I administracja sadowa common law w zasadzie przestała się rozwijać. Stosunkowo szybko okazało się jednak, iż obowiąujacy model stosowania prawa przestał być skuteczny. W ten sposób zrodziło się zapotrzebowanie na powstanie elastycznego systemu prawnego, który uzupełnić miałby braki common law. W efekcie obok common law powstał system zwany equity. Zrodził się on dzięki sądowniczym uprawnieniom Lorda Kanclerza, które $z$ czasem przeniesione zostały na tzw. Sąd Kanclerski ${ }^{144}$.

The structure and operation of the Oxford Chancellor's court, from the sixteenth to the early eighteenth century, Journal of the Society of Archivists 6 (1978), s. 18-27.

${ }^{142}$ R. O'Day, The Professions..., s. 160.

${ }_{143}$ Por. przede wszystkim R.H. Helmholz, Three Civilian Notebooks 1580-1640, SS 127, London 2010, a także: M.E. Nys, Les Manuscrits de Sir Julius Caesar, Revue de droit international et de légistlation comparée 19 (1887), s. 461-471; K.R. Simmonds, The Gentili Manuscripts, Zeitschrift der Savigny-Stiftung für Rechtsgeschichte, Die Romanistische Abteilung 76 (1959), s. 545-550.

${ }^{144} \mathrm{O}$ genezie sadownictwa equity zob. S.F.C. Milsom, Historical Foundations..., s. 82-96; J.H. Baker, An Introduction..., s. 97-103. 
Specyfika nowego systemu prawnego polegała na tym, iż nie działał on „zamiast”, lecz „równolegle” do common law, uzupełniając je tam, gdzie archaiczne procedury uniemożliwiały osiagnięcie słusznego celu. Przyczyny powstania equity wyraźnie koresponduja z celami, dla jakich w czasach rzymskiej republiki wykształcił się system prawa pretorskiego ${ }^{145}$. W obu przypadkach pierwszoplanowa rolę odegrała potrzeba zniwelowania niedoskonałości skostniałych systemów prawnych. Trudno jednak przypuszczać, aby odwołanie się przez prawników angielskich do pojęcia equity można było łączyć z rzymska aequitas. Wyraźnie dostrzega się jednak podobieństwo w sferze przyjętej metody rozwiązania problemu.

Nie bez znaczenia pozostaje jednak fakt, iż niemal wszyscy kanclerze sprzed reformacji byli duchownymi znającymi prawo rzymskie i kanoniczne. W tym sensie zatem prawo rzymskie mogło następczo wpłynać na system equity i związane $z$ nim doktryny. Uwage na to zwraca P. Stein, który w wiedzy o prawie rzymskim i o toczących się na jego temat dyskusjach naukowych ${ }^{146}$ upatruje na przykład przyczynę ukształtowania zasad zarzadu majątkiem stanowiacym przedmiot

${ }^{145} \mathrm{Na}$ podobieństwo to zwrócili uwage m.in. W. Kunkel w swej książce Römische Rechtsgeschichte, Weimar 1964, s. 91; W.W. Buckland, Praetor and Chancellor, TLR 13 (1939), s. 176-177; P. Stein, Logic and Experience in Roman and Common Law, Boston University Law Review 59 (1979), s. 438-441 oraz K. Baran, Past performance jako reminiscencja aequitas w prawie angielskim, [w:] W. Uruszczak, P. Swięcicka, A. Kremer (red.), Leges sapere. Studia i prace dedykowane Profesorowi Januszowi Sondlowi w pięćdziesiata rocznice pracy naukowej, Kraków 2008, s. 103. Zob. również Ł. Marzec, Kilka uwag o Sadzie kanclerskim i systemie Equity $w$ Anglii, ZP UKSW 5/ 1 (2005), s. 199-200. Bardziej sceptycznie na ten temat wypowiada się D. Pugsley, On the Style of Paul's and Ulpian's Commentaries on the Edict, Acta Juridica 1973, s. 193.

${ }^{146}$ T.E. Scrutton, za H. Mainem stwierdza, iż pierwsi kanclerze odwoływali się do prawa kanonicznego, następne pokolenia kanclerzy skupiały się bezpośrednio na dorobku prawa rzymskiego, zaś kanclerze osiemnastowieczni odwoływali się do tradycji prawa rzymsko-holenderskiego, zob. T.E. Scrutton, The Influence..., s. 155-156. 
trustu ${ }^{147}$. Wplywy te przetrwały okres reformacji i istotnie wpłynęły na funkcjonowanie equity, aż do zniesienia Sądu Kanclerskiego w roku $1876^{148}$.

\subsection{Recepcja prawa rzymskiego w Szkocji (XVI-XVIII w.)}

Podobnie jak w Anglii, także w Szkocji koniec średniowiecza przyniósł znaczące zmiany kulturowe, w tym w sferze obowiązywania prawa. Duża rolę w tym procesie odgrywały przemiany okresu reformacji. Zerwanie kontaktów $z$ papiestwem oznaczało rozbrat między prawem powszechnym a prawem kanonicznym. Już jednak przykład Anglii pokazał, że zupełne odrzucenie stosowania reguł prawa kanonicznego w praktyce nie było możliwe.

Prawo rzymskie w Szkocji w XVI w., mimo swego okrzepnięcia, nadal stanowiło swoisty dodatek do systemu prawa krajowego. Jeśli było gdzieś wykorzystywane, to zazwyczaj czyniono to za pośrednictwem prawa kanonicznego. Wraz $z$ upływem czasu odwołania do utriusque iuris stawały się coraz częstsze, lecz nie miały charakteru systemowego. Wiązało się to m.in. $z$ brakiem zorganizowanej jurysdykcji, podobnej do mających kilkusetletnią tradycję angielskich sądów królewskich. Poważne znaczenie dla późniejszych losów prawa szkockiego miało zatem powołanie w roku 1532 tzw. College of Justice - organu skupiajacego wybitnych szkockich sedziów, działającego jako są najwyższy orzekający w sprawach prywatnoprawnych określany mianem Court of Session. Opierając się na dotychczasowej tradycji, wydający swe wyroki sędziowie (początkowo siedmiu duchownych, siedmiu swieckich oraz przewodniczacy im Lord Kanclerz Szkocji) od-

${ }^{147}$ P. Stein, Roman Law..., s. 88. Zob. także na ten temat W.W. Buckland, A.D. McNair, Roman Law and Common Law, rev. F.H. Lawson, Cambridge 1952, s. 177.

148 J.H. Baker, An Introduction..., s. 110-111. 
woływali się do prawa rzymskiego i kanonicznego ${ }^{149}$. Nowa wartością, która wprowadził College of Justice, było usystematyzowanie wydawanych wyroków i zapoczątkowanie linii orzeczniczej, której brakowało w poprzednich wiekach ${ }^{150}$. Podobnie jak wcześniej w Anglii, tak i w XVI wieku w Szkocji, w związku ze zmianami w sferze sądownictwa, doszło do gwałtownego rozwoju nowej literatury prawniczej zawierającej opisy postępowań sądowych (tzw. practicks) ${ }^{151}$. To na ich podstawie możliwe jest stwierdzenie rosnacej znajomości i wykorzystania autorytetu prawa rzymskiego przez szkockich sędziów. W XVI w. utrwaliła się ostatecznie zasada, zgodnie $z$ która prawo rzymskie stosowano w tych przypadkach, gdy szkockie źródła nie dostarczały, satysfakcjonujących strony i sędziów, rozwiązań prawnych ${ }^{152}$.

Sprawozdania sadowe nigdy nie stanowiły jednak pełnowartościowego źródła poznania prawa. Przedstawiały one fakty i argumenty, jednak nie dostarczały ostatecznych odpowiedzi na pytania dotyczace istoty systemu prawa - dopiero analiza wielu następujących po sobie sprawozdań dawała możliwość ustalenia treści konkretnej reguły prawa. Literatura, która uzupełniała luki tego rodzaju, pojawiła się w Szkocji dopiero w połowie XVII w. - stulecie później aniże-

${ }^{149} \mathrm{Na}$ temat procedury stosowanej w Court of Session zob. A.M. Godfrey, Ius Commune, Practick and Civil Procedure in the Sixteenth-Century Court of Session, TR 72 (2004), s. 283-295.

${ }^{150} \mathrm{Na}$ temat powstania College of Justice zob. A.M. Godfrey, Civil Justice in Renaissance Scotland. The Origins of a Central Court, Leiden 2009, s. 94-160. W zakresie odwołań do prawa rzymskiego zob. także W.M. Gordon, Roman Law in Scotland..., s. 24-25.

${ }^{151}$ Najstarsze przykłady sporządzania takich sprawozdań pochodza z XV w., jednak większość $z$ nich nie zachowała się do czasów współczesnych. Niemniej wykorzystane zostały one przez późniejszych (XVI- i XVIIwiecznych) autorów, zob. Lord Cooper, The Dark..., s. 10-11; W.M. Gordon, The Acts of the Scottish Lord of Council in the Late Fifteenth and Early Sixteenth Centuries: Records and Reports, [w:] Ch. Stebbings (ed.), Law Reporting in Britain. Proceedings of the Eleventh British Legal History Conference, London-Rio Grande, OH 1995, s. 55-71.

${ }^{152}$ W.M. Gordon, Roman Law in Scotland..., s. 26. 
li na południu Wyspy. Autorem, który zapoczatkował rozwój szkockiego piśmiennictwa prawniczego, był Thomas Craig (1538-1608), z pochodzenia edynburski mieszczanin, $z$ wykształcenia prawnik i poeta. Około roku 1606 ukończył on pisanie swego największego dzieła, zatytułowanego Jus Feudale, które wydrukowane zostało po raz pierwszy pięćdziesiąt lat później ${ }^{153}$. Praca poświęcona była przede wszystkim problematyce feudalnej własności nieruchomości. Szkot - idąc za wzorem autorów średniowiecznych - oparł swój wywód na schemacie zapożyczonym $z$ prawa rzymskiego i kanonicznego ${ }^{154}$, które, jak się wydaje, nie były mu obce. Thomas Craig odbył bowiem studia w St Andrews, a następnie przez pewien czas przebywał w Paryżu uczęszczając na tamtejszy uniwersytet $^{155}$. Lektura pracy Szkota pozwala stwierdzić, iż znał on dobrze ius commune i posługiwał się nim w ten sam sposób jak współcześni mu sędziowie oraz inni autorzy z Anglii i $z$ kontynentu ${ }^{156}$, których prace były zreszta dla Th. Craiga częstym źródłem inspiracji ${ }^{157}$.

Kolejnym szkockim autorem, który jeszcze wyraźniej powiąał szkocką i rzymska myśl prawna, był działający pod koniec XVII w. James Darlymple, Pierwszy Viscount Stair ${ }^{158}$. Do historii prawa szkockiego Lord Stair przeszedł jako pierwszy instytucjonalista ${ }^{159}$ - twórca naukowego opracowania ca-

${ }^{153}$ A.J.G. Mackay, Craig, Thomas, [w:] DNB, vol. 4, s. 1373-1376.

${ }^{154} \mathrm{~W}$ średniowieczu opierając się na doświadczeniach prawa rzymskiego i kanonicznego, prawnicy włoscy sporządzili synteze prawa feudalnego (Libri feudorum), która z czasem zaczęła być dołączana do wydań kodyfikacji justyniańskiej, zob. P. Stein, Roman Law in European..., s. 61-62.

${ }^{155}$ Por. jednak J.W. Cairns, The Breve Testamentum and Craig's Jus Feudale, TR 56 (1988), s. 316.

${ }^{156}$ W.M. Gordon, Roman Law in Scotland..., s. 27-29.

${ }^{157} \mathrm{Na}$ ich temat zob. J.W. Cairns, 'Ius civile' in Scotland, ca. 1600, Roman Legal Tradition 2 (2004), s. 150-158.

${ }^{158} \mathrm{Na}$ temat Lorda Stair zob. na przykład D.M. Walker, Viscount Stair, Denning Law Journal 6 (1991), s. 143-156.

$159 \mathrm{O}$ sposobie rozumienia pojęcia instytucjonaliści zob. J.W. Cairns, Institutional Writings in Scotland Reconsidered, [w:] A. Kiralfy, H.L. Mac- 
łego prawa szkockiego zatytułowanego The Institutions of the Laws of Scotland, wydanego w Edynburgu w roku 1681.

Postawa Lorda Stair względem prawa rzymskiego sprawia wrażenie niejednoznacznej. $Z$ jednej strony negował on wykorzystywanie prawa rzymskiego jako pomocniczego źródła prawa szkockiego, $z$ drugiej zaś wielokrotnie przywoływał w swym traktacie rzymskie rozstrzygnięcia. W jego pracy można zatem dostrzec zachowanie typowego naturalisty, negujacego $z$ jednej strony rzymskie rozwiązania prawne na rzecz rozwiązań prawa natury, $z$ drugiej zaś czerpiącego ze źródeł starożytnych w celu lepszego uargumentowania swych twierdzeń. Była to częsta postawa wielu autorów omawianego okresu $^{160}$. Lord Stair korzystał $z$ dorobku prawa rzymskiego, mimo iż nie zawsze zgadzał się $z$ jego konkretnymi rozwiąaniami. William M. Gordon wskazał, że ten siedemnastowieczny prawnik przede wszystkim powoływał się na rzymskie konstrukcje prawne w rozdziałach swej pracy poświęconych własności, zobowiąaniom oraz ogólnym zagadnieniom dziedziczenia testamentowego ${ }^{161}$. Znaczaca część wiedzy, jaka dysponował Lord Stair, pochodziła z lektury dzieł najwybitniejszych autorów kontynentalnych. Wśród tych, których wpływ na Szkota można jednoznacznie stwierdzić, wymienić trzeba Hugo Grocjusza ${ }^{162}$, Samuela von Pufendorfa ${ }^{163}$ oraz Luisa de Molinęe ${ }^{164}$.

Queen (eds.), New Perspectives in Scottish Legal History, London 1984, s. $76-117$.

${ }^{160} \mathrm{Na}$ temat relacji prawa rzymskiego i prawa natury zob. P. Stein, Roman Law in European..., s. 94-96.

${ }^{161}$ W.M. Gordon, Roman Law in Scotland..., s. 29-30.

162 A.L.M. Wilson, Stair and the Inleydinge of Grotius, ELR 14 (2010), s. 259-268.

${ }^{163} \mathrm{~W}$ samym tekście brak jednoznacznych wskazań dotyczących wykorzystania prac S. von Pufendorfa, jednak pośrednie poszlaki uprawdopodabniaja znajomość dzieł Niemca, zob. T. Richter, Did Stair Know Pufendorf?, ELR 7 (2003), s. 367-378.

${ }^{164}$ A. Rodger, Molina, Stair and the Jus Quaesitum Tertio, JR 1969, s. 35-44 i 128-151. 
Traktat przygotowany przez Lorda Stair nie bez powodu uznawany jest za wybitne osiagnięcie szkockiej myśli prawniczej. $Z$ jednej strony jego znaczenie porównać można do autorytetu Glanvilla w średniowiecznej Anglii, Lord Stair dokonał bowiem $\mathrm{w}$ zasadzie pierwszego opracowania prawa szkockiego na tego rodzaju skalę. Stworzył system, którego dotychczas w Szkocji brakowało. Z drugiej zaś strony dzieło Lorda Stair pod względem postępowości wydaje się być porównywalne $z$ pochodzącym $z$ XVIII w. opracowaniem prawa angielskiego dokonanym przez Williama Blackstone'a, który unowocześnił dawne feudalne prawo angielskie i zapoczatkował badania nad nim ${ }^{165}$. W ten sposób Lord Stair nie tylko dał pierwszy wykład całego systemu prawa szkockiego, lecz jednocześnie wyprowadził je $z$ epoki średniowiecza i włożył w nowoczesne ramy zapożyczone $z$ tradycji ius commune. Praca szkockiego prawnika miała potwierdzić indywidualność systemu krajowego i posłużyć do jego oceny i interpretacji przy wykorzystaniu klasycznych terminów prawa rzymskiego i kanonicznego ${ }^{166}$.

Zaledwie trzy lata po wydaniu pierwszej wersji Instytucji Lorda Stair, także w Edynburgu opublikowana została inna praca poświęcona systemowi prawa szkockiego, której autorem był Sir George Mackenzie. Podążała ona za wzorem wyznaczonym już przez Lorda Stair, a nawet pogłębiała go w zakresie wykorzystania prawa rzymskiego ${ }^{167}$, choć oczywiście autor nie poprzestał jedynie na przywołaniach rzymskich źródeł prawa. Podobnie jak Lord Stair oraz późniejsi szkoccy instytucjonaliści, także G. Mackenzie przedstawił swoje rozważania w perspektywie kontynentalnej myśli prawa natury ${ }^{168}$. Jednocześ-

${ }^{165}$ W.M. Gordon, Roman Law in Scotland..., s. 51-52. Na temat feudalności szkockiego prawa zob. Lord Cooper, The Dark..., s. 14.

${ }^{166}$ Por. P. Stein, Roman Law in European..., s. 83-85.

${ }_{167}$ W.M. Gordon, Roman Law in Scotland..., s. 30.

168 Por. np. rozważania A. Watsona (Some Notes on Mackenzie's 'Institutions' and the European Legal Tradition, Ius Commune 16 (1989), s. 303-313) na temat podobieństwa wypowiedzi dotyczacych prawa natury autorstwa G. Mackenziego i J. Voeta. 
nie jako opracowanie zwięźlejsze, nowa praca szybko zyskała popularność i zaczęła być wykorzystywana jako podręcznik prawa szkockiego stosowany przez studentów szkockich uniwersytetów. W ten sposób z pracy G. Mackenziego korzystano do końca lat pięćdziesiątych XVIII stulecia ${ }^{169}$.

Jeszcze szersze zastosowanie tradycji ius commune dostrzec można w pracach, które zaczęły powstawać w Szkocji w połowie XVIII stulecia. Dwoma autorami, których dzieła odcisnęły szczególne piętno na późniejszej literaturze prawniczej oraz wykorzystywane były w sadach szkockich, byli Andrew McDouall - znany lepiej jako Lord Bankton, oraz John Erskine.

Lord Bankton ${ }^{170}$ oparł swój wykład prawa szkockiego na wzorcu zaproponowanym w XVII w. przez Lorda Stair, z tym że poddał go modyfikacji. Co ciekawe, osiemnastowieczny autor zdecydował się na wyraźniejsze nawiązanie do konstrukcji Instytucji justyniańskich, od struktury których Lord Stair celowo odstapił ${ }^{171}$. Tak zaproponowany sposób pisania o prawie szkockim został przejęty następnie przez drugiego ze wspomnianych prawników - Johna Erskine'a ${ }^{172}$. W roku 1754 - jako profesor prawa szkockiego na uniwersytecie w Edynburgu - wydał on pracę zatytułowana Principles of the Law of Scotland, której zasadniczym zadaniem było zastapienie przestarzałego podręcznika G. Mackenziego. Pośmiertnie (w roku 1773) wydane zostało jego drugie dzieło (An Institute of the Law of Scotland), które w znacznym stopniu zastapiło opracowanie Lorda Stair. Zdaniem W.M. Gordona sposób traktowania prawa rzymskiego przez J. Erskine’a różnił się od sposobu, w jaki odnosili się do niego siedemnastowieczni prawnicy. Z jednej strony bowiem J. Erskine nie stronił od czę-

${ }^{169}$ W.M. Gordon, Roman Law in Scotland..., s. 31; J.W. Cairns, Rhetoric, Language, and Roman Law: Legal Education and Improvement in Eighteenth-Century Scotland, LHR 9 (1991), s. 33.

170 J.A. Hamilton, MacDowall, Andrew, Lord Bankton, [w:] DNB, vol. 12 , s. 508.

${ }^{171}$ W.M. Gordon, Roman Law in Scotland..., s. 33.

${ }^{172}$ F. Watt, Erskine, John, [w:] DNB, vol. 6, s. 849-850. 
stego i bezpośredniego przywoływania rzymskich konstrukcji, $z$ drugiej jednak bardzo często nie wpływały one na ostateczny kształt przedstawianych przez niego stanowisk ${ }^{173}$. Prawo rzymskie traktowane było zatem przez J. Erskine’a w kategoriach prawnoporównawczych, jako jedno $z$ narzędzi prowadzonych przez niego badań.

Wraz z opublikowaniem prac J. Erskine'a zakończył się dynamiczny rozwój szkockiego prawa prywatnego, u podstaw którego leżała refleksja nad tradycją romanistyczna.. Wprawdzie nigdy nie stwierdzono oficjalnie, iż rozwiąania prawne odziedziczone po starożytnych stanowić miały w Szkocji ius subsidiarium, to w praktyce $\mathrm{w}$ ten sposób były one traktowane. Uwage zwraca fakt, iż akceptacja takiej roli prawa rzymskiego, prowadzaca de facto do nieformalnej recepcji, nastapiła w okresie następującym po zawarciu angielsko-szkockiej unii realnej u poczatku XVIII stulecia. Wyraźny wpływ prawa angielskiego na prawo szkockie dostrzec można dopiero kilkadziesiąt lat po zawarciu unii, najpełniej zaś w XIX w., m.in. przy okazji lektury prac George'a Josepha Bella ${ }^{174}$.

Przedstawiony powyżej rozwój szkockiej literatury prawniczej immanentnie związany był $z$ działalnościa tamtejszych uniwersytetów. Do trzech powstałych jeszcze w XV w., w roku 1583 na mocy królewskiego nadania dołączył czwarty - Uniwersytet Edynburski. Wprawdzie we wszystkich istniejacych wówczas szkockich uczelniach pracowali wykładowcy prawa rzymskiego i kanonicznego (byli to jednak tutorzy, nie zaś profesorowie posiadajacy własne katedry), to jednak ich rola w kształtowaniu się narodowej świadomości prawnej była niewielka. Umniejszenie znaczenia rodzimych wykładowców związane było zreszta $z$ uprzedzeniami, jakie żywili do nich członkowie sprawnie już wówczas działającej korporacji adwokatów $^{175}$. Niemniej to właśnie oni w XVII w. zainicjowali

${ }^{173}$ W.M. Gordon, Roman Law in Scotland..., s. 32-33.

174 J. MacMullen Rigg, Bell, George Joseph, [w:] DNB, vol. 2, s. 158-159.

175 J.W. Cairns, H.L. MacQueen, Learning and Law. A Short History of the Edinburgh Law School, Edinburgh 2013 (www.law.ed.ac.uk/history/ [ostatnia wizyta 02.03.2016]). 
proces, który z czasem spowodował rozkwit studiów prawniczych przede wszystkim w dwóch ośrodkach - Glasgow oraz Edynburgu ${ }^{176}$. Zmiana ta podyktowana była przyczynami natury ekonomicznej, powszechne było bowiem posiadanie przez członków szkockiej korporacji prawniczej wykształcenia wyższego. Dotychczas jednak większość adwokatów kończyła studia na uczelniach kontynentalnych, co wiązało się z ponoszeniem wysokich kosztów, a przez to utrudniało zdobywanie wymaganych kwalifikacji.

Warto zwrócić uwagę, iż model uniwersyteckiego kształcenia prawników zapożyczony został $z$ uczelni kontynentalnych. Obok prawa rzymskiego nauczane było także prawo krajowe - początkowo przez prywatnych tutorów, następnie zaś przez specjalnie powoływanych do tego celu profesorów. W roku 1707 ustanowiono na Uniwersytecie w Edynburgu pierwszą katedrę prawnicza - Królewską Katedrę Prawa Publicznego oraz Prawa Natury i Narodów, zaś w roku 1710 - Katedrę Prawa Rzymskiego ${ }^{177}$. Kilka lat później, w roku 1714, w Glasgow, na mocy decyzji królowej Anny, powołana została z kolei Królewska Katedra Prawa Rzymskiego ${ }^{178}$.

Dalsze dziesięciolecia przyniosły intensyfikację działalności szkockich uniwersytetów - dostrzegalną zarówno w związku $z$ rosnacca liczbą katedr prawniczych (do roku 1722 w Edynburgu były ich już cztery $^{179}$ ), jak i studentów, którzy decydowali się na podjęcie studiów. Obserwowany wzrost liczby publikowanych w Szkocji w XVIII i XIX wieku prac naukowych dotyczacych prawa stanowił bezpośrednie następstwo procesów zachodzących na uniwersytetach.

${ }^{176}$ Por. J.W. Cairns, Rhetoric, Language, and Roman Law..., s. 32.

${ }^{177} \mathrm{Na}$ temat pierwszych katedr w Edynburgu zob. J.W. Cairns, H.L. MacQueen, Learning..., (www.law.ed.ac.uk/history/).

${ }^{178} \mathrm{O}$ genezie Królewskiej Katedry w Glasgow zob. J.W. Cairns, The Origins of the Glasgow Law School: The Professors of Civil Law, 1714-61, [w:] P. Birks (ed.), The Life of the Law. Proceedings of the Tenth British Legal History Conference, Oxford 1991, London-Rio Grande, OH 1993, s. 152-183.

179 J.W. Cairns, H.L. MacQueen, Learning... (www.law.ed.ac.uk/history/). 
Wspomniani wcześniej J. Erskine czy G.J. Bell byli prawnikami-naukowcami ${ }^{180}$. Wyraźnie kontrastuje to ze schematem myślenia o prawie i jego nauczaniu w Anglii, gdzie profesjonalna literatura prawnicza - pisana przez naukowców, nie zaś praktyków - pojawiła się dopiero w drugiej połowie XIX w.

Trzecim „filarem” szkockiego zainteresowania prawem rzymskim była tamtejsza adwokatura ${ }^{181}$. W znacznym stopniu to jej przedstawiciele przyczynili się do utrwalenia potrzeby studiowania prawa rzymskiego. Wśród wymagań, jakie korporacja stawiała kandydatom chcacym wstapic w jej szeregi, przynajmniej od XVII w., wymieniano obowiązek odbycia studiów wyższych, który stopniowo przeradzał się w wymóg ukończenia konkretnych studiów - z zakresu prawa rzymskiego $^{182}$. Na zakończenie szkolenia każdy kandydat ubiegający się o tytuł adwokata musiał wygłosić w języku łacińskim referat poświęcony wybranemu zagadnieniu odnoszacemu się do problematyki prawa starożytnych Rzymian (tzw. cramp speech) ${ }^{183}$.

${ }^{180}$ Tendencje do łączenia praktyki oraz nauki prawa uwidaczniaja dziś zachowane zbiory prywatnych bibliotek znanych prawników, zob. T. Miller, Judge-Admiral James Graham of Airth (1702-1746) with Special Reference to His Civil Law Library, JR 49 (1937), s. 390-413, w szczeg. 410-412; czy K. Baston, Charles Areskine's Library. Lawyers and Their Books at the Dawn of the Scottish Enlightenment, Leiden 2016.

${ }^{181}$ Jej początki sięgaja schyłku XV w., gdy po raz pierwszy źródła sądowe wyraźnie wspominaja udział fachowych zastępców procesowych, por. Lord Cooper, The Dark..., s. 23.

${ }^{182}$ W.M. Gordon, Roman Law in Scotland..., s. 31. O podobnych praktykach w XV i XVI w. na kontynencie wspomina także D. Ibbetson w swej pracy English Law and the European 'Ius Commune' 1450-1650, Cambridge Year Book of European Legal Studies 8 (2005-2006), s. 118.

${ }^{183} \mathrm{O}$ procedurze powoływania adwokatów zob. J.W. Cairns, Advocates' Hats, Roman Law and Admission to the Scots Bar, 1580-1812, JLH 20/2 (1999), s. 24-61. 


\subsection{Prawo rzymskie w Anglii w drugiej polowie XVIII i w XIX w.}

Połowa XVIII wieku może być uznana za punkt zwrotny $\mathrm{w}$ myśleniu o prawie angielskim. W tym bowiem okresie swa działalność prowadziło wiele osób, które dziś uważane sa za kluczowe postacie dla dalszych dziejów prawa angielskiego. Dwie $z$ nich spełniły rolę szczególna. Sa to William Blackstone i William Murray - znany lepiej jako Lord Mansfield. Działalność tego pierwszego zainicjowała proces profesjonalizacji nauki prawa angielskiego, działalność zaś drugiego w znacznym stopniu ukształtowała praktyczny fundament prawa współcześnie obowiązującego. Obaj prawnicy sa szczególnie ważni nie tylko ze względu na fakt, iż uważa się ich dziś za ojców nowoczesnego common law, lecz także dlatego, iż prawo rzymskie nie było im obce.

Model edukacji prawniczej, ukształtowany za rządów Tudorów i Stuartów, przetrwał $\mathrm{w}$ niezmienionej w zasadzie postaci aż do połowy XVIII w. Jedynym obowiazujacym przedmiotem prawniczym na angielskich uczelniach pozostawało prawo rzymskie wykładane przez królewskich profesorów, zaś praktyczna wiedza prawnicza zdobywana mogła być tylko w londyńskich Inns of Court. W praktyce jednak obie ścieżki edukacji prawniczej oceniane były źle. Królewscy profesorowie coraz częściej byli powoływani na swój urząd ze względów politycznych, a nie merytorycznych, co w znaczny sposób przyczyniło się do upadku autorytetu, jakim królewskie katedry się cieszyły. System stworzony w Inns of Court także przestał spełniać swoje dotychczasowe zadanie. Prawnicy praktykujacy w sądach nie mieli ochoty poświęcać swego wolnego czasu na nauczanie młodych adeptów prawa. Edukacyjne obowiązki nakładane na nich przez korporacje stanowiły ciężkie brzemię, które dodatkowo nie przynosiło oczekiwanych korzyści finansowych. Zarówno zatem osobom chcacym poznać prawo rzymskie, jak i angielskie pozostawało samokształcenie, oparte przede wszystkim na lekturze odpowiednich dzieł prawniczych. 
Reakcja na niedostatki obowiazującego modelu nauczania prawników był ruch zmierzający do nadania nauce prawa krajowego rangi dyscypliny akademickiej. Pierwsze próby nauczania prawa angielskiego podejmowano wprawdzie w Oxfordzie już na przełomie XVII i XVIII w., lecz ich oddźwięk był niewielki ${ }^{184}$. Nowoczesne metody dyskursu prawniczego pragnął zainicjować następnie Charles Viner, który wydał wielotomowe dzieło zatytułowane A General Abridgment of Law and Equity, Alphabetically Digested under Proper Titles, With Notes and References to the Whole ${ }^{185}$. Miało ono na celu systematyzację wiedzy dotyczącej ówczesnego prawa angielskiego. Wprawdzie sam $\mathrm{Ch}$. Viner nigdy nie zajmował się nauczaniem prawa, jednak właśnie $z$ jego fundacji powstała pierwsza katedra prawa angielskiego, która w roku 1758 objął William Blackstone ${ }^{186}$. Powierzenie katedry właśnie temu prawnikowi wiązało się $z$ faktem, iż już od roku 1753 nauczał on prawa angielskiego w Oxfordzie. Jego wykłady nie tylko cieszyły się duża popularnościa, ale bardzo szybko okazały się być płaszczyzna dyskusji naukowej, która $z$ czasem wprowadziła prawo angielskie w sfere nowoczesnej nauki prawa ${ }^{187}$. Wydane przez W. Blackstone'a w latach 1765-1769 Commentaries on the Laws of England, stanowiące zapis jego wcześniejszych wykładów, były pierwsza od czasów średniowiecza udana próbą systematycznego wyłożenia całej materii common law.

Co jednak ciekawe, praca W. Blackstone'a, choć pomyślana była jako wykład prawa krajowego, wyraźnie wpisywała się także w trendy myślowe współczesnych doktryn prawno-politycznych. Ponadto W. Blackstone, mimo swego typowo angielskiego podejścia do zagadnień rozwoju prawa

${ }^{184}$ R.B. Robinson, The Two Institutes..., s. 433.

${ }^{185}$ Dzieło wydane zostało po raz pierwszy w latach 1741-1753.

${ }^{186} \mathrm{Na}$ temat powstania katedry i kulisów powierzenia jej W. Blackstone'owi zob. H.G. Hanbury, The Vinerian..., s. 11-16.

${ }^{187}$ Jednym $z$ najpoważniejszych przeciwników W. Blackstone'a był J. Bentham. Więcej na temat konfliktu zob. T. Tulejski, Od zasady użyteczności do demokracji. Filozofia polityczna Jeremy Benthama, Łódź 2004, s. $110-118$. 
i dostrzegania wyższości prawa angielskiego nad innymi systemami prawnymi świata, chętnie w swych rozważaniach odwoływał się do prawa rzymskiego - jako nośnika pewnych wartości czy zasad właściwego postępowania. Najwyraźniej wpływy prawa rzymskiego dostrzec można w warstwie systematyki Komentarzy. Wykorzystany został bowiem przez W. Blackstone'a gajański podział prawa na personae - res actiones, rozbudowany dodatkowo o crimina. Była to zreszta praktyka znana w europejskim piśmiennictwie prawniczym poczawszy od XVI w., gdy włoski kanonista G.P. Lancelotti opublikował swój podręcznik zatytułowany Institutiones iuris canonici $^{188}$. Nieskrywana estyma, jaką W. Blackstone darzył prawo rzymskie, nie może dziwić, gdy weźmie się pod uwagę fakt, że angielski prawnik był doktorem prawa cywilnego, jak również w roku 1753 ubiegał się o przyznanie mu królewskiej katedry w Oxfordzie ${ }^{189}$.

Oprócz odwołań do prawa rzymskiego, W. Blackstone korzystał również $z$ bogatego dorobku kontynentalnej nauki prawa natury ${ }^{190}$. W starszej literaturze wskazywano, iż W. Blackstone w głównej mierze opierał się w toku swego wykładu na dziełach H. Grocjusza, S. von Puffendorfa oraz na pismach holenderskich i niemieckich autorów zajmujacych się prawem i moralnością ${ }^{191}$. Nowsze badania dodały do tego grona także Ch. Montesquieu oraz C. Beccarię ${ }^{192}$.

${ }^{188}$ A. Dębiński, Prawo rzymskie a systematyka prawa kanonicznego, [w:] W. Uruszczak, P. Święcicka, A. Kremer (red.), Leges Sapere. Studia $i$ prace dedykowane Profesorowi Januszowi Sondlowi w pięćdziesiata rocznice pracy naukowej, Kraków 2008, s. 139.

${ }^{189}$ Na temat wykorzystania prawa rzymskiego przezW. Blackstone'a zob. Ł.J. Korporowicz, William Blackstone a prawo rzymskie. Uwagi na temat prawa rzymskiego $w$ 'On the study of law', [w:] E. Kozerska, P. Sadowski, A. Szymański (red.), Ze studiów nad tradycja prawa, Warszawa 2012, s. $39-57$.

190 O relacji prawa rzymskiego i prawa natury w XVIII w. zob. P. Stein, Roman Law in European..., s. 94-96.

${ }^{191}$ T.E. Scrutton, The Influence..., s. 143.

192 P. Stein, Continental Influences on English Legal Thought, 16001900, [w:] idem, The Character..., s. 217-218. Zob. także N.E. Simmonds, 
Akademicka działalność W. Blackstone’a wywarła znaczący wpływ na dalszy rozwój nauczania prawa w Anglii. Wprawdzie nie da się wykazać bezpośredniego wpływu angielskiego prawnika na podniesienie rangi nauczania prawa rzymskiego w Oxfordzie i Cambridge, jednak trzeba przyznać, iż to właśnie jeden $z$ przyjaciół W. Blackstone'a - Robert Vansittart - uznawany jest za pierwszego „kompetentnego” królewskiego profesora prawa rzymskiego w Oxfordzie po ponadstuletniej przerwie $^{193}$. Zmiany zapoczatkowane w drugiej połowie XVIII w. przyniosły widoczne efekty z początkiem wieku XIX. Potwierdzaja to zapisy w tzw. University Calendars - informatorach dostarczających wiedzy o codziennej działalności uniwersytetu. W zakresie prawa rzymskiego pozwalaja one na dokonanie ciekawych obserwacji dotyczących sposobów jego nauczania. W roku $1804^{194}$ wykład $z$ prawa rzymskiego prowadzony był w Cambridge przez profesora Josepha Jowetta ${ }^{195}$. Odbywał się on w pomieszczeniach Trinity Hall od godziny 10 do godziny 11. Cały kurs trwał trzy semestry. Udział w pierwszym wykładzie nakładał na słuchaczy obowiązek wpłaty pięciu gwinei, zaś uczestnictwo w następnych wykładach było bezpłatne. W kalendarzu podana została ponadto informacja, iż decyzja uniwersyteckiego Senatu z 1768 roku nakazano, aby kandydat do stopnia doktora prawa (LL.D.) przedstawił Caput ${ }^{196}$ (ciału zarzadzającemu Uniwersytetem Cambridge przed reforma $z$ roku 1856) potwierdzenie swego uczestnictwa w pełnym kursie prawa rzymskiego trwajacym trzy semestry. Wskazano ponadto, iż obowiązujaca lektura było czwarte wydanie pracy

Reason, History, and Privilege: Blackstone's Debt to Natural Law, Zeitschrift der Savigny-Stiftung für Rechtsgeschichte, Die Germanistische Abteilung 105 (1988), s. 200-213.

${ }^{193}$ H.G. Hanbury, The Vinerian..., s. 10.

194 The Cambridge University Calendar for the year 1804, Cambridge 1804 , s. 25-26.

195 J. Willis Clark, Jowett, Joseph, [w:] DNB, vol. 10, s. 1103.

196 Caput był organem zarzadzajacym uniwersytetem, powstałym w trakcie reformy Uniwersytetu w epoce elżbietańskiej. Istniał aż do wydania przez parlament w roku 1856 ustawy reformującej ustrój Uniwersytetu. Zob. więcej. P. Searby, HUC, vol. 3, Cambridge 1997, s. 46, 53-54. 
zatytułowanej An Analysis of the Roman Civil Law autorstwa Samuela Hallifaxa ${ }^{197}$ - królewskiego profesora w Cambridge w latach 1770-1781. Autorzy kalendarza wskazali, iż w pracy tej autor dokonuje pewnych porównań prawa rzymskiego i prawa angielskiego. Wpis kończy krótka lista osiemnastowiecznych profesorów prawa rzymskiego z Cambridge. W roku 1813 królewską katedrę objął nowy profesor - James William Geldart ${ }^{198}$. Pod wpływem jego działalności wprowadzone zostały istotne zmiany w zakresie nauczania prawa rzymskiego. Nadal na potrzeby wykładu wykorzystywano podręcznik S. Halifaxa, który w roku 1836 doczekał się nowego wydania, przygotowanego właśnie przez J.W. Geldarta ${ }^{199}$. Ponadto wprowadzony został obowiązek złożenia egzaminów kończących uczestnictwo w wykładach. Kalendarze uniwersyteckie $z$ lat trzydziestych zaopatrzone zostały w dokładny opis wymagań stawianych studentom przystępujacym do egzaminu. Dzielono ich na dwie, a następnie trzy klasy w zależności od osiaganych wyników egzaminacyjnych. Wymagania wobec słuchaczy przypisanych do pierwszej klasy były zawsze nieco wyższe niż wobec słuchaczy dwóch pozostałych klas. Musieli oni znać treść całego podręcznika S. Hallifaxa, zaś pytania egzaminacyjne obejmowały jedynie wybrane uprzednio przez wykładowcę rozdziały. Pozostali studenci powinni w stopniu satysfakcjonującym znać cała pierwsza księgę An Analysis of the Roman Civil Law oraz siedem pierwszych rozdziałów księgi drugiej ${ }^{200}$. Po tych wymaganiach, w kolejnych kalen-

197 W.P. Courtney, Halifax, Samuel, [w:] DNB, vol. 8, s. 996-998.

198 G.C. Boase, Geldart, James William, [w:] DNB, vol. 7, s. 991-992.

199 Ibidem.

200 Por. The Cambridge University Calendar for the year 1833, Cambridge 1833, s. 22; The Cambridge University Calendar for the year 1837, Cambridge 1837, s. 20. Systematyka pracy S. Halifaxa, podobnie jak wcześniej W. Blackstone’a, została oparta na systematyce gajańskiej. Materiał egzaminacyjny obejmował: ksiege pierwsza zatytułowana The Rights of Person. Jej dwa pierwsze rozdziały dotyczyły zagadnień ogólnych (ch. 1: The Roman Civil Law and Canon Laws, and Their Authority in England; ch. 2: The Nature of Law in general; and the divisions and parts of Civil Law), natomiast kolejne dotyczyły już prawa osobowego w ścisłym tego 
darzach podawano nazwiska wszystkich absolwentów kursu prowadzonego przez J.W. Geldarta od roku 1815 do 1847, zaznaczając, iż niektórzy uczestnicy wykładów nie zostali dopuszczeni do zdawania stosownego egzaminu. Taka sama praktyka dotyczyła także egzaminów prowadzonych przez kolejnych profesorów prawa rzymskiego. Kalendarz z roku 1850 wykazuje, iż począwszy od wprowadzenia obowiązkowego egzaminu z prawa rzymskiego trzydzieści pięć lat wcześniej, zaliczenie uzyskało czterystu piętnastu studentów, z czego stu czterdziestu dwóch jako studenci pierwszej klasy ${ }^{201}$. Ten model egzaminowania kontynuowany był w Cambridge do roku akademickiego 1856/1857. W ciagu ośmiu lat do egzaminu przystapiło kolejnych stu sześćdziesięciu ośmiu studentów ${ }^{202}$. Poczawszy od roku 1858 wprowadzony został w Cambridge nowy system egzaminowania, zwany Tripos. Kalendarz uniwersytecki $z$ roku 1886 wskazuje, iż Law Tripos powinny obejmować: zagadnienia ogólne i porównawcze $z$ zakresu prawoznawstwa, tłumaczenie passusów pochodzących z rzymskich źródeł (,particulary from Gaius, Ulpian, Justinian, and some specified portion of the Digest"), zagadnienia dotyczace prawa rzymskiego i jego historii, angielskie prawo własności osobistej oraz własności nieruchomości, prawo karne, histo-

słowa znaczeniu (ch. 3: Of Persons in general; and of Freemen and Slaves; ch. 4: Of Citizens and Strangers; Natives and Aliens; by the Roman and English Laws; ch. 5: Of the Power of Father; ch. 6: Of Marriage; ch. 7: Of Legitimation; ch. 8: Of Adoption; ch. 9: Of Guardianship; ch. 10: Of Corporations). Księga druga zatytułowana była Of the Rights of Things i składała się $z$ dwudziestu siedmiu rozdziałów, $z$ czego materiał wymagany na egzaminie obejmował: ch. 1: Of Property in general; ch. 2: Of the Natural Modes of acquiring Property; ch. 3: Of Rights of Things Incorporeal; and of Real and Personal Services; ch. 4: Of the Persons, by whom Property might be acquired; and of the Peculium of a Son under Power; ch. 5: Of the Civil Modes of acquiring Property: And, First, of Usucapion or Prescription; and of Donation; ch. 6: Of Succession by Testament; ch. 7: Of Legacies.

${ }^{201}$ The Cambridge University Calendar for the Year 1850, Cambridge 1850, s. 112-117.

${ }^{202}$ The Cambridge University Calendar for the Year 1886, Cambridge 1886, s. 299-301. 
rię prawa i ustroju Anglii, prawo międzynarodowe publiczne. Dodatkowo wymagane było napisanie rozprawy dotyczącej jednego $z$ powyższych zagadnień. Wskazywano także, iż przewodniczacym komisji egzaminacyjnej powinien być królewski profesor prawa rzymskiego ${ }^{203}$. Zasada ta była przestrzegana bardzo skrupulatnie. Warto ponadto zwrócić uwagę, iż w komisjach oceniajacych Tripos wielokrotnie zasiadało jednocześnie kilku specjalistów zajmujących się prawem rzymskim. Na przykład w roku 1859, gdy komisji przewodniczył J.T. Abdy (królewski profesor w latach 1854-1873) ${ }^{204}$, innym jej członkiem był H.J. Roby ${ }^{205}$ - profesor prawa wykładajacy w latach 1866-1868 prawo rzymskie w Londynie ${ }^{206}$. W roku 1866 oraz 1872 w komisji oprócz J.T. Abdy'ego zasiadał E.C. Clark ${ }^{207}$, który w latach 1873-1914 sam pełnił funkcję królewskiego profesora prawa rzymskiego w Cambridge. Zaś w latach 1873 i 1876 w komisji pod przewodnictwem E.C. Clarka uczestniczył także J.T. Abdy już jako profesor emerytowany ${ }^{208}$. Do końca XIX w., mimo zmienionych przepisów (w roku 1889 zniesiono nakaz przewodniczenia komisji egzaminacyjnej przez królewskiego profesora), nadal zasiadali w niej liczni przedstawiciele nauki prawa rzymskiego. Wspomniany już E.C. Clark w latach 1889-1890 oraz 18961897 przewodniczył pracom komisji, zaś w roku 1895 był jej członkiem $^{209}$. W latach 1889-1891 oraz 1899-1900 w komisji zasiadał oxfordczyk J.B. Moyle - autor angielskiego tłu-

203 Ibidem, s. 51.

204 Th. Cooper, Men of the Time: A Dictionary of Contemporaries containing Bibliographical Notices of Eminent Characters of Both Sexes, ed. 11, London 1884, s. 3, s.v. Abdy, John Thomas.

205 R.S. Conway, Roby, Henry John, [w:] DNB 1912-1921, s. 473-475.

206 The Cambridge University Calendar for the Year 1886..., s. 301.

${ }^{207}$ Ibidem, s. 303 i 305. Na temat E.C. Clarka zob. J. Foster, Men-atthe-Bar, London-Aylesbury 1885, s. 86, s.v. Clark, Edwin Charles.

208 The Cambridge University Calendar for the Year 1886..., s. 305 i 307 .

209 The Cambridge University Calendar for the Year 1900-1901, Cambridge 1900, s. 457-458, 463-465. 
maczenia i komentarza do Instytucji Justyniana ${ }^{210}$, w latach 1891-1893 oraz 1898-1900 w pracach komisji brał udział W.W. Buckland ${ }^{211}$. W latach 1886-1888, 1893-1895 i w roku $1897 \mathrm{w}$ komisji zasiadał inny jeszcze romanista $z$ Cambridge H. Bond (w roku 1888 przewodniczył pracom komisji) ${ }^{212}$.

Inaczej niż w Cambridge potoczyły się w XIX stuleciu dzieje prawa rzymskiego w Oxfordzie. Można stwierdzić, iż przeżywało ono ponowny kryzys, podobny do tego, który miał miejsce w XVII i w pierwszej połowie XVIII stulecia. Doprowadził on ostatecznie do zamknięcia wykładu ze względu na brak chętnych do uczestnictwa w nim ${ }^{213}$. W omawianym okresie doszło jednak do pewnej istotnej zmiany w zakresie dwubiegunowego nauczania akademickiego w Anglii. Możliwość studiowania, począwszy od roku 1826, nie ograniczała się już jedynie do Cambridge i Oxfordu. Nowa uczelnia powołana została w Londynie. Poczatkowo powstały dwa kolegia - w roku 1826 University College, zaś w 1829 King's College. W roku 1836 z królewskiego nadania powstał Uniwersytet Londyński, który inkorporował dwie wcześniejsze instytucje. Prawo nauczane było w Londynie już od roku 1826, gdy w strukturach University College powołano Faculty of Arts and Laws - był to zatem pierwszy działajacy wydział prawa w Anglii ${ }^{214}$. Jego działalność w niewielkim tylko stopniu przypominała

${ }^{210}$ Ibidem, s. 456-459, 466-468. Tłumaczenie J.B. Moyle'a, The Institutes of Justinian, Oxford 1883, doczekało się łącznie pięciu wydań, ostatnie z roku 1912, oraz wielu późniejszych wznowień. Równolegle do tłumaczenia J.B. Moyle opublikował tekst oryginalny z komentarzem i specjalistycznymi wyjaśnieniami: Imperatoris Iustiniani Institutionum Libri Quattor with Introductions, Commentary and Excurses, Oxford 1883.

${ }^{211}$ The Cambridge University Calendar for the Year 1900-1901..., s. 459-461, 466-468.

${ }^{212}$ Ibidem, s. 448, 454-455, 461-463, 465. Na temat kondycji prawa rzymskiego oraz sytuacji Wydziału Prawa w Cambridge na przełomie XIX i XX w. zob. S.B. Kitchin, The Cambridge School of Law, South African Law Journal 43 (1926), s. 130-132.

${ }^{213}$ W.L. Twining, Laws, [w:] F.M.L. Thompson (ed.), The University of London and the World of Learning, 1836-1986, London 1990, s. 83 ${ }^{214}$ Ibidem. 
działalność uczelni kontynentalnych, czy dwóch „starych" uniwersytetów. Szybko ujawniły się jednak problemy finansowe oraz kadrowe zwiazane $z$ funkcjonowaniem uczelni. Założyciele University College pragnęli utworzenia trzech katedr prawniczych - katedry prawoznawstwa, prawa rzymskiego i prawa angielskiego. Plany te jednak $z$ różnych względów nie mogły być zrealizowane. Katedra prawa rzymskiego długo wakowała ${ }^{215}$. Szybko została natomiast obsadzona katedra prawoznawstwa. Profesorem tego przedmiotu (Professor of Jurisprudence) mianowano Johna Austina - bliskiego współpracownika i ucznia Jeremy'ego Benthama. Wprawdzie J. Austin był prawnikiem, jednak nigdy nie odebrał wykształcenia akademickiego. Prawa nauczył się terminujacc w Inner Temple. Zaraz zatem po swojej nominacji zdecydował się na roczny wyjazd naukowy. W latach 1826-1827 przebywał w Niemczech, gdzie w Bonn i w Heidelbergu poznawał metody badania prawa. Tam też mógł studiować prawo rzymskie, choć jednoznaczna ocena zdobytej przez J. Austina wówczas wiedzy jest trudna. Prywatnie prawo rzymskie studiował już wcześniej, bo na poczatku lat dwudziestych XIX w., gdy był nauczycielem Johna Stuarta Milla - syna swego przyjaciela, w przyszłości znanego angielskiego filozofa prawa. Zdaniem M.H. Hoeflicha, J. Austin poznawał wówczas prawo Rzymian za pośrednictwem rudymentarnej pracy Johanna Heinecciusa zatytułowanej Elementa Iuris Civilis ${ }^{216}$. Bardziej usystematyzowane studia nad prawem rzymskim angielski myśliciel podjął dopiero w czasie swego pobytu w Niemczech. Tam zetknął się z przedstawicielami dwóch zwalczających się szkół

215 Katedrę prawa rzymskiego otrzymać miał w roku 1827 Thomas Jefferson Hogg, jednak ze względów finansowych okazało się to niemożliwe. Niedoszły profesor w roku 1831 opublikował przygotowany przez siebie wykład inauguracyjny pod tytułem An introductory lecture on the study of the Civil Law, intended to have been read at the University of London, London 1831.

${ }^{216}$ M.H. Hoeflich, Roman and Civil Law and the Development of Anglo-American Jurisprudence in the Nineteenth Century, Athens-London 1997, s. 11 . 
prawniczych - szkoły prawa natury oraz szkoły historycznoprawnej $^{217}$. Niemiecka Pandektystyka wywarła duży wpływ na poglądy J. Austine'a, co można zauważyć w opublikowanych w roku 1832 jego wykładach zatytułowanych The Province of Jurisprudence Determined ${ }^{218}$. Choć praca ta poświęcona została problematyce filozofii prawa, to jednak zdecydowana jej część nawiązuje do cywilistycznej tradycji prawnejej ${ }^{219}$. Wspomnieć można na przykład o omówieniu przez J. Austina koncepcji osoby prawnej autorstwa F.C. van Savigny'ego, która dotychczas była nieznana w common law ${ }^{220}$. Także systematyka prawa przyjęta przez Anglika, choć zmodyfikowana, nawiązywała do gajańskiego trójpodziału materii prawnej. John Austin odmawiał jednak kategorii actiones samodzielnego bytu i w związku $z$ tym twierdził, iż uprawnienia (rights) dziela się na dwie kategorie - persons, w ramach których umiejscawial rights relating to persons i actions relating to persons, oraz things, w ramach których znajdowały się odpowiednio rights relating to things $\mathrm{i}$ actions relating to things ${ }^{221}$.

Do końca XIX w. Uniwersytet Londyński, mimo licznych prób zreformowania systemu kształcenia, prezentował niski poziom nauczania prawa. Wprawdzie kolejni wykładowcy zdobywali coraz większe zaufanie środowiska naukowego i uważani byli za czołowych specjalistów w swych dziedzinach, jednak chaotyczność administrowania Wydziałem Praw UCL

217 Ibidem, s. 11-12.

${ }^{218}$ Wpływy te były raczej nieuporzadkowane. $Z$ jednej strony da się zauważyć fascynację J. Austina niemieckim prawoznawstwem, $z$ drugiej jednak strony jego krytykę wielu rozwiązań zaproponowanych przez filozofów niemieckich, czy, co szczególnie znamienne, jego predylekcję do powoływania się na autorytet swego mistrza - Jeremy Benthama. Zob. więcej. W.E. Rumble, Doing Austin Justice. The Reception of John Austin's Philosophy of Law in Nineteenth-Century England, London-New York 2005, s. 17-19.

${ }^{219}$ P. Stein, Continental Influences..., s. 224.

${ }^{220}$ M.H. Hoeflich, Roman and Civil..., s. 19. Na temat zastosowania teorii osób prawnych w angielskim orzecznictwie w drugiej połowie XIX w. zob. Ł.J. Korporowicz, Spółka akcyjna..., s. 103 (tam również dalsza literatura).

${ }^{221}$ Zob. więcej M.H. Hoeflich, Roman and Civil..., s. 20-21. 
spowodowała, iż przez prawie siedemdziesiąt lat ukończyło go ze stopniem bakałarza prawa (LL.B.) jedynie stu trzydziestu pięciu studentów. Pod koniec lat sześćdziesiątych XIX w. najpopularniejszym wykładem był kurs prawa rzymskiego, na który uczęszczało dziewięciu studentów ${ }^{222}$. Samo prawo rzymskie wykładane było nadal przez profesora prawoznawstwa H.J. Roby'ego. Dopiero w roku 1869 utworzono katedrę prawa rzymskiego, którą na kolejnych dziewięć lat objął William Alexander Hunter. Ten polityk i prawnik zapisał się w dziejach angielskiej romanistyki jako autor dwóch popularnych w tym okresie prac - Roman Law in the Order of Code oraz Introduction to Roman Law. W roku 1878, gdy W.A. Hunter objął katedrę prawoznawstwa, nowym profesorem prawa rzymskiego został Edmund Robertson, który jednak już kilka lat później ustapił. W roku 1883 katedrę objął na ponad czterdzieści lat Alexander Falconer Murison ${ }^{223}$.

Druga połowa XVIII i pierwsza połowa XIX wieku stanowiły także okres burzliwych przeobrażeń w środowisku cywilistów angielskich. Oprócz tego, że common law zaczęło zyskiwać status dyscypliny akademickiej, to jednocześnie coraz głośniej zaczęto nawoływać do reform ustrojowych. Procesy te doprowadziły do podjęcia pierwszych prób reformy skostniałego angielskiego systemu sądowniczego ${ }^{224}$. Dla cywilistów oznaczało to utratę ich dotychczasowej pozycji.

Korporacja Doctors' Commons mimo wyraźnej utraty znaczenia nie podjęła w tym okresie żadnych prób zmierzających do zreformowania swych struktur. Wiazało się to chyba z utrzymującym się wśród jej członków przekonaniem o ich niezagrożonym wpływie na funkcjonowanie angielskiego sy-

${ }^{222}$ W.L. Twining, Laws, [w:] F.M.L. Thompson (ed.), The University..., s. 95-96.

${ }^{223}$ J.H. Morgan, Murison, Alexander Falconer, [w:] DNB, 1931-1940, s. 636-637.

${ }^{224}$ Ogólnie na temat podejmowanych reform zob. A.H. Manchester, Law Reform in England and Wales 1840-80, [w:] W. de Vos, W.H.B. Dean, I. Leeman (eds.), Essays in Honour of Ben Beinart, vol. 2, Cape Town-Wetton-Johannesburg 1979, s. 189-202, w szczeg. 191. 
stemu prawnego. W rzeczywistości jednak cywiliści angielscy stanowili obiekt kpin i szyderstw. Utrwalone zostały one m.in. w powieściach Charlesa Dickensa. Ich wartość dla poznania ówczesnych nastrojów towarzyszacych korporacji cywilistów jest o tyle duża, iż angielski pisarz w młodości był dziennikarzem sądowym, który dzięki koneksjom rodzinnym mógł obserwować postępowania prowadzone właśnie przez przedstawicieli Doctors' Commons ${ }^{225}$.

Upadek korporacji cywilistów łączyć należy ze stopniowym rozszerzeniem jurysdykcji sądów common law o sprawy, które dotychczas leżały jedynie w sferze jurysdykcji tzw. concilliary courts. $Z$ jednej strony proces ten wpłynał na "anglicyzację" silnie zromanizowanych gałęzi prawa angielskiego, $z$ drugiej jednak strony stał się początkiem częstszego sięgania przez angielskich sędziów do rzymskiej tradycji prawnej i wykorzystywania jej przy argumentowaniu wydawanych przez nich wyroków. Działania takie nie były może powszechne, ale na tyle częste, iż łatwo je dziś wyśledzić w pochodzących z XVIII czy z początków XIX wieku zbiorach orzecznictwa. Kluczową rolę w tym procesie odgrywał Lord Mansfield - w latach 1756-1788 Lord Chief Justice Sacu Ławy Królewskiej226. W przeciwieństwie do W. Blackstone'a, Lord Mansfield nigdy

${ }^{225}$ Zagadnienie opisu rzeczywistości prawniczej przez Ch. Dickensa oraz jego kariera dziennikarza sądowego stanowia przedmiot licznych opracowań, wśród których miejsce szczególne zajmuje książka autorstwa W.S. Holdswortha zatytułowana Charles Dickens as a Legal Historian, New Haven 1928. Negatywna opinia Ch. Dickensa na temat prawników nie ograniczała się zreszta tylko do cywilistów. W Klubie Pickwicka np. tak opisuje on kancelarie adwokackie i działalność prawników: „owe zakazane dziury sa to publiczne biura profesji prawniczej, gdzie pisze się skargi, podpisuje wyroki, wypełnia deklaracje i wprowadza w ruch wiele innych maszynerii, wymyślonych gwoli torturowania poddanych Jej Królewskiej Mości, a ku radości i pożytkowi ludzi uprawiających zawód prawniczy" (Ch. Dickens, Klub Pickwicka, t. 2, tłum. W. Górski, uzup. Z. i W. Popławscy, Warszawa 1987, s. 16).

${ }^{226}$ Więcej na temat Lorda Mansfield por. przede wszystkim rozdział pierwszy pracy J. Oldhama, English Common Law in the Age of Mansfield, Chapel Hill-London 2004, s. 3-11. 
nie zajmował się prawem w sposób naukowy, lecz cała swa działalność poświęcił praktyce prawa. Romanistyczna wiedza, jaka posiadał, stanowiła owoc jego własnych studiów, zarówno w Oxfordzie, jak i później w palestrze. Szczególną uwagę zwraca fakt, iż Lord Mansfield dysponował stosunkowo dobra, jak na prawnika-praktyka common law, wiedza na temat prawa rzymskiego. Wiedzę tę wykorzystywał także w sądzie, co zostało udokumentowane w orzeczeniach jego autorstwa, choć jednocześnie spotykało się z poważną krytyką wielu jego przeciwników ${ }^{227}$. Wzorcowym przykładem orzeczenia tego rodzaju jest uzasadnienie przygotowane przez Lorda Mansfield w sprawie Wyndham $v$. Chetwynd rozpatrywanej przez Sad Ławy Królewskiej w roku $1757^{228}$. Postępowanie dotyczyło znaczenia pojęcia credible witness na tle Statute of Frauds i, co za tym idzie, zagadnienia stopnia "niezainteresowania” (disinterestedness) świadków testamentu przysporzeniami $z$ niego płynacymi, a w rezultacie także ewentualną nieważnościa całego testamentu ${ }^{229}$. Sędzia wskazał, wśród licznych precedensów, na uzasadnienie wyroku wydane przez Sir Williama Lee (Lord Chief Justice Sądu Ławy Królewskiej w latach 1737-1754) ${ }^{230}$, w którym ten ostatni powołał się na rzymska zasadę prawa spadkowego brzmiaca: Conditionem testium inspicere debemus, eo tempore cum signarent ${ }^{231}$. Komentujac ja, Lord Mansfield przedstawił krótka historię rzymskiego prawa spadkowego, wskazujacc istnienie testamentów in procinctu oraz testamentu zatwierdzanego na zgromadzeniu ludowym w początkach rzymskiej państwowości, następnie zaś omówił

${ }^{227} \mathrm{Na}$ temat wykorzystywania cywilistycznej tradycji prawnej przez Lorda Mansfield zob. T.E. Scrutton, The Influence..., s. 180-181; J. Oldham, English ..., s. 386.

${ }^{228}$ Wyndham v. Chetwynd (1757), 1 Black. W. 96; 96 Eng. Rep. 53.

229 J. Oldham, English..., s. 359.

230 J. MacMullen Rigg, Lee, Sir William, [w:] DNB, vol. 11, s. 824-826.

${ }^{231}$ Zasada ta stanowi skrócona wersję fragmentu D. 28, 1, 22, 1 (Ulpianus libro 39 ad edictum) „Condicionem testium tunc inspicere debemus, cum signarent, non mortis tempore: si igitur cum signarent, tales fuerint, ut adhiberi possint, nihil nocet, si quid postea eis contigerit'. 
wprowadzenie przepisami Ustawy XII tablic testamentu mancypacyjnego ${ }^{232}$. Na koniec powołał także fragmenty pochodzace $z$ mowy Cycerona w obronie Milona („Una fui, testamentum simul obsignavi cum"233) oraz passus z drugiej ksiegi Instytucji Justyniana ${ }^{234}$.

Zmiany objęły także sferę sądownictwa kościelnego. Coraz liczniejsze głosy wskazujące na archaiczność jego struktur ${ }^{235}$ przyczyniły się w XIX w. do przeforsowania w parlamencie ustaw, które odebrały sadom duchownym uprawnienia do sadzenia w sprawach dotyczacych zniesławienia ${ }^{236}$, w sprawach małżeńskich (w tym w sprawach rozwodowych) ${ }^{237}$, czy orzekania o ważności testamentu (tzw. probate) ${ }^{238}$. Wart podkreślenia jest jednak fakt, iż w ostatnich kilkudziesięciu latach ich funkcjonowania starano się zminimalizować odmienności dzielące je od sądów świeckich (tzw. temporal courts), czego dowodem jest powoływanie się w sądach kościelnych na orzeczenia sacdów common law.

${ }^{232}$ Opis dziejów rzymskich testamentów dokonany przez Lorda Mansfield nie jest w pełni prawidłowy. Chwila wprowadzenia testamentu mancypacyjnego do prawa rzymskiego nie jest bowiem znana. Wiadomo, że istniał on w okresie obowiazywania Ustawy XII tablic, lecz w samej ustawie nie jest opisany. Więcej na temat testamentów w archaicznym prawie rzymskim zob. ostatnio J. Zabłocki, Najstarsze formy testamentu rzymskiego, [w:] M. Mikołajczyk (et al.), O prawie i jego dziejach księgi dwie. Studia ofiarowane Profesorowi Adamowi Lityńskiemu w czterdziestopięciolecie pracy naukowej $i$ siedemdziesięciolecie urodzin, Białystok-Katowice 2010, s. 137-145.

${ }^{233}$ Cic., Pro Mione 18, 48.

${ }^{234}$ I. 2, 10, 10. Na temat krytyki wykorzystania przez Lorda Mansfield prawa rzymskiego w omawianym orzeczeniu zob. J. Oldham, English..., s. $359-360$.

${ }^{235}$ Zdaniem A.H. Manchestera struktura sądownictwa kościelnego wykształcona została w średniowieczu i nawet reformy czasów Henrycjańskich jedynie w niewielkim stopniu wpłynęły na jej kształt, por. A.H. Manchester, The Reform of the Ecclesiastical Courts, AJLH 10 (1966), s. 53.

${ }^{236}$ Ecclesiastical Courts Act 1855 (17 \& 18 Vict., c. 47).

${ }^{237}$ The Divorce and Matrimonial Causes Act 1857 (20 \& 21 Vict., c. 85).

${ }^{238}$ The Court of Probate Act 1857 (20 \& 21 Vict., c. 77). Więcej na temat tych trzech ustaw i prac legislacyjnych ich dotyczacych zob. R.B. Outhwaite, The Rise and Fall..., s. 157-173. 
Procesy ograniczające znaczenie i potrzebę dalszego istnienia sądów posługujących się na co dzień prawem rzymskim spowodowały stopniowy zanik korporacji cywilistów. W roku 1861 wyprzedane zostały zbiory zgromadzone w bibliotece Doctors' Commons, zaś w roku 1865 sprzedano budynki, w których korporacja rezydowała przez ponad trzysta pięćdziesiąt lat. Ostatni adwokat - dr T.H. Tristram - zmarł w roku $1912^{239}$.

Status prawa rzymskiego w Anglii u schyłku XIX w. nie był jednoznaczny. $Z$ jednej strony $z$ archaicznego systemu sądownictwa usunięte zostały wyspecjalizowane sądy orzekajace według zasad prawa rzymskiego, z drugiej zaś coraz dynamiczniej zaczęła rozwijać się nauka prawa rzymskiego. Po okresie marazmu intelektualnego zaczęła kształtować się w Anglii szkoła prawa rzymskiego - samodzielna, lecz pozostajaca $\mathrm{w}$ ciagłym kontakcie $\mathrm{z}$ romanistyka kontynentalna (szczególnie $z$ romanistyką niemiecką ${ }^{240}$ ). To właśnie schyłek wieku XIX dał angielskiej nauce prawa rzymskiego jej najwybitniejszą chyba postać - W.W. Bucklanda ${ }^{241}$.

239 J.H. Baker, An Introduction..., s. 170. Na temat ostatnich kilkudziesięciu lat funkcjonowania korporacji zob. G.D. Squibb, Doctors' Commons..., s. 102-109.

${ }^{240}$ Owe bliskie kontakty dały się zauważyć także później, w okresie II wojny światowej, gdy kilku niemieckich romanistów żydowskiego pochodzenia wybrało właśnie Wielką Brytanię na miejsce swego politycznego i naukowego azylu; zob. noty biograficzne na temat Fritza Schulza (autorstwa W. Ernsta), Fritza Pringsheima (autorstwa T. Honoré'a), Davida Daube (autorstwa A. Rodgera), a także Hermanna Kantorowicza i Waltera Ulmanna (autorstwa D. Ibbetsona), zamieszczone w pracy zbiorowej pod redakcja J. Beatsona i R. Zimmermanna zatytułowanej Jurists Uprooted. Germanspeaking Émigré Lawyers in Twentieth-Century Britain, Oxford 2004.

${ }^{241} \mathrm{Na}$ temat W.W. Bucklanda zob. M.H. Hoeflich, Roman and Civil..., s. 120-123. 


\section{Rozdzial 2}

\section{UPRAWNIENIA SĄDOWNICZE IZBY LORDÓW}

\subsection{Działalność sądownicza Izby Lordów przed 1873 rokiem}

Początki angielskiego parlamentaryzmu sięgaja czasów anglosaskich ${ }^{242}$. Praktyka odbywania spotkań monarchów z najważniejszymi przedstawicielami królestwa kontynuowana była również po roku 1066. W tym samym czasie zaczą kształtować się pogląd o sprawowaniu przez monarchę najwyższych uprawnień sędziowskich $\mathrm{w}$ królestwie. $Z$ trudem jednak zgadzano się na to, aby monarcha mógł orzekać w konkretnych sprawach. W przekonaniu średniowiecznych prawnikow to sady lokalne czy manorialne sprawowały zwyczajna jurysdykcję, zaś król, a następnie reprezentujące go tzw. sądy królewskie posiadały uprawnienia o charakterze nadzwyczajnym. Ujawniać miało się to przede wszystkim w konieczności uzyskania rytu procesowego, czyli de facto administracyjne-

${ }^{242}$ Uważa się, iż rolę pierwszych angielskich parlamentów spełniały ogólnokrajowe zgromadzenia zwoływane od X w. przez anglosaskich monarchów (tzw. witengamot), więcej zob. J.R. Maddicott, The Origins of the English Parliament, Oxford 2010, s. 1-56. Już w tym okresie można wskazać istnienie pewnych uprawnien sądowniczych przysługujących tym zgromadzeniom (realizowane były one w postaci prerogatywy królewskiej wykonywanej przy współudziale zebranych doradców), zob. J.H. Baker, An Introduction..., s. 9. Co do odmiennej opinii zob. T. Beven, The Appellate Jurisdiction of the House of Lords, LQR 17 (1901), s. 155. 
go upoważnienia sądu do orzekania w konkretnej sprawie. Dopiero $z$ czasem zaczęto podkreślać, iż władca realizujacy samodzielnie bądź poprzez swoich przedstawicieli kompetencje sądownicze jest najwyższym gwarantem sprawiedliwości w królestwie.

Izba Lordów jako ukonstytuowane ciało ukształtowała się nieco później, w XIII wieku, za rządów Edwarda I ${ }^{243}$. Zdaniem T. Bevena, podstawową funkcją ówczesnej Izby nie była funkcja ustawodawcza, lecz sądownicza. Wydaje się zresztą, że w tym okresie także Izba Gmin posiadała uprawnienia sądownicze, których wykonanie nadzorowane było jednak przez lordów ${ }^{244}$. Zmiany przyniósł wiek XVI. Parlament stał się przede wszystkim miejscem stanowienia prawa, zaś sądownictwo, w tym to najwyższe, sprawowane było przez licznie tworzone w tym czasie specjalne trybunały. Ponowne zmiany, wiążące się z przywróceniem Izbie dawnych uprawnień sądowniczych, wiązać należy $z$ uchwaleniem w roku 1585 (za rządów Elżbiety I) ustawy potwierdzającej kompetencje lordów do orzekania w postępowaniach $z$ writ of error. Postępowanie takie nie było wprawdzie postępowaniem odwoławczym we współczesnym tego słowa rozumieniu, lecz może być traktowane jako jego substytut ${ }^{245}$. Geneza writ of error sięga czasów średniowiecza. Jeśli strona niezadowolona $z$ zapadłego wyroku zdecydowała się wykorzystać ryt procesowy, orzekajaccy sąd był zobowiązany odesłać akta

${ }^{243}$ Wprawdzie już w XII w. dochodziło do powoływania tzw. commune concilium baronum, lecz spotkania te nie miały ustalonej formuły i wynikały $z$ aktualnych zachcianek monarchów, por. T. Beven, The Appellate Jurisdiction..., s. 160.

${ }^{244}$ Ibidem, s. 162. Zob. także L. Blom-Cooper, G. Drewry, Final Appeal. A Study on the House of Lords in Its Judicial Capacity, Oxford 1972, s. 18; D.L. Jones, The Judicial Role of the House of Lords before 1870, [w:] Jud. HL, s. 3.

${ }^{245} \mathrm{~W}$ polskiej literaturze na temat writ of error pisał J. Halberda, Środki odwoławcze $w$ średniowiecznym i nowożytnym common law, [w:] S. Grodziski, A. Dziadzio (red.), Regnare-Gubernare - Administrare. Prawo i władza na przestrzeni wieków. Prace dedykowane profesorowi Jerzemu Malcowi z okazji 40-lecia pracy naukowej, Kraków 2012, s. 45-48. 
sprawy do sądu wyższej instancji, nazywanego wówczas court of error. Powyższa procedura rodziła jednak niedogodności polegające m.in. na tym, iż sąd „odwoławczy” mógł zbadać sprawę jedynie wówczas, gdy skarżący wykazał tzw. manifest error (błąd formalnoprawny, którego można było dowieść badajac akta sprawy), bądź pojawiły się nowe fakty. Wykazanie błędów materialnoprawnych było, aż do XVI w., praktycznie niemożliwe. Przeprowadzone wówczas zmiany proceduralne (pojawienie sie action on the case $e^{246}$ - oraz tzw. special verdi$c t^{247}$ ) doprowadziły do objęcia działaniem writ of error także błędów co do prawa ${ }^{248}$. Z czasem na bazie tych konstrukcji wykształciła się procedura apelacyjna, która począwszy od XVIII w. występowała obok procedury z rytu, a z czasem ostatecznie ja zastąiła ${ }^{249}$.

Oprócz tego wyższa izba parlamentu występowała także, jako sąd pierwszej instancji, w dwóch przypadkach - gdy działała jako sąd parów oraz gdy rozpatrywała postępowania w trybie impeachment ${ }^{250}$. Począwszy od czasów panowania Karola II (1660-1685) Izba posiadała także specyficzne uprawnienia w zakresie udzielania rozwodów. Uprawnienia te nie miały jednak w pełni charakteru sądowego. Izba Lordów nie wydawała wyroku, w którym orzekano o ustaniu związku małżeńskiego, lecz prywatną ustawę rozwodową.

${ }^{246}$ Więcej zob. J.H. Baker, An Introduction..., s. 61-64.

${ }^{247}$ Ibidem, s. 81.

${ }^{248}$ Więcej na temat writ of error zob. ibidem, s. $136-138$ oraz S.F.C. Milsom, Historical..., s. 55-58.

${ }^{249}$ Prawo do odwołania się strony do sądu wyższej instancji zostało po raz pierwszy wyraźnie sformułowane w roku $1723 \mathrm{w}$ orzeczeniu autorstwa Sir Johna Pratta w sprawie $R v$. Cambridge University (1723) 1 Strange 557; 93 Eng. Rep. 698. Zob. również J. Halberda, Środki odwoławcze..., s. $47-48$.

${ }^{250}$ L. Blom-Cooper, G. Drewry, Final Appeal..., s. 18-19. Po raz ostatni Izba Lordów, jako sąd parów, orzekała w roku 1935 (sprawa Lorda de Clifforda). W roku 1948 przywilej osądzania parów został zniesiony (zob. R.M. Jackson, The Machinery of Justice in England, Cambridge 1972, s. 131). W przypadku procedury impeachment, ostatnia sprawa tego rodzaju rozpatrywana była w roku 1806. 
Uprawnienia te zniesiono dopiero na mocy Matrimonial Causes Act $1857^{251}$.

Najważniejsze dla późniejszych losów Izby Lordów były stulecia XVII i XVIII. Był to okres burzliwych zmian w zakresie jej jurysdykcji, jak również znaczenia w systemie całego sądownictwa angielskiego ${ }^{252}$. Znaczacym wydarzeniem stało się wydanie w roku 1630 podręcznika procedury sądowej stosowanej w Izbie Lordów. Autorem opracowania był parlamentarny urzędnik Henry Elsyng ${ }^{253}$. Jego praca podsumowała sadowa działalność Izby u zarania zmian, do jakich miało dojść w kolejnych kilkudziesięciu latach. Był to jednak proces rozłożony na wiele lat.

Protokoły parlamentarne za lata 1514-1589 zawieraja doniesienia o jedynie pięciu sprawach $z$ tytułu writ of error $^{254}$, zaś protokoły $z$ lat 1589-1621 nie zawieraja żadnych takich wzmianek. Elizabeth R. Foster stwierdza wprawdzie, iż niezwykle trudno jest ocenić, czy brak stosownych wpisów oznacza brak napływajacych spraw, czy stanowi raczej zaniedbanie parlamentarnych urzędników. Niemniej prawnicy znali w tym okresie procedurę odwołania do Izby Lordów, czego dowodzi wspomniana już wcześniej praca H. Elsynga $^{255}$. Trzeba również zauważyć, w ślad za Janem Halberda, że na mocy statutów $z$ roku 1585 oraz 1589 uprawnienia do rozpatrywania spraw $z$ tytułu writ of error przeją Sąd Izby Szachownicy ${ }^{256}$. Przełom przyniósł rok 1621, gdy z inicjatywy Jakuba I Izba Lordów została poproszona o rozpatrzenie sprawy Edwarda Ewera. Za monarszym przykładem podążyli także członkowie Izby Gmin, którzy zaledwie kilka

${ }^{251}$ A.S. Turberville, The House of Lords in the Age of Reform, 17841837, London 1958, s. 210.

252 Por. L. Blom-Cooper, G. Drewry, Final Appeal..., s. 18.

${ }^{253}$ H. Elsyng, Judicature in Parliament, ed. E.R. Foster, London-Rio Grande, OH 1991.

254 D.L. Jones, The Judicial Role..., s. 3.

${ }^{255}$ E.R. Foster, The House of Lords 1603-1649. Structure, Procedure, and The Nature of Its Business, Chapel Hill-London 1983, s. 149, 179-180. 256 J. Halberda, Środki odwoławcze..., s. 47. 
dni później wnieśli wnioski o rozpatrzenie przez Izbę Lordów kilku innych spraw o podłożu politycznym ${ }^{257}$. Owo ożywienie sądowniczych uprawnień lordów za sprawą króla i Izby Gmin wkrótce dało asumpt znacznej grupie skarżących do wnoszenia do kancelarii Izby wniosków o rozpatrzenie ich spraw. Tylko w latach 1640-1641 (w pierwszym roku obradowania Długiego Parlamentu) przedłożono 640 wniosków tego rodzaju ${ }^{258}$.

Dzieje uprawnień sądowniczych Izby Lordów od XVII do XVIII w. zostały przede wszystkim zdominowane przez spory dotyczące zakresu jej jurysdykcji. Prowadzone były one w czterech sferach kognicji Izby - jurysdykcji pierwszoinstancyjnej (tzw. original jurisdiction), możliwości wydawania orzeczeń w sprawach będących odwołaniami od wyroków Sądu Kanclerskiego, jurysdykcji w sprawach pochodzących ze Szkocji oraz jurysdykcji w sprawach pochodzących $z$ Irlandii.

Problem tzw. original jurisdiction w zakresie indywidualnych wniosków składanych do kancelarii Izby pojawił się wraz z nagłym ożywieniem jej sądowniczych uprawnień $\mathrm{w}$ roku $1621^{259}$. Dotyczył on zasadniczej kwestii - czy Izba

${ }^{257}$ J.S. Hart, Justice upon Petition. The House of Lords and the Reformation of Justice 1621-1675, London 1991, s. 1; D.L. Jones, The Judicial Role..., s. 4-5. Na temat postępowań prowadzonych na wniosek Izby Gmin zob. E.R. Foster, The House of Lords..., s. 153-162.

${ }^{258}$ Zdaniem J.S. Harta takie zjawisko było kontynuacja dotychczasowej praktyki postrzegania Izby Lordów jako organu sądowniczego, nie zaś ustawodawczego. Protokoły z posiedzeń Długiego Parlamentu wyraźnie wskazują na podział zadań między dwiema Izbami - Izba Gmin realizowała funkcje legislacyjne, zaś Izba Lordów funkcje sadownicze, zob. szerzej J.S. Hart Jr, Judicial Review in the House of Lords (1640-43), [w:] A. Kiralfy, M. Flatter, R. Virgoe (eds.), Custom, Courts and Counsel. Selected Papers of the 6th British Legal History Conference, Norwich 1983, London 1985, s. 65-78. W sprzeczności do tak postawionej tezy stoi wypowiedź A. Swatlanda, który uważa, że jednym z najważniejszych osiagnięć parlamentaryzmu brytyjskiego w XVII w. było nabycie uprawnień sądowniczych przez Izbę Lordów, zob. A. Swatland, The House of Lords in the Reign of Charles II, Cambridge 1996, s. 71.

${ }^{259}$ Jurysdykcja pierwszoinstancyjna w zakresie sądzenia parów była przyznana Izbie na mocy przepisów Wielkiej Karty Swobód (Art. 21 Wielkiej 
Lordów, nie stanowiąc elementu systemu sądów „powszechnych”, miała prawo ferować wyroki jako sac pierwszej instancji. Problem został rozstrzygnięty w następstwie konfliktu, jaki narósł między Izbą Gmin a Izbą Lordów w latach 1666-1669 na tle procesów sądowych, których stronami byli kupiec Thomas Skinner oraz Kompania Wschodnioindyjska. Skinner po dotarciu do Indii został zmuszony do uiszczenia na rzecz Kompanii wysokich opłat, które pozbawiły go możliwości kontynuowania prowadzonych przez niego interesów. Na skutek tego, po powrocie do Londynu, T. Skinner złożył wniosek do króla, aby ten ocenił legalność działań podjętych przez kompanię handlowa. Monarcha zdecydował się na przekazanie sprawy do rozpatrzenia Izbie Lordów, która orzekła wysokie odszkodowanie na korzyść skarżącego. W odpowiedzi na to Kompania zażądała ukarania kupca i skierowała wniosek w tej sprawie do Izby Gmin. Lordowie uznali ten akt za atak na ich niezależność. Sprawa została wznowiona w wyższej Izbie, czego skutkiem było podwojenie odszkodowania oraz zasądzenie grzywny dla przedstawiciela Kompanii. Ostatecznie sprawa została rozstrzygnięta przez monarchę w ten zaskakujący sposób, iż nakazał on usunięcie informacji o obu postępowaniach $z$ archiwów izb parlamentarnych. Można zastanawiać się, czy działania podjęte przez Izbę Lordów były zgodne $z$ prawem. $Z$ pewnością trzeba jednak na nie patrzeć $z$ perspektywy próby naruszenia

Karty Swobód, Comites et barones non amercientur nisi per pares suos, et non nisi secundum modum delicti), zaś procedura impeachment obowiazywała od co najmniej 1376 r. (dokładna data jej pojawienia się nie jest znana), zob. więcej T.F.T Plucknett, The Origin of Impeachment, Transactions of the Royal Historical Society (fourth series) 24 (1942), s. 47-71; idem, The Impeachment of 1376, Transactions of the Royal Historical Society (fifth series) 1 (1951), s. 153-164. Por. także G. Lambrick, The Impeachment of the Abbot of Abingdon 1368, EHR 82 (1967), s. 250-276. W polskiej literaturze zob. m.in. pracę K. Baran, Impeachment a poczatki odpowiedzialności politycznej ministrów w Anglii, Zeszyty Naukowe UJ. Prace Prawnicze 51 (1971), s. 7-30; idem, King versus Parliament. Rediscussion of constitutional cases illustrative of the Stuart reign till 1642, Zeszyty Naukowe UJ. Prace Prawnicze 86 (1980), s. 24-27. 
przez Izbę zasady supremacji parlamentu ${ }^{260}$. Było to ostatnie postępowanie, w którym podniesiony został problem jurysdykcji pierwszoinstancyjnej Izby Lordów ${ }^{261}$.

Drugim polem nieporozumień i sporów dotyczących jurysdykcji Izby były odwołania stron w sprawach uprzednio rozpatrywanych przez Sad Kanclerski. Źródłem problemu był, na co zwraca uwagę J.S. Hart, brak wypracowanej metody postępowania w tego rodzaju przypadkach. Przed upadkiem znaczenia Izby na przełomie XV i XVI w., odwołania od sądów królewskich stanowiły przeważająca część rozpatrywanych przez lordów spraw, odwołania składane od wyroków wydanych przez Sąd Kanclerski stanowiły zaś, wobec omawianej restytucji uprawnień Izby, novum ${ }^{262}$. Sami lordowie nie byli zreszta przekonani, czy taka jurysdykcja im przysługuje. W roku 1624 zadecydowano o odmowie rozpatrzenia sprawy Matthews $v$. Matthews i wniesiono do króla o powołanie specjalnej komisji, która miałaby wydać wyrok. Praktyka ta została utrwalona na kilkanaście kolejnych lat. Przerwało ja dopiero powołanie Długiego Parlamentu ${ }^{263}$. Lordowie uznali swoja zdolność do wykonywania jurysdykcji odwoławczej od wyroku sądu equity i sprawowali ja nieprzerwanie (choć nie bez kontrowersji), aż do roku 1675, gdy wszczęte zostało postępowanie w sprawie Shirley $v$. Fagg. Stronami w postępowaniu byli lekarz królewski, Thomas Shirley i członek Izby Gmin, Sir John Fagg. Ten ostatni został wezwany przez lordów do stawiennictwa, lecz ani on, ani jego prawnik, nie uczynili tego. W odpowiedzi na to zachowanie Izba postanowiła ukarać pozwanego, umieszczając go w areszcie domowym. Doprowadziło to do kolejnego sporu między obie-

${ }^{260}$ Przebieg poszczególnych etapów całego postępowania zachowany został dzięki pochodzacemu z XIX w. zbiorowi autorstwa T.B. Howella zatytułowanemu State Trials, vol. 6, kol. 709-770.

${ }^{261}$ Problem ten pojawił się wprawdzie jeszcze raz w 1693 r., ale wniosek w sprawie został wycofany przed jego rozpatrzeniem, zob. L. Blom-Cooper, G. Drewry, Final Appeal..., s. 21.

262 J.S. Hart, Justice upon Petition..., s. 3-4.

${ }^{263}$ T. Beven, The Appellate Jurisdiction..., s. 166-167. 
ma izbami. Zdaniem A. Swatlanda rzeczywisty spór między izbami dotyczył ich przywilejów, nie zaś - jak sugerowali dawniejsi historycy - problematyki jurysdykcji. Ta ostatnia znalazła swoje rozwiązanie w tej sprawie poniekad przez przypadek $^{264}$. Propozycja kompromisu zasugerowana izbom parlamentarnym przez Karola II nie przyniosła oczekiwanych rezultatów. Król zawiesił zatem obrady Parlamentu. Ponownie zebrał się on dopiero w 1677 r. Izba Lordów podjęła dalsze czynności procesowe, zaś Izba Gmin nie sprzeciwiła się temu. Zdaniem T. Bevena owa zmiana nastawienia wynikała przede wszystkim $z$ obawy przed możliwymi machinacjami monarchy dotyczacymi praw obywatelskich. Alternatywa dla postępowania przed Izba Lordów byłoby powołanie specjalnej komisji (tak jak miało to miejsce przed 1640 r.), w której zasiadłyby osoby z otoczenia monarchy. Rezygnacja Izby Gmin z jej wcześniejszego stanowiska i uznanie kognicji Izby Lordów nad sprawami będącymi odwołaniami od wyroków Sądu Kanclerskiego powinno być zatem postrzegane jako ustępstwo o charakterze politycznym, wynikajace $z$ chęci ochrony kompetencji parlamentu przed działaniami podejmowanymi przez króla 265 .

Kolejny problem jurysdykcyjny Izby Lordów dotyczył jej uprawnień do rozpatrywania odwołań od wyroków sądów szkockich. W roku 1707 między królestwami Anglii i Szkocji zawarta została unia realna (Acts of Union 1707). W zakresie jurysdykcji sądowej lordów kluczowe były postanowienia dwóch jej artykułów. Artykuł III stanowił, iż „Zjednoczone Królestwo Wielkiej Brytanii będzie reprezentowane przez je-

${ }^{264}$ A. Swatland, The House of Lords..., s. 74.

${ }^{265}$ Zob. T. Beven, The Appellate Jurisdiction..., s. 170. Opinia T. Bevena znajduje potwierdzenie w ustaleniach poczynionych przez A. Swatlanda, który zwraca uwagę, iż monarcha wyraźnie starał się utrzymać kontrolę nad procesami decyzyjnymi zapadajacymi w Parlamencie, zob. więcej A. Swatland, The Role of Privy Council in the House of Lords, 1660-1681, [w:] C. Jones (ed.), A Pillar of the Constitution: The House of Lords in British Politics, 1640-1784, London-Ronceverte 1989, s. 52. 
den Parlament"266, natomiast artykuł XIX zachował kompetencje sądów szkockich, wypowiadając jednocześnie zasadę, zgodnie $z$ która „żadna sprawa szkocka nie powinna być rozpatrywana przez Sąd Kanclerski, Ławę Królewską, Sąd Spraw Pospolitych, czy jakikolwiek inny sąd w Westminster Hall; i żaden $z$ wymienionych sądów, ani jakikolwiek inny o takim samym charakterze, nie powinien mieć po unii możliwości rozpatrywania, rewidowania, czy zmieniania decyzji bądź wyroków sędziów szkockich, czy powstrzymywania ich egzekucji" ${ }^{267}$. Zdziwienie może budzić fakt, iż pośród wymienionych organów sądowych zabrakło Izby Lordów. Domniemywać można zatem, iż jej jurysdykcja miała zostać rozciagnięta na terytorium Szkocji. Pozostaje to zresztą w zgodności z praktyką znana na północy Brytanii od lat dziewięćdziesiątych XVII w. W tym czasie szkocki parlament uzyskał prawo rozpatrywania odwołań od wyroków wydanych przez Court of Session $^{268}$. Wprawdzie skuteczne egzekwowanie tych praw jest dziś w nauce kwestionowane, to jednak formalnie obowiazujące przepisy zostały zaadaptowane po roku 1707 przez Izbę Lordów ${ }^{269}$. Brak bezpośredniego wskazania jej uprawnień do rozpatrywania spraw szkockich tłumaczony jest także obawami, które towarzyszyły zarówno Szkotom, jak i Anglikom. Ich przyczyny były jednak odmienne. W Szkocji obawiano się, iż bezpośrednio wskazane rozciagnięcie kognicji Izby Lordów

${ }^{266}$ Art. III Act of Union with Scotland 1707 (5 \& 6 Ann., c. 11), „That the United Kingdom of Great Britain be Represented by one and the same Parliament to be stiled the Parliament of Great Britain".

${ }^{267}$ Art. XIX Act of Union with Scotland 1707, ,[...] no Causes in Scotland be cognoscible by the Courts of Chancery, Queens-Bench, CommonPleas or any other Court in Westminster-hall And that the said Courts or any other of the like nature after the Unions shall have no power to Cognosce Review or Alter the Acts or Sentences of the Judicatures within Scotland or stop the Execution of the same".

${ }^{268} \mathrm{Na}$ temat powstania Court of Session zob. w literaturze polskiej A. Stępkowski, Kształtowanie się szkockiego..., s. 215-218.

${ }^{269}$ L. Blom-Cooper, G. Drewry, Final Appeal..., s. 31-32; J.W. Cairns, Historical Introduction..., s. 123; P.H. Brodie, From Scotland to Ireland (a) Scotland after 1707, [w:] Jud.HL, s. 280. 
na sprawy pochodzące „zza północnej granicy” mogłoby wywołać próbę obstrukcji ustawy zatwierdzajacej unię. W Anglii z kolei zaledwie kilka lat wcześniej zakończył się kolejny spór na linii Izba Gmin-Izba Lordów dotyczacy jurysdykcji tej ostatniej270. Niezależnie jednak od tych obaw już w lutym 1708 r. do Londynu dotarł pierwszy wniosek o rozpatrzenie apelacji od wyroku sądu szkockiego w sprawie Rosebery $v$. Inglis (uznano jurysdykcję Izby, lecz sama sprawa nie została rozpatrzona, ponieważ Parlament został rozwiąany przed końcem posiedzenia sądowego) ${ }^{271}$. Pewne znaczenie miało tu również ustanowienie, jeszcze w roku 1707, szkockiego Sądu Exchequeru, od wyroków którego apelacja składana miała być do Izby Lordów ${ }^{272}$. W roku 1709 natomiast wprowadzona została zasada (wyrokiem w sprawie Brand $v$. Mackenzie), wedle której egzekucja wyroku wydanego przez sąd szkocki była zawieszana, jeśli jedna ze stron złożyła odwołanie do Izby Lordów ${ }^{273}$. Skutkiem tego był nagły wzrost nadsyłanych do rozpatrzenia apelacji. Ich liczba rosła w sposób skokowy, osiagając na przełomie XVIII i XIX w. rekordowe wartości, znacznie przewyższające liczbę spraw angielskich. Według L. Blom-Coopera i G. Drewry'ego, w latach 1794-1807 Izba Lordów rozpatrywała łącznie pięćset jeden spraw, z czego czterysta dziewiętnaście pochodziło ze Szkocji ${ }^{274}$.

270 D.L. Jones, The Judicial Role..., s. 7-8.

${ }^{271}$ A.J. MacLean, The 1707 Union: Scots Law and the House of Lords, JLH 4/3 (1984), s. 51-52.

${ }^{272}$ Exchequer Court (Scotland) Act 1707 (6 Ann., c. 53).

${ }^{273}$ Zob. J.W. Cairns, Historical Introduction..., s. 124; R.S. Tompson, James Greenhields and the House of Lords: A Reappraisal, [w:] W.M. Gordon, T.D. Fergus (eds.), Legal History in the Making. Proceedings of the Ninth British Legal History Conference Glasgow 1989, London-Rio Grande, OH 1991, s. 109-110.

${ }^{274}$ L. Blom-Cooper, G. Drewry, Final Appeal..., s. 32. Zob. także rozważania Lorda Hope of Craighead na temat historii szkockich apelacji do Izby Lordów, w tym w szczególności jego uwagi na ich temat w XX w., zob. Lord Hope of Craighead, Taking the Case to London - Is It All Over?, JR 1998, s. 135-149. 
$\mathrm{Na}$ uboczu tych zjawisk pozostawała jurysdykcja Izby Lordów dotycząca spraw karnych nadsyłanych ze Szkocji. Odpowiednikiem Court of Session dla spraw karnych jest High Court of Justiciary. Parlament szkocki, przed jego rozwiąaniem (1707), nie posiadał uprawnień umożliwiajaccych $\mathrm{mu}$ rozpatrywanie apelacji $\mathrm{w}$ sprawach karnych. Początkowo zasadę tę honorowała także Izba Lordów. Jednak w roku 1713, w sprawie Magistrates of Elgin v. Ministers of Elgin ${ }^{275}$, Izba rozpatrzyła apelacje od wyroku High Court of Justiciary. Wprawdzie już w roku 1781 Lord Mansfield w sprawie Bywater v. Lord Advocate ${ }^{276}$ stwierdził, iż Izba Lordów nie może uzurpować sobie praw, których nie posiadał szkocki parlament $^{277}$, ale Izba ostatecznie odstapiła od orzekania w tego typu postępowaniach dopiero w orzeczeniu w sprawie Macintosh v. Lord Advocate z $1876 \mathrm{roku}^{278}$.

Odmiennie od powyższej kształtowała się jurysdykcja Izby Lordów w stosunku do apelacji składanych od wyroków sądów irlandzkich. Jeszcze w okresie panowania Henryka VI postanowiono, iż odwołania od wyroków irlandzkiego Sądu Ławy Królewskiej rozpatrywane według procedury in error kierowane mogły być do angielskiego Sądu Ławy Królewskiej bądź do irlandzkiej Izby Lordów. W przypadku ponownej próby odwołania się od zapadłego wyroku sprawa kierowana miała być do angielskiej Izby Lordów ${ }^{279}$. Taki rodzaj procedury mógł być $z$ łatwościa stosowany, gdyż $\mathrm{w}$ przeciwieństwie do Szkocji, która zachowała własny system prawny (Scots law), Irlandia zaadoptowała $\mathrm{w}$ dużej mierze angielskie common law, w tym także organizację sądownictwa ${ }^{280}$. Skomplikowany system odwoławczy przestał prawidłowo funkcjonować w XVII wie-

${ }^{275}$ Magistrates of Elgin v. Ministers of Elgin (1713) Robertson 69, 74.

${ }^{276}$ Bywater v. Lord Advocate (1781) 2 Patton's App. 564, 565.

${ }^{277}$ Więcej na ten temat zob. D.L. Jones, The Judicial Role..., s. 8; A.J. MacLean, The House of Lords and Appeals from the Court of Justiciary, 1707-1887, JR 30 (1985), s. 192-226.

${ }^{278}$ A.J. MacLean, The House of Lords..., s. 192.

${ }^{279}$ L. Blom-Cooper, G. Drewry, Final Appeal..., s. 35.

${ }^{280}$ J.H. Baker, Introduction..., s. 31-32. 
ku, gdy na skutek coraz wyraźniejszych dążeń separatystycznych, irlandzka Izba Lordów poczęła przeciwstawiać się swojej londyńskiej odpowiedniczce ${ }^{281}$. Te zdarzenia doprowadziły do uchwalenia przez parlament brytyjski w roku 1719 Declaratory $A c t^{282}$, którego celem było pozbawienie dublińskiej Izby Lordów uprawnień sądowniczych i oddanie ich niepodzielnej kognicji Izby londyńskiej. Ustawa ta przestała obowiązywać w roku 1782, gdy lobby irlandzkie zdołało wykorzystać problemy Wielkiej Brytanii związane $z$ wydarzeniami w Ameryce Północnej ${ }^{283}$. W ten sposób irlandzka Izba Lordów odzyskała odebrane jej wcześniej uprawnienia ${ }^{284}$. Zwycięstwo było jednak krótkotrwałe. W roku 1800 Irlandia, tak jak prawie wiek wcześniej Szkocja, przystąpiła do unii realnej z Wielka Brytanią i stworzone zostało Zjednoczone Królestwo Wielkiej Brytanii i Irlandii. Artykuł VIII Unii przewidywał wyłączność londyńskiej Izby Lordów do rozpatrywania wszelkich odwołań składanych od wyroków sądów irlandzkich ${ }^{285}$.

Dopiero zatem na początku XIX w. Izba Lordów miała po raz pierwszy w dziejach ściśle określony zakres swych kompetencji. Jednocześnie przemiany w sferze parlamentaryzmu brytyjskiego, do jakich doszło w XVIII w., doprowadziły do radykalnej zmiany pozycji ustrojowej Izby. Funkcja sądownicza musiała ustapić miejsca funkcji ustawodawczej. Nie oznaczało to jednak zaniku tej pierwszej, lecz doprowadziło do licznych trudności natury proceduralnej, dodatkowo potęgowanych zwiększajacca się liczbą napływających spraw ${ }^{286}$. Coraz

${ }^{281}$ R. Keane, From Scotland to Ireland (b) Ireland, [w:] Jud.HL, s. 296.

${ }^{282}$ Declaratory Act 1719 (6 Geo. I, c. 12).

${ }^{283}$ D.L. Jones, The Judicial Role..., s. 9.

${ }^{284}$ A. Lyall, The Irish House of Lords as a Judicial Body, 1783-1800, Irish Jurist 28-30 (1993-1995), s. 314-360.

${ }^{285}$ Art. 8 Act of Union with Ireland 1800 (39 \& 40 Geo. III, c. 67), „[...] all Writs of Error and Appeals depending at the Time of the Union or hereafter to be brought, and which might now be finally decided by the House of Lords of either Kingdom, shall, from and after the Union, be finally decided by the House of Lords of the United Kingdom".

${ }^{286} \mathrm{Na}$ ten temat por. P. Polden, The Judicial Roles of the House of Lords and Privy Council, 1820-1914, OHLE, vol. 11, Oxford 2010, s. 528-529. 
wyraźniej dostrzegano brak przystosowania $z$ gruntu średniowiecznych rozwiązań do wymogów zmieniającego się świata. Problem ten dotyczył nie tylko ustroju Izby Lordów i jej funkcji sadowniczych, lecz całego systemu sądownictwa ${ }^{287}$.

Pierwszym niezmiernie ważnym zagadnieniem, które oddziaływało na działalność sądowniczą Izby w XIX w., była liczba wpływających do rozpatrzenia spraw i, co za tym idzie, także szybkość ich rozpatrywania. Dzięki konsekwencji Lorda Eldon (Lorda Kanclerza w latach 1801-1806 i 1807-1827) w marcu 1811 roku powołana została komisja parlamentarna (tzw. select committee), której zadaniem było zaproponowanie modelu reformy uprawnień sądowniczych Izby oraz zredukowanie liczby oczekujacych na rozpatrzenie spraw (według różnych wyliczeń liczba oczekujących apelacji wynosiła wówczas między 270 a 296, zaś rytów of error $-42^{288}$ ). $\mathrm{Na}$ zakończenie swoich prac komisja zarekomendowała zmiany, które zostały następnie przyjęte przez całą Izbę. Ustalono, iż posiedzenia sądowe powinny odbywać się trzy razy w tygodniu od godziny 10.00 do godziny 16.00. Kontynuacja zaproponowanych reform było powołanie w styczniu 1812 roku specjalnego komitetu apelacyjnego, który miał za zadanie dokonywać wstępnej oceny napływających do Izby wniosków odwoławczych ${ }^{289}$.

Pokładane w reformie lat 1811-1812 nadzieje okazały się jednak płonne. W roku 1823 powołana została kolejna komisja parlamentarna (komisja Lorda Colchester), która oceniła, iż w Izbie oczekuje na rozpatrzenie 225 apelacji oraz 24 ryty

${ }^{287}$ Zdaniem L. Blom-Coopera i G. Drewry'ego, ,the half-century from 1830 to 1881 saw a quite astonishing number of reforms which, taken together, amounted to a complete overhaul of the machinery of Justice. Almost at one blow a court structure representing some six hundred years of legal evolution was swept away and a new era ushered. Today's courts stand as worthy monuments to Victorian reformist zeal", L. Blom-Cooper, G. Drewry, Final Appeal..., s. 22.

${ }^{288}$ A.S. Turberville, The House of Lords..., s. 204-205; D.L. Jones, The Judicial Role..., s. 10.

${ }^{289}$ A.S. Turberville, The House of Lords..., s. 205. 
procesowe ${ }^{290}$. Wśród wielu propozycji, dotyczących m.in. przeniesienia obowiązku rozpatrywania przynajmniej niektórych spraw na sędziów sądów królewskich, znalazła się i taka, aby lordowie orzekajacy w sprawach sądowych spotykali się codziennie od poniedziałku do piatku, w godzinach zaproponowanych wcześniej przez komisję Lorda Eldon. Ustalono także quorum (czterech lordów) niezbędne dla rozpoczęcia posiedzenia ${ }^{291}$. Podobnie jednak jak dwanaście lat wcześniej, decyzja ta spotkała się z krytyka. Mimo to udało się, przynajmniej tymczasowo, oddalić niebezpieczeństwo narastania liczby wniosków odwoławczych.

Problemem, który szczególnie wyraźnie rzutował na prawidłowa działalność Izby jako organu sądowniczego, był skład osobowy "sędziów” orzekajacych w sprawach trafiających do rozpatrzenia. Parlamentarny uzus zakładał wprawdzie, iż uprawnionymi do udziału w takich posiedzeniach, ze względu na doświadczenie zawodowe, byli jedynie Lord Kanclerz oraz ci spośród lordów, którzy posiadali doświadczenie prawnicze $^{292}$. Praktyka jednak niejednokrotnie odbiegała od powyżej opisanej. Co najmniej dwukrotnie dzięki koneksjom i wpływom zewnętrznym udało się zebrać wystarczająca liczbę lordów niebędących prawnikami, którzy spektakularnie przegłosowali lordów prawników ${ }^{293}$.

${ }^{290}$ D.L. Jones, The Judicial Role..., s. 10.

${ }^{291}$ A.S. Turberville, The House of Lords..., s. 207. Nie zawsze quorum ukonstytuowane było $z$ grona lordów prawników. W latach pięćdziesiątych XIX w. zdarzało się, iż wyroki wydawał jednoosobowo Lord Brougham przy niemym udziale trzech tzw. lay lords, zob. P. Polden, Judicial Roles..., s. 534.

${ }^{292}$ L. Blom-Cooper, G. Drewry, Final Appeal..., s. 23. W XIV w. powołana została specjalna komisja (auditores petitionum) złożona $z$ trzech biskupów, dwóch baronów oraz czterech sędziów, której zadaniem było rozpatrywanie w imieniu Izby napływajacych spraw sadowych. Po roku 1335 jednak komisja ta zaczęła wykonywać jedynie funkcje o charakterze przygotowawczym, decydowała m.in. o dopuszczeniu wniosku odwoławczego przed cała Izbe, zob. T. Beven, The Appellate Jurisdiction..., s. 163.

${ }^{293}$ Symptomatyczny wydaje się być tu artykuł z "The Times" datowany na 6 stycznia 1785 r., przywoływany przez D.L. Jones'a: „the business 
Już od czasów średniowiecza lordowie zwykli posługiwać się radą sędziów wykonujacych funkcje asesorów (wydających swoje opinie prawne) przy rozpatrywaniu spraw. Był to jednak jedynie procesowy zwyczaj, nie zaś norma ustrojowa. Nie później niż w roku 1834 ustalono ostatecznie, iż lordom pomagać będzie dwunastu sędziów westminsterskich ${ }^{294}$.

Kres udziałowi tzw. lay lords w sacdowych obradach położył wyrok w sprawie O'Connell v. R. z roku $1844^{295}$. Sprawa budziła szerokie zainteresowanie społeczne przede wszystkim ze względów politycznych. Daniel O'Connell był irlandzkim działaczem politycznym walczaccym m.in. o niepodległość Irlandii oraz o wolność wyznawania w niej religii katolickiejej ${ }^{296}$. Począwszy od roku 1843 D. O'Connell aktywnie nawoływał do uchylenia Act of Union z 1800 roku. Jego działalność uznana została za spisek skierowany przeciwko Zjednoczonemu Królestwu i na podstawie wyroku irlandzkiego Sąu Lawy Królewskiej D. O'Connell został osadzony $\mathrm{w}$ zakładzie karnym. Odwołanie w trybie writ of error złożone zostało do Izby Lordów. Ze względu na polityczny charakter sprawy wiadomo było, iż w posiedzeniu udział weźmie wielu lay lords. Dzięki licznym zabiegom politycznym ${ }^{297}$ $\mathrm{w}$ trakcie posiedzenia sadowego Lord President of the Council, Lord Wharncliffe, wygłosił ustalona zawczasu opinię: "if noble lords unlearned in the law should interfere to decide such questions by their votes instead of leaving them to the decision of the law lords, I very much fear that the authority of this House as a court of justice would be greatly impaired" 298 . Lordowie zaakceptowali stanowisko Lorda Wharncliffe i opuścili posiedzenie. Sam D. O'Connell został

of appeals in the House of Lords [is] making an encrease of Law Lords a matter of necessity", zob. D.L. Jones, The Judicial Role..., s. 8-9.

${ }^{294}$ L. Blom-Cooper, G. Drewry, Final Appeal..., s. 24.

${ }^{295}$ O’Connell v. R. (1844) 11 Cl. \& Fin. 155; 8 Eng. Rep. 1061.

${ }^{296}$ Więcej zob. R. Dunlop, O'Connel, Daniel, [w:] DNB, vol. 14, s. 816-864.

${ }^{297}$ Zob. D.L. Jones, The Judicial Role..., s. 11.

${ }^{298}$ Cytat za L. Blom-Cooper, G. Drewry, Final Appeal..., s. 24. 
natomiast uwolniony od stawianych mu zarzutów większością głosów trzy do dwóch ${ }^{299}$.

Tym samym, poczawszy od roku 1844, powszechnie ustalona i akceptowana była zasada, zgodnie z którą w sprawach sądowych rozpatrywanych przez Izbę Lordów orzekali jedynie ci lordowie, którzy posiadali uprawnienia do bycia sędziami, zaś pomoca służyli im sędziowie sądów królewskich. Zaproponowany w roku 1823 system niezbędnego quorum umożliwiajacy prowadzenie czynności procesowych w konkretnym dniu nie był wolny od wad. Regulacja parlamentarna przewidywała wprawdzie quorum, lecz nie nakładała na lordów obowiązku uczestniczenia w każdym dniu procesu. Oznaczało to, iż składy orzekające zmieniały się codziennie, a wyrok w sprawie wydawali sędziowie, którzy nie uczestniczyli w wysłuchaniu stanowisk stron ${ }^{300}$. Sir Richard Bethell - Solicitor General Anglii i Walii, biorac udział w roku 1855 w dyskusji nad projektem ustawy reformujacej Sacd Kanclerski zaproponował, by Izba posiadała w swym gronie doświadczonego sędziego, który jednoosobowo realizowałby jej uprawnienia sadownicze ${ }^{301}$. Postulat ten starano się zrealizować rok później tworzac dożywotni tytuł Barona Wensleydale dla prominentnego prawnika Sir Jamesa Parke'a. Plany te spotkały się jednak z krytyką lordów dziedzicznych, którzy uznali to działanie za atak i próbę obalenia utrwalonego ładu konstytucyjnego. Sprzeciw dotyczacy nowego lorda zmusił ostatecznie królową Wiktorię do uznania tytułu Barona Wensleydale za dziedziczny ${ }^{302}$. W tym samym jeszcze

${ }^{299}$ Zob. także M. Barrett, The Law Lords. An Account of the Workings of Britain's Highest Judicial Body and the Men who Preside Over It, Basingstoke 2001, s. 11-13.

${ }^{300}$ A.S. Turberville, The House of Lords..., s. 207.

${ }^{301}$ D.L. Jones, The Judicial Role..., s. 11; O. Anderson, The Wensleydale peerage case and the position of the house of lords in the mid-nineteenth century, EHR 82 (1967), s. 489.

${ }^{302}$ Szczególna uwage należy zwrócić na fakt, iż lordowie dziedziczni nie byli przeciwni samej idei wprowadzenia do swego grona wyspecjalizowanych law lords, którzy otrzymać mieliby tytuł dożywotni. Kontrowersje budziła szybkość podejmowanych przez rząd decyzji. Uważano, iż Sir Ja- 
roku podjęto próbę ustawowego uregulowania problemu. Zaproponowano ustanowienie czterech dożywotnich tytułów lordowskich dla sędziów, którzy mieliby sprawować jurysdykcję apelacyjna w imieniu Izby. Dodatkowa pomoca służyliby im dwaj wykwalifikowani urzędnicy sądowi. Wszystkie sprawy rozpatrywane miałyby być natomiast w przerwach między sesjami parlamentarnymi. Wprawdzie projekt został pozytywnie oceniony przez Izbę Lordów, spotkał się jednak ze znaczna krytyka ze strony Izby Gmin i ostatecznie zaniechano dalszych prac nad nim ${ }^{303}$.

Warto wspomnieć, iż reformy, do jakich dochodziło „wewnatrz" Izby Lordów, wpisywały się w szerszy ruch reform zmierzających do unowocześnienia angielskiego ustroju sądowego. Te $z$ kolei były pokłosiem zmian w systemie prawa angielskiego.

Proces reform był rozłożony na wiele lat, lecz jego podstawowa wada polegała na braku skoordynowania poszczególnych działań. Reformy procedury oraz sądów dokonywano ad hoc, gdy sytuacja polityczna i większość parlamentarna na to pozwalały. Wśród tych reform za najważniejsze uznać można ${ }^{304}$ : utratę w roku 1830 przez Sąd Ławy Królewskiej prawa do rozpatrywania odwołań od wyroków Sądu Spraw Pospolitych $z$ rytu of error na rzecz nowo powstałego Court of Exchequer Chamber ${ }^{305}$, reformę Tajnej Rady w roku $1833^{306}$,

mes Parke ma być zaledwie pierwszym $z$ grona wyśmienitych naukowców i profesjonalistów, którzy mieliby zastapić lordów dziedzicznych. Pomysł ten wiązano z królewskim małżonkiem Księciem Albertem, którego podejrzewano o wzorowanie się na niemieckich rozwiązaniach ustrojowych. $\mathrm{Na}$ temat kulisów tych wydarzeń zob. P. Polden, The Judicial Roles..., s. 534555 oraz przywołany w poprzednim przypisie artykuł O. Anderson.

${ }^{303}$ D.L. Jones, The Judicial Role..., s. 11. Na temat odmowy przyjęcia ustawy przez Izbę Gmin zob. O. Anderson, The Wensleydale ..., s. 499-501.

${ }^{304}$ Por. także L. Blom-Cooper, G. Drewry, Final Appeal..., s. 23.

${ }^{305}$ Law Terms Act 1830 (11 Geo. 4 \& 1 Will. 4, c. 70).

${ }^{306}$ Judicial Committee Act 1833 (3 \& 4 Will. 4, c. 41). Zob. więcej P.A. Howell, The Judicial Committee of the Privy Council, 1833-1876, Cambridge 1979, passim, w szczeg. s. 23-48. 
powstanie Centralnego Sadu Karnego w roku $1834^{307}$, powstanie lokalnych sąów nazywanych County Courts w roku $1846^{308}$, powstanie quasi-apelacyjnego sadu karnego Court for Crown Cases Reserved w roku $1848^{309}$ oraz Kanclerskiego Sadu Apelacyjnego w roku $1851^{310}$ czy przeniesienie uprawnień do orzekania w sprawach spadkowych i rozwodowych $z$ sądów kościelnych na powstały w roku 1857 Probate and Divorce Court ${ }^{311}$. Wprawdzie powyższe zmiany miały ogromne znaczenie dla funkcjonowania brytyjskiego systemu prawnego, jednak nie rozwiązały wszystkich problemów, jakie stały przed prawnikami i sędziami tamtej epoki. Dla naprawienia systemu konieczne okazało się przeprowadzenie gruntownej reformy, która swym zasięgiem objęłaby całokształt sądownictwa, usuwając jednocześnie wszelkie pozostałości, ciagle obecnego w brytyjskich salach sadowych, średniowiecza. Postulat ten osiągnięto wydając jeden $z$ najważniejszych aktów prawnych w dziejach Zjednoczonego Królestwa - Judicature Acts 1873-1875.

${ }^{307}$ Central Criminal Court Act 1834 (4 \& 5 Will. 4, c. 36). Więcej zob. A.N. May, The Bar and the Old Bailey, 1750-1850, Chapel Hill-London 2003, s. 146-175.

${ }^{308}$ County Courts Act 1846 (9 \& 10 Vict., c. 95). Zob. więcej P. Polden, History of the County Court, 1846-1971, Cambridge 1999, s. 13-37.

${ }^{309}$ Crown Cases Act 1848 (11 \& 12 Vict., c. 78). Zob. więcej P. Handler, The Court for Crown Cases Reserved, 1848-1908, LHR 29/1 (2011), s. 261-271.

${ }^{310}$ Court of Chancery Act 1851 (14 \& 15 Vict., c. 83). Por. M. Lobban, Preparing for Fusion: Reforming the Nineteenth-Century Court of Chancery, part I, LHR 22 (2004), s. 423.

${ }^{311}$ Court of Probate Act 1857 (20 \& 21 Vict., c. 77). Zob. również R.B. Outhwaite, The Rise and Fall..., s. 159-167. 


\subsection{Judicature Acts 1873-1875 i Appellate Jurisdiction Act $1876^{312}$}

Prace nad największą reformą sądownictwa brytyjskiego rozpoczęły się w roku 1867 ustanowieniem tzw. Judicature Commission. Efekty prac komisji budza do dziś liczne kontrowersje wśród naukowców ${ }^{313}$. Oficjalnie zagadnienia dotyczące uprawnień sądowniczych Izby Lordów, jak również Tajnej Rady, nie pozostawały w gestii komisji ${ }^{314}$. Jednak uważa się, że w pewien dorozumiany sposób członkowie komisji wiedzieli, iż mieli możliwość formułowania postulatów także w stosunku do tych organów władzy sądowniczej. Było to zreszta oczywiste, gdy weźmie się pod uwagę fakt, że reformie poddany miał zostać cały system sądownictwa zwyczajnego.

Swój pierwszy raport komisja przedstawiła w roku 1869, zaś rok później na jego podstawie zaprezentowany został Parlamentowi pierwszy projekt ustawy reformujacej, tzw. Appellate Jurisdiction Bill. Jego pomysłodawca był Lord Hatherley, zajmujący pozycję Lorda Kanclerza w liberalnym rządzie Williama Ewarta Gladstone'a. Projekt zakładał powstanie tzw. Supreme Court, który składać się miał z High Court oraz Court of Appeal. Mimo braku rekomendacji ze strony komisji, Lord Hatherley zaproponował, aby zachowana została możliwość składania apelacji do Izby Lordów, konieczne było jednak jej zreformowanie. Projekt ustawy zakładał utworzenie tzw. Judicial Committee, której członkowie wybierani mieli być za-

${ }^{312}$ Ustalenia zawarte w poniższym podrozdziale zostały w większości oparte na fundamentalnej i wyczerpującej pracy autorstwa R. Stevensa zatytułowanej The Final Appeal: Reform of the House of Lords and Privy Council, 1867-1876, LQR 80 (1964), s. 343-369. Nowsze badania, dotyczace przede wszystkim działalności i zmian poglądów głównych protagonistów reform przedstawione zostały ostatnio przez D. Steele'a, The Judicial House of Lords: Abolition and Restoration 1873-6, [w:] Jud.HL, s. 13-29.

${ }^{313}$ Zob. P. Polden, The Judicature Acts, OHLE, vol. 11, Oxford 2010, s. 761 .

${ }^{314}$ R. Stevens, The Final Appeal..., s. 345. 
wsze na poczatku nowej sesji parlamentarnej. W jej skład wchodzić mieli także członkowie Privy Council ${ }^{315}$.

Drugi projekt, Supreme Court of Appeal Bill, przedstawiony został przez Lorda Hatherley w roku 1872. Projekt skierowany został wkrótce do zbadania przez specjalnie powołana komisje parlamentarna, która zasugerowała, ażeby w miejsce dotychczasowych samodzielnych uprawnień sądowniczych Izby Lordów i Tajnej Rady, powołana została połączona Judicial Committee złożona $z$ Lorda Kanclerza oraz czterech pobierających wynagrodzenie sędziów. Ponadto w pracach takiego organu mogliby ex officio uczestniczyć także inni członkowie brytyjskiej judykatury $^{316}$. Projekt, mimo iż spotkał się z poparciem wielu parlamentarzystów i prawników, nie mógł być zrealizowany. W październiku 1872 roku miejsce Lorda Hatherley na stanowisku Lorda Kanclerza zają przeciwnik utrzymywania uprawnień sądowniczych Izby Lordów - Roundell Palmer, Lord Selborne, który, co ciekawe, w roku 1867 był odpowiedzialny za powołanie komisji reformujaccej ${ }^{317}$.

Zmiana na stanowisku Lorda Kanclerza doprowadziła do przyjęcia w roku 1873 tzw. Judicature Bill. Jego podstawa były propozycje przedstawione w raporcie $z 1869$ r. Przede wszystkim zamierzano usunąć $z$ angielskiego systemu prawnego model dwustopniowej apelacji, odbierając Izbie Lordów uprawnienia sacdowe w sprawach pochodzacych z Anglii. Tymczasowo zachowane miały zostać jedynie uprawnienia Izby w zakresie rozpatrywania odwołań od orzeczeń sądów kościelnych, szkockich i irlandzkich ${ }^{318}$. Co ciekawe, plany Lorda Selborne'a zostały życzliwie przyjęte tak przez większość parów, jak i przez palestrę angielską. Dopiero w Izbie Gmin autor projektu napotkał trudności. Starano się ostatecznie usunać wszelkie pozostałości funkcji sądowniczych Izby Lordów poprzez oddanie apelacji szkockich i irlandzkich kogni-

315 Ibidem, s. 346-347.

316 Ibidem, s. 350-351.

317 Ibidem, s. 351.

${ }^{318}$ Ibidem, s. 352. 
cji nowego Sadu Apelacyjnego ${ }^{319}$. William Gladstone - autor tych propozycji, który w opinii R. Stevensa „poruszył celtyckie gniazdo szerszeni", musiał szybko ustapić. Podniesiono, iż zaproponowane przez niego zmiany naruszaja przywileje przysługujące Izbie Lordów. Ostatecznie projekt w swym oryginalnym kształcie zyskał królewską aprobatę w sierpniu 1873 roku $^{320}$, zaś jego wejście w życie przewidziano na listopad następnego roku.

Nim to jednak nastapiło, w lutym 1874 r. upadł rzad W. Gladstone'a. Nowym premierem został torys, Benjamin Disraeli. Początkowo nowy gabinet starał się kontynuować politykę swojego liberalnego poprzednika w zakresie reformy sadownictwa, podjęte zostały nawet działania mające uzupełnić postanowienia ustawy $z$ roku 1873 . W połowie roku zadecydowano jednak, iż konieczne jest przesunięcie daty wejścia w życie ustawy ze względów technicznych. Postanowiono, iż Judicature Act 1873 wejdzie w życie dopiero w listopadzie 1875 r. ${ }^{321}$

Tymczasem jesienią roku 1874 coraz częściej zaczęły podnosić się głosy nawołujące do przywrócenia Izbie Lordów jej uprawnień sądowniczych. Grupie, której przewodził Sir George Bowyer - barrister i poseł Izby Gmin, udało się uzyskać poparcie różnych środowisk prawniczych, zarówno w Anglii, jak i poza jej granicami. Także nastawienie członków gabinetu, w tym premiera, zaczęło się zmieniać i coraz wyraźniejsze było poparcie dla propozycji napływajacych z Izby Gmin. W lutym 1875 roku Lord Kanclerz Cairns przedstawił projekt zmian Judicature Act 1873 . W marcu na jednym z po-

${ }^{319}$ Ibidem, s. 355.

${ }^{320}$ Judicature Act 1873 (36 \& 37 Vict., c. 66). Zob. także L. Blom-Cooper, G. Drewry, Final Appeal..., s. 27. Zdaniem D. Steele'go należy pamiętać, iż reforma Izby Lordów nie może być oceniana jedynie przez pryzmat odebrania jej uprawnień sądowniczych. Decyzja taka podyktowana była także innymi względami. Przede wszystkim chodziło o usunięcie systemu podwójnej apelacji, jak również starano się znieść anachroniczny podział na sądy common law i sądy equity, zob. więcej D. Steele, The Judicial House..., s. $15-16$.

${ }^{321}$ R. Stevens, The Final Appeal..., s. 361. 
siedzeń Izby Gmin otwarcie podniesiono, iż konieczne jest przywrócenie jednego sądu apelacyjnego wspólnego wszystkim trzem jurysdykcjom brytyjskim (angielskiej, szkockiej i irlandzkiej). Rolę tę mogłaby pełnić, zdaniem wielu, jedynie Izba Lordów. W kwietniu Lord Kanclerz przedstawił projekt kolejnej ustawy nowelizującej. W sposób jasny i niepozostawiający już żadnych wattpliwości uznano, iż konieczne jest przywrócenie dwustopniowego modelu apelacji. Nadal jednak nie wskazano, jaki organ miałby być powołany do rozpatrywania spraw apelacyjnych drugiego stopnia. Izba Lordów nie została w projekcie ustawy wymieniona. W tym, nieco dziwnym, kształcie uchwalona została ustawa nowelizująca (tzw. Judicature Act 1875) 322 .

Na początku 1876 roku do Parlamentu złożony został przez Lorda Cairnsa nowy projekt ustawy, mający doprecyzować postanowienia Judicature Acts 1873-1875. Izba Lordów uznana została za jedyny organ, który posiada wystarczający autorytet, aby móc służyć jako najwyższy sąd odwoławczy od wyroków wydawanych przez sądy angielskie, szkockie i irlandzkie. Debata w obu izbach Parlamentu przebiegła nadzwyczaj spokojnie. W sierpniu 1876 roku ustawa została zatwierdzona przez królową Wiktorię ${ }^{323}$. Nowy sąd rozpoczą swoja działalność w roku $1877^{324}$. Według L. Blom-Coopera oraz G. Drewry'ego, nowo powstały sąd Izby Lordów był niczym feniks, „który wyrastając $z$ popiołów stał się czymś zupełnie nowym, przypominającym dawny trybunał jedynie z nazwy i miejsca [posiedzeń] $]^{325 ”}$.

322 Judicature Act 1875 (38 \& 39 Vict., c. 77). Więcej na temat procesu legislacyjnego zob. R. Stevens, The Final Appeal..., s. 361-365; L. BlomCooper, G. Drewry, Final Appeal..., s. 28.

${ }^{323}$ R. Stevens, The Final Appeal..., s. 368.

${ }^{324}$ L. Blom-Cooper, G. Drewry, Final Appeal..., s. 29.

${ }^{325}$ Ibidem, s. 37. 


\subsection{Działalność sądownicza Izby Lordów w latach 1876-2009}

Ustawy $z$ lat 1873-1876 niosły prawdziwie rewolucyjne zmiany - zniesiono rozróżnienie na common law i equity, $\mathrm{w}$ miejsce dawnych sądów westminsterskich wprowadzono nowe (Hight Court of Justice, Court of Appeal oraz Izbę Lordów) - lecz reformy te nie rozwiązywały wszystkich kwestii, które przez minione dziesięciolecia podnoszone były jako istotne dla prawidłowego działania sądu Izby Lordów. Wprawdzie dokonano formalnego rozdzielenia funkcji ustawodawczych i sądowniczych, wyroki ogłaszane miały być w imieniu „Jej Wysokości Królowej w Jej Sądzie Parlamentarnym”326, to jednak nie zdecydowano się na utworzenie wyodrębnionego Judicial Committee, jak było to proponowane w projektach Lorda Hatherley w latach 1869 i 1872. Autorzy ograniczyli się jedynie do wskazania w sekcji piątej ustawy tych osób, tzw. Lordów Apelacyjnych, których obecność była wymagana, aby sprawa mogła zostać rozpatrzona. Byli to Lord Kanclerz, Lordowie Apelacyjni (zwyczajni), których powołanie także przewidywała ustawa, oraz parowie, którzy dzierżyli w przeszłości lub zajmuja obecnie wysokie stanowisko sądowe wskazane w ustawie ${ }^{327}$. Quorum dla prowadzenia postępowania wynosiło trzech sędziów $z$ powyższej listy zasiadajacych w składzie orzekajacym ${ }^{328}$.

326 Sec. 4.

${ }^{327}$ Pod pojęciem high judicial office rozumiano stanowiska Lordów Kanclerzy Wielkiej Brytanii oraz Irlandii, sędziów zasiadających w Komitecie Sadowym Tajnej Rady, oraz sędziów orzekających w angielskich sadach: High Court of Justice, Court of Appeal, w irlandzkich sądach w Dublinie, oraz w szkockim Court of Session, zob. Sec. 25.

${ }^{328}$ Sec. 5. Warto zwrócić uwage na fakt, iż ustawa nie wprowadzała bezpośredniego zakazu uczestnictwa w obradach sadowniczych Izby tych jej członków, którzy nie posiadali uprawnień sądowniczych. Obowiązująca była nadal zasada zwyczajowa ustalona $\mathrm{w}$ trakcie postępowania w sprawie O'Connella. Potwierdzona została ona w roku $1883 \mathrm{w}$ sprawie Bradlaugh v. Clarke (1883) 8 App. Cas. 354, gdy lay lord Denman podniósł rękę w czasie 
Tak jak w okresie przed reforma, uprawnionymi do brania udziału w obradach sądowych Izby Lordów byli Lord Kanclerz oraz parowie, którzy sprawowali wysokie urzędy sędziowskie. Nowościa było natomiast ustanowienie dwóch Lordów Apelacyjnych Zwyczajnych (Lords of Appeal in Ordinary). Ich powołanie stanowiło następstwo formułowanych wielokrotnie wcześniej propozycji, których genezę można dostrzec już $\mathrm{w}$ połowie lat 50. XIX w. Ustawa $z$ roku 1876 przewidywała, iż Lordem Apelacyjnym może zostać osoba, która przez okres co najmniej dwóch lat zajmowała jedno $z$ wysokich stanowisk sądowych bądź przez okres co najmniej piętnastu lat wykonywała zawód barristera w Anglii albo Irlandii lub adwokata w Szkocji. Postanowiono również, iż każdy nowy sędzia ma otrzymać dożywotni tytuł barona ${ }^{329}$. Nowa kategoria lordów występować miała przede wszystkim w sferze jurysdykcyjnej Izby, chociaż nigdy nie istniała formalna przeszkoda uniemożliwiająca im uczestnictwa w obradach ustawodawczych ${ }^{330}$.

Ustawa określała także zasady odnoszące się do sposobu obradowania lordów wykonujących sądownicze uprawnienia Izby. Wskazano, iż powinni oni realizować swoje zadania nieustannie, tak $\mathrm{w}$ okresach odbywania się sesji parlamentarnych, jak i w przerwach między nimi ${ }^{331}$. W sytuacjach wyjątkowych, gdy chodziło o zachowanie zasad ekonomiki procesowej, monarcha miał prawo wezwać sędziów do orzekania także wówczas, gdy Parlament byłby rozwiązany ${ }^{332}$.

Jak wcześniej wskazano, ustawa przewidywała powołanie dwóch dożywotnich stanowisk sędziowskich. Pierwszymi, którzy zostali mianowani do wykonywania tych funkcji,

głosowania, lecz został zignorowany przez prowadzącego obrady, zob. P. Polden, The Early Years of the House of Lords, 1876-1914, [w:] Jud.HL, s. 181. ${ }^{329}$ Sec. 6.

${ }^{330}$ P. Polden, The Early Years..., s. 187. Na temat uczestnictwa law lords w pracach dotyczacych ogłoszenia niepodległości Irlandii zob. D.G.T. Williams, A Developing Jurisdiction, 1914-1945, [w:] Jud.HL, s. 200. ${ }^{331}$ Sec. 8. ${ }^{332}$ Sec. 9. 
byli Lord Blackburn of Kilearn ${ }^{333}$ oraz Lord Gordon of Drumearn ${ }^{334}$. Jeden reprezentował judykaturę angielska, drugi szkocka. Decyzja ta pozwoliła ukształtować się w przyszłości zasadzie, zgodnie $z$ która lordowie prawa powinni reprezentować wszystkie systemy, które współtworzą ustrój prawny Zjednoczonego Królestwa ${ }^{335}$. Sądownictwo irlandzkie zaczęło być reprezentowane w roku 1882, gdy po raz pierwszy zdecydowano się powiększyć grono Lordów Apelacyjnych. Nowym sędzia został wówczas Lord FitzGerald of Klimarnock ${ }^{336}$. Chociaż ideę stojąca za tymi działaniami ocenić należy pozytywnie, to jednak, jak zauważa P. Polden, w praktyce, szczególnie na przełomie XIX i XX wieku, doszło do znaczacego upolitycznienia nominacji lordowskich ${ }^{337}$.

$\mathrm{W}$ poczatkowym okresie istnienia nowego sądu istotnym problemem pozostawała pozycja Lorda Kanclerza. Coraz wyraźniej bowiem dostrzegano wewnętrzny konflikt interesów. $Z$ jednej strony kolejni Lordowie Kanclerze byli czołowymi postaciami życia politycznego, majacymi wpływ na kształt aktualnej polityki Królestwa, przewodniczyli posiedzeniom legislacyjnej części Izby Lordów, a jednocześnie ferowali wyroki i $z$ racji swego urzędu przewodniczyli posiedzeniom lordowskiej judykatury ${ }^{338}$.

333 J. MacMullen Rigg, Blackburn, Colin, Baron Blackburn, [w:] DNB, vol. 22, Supp., s. 203-204.

${ }^{334}$ G.C. Boase, Edward Gordon, Baron Gordon of Drumearn, [w:] DNB, vol. 8 , s. 177 .

335 Więcej na temat początków powoływania szkockich sędziów do Izby Lordów zob. A.A. Paterson, Scottish Lords of Appeal, 1876-1988, JR 33 (1988), s. 238.

${ }^{336}$ J. Donohoe FitzGerald, Fitzgerald, John David, Lord Fitzgerald, [w:] DNB, vol. 22, Supp., s. 640-641.

${ }^{337}$ Zob. P. Polden, The Early Years..., s. 187. Por. także uwagi poczynione na ten temat przez R. Stevensa, Law and Politics. The House of Lords as a Judicial Body, 1800-1976, Chapel Hill 1978, s. 84-86.

${ }^{338}$ R. Stevens zwraca uwagę, iż wszyscy Lordowie Kanclerze (Lordowie Selborne, Cairns, Halsbury i Loreburn), aż do początków XX w., gdy w 1911 r. doszło do znacznego ograniczenia uprawnień legislacyjnych Izby Lordów, zajmowali istotna pozycję w świecie brytyjskiej polityki, zob. R. Stevens, Law and Politics..., s. 84. 
Kwestią, która również stanowiła dosyć duży problem przy wyborze kolejnych sędziów, była nieznajomość przez wielu $z$ nich dziedzin prawa, które do roku 1875 były formalnie i praktycznie rozdzielone. Wielu sędziów reprezentujących jurysdykcję common law wykazywało się znaczna niewiedza $z$ zakresu equity, co niejednokrotnie prowadziło do wydawania kontrowersyjnych wyroków. Nie inaczej było także w przypadku apelacji szkockich, wymagających często znajomości podstawowych zasad prawa rzymskiego, na które powoływali się pełnomocnicy stron.

Mimo różnorakich problemów, jakie dotykały sądową emanację Izby, dosyć szybko zyskała ona autorytet i dzięki sprawnej oraz przemyślanej metodzie pracy zaproponowanej przez kolejnych Lordów Apelacyjnych, utrwalone zostały nowe mechanizmy jej działania, umożliwiajace sprawne procedowanie. Liczba law lords, jak zaczęto ich nazywać, stale się zwiększała. Z końcem XIX w. powoływano już czterech parów dożywotnich do pełnienia funkcji sądowniczych (w roku 1891 Lordem Apelacyjnym mianowany został Lord Hannen of Burdock) ${ }^{339}$. Ponadto duże wsparcie w trakcie posiedzeń sądowych zapewniali lordowie wskazani w ustawie, jako dzierżyciele high judicial offices. Do wybuchu I wojny światowej kilkunastu takich lordów uczestniczyło w pracach Izby. Wśród nich były częstokroć osoby należace do elity środowiska prawniczego Zjednoczonego Królestwa, jak Lord Kanclerz Irlandii Thomas O'Hagan, czy sędziowie szkockiego Court of Session ${ }^{340}$.

Okres dwóch wojen światowych oraz dwudziestolecia międzywojennego miał dla działalności sądowej Izby Lordów znaczenie dosyć istotne. Wprowadzona w poprzednim okresie praktyka funkcjonowania Izby utrwaliła się, zaś potrzeba istnienia „drugiej apelacji” przestała być już dyskredytowana $^{341}$. Ponownie zwiększono liczbę Lords of Appeal, których

339 P. Polden, The Early Years..., s. 183.

340 Ibidem, s. 183-186.

${ }^{341}$ Por. jednak D.G.T. Williams, A Developing Jurisdiction..., s. 198-199. 
począwszy od roku 1929 zasiadało w Izbie już siedmiu ${ }^{342}$. Ponadto w roku 1934 na mocy sekcji pierwszej Administration of Justice (Appeals) Act ${ }^{343}$ wprowadzono zasadę, iż apelacja od wyroku Sąu Apelacyjnego, aby mogła być przedłożona Izbie Lordów, wymagała uprzedniej zgody na podjęcie tego rodzaju działań wydanej przez sam Sąd Apelacyjny bądź Izbę Lordów (tzw. leave to appeal). Oznaczało to konieczność powołania specjalnej komisji, której zadaniem było wstępne badanie zasadności wniosków apelacyjnych.

Po zakończeniu II wojny światowej, w roku 1948, w nawiązaniu do postulatów podnoszonych już od początków XIX w., powołana została Appellate Committee. Bezpośrednia przyczyna tych zmian były problemy związane $z$ funkcjonowaniem Parlamentu po zbombardowaniu jego gmachu w trakcie wojny, nie zaś argumenty merytoryczne. Sala posiedzeń Izby Gmin została zburzona, przez co posłowie korzystać musieli $z$ sali Izby Lordów. Lordowie wykonujący funkcje sędziowskie Izby zostali de facto zmuszeni do prowadzenia obrad sadowych w salach komisji parlamentarnych. Tymczasowe rozwiazanie okazało się na tyle praktyczne, iż ostatecznie powołany został Komitet Apelacyjny. $Z$ technicznego punktu widzenia usunięta została $z$ brytyjskiego systemu sądownictwa fikcja przyjmujaca wnoszenie apelacji do pełnej Izby Lordów ${ }^{344}$.

Druga istotna zmiana okresu powojennego było stopniowe zaniechanie uczestniczenia Lordów Kanclerzy w obradach Komitetu Apelacyjnego. W praktyce posiedzeniom sądowym przewodniczył jeden $z$ lordów, którego poczęto określać mia-

${ }^{342}$ W roku 1913 ustanowiono dwa nowe stanowiska sędziowskie, które powierzono Lordowi Dunedin oraz Lordowi Sumnerowi, zaś w roku 1929 dodatkowym sędzia powołany został Lord Tomlin.

${ }^{343}$ Sec. 1 (1) Administration of Justice (Appeals) Act 1934 (24 \& 25 Geo. 5, c. 40). W opinii L. Blom-Coopera i G. Drewry'ego dzięki zmianom wprowadzonym tą ustawą sędziowie mogli wreszcie kontrolować liczbę przyjmowanych do rozpatrzenia spraw, zob. L. Blom-Cooper, G. Drewry, Final Appeal..., s. 38.

${ }^{344}$ Ibidem. Szerzej na temat powołania Komitetu Apelacyjnego zob. J. Vallance White, The Judicial Office, [w:] Jud.HL, s. 36-37. 
nem senior law lord. Ze względu na nieformalny charakter stworzonego urzędu trudno określić jednoznacznie datę jego powstania, jeden $z$ sędziów posiadał po prostu status primus inter pares. Regularne używanie określenia senior law lord łączyć można $z$ okresem sprawowania urzędu przez Lorda Reida w latach 1948-1975. W praktyce jednak to Lord Kanclerz sprawował zawsze nadrzędną kontrolę nad pracami Komitetu Apelacyjnego. Praktyka ta przełamana została dopiero w roku 2000, gdy wprost wskazano, iż na stanowisko senior law lord zostanie powołany Lord Bingham of Cornhill ${ }^{345}$.

Komitet Apelacyjny w kształcie utrwalonym w okresie powojennym przetrwał w zasadzie bez większych zmian aż do czasów jego rozwiązania w roku 2009. Wszelkie późniejsze zmiany miały już raczej charakter kosmetyczny (zwiększenie liczby lordów w latach 1947, 1968, 1992 i 1994, zmiany w organizacji sekretariatu Komitetu, określenie zasady posiedzeń w składach pięcioosobowych, a w wyjattkowych przypadkach - siedmioosobowych).

Spory budził nadal zakres jurysdykcji Izby Lordów. Reformy $z$ lat 1873-1876 przyniosły w tej kwestii oczekiwane zmiany. Problem dużej liczby szkockich apelacji przestał być już aktualny. Na poczatku XX w. około 20\% rozpatrywanych co roku spraw pochodziło ze Szkocji. Na przełomie wieków XX i XXI odsetek ten spadł nawet poniżej $10 \%$ spraw rocznie ${ }^{346}$. W przypadku Irlandii spadek liczby rozpatrywanych spraw był dodatkowo pogłębiony wydarzeniami politycznymi. Przed rokiem 1922 około 8-12\% wszystkich spraw rozstrzyganych przez Izbę Lordów pochodziło z Irlandii. Po uznaniu jej niepod-

345 J. Vallance White, The Judicial Office..., s. 34-35.

346 Według L. Blom-Coopera i G. Drewry’ego, w okresie bezpośrednio poprzedzajacym reformę sprawy szkockie stanowiły około połowy wszystkich wpływających do Izby Lordów wniosków. Po reformie z roku 1876 ich liczba zaczęła spadać najpierw do około 1/3 wszystkich napływających spraw, aby na początku XX w. osiagnać pułap około 20\% wpływających wniosków, zob. L. Blom-Cooper, G. Drewry, Final Appeal..., s. 35. Na temat danych statystycznych dotyczących końcowego okresu sądowej działalności Izby Lordów zob. P.H. Brodie, From Scotland to Ireland..., s. 283-284. 
ległości, liczba spraw napływających $z$ Irlandii Północnej spadła zaledwie do około $3 \% \mathrm{w}$ połowie $\mathrm{XX} \mathrm{w.}{ }^{347}$, aby na przełomie XX i XXI w. ponownie nieco wzrosnąc do około $4,5-5 \%{ }^{348}$.

W zakresie właściwości rzeczowej Izba Lordów początkowo orzekała w tego samego rodzaju sprawach, co przed reformami $z$ lat 1873-1876. Dokonane w tym czasie modyfikacje miały raczej marginalne znaczenie. Przede wszystkim Izba uzyskała prawo rozpatrywania apelacji od wyroków wydanych przez sady admiralicji. Wcześniej odwołania kierowane były do Tajnej Rady. Ponadto w sprawach małżeńskich uprawniona była jedynie do rozpatrywania spraw dotyczacych prawa, nie zaś faktów. Uprawnienia do rozstrzygania apelacji karnych od wyroków sądów angielskich Izba Lordów uzyskała dopiero w roku $1907^{349}$. Te ostatnie były jednak znacznie ograniczone i dopiero zmiany wywołane uchwalaniem Administration of Justice Act 1960 doprowadziły do widocznego zwiększenia znaczenia Izby Lordów w sferze orzecznictwa karnego ${ }^{350}$. Ustawa zniosła wymóg udzielania przez Attorney General (wysokiego urzędnika rządowego, w tym wypadku wykonującego uprawnienia prokuratora generalnego) tzw. fiat - zaświadczenia, iż dana sprawa karna może być rozpatrywana w trybie apelacji przez law lords ze względu na istotny dla opinii publicznej problem prawny ${ }^{351}$. W roku 1960 wymóg ten usunięto i sprawy karne mogły być rozpatrywane przez law lords po uzyskaniu zgody wydanej przez Są Apelacyjny w drodze procedury leave to appeal, bądź wydanej przez samą Izbę ${ }^{352}$.

${ }^{347}$ Por. L. Blom-Cooper, G. Drewry, Final Appeal..., s. 36.

${ }^{348}$ Zob. na przykład House of Lords Judicial Business Statistics 2002. Wyjątkowy był rok 2008, gdy liczba spraw irlandzkich stanowiła $8,21 \%$ (zob. Judicial and Court Statistics 2008, Ministry of Justice 2009, s. 19).

${ }^{349}$ P. Polden, The Early Years..., s. 188.

${ }^{350} \mathrm{Na}$ temat statystyki rozpatrywanych przez Izbę Lordów spraw karnych zob. J.R. Spencer, Criminal Law, [w:] Jud.HL, s. 594.

${ }^{351}$ Sec. 1 (6) Criminal Appeal Act 1907 (7 Edw. 7, c. 23).

${ }^{352}$ Sec. 1 (1) i (2) Administration of Justice Act 1960 (8 \& 9 Eliz. 2, c. 65). 
W okresie po II wojnie światowej doszło także do stopniowego wzrostu znaczenia Izby Lordów w sferze prawa publicznego. Wcześniej podstawowym obszarem orzekania lordów było prawo prywatne. Począwszy od lat sześćdziesiątych dało się zauważyć rosnaca liczbę apelacji publicznoprawnych dotyczacych materii prawa administracyjnego czy podatkowego $^{353}$. Koniec XX wieku przyniósł ponadto zwyczaj coraz częstszego formułowania przez niektórych przynajmniej lordów postulatów de lege ferenda, szczególnie w odniesieniu do spraw z pogranicza prawa i moralności ${ }^{354}$.

Oddzielnym zagadnieniem, które w istotny sposób, począwszy od lat siedemdziesiątych, wpływało na jurysdykcję Komitetu Apelacyjnego, było przystapienie Zjednoczonego Królestwa do struktur Wspólnot Europejskich, jak i ogólnie zauważalny w drugiej połowie XX w. wzrost znaczenia organizacji międzynarodowych i prawa przez nie stanowionego. W tym drugim przypadku szczególną rolę odegrało uchwalenie przez Parlament w roku 1998 Human Rights Act ${ }^{355}$, który stanowił krajowe uzupełnienie postanowień Europejskiej Konwencji Praw Człowieka.

Druga połowa XX wieku i poczatek kolejnego przyniosły również wzrost liczby spraw, które odnosiły się do zagadnień ustrojowych. Stanowiło to następstwo wskazanego już wcześniej wzrostu znaczenia spraw publicznoprawnych rozpatrywanych przez Komitet Apelacyjny. Izba Lordów nigdy, tak przed, jak i po reformach $z$ lat 1873-1876, nie rościła sobie praw do bycia sądem konstytucyjnym, na wzór Sądu Najwyższego Stanów Zjednoczonych. Stanowisko to w wyraźny sposób wykazane zostało m.in. w orzeczeniu $z$ roku 1974

${ }^{353}$ Szerzej na temat rozwoju kognicji w sprawach publicznoprawnych w latach 60. XX w. zob. G. Drewry, Towards a System of Administrative Law: The Reid and Wilberforce Era 1945-82, [w:] Jud.HL, s. 217-226.

${ }^{354}$ M. Beloff, The End of the Twentieth Century: The House of Lords 1982-2000, [w:] Jud.HL, s. 240-241. Dla lat 1952-1968 praktyka taka potwierdzona jest jedynie dla czternastu wydanych w tym czasie orzeczeń, zob. L. Blom-Cooper, G. Drewry, Final Appeal..., s. 209.

${ }^{355}$ Human Rights Act 1998 (c. 42). 
w sprawie Pickin v. British Railways Board ${ }^{356}$, gdzie Lord Reid stwierdził: "the idea that a court is entitled to disregard a provision in an Act of Parliament on any ground must seem strange to anyone with any knowledge of the history and law of our constitution". W świetle tego orzeczenia jasne było, że Komitet Apelacyjny nie ma prawa badać konstytucyjności aktów prawnych. Należy przy tym zauważyć, iż pewność, $z$ jaka lord prawa wypowiadał się na ten temat, wynikała $z$ fundamentalnej zasady ustrojowej, tj. supremacji Parlamentu. Zasada ta - współcześnie już nieco osłabiona - zakłada najwyższa pozycję ustrojową Parlamentu, co równocześnie wyklucza podległość jakimkolwiek innym podmiotom czy organom ${ }^{357}$.

Niezależnie od powyższego, jak i od zapewnień składanych w roku 1974 przez Lorda Reid, pewne kwestie ustrojowe były przez lordów rozstrzygane. Zdaniem B. Hadfield możliwe jest wskazanie trzech kategorii takich spraw. Po pierwsze, były to sprawy dotyczace wzajemnych relacji władzy ustawodawczej, wykonawczej i sadowniczej. Po drugie, były to sprawy odnoszące się do prerogatyw królewskich. Do ostatniej kategorii zaś brytyjska autorka zaliczyła sprawy, w których law lords odnieśli się do problematyki niezależności Parlamentu ${ }^{358}$.

$\mathrm{Z}$ zagadnieniem jurysdykcji Izby Lordów wiąże się także kwestia stosowania przez najwyższy sąd Zjednoczonego Królestwa zasady stare decisis. Zasada ta stanowi w praktyce lapidarne ujęcie charakterystycznej dla systemu prawa anglo-amerykańskiego doktryny precedensu. W całości zasada ta brzmi stare decisis et non quieta movere. Rozumiana jest jako nakaz postępowania zgodnie $z$ zasadami wyznaczonymi przez precedens, wówczas gdy strony przedstawia takie same okoliczności faktyczne ${ }^{359}$. W konsekwencji sądy niższej instancji

${ }^{356}$ British Railways Board v. Pickin [1974] A.C. 765.

${ }^{357}$ P. Sarnecki, Ustroje konstytucyjne państw współczesnych, wyd. 5, Warszawa 2013, s. 21-22.

${ }^{358}$ B. Hadfield, Constitutional Law, [w:] Jud.HL, s. 502-505.

359 Por. np. E.A. Martin, Oxford Dictionary of Law, Oxford 2003, s. 475, s.v. stare decisis. 
podlegaja precedensom wydanym przez sąy instancji wyższej ${ }^{360}$. W przypadku Izby Lordów bardzo długo przedmiotem poważnej dyskusji było pytanie o to, czy podlega ona swoim własnym precedensom, czy też może je dowolnie zmieniać wbrew regule stare decisis.

Obowiazywanie doktryny precedensu w Izbie Lordów stanowiło dobrze utrwalony zwyczaj już w chwili rozpoczęcia działalności przez zreformowaną Izbę w roku $1876^{361}$. Jednak w roku $1898 \mathrm{w}$ sprawie London Tramways $v$. London County Council $^{362}$ podjęta została próba obalenia dotychczasowego precedensowego status quo. Argumentacja przedstawiona przez jedna ze stron procesowych okazała się jednak zbyt wątła, aby móc obalić dotychczasowe stanowisko. W wyroku lordowie potwierdzili wcześniejszy zwyczaj. Lord Kanclerz Halsbury wskazał: „a decision of this House upon a question of law is conclusive, and that nothing but an Act of Parliament can set right that which is alleged to be wrong in a judgment of this House".

Zasada potwierdzona w London Tramways wydawała się oczywista. W praktyce jednak stanowiła ona przedmiot prawniczej żonglerki dostosowanej do potrzeb sprawy, a w szczególności do potrzeb lordów orzekających w konkretnej sprawie. Sam tylko Lord Kanclerz Halsbury w ciagu dziesięciolecia następujacego po wydaniu omawianego orzeczenia wielokrotnie korygował zakres stosowania zasady ${ }^{363}$.

Niezależnie jednak od powyższego, oficjalnie reguła potwierdzona w orzeczeniu Izby z 1898 roku obowiązywała do

${ }^{360}$ Na temat doktryny precedensu zob. ibidem, s. 374, s.v. precedent. Na temat jej ukształtowania się w XVIII w. zob. J. Oldham, Lord Mansfield, 'Stare Decisis', and the 'Ratio Decidendi' 1756 to 1788, [w:] W.H. Bryson, S. Dauchy (eds.), 'Ratio decidendi'. Guiding Principles of Judicial Decisions, Berlin 2006, s. 138-144. W polskiej literaturze zob. również M. Weglarz, Specyfika prawa angielskiego - doktryna precedensu, Studenckie Zeszyty Prawnicze TBSP 4/9 (2000), s. 62-66.

${ }^{361}$ D. Pugsley, London Tramways (1898), JLH 17/2 (1996), s. 172.

${ }^{362}$ London Street Tramways Co. Ltd. v. London County Council [1898] A.C. 375 .

363 Szerzej na ten temat zob. R. Stevens, Law and Politics..., s. 90-98. 
roku 1966. Wówczas law lords podjęli być może jedną z najważniejszych decyzji. Co ciekawe, podjęta została ona w sposób nieformalny i nie była związana $z$ żadnym toczącym się wówczas w Izbie postępowaniem. Dnia 26 lipca 1966 roku Lord Kanclerz Gardiner w obecności dziewięciu law lords ogłosił tzw. Practice Statement ${ }^{364}$. Było to krótkie oświadczenie, w którym stwierdzono, iż chociaż doktryna precedensu ma fundamentalne znaczenie dla funkcjonowania i pewności prawa, to jednak zbyt ścisłe powoływanie się na nia prowadzić może do niesprawiedliwości i ograniczenia prawidłowego rozwoju prawa. Lordowie przyjęli zatem, że dotychczasowe precedensy będa "normalnie obowiąujace” (normally binding), jednak w sytuacji gdy uznane to zostanie za konieczne, będzie można od nich odstąpić („to depart from previous decision when it appears right to do so").

W praktyce oświadczenie to niwelowało zakres stosowania zasady stare decisis wyrażonej w sprawie London Tramways. Chociaż miało charakter nieformalny, to trzeba jednak pamiętać, iż konieczne jest jego postrzeganie w szerszym kontekście. W roku 1962 na łamach „Modern Law Review” opublikowany został artykuł autorstwa Geralda Dworkina, w którym autor wykazał techniki omijania przez law lords sztywnej zasady stare decisis (np. poprzez wykazywanie przez sędziów, iż dane sformułowanie powołane jako zasada prawna w rzeczywistości stanowiło element obiter dicta sprawy, nie zaś jej ratio decidendi), jak również zreferował dotychczasowe poglądy różnych sędziów, którzy, poczynając od lat czterdziestych XX w., negatywnie wypowiadali się na temat ścisłego przestrzegania zasady przez Izbę ${ }^{365}$. Warto także pamiętać, iż Lord Gardiner przed swoim powołaniem na stanowisko Lorda Kanclerza uczestniczył w redagowaniu pracy zatytułowanej Law Reform Now ${ }^{366}$, w której m.in. postulowano

${ }^{364}$ Practice Statement (Judicial Precedent) [1966] 1 W.L.R. 1234.

365 G. Dworkin, Stare Decisis in the House of Lords, MLR 25 (1962), s. $166-174$.

${ }^{366}$ G. Gardiner, A. Martin (eds.), Law Reform Now, London 1963. 
powołanie stałej komisji czuwającej nad zmianami w prawie (taka Law Commission powstała w roku 1965 ${ }^{367}$ ) oraz sugerowano przeprowadzanie gruntownej reformy systemu prawnego. W ten sposób Practice Statement postrzegane powinny być jako oczekiwane przez doktrynę. Świadcza o tym zreszta przychylne dla niej oceny tak naukowców brytyjskich, jak i amerykańskich ${ }^{368}$.

Mimo pewnych obaw, które podnoszone były tuż po ogłoszeniu Practice Statement, Komitet Apelacyjny Izby Lordów tylko wyjątkowo korzystał $z$ nowych uprawnień. Do chwili zakończenia swojej działalności w roku 2009 lordowie wykorzystali przysługujace im uprawnienie zmiany dotychczasowej linii orzeczniczej jedynie dwadzieścia jeden razy ${ }^{369}$. Jednocześnie kilkakrotnie law lords wypowiedzieli się na temat zasad, jakimi należy kierować się chcąc pominąc dotychczas obowiąujacy precedens. Ogólny wniosek, jaki można wyciągnąć $z$ rozważań lordów, to fakt, iż obalenie precedensu zawsze musiało być poprzedzone ocena, czy dalsze jego obowiązywanie może prowadzić do stanu niesprawiedliwości, jak również, czy sama zmiana nie doprowadzi do powstania negatywnych konsekwencji dla uczestników obrotu prawnego ${ }^{370}$.

${ }^{367} \mathrm{Na}$ temat powołania Law Commission zob. np. R.M. Jackson, The Machinery..., s. 528-559.

368 Zob. np. R.W.M. Dias, Precedents in the House of Lords-Much Needed Reform, CLJ 1966, s. 153-156; W.B. Leach, Revisionism in the House of Lords: The Bastion of Rigid Stare Decisis Falls, HLR 80 (1966-1967), s. 797-803. Odmiennie J.H. Langbein, Modern Jurisprudence in the House of Lords: The Passing of London Tramways, CLR 53 (1967-1968), s. 813.

${ }^{369}$ L. Blom-Cooper, 1966 and All That: The Story of the Practice Statement, [w:] Jud.HL, s. 143.

${ }^{370}$ L. Blom-Cooper, 1966 and All That..., s. 136-137. 


\subsection{Reforma konstytucyjna i powolanie Sądu Najwyższego}

Wygranie wiosna 1997 roku wyborów parlamentarnych przez Partię Pracy, a następnie utworzenie gabinetu Tony'ego Blaira, otworzyły nowy okres w dziejach brytyjskich reform ustrojowych. Rząd labourzystów podjął m.in. szereg działań, które doprowadzić miały do modernizacji mechanizmów parlamentarnych. Pierwsze poważne zmiany wprowadzone zostały na mocy House of Lords Act 1999371. Twórcy ustawy, powołując się na anachroniczność obowiąujacych rozwiązań ustrojowych, znieśli powszechne uprawnienie członków rodowej arystokracji do zasiadania w Izbie. Obecnie jedynie dziewięćdziesięciu dwóch hereditary peers może brać udział w jej obradach, $z$ tym że sa oni wybierani przez poszczególne partie, przez cała Izbę, bądź zasiadają w Izbie $z$ racji pełnionych urzędów dworskich ${ }^{372}$. Główny ciężar prac spoczywa zatem na tzw. lordach dożywotnich (life peers). Ponadto ustawa dopuściła dalszy udział w pracach Izby dwudziestu sześciu biskupów i dwóch arcybiskupów Kościoła anglikańskiego (lords spiritual) oraz law lords. Uprawnienia tych ostatnich zostały jednak wkrótce także podważone, podobnie zreszta jak rola ustrojowa przewodzącego Izbie Lorda Kanclerza. Ostatecznie uchwalona została kolejna ustawa, która w miejsce dotychczasowego Komitetu Apelacyjnego Izby Lordów ustanawiała Sąd Najwyższy Zjednoczonego Królestwa, zaś Lorda Kanclerza uczyniła Ministrem Sprawiedliwości. Stanowisko przewodniczącego Izby Lordów powierzono nowemu urzędnikowi, który na wzór Izby Gmin nazwany został Lordem Speakerem.

${ }^{371}$ House of Lords Act 1999 (c. 34).

${ }^{372}$ Każda $z$ partii politycznych, tzw. crossbenchers, czyli lordowie niezrzeszeni oraz cała Izba, posiadaja obecnie prawo do wytypowania określonej liczby lordów dziedzicznych, którzy uczestniczyć będą w obradach Izby. Ponadto monarchę reprezentuje dwóch wysokich urzędników dworskich - Lord Marszałek (Earl Marshal) oraz Lord Szambelan (Lord Great Chamberlain). 
Informacje na temat planowanej reformy ogłoszono w czerwcu 2003 roku. W praktyce jednak, mimo powtarzanych wielokrotnie zapewnien, środowiska związane w mniejszym bądź większym stopniu z rządem Tony'ego Blaira rozpatrywały możliwość rozwiązania Komitetu Apelacyjnego i powołanie w jego miejsce nowej instytucji sądowej co najmniej od roku 1999. Jednym $z$ apologetów takich reform był Lord Bingham, nominowany w roku 2000 na stanowisko senior law lord ${ }^{373}$. W lipcu 2003 roku Department of Constitutional Affairs opublikował raport zatytułowany Constitutional Reform: A Supreme Court for the United Kingdom. Uwzględniono w nim wiele uwag, które później zostały włączone do treści właściwej ustawy. Wśród argumentów, które uzasadnić miały planowane zmiany, znalazł się m.in. taki, że poprzez sprawowanie jednocześnie funkcji sądowniczych i ustawodawczych Izba Lordów zaciera granice, które wyznacza zasada trójpodziału władzy. Podkreślano także, iż pełnienie przez Lorda Kanclerza podwójnej roli przewodniczącego obu emanacji Izby Lordów rodzić może obawy co do jego niezależności i bezstronności. Mimo iż argumenty te $z$ latwością można było obalić, odwołując się chociażby do utartej praktyki ceremonialnego nadzoru Lorda Kanclerza nad Lordami Apelacyjnymi, to jednak rząd labourzystowski nie zamierzał przerwać podjętych już działań. Innym argumentem, który podnoszono we wspomnianym powyżej raporcie, była możliwość naruszenia art. 6 Europejskiej Konwencji Praw Człowieka, który zapewnia prawo do rzetelnego procesu sadowego ${ }^{374}$.

${ }^{373} \mathrm{Na}$ temat pierwszych głosów zabieranych w sprawie reformy Komitetu Apelacyjnego zob. A. Le Sueur, From Appellate Committee to the Supreme Court: A Narrative, [w:] Jud.HL, s. 64-66. Na temat opinii Lorda Binghama zob. jego wykład wygłoszony w dniu 1 maja 2002 r. na UCL, Lord Bingham, A New Supreme Court for the United Kingdom, London 2002. W tym samym roku opublikowany został także artykuł innego członka Komitetu Apelacyjnego - Lorda Steyna, w którym pomysł zmian ustrojowych również oceniony został pozytywnie, zob. J. Steyn, The Case for a Supreme Court, LQR 118 (2002), s. 382-396.

${ }^{374}$ Constitutional Reform: a Supreme Court for the United Kingdom, London 2003, s. 11. 
Uważano, że skoro Izba spełnia jednocześnie funkcje sądownicze i ustawodawcze, to istnieje niebezpieczeństwo skierowania skargi przeciwko Zjednoczonemu Królestwu do ETPC w Strasburgu. W praktyce rzeczywiście zdarzało się, iż law lords przysłuchiwali się obradom „ustawodawczej” Izby Lordów, lecz nigdy nie doprowadziło to do podniesienia zarzutu kierowania się przez nich partykularyzmami partyjnymi ${ }^{375}$. Ponadto nigdy, od chwili gdy Zjednoczone Królestwo stało się sygnatariuszem Konwencji w roku 1951, aż do zakończenia prac Komitetu Apelacyjnego w roku 2009, nie wpłynęła do Strasburga skarga, w której zarzucano by naruszenie przez law lords art. 6 Konwencji.

Ostatecznie ustawa noszaca tytuł Constitutional Reform Act została uchwalona przez Parlament w roku 2005 376 . Jej wejście w życie przesunięto jednak o cztery lata - do 1 października 2009 roku. W tym czasie rząd starał się zapewnić sprawną transformację Komitetu Apelacyjnego w Sąd Najwyższy. Ustawa proklamowała wprawdzie nowy organ sądownictwa, lecz wiele kwestii szczegółowych nie zostało w niej w ogóle uregulowanych. Wraz zatem $z$ przyjęciem ustawy nie było chociażby wiadomo, w jaki sposób, na podstawie jakich norm procesowych, nowy sąd będzie działał, czy gdzie będzie się mieścil. Koszty tych reform osiagnęly ostatecznie sumę 58 milionów funtów, mimo początkowych zapewnien, że nie przekroczą kwoty 32 milionów funtów ${ }^{377}$.

${ }^{375}$ Zob. więcej L. Blom-Cooper, G. Drewry, Final Appeal..., s. 196-215; D. Hope, Voices from the Past - The Law Lords' Contributions to the Legislative Process, LQR 123 (2007), s. 547-570.

376 Constitutional Reform Act 2005 (c. 4).

${ }^{377} \mathrm{Na}$ temat kosztów w wysokości 32 milionów funtów informowal w lutym 2004 r. ówczesny Lord Kanclerz Falconer of Thoroton (zob. Supreme court 'could cost £32m', http://news.bbc.co.uk/2/hi/uk_news/ politics/3519083.stm, [ostatnia wizyta 02.03.16]). W roku 2010 natomiast jego następca Lord Kanclerz Jack Straw oświadczał, iż pełen koszt reform wyniósł 58 milionów funtów (zob. Daily Hansard Vol. 507 Part 55 - Written Ministerial Statements for 11 March 2010, http:/ / www.publications.parliament.uk/pa/cm200910/cmhansrd/cm100311/wmstext/100311 m0002. htm, [ostatnia wizyta 02.03.2016]). 
Reforma konstytucyjna z roku 2005 ogłoszona została przez ówczesny rząd jako wielki sukces jego polityki. $Z$ opinia ta nie zgadzał się jednak zdecydowany odsetek brytyjskich prawników, czego echa dostrzec można jeszcze dziś. Podjęcie decyzji o przekreśleniu kilkusetletniej tradycji sądowniczych funkcji Izby Lordów powinno nieść ze sobą znaczace zmiany co do formy i zasad postępowania sądowego. W rzeczywistości dokonane zmiany miały bardzo niewielki wymiar. Gdy w roku 1876 Izba Lordów rozpoczynała swoją sądową działalność od nowa, wyraźnie dostrzegano, iż system sądownictwa brytyjskiego wzbogacił się o pewna nowa jakość. W roku 2009 dostrzec można było jedynie zmianę budynku, w którym pracuja obecnie sędziowie Sądu Najwyższego. We wczesnych fazach przygotowywania reformy podnoszono m.in. archaiczność procedury, jej parlamentarny, a nie stricte sądowy charakter (podnoszono m.in. kwestie terminologii stosowanej na określenie poszczególnych czynności procesowych; były one tożsame $z$ terminologia stosowana w procedurze legislacyjnej, nie zaś w postępowaniu sądowym), czy wreszcie kwestię nazywania sędziów lordami i przyznawania im dożywotnich tytułów arystokratycznych.

Osiągnięty efekt odbiega od zamierzonego. Archaiczność procedury (o ile o takiej można w ogóle mówić) nie została usunięta, gdyż Supreme Court stosuje te same przepisy co wcześniej Komitet Apelacyjny. Zmiana dostrzegalna jest złaczenie w jeden akt prawny tzw. Practice Directions and Standings Orders, które przed 2009 wydawane były oddzielnie dla spraw prywatnoprawnych i oddzielnie dla spraw karnych. Reforma kosztów sądowych natomiast wydaje się być niewystarczającym argumentem do mówienia o zmianie stosowanej procedury. Unowocześnienia procedury trudno także dopatrywać się w modyfikacjach o charakterze terminologicznym. Zmieniono na przykład sformułowanie petition for leave to appeal ${ }^{378}$ na application for permission

378 Practice Directions and Standings Orders Applicable to Civil Appeals 3.7 . 
to appeal ${ }^{379}$. Innym przykładem tej samej praktyki jest zmiana nazwy nadzwyczajnej skargi składanej przeciwko wyrokowi wydanemu przez High Court z opisowego sformułowania Petitions brought direct from the High Court ${ }^{380}$ na używane od dawna w praktyce Leapfrog appeals ${ }^{381}$. Znaczna zaś część regulacji procesowych została przepisana $z$ dawnych reguł działania Komitetu Apelacyjnego.

379 The Supreme Court of the United Kingdom Practice Directions 2.1.18.

${ }^{380}$ Practice Directions and Standings Orders Applicable to Civil Appeals 6.1-6.15.

${ }^{381}$ The Supreme Court of the United Kingdom Practice Directions 3.6.13.6.16. 

Rozdział 3

\section{PRAWO RZYMSKIE JAKO AUTORYTET I ŹRÓDLO UZUPEENIENIA LUK PRAWNYCH}

\subsection{Powoływanie prawa rzymskiego bez skutku dla rozstrzygnięcia sprawy}

Po przedstawieniu historii prawa rzymskiego w Anglii i Szkocji oraz po zarysowaniu najważniejszych wątków dotyczących rozwoju uprawnień sądowniczych Izby Lordów możliwe jest podjęcie analizy stanowiącej zasadniczy temat niniejszej ksiażzi. Prawo rzymskie powoływane było przez law lords $\mathrm{w}$ ich orzeczeniach w różnorakim kontekście. Po pierwsze odwoływano sie do niego jako do swoistego autorytetu rozumianego jednak w wieloraki sposób.

Jedna $z$ bardziej charakterystycznych spraw, w których sędziowie powołali się na autorytet prawa rzymskiego, jest sprawa $z$ roku 1914 Hammerton \& Co. $v$. Earl of Dysart ${ }^{382}$. Jej stan faktyczny dotyczył przywileju przeprawy promowej na Tamizie, do świadczenia której uprawniony był Earl of Dysart, a samo uprawnienie wykonywał jego dzierżawca. W roku 1912 ukończona została budowa nowego połączenia promowego znajdujaccego się nieopodal dotychczasowego. Zdaniem Earl of Dysart było to naruszenie posiadanych przez niego uprawnień nadanych mu w drodze królewskiego przywileju.

${ }^{382}$ Hammerton \& Co. v. Earl of Dysart [1916] 1 A.C. 57. 
Orzekający $^{383} \mathrm{w}$ sprawie Viscount Haldane, L.C. ${ }^{384}$ dostrzegł, że źródła królewskiego przywileju sa takie same jak przywilejów dotyczacych organizowania dni targowych. Lord prawa przywołał $\mathrm{w}$ zwiąku $\mathrm{z}$ tym fragment $\mathrm{z}$ orzeczenia sędziego Wilmota w sprawie Rex $v$. Marsden $z$ roku 1765: „the reason why a market or fair cannot be holden without a grant is not merely for the sake of promoting traffic and commerce; but also, for the like reason as in the Roman law, for the preservation of order, and prevention of irregular behaviour; $u b i$ est multitudo, ibi debet esse rector" ${ }^{385}$. Określenie "as in the Roman law" budzi uzasadnione wątpliwości. Powyższa maksyma nie występuje bowiem w Corpus Iuris Civilis. W law report nie została $z$ kolei opatrzona żadną wskazówka, skąd mogła zostać zaczerpnięta. Wydaje się, iż źródeł jej powstania można dopatrywać się nie w źródłach prawa rzymskiego, lecz w $A b$ urbe condita Liwiusza. Rzymski historyk przytoczył treść s.c. de Bacchanalibus z roku 186 p.n.e. Zdanie autorstwa Liwiusza - „et ubicumque multitudo esset, ibi et legitimum rectorem multitudinis censebant esse debere" ${ }^{386}$ - jest niezwykle podobne do sformułowania wykorzystanego w XVIII w. przez sędziego Wilmota. Warto nadmienić jednak, iż pochodzi ono $z$ fragmentu pracy Liwiusza, w którym historyk opisuje odnoszące sie do kwestii ustrojowych zwyczaje przodków - maiores. W tym względzie można dopatrywać się elementów prawa rzymskiego.

${ }^{383} \mathrm{Na}$ gruncie niniejszej pracy pojęcia „wyrok” oraz „orzeczenie” będa używane w następujących znaczeniach: wyrok (ang. judgement) oznacza zasadę prawna wypracowana wspólnie przez wszystkich orzekających lordów prawa, zaś orzeczenie (ang. opinion) to argumentacja zestawiona ze stanem faktycznym sprawy prezentowana przez każdego $z$ lordów $z$ osobna. Większość zbieżnych orzeczeń w danej sprawie daje podstawę do wydania wyroku. Należy ponadto dodać, iż w trakcie obrad Izby Lordów kolejność prezentowanych orzeczeń uzależniona była od starszeństwa lordów, nie zaś od prezentowanych przez nich opinii.

${ }^{384} \mathrm{Na}$ temat postaci Lorda Kanclerza Haldane'a zob. J.G. Hall, D. F. Martin, Haldane. Statesman, Lawyer, Philosopher, Chichester 1996, s. 165-179. ${ }^{385}$ Hammerton \& Co. v. Earl of Dysart [1916] 1 A.C. 57, 68. Cytat za Rex v. Marsden (1765) 3 Burr 1812, 1818; 97 Eng. Rep. 1113, 1116. ${ }^{386}$ Liv. 39, 15, 11. 
Wkrótce po wydaniu powyższego orzeczenia, w roku 1916, autorytet prawa rzymskiego powołany został przez lordów prawa w sprawie Admiralty Commissioners v. S.S. Amerika ${ }^{387}$ dotyczącej odpowiedzialności deliktowej. $Z$ łodzia podwodną Królewskiej Marynarki Wojennej zderzył się prywatny statek. Okręt zatoną i niemal wszyscy członkowie jego załogi zginęli. Komisarze Admiralicji wnieśli do sądu pozew. Właściciel parowca zgodził się pokryć koszty 95\% odszkodowania zgodnie $z$ wyliczeniami dokonanymi przez sama Admiralicję. Ta jednak domagała się dodatkowo skapitalizowanej sumy zapomóg wypłacanych na rzecz bliskich ofiar.

W rezultacie sprawa trafiła do Izby Lordów. Do problematyki prawa rzymskiego nawiazali prawnicy reprezentujący Admiralicję. Odwołali się oni do orzeczenia autorstwa Lorda Ellenborough wydanego $\mathrm{w}$ precedensowej sprawie Baker $v$. Bolton $^{388}$. Zanegowali słuszność argumentów użytych przez sędziego. Pośród trzech głównych zarzutów, jakie zostały podniesione, dwa zasługuja na szczególna uwagę. Prawnicy starali się przekonać lordów prawa, iż Lord Ellenborough błędnie zrozumiał i zastosował maksymę actio personalis cum persona moritur ${ }^{389}$. Ponadto wytknęli sędziemu, iż ten odwołał się do autorytetu prawa rzymskiego, choć nie było ku temu przesłanek.

Powyżej przedstawione zarzuty skłoniły Lorda Parkera of Waddington do podjęcia polemiki $z$ pełnomocnikami strony apelującej. Sędzia nie podzielił ich przekonań, stwierdził natomiast, iż zakres stosowania zasady actio personalis cum per-

${ }^{387}$ Admiralty Commissioners v. Owners of the S.S. Amerika [1917] A.C. 38 .

${ }^{388}$ Baker v. Bolton [1808] 1 Camp. 493; 170 Eng. Rep. 1033. Ostatnio na temat orzeczenia zob. P. Handford, Lord Campbell and the Fatal Accidents Act, LQR 129 (2013), s. 424-432.

${ }^{389} \mathrm{Na}$ temat rozwoju historycznego zasady actio personalis cum persona moritur zob. J. Halberda, Dzieje doktryny actio personalis cum persona moritur w angielskim common law, [w:] W. Uruszczak, D. Malec, M. Mikuła (red.), Krakowskie studia $z$ historii państwa i prawa, vol. 3, Kraków 2010, s. 37-49. 
sona moritur musiał być dobrze znany Lordowi Ellenborough, skoro reguły odnoszace się do jej wykorzystania sformułowane zostały znacznie wcześniej. Lord Parker wskazał, iż doprecyzowanie wspomnianych reguł nastapiło w sprawie Higgins $v$. Butcher, która rozpatrywana była przez Sąd Ławy Królewskiej już w roku 1607. Trzeba podnieść zaś, że sama zasada występuje w angielskim obrocie prawnym co najmniej od XII bądź XIII wieku. Początkowo była ogólną zasada, wedle której wraz $z$ chwila śmierci uprawnionego lub zobowiazanego wygasały wszystkie potencjalne roszczenia, tak przysługujace jemu, jak i przeciwko niemu. $Z$ czasem zasada ta doznała jednak ograniczeń, które sprawiły, że na regułę można było powoływać się zasadniczo jedynie w odniesieniu do roszczeń deliktowych ${ }^{390}$.

Gdy chodzi o prawo rzymskie, Lord Parker stwierdził, iż nie znajduje żadnych argumentów, na podstawie których można byłoby sądzić, że prawo rzymskie leży u genezy omawianej zasady ${ }^{391}$. Wypowiedź sędziego zdaje się tym razem nazbyt kategoryczna. Analiza raportu sadowego zachowanego w sprawie Baker $v$. Bolton nastręcza bowiem pewnych trudności. Sprawozdanie zawarte w English Reports, w porównaniu $z$ innymi umieszczonymi w tym zbiorze orzeczeniami, jest wyjątkowo krótkie. Zamyka się ono zaledwie w kilku zdaniach i bardziej przypomina raporty sądowe pochodzace $z$ XVII bądź początków XVIII wieku aniżeli sprawozdanie sprawy, która była przedmiotem orzekania w XIX wieku. Po przedstawieniu stanu faktycznego, sprawozdawca oznajmił, iż Lord Ellenborough stwierdził: „in a civil Court, the death of a human being could not be complained as an injury". Przedmiotem sporów pozostawało w angielskiej literaturze i orzecznictwie użycie sformułowania civil court. Sugerowano bowiem, iż oznaczać miałoby ono odwołanie się angielskiego sędziego do tradycji prawa rzymskiego.

Najobszerniej na ten temat wypowiedział się Sir W.S. Holdsworth, który w artykule z 1916 r. - wydanym jeszcze przed

390 Ibidem, s. 47.

${ }^{391}$ Admiralty Commissioners v. S.S. Amerika [1917] A.C. 38, 43-44. 
ogłoszeniem wyroku w sprawie Admiralty Commissioners $v$. Owners of the S.S. Amerika - opowiedział się za angielskim pochodzeniem zasady ${ }^{392}$. Co ciekawe jednak, sędzia Kennedy, orzekający w sprawie statku Amerika w Sązie Apelacyjnym, pośrednio zasugerował rzymskie pochodzenie reguły ${ }^{393}$, którego dopatrzył się $\mathrm{w}$ passusie pochodzacym od Ulpiana komentującego postanowienia edyktu dotyczące zobowiązania jak gdyby $z$ deliktu effusum vel deiectum - in homine libero nulla corporis aestimatio fieri potest ${ }^{394}$.

Poszukujac rozwiąań paralelnych w prawie rzymskim i angielskim, wskazać można także rzymską regułę prawa deliktowego, zgodnie $z$ która dziedzic nie był zobowiązany do spłacania kar prywatnych nałożonych na spadkodawcę, gdyż te miały charakter ściśle osobisty ${ }^{395}$. Wydaje się zatem, iż należy dziś przyznać rację W.W. Bucklandowi i A.D. MacNairowi, którzy kilkadziesiąt lat po wydaniu orzeczenia w sprawie Admiralty Commissioners v. Owners of the S.S. Amerika stwierdzili, że przedmiotowa maksyma nie pochodzi $z$ prawa rzymskiego, choć istniały w nim pewne regulacje, które mogłyby takie pochodzenie sugerować ${ }^{396}$.

$\mathrm{Na}$ marginesie powyższych rozważań można brać pod uwagę inne jeszcze wyjaśnienie użycia przez Lorda Ellenborough terminu civil court. Ze względu na jego wykorzystanie $\mathrm{w}$ orzeczeniu sadowym, naturalne było łączenie tego termi-

${ }^{392}$ W.S. Holdsworth, The Origin of the Rule in Baker v. Bolton, LQR 32 (1916), s. 431-437. Na ten temat negatywnie zob. także F.P. Walton, Actio personalis and the French Law, Journal of Comparative Legislation and International Law 18 (1936), s. 40-59, w szczeg. 43.

${ }^{393}$ The Amerika [1914] P. 167, 185.

${ }^{394}$ D. 9, 3, 1, 5 (Ulpianus libro vicensimo tertio ad edictum). W polskiej literaturze na temat wskazanego jak gdyby deliktu zob. T. Palmirski, Obligationes quasi ex delicto. Ze studiów nad źródłami zobowiazań $w$ prawie rzymskim, Kraków 2004, s. 84-98.

${ }^{395}$ Por. I. 4, 12, 1. Więcej na ten temat zob. E. Żak, Niedziedziczność pasywna skarg wynikajacych $z$ deliktów $w$ rzymskim prawie klasycznym, [w:] A. Dębiński, M. Wójcik, Współczesna romanistyka prawnicza w Polsce, Lublin 2004, s. 353-365.

${ }^{396}$ W.W. Buckland, A. MacNair, Roman Law and Common Law..., s. 416. 
nu $z$ civil law. Możliwe jednak, iż termin ten zastosowany został przez sędziego w znaczeniu „cywilizowanego”, bądź „sprawiedliwego" sądu, a takie znaczenie można przypisać słowu civil w języku angielskim, którym posługiwano się na początku XIX w.

W odniesieniu do tego samego zagadnienia wypowiedział się również inny z orzekających w sprawie sędziów - Lord Sumner ${ }^{397}$. W swym orzeczeniu przywołał on sprawę Armsworth v. South Eastern Railway Company ${ }^{398}$ z roku 1847. Orzekający w niej sędziowie podkreślili między innymi, że niemożliwe jest dokonanie oszacowania wartości ludzkiego życia. Lord Sumner komentując ten passus zauważył, iż wprawdzie niektóre osoby starają się dowieść rzymskiego rodowodu omawianej zasady, w tym odwołujac się do porównania wartości niewolnika i życia osoby wolnej, niemożliwe jest jednak dziś udowodnienie starożytnego pochodzenia reguły actio personalis cum persona moritur. Choć lord prawa nie wyjaśnił, o czyich rozważaniach wspomina w swym orzeczeniu, wydaje się, iż nawiazal on do pracy Sir W.S. Holdswortha. Angielski historyk prawa reagujac na orzeczenie sędziego Kennedy'ego w sprawie Amerika rozstrzyganej w Sądzie Apelacyjnym podkreślił, że niemożliwość oszacowania wartości człowieka wolnego, o której wspominał Ulpian („in homine libero nulla corporis aestimatio fieri potest') stanowiła podkreślenie różnicy między człowiekiem wolnym a niewolnikiem, a zatem podmiotem i przedmiotem prawa.

Powyższe romanistyczne rozważania stanowiły, jak wskazano, odpowiedź sędziów na uwagi poczynione przez pełnomocników Admiralicji. Stąd niemożliwe było, aby prawo rzymskie wpłynęło na ostateczny kształt wyroku, szczególnie

${ }^{397}$ Na temat działalności Lorda Sumnera jako lorda prawa zob. A. Lentin, The Last Political Law Lord: Lord Sumner (1859-1934), Newcastle upon Tyne 2008, s. 51-55.

${ }^{398}$ Armsworth v. South Eastern Railway Company (1847) 11 Jur. 758, 759. 
że lordowie prawa potwierdzili stosowanie zasady actio personalis cum persona moritur ${ }^{399}$.

Niecały rok później, w maju 1917 roku, do prawa rzymskiego odwołał się Lord Kanclerz Finlay w sprawie Dickson v. National Bank of Scotland ${ }^{400}$. Dotyczyła ona depozytu bankowego złożonego w Narodowym Banku Szkocji w interesie spółki, w obrębie której doszło $z$ czasem do przeobrażeń podmiotowych. Ostatecznie powstało zatem pytanie, na rzecz kogo powinien zostać wypłacony depozyt złożony uprzednio $\mathrm{w}$ banku. Jednym $\mathrm{z}$ kluczowych zagadnień w przedmiotowej sprawie było ustalenie sposobu interpretacji sekcji 38 Partnership Act 1890 401 , która stanowiła o możliwej ciagłości uprawnień dawnych wspólników w sytuacji, gdy chodziłoby o dobro spółki bądź wykonanie zaciagniętych przez nia zobowiazań. Zdaniem Lorda Kanclerza postanowienia sekcji 38 stanowią bezpośrednia kontynuację rozwiązań prawnych zaproponowanych przez rzymskich jurystów ${ }^{402}$. Sędzia wskazał, że Sir Frederick Pollock w komentarzu do ustawy powołał passus autorstwa Paulusa ${ }^{403}$. Rzymski jurysta wypowiadając się na temat konstrukcji negotiorum gestio, na uboczu swych głównych rozważań wskazał, iż w razie śmierci jednego ze wspólników czynności prawne rozpoczęte za jego życia moga zostać zakończone, gdyż zasadniczym jest moment ich podjęcia, a nie zakończenia („quo tempore consummentur, sed quo tempore inchoarentur"). Sir F. Pollock przywołał w swym komentarzu jedynie pierwszą część wspomnianego tekstu Paulusa, która odnosi się do prowadzenia cudzych spraw bez zlecenia. Lord Kanclerz nie poprzestał jednak w swojej anali-

${ }^{399} \mathrm{Na}$ marginesie romanistycznych rozważań można zauważyć, iż sędziowie Izby odwołali się dodatkowo w swojej argumentacji do doktryny znikomości (doctrine of remoteness), wskazując że Admiralicja nie mogła żądać pokrycia przez właściciela statku kosztów wypłacenia dobrowolnych zapomóg na rzecz rodzin ofiar.

400 Dickson v. National Bank of Scotland 1917 S.C. (H.L.) 50.

${ }^{401}$ Partnership Act 1890 (53 \& 54 Vict., c. 39).

402 Dickson v. National Bank of Scotland 1917 S.C. (H.L.) 50, 54.

${ }^{403}$ D. 3, 5, 20, 2 (Paulus libro nono ad edictum). 
zie tekstu Paulusa jedynie na fragmencie zacytowanym przez F. Pollocka, gdyż wyraźnie odwołał się do śmierci wspólnika. Wydaje się zatem, iż angielski sędzia korzystał $z$ pełnego wydania Digestów justyniańskich.

Wypada stwierdzić jeszcze, że hipoteza o rzymskim pochodzeniu regulacji zawartej w sekcji 38 Partnership Act 1890, stawiana ostrożnie przez F. Pollocka i dużo bardziej zdecydowanie przez Lorda Finlaya, powinna być potraktowana $z$ rezerwą. Brak bowiem jakichkolwiek dowodów mogących świadczyć o recypowaniu opinii Paulusa do tekstu brytyjskiej ustawy. Jest to raczej przykład nierzadkiego zjawiska wypracowywania podobnych czy wręcz analogicznych rozwiązań prawnych przez prawników żyjących w innych epokach i działających w obrębie różnych systemów prawnych.

Warto w tym miejscu wskazać inne, dosyć przypadkowe, odwołanie się przez sędziego Izby Lordów do konstrukcji negotiorum gestio. W roku 1989 rozpatrywana była przez Komitet Apelacyjny sprawa In re F. (Mental patient: sterilisation) ${ }^{404}$. Dotyczyła ona trzydziestosześcioletniej kobiety cierpiącej na poważne zaburzenia psychiczne. W trakcie pobytu w szpitalu psychiatrycznym kobieta nawiązała bliska relację $z$ mężczyzna chorym na schizofrenię. W obawie przed możliwościa zajścia kobiety w ciążę, dyrekcja szpitala uznała, iż chroniąc interesy pacjentki należałoby poddać ja zabiegowi sterylizacji. Sprawująca nad kobietą opiekę jej matka uznała wniosek szpitala za zasadny i wniosła do sądu o wydanie stosownego sądowego pozwolenia na dokonanie zabiegu. W trakcie postępowania podniesiono jednak, czy rzeczywiście dokonanie tak inwazyjnej operacji bez zgody chorej kobiety może być uznane za działanie w jej najlepszym interesie.

Lord Goff of Chieveley odniósł się do autorytetu prawa rzymskiego tylko raz. Rozważajac kwestię nadzwyczajności przeprowadzenia zabiegu sterylizacji, lord prawa stwierdził, iż co do zasady zawsze powinno się uczynić wszystko, ażeby uzyskać zgodę takiej osoby. Sama przesłanka nagłości

${ }^{404}$ In re F. (Mental patient: sterilisation) [1990] 2 A.C. 1. 
(emergency) nie powinna uzasadniać podjęcia tak dalekich w swych konsekwencjach działań. Niemniej w pewnych okolicznościach konsultacja $z$ osoba, której interes prawny ma być chroniony, nie jest możliwa; w takiej sytuacji wystapienie bądź nie „przesłanki nagłości” jest bez znaczenia dla dalszych działań. Jako przykład ilustrujacy sytuację tego rodzaju prawnik wskazał, że „the old Roman doctrine of negotiorum gestio presupposed not so much an emergency as a prolonged absence of the dominus from home as justifying intervention by the gestor to administer his affairs" 405 . Trzeba przyznać rację sędziemu, iż w tekstach jurystów rzymskich dotyczących prowadzenia cudzych spraw bez zlecenia podkreśla sie jako główną okoliczność nieobecność zainteresowanego w miejscu dokonywania czynności prawnej. Wypada jednak zauważyć, że w źródłach można odnaleźć także wskazania dotyczące konieczności (necessitas) prowadzenia spraw w cudzym imieniu. Konieczność ta może być zaś uznana za tożsamą z przesłanka nagłości, która była przedmiotem rozważań Lorda Goff of Chieveley. Jako przykład posłużyć może fragment komentarza Ulpiana do edyktu, w którym rzymski prawnik wskazuje, że skarga $z$ tytułu negotiorum gestio przysługuje nie tylko przeciwko temu, kto samowolnie podejmuje prowadzenie cudzych spraw, lecz także przeciwko takim osobom, które czynia to $z$ wielkiej konieczności (necessitas urgens) bądź sa mylnie przekonane o wystapieniu takiej wielkiej konieczności ${ }^{406}$.

Angielskie odwołania do rzymskiej negotiorum gestio - jak miało to miejsce $\mathrm{w}$ przedstawionym kazusie - zawsze zdaja się trudne do jednoznacznej oceny. Pamiętać trzeba bowiem, iż prawo angielskie stoi zasadniczo na stanowisku odrzucania koncepcji prowadzenia cudzych spraw bez zlecenia. Tylko w wyjatkowych sytuacjach recepcja rzymskiej konstrukcji została dopuszczona ${ }^{407}$.

${ }^{405}$ In re F. (Mental patient: sterilisation) [1990] 2 A.C. 1, 74-75.

${ }^{406}$ D. 3, 5, 3, 10 (Ulpianus libro decimo ad edictum).

${ }^{407}$ Więcej na ten temat J. Halberda, Historia zobowiazań..., s. 324-325. 
Odwołanie się do autorytetu prawa rzymskiego miało również miejsce $\mathrm{w}$ roku $2000 \mathrm{w}$ sprawie Foskett $v$. Mc Keown ${ }^{408}$, w której sędziowie rozstrzygnęli spór dotyczący konkurencji skarg $z$ tytułu niesłusznego wzbogacenia oraz prawa własności ${ }^{409}$.

W roku 1986 Timothy Murphy wykupił polisę ubezpieczeniowa, której wartość wynosiła milion funtów. Jednocześnie zobowiązał się do wpłacania raz do roku składki ubezpieczeniowej w wysokości 10.220 funtów. Stosowne składki wpłacane były w kolejnych latach od roku 1986 do roku 1990. Tymczasem, w roku 1988 T. Murphy stał się udziałowcem angielskiej spółki, która wraz z portugalskim partnerem prowadziła obrót nieruchomościami. Klienci spółki zainteresowani nabyciem nieruchomości wpłacali na rachunek bankowy specjalnie w tym celu utworzonego trustu określona sumę pieniędzy, która wykorzystywana była do zagospodarowania terenu pod inwestycję. Jeśli po upływie dwóch lat nieruchomość nie została zagospodarowana (tak się stało w przedmiotowej sprawie), klienci mieli odzyskać wpłacone pieniądze wraz $z$ odsetkami. Gdy projekt brytyjsko-portugalskiej inwestycji upadł, klienci spółki zażądali zwrotu wpłaconych przez siebie pieniędzy. Okazało się jednak, iż $z$ funduszu trustu zniknęło 20.440 funtów. Zostały one przeznaczone na opłacenie przez T. Murphy'ego dwóch składek na rzecz firmy ubezpieczeniowej w roku 1989 oraz 1990. W marcu 1991 roku sam T. Murphy popełnił samobójstwo, zaś ubezpieczyciel wypłacił jego żonie i dzieciom kwotę 1.000.580,04 funtów. Wierzyciele wystąpili z żądaniem wypłacenia im 40\% wartości polisy, uznając, iż skoro ich pieniądze zostały wykorzystane na opłacenie dwóch składek ubezpieczeniowych, stali się oni tym samym beneficjentami polisy. Sąd Apelacyjny orzekł, iż

${ }^{408}$ Foskett v. McKeown [2001] 1 A.C. 102. W polskiej literaturze zob. Ł.J. Korporowicz, Prawo rzymskie w wybranych orzeczeniach Izby Lordów w latach 1999-2009, Z Dziejów Prawa 4/ 12 (2011), s. 286-288.

${ }^{409}$ Zob. G. Virgo, Vindicating vindication: Foskett $v$. McKeown reviewed, [w:] A. Hudson (ed.), New Perspectives on Property Law, Obligations and Restitution, London 2004, s. 203. 
wierzycielom powinna zostać wypłacona suma jedynie 20.440 funtów sprzeniewierzonych przez zmarłego oraz naliczone od tej kwoty odsetki. Rodzina zmarłego uzyskała bowiem tę część polisy na skutek niesłusznego wzbogacenia.

Romanistyczna argumentacja została niespodziewanie zastosowana przez Lorda Hoffmanna, który komentujac propozycję innego sędziego stwierdził, że opisywany stan faktyczny można uznać za mixed substitution. Jest to konstrukcja występująca na gruncie equity, która ujmowana jest jako zmieszanie środków finansowych w części pochodzących od beneficjentów trustu, w części natomiast od trustees ${ }^{410}$. Sędzia uznał, iż rzymscy juryści potraktowaliby tę konstrukcję za przykład confusio ${ }^{41}$. $Z$ opinia taka nie zgodził się jednak szkocki sędzia - Lord Hope of Craighead, który podkreślił, że juryści w starożytnym Rzymie pojęcia zmieszania rzeczy używali w odmiennym kontekście aniżeli zaproponowany przez Lorda Hoffmanna. Szkocki sędzia podniósł, iż terminy confusio oraz commixtio stosowane były na oznaczenie trudności związanych ze zmieszaniem bądź zlaniem rzeczy ruchomych. Lord prawa poparł swoja tezę, wskazując na odpowiedni fragment pochodzacy $z$ Instytucji Justyniana ${ }^{412}$. Kontynuując, sędzia podniósł dodatkowo, iż na gruncie prawa rzymskiego powyższe pojęcia łączyć można byłoby raczej $z$ zasada accessorium principale sequitur ${ }^{413}$. Sędzia wymienił poszczególne rodzaje akcesji znane rzymskim jurystom: złączenie ruchomości $z$ nieruchomościa, ruchomości $z$ ruchomością, nieruchomości $z$ nieruchomością. Odwołanie Lorda Hope do problematyki akcesji znajduje uzasadnienie

${ }^{410}$ G. Watt, Equity and Trusts Law, ed. 3, Oxford 2012, s. 414.

${ }^{411}$ Foskett v. McKeown [2001] 1 A.C. 102, 116.

${ }^{412}$ I. 2, 1, 27-28.

${ }^{413}$ Maksyma podana przez Lorda Hope stanowi skrócona wersję paremii accessorium non ducit, sed sequitur suum principale stworzonej przez Edwarda Coke'a na podstawie wcześniejszej tradycji prawa angielskiego oraz w nawiazaniu do popularnej w kręgu tradycji kontynentalnej paremii accessio cedit principali opartej na fragmencie autorstwa Ulpiana zawartym w D. 34, 2, 19, 13. 
jedynie w przypadku złączenia dwóch ruchomości. Pozostałe wymienione przypadki służyły jedynie ukazaniu erudycji szkockiego lorda prawa ${ }^{414}$.

Niezależnie od powyższego warto zauważyć, że krytyka autorstwa Lorda Hope - co podniósł w swym artykule James Lee - oparta została nie tylko na błędnym wykorzystaniu pojęcia confusio przez Lorda Hoffmana, lecz odnosiła się także do istoty omawianego problemu ${ }^{415}$. Zmieszanie rzeczy w prawie rzymskim zakładało bowiem ich materialny charakter, zaś przedmiotem analizowanej sprawy było zmieszanie ekwiwalentów środków pieniężnych na kontach bankowych, co powinno być traktowane jako zmieszanie rzeczy niematerialnych. Ponadto, na co także zwrócił uwagę J. Lee, rzymscy prawnicy spierali się co do możliwości zmieszania się pieniędzy i powstania w ten sposób współwłasności ${ }^{416}$.

Szkocki law lord zauważył, iż „problems relating to rights arising out of payments made by the insurers under the policy would have belonged in Roman law to the law of obligations, and it is likely that the remedy would have been found in the application of an appropriate condictio"417. Koncząc swoje romanistyczne rozważania, Lord Hope powrócił do problematyki akcesji w prawie rzymskim, przytaczajac znany z Digestów kazus dotyczący własności obrazu ${ }^{418}$. Odmienne poglądy Gaiusa ${ }^{419}$ i Paulusa ${ }^{420}$ dotyczyły własności obrazu namalowanego na cudzym materiale. Według Paulusa namalowany obraz stawał się własnością tego, kto był właścicielem

${ }^{414}$ Por. W.W. Buckland, A Text-book of Roman Law: From Augustus to Justinian, ed. 3, rev. P. Stein, Cambridge 1963, s. 209.

$415 \mathrm{~J}$. Lee, Confusio: Reference to Roman Law in the House of Lords and the Development of English Private Law, Roman Legal Tradition 5 (2009), s. 45.

${ }^{416}$ Ibidem.

${ }^{417}$ Foskett $v$. McKeown [2001] 1 A.C. 102, 121.

${ }^{418}$ Foskett $v$. McKeown [2001] 1 A.C. 102, 122.

419 D. 41, 1, 9, 2 (Gaius libro secundo rerum cottidianarum sive aureorum).

${ }^{420}$ D. 6, 1, 23, 3 (Paulus libro 21 ad edictum). 
pokrytego farba podłoża obrazu, zdaniem Gaiusa zaś obraz stawał się własnościa jego twórcy.

Powyższe rozważania nie przyniosły wymiernych efektów w kontekście wydania ostatecznej decyzji przez lordów prawa. Stanowiły one jedynie reakcję Lorda Hope na błędne powołanie rzymskiej instytucji prawnej przez Lorda Hoffmanna. W odniesieniu zaś do meritum sprawy, większość lordów potwierdziła wcześniejszy wyrok Sąu Apelacyjnego i nakazała zwrot równowartości sprzeniewierzonych środków finansowych wierzycielom zmarłego.

Należy zauważyć, iż znaczący odsetek powołań prawa rzymskiego dokonywanych przez sędziów Izby Lordów służył jedynie wykazaniu ich znajomości obcego prawa i podkreśleniu ich wszechstronnego, erudycyjnego wykształcenia. W roku 1999, na przykład, Lord Hoffmann w sprawie O'Neill v. Phillips ${ }^{421}$ wskazal, że pojęcie company (spółka prawa handlowego) wyrosło na drodze długiego procesu ewolucji z konstrukcji nazywanej partnership (spółka prawa cywilnego) opartej na zasadach słuszności (equity), podobnie jak rzymska societas, powstajaca w drodze kontraktu bonae fidei ${ }^{422}$. Ponadto sędzia przywołał precedens $z$ roku 1853 Blisset $v$. Da$n^{n i e}{ }^{423}$, w treści którego odnaleźć można fragment pochodzący $z$ tytułu De societate Instytucji justyniańskich ${ }^{424}$.

Także w rozpatrywanej w roku 2004 sprawie $R$. v. Immigration Officer at Prague Airport ${ }^{425}$ law lords odnieśli się do pojęć prawa rzymskiego, jednak bez skutku dla ostatecznego rozstrzygnięcia sprawy. Stan faktyczny dotyczył odmowy udzielenia pozwolenia na wjazd do Wielkiej Brytanii sześciu obywatelom czeskim romskiego pochodzenia. Decyzję wydał

${ }^{421}$ O'Neill v. Phillips [1999] 1 W.L.R. 1092.

422 O'Neill $v$. Phillips [1999] 1 W.L.R. 1092, 1098. Na temat rzymskich korzeni angielskiego prawa spółek zob. T.E. Scrutton, The Influence..., s. $159-161$.

${ }^{423}$ Blisset v Daniel (1853) 10 Hare. 493; 68 Eng. Rep. 1022.

${ }^{424}$ I. 3, 25, 4; Blisset v. Daniel (1853) 10 Hare. 493,523; 68 Eng. Rep. $1022,1035$.

${ }^{425}$ R. v. Immigration Office at Prague Airport [2005] 2 W.L.R. 1. 
brytyjski urzędnik imigracyjny pracujący na lotnisku w Pradze. Przypadkiem sześciu Romów zainteresowała się organizacja pozarządowa $z$ siedziba $w$ Budapeszcie, której celem była ochrona praw osób pochodzenia romskiego. Zdaniem jej przedstawicieli władze brytyjskie, reprezentowane przez urzędnika imigracyjnego, naruszyły postanowienia międzynarodowej konwencji o statusie uchodźców z roku 1951, której sygnatariuszem było Zjednoczone Królestwo.

Do problematyki prawa rzymskiego odwołał się w swym orzeczeniu Lord Hope of Craighead, który zwrócił uwage na fakt, że Lord Lester - barrister reprezentujący organizację pozarządowa oraz Romów, uznał działania urzędnika imigracyjnego za naruszające powszechnie obowiazujaca w prawie międzynarodowym zasadę dobrej wiary. Szkocki sędzia zauważył, iż należy zgodzić się z opinia pełnomocnika. Dodał jednocześnie, że wprawdzie $\mathrm{w}$ analizowanej sprawie termin "dobra wiara" - bona fides został użyty w odniesieniu do stosunków międzynarodowych, to jednak dla pełnego zrozumienia konieczne jest wskazanie jego prywatnoprawnego pochodzenia. Lord Hope wyjaśnił, że współczesną teorię prawa umów można wywieść $z$ rzymskich kontraktów konsensualnych, które opierały się na zasadzie dobrej wiary ${ }^{426}$. Poszukując potwierdzenia dla swojego przekonania, sędzia odwołał się do pierwszego wydania fundamentalnej pracy niemieckiego historyka prawa R. Zimmermanna na temat rzymskich zobowiązañ ${ }^{427}$. Na uwagę zasługują dalsze rozważania lorda prawa. W jego przekonaniu znaczenie zasady dobrej wiary jest różne w różnych systemach prawnych - od jej pełnego zaakceptowania w systemach opartych na prawie rzymskim, aż po jej brak w systemach common law. Wyraźna ilustrację tak zarysowanego stanowiska odnaleźć można w dalszej części orzeczenia Lorda Hope, gdzie sędzia wskazał na trwała obecność zasady dobrej wiary w szkockiej kulturze prawnej

${ }^{426}$ R. v. Immigration Office at Prague Airport [2005] 2 W.L.R. 1, 36.

${ }^{427}$ R. Zimmermann, The Law of Obligations. Roman Foundation of the Civilian Tradition, Deventer 1992, s. 674. 
i jej brak w prawie angielskim ${ }^{428}$. Pozostajac w kręgu problematyki Scots law, sędzia dodał za H. MacQueenem, że zasada bonae fidei traktowana jest przez prawników szkockich jako podstawowa reguła służąca wyjaśnianiu oraz sankcjonowaniu umów. W ten sposób miałaby ona charakter następczy, nie wiazałaby się natomiast $z$ samym zawarciem kontraktu ${ }^{429}$. Szkocki sędzia zauważył, że powyższe rozważania H. MacQueena śmiało przyrównać można do sposobu postrzegania przedmiotowej zasady przez Rzymian.

Przechodząc na grunt prawa rzymskiego sędzia przywołał kluczowy dla starożytnych podział zobowiązań, a co za tym idzie także skarg na skargi bonae fidei oraz stricti iuris ${ }^{430}$. Jako źródło swej romanistycznej wiedzy Lord Hope wskazał podręcznik W.W. Bucklanda ${ }^{431}$. Trzeba przyznać rację sędziemu, posługującemu się technicznym zwrotem bonae fidei iudicia, iż zasada dobrej wiary miała istotne znaczenie dla sposobu prowadzenia przez Rzymian procesu prywatnego i w znacznej mierze rzutowała na sposób konstruowania formułki procesowej w tzw. postępowaniu formułkowym. Wydaje się jednocześnie, że lord prawa nazbyt uprościł omawiana problematykę. Pamiętać trzeba, że choć zasada bonae fidei faktycznie znajdowała zastosowanie przede wszystkim w odniesieniu do ewentualnych roszczen, to jednak w immanentny sposób związana była również $z$ samą istota kontraktów konsensualnych.

Powyższe rozważania zdaja się być zbytecznym dodatkiem, niewiele wnoszacym do interpretacji rozpatrywanego kazusu. Genezy zasady dobrej wiary na gruncie prawa międzynarodowego należy bowiem poszukiwać w rozważaniach autorów XVI-XVIII w., którzy położyli fundamenty pod rozwój tej gałęzi prawa.

${ }^{428}$ R. v. Immigration Office rat Prague Airport [2005] 2 W.L.R. 1, 36-37.

${ }^{429}$ H. MacQueen, Delict, Contract, and the Bill of Rights: A Perspective from the United Kingdom, South African Law Journal 121 (2004), s. 382.

${ }^{430}$ R. v. Immigration Office rat Prague Airport [2005] 2 W.L.R. 1, 37.

${ }^{431}$ W.W. Buckland, A Text-book of Roman Law from Augustus to Justinian, ed. 2, Cambridge 1932, s. 678, 704. 
Historyczna nieadekwatność podobnych do powyższych rozważań, której nie dostrzegł Lord Hope w swoim orzeczeniu, została podniesiona przez Lorda Rodgera of Earlsferry w rozpatrywanej tego samego roku sprawie $R$. $v$. Secretary of State for the Home Department ${ }^{432}$. Skarżacy zarzucal władzom brytyjskim naruszenie postanowienia art. 7 EKPC, który stanowi, że „nikt nie może być uznany za winnego popełnienia czynu polegającego na działaniu lub zaniechaniu działania, który według prawa wewnętrznego lub międzynarodowego nie stanowił czynu zagrożonego kara w czasie jej popełnienia. Nie będzie również wymierzona kara surowsza od tej, która można wymierzyć w czasie, gdy czyn zagrożony kara został popełniony". Wskazana norma konwencyjna stanowi zatem wyraz znanej powszechnie zasady nulla poena sine lege. Starając się uciąc wszelkie nieuzasadnione interpretacje, szkocki lord prawa wskazał, że chociaż korzeni zasady można dopatrzeć się w pismach autorstwa Bartolusa de Saxoferrato w XIV w. ${ }^{433}$, to jednak jej rozwój datować należy dopiero na wiek XVIII ${ }^{434}$.

Równie mało wnoszące do przedmiotu analizowanej sprawy było powołanie prawa rzymskiego przez Lorda Hoffmanna. Niecały rok po wydaniu dwóch poprzednich rozstrzygnięć, w październiku 2005 roku, law lords zajęli się sporem narosłym między znaną modelką Naomi Campbell a koncernem prasowym MGN ${ }^{435}$. Modelka zarzucała wydawnictwu naruszenie jej prawa do prywatności poprzez publikację zdjęć oraz informacji dotyczących jej domniemanego leczenia odwyko-

\footnotetext{
${ }^{432}$ R. v. Secretary of State for Home Department. Ex parte Uttley [2004] UKHL 38.

${ }^{433}$ Bartolus de Saxoferrato, Commentaria ad digestum vetus, 1, 9, 49-51.

${ }^{434}$ Warto zwrócić jednak uwagę, iż mimo stosunkowo późnego pochodzenia zasady, da się dostrzec także jej rzymska genezę. Jej brzmienie koresponduje bowiem $z$ procesem łagodzenia rzymskich rozwiązań prawnokarnych, dokonywane m.in. w oparciu o ideę humanitas. Więcej na ten temat K. Amielańczyk, Rzymskie prawo karne $w$ reskryptach cesarza Hadriana, Lublin 2006, s. 249-255.

${ }^{435}$ Campbell v. MGN Ltd. [2005] 1 W.L.R. 3394.
} 
wego. Lord Hoffmann - odwołując się do wyroku ETPC dotyczącego niedopuszczalności ograniczania wypowiedzi mediów - wyraził nadzieję, iż wyrok ten nie zostanie potraktowany jako przyzwolenie udzielone mediom na publikowanie oszczerczych tekstów. Sędzia wyraził obawę, że możliwy do przewidzenia jest scenariusz, zgodnie $z$ którym koncerny prasowe, dysponując odpowiednim zabezpieczeniem finansowym, będa celowo wydawały znieważające teksty, uwzględniając przy ich publikacji koszty ewentualnego postępowania i odszkodowania ${ }^{436}$. Gdyby tak istotnie było, sytuacja przypominałaby historię przytoczona przez rzymskiego pisarza Aulusa Gelliusa w jego Noctes Atticae. Rzymski antykwarysta przedstawił postać Lucjusza Veratiusa, który wykorzystując fakt dewaluacji pieniądza przechadzał się po forum i policzkował przypadkowo napotkanych ludzi. Tuż za nim kroczyć miał jego niewolnik, który wypłacał poszkodowanym odliczona kwotę przewidziana przepisami Ustawy XII tablic za najlżejszy przypadek zniewagi ${ }^{437}$.

Uwaga Lorda Hoffmana nic nie wniosła na dalszym etapie rozstrzygania przedmiotowej sprawy, $z$ pewnością może być jednak potraktowana jako dowód gruntownego oczytania sędziego i jego szerokiej wiedzy na temat starożytności i prawa rzymskiego.

Czasami prawo rzymskie powoływane było przez prawników reprezentujących strony oraz przez lordów prawa w zupełnie niezrozumiałych okolicznościach. Odwołania takie służyły jeszcze wyraźniej podkreśleniu jedynie ich wiedzy i być może zaciekawieniu innych uczestników procesu. Pośród takich spraw wymienić można na przykład sprawę Duff Development Co. Ltd. v. Government of Kelantan ${ }^{438}$, gdzie Lord Dunedin rozważając zagadnienia dotyczace arbi-

${ }^{436}$ Campbell v. MGN Ltd. [2005] 1 W.L.R. 3394, 3400.

${ }^{437}$ Gell. 20, 1, 13. Na temat historii Lucjusza Veratiusa i jej analizy prawnej zob. J. Zabłocki, Rozważania o procesie rzymskim $w$ 'Noctes Atticae' Aulusa Gelliusa, Warszawa 1999, s. 66-68.

${ }^{438}$ Duff Development Co. Ltd. v. Government of Kelantan [1924] A.C. 797 . 
trażu wspomniał, iż w prawie rzymskim stawienie się przed arbitrem uniemożliwiało wystąpienie ze skarga przeciwną ${ }^{439}$. $Z$ kolei Lord Evershed w roku 1964 w sprawie Ridge v. Bald$w_{i n}^{440}$ odwołał się do pracy znanego angielskiego prawnika Sir F. Pollocka zatytułowanej History of the Law of Nature ${ }^{441}$ w kwestii jego wypowiedzi na temat naturalnej sprawiedliwości. Wskazał on ${ }^{42}$, iż F. Pollock w swej argumentacji powołał się na Arystotelesa oraz prawników rzymskich. Sędzia nie wyjaśnił jednak, jakie dokładnie odwołania poczynił naukowiec $^{443}$. Kilkanaście lat później, w roku 1976, Izba Lordów rozpatrywała sprawę dotyczącą odpowiedzialności z tytułu utraty bądź zniszczenia rzeczy, objętej w posiadanie przez pośrednika handlowego. Lordowie prawa nie powołali się wprawdzie w sprawie Albacruz $v$. Albazero ${ }^{444}$ na prawo rzymskie, jednak, jak wynika $z$ opisu argumentów wysuwanych przez prawników stron, jeden $z$ nich wskazał ${ }^{445}$, iż wręczenie przewoźnikowi listu przewozowego może być porównane ze znanym $z$ prawa rzymskiego kazusem wręczenia kluczy do magazynu skutkującym nabyciem posiadania znajdujacych się w nim rzeczy ${ }^{446}$.

Nietypowa była również apelacja $R . v$. Bentham ${ }^{447}$ z roku 2005, w której problem prawny wyrażał się w stosunkowo

${ }^{439}$ Duff Development Co. Ltd. v. Government of Kelantan [1924] A.C. 797,821 .

${ }^{440}$ Ridge v. Baldwin [1964] A.C. 40.

${ }^{441}$ F. Pollock, The History of the Law of Nature: A Preliminary Study, Journal of the Society of Comparative Law 2 (1900), s. 418-433.

${ }^{442}$ Ridge v. Baldwin [1964] A.C. 40, 86.

${ }^{443}$ Angielski prawnik skupił się przede wszystkim na przeciwstawieniu terminów ius naturale i ius gentium. Wprawdzie często posługuje się on stwierdzeniem „rzymscy prawnicy”, to jednak w rzeczywistości do konkretnych jurystów odwołał się jedynie dwukrotnie - do Tryphoniana (D. 12, 6, 64) oraz do Ulpiana (D. 1, 1, 1,3). Dodatkowo przywołał definicję prawa natury pochodzaca $z$ De Inventione $(2,161)$ Cycerona.

${ }^{444}$ Albacruz v. Albazero [1977] A.C. 774.

${ }^{445}$ Albacruz v. Albazero [1977] A.C. 774, 839.

${ }^{446}$ I. 2, 1, 45.

${ }^{447}$ R. v. Bentham [2005] 1 W.L.R. 1057. 
prostym pytaniu - czy osoba trzymająca dłoń pod kurtka i udająca, że trzyma w niej broń, może zostać skazana na podstawie przepisów Firearms Act 1968 o posługiwaniu się imitacja broni ${ }^{448}$ ? Sac pierwszej instancji, jak i Sąd Apelacyjny, uznały, że palce schowane pod kurtka moga, szczególnie w sytuacji gdy ktoś jest pod wpływem emocji, być uznane za broń. Rozumowanie to zostało jednak odrzucone przez lordów prawa. Wskazali oni bowiem (główne orzeczenie w sprawie wydał Lord Bingham of Cornhill), iż ustawa mówiąc o imitacji broni, mówi o jej posiadaniu, nie zaś udawaniu, że broń (czy nawet jej imitację) trzyma się w dłoni. $Z$ tego powodu sędziowie jednogłośnie uznali apelację. Lord Rodger of Earlsferry w swoim krótkim, liczacym zaledwie kilka linijek tekstu, orzeczeniu poczynił uwagę natury romanistycznej ${ }^{449}$. Rozpoczał ją od łacińskiego cytatu - „dominus membrorum suorum nemo videtur" - pochodzaccego $z$ dziewiatej księgi Digestów justyniańskich ${ }^{450}$. Wyjaśnił, iż nie tylko nikt nie może zostać uznany za właściciela swoich kości, lecz także nie może zostać uznany za ich posiadacza. $Z$ tego względu argument o posiadaniu palców imitujących broń palną, przedstawiony przez prawników reprezentujących Koronę, został obalony.

W roku 2006 w sprawie North Wales Training and Enterprise Council Ltd $v$. Astley ${ }^{451}$ lordowie analizowali m.in. sposób interpretacji przepisów dyrektywy unijnej dotyczącej praw pracowników zatrudnionych w przedsiębiorstwach, zakładach lub ich częściach, które poddawane były procesowi przejęcia $^{452}$. Lord Rodger oceniając metody interpretacji przepisów dyrektywy wskazał, iż proponowana w przedmiotowej sprawie fikcja prawna odgrywałaby równie spektakularna

${ }^{448}$ Firearms Act 1968, c. 27.

${ }^{449}$ R. v. Bentham [2005] 1 W.L.R. 1057, 1062.

${ }^{450}$ D. 9, 2, 13, pr. (Ulpianus libro 18 ad edictum).

${ }^{451}$ North Wales Training and Enterprise Council Ltd v. Astley [2006] 1 W.L.R. 2420.

${ }^{452}$ Dyrektywa 1977/187/EEC zmieniona dyrektywa 2001/23/EC. 
rolę $\mathrm{w}$ prawie Wspólnot Europejskich, co fikcja na gruncie prawa starożytnych Rzymian ${ }^{453}$.

W tej samej tonacji utrzymana jest uwaga Lady Hale na kanwie rozstrzyganej w roku 2007 sprawy OBG Ltd. v. Al$l e n^{454}$. Sędzia wskazała, iż prawo angielskie nie zna ogólnej skargi rzeczowej, podobnej do rzymskiej rei vindicatio. Zamiast tego zna ono skargi szczegółowe dotyczace konkretnych stanów faktycznych, w których doszło do bezprawnego posłużenia się rzeczą. To krótkie powołanie prawa rzymskiego trzeba ponownie traktować jako erudycyjny ozdobnik bez konsekwencji dla ostatecznego rozstrzygnięcia sprawy.

Wreszcie na rok przed zakończeniem swojej działalności, Komitet Apelacyjny wydał wyrok w sprawie R. $v$. Davies ${ }^{455}$. Dotyczyła ona dopuszczalności zeznań świadków incognito. Troje świadków, obawiając się konsekwencji swoich zeznań, wniosło o dokonanie przesłuchania bez podawania ich danych, nagranie ich zeznań oraz o elektroniczna zmianę głosów. Oskarżony stwierdził, że tego rodzaju działania stanowia naruszenie zasad postępowania karnego, wedle których może on skonfrontować się ze świadkami i przeciwstawić się ich twierdzeniom. Zasada ta, na co wskazał w ślad za oskarżonym Lord Bingham, wywodziła się ze starożytnego Rzymu ${ }^{456}$. Sędzia nie wyjaśnił tej tezy, wskazał jedynie jako jej potwierdzenie dwa amerykańskie orzeczenia. W pierwszym $z$ nich (Coy v. Iowa z 1988 ${ }^{457}$ ) sędzia Antonin Scalia podniósł, iż wyrażona w szóstej poprawce do Konstytucji Stanów Zjednoczonych zasada, zgodnie $z$ którą oskarżony ma prawo skonfrontować się $z$ osobami świadczacymi przeciwko niemu, odwołuje się do początków zachodniej tradycji prawnej. Potwierdzać miałby to fragment pochodzący z Dziejów Apostolskich św. Łukasza, w którym rzymski trybun Festus wyjaśnił królowi Agryppie,

${ }^{453}$ North Wales Training and Enterprise Council Ltd v. Astley [2006] 1 W.L.R. 2420, 2447.

${ }^{454}$ OBG Ltd. v. Allen [2007] 2 W.L.R. 920, 997.

${ }^{455}$ R. v. Davies [2008] 1 A.C. 1128.

${ }^{456}$ R. v. Davies [2008] 1 A.C. $1128,1137$.

${ }^{457}$ Coy v. Iowa 487 U.S. 1012 (1988). 
iż „Rzymianie nie mają zwyczaju skazywania kogokolwiek na śmierć zanim oskarżony nie stanie wobec oskarżycieli i nie będzie miał możności bronienia się przed zarzutami" ${ }^{58}$. Na koniec amerykański sędzia wskazał źródło swojej wiedzy artykuł Daniella H. Pollitta dotyczacy prawa do konfrontowania się ze soba stron ${ }^{459}$. W drugim orzeczeniu (Crawford v. Washington ${ }^{460}$ ) sędzia William Rehnquist przywołał wcześniejsze orzeczenie i raz jeszcze wskazał „rzymskie” źródła gwarancji procesowych.

Powyższe romanistyczne uwagi trudno komentować, gdyż $z$ jednej strony nie wpłynęły one $\mathrm{w}$ ogóle na treść ferowanych wyroków, $z$ drugiej zaś brakuje jednoznacznego kontekstu ich powołania. O wątłości przedstawionych argumentów świadczy ponadto fakt, iż niemal w żadnej z powołanych powyżej spraw nie wskazano źródeł, na których oparte zostały stawiane przez strony i sędziów tezy.

\subsection{Pośrednie wykorzystanie autorytetu prawa rzymskiego}

W roku 1982 Komitet Apelacyjny Izby Lordów rozstrzygał sprawę Sudbrook Trading Estate Ltd. v. Eggleton ${ }^{461}$. Jej stan faktyczny dotyczył najmu kilku nieruchomości. W treści zawartych umów wskazano wszakże, iż najemca ma prawo poinformować wynajmującego o chęci nabycia nieruchomości po cenie nie niższej niż 12 tysięcy funtów, oszacowanej przez dwóch rzeczoznawców wskazanych przez każda z zainteresowanych stron. Gdy najemca wyraził wolę skorzystania z przysługujących mu uprawnień, wynajmujący odmówił wy-

${ }^{458}$ Act. 25, 16 (tłumaczenie za Biblia Tysiaclecia, wyd. 3, Poznań-Warszawa 1980, s. 1269).

${ }^{459}$ D.H. Pollitt, The Right of Confrontation: Its History and Modern Dress, Journal of Public Law 8 (1959), s. 384.

${ }^{460}$ Crawford $v$. Washington 541 U.S. 36 (2004).

${ }^{461}$ Sudbrook Trading Estate Ltd. v. Eggleton [1983] 1 A.C. 444. 
znaczenia własnego rzeczoznawcy uznając, iż postanowienia umowy o sprzedaży nieruchomości nie obowiązują.

Prawnicy reprezentujacy wynajmujacego powołali wiele precedensów, pośród których znalazły się dwa dziewiętnastowieczne orzeczenia, gdzie sędziowie odnieśli się do prawa rzymskiego ${ }^{462}$. Pełnomocnicy wskazali, iż zgodnie $z$ prawem rzymskim konstytutywnym elementem umowy kupna-sprzedaży było ustalenie ceny ${ }^{463}$. Argument ten podważony został jednak przez przeciwników procesowych, którzy wyrazili dezaprobatę dla doboru precedensów przywołanych przez prawników reprezentujących wynajmującego. Opinię prawników najemcy podzielił orzekajacy w sprawie Lord Fraser of Tullybelton. Po pierwsze wskazał on, iż w sprawie Hall v. Warren ${ }^{464}$ $z$ roku 1804, Sir William Grant, M.R., mówiąc o problematyce oceny wartości przedmiotu sprzedaży uznał, iż musi być ona „equivalent, and [...] effectual and fair"465. Po drugie, odwołując się do passusu pochodzącego z Instytucji justyniańskich, sędzia wyjaśnił, iż powierzenie możliwości określenia ceny przedmiotu sprzedaży osobie trzeciej, niebędącej strona stosunku prawnego, było w Rzymie przedmiotem watpliwości. W tak sformułowanej opinii lorda prawa należy dostrzec jego dobra znajomość omawianego zagadnienia. Wprawdzie sędzia nie wskazał tego w swym orzeczeniu, to wspomniane przez niego wątpliwości opisane zostały przez Gaiusa w jego Instytucjach ${ }^{466}$. Lord prawa stwierdził ponadto, że rozwiazanie zezwalajace osobie trzeciej na oszacowywanie wartości przedmiotu umowy kupna-sprzedaży zostało ostatecznie zaakceptowane przez Justyniana, który nakazał sprzedającemu oraz kupującemu akceptować tę wycenę ${ }^{467}$.

462 Sudbrook Trading Estate Ltd. v. Eggleton [1983] 1 A.C. 444, 468. Prawnicy wskazali następujacce precedensy: Milnes v. Gery (1807) 14 Ves. Jun. 399; 33 Eng. Rep. 574; Vickers v. Vickers (1867) L.R. 4 Eq. 529. ${ }_{463}^{4}$ Por. I. 3, 23, 1; C. 4, 38, 15, 2.

${ }^{464}$ Hall $v$. Warren (1804) 9 Ves. Jun. 605; 32 Eng. Rep. 738.

${ }^{465}$ Hall $v$. Warren (1804) 9 Ves. Jun. 605, 612; 32 Eng. Rep. 738, 740.

${ }^{466}$ G. 3, 140.

${ }^{467}$ Sudbrook Trading Estate Ltd. v. Eggleton [1983] AC 444, 482. 
W swym wyroku lordowie uznali, iż umowy najmu zawierające klauzulę sprzedaży powinny być traktowane jako umowy sprzedaży, które osiagaja pełna moc prawna wraz ze spełnieniem się dołączonych wcześniej warunków ${ }^{468}$. Można zatem uznać, iż argument wskazany przez Lorda Frasera of Tullybelton dotyczacy oszacowywania ceny przedmiotu umowy sprzedaży pośrednio przyczynił się do wydania tak sformułowanego wyroku.

Nietypowe nawiązanie do prawa rzymskiego odnaleźć można $z$ kolei w orzeczeniu Lorda Hobhouse'a of Woodborough w pochodzacej z roku 2001 sprawie Manifest Shipping Co. Ltd. v. Uni-Polaris Insurance Co. $L t d .{ }^{469} \mathrm{Jej}$ stan faktyczny dotyczył wysłania statku dalekomorskiego w rejs w stanie, który uniemożliwiał podjęcie takiej podróży. Podczas trwania rejsu statek spłonął na skutek pożaru, który wybuchł w maszynowni. Spółka, będąca właścicielem statku, wystąpiła o wypłacenie ubezpieczenia. Underwriters ${ }^{470}$ odmówili jednak twierdzac, że statek został celowo wyekspediowany w złym stanie oraz wskazali, iż niezdolność statku do podjęcia wyprawy była oczywista (prawnicy użyli określenia blind-eye knowledge).

Lord Hobhouse of Woodborough wskazał, że umowa ubezpieczenia, która stanowiła przedmiot oceny sędziów, należy na gruncie prawa angielskiego do kategorii umów uberrimae fidei, czyli najwyższej (dosłownie najżyźniejszej) dobrej wiary. Mimo użycia języka łacińskiego, termin określający tę

${ }^{468}$ Do rzymskiego najmu lordowie prawa odwołali się pośrednio w jednym z ostatnich swoich orzeczeń - TRM Copy Centres (UK) Ltd. v. Lanwall Services Ltd. [2009] 1 W.L.R. 1375 - gdzie Lord Hope of Craighead zacytował fragment pracy G.J. Bella, w którym szkocki autor podał definicję kontraktu locatio conductio.

${ }^{469}$ Manifest Shipping Co. Ltd. v. Uni-Polaris Insurance Co. Ltd. [2003] 1 A.C. 469.

${ }^{470}$ Underwriters wprowadzeni zostali do brytyjskiego systemu ubezpieczeń za pośrednictwem Lloyd's of London. Decyduja się oni przyjać na siebie część ryzyka związanego $z$ ubezpieczeniem w zamian za możliwość uzyskania określonych profitów - np. korzystania z zasobów ubezpieczanej spółki, zob. E.A. Martin, Oxford Dictionary..., s. 515, s.v. undedrwriter. 
specyficzną kategorię umów pojawił się w prawie angielskim dopiero w XIX wieku ${ }^{471}$. Sędzia wskazał jednak ${ }^{472}$, iż możliwą inspiracją dla twórców pojęcia było sformułowanie użyte w konstytucji Dioklecjana i Maksymiana, w której Augustowie, wyjaśniając charakter prawny umowy spółki, użyli sformułowania fides exuberet, tj. „wiara obfitująca 473 ".

Trudno jednak przypuszczać, aby powyższa konstytucja była inspiracja dla wspomnianej kategorii umów. Pytanie prawne zadane imperatorom przez żołnierza Aureliusa Victora dotyczyło uprawnień przysługujących mu w związku ze śmiercią ojca, wspólnika w spółce zawiązanej w celu uruchomienia salin. Przed swoja śmiercią mężczyzna nie otrzymał jednak udziału w zyskach. Augustowie wskazali, że umowa spółki jest przede wszystkim umowa dobrej wiary, co oznacza, że do jej istoty należy podział zysków zgodnie $z$ zasadami aequitas. Stąd żołnierz ma prawo domagać się należnego jego ojcu udziału w zyskach. W tych okolicznościach należy stwierdzić, iż wprawdzie propozycja Lorda Hobhouse of Woodborough wydaje się być interesująca, to jednak trudna jest do jednoznacznego zweryfikowania. Warto na koniec zauważyć jeszcze, że istniałaby możliwość odwołania się przez sędziów do prawa rzymskiego - tj. do konstrukcji tzw. casus mixtus, opisanego m.in. przez Gaiusa, gdzie nawet okoliczności siły wyższej nie zwolniłyby właściciela statku od odpowiedzialności $z$ tytułu wcześniejszego zawinienia (culpa eius interveniant) ${ }^{474}$.

${ }^{471}$ Więcej na temat umów tego rodzaju zob. R. Halson, Contract Law, Harlow 2001, s. 98-99.

${ }^{472}$ Manifest Shipping Co. Ltd. v. Uni-Polaris Insurance Co. Ltd. [2003] 1 A.C. $469,492$.

${ }^{473}$ C. $4,37,3$. Termin fides exuberet można dosłownie przetłumaczyć sformułowaniem "niech wiara tryska, obfituje”.

${ }^{474}$ D. 44, 7, 1, 4 (Gaius libro secundo aureorum). 


\subsection{Powolanie prawa rzymskiego w celach prawnoporównawczych}

W roku 1945 lordowie wydali orzeczenie w sprawie Hickman v. Peacey ${ }^{475}$. Pięć osób, spośród których dwie pozostawiły testamenty na rzecz pozostałych osób biorących udział w feralnym wydarzeniu, zginęło na skutek wybuchu bomby w trakcie nalotów na Londyn we wrześniu 1940 roku. Budynek, w którym schroniły się wspomniane osoby, rozpadł się, grzebiąc wszystkich w środku. Ze względu na fakt, że poszczególne pozostające w budynku osoby były ze sobą w różnoraki sposób powiąane i miały wzajemnie po sobie dziedziczyć, kluczowe okazało się określenie momentu ich śmierci. Wśród zabitych było m.in. dwóch braci. Jeden $z$ nich pozostawił testament, w którym wskazał, iż jego majątek ma odziedziczyć brat, jeśli będzie żył w chwili jego śmierci oraz gospodyni domowa, która także zginęła w czasie tego samego bombardowania. $Z$ kolei drugi $z$ braci rozporząził, iż majątek po nim dziedziczyć ma właścicielka domu, który został zburzony, gospodyni domowa (ta sama co poprzednio) oraz jego brat.

W sądzie pierwszej instancji sędzia uznał, że nie ma żadnych przesłanek, które pozwalaja stwierdzić, iż śmierć wszystkich ofiar nastapiła w tym samym momencie. Następnie jednak w Sądzie Apelacyjnym stwierdzono, że śmierć musiała nastapić jednocześnie, skoro wszystkie ofiary przebywały w prowizorycznym schronie skonstruowanym w piwnicy zburzonego domu. Wyrok sądu nie spotkał się jednak $z$ akceptacją żyjących krewnych zmarłych. Jeden $z$ nich zdecydował się złożyć do Izby Lordów apelację skierowana przeciwko zarządcom i wykonawcom pozostawionych testamentów oraz pozostającemu przy życiu bratu zmarłych mężczyzn.

Argumentacja prawników obu stron zmierzała przede wszystkim do określenia sposobu interpretacji sek. 184 Law of Property Act 1925476, która stanowiła: „in all cases where

${ }^{475}$ Hickman v. Peacey [1945] A.C. 304.

${ }^{476}$ Law of Property Act 1925 (15 \& 16 Geo. 5, c. 20). 
[...] two or more persons have died in circumstances rendering it uncertain which of them survived the other or others, such deaths shall (subject to any order of the court), for all purposes affecting the title to property, be presumed to have occurred in order of seniority, and accordingly the younger shall be deemed to have survived the elder". Na postanowienia ustawy jako pierwszy powołał się Viscount Simon, L.C. Zwrócił uwagę, iż podobne regulacje prawne odnaleźć można także w prawie rzymskim, $z$ tym jednak zastrzeżeniem, że prawo to przewidywało zastosowanie odpowiednich regulacji w sytuacji wspólnego zagrożenia, zaś ustawa angielska nie wymagała, aby zagrożenie było jednoczesne, np. sek. 184 mogła być stosowana także wówczas, gdy dwoje małżonków zmarło w tym samym czasie - mąż jako marynarz na statku, zaś żona w trakcie operacji, pozostając w kraju ${ }^{477}$.

Szerzej na temat prawa rzymskiego wypowiedział się Lord Macmillan. Podobnie jak wcześniej Lord Kanclerz, szkocki sędzia zwrócił uwagę, że choć w prawie angielskim problem śmierci w tym samym momencie po raz pierwszy stał się przedmiotem wykładni prawnej, to jednak historia prawa zna przykłady, gdzie określone zostały zasady rządzące tego typu przypadkami. Prawo rzymskie rozwiazało ten problem tworzac domniemanie oparte na „względach biologicznych"478. Jako przykład sędzia wskazał przypadek, w którym uważa się, iż dorosły syn przeżył śmierć swoich rodziców: „[...] cum explorari non possit, uter prior exstinctus sit, humanius est credere filium diutius vixisse" ${ }^{\prime 79}$.

477 Hickman v. Peacey [1945] A.C. 304, 314.

478 Hickman v. Peacey [1945] A.C. 304, 320.

${ }^{479}$ D. 34, 5, 22(23) (Iavolenus libro quinto ex Cassio). Warto zwrócić uwagę, iż powyższy passus z Digestów w rzeczywistości, o czym nie wspomniał Lord Macmillan, odnosił się do przypadku jednoczesnej śmierci dojrzałego syna i jego matki wspólnie podróżujących statkiem, który zatonął. Opinie nauki na temat właściwego rozumienia tego tekstu zestawiła A.R. Jurewicz, Problem domniemania $w$ rzymskim 'ius quod ad personas pertinet', Olsztyn 2009, s. 150-154. 
Lord prawa wyjaśnil, że w takiej sytuacji konieczność przeprowadzenia dowodu ustępowała miejsca domniemaniu. Odnosząc się do powyższego passusu Lord Macmillan stwierdził, iż w literaturze kontynentalnej wzbudził on liczne kontrowersje, a na potwierdzenie swych słów przywołał pierwsze wydanie pracy Williama Burge'a zatytułowanej Commentaries on Colonial and Foreign Laws, gdzie autor skrupulatnie przedstawił rozwój omawianej konstrukcji prawnej w różnych krajach $^{480}$.

Do prawa rzymskiego odwołał się także Lord Porter. Przede wszystkim wskazał on, że zasadnicza różnica pomiędzy dwoma systemami prawnymi dotyczy tego, iż prawo angielskie zawsze wymagało udowodnienia przeżycia którejś $z$ ofiar dłużej niż pozostałych ${ }^{481}$. Prawo rzymskie natomiast rozwiązało ten problem tworząc fikcje prawna w postaci domniemania. Lord prawa przywołał następnie w celu udowodnienia przedstawionych przez siebie tez fragmenty $z$ komentarza i nowej edycji Digestów sporządzonej przez Roberta-Josepha Pothiera $^{482}$. Na początku zacytował on ustęp autorstwa francuskiego prawnika ze wstępu otwierającego tytuł piąty księgi trzydziestej czwartej Digestów: „[...] superest ea tantum dubii species quae ex incerto ordine morientium aut nascentium proficiscitur: de qua re paucas regulas proponemus" 483 .

$\mathrm{W}$ passusie tym wskazano, że w sytuacjach niepewności powinno się podążá za porzą̨kiem śmierci lub narodzin,

${ }^{480}$ W. Burge, Commentaries on Colonial and Foreign Laws, vol. 4, London 1838, s. 11-29. Lord Macmillan przywołał także fragment pochodzacy z pracy Kanclerza Kenta, w której amerykański sędzia wyraził opinię, iż angielscy prawnicy rozważnie odmówili stosowania wszelkich „wymyślnych podziałów" wykorzystywanych w tego rodzaju sprawach przez cywilistów, zob. J. Kent, Commentaries on American Law, vol. 2, ed. 14, Boston 1896, s. 435 .

${ }^{481}$ Hickman v. Peacey [1945] A.C. 304, 332.

${ }^{482}$ R.J. Pothier, Pandectae Justinianeae, vol. 2, ed. 4, Pariisis 1821. Ostatnio na temat postaci francuskiego prawnika zob. A. Kaczmarczyk, R. Wojciechowski, Robert-Joseph Pothier (1699-1772), Kwartalnik Prawa Prywatnego 21/1 (2012), s. 5-49.

${ }^{483}$ R.J. Pothier, Pandectae Justinianeae, s. 550. 
które przedstawione zostały w kilku niewielkich zasadach. Następnie Lord Porter przywołał czwarta $z$ reguł opracowanych przez R.J. Pothiera, która zacytował w swym orzeczeniu: „cum nulla ratio occurrit dignoscendi aut praesumendi utra ex duabus personis praemortua sit, adversus eum cui, una ex illis personis praemortua, petitio competeret, pro possessore reponetur" 484 . Francuski prawnik zilustrował wyrażona przez siebie zasadę kilkoma paragrafami pochodzacymi z księgi trzydziestej czwartej Digestów justyniańskich. Lord Porter ograniczył się wszakże w swym orzeczeniu do wskazania, iż w każdym $z$ powołanych przez R.J. Pothiera przykładów mowa jest o domniemaniu wspólnej śmierci i zacytował użyte w poszczególnych ustępach określenia: „quod si simul"485, "quod de pariter mortuir tractamus"486, "simul cum marito perierit"487, „si maritus et uxor simul perierint"488, „si dominus cum servis simul vita functus sit"489. Powyższe przykłady pozwoliły lordowi prawa sformułować wniosek, że łacińskie terminy simul oraz pariter nie były używane przez rzymskich jurystów na oznaczenie sytuacji, w których rzeczywiście doszło do równoczesnej śmierci, lecz na oznaczenie przypadków, gdy co najmniej dwie osoby zmarły na skutek wspólnego niebezpieczeństwa, zaś kolejność zgonów była niemożliwa do jednoznacznego ustalenia ${ }^{490}$. W tym samym tonie, zdaniem Lorda Portera, utrzymane były przepisy francuskiego kodeksu cywilnego. Sędzia zacytował przepis art. 720 kodeksu („Si plusieurs personnes respectivement appelées à la succession l'une de l'autre, périssent dans une même événement, sans qu'on puisse reconaître laqualle est décédée la première, la présomption de survie est déterminée par les circonstances

\footnotetext{
484 Ibidem, s. 551.

485 D. 34, 5, 8(9) (Paulus libro secundo sententiarum).

${ }^{486} \mathrm{D}, 34,5,16(17)$, pr. (Marcianus libro tertio regularum).

487 D. 34, 5, 17(18) (Paulus libro 12 ad Plautium).

488 D. 34, 5, 9(10), 4 (Tryphoninus libro 21 disputationum).

489 D. 34, 5, 18(19), 1 (Marcianus libro tertio regularum).

${ }^{490}$ Hickman v. Peacey [1945] A.C. 304, 333.
} 
du fait, et, à leur défaut, par le force de l'âge ou de sexe"491) oraz poczattek art. 721 („si ceux qui ont péri ensemble”). Wskazał on, iż słowo ensemble oznacza tyle co „na skutek tego samego zagrożenia”, nie zaś „dokładnie w tym samym momencie", a zatem odpowiada ono konstrukcji stworzonej oryginalnie przez rzymskich jurystów.

Ostatecznie lordowie prawa zadecydowali o uznaniu zastosowania wyrażonej w sekcji 184 Law of Property Act 1925 zasady starszeństwa, wedle której domniemywa się, iż osoby starsze umarły przed młodszymi. Uwagę zwraca jednak skrupulatna analiza dokonana szczególnie przez Lorda Portera $\mathrm{w}$ odniesieniu do rzymskich oraz francuskich zasad rzadzacych kontrowersyjnym zagadnieniem.

Powołania prawa rzymskiego przedstawione w powyższej sprawie dotyczyły konkretnych passusów pochodzacych $z$ kodyfikacji justyniańskiej oraz ich komentarza autorstwa R.J. Pothiera. Inny charakter miało natomiast przywołanie autorytetu prawa rzymskiego w jednym $z$ orzeczeń w sprawie Nordenfelt $v$. Maxim Nordenfelt Guns and Ammunition Co. ${ }^{492}$ $z$ roku 1894 . Sprawa dotyczyła charakterystycznej dla systemu common law doktryny restraint of trade, która stanowi środek balansujący w przypadku konfliktu zasady wolności umów i zasady wolnego rynku ${ }^{493}$. W przypadku podniesienia zarzutu naruszenia zasady wolnego rynku poprzez swobodę kreowania treści umów, konieczne jest dokonanie oceny ważności zawartej umowy. Kwestie dotyczące tej oceny były przedmiotem licznych wyroków wydanych przez sądy angielskie. Dopiero jednak wyrok w omawianej sprawie ustalił obowiazujace zasady dotyczace tej interpretacji.

Thorsten Nordenfelt zobowiazał się, że przez okres dwudziestu pięciu lat od chwili podpisania umowy nie będzie

${ }^{491}$ Treść art. 720 francuskiego k.c. została poddana całkowitej nowelizacji w roku 2001.

${ }^{492}$ Nordenfelt $v$. Maxim Nordenfelt Guns and Ammunition Co. [1894] A.C. 535 .

${ }^{493}$ Zob. więcej np. R. Stone, Modern Law of Contract, Abingdon-New York 2009, s. 515-527. 
w żaden sposób współpracował $\mathrm{z}$ przedsiębiorstwami produkującymi broń lub amunicję poza Maxim Nordenfelt Guns and Ammunition Co. Ze względu na fakt, iż nie dotrzymał swojego zobowiązania, brytyjska spółka wystapiła przeciwko niemu do sądu.

Lord Herschell, L.C., przedstawił w swym orzeczeniu dotychczasowe bogate orzecznictwo zwiąane $z$ restraint of trade. Przede wszystkim odniósł się jednak do sprawy rozpatrywanej w roku 1711 przez Sad Kanclerski - Mitchel $v$. Reynolds ${ }^{494}$, gdzie m.in. postanowiono o rozróżnieniu ograniczeń w handlu na ogólne i szczególne, jak również wskazano, iż co do zasady ograniczenia, o ile $z$ samej swej istoty nie sa sprzeczne $z$ prawem, powinny być uważane za dozwolone ${ }^{495}$. Następnie angielski prawnik przywołał wypowiedź Lorda Macclesfield ${ }^{496}$, który stwierdził, iż ograniczenia o charakterze ogólnym powinny być uznane za niezgodne $z$ prawem, ze względu na ich surowość, jak również fakt, że żadna ze stron nie czerpie $z$ nich korzyści. Dodatkowo osiemnastowieczny prawnik zauważył, iż ograniczenia o charakterze ogólnym w większości przypadków nie przynosza żadnych korzyści zobowiazanym. W jego przekonaniu nie byłoby sprawiedliwe przypisywanie strat tylko jednej stronie takiej umowy. Wreszcie Lord Macclesfield wyjaśnił, iż prawo rzymskie nie udzieliłoby ochrony umowie tego rodzaju. Swoje przekonanie sędzia poparł wskazując na fragment De iure naturae et gentium autorstwa S. von Pufendorfa ${ }^{497}$.

Paragraf De iure naturae et gentium, do którego odwołał się angielski sędzia, dotyczy rzymskich umów nieformalnych (pacta), które nie były objęte system skargowym. Wydaje się on być ciekawy $z$ kilku powodów. Po pierwsze niemiecki

${ }^{494}$ Mitchel v. Reynolds (1711) P. Wms. 181; 24 Eng. Rep. 347.

495 Nordenfelt $v$. Maxim Nordenfelt Guns and Ammunition Co. [1894] A.C. 535,545 .

${ }^{496}$ Mitchel $v$. Reynolds (1711) P. Wms. 181, 183; 24 Eng. Rep. 347, 348.

${ }^{497} \mathrm{~S}$. von. Pufendorf, De iure naturae et gentium, 5, 2, 3. Mitchel $v$. Reynolds (1711) P. Wms. 181, 191; 24 Eng. Rep. 347, 350. 
prawnik nie powołał w przedmiotowym fragmencie swojego dzieła żadnego rzymskiego źródła prawa, lecz nieco przypadkowo, jak się wydaje, wskazał fragmenty autorstwa Strabona, Seneki oraz Plauta. Ponadto przytoczył zniekształconą wersję znanego sformułowania ex nudo enim pacto inter cives Romanos actio non nascitur, nie wskazując jednak na pochodzenie paremii $z$ Sentencji Paulusa ${ }^{498}$. Wreszcie przyczyn wykluczenia pacta $\mathrm{z}$ kategorii umów chronionych skargami niemiecki teoretyk prawa upatrywał w próbie uniknięcia przez Rzymian zbyt dużej liczby wytaczanych w sądach powództw. To twierdzenie S. von. Puffendorfa trudne jest jednak do zaakceptowania i zniekształca złożoność problematyki wykorzystywania pacta w rzymskim obrocie prawnym, które mogły przecież zostać objęte ochrona procesowa choćby poprzez dołączenie do ich treści stypulacji ${ }^{499}$.

Powyższe pośrednie powołanie - najpierw przez Lorda Macclesfield, następnie zaś przez Lorda Herschell - jest dowodem na wykorzystanie przez angielskich sędziów jedynie idei prawa rzymskiego, bez zwrócenia uwagi na konkretne źródła prawa. Warto również podkreślić nieporadność S. von Puffendorfa w prowadzonym przez niego wywodzie naukowym. Jest to szczególnie ciekawe w kontekście popularnego przekonania o wyjątkowej znajomości prawa rzymskiego przez tego niemieckiego myśliciela.

Ciekawym przykładem odwołania się do prawa rzymskiego dla celów prawnoporównawczych jest orzeczenie z roku $1975 \mathrm{w}$ sprawie karnej DPP for Northern Ireland $v$. Lynch $^{500}$. Warto w tym miejscu zwrócić uwagę na kilka okoliczności związanych $z$ tą sprawą. Po pierwsze, włącza się ona w grupę pierwszych spraw karnych, które rozpatrywane były przez Komitet Apelacyjny Izby Lordów po zniesieniu obostrzeń dotyczących możliwości wnoszenia tego rodzaju

498 PS. 2, 14, 1.

$499 \mathrm{Na}$ temat niezaskarżalności pacta por. G. Diósdi, Contract in Roman Law. From the Twelve Tables to the Glossators, Budapest 1981, s. 119-120. ${ }^{500}$ DPP for Northern Ireland v. Lynch [1975] A.C. 653. 
spraw na początku lat sześćdziesiątych XX wieku. Po drugie, była to jedna $z$ nielicznych spraw pochodzących $z$ omawianego okresu, w której prawo rzymskie powołane zostało szerzej. Po trzecie wreszcie, prawo rzymskie powołane zostało w sprawie karnej, co również musi być uznane za zjawisko raczej wyjątkowe, gdy weźmie się pod uwagę tradycyjny pogląd o kluczowej roli prawa rzymskiego dla rozwoju prawa prywatnego w Europie.

Joseph Lynch był jednym $z$ trzech oskarżonych w sprawie o zabójstwo funkcjonariusza policji dokonane w dniu 28 stycznia 1972 roku w Belfaście. W połowie tego samego roku został on skazany na karę dożywotniego pozbawienia wolności. W trakcie procesu podnosił, że powinien być uwolniony od odpowiedzialności karnej ze względu na fakt, iż działał pod wpływem przymusu (został zmuszony do uczestnictwa w morderstwie zaplanowanym przez członka IRA). Sacd skazał oskarżonego za pomocnictwo i podżeganie do popełnienia czynu przestępczego. W odwołaniu złożonym do Sądu Apelacyjnego oskarżony starał się wykazać, że sędzia prowadzacy sprawę w pierwszej instancji bezprawnie poinformował ławę przysięgłych, iż w przypadku zabójstwa nie można powoływać się w ramach prezentowanej linii obrony na przymus. Sąd Apelacyjny odrzucił jednak argumenty przedstawione przez prawników oskarżonego.

Gdy sprawa trafiła przed oblicze lordów prawa, jasne stało się, że kluczowym do zbadania zagadnieniem była kwestia przymusu (po angielsku nazywanego duress ${ }^{501}$ ). Do prawa rzymskiego w tym zakresie odwołał się angielski prawnik Lord Simon of Glaisdale. Wskazał on, że utarta praktyka prawa

${ }^{501}$ Duress należy do kategorii tzw. defences, obok np. obrony koniecznej (self-defence), nieletniości czy niepoczytalności. W polskiej literaturze na ich temat zob. K. Baran, $Z$ dziejów prawa karnego Anglii. Między renesansem a oświeceniem XVI-XVIII w., Kraków 1996, s. 60-73. Na temat duress zaś por. ibidem, s. 65-67; K. Baran, M. Małek, K. Szczurek, Z dziejów angielskich defences: obrona konieczna i stan wyższej konieczności, [w:] A. Lityński, M. Mikołajczyk (red.), Przez tysiaclecia: państwo-prawo - jednostka, Katowice 2001, s. 56-59. 
angielskiego nie dopuszczała przymusu, podobnie jak działania w stanie wyższej konieczności oraz przymusu w formie coercion $^{502}$ jako okoliczności wyłączających czy ograniczających odpowiedzialność karna $z$ tytułu zabójstwa ${ }^{503}$. Dalej sędzia wskazał, iż w orzecznictwie, ustawodawstwie, jak również w literaturze przedmiotu techniczne określenie nastawienia woli sprawcy do popełnianego przez niego czynu nigdy nie zostało jednoznacznie zdefiniowane i określane jest przy pomocy licznych terminów, których zakresy znaczeniowe czasami w niewielkim jedynie stopniu się pokrywaja. Stwierdził ponadto, że nieprzydatne jest także odwołanie się do terminologii łacińskiej, gdzie na określenie woli sprawcy używane moga być terminy animus oraz mens rea ${ }^{504}$.

W dalszej części swojego orzeczenia Lord Simon podją próbę zdefiniowana terminu „wolna wola”. Odwołał się w tym celu do definicji zamieszczonej w A Dictionary of the English Language autorstwa Samuela Johnsona z połowy XVIII w. ${ }^{505}$, w której angielski filolog wskazał, iż „wolna wola” to "the power of directing our own action without restraint by necessity or fate". Komentując tę definicję lord prawa stwierdzil, iż nosi ona cechy metafizyczne i teologiczne, niemniej może być wykorzystana w przedmiotowej sprawie. Sędzia wskazał również, iż tam, gdzie zachodzi przypadek wystapienia siły wyższej, nie można mówić o podejmowaniu żadnych działań, gdyż są one niezależne od nas ${ }^{506}$. Zacytował tu sentencję pochodzaca $z$ pracy Matthew Hale'a The History of the Pleas

${ }^{502}$ Coercion to specjalna forma przymusu, która dotyczy jedynie kobiet zamężnych, które działały pod wpływem swojego męża, zob. E.A. Martin, Oxford Dictionary..., s. 87, s.v. coercion.

${ }^{503}$ DPP for Northern Ireland v. Lynch [1975] A.C. 653, 686.

${ }^{504}$ DPP for Northern Ireland v. Lynch [1975] A.C. 653, 689.

${ }^{505}$ Lord Simon określił pracę S. Johnsona jako Oxford English Dictionary. Jest to jednak ewidentny błąd sędziego, który nazwał oryginalna pracę Johnsona tytułem serii wydawniczej publikowanej przez University of Oxford od końca XIX w., która w znacznym stopniu zastapiła przestarzały słownik S. Johnsona.

${ }^{506}$ DPP for Northern Ireland v. Lynch [1975] A.C. 653, 691. 
of the Crown brzmiaca necessitas quod cogit defendit ${ }^{507}$. Kontynuując swe rozważania, Lord Simon przywołał również maksymę prawnicza legem non habet necessitas ${ }^{508}$, która wywodził z pism św. Augustyna, udowadniając jednocześnie, że angielski termin necessity nie został ściśle zdefiniowany na potrzeby języka prawniczego. Sposób rozumowania przedstawiony przez sędziego obarczony jest jednak pewnym błędem, gdyż utożsamia on angielski termin necessity z łacińska necessitas ${ }^{509}$, w sytuacji gdy necessity oznacza siłę wyższa (łacińska vis maior ${ }^{510}$ ), zaś necessitas - to konieczność określonego działania, które nie zawsze oznacza znajdowanie się pod wpływem siły wyższej. Angielski prawnik dostrzegł sam ten błąd i wskazał, że termin necessity był błędnie rozumiany jako wybór między dwiema negatywnymi okolicznościa$\mathrm{mi}^{511}$. W dalszej części swego orzeczenia sędzia odwołał się jeszcze do Maxims of the Law autorstwa Francisa Bacona, $z$ których zacytował następujaca sentencję: necessitas inducit privilegium quoad jura privata ${ }^{512}$. Zwrócil jednak uwagę, że jej rozumienie nie zakłada rozróżnienia na prawo prywatne i publiczne w klasycznym ujęciu. Sentencja dotyczyła raczej dawnej metody pojmowania odpowiedzialności karnej określającej odpowiedzialność $z$ tytułu zabójstwa jako lex publica i przeciwstawiającej ją odpowiedzialności $z$ tytułu zdrady nazywanej lex privata. Tego rodzaju rozróżnienie ma walor jedy-

${ }^{507}$ M. Hale, Historia Placitorum Coronae. The History of the Pleases of the Crown, vol. 1, London 1736, s. 54.

${ }^{508}$ Fragment przypisywany św. Augustynowi pochodzi z traktatu zatytułowanego De spiritu et animae liber unus autorstwa tzw. Pseudo-Augustyna. Występuje on również $\mathrm{w}$ innych tekstach prawniczych i filozoficznych okresu średniowieczna, m.in. w Dekrecie Gracjana (C.1 q. 1, dictum post c. 39).

${ }^{509}$ A. Berger, Encyclopaedic Dictionary of Roman Law, Philadelphia, PA, 1953, s. 593, s.v. Necessitas.

${ }^{510}$ Ibidem, s. 769 , s.v. Vis maior.

${ }^{511}$ DPP for Northern Ireland v. Lynch [1975] A.C. 653, 691-692. Por. również K. Baran, M. Małek, K. Szczurek, $Z$ dziejów angielskich..., s. 56.

${ }^{512}$ F. Bacon, Maxims of the Law, [w:] idem, The Works of Francis Bacon, vol. 2, London 1753, s. 15. 
nie historyczny i nie odnosi się do współczesnych uregulowań prawa angielskiego ${ }^{513}$.

$\mathrm{Na}$ kolejnych stronach swego orzeczenia Lord Simon zauważył wreszcie, że wystapienie przymusu nie powinno wyłączać odpowiedzialności karnej, lecz jedynie ją łagodzić. Prawidłowość tę, zdaniem sędziego, można dostrzec porównując omawiane rozwiązania $z$ paralelnymi rozwiązaniami znanymi obcym systemom prawnym. Wskazal on, iz "the great classical jurist, Paulus, discusses the doctrine, presumably in relations to the damnosa hereditas"514. Następnie law lord zawarł w swym orzeczeniu własne tłumaczenie wspomnianego passusu pochodzącego $z$ Digestów ${ }^{515}$. Wskazał także, iż użyty przez jurystę termin coactus volui znalazł zastosowanie we współczesnym prawie angielskim, gdzie został użyty chociażby w podręczniku prawa karnego autorstwa Glanville'a Williamsa ${ }^{516}$.

Ostatecznie Izba Lordów orzekła, że konieczne jest zwrócenie sprawy do Sądu Apelacyjnego w celu ponownego przeprowadzenia postępowania sądowego. W zakresie możliwości powoływania się na przymus jako okoliczność łagodzącą odpowiedzialność karna związaną z przestępstwem zabójstwa, lordowie wypowiedzieli sie jednak negatywnie ${ }^{517}$.

Do prawa rzymsko-holenderskiego, i tym samym pośrednio do prawa rzymskiego, odwołał się w roku 1990 Lord

${ }^{513}$ DPP for Northern Ireland v. Lynch [1975] A.C. 653, 692.

${ }^{514}$ DPP for Northern Ireland v. Lynch [1975] A.C. 653, 694.

515 D. 4, 2, 21, 5 (Paulus libro 11 ad edictum).

${ }^{516}$ G.L. Williams, Criminal Law. The General Part, London 1961, s. 751.

${ }^{517}$ Problematyki przymusu dotyczyła również sprawa $R$. v. Hove [1987] A.C. 417. Oskarżeni, podobnie jak dekadę wcześniej J. Lynch, twierdzili, iż wzięli udział w zabójstwie ze względu na fakt, iż obawiali się, że sami poniosa śmierć, jeśli tego nie uczynią. Lord Hailsham of St. Marylebone nawiazał do południowoafrykańskiej sprawy S. v. Goliath 1972 (3) SA 1 (A), 465, która - jak sam wskazał - rozstrzygnięta została na podstawie prawa rzymsko-holenderskiego. Zgodnie $z$ jej rozstrzygnięciem dopuszczalne jest powołanie się na przymus, w kontekście oskarżenia o zabójstwo. Lord Hailsham odmówił jednak możliwości stosowania południowoafrykańskiego kazusu w prawie angielskim. 
Bridge of Harwich w sprawie McMonagle $v$. Westminster City Council $^{18}$. Sprawa dotyczyła bezprawnego ustawienia przez pozwana w jej sklepie maszyny, która zawierała zdjęcia pornograficzne. Zgodnie $z$ lokalnymi regulacjami maszyna taka mogła być wykorzystywana jedynie po wcześniejszym uzyskaniu pozwolenia wydanego przez władze miejskie. Spór stron dotyczył m.in. właściwej interpretacji przepisów samorządowych. Lord prawa w swym orzeczeniu dostrzegł, iż możliwe jest, aby ustawa, bądź inny akt prawny w części był jasny i możliwy do bezpośredniego zastosowania, w innej zaś części poddany stosowej interpretacji, np. ze względu na braki w znajomości techniki legislacyjnej twórców danego aktu prawnego ${ }^{519}$. Jako przykład Lord Bridge przywołał orzeczenie Komitetu Apelacyjnego Tajnej Rady z 1886 roku ${ }^{520}$, w którym sędziowie rozstrzygali o sposobie rozumienia zasady prawa rzymsko-holenderskiego skonfrontowanej $z$ ordonansem wydanym w 1856 roku przez władze kolonii Natal w południowej Afryce. W swym orzeczeniu lord prawa wyjaśnił jedynie, iż rzymsko-holenderska zasada dotyczyła ograniczenia nabywania droga dziedziczenia testamentowego pewnych składników majątku przez kobietę, której zmarły mąż miał dzieci pochodzace $z$ wcześniejszego małżeństwa ${ }^{521}$. W orzeczeniu Tajnej Rady wskazano natomiast wprost, że przedmiotowa zasada - Hac edictali- pochodziła $z$ piątej księgi Kodeksu justyniańskiego ${ }^{522}$.

\subsection{Odrzucenie autorytetu prawa rzymskiego}

W przypadku niektórych powołań prawa rzymskiego dostrzec można tendencję lordów prawa do udowadniania braku skuteczności starożytnych rozwiązań prawnych i ich

${ }^{518}$ McMonagle v. Westminster City Council [1990] 2 A.C. 716.

${ }^{519}$ McMonagle v. Westminster City Council [1990] 2 A.C. 716, 726.

${ }_{520}$ Salmon v. Duncombe (1886) 11 App.Cas. 627.

${ }^{521}$ McMonagle v. Westminster City Council [1990] 2 A.C. 716, 727.

522 C. 5, 9, 6, pr. 
wpływu na prawo angielskie. W przypadkach tego rodzaju można byłoby mówić zatem o „negatywnym autorytecie” prawa rzymskiego.

Jednym $z$ ciekawszych, ale i szczególnie ważnym dla sposobu rozumienia istoty angielskiej własności, jest orzeczenie wydane w roku $1895 \mathrm{w}$ sprawie Bradford $v$. Pickles ${ }^{523}$. Spór prowadzili przedstawiciele okręgu Bradford, którego mieszkańcy korzystali z usług Bradford Waterworks Company, oraz Edward Pickles - właściciel nieruchomości graniczącej z ziemiami należącymi do przedsiębiorstwa wodociagowego. Edward Pickles osuszył wody gruntowe znajdujace się pod częścia jego nieruchomości, tak aby móc dostać się do leżących niżej pokładów wapienia. W ten sposób doprowadził do odcięcia podziemnego dopływu wody do rezerwuarów wykorzystywanych przez Bradford Waterworks Company. Beneficjenci złożyli pozew do Sadu Kanclerskiego o zakazanie E. Picklesowi podejmowania działań tego rodzaju. Po oddaleniu sprawy przez sad pierwszej instancji trafiła ona do Kanclerskiego Sądu Odwoławczego, a następnie do Izby Lordów. $\mathrm{W}$ jej orzeczeniu rzymskie rozwiązania prawne powołane zostały przez Lorda Watsona, który jednak negatywnie ocenił możliwość ich zastosowania w sprawie. Przedmiotem jego wypowiedzi była zasada pochodzaca od rzymskiego jurysty Marcellusa - „Denique Marcellus scribit cum eo, qui in suo fodiens vicini fontem avertit, nihil posse agi, nec de dolo actionem: et sane non debet habere, si non animo vicino nocendi, sed suum agrum meliorem faciendi id fecit" 524 .

Autor powołanego przez Lorda Watsona fragmentu odmawia przyznania skargi (w tym także skargi $z$ tytułu podstępu) właścicielowi gruntu wówczas, gdy jego sąsiad, prowadząc prace na własnym terenie, przetnie ciek wodny zasilajacy nieruchomość pierwszego. Konieczne jest jednak wykazanie,

${ }^{523}$ Bradford v. Pickles [1895] A.C. 587. Ostatnio obszernie na temat kulisów sprawy M. Taggart, Private Property and Abuse of Rights in Victorian England. The Story of Edward Pickles and the Bradford Water Supply, Oxford 2002.

${ }^{524}$ D. 39, 3, 1, 12 (Ulpianus libro 53 ad edictum). 
iż podejmujący opisywane czynności nie działał w celu wyrządzenia szkody oraz że jego celem było polepszenie jakości własnego gruntu. Wprawdzie przytoczony passus z Digestów koresponduje ze stanem faktycznym sprawy, trudno jednak w wypowiedzi Lorda Watsona znaleźć uzasadnienie jego powołania, szczególnie że nie stanowił on następnie przedmiotu rozważań pozostałych law lords ${ }^{525}$. Trzeba tu wyjaśnić, iż szkocki sędzia nawiązał w ten sposób do faktu powołania powyższego fragmentu Marcellusa przez orzekającego w pierwszej instancji sędziego Northa, który stwierdził: „that passage certainly does indicate that an action might lie, if the act damaging the neighbour was done, not for the improvement of the actor's own property, but for the purpose of levying blackmail upon the neighbour"526.

Nie ulega wątpliwości, że interpretacja sędziego Northa zgodna jest $z$ oryginalnym przesłaniem omawianego passusu. Jednak powołanie się na - jak to ujął Lord Watson - „doktrynę Marcellusa” było błędne na gruncie prawa angielskiego. Zgodnie bowiem $\mathrm{z}$ orzeczeniem $\mathrm{w}$ sprawie Chasemore $v$. Richards $^{527} \mathrm{z}$ roku 1859 odrzucono rzymskie rozwiazania, określając odmiennie zakres odpowiedzialności właściciela prowadzacego prace ziemne na własnym gruncie.

Rok po wydaniu wyroku $\mathrm{w}$ sprawie Bradford $v$. Pickles Izba Lordów raz jeszcze odrzuciła autorytet prawa rzymskiego, orzekajac tym razem w sprawie Scholfield v. Earl of Londesborough $^{528}$ odnoszacej się do problematyki prawa wekslowego

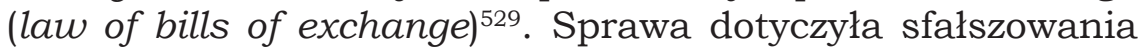

${ }^{525}$ Bradford v. Pickles [1895] A.C. 587, 597. Na temat przyczyn nieodwołania się przez pozostałych lordów do kwestii wypowiedzi rzymskiego prawnika zob. M. Taggart, Private Property..., s. 63-67.

${ }^{526}$ Corporation of Bradford v. Pickles [1894] 3 Ch. 53, 68. Na temat genezy powołania się na stanowisko Marcellusa przez sędziego Northa zob. M. Taggart, Private Property..., s. 51-55.

${ }^{527}$ Chasemore v. Richards (1859) VII H.L.C. 349; 11 Eng. Rep. 140.

${ }^{528}$ Scholfield $v$. Earl of Londesborough [1896] A.C. 514.

${ }^{529} \mathrm{Na}$ temat historycznego rozwoju bill of exchange na gruncie common law zob. D.J. Ibbetson, A Historical Introduction to the Law of Obligations, Oxford 1999, s. 204-206. Na temat wcześniejszych dziejów prawa wek- 
weksla, który opiewał na kwotę 500 szylingów. Po podpisaniu dokumentu doszło do zmiany wartości weksla na 3.500 szylingów. Było to możliwe dzięki uprzednim zabiegom podjętym przez trasanta, który zadbał o pozostawienie miejsca na druku weksla, tak aby dopisać na nim dodatkowe słowa, jak również nakleił znaczek skarbowy o wyższym nominale, aniżeli konieczny był w przypadku dokonywania transakcji opiewającej na 500 szylingów. W trakcie postępowania sadowego podnoszono, że wprawdzie nie ulega wattpliwości, iż weksel został sfałszowany, to jednak możliwość dokonania fałszerstwa wynikała $z$ niedbalstwa, jakiego dopuścił się trasat, który podpisał weksel, mimo iż oczywiste były jego braki formalne oraz naklejenie znaczka wyższej wartości, aniżeli było to konieczne ${ }^{530}$.

Oceniając okoliczności faktyczne i stan prawny dotyczący przedmiotowej sprawy, Lord Kanclerz Halsbury odniósł się m.in. do precedensu Young $v$. Grote ${ }^{531}$ rozpatrywanego przez Sąd Ławy Królewskiej w roku 1827, którego stan faktyczny dotyczył problematyki niedochowania należytej staranności przy wypełnianiu czeku bankowego. Lord Halsbury zwrócił uwagę, iż Chief Justice Best odwołał się w swym orzeczeniu do fragmentów pochodzących $z$ pracy R.J. Pothiera zatytułowanej Traité du Contrat de Change ${ }^{532}$, w których francuski praw-

slowego oraz innych podobnych instrumentów finansowych w Anglii zob. J.S. Rodgers, The Early History of the Law of Bills and Notes, Cambridge 1995, s. 44-54.

${ }^{530}$ Zagadnienia fałszerstwa dotyczyła również sprawa stanowiąca przedmiot orzekania lordów prawa w roku $1960 \mathrm{w}$ sprawie Welham v. DPP [1961] A.C. 103. Przedstawiciel prokuratury podniósł, iż angielski termin fraudulently jest bardzo stary, a jego geneza sięga prawa rzymskiego. Jak sam prawnik wskazał, oparł on swoje twierdzenie na pracy pochodzacej $\mathrm{z}$ początków XIX w. zatytułowanej A Treatise of the Plesas of the Crown autorstwa E.H. Easta. Dziewiętnastowieczny prawnik zacytował w przypisie swojej pracy ustęp pochodzacy $z$ Instytucji justyniańskich $(4,1,1)$ - "furtum est contrectatio rei fraudulosa vel ipsius rei vel etiam usus eius possessionisve".

${ }^{531}$ Young v. Grote (1827) 4 Bing 253; 130 Eng. Rep. 764.

${ }^{532}$ R.J. Pothier, Traité du Contrat de Change, Paris 1809. 
nik komentował obszernie rozważania siedemnastowiecznego znawcy prawa rzymskiego Sigismunda Scaccia, zawarte $\mathrm{w}$ jego pracy Tractatus de comerciis et cambio ${ }^{533}$. Lord Halsbury pragnąc właściwie ustosunkować się do omawianego zagadnienia, postanowił zacytować obszernie fragment dzieła R.J. Pothiera ${ }^{534}$, jak również przywołał cały passus $z$ pracy S. Scaccii ${ }^{535}$. Oba cytaty zajęły ponad sześć $z$ jedenastu stron orzeczenia Lorda Kanclerza ${ }^{536}$. Zabieg ten nie przyczynił się jednak do uznania autorytetu prawa rzymskiego w przedmiotowej sprawie, zaś sam sędzia, tuż po przytoczeniu dwóch wspomnianych cytatów stwierdził, iż problematyka umowy zlecenia opartej na tradycji prawa rzymskiego nie stanowi części angielskiego prawa handlowego, a poglądy reprezentowane przez włoskiego, jak i francuskiego prawnika nie maja większego znaczenia dla przedmiotowej sprawy, o ile koncepcji przedstawionych przez R.J. Pothiera nie dostosuje się uprzednio do wymogów angielskiego systemu prawa ${ }^{537}$. Mimo tych uwag sędzia zdecydował się przeanalizować „doktrynę" francuskiego prawnika. W tej części swego orzeczenia Lord Halsbury wskazał, że zbudowana została ona na przykładach zaczerpniętych $z$ prawa rzymskiego, lecz angielski sędzia bezpośrednio powołał tylko jeden. Zwrócił on uwagę, że sprzedaż niewolnika-złodzieja przez właściciela, który wiedział o jego profesji, rodziła na gruncie prawa rzymskiego odpowiedzialność sprzedawcy związana z każdą kradzieżą dokonana przez niewolnika ${ }^{538}$. Kluczowe w kontekście omawianej sprawy jest zagadnienie staranności (dilgentia), choć sam lord prawa nie

${ }^{533}$ S. Scaccia, Tractatus de comerciis et cambio, Roma 1619.

${ }^{534}$ R.J. Pothier, Traité..., s. 59-62.

${ }^{535}$ S. Scaccia, Tractatus..., 2, 5, 15.

536 Scholfield v. Earl of Londesborough [1896] A.C. 514, 524-531.

${ }^{537} \mathrm{~W}$ orzeczeniu w sprawie Arthur J.S. Hall and Co. v. Simon [2002] 1 A.C. 615 (będącej apelacja angielska) Lord Hope of Craighead odniósł się jednak do szkockich rozwiązań dotyczących kontraktu zlecenia zaznaczając, iż zaczerpnięte zostały one $z$ prawa rzymskiego. Na potwierdzenie swej opinii wskazał właściwy paragraf pochodzacy z pracy Lorda Stair (Institutions of the Laws of Scotland, 1, 12, 10).

${ }^{538}$ D. 17, 1, 26, 7 (Paulus libro 32 ad edictum). 
wskazał na to. W przywołanym przez sędziego kazusie, Paulus podkreślał brak winy w postępowaniu mandanta. Przykład ten miałby uzasadniać ewentualne niedbalstwo trasata $\mathrm{w}$ ocenianym stanie faktycznym. Ciekawe jest jednak to, że sędzia przywołując powyższy stan faktyczny, wyraźnie wskazał na sprzedaż niewolnika, nie zaś na stosunek prawny wynikajacy $z$ kontraktu zlecenia. Zwiazane jest to najprawdopodobniej $z$ faktem, iż o sprzedaży niewolnika pisał także w swym traktacie R.J. Pothier. Wyjaśnia to zatem, dlaczego Lord Halsbury nie zacytował źródła, ani też nie wskazał jego oznaczenia. Należy także wyjaśnić, że argumentem przemawiającym za odrzuceniem koncepcji francuskiego prawnika było przekonanie angielskiego sędziego o braku podobieństwa między umowa zlecenia a wekslem. Nie ulega również wątpliwości, iż długie, choć niemające przełożenia na ostateczne rozstrzygnięcie sprawy, rozważania Lorda Kanclerza trzeba uznać jedynie za próbę demonstracji jego znajomości naukowej literatury.

Powyższe rozważania zainteresowały także Lorda Watsona, który wskazał $z$ kolei, że francuski prawnik w swej pracy nie tylko skomentował wcześniejsza pracę S. Scaccii, lecz także za przykładem Włocha przejął do swojej pracy łacińską maksymę mandator debet refundere mandatario quidquid ei inculpabiliter abest ex causa mandati ${ }^{39}$, która stanowiła podsumowanie reguł prawnych zawartych w kilku kolejnych paragrafach tytułu Mandanti vel contra Digestów justyniańskich ${ }^{540}$. W stosunkach łaczacych instytucje bankowe $z$ ich klientami wykorzystanie powyższej paremii w istotny sposób łagodzić miało odpowiedzialność klientów zwiąana z obowiąkiem dochowania przez nich należytej staranności przy wypisywaniu czeku.

Do koncepcji autorstwa R.J. Pothiera odwoływali się także pozostali sędziowie orzekający w sprawie Scholfield $v$. Earl of Londesborough, pozostawiajac jednak romanistyczne rozważania na marginesie głównego toku swoich wypowiedzi.

${ }_{539}^{5}$ D. $17,1,53-59$.

${ }^{540}$ D. 17,1 . 
Podkreślono, iż „doktryna Pothiera” oparta została na relacji mandansa i mandatariusza i nie jest ona tożsama $z$ relacja trasanta i trasata, której dotyczyło postępowanie. W ten sposób law lords odrzucili stosowanie precedensu Young $v$. Grote. Ostateczne rozstrzygnięcie odpowiadało wszakże cywilistycznej koncepcji Francuza, gdyż sędziowie zadecydowali, że trasat nie jest zobowiązany badać weksel na okoliczność jego potencjalnego sfałszowania.

Rozwiazania prawa rzymskiego znajdywały czasami zastosowanie w sprawach $z$ zakresu prawa ubezpieczeniowego. Jedna $z$ nich była rozpatrywana w roku 1899 sprawa Ruabon Steamship Co. Ltd. v. London Assurance ${ }^{541}$. Statek należacy do Ruabon Steamship Co. Ltd. został w czasie jednego z rejsów uszkodzony. W zwiazku z tym przetransportowano go do suchego doku w porcie Cardiff, gdzie przeprowadzone zostały stosowne naprawy. Łaczny koszt remontu statku, wraz $z$ jego wprowadzeniem i wyprowadzeniem $z$ doku, wynosił 822 funty, 14 szylingów i 10 pensów. Sumę tę na mocy umowy ubezpieczenia pokryć powinni tzw. underwriters, tzn. reasekuranci ubezpieczenia, wśród których znajdowało się także London Assurance, które wedle obliczeń armatora powinno zapłacić 82 funty i 5 szylingów. Londyńskie przedsiębiorstwo ubezpieczeniowe uznało jednak, iż nie tylko underwriters powinni w tym przypadku ponieść koszty remontu statku, lecz także spółka będąca jego właścicielem. London Assurance wypłaciło właścicielowi jedynie 80 funtów, stwierdzając, że pozostałe 2 funty i 5 szylingów Ruabon Steamship Co. Ltd. musi wyłożyć $z$ własnych środków.

W powyższej sprawie do prawa rzymskiego odwołał się Lord Kanclerz Halsbury. Zwrócił on uwage, że prawnicy reprezentujacy właściciela statku przywołali w swym wystapie-

${ }^{541}$ Ruabon Steamship Co. Ltd. v. London Assurance [1900] A.C. 6. Warto zwrócić uwagę, iż była to ostatnia sprawa, której przysłuchiwał się Lord Watson, jeden $z$ bardziej twórczych lordów prawa, odwołujący się w swych orzeczeniach do prawa rzymskiego. Zmarł on jednak w czasie wakacyjnej przerwy, przez co jego orzeczenie nie znalazło się już w oficjalnym raporcie sądowym. 
niu doktrynę particular average loss ${ }^{542}$, stanowiąca element tradycji prawa morskiego. Angielski prawnik zauważył także, iż genezę powyższej doktryny wywodzić należy już z rozwiazań prawa morskiego znanego na wyspie Rodos. Jako potwierdzenie swej tezy przywołał ${ }^{543}$ orzeczenie Lorda Watsona wydane w sprawie Strange, Steel \& Co. $v$. Scott ${ }^{544}$ rozpatrywanej kilka lat wcześniej przez sąd Tajnej Rady. Szkocki prawnik stwierdził: "the rule of contribution in cases of jettison has its origin in the maritime law of Rhodes, of which the text of preservered by Paulus [...], is, si levandae navis gratia iactus mercium factus est, omnium contributione sarciatur quod pro omnibus datum est"545. Następnie Lord Watson wskazał, iż wprawdzie według Lorda Bramwella, orzekającego w sprawie Wright v. Marwood ${ }^{46}$, możliwość wyrzucenia towaru i podział ryzyka związanego $z$ pokryciem kosztów wyprawy morskiej wynikały $z$ zawartej uprzednio umowy, to jednak Lord Esher, w sprawie Burton \& Co. v. English \& Co. ${ }^{547}$ stwierdził, że w prawie angielskim powyższa zasada nie wynika $z$ żadnej umowy, lecz ze starożytnego prawa rodyjskiego, które zostało przejęte do systemu prawa angielskiego za pośrednictwem „prawa oceanu”. Dalej jeszcze Lord Kanclerz przywołał fragment orzeczenia wydanego w sprawie Stirling $v$. Forrester ${ }^{54}$, w którym Lord Redesdale stwierdził, iż zasada rozdzielania ryzyka, jak i obowiazek pokrycia strat poniesionych przez jednego $z$ pasażerów czy kupców transportujących swoje towary na statku dotyczy wszystkich, którzy nim podróżują. Stają się oni współodpowiedzialni nie przez wzgląd na zawartą umowę, lecz na skutek powszechnych zasad słuszności.

Mimo przywołania powyższych orzeczeń, Lord Kanclerz stwierdził ostatecznie, iż żaden $z$ powyższych precedensów

${ }^{542}$ Por. E.A. Martin, Oxford Dictionary..., s. 41-42, s.v. Average.

${ }^{543}$ Ruabon Steamship Co. Ltd. v. London Assurance [1900] A.C. 6, 10.

${ }^{544}$ Strange, Steel \& Co. v. Scott (1889) 14 App. Cas. 601, 607.

${ }^{545}$ D. 14, 2, 1 (Paulus libro secundo sententiarum).

${ }^{546}$ Wright v. Marwood (1881) 7 Q.B.D. 62, 67.

${ }^{547}$ Burton \& Co. v. English \& Co. (1883) 12 Q.B.D. 218, 220.

${ }^{548}$ Stirling $v$. Forrester (1821) 3 Bligh 575, 596; 4 Eng. Rep. 712, 719. 
nie daje odpowiedzi na pytanie, które stało się przedmiotem analizowanej sprawy. Wynika to bowiem $z$ faktu, iż stosunek prawny, który łączył właściciela statku oraz reasekuranta ubezpieczeniowego, nie był w żaden sposób podobny do relacji współwłaścicieli przewożonego na statku towaru, czy nawet do stosunków łączących niezależnych kupców, którzy podróżowali tym samym statkiem. W przedmiotowej sprawie nie można mówić o długu, który stanowiłby następstwo poniesionej w wyniku niebezpieczeństwa szkody. Ostatecznie wszyscy lordowie orzekli na korzyść apelującego właściciela statku.

\subsection{Argument ,już w prawie rzymskim"}

Pośród licznych przypadków powołania się na prawo rzymskie, lordowie prawa odwoływali się również do jego autorytetu, używając argumentu dawnego pochodzenia określonego rozwiazania prawnego. Ten swoisty argument iam ex iure Romano (,już w prawie rzymskim") powoływany był przez brytyjskich sędziów i prawników w zróżnicowanych przypadkach. Zauważyć trzeba jednak, że przedmiotowy argument był przede wszystkim wykorzystywany przez sędziów niższych sądów.

Przykładem takiego powołania rzymskiej konstrukcji prawnej jest fragment orzeczenia autorstwa Viscount $\mathrm{Si}-$ mondsa w sprawie Kirkness $v$. John Hudson \& Co. ${ }^{549} \mathrm{z}$ roku 1955, który zwrócił uwagę, że według literatury i orzecznictwa angielskiego sprzedaż określana jest jako bargain and sale of goods. Określenie bargain („targować się”) natomiast, w jego przekonaniu, wyrażało konsensualny charakter umowy sprzedaży. Koncepcja porozumienia zaś jako konstytutywnego elementu sprzedaży znana była prawu rzymskiemu. Lord prawa udowodnił swoje twierdzenie przytaczając otwierające zdanie dwudziestego trzeciego tytułu księgi trzeciej Instytucji justyniańskich - „emptio et venditio contrahitur, si-

${ }^{549}$ Kirkness v. John Hudson \& Co. [1955] A.C. 696. 
mulatque de pretio convenerit' ${ }^{550}$. Powołanie to, choć trudno zarzucić mu brak trafności, w praktyce nic nie wniosło do prowadzonych przez sędziego rozważań.

Ten sam typ argumentacji odnaleźć można również w pochodzacym z roku 1999 orzeczeniu Lorda Slynn of Hardley w sprawie Fitzpatrick $v$. Sterling Housing Association Ltd. ${ }^{551}$ Problem prawny dotyczył uprawnień Martina Fitzpatricka do mieszkania, którego dotychczasowym właścicielem był jego zmarły partner. W trakcie toczącego się postępowania podniesiono problem zdefiniowania rodziny na gruncie prawnym. Lord prawa wskazał, iż wieloznaczność tego terminu („Do you have any family?, We are having a family gathering, the family of nations, the Christian family") nie tylko charakteryzuje czasy współczesne, lecz znana była także Rzymianom. Pojęcie familia rozumiano bowiem jako termin określający wszystkich członków danej jednostki społecznej, których prawa w jej obrębie różniły się jednak od siebie. Różnie ukształtowane uprawnienia przysługiwały bowiem małżonkom, inne zaś dziedzicom powołanym do nabycia rodzinnego majątku ${ }^{552}$. Warto $\mathrm{w}$ tym miejscu dodać, że Lord Slynn pominął w swej uwadze jeszcze jedną ważną cechę rzymskiej rodziny. Pamiętać trzeba bowiem, że termin familia używany był przez jurystów nie tyle jako określenie zespołu osób, ale przede wszystkim majątku, którym zarządzał w imieniu całej rodziny pater familias ${ }^{553}$.

W dwóch przedstawionych powyżej orzeczeniach argument ,już w prawie rzymskim” wykorzystany był jako samodzielne nawiązanie do starożytnej tradycji prawnej. Pamiętać należy równocześnie, że ten sam argument stosowany był wielokrotnie także przy okazji innych odwołań do prawa rzymskiego, co można dostrzec $\mathrm{w}$ dalszej części pracy przy okazji omawiania kolejnych orzeczeń.

550 I. 3, 23, pr. = G. 3, 139.

${ }^{551}$ Fitzpatrick $v$. Sterling Housing Association Ltd. [2001] 1 A.C. 27.

${ }^{552}$ Fitzpatrick $v$. Sterling Housing Association Ltd. [2001] 1 A.C. 27, 34.

${ }^{553} \mathrm{O}$ różnych znaczeniach terminu familia w prawie justyniańskim zob. D. 50, 16, 195 (Ulpianus libro 46 ad edictum). 


\subsection{Prawo rzymskie jako źródło uzupełnienia luk prawnych}

Angielski romanista Raphael Powell, profesor prawa rzymskiego na University College London w latach 19551964, na kilka lat przed swoja śmiercia opublikował interesujace opracowanie zatytułowane Roman Law in Common Law Courts. Autor - po wcześniejszej wszechstronnej analizie różnych angielskich orzeczeń - wskazał zasady, zgodnie z którymi możliwe jest powoływanie się na prawo rzymskie przez sady common law. Jego zdaniem, prawo rzymskie może zostać wykorzystane jedynie wówczas, gdy prawo angielskie „milczy”. Oznacza to zatem, iż R. Powell dopuszczał stosowanie prawa rzymskiego jedynie w przypadkach luki prawnej. Romanista podkreślał jednocześnie, że rzymska regulacja musi odpowiadać specyfice czasów, w których ma być zastosowana. Ostatecznie uczony wskazał, iż przejęcie do prawa angielskiego określonej rzymskiej doktryny bądź instytucji nie oznacza jednocześnie zaadaptowania wszystkiego, co się $z$ dana doktryna czy instytucją wiąże w prawie rzymskim ${ }^{554}$.

Okoliczności wymienione przez R. Powella moga być przedmiotem dyskusji i wydaje się, że trudno byłoby je współcześnie obronić, wskazuja one jednak na zagadnienie istnienia luk prawnych i konieczność ich uzupełniania instytucjami prawnymi zaczerpniętymi $z$ tradycji prawa rzymskiego, co z kolei wyraźnie wskazuje na jego autorytet. Pierwszą ze spraw badanych przez Izbę Lordów, w których starano się wykorzystać prawo rzymskie w tym celu, była sprawa Keighley, Maxsted \& Co. v. Durant ${ }^{555}$ rozpatrywana przez law lords w roku 1901.

Przedmiotem sporu były okoliczności działania bez stosownego umocowania przedstawiciela handlowego. Poczatkowo Keighley, Maxsted and Co. upoważniła przedstawiciela

${ }^{554}$ R. Powell, Roman Law in Common Law Courts, Current Legal Problems 1958, s. 31-34.

${ }^{555}$ Keighley, Maxsted \& Co. v. Durant [1901] A.C. 240. 
handlowego nazwiskiem Roberts (w raportach sadowych nie wskazuje się jego imienia) do nabycia, na wspólny rachunek jego oraz spółki, zboża po wcześniej określonej cenie. Po początkowym niepowodzeniu Roberts zawarł umowę ze spółką Bryan Durant \& Co., zgadzając się na wyższą cenę aniżeli określona w treści jego pełnomocnictwa. Umowa zawarta została przez Robertsa w jego własnym imieniu, lecz jak później zapewniał, jego wola było zawarcie jej we wspólnym interesie - jego własnym i spółki, którą reprezentował. Następnego dnia przedstawiciel spółki zatwierdził działania pełnomocnika, ale zboże ostatecznie nie zostało odebrane od Bryan Durant \& Co., a spółka wycofała się z zatwierdzenia czynności. $\mathrm{W}$ zwiazku $\mathrm{z}$ tym zboże zostało ponownie sprzedane przez pokrzywdzona spółkę, ale już za niższa cenę, a Keighley, Maxsted \& Co. została pozwana. Ta ostatnia uznała, że nie powinna odpowiadać za straty poniesione przez Bryan Durant $\&$ Co., ponieważ w chwili podpisania umowy przez Robertsa nie była jej strona. Podnoszono, iż nie nastapiła tzw. ratification, czyli formalne zatwierdzenie działań podjętych przez pełnomocnika. Wynikało to $z$ faktu, że Roberts zawarł umowe $\mathrm{w}$ swoim własnym imieniu, nie zaś w imieniu spółki, przy braku stosownego upoważnienia do podjęcia takich działań. Zdaniem prawników Bryan Durant \& Co., argumentacja apelującej strony była bezzasadna, gdyż prawo angielskie znało precedensy, w których procedura ratification zastosowana była $\mathrm{w}$ przypadkach odpowiadajacych stanowi faktycznemu ich sprawy. Jak wskazal autor law report, prawnicy Bryan Durant \& Co. przywołali ${ }^{556}$ na poparcie swoich tez passus pochodzacy $\mathrm{z}$ drugiego tomu Commentaries on Roman-Dutch Law autorstwa siedemnastowiecznego holenderskiego cywilisty Simona Van Leeuvena ${ }^{557}$.

Kwestia prawa rzymskiego została podniesiona w sadzie Izby Lordów nie ze względu na argumenty stron, lecz ze względu na odwołanie się do jego zasad przez jednego $z$ sę-

${ }^{556}$ Keighley, Maxsted \& Co. v. Durant [1901] A.C. 240, 243.

${ }^{557}$ S. van Leeuven, Het Rooms-Hollands-regt, 4, 26. 
dziów Sądu Apelacyjnego. Lord Justice Collins ${ }^{558}$ twierdzacc, iż brakuje w prawie angielskim zasad, które pozwoliłyby rozstrzygnąc sprawę dwóch spółek, zdecydował się na przytoczenie kilku ustępów pochodzacych $z$ tytułu De negotiis gestis, umieszczonego w trzeciej księdze Digestów ${ }^{559}$. Opinia sędziego Sąu Apelacyjnego nie spotkała się jednak $z$ uznaniem law lords, którzy jednomyślnie odrzucili stosowanie rzymskich rozwiazań dotyczacych prowadzenia spraw bez zlecenia i uznali je za obce angielskiemu systemowi prawnemu ${ }^{560}$. Najobszerniejsze wyjaśnienie takiej postawy zawarł w swym orzeczeniu Lord Robertson. Szkocki prawnik wskazał, że Lord Collins przede wszystkim oparł swoja romanistyczna argumentację na pismach jurystów odnoszacych się do zasad wymagalności roszczenia przez działającego bez zlecenia. Zwrócił ponadto uwage, iż kluczowa dla zrozumienia problematyki działania bez zlecenia jest przesłanka contemplatio, czyli domniemanej woli ustanowienia pełnomocnika. Zaznaczył jednocześnie, że mówienie o contemplatio wymaga uwzględnienia długiej dyskusji, która jej dotyczyła, zaś passusy wyjęte przez Lorda Collinsa na jej temat $z$ Digestów sa jedynie „zwykłym epizodem". Lord prawa stwierdził, iż akademicka dyskusja dotyczyła próby odpowiedzi na pytanie o to, w jakich okolicznościach osobie działającej bez zlecenia przysługuje skarga przeciwko temu, na rzecz kogo czynności były podejmowane. Wyjaśnił jednocześnie, iż działanie bez umocowania prawnego powinno mieć charakter przyjacielskiej pomocy, nie powinno być zaś działaniem „samolubnym”, podejmowanym w swoim własnym interesie. W takich jedynie okolicznościach, zdaniem Lorda Robertsona, powinno rozstrzygać się kwestię zastosowania contemplatio ${ }^{561}$. Potwierdzeniem tego jest pochodzacy z komentarza Ulpiana do edyktu kazus Seiusa: "Idem ait, si Titii debitorem, cui te heredem putabam,

${ }^{558}$ Durant \& Co. v. Roberts and Keighley, Maxsted and Co. [1900] 1 Q.B. $629,647$.

${ }^{559}$ D. 3, 5.

560 Por. infra, s. 127.

${ }^{561}$ Keighley, Maxsted \& Co. v. Durant [1901] AC 240, 259-260. 
cum esset Seius heres, convenero similiter et exegero, mox tu ratum habueris: esse mihi adversus te et tibi mutuam negotiorum gestorum actionem. Adquin alienum negotium gestum est: sed ratihabitio hoc conciliat: quae res efficit, ut tuum negotium gestum videatur et a te hereditas peti possit'562.

Sędzia wyjaśnił, że wprawdzie w kazusie okazało się, iż prawdziwym wierzycielem człowieka, na rzecz którego podjęto działania, był ktoś inny, to jednak istotne było, że działania te podjęte zostały w cudzym interesie. W tym przypadku podjęcie działań wynikało $z$ nieobecności osoby, na rzecz której działania były podejmowane, nie zaś na rzecz osoby trzeciej $^{563}$. Lord Robertson negatywnie ustosunkował się także do innego rzymskiego zapożyczenia dokonanego przez Lorda Collinsa, który odniósł się do problematyki deliktów ${ }^{564}$. Lord prawa podkreślił, iż w przedmiotowej sprawie spór dotyczy kontraktu, nie zaś deliktu ${ }^{565}$. Ostatecznie większość lordów nakazała oddalenie apelacji i przywrócenie wyroku pierwszej instancji, w którym stwierdzono, iż ratification nie miała miejsca, a pozwany powinien być jedynie pełnomocnik Roberts.

Warto zwrócić dodatkowo jeszcze uwage na wypowiedź Earl of Halsbury, L.C., który po odrzuceniu przydatności rozwiązań rzymskich zaproponowanych przez Lorda Collinsa stwierdził: „there are parts of the Roman law which undoubtedly we have made part of our own law, and they are binding on us, not because they are part of the Roman law, but because they have become part of our law"566.

W listopadzie 1957 roku sędziowie Komitetu Apelacyjnego wydali orzeczenie w szczególnej sprawie. Przedmiotem ana-

562 D. 3, 5, 5, 12(10) (Ulpianus libro decimo ad edictum).

${ }^{563}$ Więcej na temat kazusu Seiusa zob. A. Kacprzak, La Ratihabitio nel diritto romano classico, Napoli 2002, s. 77-79.

564 Durant \& Co. v. Roberts and Keighley, Maxsted and Co. [1900] 1 Q.B. 629, 648; D. 43, 16, 1, 14 (Ulpianus libro 69 ad edictum). Jednocześnie Lord Collins uważał, iż ta zasada potwierdzona została w D. 50, 17, 152 (Ulpianus libro 69 ad edictum) i 160 (Ulpianus libro 76 ad edictum).

${ }^{565}$ Keighley, Maxsted \& Co. v. Durant [1901] A.C. 240, 260-261.

${ }^{566}$ Keighley, Maxsted \& Co. v. Durant [1901] A.C. 240, 244. 
lizy lordów w precedensowym postępowaniu National Bank of Greece and Athens S.A. v. Metliss ${ }^{567}$ stało się zagadnienie następstwa prawnego osób prawnych. W roku 1927 Narodowy Bank Hipoteczny Grecji wyemitował serię obligacji w funtach szterlingach. Ich wartość miała być wypłacona posiadaczom w roku 1957. Zabezpieczenie wypłacalności kwoty bazowej oraz odsetek zapewnił Narodowy Bank Grecji. Umowa, która podpisywali chętni na zakup obligacji, stanowiła, iż w przypadku jakichkolwiek sporów zwiazanych $z$ istota zobowiązania właściwymi będa sady angielskie. W roku 1941, w związku $z$ toczącą się wojna, wypłata odsetek wynikających z zawartych umów została jednak zawieszona. Po zakończeniu wojny, w roku 1949, rząd grecki ogłosił moratorium, w którym stwierdzono zawieszenie wypłacania wszelkich greckich obligacji bankowych ustanowionych $\mathrm{w}$ obcych walutach. Wreszcie w roku 1953, na mocy ustawy wydanej przez grecki parlament, dotychczasowy Narodowy Bank Grecji został połączony z Bankiem Aten. W ten sposób doszło do powstania nowego Narodowego Banku Grecji i Aten S.A. Jednocześnie uznano, iż nowy bank powinien być traktowany jako następca prawny dwóch banków, które go tworzyły.

Spór, jaki toczył się między bankiem a Cyrilem Metlissem, który był właścicielem obligacji opiewających na kwotę 29.700 funtów, stanowił poważny problem dla angielskich sędziów orzekających w kolejnych instancjach. Pełnomocnicy banku podnosili fakt, iż sądy angielskie stosować moga jedynie prawo angielskie, nie zaś greckie, a w związku $z$ tym nowy bank nie powinien być odpowiedzialny za zobowiąania zaciagnięte przez Narodowy Bank Hipoteczny Grecji i zabezpieczone przez "stary” Narodowy Bank Grecji, co związane było $z$ brakiem uznawania $\mathrm{w}$ tego rodzaju przypadkach sukcesji uniwersalnej ${ }^{568}$.

Ostatecznie sprawa trafiła do Komitetu Apelacyjnego $z$ apelacji złożonej przez prawników reprezentujących inte-

567 National Bank of Greece and Athens S.A. v. Metliss [1958] A.C. 509. 568 J.G. Collier, Conflict of Laws, ed. 3, Cambridge 2001, s. 19. 
resy banku. Kluczowe orzeczenie w sprawie wydane zostało przez pełniącego wówczas obowiązki Lorda Kanclerza Viscounta Simondsa. Sędzia wskazał, iż źródła prawa angielskiego dostarczaja niewielu argumentów, które umożliwiłyby wydanie sprawiedliwego wyroku $\mathrm{w}$ przedmiotowej sprawie. $\mathrm{W}$ zwiazku $\mathrm{z}$ tym konieczne było, jego zdaniem, odwołanie się bądź do analogii, bądź do ogólnych zasad prawa. Sędzia podkreślił jednak, że oba środki argumentacji nie daja pokładanej w nich pewności wymaganej dla wydania wyroku. Jego zdaniem analogia jest niebezpieczna metoda argumentacji, zaś ogólne zasady prawa bywaja trudne do precyzyjnego określenia $^{569}$. Ostatecznie Lord Kanclerz zdecydował się na zastosowanie w swym orzeczeniu analogii. Odwołał się on do koncepcji sukcesji uniwersalnej, o której zresztą wspominała ustawa grecka ustanawiająca „nowy” Narodowy Bank Grecji. Pojęcie sukcesji uniwersalnej nie było dotychczas znane prawu angielskiemu, jednakże sędziowie Izby Lordów stosowali je w odniesieniu do apelacji szkockich. W prawie szkockim, o czym także wspomniał Viscount Simonds, znana była maksyma eadem persona cum defuncto, odnosząca się właśnie do konstrukcji następstwa prawnego. Zasada występowała już $\mathrm{u}$ instytucjonalistów szkockich, m.in. u Lorda Stair ${ }^{570}$ oraz J. Erskine'a ${ }^{571}$.

Podsumowując swoje orzeczenie angielski prawnik wskazał, iż cywilistyczna konstrukcja powinna znaleźć zastosowanie w przedmiotowej sprawie, a jeśli sam miałby wskazać zasadę prawa, która dodatkowo mogłaby uzasadnić taki wyrok, byłaby to zasada racjonalnej sprawiedliwości (rational justice) ${ }^{572}$. Stwierdzenie to jest symptomatyczne. Sędzia wyraźnie starał się bowiem oddalić od siebie zarzut pochopnego wykorzystania wzorców pochodzących $z$ romanistycznej tradycji prawnej

${ }^{569}$ National Bank of Greece and Athens S.A. v. Metliss [1958] A.C. $509,524$.

570 Lord Stair, Institutions..., 1, 17, 14.

${ }^{571} \mathrm{~J}$. Erskine, An Institute of the Law of Scotland, 3, 8, 51.

${ }^{572}$ National Bank of Greece and Athens S.A. v. Metliss [1958] A.C. $509,525$. 
(w jej szkockiej odsłonie) i poczuł się zmuszony do wskazania drugiej, niezależnej podstawy swojego wyrokowania.

Do problematyki zastosowania sukcesji uniwersalnej odniósł się także szkocki sędzia Lord Keith of Avonholm. Wyjaśnił on, iż konstrukcja ta dotyczyła w prawie rzymskim przede wszystkim kwestii zwiazanych z prawem spadkowym, gdzie dziedzic wraz ze śmiercia spadkodawcy stawał się m.in. odpowiedzialny $z$ tytułu zobowiązań zaciagniętych przez niego. W ten sposób traktowany był on jako przedstawiciel zmarłego, czy wręcz, jak zauważył Lord Keith, osoba zmarłego była „kontynuowana” w osobie dziedzica, co znalazło wyraz $\mathrm{w}$ znanej prawu szkockiemu paremii eadem persona cum defuncto ${ }^{573}$.

Law lord wskazał, iż na gruncie prawa angielskiego podobna rolę odgrywa egzekutor czy też administrator majątku zmarłego. Osoby takie nie sa stronami żadnej umowy, lecz jedynie wykonuja polecenia pozostawione im przez zmarłego. $\mathrm{O}$ analogiczności angielskich i szkockich rozwiazań prawnych Lord Keith zaświadczył powołując passus pochodzacy $z$ pracy Lorda Stair dotyczacy sposobu definiowania sukcesji uniwersalnej ${ }^{574}$. Przyznać należy jednak, iż przywołana analogia trudna jest do zaakceptowania $z$ romanistycznego punktu widzenia. Dużo lepsze byłoby raczej porównanie administratora majątku do familiae emptor - jednego $z$ podmiotów niezbędnych dla ustanowienia testamentu mancypacyjnego.

Ostatecznie wszyscy sędziowie oddalili apelację złożona przez prawników Narodowego Banku Grecji, uznając tym samym możliwą właściwość sądów angielskich w toczącym się postępowaniu ${ }^{575}$. Do systemu prawa angielskiego wprowadzona została zatem zasada sukcesji uniwersalnej zaczerpnięta z prawa rzymskiego. Szczególną uwagę zwraca jednak fakt,

${ }^{573}$ National Bank of Greece and Athens S.A. v. Metliss [1958] A.C. 509, 530 .

${ }^{574}$ Lord Stair, Institutions..., 3, 4, 23.

${ }^{575}$ Więcej na temat tej sprawy oraz pozostałych spraw wchodzacych w skład tzw. Greek Bond Cases zob. J.K. Grodecki, The Greek Bond Cases, MLR 24/6 (1961), s. 701-714. 
iż recepcja nastapiła za pośrednictwem prawa greckiego, zaś argumentacja wywodząca się ze Scots law jedynie utwierdziła lordów, nie była zaś podstawowym jej źródłem.

W niektórych orzeczeniach Izba Lordów rozwijała uzupełnienia luk prawnych argumentami z prawa rzymskiego, które już zawczasu podnoszono przy okazji innych spraw przed niektórymi niższymi sądami. Przykładem takiego potraktowania prawa rzymskiego może być sprawa $\mathrm{z}$ roku $1999, D P P$ v. Jones ${ }^{576}$. Mimo iż zasadniczo była ona apelacja karna, to jednak sędziowie wypowiedzieli się także w kontekście pewnych zagadnień prawnorzeczowych. Stan faktyczny sprawy dotyczył bezprawnego zgromadzenia odbywajacego się na prywatnej nieruchomości (tresspassory assembly). W czerwcu 1995 roku grupa ponad dwudziestu osób upamiętniająca tzw. battle of Beanfield ${ }^{577}$ stała na trawniku znajdujacym się pomiędzy droga krajowa A344 a płotem okalajacym słynny kompleks megalityczny Stonehenge. Według oficerów policji, grupa dokonała w ten sposób nieuprawnionego wejścia na prywatny teren i zagrażała porządkowi publicznemu, jak również obiektowi o wartości historycznej (wyczerpywało to przesłanki tresspassory assembly zawarte w Public Order Act $1986^{578}$ ).

W swoim orzeczeniu Lord Hope of Craighead powołał wcześniejsze podobne sprawy, w tym Attorney-General $v$. Antrobus $^{579} \mathrm{z}$ roku 1905 rozstrzygana przez Wydział Kanclerski High Court of Justice. Przedmiotem postępowania była ocena możliwości nabycia przez społeczeństwo prawa używania drogi w celu oglądania zabytku (sprawa również dotyczyła kompleksu Stonehenge). Nabycie tego rodzaju określane jest

${ }^{576}$ DPP V. Jones [1999] 2 A.C. 240.

577 Battle of Beanfield było to starcie pomiędzy wyznawcami ideologii New Age a policją, do którego doszło w 1985 roku na terenie Stonehenge, gdy konwój wyznawców ruchu starał się przedostać na teren obiektu, ażeby rozpocząc doroczne obchody związane $z$ letnim przesileniem słonecznym.

578 Sec. 14A Public Order Act 1986 (c. 64) dodana przepisami Criminal Justice and Public Order Act 1994 (c. 33).

${ }^{579}$ Attorney-General v. Antrobus [1905] 2 Ch. 188. 
w tradycji common law łacińskim terminem ius spatiandi. Orzekający w sprawie sędzia Farwell stwierdził jedynie, iż nie istnieje w prawie angielskim techniczna możliwość „zasiedzenia" uprawnienia do poruszania się po cudzej nieruchomości. Referujac rozwój koncepcji ius spatiandi, Lord Hope przywołał następnie orzeczenie Sir Raymonda Evershed, M.R., wydane w roku 1956 w sprawie In re Ellenborough Park ${ }^{580}$. Sędzia przyznał słuszność wcześniejszym twierdzeniom sędziego Farwella $z$ roku 1905. Zauważył jednak, że jego poprzednik nie powołał się na żadne źródła prawa, które uzasadniałyby przedstawione twierdzenia. Sędzia R. Evershed, M.R., wskazał, iż prawdopodobnie sędzia Farwell oparł się na wypowiedzi Paulusa zawartej w Digestach justyniańskich: „Ut pomum decerpere liceat et ut spatiari et ut cenare in alieno possimus, servitus imponi non potest'581.

W powołanym przez sędziego passusie Paulus stwierdził, iż nie można ustanowić służebności przechodu w celu zrywania owoców, spacerowania bądź spożywania posiłków. Angielski sędzia zauważył jednak, iż powyższa zasada nie stoi w sprzeczności $z$ możliwością formalnego nabycia ius spatiandi przez dana społeczność. Tak skonstruowane uprawnienie może być traktowane jako easement - angielska odmiana służebności.

Orzekajacy w sprawie DPP $v$. Jones Lord Hope of Craighead przychylił się do argumentacji sędziego R. Evesheda, lecz zastrzegł, iż swobodne przyznanie uprawnień do korzy-

${ }^{580}$ In re Ellenborough Park [1956] Ch. 131. Warto zwrócić uwage, iż opierając się na pracy Modern Real Property autorstwa G. Cheshire'a, sędzia Evershed wprowadził do orzecznictwa angielskiego zasady rzadzace jego służebnościami. Interesujący wydaje się fakt, iż są one bardzo podobne do zasad rządzacych służebnościami w prawie rzymskim. Geoffrey Cheshire, a za nim sędzia Evershed, wymieniają: (1) konieczność występowania gruntu panującego i służebnego, (2) easement musi przynosić korzyść gruntowi dominujacemu, (3) właściciel gruntu panujacego i służebnego nie może być tą samą osoba, (4) uprawnienie względem gruntu nie może stać się służebnością, jeśli nie jest on zdolny do bycia przedmiotem nadania [tj. nie jest zdolny do bycia służebnościa - Ł.J.K.].

${ }^{581}$ D. 8, 1, 8, pr. (Paulus libro 15 ad Plautium). 
stania $\mathrm{z}$ drogi, czy gromadzenia się przed prywatnymi obiektami, tylko na podstawie ciagłego realizowania tego rodzaju działań, może wywołać poważne konsekwencje dla właścicieli takich obiektów ${ }^{582}$.

$\mathrm{W}$ ten sposób sędziowie Izby Lordów potwierdzili istnienie na gruncie prawa angielskiego ius spatiandi, ograniczajac jednak możliwość jego nadmiernego wykorzystywania.

${ }^{582}$ DPP v. Jones [1999] 2 A.C. 240, 276. 



\section{Rozdzial 4}

\section{PRAWO RZYMSKIE JAKO ELEMENT ANGIELSKIEJ LINII ORZECZNICZEJ}

\subsection{Rzymskie zasady prawne dotyczące nabycia wlasności}

Już w okresie średniowiecza rzymskie rozwiązania prawne dotyczące zasad pierwotnego nabywania własności zostały recypowane do prawa angielskiego. Odniesienia takie odnaleźć można już w traktacie Bractona ${ }^{583}$. Uwagę zwraca fakt, że angielscy prawnicy interesowali się zasadniczo jedynie tymi regulacjami pochodzącymi $z$ ius Romanum, które dotyczyły pierwotnych sposobów nabywania własności, na przykład odniesienia dotyczące stawania się właścicielem pochwyconych dzikich zwierzat ${ }^{584}$, które $z$ czasem przejęte zostały nawet do prawa amerykańskiego ${ }^{585}$. Wpisując się w tę tradycję, także Izba Lordów kilkakrotnie wypowiadała się na temat stosowania odnośnych reguł.

W roku 1913 lordowie rozstrzygali sprawę, w której odwołano się do problematyki commixtio. Sprawa Sandeman and

${ }^{583}$ Zob. obszerny tytuł De Adquirendo rerum dominio w pierwszym tomie dzieła Bractona.

${ }^{584}$ Por. np. sprawę Keeble v. Hickeringill (1707) Holt, K.B. 16; 90 Eng. Rep. 906; A.W.B. Simpson, Leading Cases in the Common Law, Oxford 1995, s. 45-75.

585 Pierson v. Post 3 Cai. R. 175 (1805). 
Sons $v$. Tyzack ${ }^{586}$ dotyczyła pakunku bel juty transportowanych $z$ Kalkuty, które miały być oznaczone i wydane różnym odbiorcom wraz z przybyciem statku do portu w Dundee. Po wyładowaniu ładunku okazało się, że jedenaście bel nie zostało właściwie oznaczonych, zaś czternastu innych brakuje. W związku z powyższym właściciel statku postanowił rozdzielić jedenaście niezidentyfikowanych bel proporcjonalnie do braków, jakie stały się udziałem czterech odbiorców towaru. Decyzja ta spotkała się jednak $z$ odmowa ze strony odbiorców. Armator postanowił sądownie zmusić kontrahentów do odbioru pozostałych bel juty. W związku $z$ niekorzystnym wyrokiem wydanym przez Court of Session sprawa w drodze apelacji złożonej przez jednego $z$ kontrahentów trafiła do Izby Lordów.

Wypowiadający się jako pierwsi Earl Loreburn, L.C., oraz Lord Shaw of Dunfermline, konsekwentnie odrzucili możliwość powołania się na commixtio w przedmiotowej sprawie. Lord Kanclerz podkreślał, iż fakt zmieszania rzeczy nie może zaburzyć relacji wynikajacych $z$ zawartej umowy ${ }^{587}$. Dopiero trzeci $z$ orzekających sędziów - Lord Moulton - szerzej wypowiedział się w kwestii rozwiąań prawa rzymskiego. Zauważył, że konieczne jest prześledzenie dotychczasowego sposobu rozumienia pojęcia zmieszania rzeczy w prawie angielskim. W związku $z$ tym przywołał definicję commixtio zaczerpnięta z Commentaries autorstwa amerykańskiego sędziego Kanclerza Kenta ${ }^{588}$. Ten ostatni wyróżnił dwa przypadki, gdy do zmieszania rzeczy doszło na skutek celowego działania jednego $z$ właścicieli rzeczy oraz gdy zmieszanie stanowiło następstwo zwykłego przypadku. W pierwszej sytuacji poszkodowany właściciel mógł domagać się zwrócenia mu rzeczy, w drugiej natomiast, na zasadach słuszności, dochodziło do uznania właścicieli dwóch zmieszanych rzeczy za ich współwłaścicieli. Kontynuując swój wywód Lord Moulton zauważył, iż zagadnienie przypadkowej commixtio jest problematyczne, na

586 Sandeman and Sons v. Tyzack [1913] A.C. 680.

587 Sandeman and Sons $v$. Tyzack [1913] A.C. 680, 689.

${ }^{588}$ Sandeman and Sons $v$. Tyzack [1913] A.C. 680, 695. 
co wskazuje także dotychczasowe orzecznictwo ${ }^{589}$. Najpierw angielski prawnik przywołał pochodząca z roku 1863 sprawę Buckley v. Gross ${ }^{590}$. Orzekajacy wówczas sędzia Blackburn uznał, że dotychczasowi właściciele zmieszanych rzeczy staja się współwłaścicielami w częściach równych. W innym natomiast orzeczeniu, Spence v. Union Marine Insurance Co. ${ }^{591}$ $z$ roku 1868, stwierdzono, iż własność zmieszanej masy przysługuje współwłaścicielom w częściach odpowiadających ich przypuszczalnemu „wkładowi”. Podsumowujac swoje rozważania, lord prawa orzekł, że problem przypomina węzeł gordyjski, a rozbieżne orzeczenia wydawane $\mathrm{w}$ tego typu spawach stanowią próby jego przecięcia ${ }^{592}$.

W swoim ostatecznym wyroku lordowie zadecydowali o uznaniu odpowiedzialności przewoźnika na zasadzie ryzyka za skutki zagubienia bel juty i nakazali wypłacić ich równowartość pokrzywdzonym odbiorcom. Odrzucili tym samym możliwość wykorzystania w przedmiotowej sprawie rzymskiej konstrukcji commixtio.

W powyższej sprawie zwraca uwagę fakt, iż sędziowie nie powołali się na rzymskie źródła. Wystarczającym autorytetem okazał się dla nich Kanclerz Kent. Dopiero sięgnięcie do Commentaries amerykańskiego prawnika ujawnia, że w znacznej części oparł on swój wywód na wcześniejszych rozważaniach romanistycznych ${ }^{593}$. Uznając zatem, iż Lord Moulton zaakceptował sposób rozumowania przedstawiony przez Kanclerza Kenta, można mówić o śladowym wpływie prawa rzymskiego na omawiana sprawę, trudno jednak mówić o chociażby pośredniej recepcji starożytnych rozwiąań.

Warto dodać, iż oprócz wzmiankowanej sprawy sędziowie Izby Lordów w latach 1876-2009 nie podejmowali więcej prób

589 Sandeman and Sons $v$. Tyzack [1913] A.C. 680, 695.

${ }^{590}$ Buckley v. Gross (1863) 3 B. \& S. 566; 122 Eng. Rep. 213.

${ }^{591}$ Spence $v$. Union Marine Insurance Co. (1867-68) L.R. 3 C.P. 427.

592 Sandeman and Sons $v$. Tyzack [1913] A.C. 680, 695.

${ }^{593}$ Fragment przytoczony przez Lorda Moultona jest mocno nasycony rozważaniami romanistycznymi, zob. J. Kent, Commentaries on American Law, vol. 2, ed. 10, Boston 1860, s. 465-466. 
interpretacji rzymskiej commixtio i jej zastosowania na gruncie prawa angielskiego. Jednakże w ostatnich latach działalności Komitetu Apelacyjnego dwukrotnie powoływali się na rzymskie pochodzenie terminu confusio - pokrewnego commixtio pod względem instytucjonalnym. W obu przypadkach uczynili to jednak w sposób nieprecyzyjny i nieprzekładający się na ostateczne rozstrzygnięcie sprawy. W roku $2000 \mathrm{w}$ sprawie Foskett v. McKeown do rzymskich rozwiązań odwołał się Lord Hoffmann ${ }^{594}$. W roku 2007 natomiast, w sprawie Rhone-Poulenc Rorer International Holdings Inc. $v$. Yeda Research and Development Co. Ltd., Lord Walker of Gestingthorpe wskazał z kolei, iż możliwość oparcia się na rzymskiej confusio, w odniesieniu do praw własności intelektualnej w nawiązaniu do prowadzonych prac badawczych majacych na celu opatentowanie wynalazku, nie znajduje zastosowania ${ }^{595}$.

W interesujacy sposób Izba Lordów wykorzystała także łacińską zasadę quicquid plantatur solo, solo cedit ${ }^{596}$, której rzymskie pochodzenie nie ulega wattpliwości. Angielska zasada wyraźnie nawiazuje bowiem do zasady wyrażonej przez Gaiusa w jego Res cottidianae, zachowanej w Digestach, brzmiacej: quia omne quod inaedificatur solo cedit ${ }^{597}$, czy lepiej znanej jej wersji: superficies solo cedit ${ }^{598}$.

Maksyma była przedmiotem analizy law lords w roku 1883 w sprawie Wake $v$. Hall ${ }^{599}$. Stan faktyczny sprawy dotyczył wybudowania przez górników kilku obiektów oraz ustawie-

594 Więcej zob. supra 128-131.

${ }^{595}$ Rhone-Poulenc Rorer International Holdings Inc. $v$. Yeda Research and Development Co. Ltd. [2007] Bus. L.R. 1797, 1813.

${ }^{596}$ Brokarda po raz pierwszy pojawiła się już u Bractona w formie quicquid plantatur, servitur vel inaedificatur, omne solo cedit, redices si tamen egit, H. Bracton, Tractatus de Legibus et Consuetudinibus Regni Angliae, f. 10a.

${ }^{597}$ D. 41, 1, 7, 10 (Gaius libro secundo rerum cottidianarum sive aureorum).

${ }^{598}$ G. 2, 73. W polskiej literaturze zob. szerzej A. Sokala, Zasada superficies solo cedit $w$ prawie rzymskim, Acta Universitatis Nicolai Copernici. Prawo XXV. Nauki Humanistyczno-Społeczne 172 (1987), s. 143-160.

${ }^{599}$ Wake v. Hall (1883) 8 App. Cas. 195. 
nia maszyn na prywatnym terenie zgodnie $z$ postanowieniami High Peak Mining Customs and Mineral Courts Act $1851^{600}$. Regulacja ustawowa, która w praktyce stanowiła zapisana formę zwyczajów górniczych stosowanych w setni High Peak (dzisiejsze Derbyshire) od stuleci, przewidywała m.in. możliwość niemalże nieograniczonego poszukiwania złóż ołowiu - nawet pod cudzymi nieruchomościami. Jednocześnie właściciele byli zobowiązani znosić obecność górników tak długo, aż nie wyczerpią oni zasobów metalu w danym miejscu, jak również musieli zapewnić górnikom możliwość przejazdu przez ich grunt, $z$ tym że droga taka nie stawała się droga publiczna, a jej wykorzystanie ograniczone powinno być do minimum. W przedmiotowej sprawie spór powstał w związku z kwestią opuszczenia jednej z kopalń na kilka lat. W następstwie tego zrodziła się wątpliwość, czy właściciel gruntu stał się właścicielem pozostawionych budynków i maszyn, jak również czy wraz $z$ opuszczeniem kopalni wygasł interes prawny górników w odniesieniu do materiałów, które posłużyły do skonstruowania budynków oraz uruchomienia potrzebnych im maszyn. Podnoszono bowiem, iż wybudowanie spornych obiektów miało "cel górniczy”, nie zaś stałe ich połaczenie $z$ gruntem.

Analizujac te zagadnienia, Lord Blackburn w swym orzeczeniu podkreślił, iż zasada quicquid plantatur solo, solo cedit, wyrażona w cytowanym przez zastępców procesowych orzeczeniu Elwes $v$. Maw ${ }^{601}$ z 1802 roku, wywodzi się z prawa rzymskiego ${ }^{602}$. Sędzia stwierdził, że wspomnianą zasadę przytacza już Gaius, lecz najprawdopodobniej powstała ona jeszcze przed okresem działalności jurysty. Następnie brytyjski prawnik zauważył, iż ta sama zasada została dołaczona do paragrafu siódmego, tytułu pierwszego, ksiegi czterdziestej pierwszej Digestów justyniańskich, w którym poruszone

${ }^{600}$ High Peak Mining Customs and Mineral Courts Act 1851 (14 \& 15 Vict., c. 94).

${ }^{601}$ Elwes v Maw (1802) 3 East. 37; 102 Eng. Rep. 510.

${ }^{602}$ Wake $v$. Hall (1883) 8 App. Cas. 195, 203. 
zostały różne przypadki zmiany istoty rzeczy należącej do kogoś innego. Mając na celu ukazanie doniosłości omawianego problemu, lord prawa wymienił ponadto kilka przykładów takich zmian, które $z$ punktu widzenia nauki prawa rzymskiego odnosiły się do metody nabycia własności w drodze specificatio - przetopienie srebra w waze, przerobienie bloku marmuru w posag, czy winogron w wino ${ }^{603}$.

Sędzia powołał gajańskie sformułowanie quia omne quod inaedificatur solo cedit. W jego przekonaniu reguły przedstawione przez Gaiusa, a następnie zaakceptowane przez twórców Digestów, posiadaja szersze zastosowanie aniżeli powstała jedynie na ich podobieństwo angielska zasada quicquid plantatur solo, solo cedit. Różnica między prawem rzymskim a angielskim wynikała bowiem $z$ charakteru prawnego rzeczy ruchomych i nieruchomych w obu systematach prawnych. Klasyczne prawo rzymskie nie różnicowało sposobów nabycia i dziedziczenia rzeczy ruchomych i nieruchomych. Prawo angielskie posługuje się natomiast podziałem na real property oraz chattels, który stanowi pokłosie średniowiecznej angielskiej koncepcji własności opartej na prawie feudalnym. Pierwsza kategoria obejmuje grunty oraz większość uprawnień przysługujących osobom władajacym gruntami, jak np. służebności. Chattels natomiast to w zasadzie wszystkie pozostałe rzeczy, jak również wyjątkowo tzw. chattels real, tzn. prawa odnoszace się do dzierżawy gruntów. Sposoby nabywania, jak również dziedziczenia obu rodzajów rzeczy były w przeszłości zgoła odmienne (chociaż i we współczesnym prawie angielskim różnice te są dostrzegalne) ${ }^{604}$. W przypadku stosowania zasady quicquid plantatur solo, solo cedit dochodzi zatem do sytuacji, w której rzecz z kategorii chattels (np.

${ }^{603}$ Pierwszy i trzeci przykład przywołane przez Lorda Blackburna pochodza $z$ D. 41, 1, 7, 7 (Gaius libro secundo rerum cottidianarum sive aureorum), natomiast przykład dotyczacy posagu zaczerpnięty został $z$ tekstu autorstwa Paulusa zamieszczonego w D. 41, 1, 24 (Paulus libro 14 ad Sabinum).

${ }^{604}$ Zob. więcej W. Swadling, Property. General Principles, [w:] P.H. Birks (ed.), English Private Law, Oxford 2000, s. 221-223. 
belka) po trwałym połączeniu z gruntem stała się elementem real property. $Z$ tego względu Lord Blackburn podkreślił, iż dla oceny sposobu funkcjonowania zasady w prawie angielskim szczególnie ważne są: wola stawiających obiekt na cudzym gruncie, jak i przeznaczenie konstrukcji.

$\mathrm{Na}$ temat zastosowania zasady wypowiedział się również Lord Watson, który podobnie jak Lord Blackburn podkreślił, że przedmiotowa zasada została zaczerpnięta $z$ prawa rzymskiego ${ }^{605}$. Szkocki prawnik stwierdził, iż w jego przekonaniu oryginalna rzymska zasada stosowana była w przypadku dwóch rodzajów podmiotów - po pierwsze w przypadku osób, które wybudowały coś na solum alienum ze swych własnych materiałów, lecz bez wymaganego prawem tytułu oraz $\mathrm{w}$ złej wierze, po drugie do osób, które wybudowały coś $\mathrm{w}$ dobrej wierze w mylnym przekonaniu co do przysługujacych im uprawnień. Budowniczy w złej wierze tracił własność wybudowanego obiektu na rzecz właściciela gruntu, natomiast budowniczy w dobrej wierze miał prawo usunać wykorzystane materiały, chyba że właściciel gruntu zapłacił mu ich równowartość. W przekonaniu Lorda Watsona, w takich okolicznościach rzymska zasada nie może zostać zastosowana w przedmiotowej sprawie, gdyż nie dotyczy ona w ogóle kwestii dobrej bądź złej wiary, zaś sama budowa wprawdzie dokonana została na cudzym gruncie, lecz z zachowaniem uznanych przez prawo okoliczności. Zgodnie bowiem z postanowieniami ustawy $z$ roku 1851, właścicielami wybudowanych obiektów byli górnicy.

W tym samym tonie wypowiedzieli się na temat stosowania zasady dwaj pozostali orzekający sędziowie - Lordowie Bramwell i Fitzgerald. Choć nie odwołali się oni już bezpośrednio do prawa rzymskiego, to jednak na uwagę zasługuje komentarz poczyniony przez irlandzkiego lorda prawa Fitzgeralda na temat różnic w stosowaniu analizowanej zasady w przeszłości i w czasach jemu współczesnych. Stwierdził on:

${ }^{605}$ Wake v. Hall (1883) 8 App. Cas. 195, 206. Por. I. 2, 1, 30; D. 41, 1, 7, 12 (Gaius libro secundo rerum cottidianarum sive aureorum). 
„like all other rules it has received from time to time judicial modifications to suit the exigencies of modern life and modern progress"606.

Oddzielną grupą orzeczeń wydawanych przez sędziów Izby Lordów, w których pojawiały się odwołania do prawa rzymskiego, były orzeczenia odnoszace się do problematyki zasiedzenia. Już w roku 1881 odnaleźć można w sprawie Dalton $v$. Angus \& Co. ${ }^{607}$ szereg romanistycznych uwag poczynionych na kanwie rozpatrywanego stanu faktycznego. Sprawa dotyczyła zasadniczo nabycia right of lateral support - prawa bocznego podtrzymywania, służebności charakterystycznej dla prawa angielskiego. Orzekając Lord Kanclerz Selborn powołał się na autorytet wcześniejszego precedensu, znanego jako Pelham v. Pickersgill608, gdzie sędzia Ashurst zauważył, iż „every prescription is good, if by any possibility it can be supposed to have had a legal commencement"609. Komentując tę wypowiedź sędziego, Lord Kanclerz stwierdził, iż ma ona charakter teoretyczny, zaś prawdziwych źródeł zasiedzenia powinno poszukiwać się w rzymskiej konstrukcji usucapio. Następnie zaś przywołujac pracę Edwarda Coke'a wskazał, że na zasiedzenie składaja się dwa nieodzowne elementy - posiadanie oraz czas. Gdy chodzi zaś o posiadanie, to powinno ono mieć trzy cechy: być długie, nieprzerwane oraz spokojne ${ }^{610}$. Warto zauważyć, że określenia wykorzystane w XVI w. przez angielskiego prawnika zdradzaja pewne romanizujące cechy, jednak zasadniczo są one nieprecyzyjne. Można odnieść wrażenie, iż autor - a wraz z nim Lord Kanclerz - zestawił cechy charakteryzujące raz zasiedzenie, kiedy indziej zaś posiadanie. Należy również pamiętać, iż E. Coke był zasadniczo oponentem pra-

${ }^{606}$ Wake v. Hall (1883) 8 App. Cas. 195, 211.

${ }^{607}$ Dalton v. Angus \& Co. (1881) 6 App. Cas. 740.

${ }^{608}$ Pelham v. Pickersgill (1787) 1 T.R. 659; 99 Eng. Rep. 1306.

${ }^{609}$ Pelham v. Pickersgill (1787) 1 T.R. 659, 667; 99 Eng. Rep. 1306, 1311.

${ }^{610}$ E. Coke, Commentary upon Littleton, sec. 170. 
wa rzymskiego i podkreślał w swych pismach, że nie jest ono źródłem prawa angielskiego ${ }^{611}$.

W dalszej części swego orzeczenia Lord Selborn odwołał się do kategorii nec vi, nec clam, nec precario i stwierdził, że ocena, czy doszło do uznanego przez prawo zasiedzenia, wymaga określenia okoliczności wejścia w posiadanie ${ }^{612}$. Warto w tym miejscu zauważyć, iż powołana klauzula stanowi bardzo częste i popularne w angielskich i szkockich orzeczeniach odwołanie się do rzymskiej tradycji prawnej. Zazwyczaj jednak - w oderwaniu od jej oryginalnego znaczenia na gruncie rzymskiego posiadania.

W tej samej sprawie wypowiedział się również Lord Blackburn, który nie tylko powołał prawo rzymskie, lecz spróbował także dokonać wszechstronnej interpretacji instytucji rzymskiego zasiedzenia ${ }^{613}$. Lord prawa rozpoczal od przywołania passusu pochodzacego $z$ pracy Lorda Stair, w której ten stwierdził, iż zasiedzenie nie jest instytucja prawa wywodząca się $z$ prawa naturalnego, lecz z prawa pozytywnego, gdyż stworzone zostało ze względów praktycznych, nie zaś dla celów słusznościowych ${ }^{614}$. Następnie law lord wskazał, iż początkowo Rzymianie na określenie zasiedzenia używali terminu usucapio, na potwierdzenie tego przywołał odpowiedni passus z Digestów justyniańskich ${ }^{615}$. Sędzia zaprezentował własną interpretację rozwoju rzymskiego zasiedzenia. Próbę tę należy uznać jednak za jedynie częściowo udaną. Lord prawa powołał fragment Ustawy XII tablic dotyczący dwuletniego okresu zasiedzenia gruntów oraz rocznego okresu zasiedzenia wszystkich innych rzeczy $^{616}$. Wskazał ponadto, iż

${ }^{611} \mathrm{Na}$ temat postawy E. Coke względem prawa rzymskiego zob. T.E. Scrutton, The Influence..., s. 129.

${ }^{612} \mathrm{Ta}$ interdyktalna klauzula występuje często w źródłach prawa rzymskiego: np. D. 43, 17, 1, pr. (Ulpianus libro 69 ad edictum); 43, 17, 1, 5 (Ulpianus libro 69 ad edictum); 43, 18, 1, pr. (Ulpianus libro 70 ad edictum).

${ }^{613}$ Dalton v. Angus \& Co. (1881) 6 App. Cas. 740, 819.

${ }^{614}$ Lord Stair, Institutions..., 2, 12, 9.

${ }^{615}$ D. 41, 3, 3 (Modestinus libro quinto pandectarum).

${ }^{616}$ Lex XII tabularum 6, 3. 
już w czasach republikańskich wymienione postanowienie Ustawy XII tablic powodowało nabycie własności - dominium - które sędzia przyrównał do angielskiego terminu legal estate. Zauważył wszakże, iż obok tego prawa na skutek działalności pretorów zaczęło kształtować się ius praetorium, które $z$ kolei na gruncie prawa angielskiego może być porównane do equity. Osiagnnięciem pretorów miałoby być - w opinii Lorda Blackburna - zastapienie dawnego prawa własnymi rozstrzygnięciami, które w szczególności na prowincji okazały się być jedynym obowiązującym prawem ${ }^{617}$.

Rozważania szkockiego sędziego wskazuja na brak jego wystarczającego przygotowania w zakresie omawianej materii. Wydaje się, iż Lord Blackburn starał się przedstawić sposób powstania w starożytnym Rzymie tzw. dominium duplex - równoczesnego istnienia własności kwirytarnej i tzw. własności bonitarnej. Rozważania te starał się połaczyć z pojawieniem się w czasach cesarstwa nowej formy zasiedzenia, jaka był zarzut długiego posiadania (longi temporis praescriptio). W tym aspekcie próbę romanistycznej argumentacji Lorda Blackburna trzeba ocenić jako nieudana i wskazującą na niedostatki jego romanistycznej wiedzy.

Lord Blackburn nie poprzestał jednak na powyższej analizie i przystąpił do dalszej interpretacji rzymskich rozwiąań prawnych. Wskazał na istnienie interdyktów restytucyjnych, powołując jednocześnie odpowiednie fragmenty Digestów ${ }^{618}$, by wreszcie odnieść się do interdyktu uti possidetis ${ }^{619}$, który przewidywał ochronę posiadaczy nec vi, nec clam, nec precario. Na koniec Lord Blackburn stwierdził, że wykształcona $\mathrm{w}$ ten sposób ochrona interdyktalna przyczyniła się do skonstruowania przez pretorów tzw. longi temporis praescriptio. $\mathrm{Na}$ potwierdzenie swych słów przywołał pogląd francuskiego

${ }^{617}$ Dalton v. Angus \& Co. (1881) 6 App. Cas. 740, 820.

${ }^{618}$ D. 43, 24, 1 (Ulpianus libro 71 ad edictum); D. 43, 26, 2 (Ulpianus libro 71 ad edictum).

${ }^{619}$ D. $43,17$. 
prawnika R.J. Pothiera ${ }^{620}$, by na koniec odnieść się jeszcze do dwóch konstytucji cesarskich zawartych w Kodeksie justyniańskim ${ }^{621}$, za pomoca których dokonana została gruntowna reforma rzymskiego systemu zasiedzenia. Warto zwrócić jednak uwagę, iż dzisiejszy stan nauki prawa rzymskiego na temat longi temporis praescriptio odbiega od stanu wiedzy, jaka prezentował Lord Blackburn. Współcześnie genezy tej instytucji upatruje się $\mathrm{w}$ działalności sądowniczej urzędników prowincjonalnych, którzy przeformułowali oryginalny zarzut procesowy w specyficzna formę zasiedzenia ${ }^{622}$.

$\mathrm{Na}$ koniec Lord Blackburn przystapił do przedstawienia dalszych losów zasiedzenia w dziejach prawa zachodniej Europy, przede wszystkim we Francji, w której rzymskie reguły zasiedzenia stosowane były do czasów Rewolucji. Następnie omówił zasady rządzące tym sposobem nabycia własności według Kodeksu Napoleona ${ }^{623}$, przywołując jednocześnie ustępy $z$ angielskiego tłumaczenia pracy Jeana Domata ${ }^{624}$. Sędzia stwierdził również, iż także w Anglii łacińska terminologia prawnicza, szczególnie początkowo, używana była na określenie zasad rządzących zasiedzeniem. Nie zostało ono jednak poddane takiemu samemu procesowi romanizacji jak we

${ }^{620}$ R.J. Pothier, Traité de la possession; traité de la prescription, Paris 1807 , s. 93. Lord Blackburn cytując pracę francuskiego prawnika wykorzystał zbiór jego prac w edycji M. Dupina.

${ }^{621}$ Lord Blackburn wskazał w tym miejscu swego orzeczenia, iż konstytucje, o których mówił, pochodzą $z$ tytułu 25 księgi 7 Kodeksu. W rzeczywistości jednak tytuł ten zawiera tylko jedna konstytucję, która dodatkowo odnosi się do problematyki usunięcia $\mathrm{z}$ rzymskiego systemu prawnego frazy ex iure Quiritum. Najprawdopodobniej law lord miał na myśli jeden $\mathrm{z}$ dalszych tytułów, w którym uszeregowano liczne konstytucje odnoszące się do szczegółowych kwestii zwiąanych z zasiedzeniem.

${ }^{622}$ Zob. więcej W.W. Buckland, A Text-book..., ed. 3, s. 248-252; P. Cornioley, De l'origine de la longi temporis praescriptio, TR 41 (1973), s. 119-130 oraz ostatnio w polskiej literaturze B. Ruszkiewicz, 'Longi temporis praescriptio' jako zarzut długiego okresu posiadania, ZP UKSW 11/1 (2011), s. 235-248.

${ }^{623}$ Art. 688-689 k.c. francuski.

${ }^{624}$ J. Domat, The Civil Law in Its Natural Order, ed. W. Straham, London 1722 , s. $485(3,7,4)$. 
Francji. Jedynie wyjątkowo rzymskie wpływy dostrzec można w wykorzystaniu przez angielskich prawników klauzuli nec vi, nec clam, nec precario ${ }^{625}$.

Trzeba przyznać, iż rozległa analiza rzymskich źródeł prawa podjęta przez Lorda Blackburna na kanwie sprawy Dalton v. Angus \& Co. nie zawsze możliwa jest do zaakceptowania przez romanistów. Sędzia sprawnie manipulując źródłami, był jednak w stanie uzasadnić określony sposób ich interpretacji oraz wykazać ich wpływ na kształtowanie się angielskiego sposobu rozumienia zasiedzenia. W orzeczeniu lorda prawa można dostrzec także typowy dla niego i wielu innych sędziów Izby Lordów powołujących się na prawo rzymskie asekurantyzm, zwiazany $z$ obawa przed jednoznacznym przyznaniem istnienia wpływów rzymskich na common law. Uwidacznia się to $\mathrm{w}$ podsumowaniu Lorda Blackburna, który stwierdza: „though the English law as to prescription was, beyond controversy, greatly derived from the Roman law [...], yet $[. .$.$] every system of law is founded on its own ideas of$ expediency, and that we must look to the English decisions to see what principles have been adopted to it [...] and what have in it been rejected as on the balance inexpedient".

Tradycja cywilistycznych odwołań w odniesieniu do zasiedzenia odnaleziona może być jeszcze kilkakrotnie w orzeczeniach Izby Lordów, w tym w orzeczeniach wydanych przez Komitet Apelacyjny w roku 2000 oraz $2003 \mathrm{w}$ sprawach $R$. $v$. Oxfordshire County Council ${ }^{626}$ oraz R. v. City of Sunderland ${ }^{627}$. Ze względu na to, iż stany faktyczne obu spraw były bardzo podobne, przedmiotem dalszej analizy będzie zasadniczo pierwsza $z$ nich ${ }^{628}$. Dotyczyła ona statusu prawnego nieruchomości przylegającej do kościoła parafialnego w Sunningwell, w hrabstwie Oxford, która od 1978 roku znajdowała się

${ }^{625}$ Dalton $v$. Angus \& Co. (1881) 6 App. Cas. 740, 822.

${ }^{626}$ R. v. Oxfordshire County Council. Ex parte Sunningwell Parish Council [2000] 1 A.C. 335.

${ }^{627}$ R. v. City of Sunderland [2004] 1 A.C. 889.

${ }^{628} \mathrm{Na}$ temat drugiej sprawy zob. Ł.J. Korporowicz, Prawo rzymskie w wybranych orzeczeniach..., s. 290-292. 
w bezpośrednim zarządzie Rady Finansowej anglikańskiej diecezji Oxfordu. Obszar, którego dotyczyła sprawa, przez lata wykorzystywany był jako miejsce wypoczynku okolicznych mieszkańców. W roku 1994 Rada Finansowa diecezji podjęła decyzję o wybudowaniu na przedmiotowej nieruchomości dwóch obiektów. Sprzeciwiajacy się jednak temu mieszkańcy złożyli wniosek u władz hrabstwa o nadanie spornemu terenowi statusu tzw. terenu zielonego (village green) na podstawie przepisów Commons Registration Act 1965629. Wniosek mieszkańców został jednak, po przeprowadzeniu odpowiednich konsultacji, odrzucony. Kluczowym argumentem dla władz hrabstwa było stwierdzenie, powtarzane przez wielu mieszkańców, iż w ich przekonaniu byli oni uprawnieni do używania spornego terenu. Nikt $z$ nich natomiast nie podnosił, iż posiadali oni prawo do samej nieruchomości. Sprawa trafiła do Komitetu Apelacyjnego, gdzie wskazano, iż najważniejszym zadaniem sędziów jest określenie sposobu definiowania pojęcia as of right na kanwie przepisów dotyczacych uznania danego obszaru za teren zielony.

W swym orzeczeniu Lord Hoffmann stwierdził, że każdy system prawa musi posiadać zestaw reguł, które zapobiegną powstawaniu niejasności związanych $z$ długim, faktycznym korzystaniem z pewnej rzeczy czy uprawnień. Dalej południowoafrykański sędzia zauważył, że w prawie rzymskim zasiedzenie traktowane było jako sposób nabycia własności. Lord prawa wyjaśnił, iż Ustawa XII tablic określała ten sposób nabycia praw rzeczowych jako usucapio ${ }^{630}$. Kontynuując swoje rozumowanie sędzia wskazał, że następstwem usucapio było skupienie własności i posiadania w jednych rękach. $Z$ tego względu niemożliwe było w prawie rzymskim nabycie na drodze zasiedzenia rzeczy skradzionych oraz rzeczy poświęconych bóstwom. Konieczne zaś było, aby nabywający

${ }^{629}$ Commons Registration Act 1965 (c. 64).

${ }^{630}$ Ustawa XII tablic trzykrotnie posługuje się terminem usucapio: 5 , $2 ; 8,17$ oraz 10,10 . 
cechował się dobrą wiarą ${ }^{631}$. Sędzia wskazał także, iż poprzedni właściciel nie uczestniczył w nabywaniu rzeczy przez nowego. Kończąc swój romanistyczny wykład prawnik wskazał, że początkowo dla zasiedzenia ruchomości konieczne było jej posiadanie przez rok, dla nieruchomości zaś przez dwa lata. Zawsze, nawet po zmianach dokonanych przez Justyniana, zasiedzenie traktowano - co podkreślił lord prawa - jako jeden ze sposobów nabycia własności i tak samo traktowane jest ono dziś w krajach, których systemy prawne oparto na prawie Rzymian. Następnie prawnik wskazał, że prawo angielskie nigdy nie wytworzyło podobnej do rzymskiej teorii zasiedzenia, chociaż dostrzegało konsekwencje prawne upływu czasu. Upływ czasu skutkował bowiem bądź powstaniem roszczenia przysługującego dotychczasowemu właścicielowi, bądź domniemywano, iż własność gruntu została przeniesiona w drodze jakiegoś dorozumianego aktu prawnego, który musiał być jednak zgodny $z$ prawem. Na kolejnych stronach swego orzeczenia Lord Hoffmann przedstawił historyczny rozwój angielskiego „zasiedzenia”632. Ostatecznie uznał - podobnie jak i inni lordowie - iż władze hrabstwa powinny uznać sporny obszar za teren zielony.

Gdy chodzi o druga ze wspomnianych spraw - Regina $v$. City of Sunderland - wypada zwrócić uwagę, że sędziowie przede wszystkim swoje rzymskie rozważania poświęcili zagadnieniu precarium. Było to związane $z$ podjęciem przez pełnomocników stron kwestii sposobu rozumienia klauzuli nec vi, nec clam, nec precario. Lord Rodger of Earlsferry przywołał definicję prekarium autorstwa Ulpiana ${ }^{633}$. Następnie sędzia zauważył, że termin ten do angielskiego prawa został wprowadzony już przez H. Bractona, który wprawdzie używał go w różnych kontekstach, zawsze jednak w odniesieniu do

${ }^{631}$ R. v. Oxfordshire County Council. Ex parte Sunningwell Parish Council [2000] 1 A.C. 335, 350.

${ }^{632}$ R. v. Oxfordshire County Council. Ex parte Sunningwell Parish Council [2000] 1 A.C. 335, 350-352.

${ }^{633}$ D. 43, 26, 1, pr. (Ulpianus libro primo institutionum). 
dobrowolnego, a jednocześnie odwołanego wyzbycia się części swoich uprawnien ${ }^{634}$.

Prawo angielskie obok konstrukcji zasiedzenia, określanego jako prescription, zna także inną konstrukcję, której skutek prawny zwiazany jest $z$ upływem czasu. Określana jest ona jako „przeciwne posiadanie”, czyli adverse posses$\operatorname{sion}^{635}$. W roku 2002 na jej temat wypowiedziała się Izba Lordów w sprawie J.A. Pye (Oxford) Ltd. v. Graham ${ }^{636}$. Sprawa dotyczyła nieruchomości stanowiącej własność spółki zajmującej się obrotem nieruchomościami (strona apelująca). Początkowo rodzina Grahamów korzystała $z$ gruntu na podstawie odnawialnej umowy. Jednakże od połowy roku 1984, aż do końca roku 1999 kolejne pokolenia rodziny uprawiały nieruchomość i wypasały na niej bydło bez stosownego pozwolenia. Rolnicy podejmowali wówczas różne prace mające na celu zabezpieczenie wartości samej nieruchomości, jak i uprawianych tam zbóż. Właściciel nieruchomości natomiast nie podejmował w tym okresie żadnych działań, które miałyby na celu potwierdzenie jego praw. W roku 1997 korzystajacy z nieruchomości Michael Graham zgłosił do Land Registry (odpowiednik sądu wieczystoksięgowego) sporną nieruchomość, wnosząc o uznanie go za jej właściciela, który nabył prawa do nieruchomości w drodze adverse possession. Sąd pierwszej instancji orzekł, że rodzina Grahamów nabyła nieruchomość zgodnie $z$ prawem. Sad Apelacyjny zmienił jednak wcześniejszy wyrok i uznał, iż rolnicy nadal wykonywali uprawnienia wynikające $z$ umowy zawartej na poczatku lat osiemdziesiatych XX w. Sprawa ostatecznie trafiła do Komitetu Apelacyjnego, gdzie w lipcu 2002 roku ogłoszony został korzystny dla Grahamów wyrok.

Do rozwiązań prawa rzymskiego odnieśli się w swych orzeczeniach dwaj lordowie - Lord Browne-Wilkinson oraz Lord Hope of Craighead. Pierwszy z nich przywołał argumen-

${ }^{634}$ R. v. City of Sunderland [2004] 1 A.C. 889, 907-908.

${ }^{635}$ E.A. Martin, Oxford Dictionary..., s. 17, s.v. adverse possession.

${ }^{636}$ J.A. Pye (Oxford) Ltd. v. Graham [2003] 1 A.C. 419. 
ty zaczerpnięte $z$ prawa rzymskiego wyjaśniając znaczenie terminu „posiadanie”637. Posłużył się przy tym orzeczeniem $z$ roku 1977 w sprawie Powell $v$. McFarlane. Orzekający wówczas sędzia Slade wyjaśnił, iż według prawa angielskiego osoba, która posiada tytuł prawny do danej nieruchomości, jest także jej posiadaczem ${ }^{638}$. Możliwe jest jednak przypisanie komuś posiadania nieruchomości także wówczas, gdy nie majac formalnego tytułu wykaże on faktyczne władztwo nad rzeczą oraz konieczna wolę władania (animus possidendi) ${ }^{639}$. Nie ulega wątpliwości, że wskazane przez sędziego przesłanki posiadania zostały zaczerpnięte $z$ tradycji prawa rzymskiego. Lord Browne-Wilkinson odnotował wszakże, iż prawnicy stron w rozstrzyganej sprawie odnieśli się negatywnie do opartej na prawie rzymskim argumentacji sędziego Slade'a, uznali, że definiując pojęcie posiadania, popełnił on błąd logiczny idem per idem. Lord prawa wyjaśnił wszakże, że wspomniany sędzia wykorzystał terminologię zaczerpniętą $z$ prawa rzymskiego i stosowana przez wiele pokoleń sędziów, jak i autorów prac naukowych. Postanowił jednak uszczegółowić definicję sędziego Slade'a stwierdzając, iż faktyczne posiadanie (factual possession) oznacza wystarczajacy poziom fizycznego nadzoru i kontroli, zaś wola posiadania to zamiar wykonywania tego nadzoru i kontroli w swoim własnym imieniu i w swoim własnym interesie prawnym. Komentując sposób okazywania zamiaru posiadania rzeczy, lord prawa odniósł się do orzeczenia London Borough of Lambeth $v$. Blackburn ${ }^{640} z$ roku 2001. Sędzia Clarke wskazał tam, że potrzebę ujawniania faktu po-

${ }^{637}$ J.A. Pye (Oxford) Ltd. v. Graham [2003] 1 A.C. 419, 435.

${ }^{638}$ Pojęcie posiadania $\mathrm{w}$ prawie angielskim definiowane jest w następujący sposób: „Actual control of property combined with the intention to use it, rightly or wrongly, as one's own. In the case of land, possession may be actual, when the owner has entered onto the land, or possession in law, when he has the right to enter but has not yet done so. Possession includes receipt of rent and profits, or the right to receive them" (E.A. Martin, Oxford Dictionary..., s. 371, s.v. possession).

${ }^{639}$ Powell v. McFarlane (1979) 38 P. \& C.R. 452.

${ }^{640}$ London Borough of Lambeth v. Blackburn (2001) 82 P. \& C.R. 39. 
siadania rzeczy należy przede wszystkim odczytywać w kontekście pojęcia „przeciwne”. Trzeba zatem udowodnić posiadanie przeciwne względem interesu właściciela wykazanego $\mathrm{w}$ dokumentach (paper owner) ${ }^{641}$. Lord Browne-Wilkinson wyjaśnił, że choć zgadza się $z$ ogólnym przesłaniem wygłoszonym przez sędziego Sądu Apelacyjnego, to jednak tak prawo rzymskie, jak i common law zawsze wymagały okazania woli posiadacza, oprócz materialnych działań natury fizycznej przez niego podejmowanych ${ }^{642}$. Rozważania te miały kluczowe znaczenie dla oceny prawnej stanu faktycznego $z$ tego względu, że w doktrynie prawa angielskiego różnica między „przeciwnym posiadaniem” a zasiedzeniem rzeczy ogniskuje się w ocenie woli podmiotu czynnego, który jest na drodze do nabycia „przeciwnego posiadania” bądź zasiedzenia rzeczy. Adverse possession ma bowiem charakter materialnoprawny i odwołuje się do świadomości podmiotu, że nie jest on posiadaczem rzeczy, lecz chce nim zostać. W przypadku zaś zasiedzenia prawo angielskie wskazuje, iż jest to konstrukcja zasadniczo odwołująca się do natury prawa procesowego i jest ono traktowane jako dowód w postępowaniu o stwierdzenie posiadania rzeczy ${ }^{643}$. Taki sposób postrzegania zasiedzenia jest ciekawy $z$ punktu widzenia romanistyki, która korzeni longi temporis praescriptio upatruje w zarzucie procesowym.

W podobny sposób do problematyki prawa rzymskiego odniósł się drugi z sędziów - Lord Hope of Craighead, który wskazał, że prawo angielskie zaczerpnęło z rzymskiego zasadę, zgodnie $z$ która w danej chwili stan posiadania konkretnej rzeczy przysługuje jednej konkretnej osobie. Sędzia podkreślił, że „wyłączność” stanowi o istocie posiadania. Wskazał także, iż zasadniczo ta sama zasada znajduje zastosowanie w przypadku współwłasności, gdzie kilka osób władających jedna rzeczą w stosunkach zewnętrznych występuje razem,

${ }^{641}$ London Borough of Lambeth v. Blackburn (2001) 82 P. \& C.R. 39, 499.

${ }^{642}$ J.A. Pye (Oxford) Ltd. v. Graham [2003] 1 A.C. 419, 435.

${ }^{643}$ Zob. M. Wonnacott, Possession of Land, Cambridge 2006, s. $167-168$. 
a jedynie w stosunkach wewnętrznych ich wzajemne prawa i obowiazki są rozgraniczane ${ }^{644}$. Jakkolwiek trzeba przyznać szkockiemu sędziemu rację, jeśli chodzi o reguły odnoszace się do stosunków łączących współwłaścicieli, to jednak nie do końca można zrozumieć, dlaczego lord prawa mówiąc o zagadnieniu posiadania przeniósł ciężar swych rozważań na prawo własności.

Powracajac do głównego toku swej analizy Lord Hope podkreślił m.in., że konieczne jest, aby osoba zbywająca rzecz wykazała zarówno wolę władania (animus), jak również okazała „jakieś działanie”, które Lord Hope utożsamił z pojęciem corpus. Sędzia podkreślał także, iż oba elementy muszą wystąpić kumulatywnie.

W uzupełnieniu swoich rozważań law lord stwierdził ponadto, że problematyka okazania woli prowadząca do nabycia posiadania stanowiła przedmiot dyskusji, szczególnie żywej $\mathrm{w}$ niemieckim środowisku naukowym ${ }^{645}$. Sędzia przywołał jednak w tym miejscu pracę angielskiego romanisty $\mathrm{H}$. Bonda, który w roku 1890 na łamach "Law Quarterly Review" opublikował rozprawę zatytułowana Possession in the Roman $L a w^{646}$, w której przedstawił ówczesny stan badań nad omawiana tematyką. Powołując się na dziewiętnastowiecznego romanistę, Lord Hope wskazał, że niezależnie od różnorakich kontrowersji zawsze pewne było, iż wola charakteryzujacca posiadacza musi być rozumiana jako chęć wyłącznej kontroli nad dana rzeczą ${ }^{647}$.

Opierając się m.in. na powyższych argumentach, sędziowie przyznali rację rodzinie Grahamów i potwierdzili nabycie przez nich własności nieruchomości. Konstrukcja adverse possession umożliwiała im bowiem uzyskanie tytułu posiadania niezbędnego do stwierdzenia nabycia własności ${ }^{648}$.

${ }^{644}$ J.A. Pye (Oxford) Ltd. v. Graham [2003] 1. A.C. 419, 445-446.

645 J.A. Pye (Oxford) Ltd. v. Graham [2003] 1 A.C. 419, 446.

${ }^{646}$ H. Bond, Possession in the Roman Law, LQR 6 (1890), s. 259-279.

${ }^{647}$ Ibidem, s. 270.

${ }^{648}$ Por. E.A. Martin, Oxford Dictionary..., s 371, s.v. possessory title. 


\subsection{Prawo rzymskie w sprawach dotyczących frustration of contract}

Ważna częścią dociekań nauki prawa w odniesieniu do prawa umów, niezależnie od systemu prawnego, są zawsze rozważania związane $z$ niewykonaniem bądź nienależytym wykonaniem zobowiazania. W przypadku prawa angielskiego oba te zjawiska określa się wspólnym pojęciem breach of contract. Przybrać może ono różnorakie formy, w tym tzw. frustration. Jest to sytuacja, w której jedna ze stron nie wykonała umowy na skutek zaistnienia nieprzewidzianych wcześniej okoliczności, które spowodowały, iż świadczenie nie może być spełnione bądź wykonanie zobowiązania byłoby niezgodne $z$ prawem. W ramach zatem angielskiej doktryny frustration mieszczą się takie rzymskie konstrukcje prawne, jak niemożliwość wykonania zobowiązania (zawierająca się w formule impossibilium nulla obligatio est ${ }^{649}$ ), czy wystapienie okoliczności określanych w tradycji kontynentalnej jako vis maior ${ }^{650}$, zaś w tradycji angielskiej jako force majeure ${ }^{651}$.

Pośród licznych wypowiedzi angielskiej doktryny i judykatury dotyczących powyższego zagadnienia stosunkowo łatwo odnaleźć można takie, których autorzy bezpośrednio powołali się na autorytet prawa rzymskiego. Odwołania takie odnaleźć można także w orzeczeniach Izby Lordów. Po raz pierwszy rzymska argumentacja w związku $z$ przesłankami upoważniajacymi do uznania kontraktu za frustrated poja-

${ }^{649}$ Ostatnio w polskiej literaturze na temat historii tej paremii zob. D. Skrzywanek-Jaworska, Nieważne zobowiazanie ex stipulation. Znaczenie 'Impossibilium nulla obligation est' Celsusa $(D .50,17,185) w$ prawie rzymskim, SPE 83 (2011), s. 205-235; eadem, Nieważne zobowiazania ex venditione. Nec emptio nec venditio sine re quae veneat potest intellegi (D. 18,1,8,pr.) Pomponiusa a Impossibilium nulla obligation est Celsusa (D. 50,17,185), SPE 84 (2011), s. 209-238.

${ }^{650} \mathrm{~W}$ polskiej literaturze na temat siły wyższej zob. M. Sobczyk, Siła wyższa $w$ rzymskim prawie prywatnym, Torun 2005, w szczeg. co do kwestii terminologicznych s. 28-35.

${ }^{651}$ Por. E.A. Martin, Oxford Dictionary..., s. 207, s.v. force majeure. 
wiła się w Izbie w roku $1916 \mathrm{w}$ sprawie Horlock v. Beal ${ }^{652}$. W maju 1914 roku marynarz Tom Rea Beal zaciagnał się na statek transportowy Coralie Horlock. W umowie, która zawarł $z$ armatorem, wskazano, że część pobieranego przez niego wynagrodzenia ma być bezpośrednio wypłacana jego żonie pozostajacej w Hull w Wielkiej Brytanii. W dniu 2 sierpnia tego samego roku Coralie Horlock wpłyną do portu w Hamburgu. Dwa dni później, w trakcie załadunku statku, ogłoszony został stan wojny między Zjednoczonym Królestwem a Cesarstwem Niemieckim. Statek internowano, zaś kilka miesięcy później jego załoga została aresztowana i przeniesiona do obozu jenieckiego pod Berlinem. W związku $z$ utrata statku armator w sierpniu 1914 roku wypłacił żonie marynarza ostatni raz należna jej część wynagrodzenia męża. W trakcie wszczętego postępowania kobieta starała się o wypłacenie jej kolejnych rat. Pełnomocnicy armatora statku podnosili jednak, że $z$ dniem wybuchu wojny ich zobowiazanie wygasło.

Do zagadnień prawa rzymskiego w swym orzeczeniu nawiązał szkocki sędzia Lord Shaw of Dunfermline. Przechodząc do omówienia statusu prawnego zawartej umowy, prawnik wskazał, iż chcąc porównać przedmiotowa sprawę $z$ rozwiązaniami prawa rzymskiego, najlepiej byłoby wziąć przykład obietnicy zawarcia umowy, której przedmiotem był niewolnik.

Sędzia wskazał, że w sytuacji gdy niewolnik zmarł bądź został uwolniony przed przekazaniem go nabywcy, taka umowa była nieważna, chyba że to sam sprzedawca zabił swego niewolnika, bądź go uwolnił. Wówczas jednak, gdy nie można było sprzedawcy przypisać winy, zniknięcie corpus certum powodowało wygaśnięcie zobowiązania ${ }^{653}$.

Lord prawa nie wskazał źródła przedstawionego przez siebie kazusu. Kontynuujac jednak swoje romanistyczne rozważania zauważył, że do rozwiązań rzymskich jurystów dotyczących niemożności wykonania zobowiązania odniósł się w przeszłości sędzia Blackburn w precedensowej sprawie

${ }^{652}$ Horlock v. Beal [1916] 1 A.C. 486.

${ }^{653}$ Horlock $v$. Beal [1916] 1 A.C. 486, 512. 
z roku 1863 Taylor v. Caldwell ${ }^{54}$. Sędzia Blackburn zacytował we wspomnianym orzeczeniu dwa fragmenty pochodzace $z$ pracy Pomponiusa ${ }^{655}$. W obu fragmentach komentarza do pism Sabinusa, rzymski jurysta wyraził opinię, zgodnie $z$ którą śmierć niewolnika przed dniem ustalonym na jego wydanie nie rodzi odpowiedzialności wydającego, o ile nie jest przez niego zawiniona. Należy uznać, że dwa rzymskie fragmenty powołane przez sędziego Blackburna pozwoliły sformułować Lordowi Shaw przywołany przez niego w orzeczeniu pogląd. Warto także odnotować, iż sędzia zacytował również wyjątki $z$ pracy R.J. Pothiera dotyczacej zobowiązañ ${ }^{656}$.

Zdaniem Lorda Shaw kazus zniszczenia, czy zniknięcia corpus certum, został recypowany przez prawo angielskie. Sędzia wyraził wręcz opinię, iż w latach poprzedzających wydawana przez niego decyzję doszło do rozszerzenia ratio rzymskiej zasady na gruncie prawa angielskiego. Wypowiadajac się na temat tych zmian Lord Shaw uznał, iż drogę, jaka obrała angielska judykatura w tym względzie, należy uznać za właściwą. Pośród licznych spraw, w których rozumienie zasady zostało rozszerzone, lord prawa wskazał jedna $z$ tzw. spraw koronacyjnych - Krell $v$. Henry ${ }^{657}$, która rozpatrywana była przez Sąd Apelacyjny w roku 1903. Uznano wówczas, że

${ }^{654}$ Taylor v. Caldwell (1863) 3 B. \& S. 826, 835; 122 Eng. Rep. 309, 313. ${ }^{655}$ D. 45, 1, 23 (Pomponius libro nono ad Sabinum); D. 45, 1, 33 (Pomponius libro 25 ad Sabinum). Należy jednak wskazać, iż cytowane przez sędziego fragmenty odnosiły się nie do umowy kupna-sprzedaży, lecz stypulacji.

${ }^{656}$ R.J. Pothier, Traité des obligations, Orléan 1761, § 668.

${ }^{657}$ Krell v. Henry [1903] 2 K.B. 740. Sprawy koronacyjne (coronation cases) była to seria spraw, które stanowiły przedmiot rozpatrzenia przez angielskie sądy w latach 1903-1904. Nazwa wywodzi się od procesji koronacyjnej króla Edwarda VII, która miała odbyć się początkowo 26 czerwca 1902 roku. $Z$ tej okazji bardzo wiele osób, chcąc zobaczyć przejazd nowego monarchy, zawarło umowy $z$ właścicielami budynków, które stały przy trasie procesji. Jednakże tuż przed planowanym wydarzeniem król zachorował, a sama ceremonię przełożono na początek sierpnia tego samego roku. Osoby, które udostępniły zawczasu swoje lokale, nie chciały zwrócić pieniędzy najmującym je kontrahentom. Ostatecznie sprawy rozstrzygnięto na korzyść tych ostatnich. Więcej na temat coronation cases zob. R.G. McEl- 
umowa staje się niemożliwa do wykonania nie tylko wtedy, gdy dochodzi do zniszczenia bądź zniknięcia rzeczy stanowiącej jej przedmiot, ale także, gdy znika przyczyna, dla której dana czynność prawna została zawarta. Warto dodać, iż zastosowanie rzymskich rozstrzygnięć odnoszacych się do angielskiej doktryny frustration podkreślił orzekajacy w sprawie Krell v. Henry sędzia Vaugham Williams ${ }^{658}$.

W formie ciekawostki należy również podnieść, że Lord Shaw zakończył swoje cywilistyczne rozważania stwierdzeniem, iż prawo rzymskie znało szersze zastosowanie omawianej zasady aniżeli to, które zostało przedstawione w sprawie Taylor $v$. Caldwell ${ }^{659}$. Zwrócił też uwagę ${ }^{660}$, iż obok dwóch tekstów Pomponiusa możliwe jest przytoczenie jeszcze jednego, autorstwa Paulusa, w którym rzymski prawnik wyraźnie mówi o sytuacji, w której przedmiot sprzedaży nadal istnieje, jednak zmiana okoliczności doprowadziła do niemożliwości spełnienia świadczenia ${ }^{661}$. Podsumowując swoje rozważania, Lord Shaw zacytował ${ }^{662}$ fragment pracy W.A. Huntera zawierajacy fikcyjny kazus ilustrujacy sytuację opisana w Digestach przez Paulusa ${ }^{663}$.

Ostatecznie Lord Shaw, podobnie jak prawie wszyscy lordowie prawa $z$ orzekajacego składu, uznał, iż apelacja była zasadna, a wybuch wojny należy uznać za okoliczność rozwiązująca umowę i wyłączająca odpowiedzialność armatora statku.

roy, G. Williams, Coronation Cases - I, MLR 4/4 (1941), s. 241-260; idem, Coronation Cases - II, MLR 5/ 1 (1941), s. 1-20.

${ }^{658}$ Krell $v$. Henry [1903] 2 K.B. 740, 748.

${ }^{659}$ Do tego samego orzeczenia sędziego Blackburna w sprawie Taylor v. Caldwell odwołał się także w roku 1980 w sprawie National Carriers Ltd. v. Panalpina (Northern) Ltd. [1981] A.C. 675 Lord Hailsham of St. Marylebone (pełniący wówczas funkcję Lorda Kanclerza).

${ }_{660}$ Horlock v. Beal [1916] 1 A.C. 486, 513.

${ }^{661}$ D. 45, 1, 91, 1 (Paulus libro 17 ad Plautium).

${ }^{662}$ Horlock $v$. Beal [1916] 1 A.C. 486, 514.

${ }^{663}$ W.A. Hunter, A Systematic and Historical Exposition of Roman Law in Order of a Code, ed. 3, London 1897, s. 638. 
Okoliczności pozwalającej na uznanie kontraktu za frustrated dotyczyła także głośna sprawa z roku 1923 Cantiere San Rocco v. Clyde Shipbuilding and Engineering Co. ${ }^{664}$ Sprawa pochodziła $z$ apelacji szkockiej, przez co zapadły w niej wyrok Izby Lordów dotyczył jedynie Scots law. Spór toczyły dwie spółki - włoska $z$ siedziba w Trieście (Cantiere San Rocco) oraz szkocka działająca w branży stoczniowej z Glasgow (Clyde Shipbuilding and Engineering Co.). W przededniu I wojny światowej oba przedsiębiorstwa zawarły umowę, której celem było dostarczenie przez szkocka spółkę specjalistycznych silników. Pełna wartość umowy opiewała na kwotę 11.550 funtów, $z$ tym że wraz z jej podpisaniem Cantiere San Rocco zobowiązała się wpłacić na rzecz Clyde Shipbuiliding and Engineering Co. pierwszą ratę w wysokości 2.310 funtów. Wydarzenia te miały miejsce w maju 1914 roku, zaś w sierpniu tego samego roku Zjednoczone Królestwo Wielkiej Brytanii i Irlandii znalazło się w stanie wojny z Cesarstwem Austrii, na terenie którego działała wówczas spółka Cantiere San Rocco. W tych okolicznościach zobowiązanie powstałe między stronami nie mogło być należycie wykonane. Po zakończeniu wojny Cantiere San Rocco, której siedziba na mocy postanowień traktatów pokojowych znalazła się na terenie Królestwa Włoch, wystapiła o zwrot wpłaconych $z$ tytułu pierwszej raty pieniędzy. W lipcu 1921 roku sąd pierwszej instancji orzekł na rzecz włoskiej spółki. Od jego decyzji odwołała się jednak spółka szkocka, która skierowała sprawę do Court of Session. Tam, rok później, sędziowie First Division orzekli na korzyść strony apelującej. Na skutek tego, w maju 1923 roku, sprawa trafiła przed oblicze law lords, którzy w lipcu tego samego roku wydali analizowany wyrok.

Prawnicy włoskiej spółki oparli swoją argumentację na twierdzeniu, że w związku $z$ niezawinionym przez którąkolwiek ze stron niewykonaniem zobowiąania należy zastoso-

${ }^{664}$ Cantiere San Rocco v. Clyde Shipbuilding and Engineering Co. 1923 S.C. (H.L.) 105. 
wać konstrukcję restitutio, znana prawu rzymskiemu oraz przejęta następnie przez prawo szkockie ${ }^{665}$.

Zdaniem pełnomocników spółki efekt ten osiąnięty mógł być za pośrednictwem skargi opartej na condictio causa data causa non secuta. Orzekający w sprawie lordowie szczegółowo odnieśli się do przedstawionej przez prawników tezy ${ }^{666}$. Earl of Birkenhead, L.C., podzielił swoje orzeczenie w tej materii na dwie części - na początku przedstawił system rzymskich condictiones, a następnie odniósł się do tradycji prawa szkockiego. Lord Kanclerz zwrócił uwage, iż condictiones stanowiły jeden $z$ rodzajów skarg, same zaś były przez rzymskich prawników dzielone ze względu na rodzaj własności, kiedy indziej zaś ze względu na kauzę. W przekonaniu Lorda Kanclerza celem condictiones była próba odzyskania pieniędzy bądź innych rzeczy, które zostały przez właściciela utracone. Wprawdzie sędzia nie wskazał źródła swojej romanistycznej wiedzy, jednak opierając się na fakcie, iż w dalszej części swego orzeczenia powołał on podręcznik rzymskiego prawa prywatnego autorstwa H.J. Roby'ego, można przypuszczać, że posłużył się nim także przy formułowaniu powyższej definicji ${ }^{667}$. Wydają się to również potwierdzać kolejne stwierdzenia sędziego, który nie zdecydował się opisywać rozwoju historycznego condictiones uznajacc, iż jest to bezcelowe, zaś ich schemat przedstawiony w Digestach justyniańskich jest „complete and logical as possible" ${ }^{668}$. Przekonanie Earl of Birkenhead oparte jest prawdopodobnie na gruntownym opracowaniu rodzajów rzymskich kondykcji przedstawionym

${ }^{665}$ Cantiere San Rocco v. Clyde Shipbuilding and Engineering Co. 1923 S.C. (H.L.) 105, 106.

${ }^{666} \mathrm{Na}$ temat wykorzystania prawa rzymskiego przez law lords $\mathrm{w}$ tej sprawie zob. J. Mackintosh, Roman Law in Modern Practice, Edinburgh 1934, s. 198-202; R. Evans-Jones, Roman Law in Britain, [w:] U. Manthe and C. Krampe (eds.), Quaestiones Iuris. Festschrift für Joseph Georg Wolf zum 70. Geburtstag, Berlin 2000, s. 86-89.

${ }^{667}$ H.J. Roby, Private Roman Law in the Times of Cicero and of the Antonines, vol. 2, Cambridge 1902, s. 76.

${ }^{668}$ Cantiere San Rocco v. Clyde Shipbuilding and Engineering Co. 1923 S.C. (H.L.) 105, 109. 
w podręczniku H.J. Roby'ego i zaopatrzonym w liczne powołania fragmentów pochodzaccych $z$ Digestów ${ }^{669}$.

Angielski prawnik wyraził ponadto przekonanie, że ustawodawstwo Justyniana w zakresie omawianej dziedziny prawa łaczyło zarówno cechy kształtujace (formative), jak i deklaratywne (expressive). Wypowiedź ta budzić może pytania dotyczące jej właściwego rozumienia. Wydaje się jednak, że należy ją postrzegać jako dostrzeżenie przez sędziego złożoności działań podejmowanych przez rzymskich prawników na zlecenie Justyniana. $Z$ jednej strony grupa pod przewodnictwem Tryboniana opracowywała materiał prawniczy już wcześniej znany i w ten sposób jedynie go proklamowała jako wiążące źródło prawa (expressive character), $\mathrm{z}$ drugiej zaś strony dostosowywała i zmieniała ten materiał w taki sposób, aby był zgodny $z$ postawionymi jej przez Justyniana założeniami systemowymi (formative character).

Powracajac do tematyki condictiones, Earl of Birkenhead raz jeszcze podjął próbę wyjaśnienia okoliczności korzystania $z$ nich. Kluczowa przesłanka dla stosowania kondykcji było dokonanie przesunięcia majątkowego, które pod wpływem okoliczności występujących już w chwili dokonywania czynności prawnej, bądź pojawiających się później, czyniło tę czynność sprzeczna $z$ zasadami uczciwości i wymuszało na przyjmującym zwrot zgodnie $z$ obowiązująca zasada rzetelności w obrocie. Zwyczajnym sposobem egzekucji tego zwrotu była powołana przez prawników włoskiej spółki kondykcja causa data causa non secuta. Sędzia zwrócił uwagę, że w źródłach justyniańskich stosowne rozważania odnaleźć można w tytule czwartym księgi dwunastej Digestów oraz w tytule szóstym księgi czwartej Kodeksu. W obu źródłach omawiana skarga została opisana jednak w odmienny sposób. W Digestach nosi ona, powołana już powyżej, nazwę causa data causa non secuta, natomiast w Kodeksie właściwy tytuł oznaczono jako De condictione ob causam datorum. W ślad za H.J. Roby'm angielski sędzia wskazał, iż pierwsze $z$ dwóch przytoczonych

${ }^{669}$ H.J. Roby, Private Roman Law..., s. 76-77. 
określeń kondykcji nie występuje nigdzie poza wspomnianym tytułem Digestów. Ponadto jest ono trudne do jednoznacznego przetłumaczenia. $Z$ tego względu - jak wskazał Earl of Birkenhead - angielski romanista zaproponował na potrzeby swojego podręcznika nowe określenie omawianej kondykcji: condictio ob rem dati, re non secuta ${ }^{670}$. Warto jednak zauważyć, że sam H.J. Roby jasno wskazał, iż stosowane przez niego trzecie określenie nie jest jego własnym pomysłem, lecz zapożyczeniem pochodzacym $z$ fragmentów autorstwa Celsusa i Paulusa zamieszczonych we wspomnianym tytule czwartym księgi dwunastej Digestów ${ }^{671}$. Na potrzeby orzeczenia sędzia zaproponował następujące tłumaczenie „nowej” nazwy kondykcji: „skarga służąca wydobyciu czegoś co zostało dane w celu, który okazał się niemożliwy do osiagnięcia” („action to recover something given for a consideration which has failed").

Lord Kanclerz zauważył, że spośród przedstawionych w źródłach prawa rzymskiego przypadków zastosowania przedmiotowej kondykcji, niewiele odpowiada stanowi faktycznemu omawianej sprawy. Choć zdecydowana część przedstawionych w Digestach kazusów istotnie dotyczy zagadnień dalekich przedmiotowi sprawy Cantiere San Rocco, to jednak wypowiedź sędziego można uznać za pochopną. Warto zauważyć bowiem, iż justyniańscy kompilatorzy umieścili w Digestach fragment pochodzaccy od Ulpiana, w którym jurysta wskazał, że skarga znajduje zastosowanie także wówczas, gdy niemożliwość wykonania zobowiązania wynika $z$ okoliczności czasu (condicio temporis), bądź ze względu na stan zdrowia (condicio valetudinis) ${ }^{672}$. Pojęcie "okoliczności czasu" należy rozumieć zaś jako odniesienie do zmian pogodowych ${ }^{673}$

670 Ibidem, s. 77.

${ }^{671}$ Ibidem, s. 77-78, przyp. 2.

${ }^{672}$ D. 12, 4, 5, pr. (Ulpianus libro secundo disputationum).

${ }^{673}$ Nowożytne tłumaczenia terminu condictio temporis sa niejednoznaczne. Angielskie tłumaczenie autorstwa C.H. Monro oddaje wspomniana frazę jako „some accidental circumstances" (C.H. Monro, Digest of Justinian, vol. 2, Cambridge 1909, s. 297). W najnowszym tłumaczniu angielskim odnaleźć można zwrot "state of the weather" (T. Mommsen, P. Krueger, 
i być może powinno się je rozpatrywać także w perspektywie humana infirmitas - czyli słabości ludzkiej uzasadnionej wystąpieniem siły wyższej, o której Gaius wspomina wskazując okoliczności zwalniające $z$ odpowiedzialności $z$ tytułu umowy pożyczki ${ }^{674}$. Przypomnieć natomiast warto, że vis maior była przedmiotem rozstrzygania omawianej sprawy.

Lord Kanclerz podjął również próbę ukazania losów kondykcji causa data causa non secuta w prawie szkockim. Przedstawił sposób interpretowania znaczenia skargi przez kolejne pokolenia szkockich prawników - Lorda Stair ${ }^{675}$, Lorda Banktona ${ }^{676}$, J. Erskine'a ${ }^{677}$ i wreszcie G.J. Bella ${ }^{678}$. Na uwagę zasługuje fakt, iż Earl Birkenhead wyraźnie podkreślił w treści swego orzeczenia, że częściowo odmienny sposób interpretacji wykorzystania kondykcji prezentowany przez Lorda Banktona związany był $z$ odwołaniem się przez instytucjonalistę do innego, aniżeli pozostali prawnicy, fragmentu dzieła Ulpiana ${ }^{679}$. Sędzia ograniczył się jednak do tej uwagi, odsyłając jednocześnie do analizy dokonanej w przedmiotowej sprawie przez Lorda Shaw. Należy zresztą podnieść, iż omówienie prac szkockich autorów dokonane zostało przez sędziego w sposób pobieżny i ustępuje ono dużo bardziej rozwiniętej analizie kluczowego dla szkockiego prawa umów orzeczenia Court of Session z roku $1871 \mathrm{w}$ sprawie Watson $v$. Shankland ${ }^{680}, \mathrm{w}$ którym jednak brak bezpośrednich odwołan do rzymskiej tradycji prawnej.

A. Watson, The Digest of Justinian, vol. 1, Philadelphia 1985, s. 375. Autorzy niemieckojęzycznych przekładów posługuja się z kolei takimi zwrotami jak „Zeitumstände” (C. Otto, B. Schilling, C. Sintenis, Das Corpus Juris Civilis in's Deutche übersetzt, vol. 2, Leipzig 1831, s. 46) oraz ,jahreszeitliche Bedingungen" (O. Behrends, R. Knütel, B. Kupisch, H.H. Seiler, Corpus Iuris Civilis. Text und Übersetzung, vol. 3, Digesten 11-20, Heidelberg 1999, s. 96).

${ }^{674}$ D. 44, 7, 1, 4 (Gaius libro secundo aureorum).

${ }^{675}$ Lord Stair, Institutions..., I 7, 7.

${ }^{676}$ Lord Bankton, An Institute of the Laws of Scotland, 1, 8, 23.

677 J. Erskine, An Institute..., 3, 1, 10.

${ }^{678}$ G.J. Bell, Principles of the Law of Scotland, sec. 530.

${ }^{679}$ D. 12, 4, 5, 4 (Ulpianus libro secundo disputationum).

${ }^{680}$ Watson $v$. Shankland (1871) 10 M. 142. 
Ostatecznie sędzia orzekł, iż przypadek wybuchu wojny nie może być uznany za okoliczność różniąca się istotnie od uznanych przez prawo przypadków zastosowania kondykcji causa data causa non secuta. W ten sposób włoska spółka miała prawo żądać od spółki szkockiej zwrotu wpłaconej kwoty ${ }^{681}$.

Drugie orzeczenie przedstawione zostało przez Viscounta Finlay’a. Sędzia rozpoczął swoją analizę sprawy od gruntownego przypomnienia znaczenia Coronation Cases na gruncie prawa angielskiego i zanegowania ich przydatności w kontekście sprawy pochodzaccej $z$ apelacji szkockiej. Następnie odwołał się do prac Lorda Stair oraz J. Erskine'a, co uczynił wszakże w ślad za pełnomocnikami włoskiej spółki. Viscount Finlay zwrócił uwagę, iż dla obu szkockich instytucjonalistów, podobnie jak i dla prawników strony apelującej, podstawę przyjętej argumentacji stanowił fragment pochodzacy z księgi drugiej Disputationes Ulpiana ${ }^{682}$. Prawnicy podążyli w swej argumentacji za opinią przedstawiona przez J. Erskine'a, który wskazał, że roszczenie $z$ tytułu niemożności wykonania zobowiązania przysługuje wówczas, gdy dłużnik nie podjął próby spełnienia świadczenia w czasie poprzedzajacym wystapienie okoliczności faktycznie uniemożliwiającej jego realizację. Fragment autorstwa Ulpiana, na którym oparta została powyższa zasada, dotyczył z kolei pytania o obowiązek zwrotu uzyskanych środków pieniężnych przez sprzedawcę niewolnika, gdy niewolnik ten zmarł przed dokonaniem przeniesienia własności. Rzymski jurysta wskazał, iż zwrot pieniędzy był konieczny wówczas, gdy sprzedawca po ich otrzymaniu nie podjął żadnych działań mających na celu sfinalizowanie postanowień umowy, tj. na przykład nie udał się do namiestnika prowincji, aby dokonać przed nim formalnej manumissio, chyba że to podróż przyczyniła się do śmierci niewolnika. Sędzia przyznał jednak, iż argumenty podane przez pełnomocników spółki, jak również powołane przez nich szkockie

${ }^{681}$ Cantiere San Rocco v. Clyde Shipbuilding and Engineering Co. 1923 S.C. (H.L.) 105, 112.

${ }^{682}$ D. 12, 4, 5, 4 (Ulpianus libro secundo disputationum). 
źródła oraz passusy pochodzące $z$ tytułu czwartego księgi dwunastej Digestów justyniańskich, nie przekonały go do racji strony apelujacej ${ }^{683}$.

Viscount Finlay zaznaczył ponadto, że w trakcie rozprawy dyskutowane było przez strony również zagadnienie ius poenitendi wywodzace się $z$ fragmentów omawianego tytułu Digestów. Ius poenitendi utożsamiane jest z condictio ex poenitentia ${ }^{684}$. Oznaczało ono możliwość domagania się zwrotu wypłaconej uprzednio sumy pieniędzy wówczas, gdy strona, która złożyła oświadczenie woli, żałowała swej decyzji. Brak negatywnych konsekwencji takiego działania, a więc przepadek wpłaconej kwoty, wyrażony został przez Ulpiana w słowach "poenitentia non facit iniuriam ei qui redemit" ${ }^{685}$. Warto jednak zauważyć, iż zastosowanie tego środka prawnego ograniczone było do niewielkiej grupy przypadków - początkowo do kontraktu użyczenia w postaci fiducia cum amico contracta, następnie zaś do kontraktów nienazwanych ${ }^{686}$. Lord prawa podkreślił, że w czasach jemu współczesnych koncepcja ius poenitendi została całkowicie odrzucona. $Z$ tego względu sędzia ograniczył swój wywód w omawianym zakresie jedynie do wskazania dwóch pozycji bibliograficznych, w których sporna tematyka została w sposób satysfakcjonujący wyjaśniona. Były to pochodzące $z$ roku 1847 wydanie Systema Juris Romani Hodie Usitati ${ }^{687}$ autorstwa niemieckiego prawnika F. Mackeldey'a oraz praca M. Ortolana pod tytułem Explication Historique des Institutes ${ }^{688}$. Powołanie obu opracowań stanowić może dowód dobrej znajomości literatury naukowej przez Viscounta Finlay'a. Potwierdza

${ }^{683}$ Cantiere San Rocco v. Clyde Shipbuilding and Engineering Co. 1923 S.C. (H.L.) 105, 114.

${ }^{684}$ R. Zimmermann, The Law of Obligations. Roman Foundations of the Civilian Tradition, ed. 2, Oxford 1996, s. 862.

${ }^{685}$ D. 12, 4, 5, 2 (Ulpianus libro secundo disputationum).

${ }^{686}$ W.W. Buckland, A Text-book..., ed. 3, s. 547.

${ }^{687}$ F. Mackeldey, Systema Juris Romani Hodie Usitati, sec. 409.

${ }^{688}$ M.J.L.E. Ortolan, Explication Historique des Institutes de Justinien, sec. 1600 . 
to pośrednio fakt samodzielnego odnalezienia przez sędziego pracy F. Mackeldey'a ${ }^{689}$.

Sędzia - choć $z$ rezerwą odnosił się do romanistycznych argumentów - ostatecznie uznał konieczność przywrócenia skuteczności korzystnego dla włoskiej spółki pierwszego wyroku wydanego przez Inner House. Można zatem przyjać, iż prawo rzymskie w sposób pośredni przyczyniło się do wydania przez lorda prawa ostatecznej decyzji.

Trzecie orzeczenie w tej samej sprawie wydał Lord Shaw of Dunfermline. Sędzia w stanowczy sposób wyraził swoje przekonania odnoszące się do problemów związanych $z$ ocena prawna rozpatrywanej przez Izbę Lordów sprawy ${ }^{690}$. Bezpośrednio po zaprezentowaniu stanu faktycznego Lord Shaw stwierdził, że w jego przekonaniu każdy szkocki sędzia powinien orzec w przedmiotowej sprawie na korzyść apelującej spółki. Podstawa orzekania powinny być zaś zasady prawa rzymskiego, które zostały przejęte przez prawo szkockie. Wszelkie powstałe wattpliwości należy uznać za przejaw wtargnięcia angielskich koncepcji na grunt prawa szkockiego. Powyżej przytoczone opinie lorda prawa uznać trzeba za jedno $z$ bardziej kategorycznych wystapień szkockiego sędziego przeciwko recepcji angielskich rozwiązań prawnych na gruncie Scots law.

Sędzia podkreślił, iż analiza zasad dotyczących stosowania kondykcji jest bezprzedmiotowa, gdyż stan faktyczny sprawy wydaje się być typowym - tak dla prawa rzymskiego, jak i szkockiego - przypadkiem, w którym należy zastosować condictio causa data causa non secuta. Lord Shaw wskazał, że upadek consideration umowy ${ }^{691}$, co do którego w przedmiotowej spra-

${ }^{689}$ Cantiere San Rocco v. Clyde Shipbuilding and Engineering Co. 1923 S.C. (H.L.) 105, 115.

${ }^{690}$ Cantiere San Rocco v. Clyde Shipbuilding and Engineering Co. 1923 S.C. (H.L.) 105, 116.

${ }^{691}$ Pojęcie consideration może być rozumiane dwuznacznie w prawie angielskim. Zazwyczaj określenie to dotyczy doktryny angielskiego prawa umów, poprzez które rozumie się związanie stron postanowieniami umów na zasadzie wzajemności. Obietnica dokonania określonej czynności jest 
wie nie ma wątpliwości, rodzi obowiąek zwrotu otrzymanych pieniędzy i jest zwyczajnym przykładem stosowania w prawie szkockim konstrukcji niesłusznego wzbogacenia.

Kierując się swymi dotychczasowymi uwagami, sędzia zdecydowaną część swego orzeczenia poświęcił omówieniu wybranych zagadnień dotyczacych stosowania kondykcji w prawie rzymskim i szkockim. Podobnie jak wcześniej Earl of Birkenhead, także Lord Shaw przywołał postać H.J. Roby'ego oraz jego prace Private Roman Law in the Times of Cicero and of the Antonines. Tak samo jak wcześniej Lord Kanclerz, sędzia podał nazwę kondykcji zaproponowana przez angielskiego romanistę i przedstawił jego uzasadnienie dokonanej zmiany ${ }^{692}$. Warto podkreślić, iż Lord Shaw obrał w swym orzeczeniu metodę obszernego cytowania powoływanych przez siebie prac i źródeł, a następnie ich komentowania, czym wyraźnie odróżnia się od pozostałych lordów prawa orzekających w tej samej sprawie.

Uwagę zwraca również fakt, że obok fragmentów pochodzacych $z$ podręcznika H.J. Roby'ego, sędzia zacytował kilka wyjątków wywodzacych się $z$ Digestów justyniańskich. Lord Shaw skupił się na tych, które jego zdaniem najlepiej charakteryzowały wykorzystanie kondykcji w celu odzyskania przedmiotu danego w celu świadczenia wzajemnego, którego podstawa następnie odpadła („to recover a thing given for a consideration where the consideration fails"). Pośród wymienionych i skomentowanych dzieł rzymskich jurystów zna-

uzależniona od złożenia przez drugą stronę umowy obietnicy spełnienia na rzecz pierwszej jakiejś korzyści bądź znoszenia jakiegoś stanu faktycznego. Zazwyczaj chodzi jednak o przeniesienie pewnej sumy pieniędzy. Wykazanie istnienia consideration sprawia, że czynność prawna staje się zaskarżalna. Dodatkowo pojęcie consideration można łączyć z niewykonaniem umowy (wówczas używa się określenia total failure of consideration). $\mathrm{Na}$ temat tych dwóch koncepcji zob. J. Halberda, Doktryna consideration $w$ angielskim prawie zobowiazan kontraktowych (XVI-XX w.), Czasopismo Prawno-Historyczne 63 (2011), s. 261-281; idem, Impossibility as the Factor in the Total Failure of Consideration, [w:] V. Knool (ed.), Nadēje právní vědy. Bykov 2010, Plzeñ 2011, s. 46-57.

${ }^{692}$ H.J. Roby, Private Roman Law..., vol. 2, s. 77, przyp. 2. 
lazły się komentarze do pism Sabinusa autorstwa Ulpiana ${ }^{693}$ oraz Quaestiones Africanusa ${ }^{694}$. Podobnie jak inni law lords, po analizie źródeł rzymskich Lord Shaw przywołał wypowiedzi szkockich autorów ${ }^{695}$.

Temat prawa rzymskiego $\mathrm{w}$ rozważaniach sędziego powrócił raz jeszcze w końcowej części jego decyzji, następującej po analizie angielskich rozwiązań prawnych. Podobnie jak na początku orzeczenia, także i w tym miejscu łatwo można dostrzec negatywny stosunek lorda prawa do jakości angielskich środków prawnych wypracowanych $\mathrm{w}$ odniesieniu do problematyki unjust enrichment. Lord Shaw wskazał, iż wspomniane zasady powstały nie ze względu na prawdziwa niemożność osiagnięcia kompromisu, lecz ze względu na to, że jego osiagnięcie było trudne. Sędzia przywołał także cywilistyczną maksymę potior est conditio possidentis. Choć nie zostało to wskazane w samym orzeczeniu, warto zwrócić uwagę, że zasada ta posiada mieszane - rzymsko-kanoniczne - pochodzenie. Choć w ostatecznym brzmieniu sformułowana została na potrzeby zbioru Regulae Iuris Bonifacego VIII ${ }^{696}$, to jednak jej źródeł należy upatrywać w prawie rzymskim ${ }^{697}$. Lord prawa zauważył, że w prawie angielskim brokarda stosowana była w rozmaitych okolicznościach, co często prowadziło do nadużyć. Stąd sędzia nie zawahał się zauważyć, że była ona powoływana przez osoby zaangażowane w zawieranie transakcji przestępczych oraz contra bonos mores. W prawie szkockim natomiast zastosowanie maksymy potior est conditio possidentis zawężone było jedynie do przypadków niemoralnej podstawy świadczenia (turpis causa) ${ }^{698}$.

${ }^{693}$ D. 12, 7, 1, 2-3 (Ulpianus libro 43 ad Sabinum).

${ }^{694}$ D. 12, 7, 4 (Africanus libro octavo quaestionum).

${ }^{695}$ Cantiere San Rocco v. Clyde Shipbuilding and Engineering Co. 1923 S.C. (H.L.) 105, 118-119.

${ }^{696}$ Liber Sextus 5, 12, 65.

${ }^{697}$ Zob. P. Stein, Regulae Iuris. From Juristic Rules to Legal Maxims, Edinburgh 1966, s. 149.

${ }^{698}$ Więcej na temat zasady $\mathrm{w}$ prawie szkockim zob. L.J. Macgregor, Pacta Illicita, [w:] HPLS, vol. 2, s. 151-153. Odwołanie do zasady ex turpi 
Będąc przekonanym o słuszności rzymsko-szkockich rozwiązań prawnych w zakresie stosowania kondykcji causa data causa non secuta, Lord Shaw ostatecznie orzekł na korzyść włoskiej spółki, uznając tym samym słuszność wyroku sądu pierwszej instancji.

W pewnej ideologicznej opozycji do poprzednika pozostawał $z$ kolei ostatni z orzekających sędziów - Lord Dunedin ${ }^{699}$. $\mathrm{W}$ jego orzeczeniu brak romanistycznych odwołan, co stanowi jednak konsekwencje jego początkowego założenia. Lord prawa zauważył, iż prawo rzymskie, choć interesujące, powinno służyć jedynie ukazaniu fundamentów, na jakich spoczywa prawo szkockie, nie powinno zaś służyć merytorycznej analizie konkretnej sprawy ${ }^{700}$.

Ostatecznie wszyscy law lords jednogłośnie uznali, że spółce Cantiere San Rocco należy się zwrot wpłaconych pieniędzy. $Z$ wyjątkiem Lorda Dunedin, sędziowie w świadomy i celowy sposób odwoływali się do tradycji prawa rzymskiego i podkreślali jego znaczenie dla omawianej sprawy. Warto zauważyć także, iż orzeczenie w przedmiotowym precedensie może być uznane za jeden $z$ najsilniej nasyconych romanistycznymi argumentami wyroków wydanych przez Izbę Lordów w badanym okresie.

Pamiętać należy, że rozstrzygnięcie w sprawie Cantiere San Rocco znalazło w pełni zastosowanie jedynie w obrębie prawa szkockiego. Prawo angielskie kierowało się nadal zasadami wypracowanymi w związku $z$ tzw. sprawami koronacyjnymi. Mimo ich powszechnej akceptacji oraz negacji rozwiązań szkockich na gruncie common law znamienne wydają się słowa Andrew Dewara Gibba, Królewskiego Profesora Prawa

causa non oritur actio (nawiązującej do C. $4,7,5$ ) poczynione zostało także w orzeczeniu Lorda Rodgera of Earslferry w sprawie Gray v. Thames Trains Ltd. [2009] 3 W.L.R. 167.

${ }^{699}$ Sprawie przysłuchiwał się jeszcze Lord Atkinson, który jednak nie zdecydował się sporządzić własnego orzeczenia, a ograniczył się jedynie do poparcia tez postawionych przez pozostałych law lords.

${ }^{700}$ Cantiere San Rocco v. Clyde Shipbuilding and Engineering Co. 1923 S.C. (H.L.) 105, 123. 
w Glasgow, jak również znanego barristera praktykującego przez wiele lat przed sądami angielskimi, który w roku 1937 na łamach „Law Quarterly Review” przewidywał: „it is hardly conceivable that the Lords' judgment in the case of 'Cantiere San Rocco' [...] could fail to influence the House in any future English appeals and that decision might possibly lead to a reconsideration of the Coronation cases"701.

Okazją do potwierdzenia opinii A.D. Gibba stała się sprawa Fibrosa Spolka Akcyjna v. Fairbairn Lawson Combe Barbour $L t d .^{702}$ rozpatrywana przez lordów prawa w roku 1942. W lipcu 1939 roku angielska spółka, mająca swoją siedzibę w Leeds, zawarła umowę $z$ polskim przedsiębiorstwem Fibrosa S.A. z siedziba w Wilnie, dotyczaca wyprodukowania i dostarczenia specjalistycznych maszyn tkackich za cenę 4.800 funtów. W dniu 18 lipca Fibrosa S.A. wpłaciła na konto swojego kontrahenta 1.000 funtów tytułem zaliczki. W dniu 1 września Polska została zaatakowana przez wojska niemieckie, zaś 3 września Zjednoczone Królestwo przystapiło do wojny $z$ Niemcami. W takiej sytuacji pełnomocnik polskiej spółki skierował w dniu 4 września do Fairbairn Lawson Combe Barbour Ltd. pismo, w którym wyjaśnił, iż ze względu na zaistniałe okoliczności wykonanie zobowiązania stało się bezprzedmiotowe i w związku $z$ tym Fibrosa S.A. prosi o zwrot wpłaconej sumy. Fairbairn odmówiła twierdzacc, iż w ciagu minionych tygodni podjęte już zostały przez nią konkretne działania zmierzajace do wykonania zawartej umowy. Ostatecznie, w maju 1940 roku, polska spółka skierowała ryt procesowy, na podstawie którego domagała się wypłacenia odszkodowania oraz zwrotu wpłaconych środków bądź zasą-

${ }^{701}$ A.D. Gibb, The Inter-Relation of the Legal Systems of Scotland and England, LQR 53 (1937), s. 76.

${ }^{702}$ Fibrosa Spolka Akcyjna v. Fairbairn Lawson Combe Barbour Ltd. [1943] A.C. 32. W literaturze polskiej na ten temat zob. Ł. Marzec, Fibrosa przeciwko Fairbairn. Polska spółka, Izba Lordów i prawo rzymskie, ZP UKSW $7 / 1$ (2007), s. 113-121 i ostatnio J. Halberda, Fibrosa S.A. v. Fairbairn Lawson Combe Barbour Ltd (1942). Spółka z Kresów przed Izba Lordów, Miscellanea Historico-Iuridica 14/1 (2015), s. 197-217. 
dzenia tzw. specific performance, czyli sacdowego nakazania pozwanej spółce określonego działania ${ }^{703}$. Orzekający w sprawie lordowie prawa wielokrotnie odnieśli się do rozstrzygnięcia swoich poprzedników w sprawie Cantiere San Rocco. Czyniąc to, zmuszeni byli również odwołać się do wpływów prawa rzymskiego na prawo szkockie.

Znaczna część lordowskich rozważań skupiła się na próbie wyliczenia podobieństw oraz różnic w sposobie rozumienia terminu frustration na gruncie prawa angielskiego i szkockiego. Angielska doktryna, opierając się na sprawach koronacyjnych, nie przewidywała możliwości dochodzenia zwrotu wypłaconych środków majątkowych w razie failure of consideration, podczas gdy prawo szkockie, jak zostało to potwierdzone w Cantiere San Rocco, w sprawie tego rodzaju stosowało tzw. doktrynę restytucji, czyli posługiwało się kondykcjami $z$ tytułu niesłusznego wzbogacenia ${ }^{704}$. Odwołania do prawa rzymskiego pojawiły się kilkakrotnie w orzeczeniach lordów w kontekście dokonywanego przez nich powyższego zestawienia $^{705}$. Jednocześnie dostrzec można w wypowiedziach sędziów dużą ostrożność w sposobie formułowaniu wypowiedzi. Zasadniczo law lords wydawali się być sceptyczni w odniesieniu do możliwości stosowania szkockich zasad restytucji opartych na prawie rzymskim w odniesieniu do spraw pochodzących $z$ jurysdykcji angielskiej.

Uwagę zwraca jednak wypowiedź Lorda Wrighta, który odwołał się w swym orzeczeniu do początków kształtowania się angielskiej doktryny niesłusznego wzbogacenia. Przywołał on znane, choć niewolne od krytyki, stanowisko Lorda Mansfield $z$ roku 1760 przedstawione w sprawie Moses $v$. Macfer$l a n^{706}$. Na kanwie rozpatrywanego przez siebie precedensu,

${ }^{703}$ Zob. szerzej E.A. Martin, Oxford Dictionary..., s. 471, s.v. specific performance.

${ }^{704}$ R. Evans-Jones, Roman Law in Britain..., s. 90.

${ }^{705} \mathrm{~W}$ ten sposób prawo rzymskie powołali Lord Atkin oraz Lord Macmillan. Podobnie także Lord Russel of Killowen.

${ }^{706}$ Moses v. Macferlan (1760) 2 Burr. 1005; 97 Eng. Rep. 676. Na temat zastosowania prawa rzymskiego przez Lorda Mansfield w sprawie 
wielki angielski prawnik z XVIII w. podjął próbę wyjaśnienia charakteru prawnego skargi for money had and received, która na wcześniejszym etapie rozwoju common law nazywana była indebitatus assumpsit ${ }^{707}$. W przekonaniu Lorda Mansfield, możliwość wykorzystywania skargi tego rodzaju uzależniona była od sytuacji opisanej słowami „tak jakby wynikało to z umowy” („as it were, upon a contract”). Sędzia wskazał ponadto, iż pojęcie to odpowiada rzymskiemu terminowi quasi ex contractu ${ }^{708}$. Komentujacc istnienie zobowiązań jak gdyby $z$ umowy, Lord Wright wyjaśnił, że istnienie takiego zobowiązania wynika nie $z$ umowy, lecz $z$ samego prawa, podobnie jak w przypadku deliktów ${ }^{709}$.

Odwołanie się przez lorda prawa do przedstawionej powyżej kategorii zobowiązań jak gdyby z umów, zaproponowanej przez Lorda Mansfield, miało duże znaczenie dla ostatecznego rozstrzygnięcia sprawy Fibrosa $v$. Fairbairn. Wskazało ono bowiem potrzebę zerwania $z$ doktryna wypracowana w związku z Coronation Cases i umieszczenia badanej materii w per-

zob. J. Halberda, Historia zobowiazań..., s. 271-290. Do sprawy Moses v. Macferlan odwołali się również lordowie prawa w roku $2007 \mathrm{w}$ sprawie Sempra Metals Ltd. v. Her Majesty's Commissioners of Inland Revenue Sempra Metals Ltd. v. Her Majesty's Commissioners of Inland Revenue [2007] 3 W.L.R. 354, 384-385.

${ }^{707} \mathrm{Na}$ temat indebitatus assumpsit zob. J.H. Baker, An Introduction..., s. 368-377. W polskiej literaturze na ten temat obszernie ostatnio J. Halberda, Historia zobowiazań..., s. 215-269.

${ }^{708}$ Moses v. Macferlan (1760) 2 Burr. 1005, 1008; 97 Eng. Rep. 676, 678.

${ }^{709}$ Pojęcie zobowiązań quasi ex contractu na gruncie prawa angielskiego zasadniczo ogranicza się do problematyki niesłusznego wzbogacenia. Uznanie jednak unjust enrichment za samodzielna podstawę dochodzenia roszczeń (samodzielna gałąź prawa) trwało bardzo długo i dopiero pod koniec XX w. doszło do pełnej akceptacji takiej koncepcji prawnej. Wyraz takiego sposobu myślenia dał na przykład Lord Steyn („After all, unjust enrichment ranks next to contract and tort as part of the law of obligations. It is an independent source of rights and obligations") w swoim orzeczeniu w sprawie Banque Financière De La Cité v. Parc (Battersea) Limited and Others [1999] 1 A.C. 221. 
spektywie niesłusznego wzbogacenia ${ }^{710}$. Sędziowie ostatecznie orzekli na korzyść polskiej spółki. Należy sądzić, iż choć nie wprost, prawo rzymskie odegrało pośrednią rolę w sformułowaniu przez lordów prawa końcowych wniosków.

\subsection{Prawo rzymskie w orzeczeniach z zakresu unjust enrichment ${ }^{711}$}

W przedstawionych powyżej orzeczeniach Cantiere San Rocco oraz Fibrosa v. Fairbairn można było zobaczyć, iż rzymskie rozwiąania prawne stanowiły przedmiot lordowskiej interpretacji nie tylko w odniesieniu do prawa umów, lecz także zagadnień niesłusznego wzbogacenia. Praktyka odwoływania się przez angielskich sędziów do romanistycznej tradycji prawnej w sprawach tego rodzaju siega przynajmniej XVIII stulecia. Pośród spraw rozpoznawanych przez Izbę Lordów szczególnie ważny jest jej wyrok z roku 1914 w sprawie Sinclair $v$. Brougham ${ }^{712}$, będacy jednym $z$ tzw. key precedents odnoszących się do quasi-kontraktów, które poprzedziły powstanie współczesnego prawa niesłusznego wzbogacenia w Anglii ${ }^{713}$.

${ }^{710}$ Warto zauważyć, że Lord Wright na końcu swojego orzeczenia powołał artykuł autorstwa W.W. Bucklanda zatytułowany Casus and Frustration in Roman and Common Law, HLR 46/8 (1933), s. 1281-1300. Angielski romanista odniósł się w nim m.in. do zasad wypracowanych przez Izbę Lordów na kanwie jednej ze spraw koronacyjnych: Chandler $v$. Webster [1904] 1 K.B. 493.

711 Termin ten we współczesnej nauce prawa cywilnego na język polski zwyczajowo tłumaczony jest jako „bezpodstawne wzbogacenie”. Warto jednak zauważyć, iż słowo unjust odpowiada raczej polskiemu przymiotnikowi „niesłuszny”. Określenie to bliższe jest także klasycznemu prawu rzymskiemu, które już od czasów veteres posługiwało się opisowym określeniem ex iniusta causa (D. 12, 5, 6).

712 Sinclair v. Brougham [1914] A.C. 398.

${ }^{713} \mathrm{Na}$ temat historii angielskich zobowiązań quasi-kontraktowych zob. J.H. Baker, The History of Quasi-Contract in English Law, [w:] W.R. Cornish, R. Nolan, J. O’Sullivan, G. Virgo (eds.), Restitution. Past, Present and 
Sprawa dotyczyła roszczeń depozytariuszy, którzy złożyli swoje oszczędności w banku stanowiącym odłam Benefit Building Society. Stowarzyszenie założono w roku $1851 \mathrm{w}$ celu gromadzenia przez jego członków środków finansowych, które miałyby w przyszłości umożliwić im nabycie domu bądź nieruchomości pod jego wybudowanie. Zarząd stowarzyszenia upoważniony został natomiast do dysponowania zgromadzonymi środkami. W ten sposób w ramach struktury organizacyjnej Benefit Building Society powstał w praktyce bank, znany jako Birbeck Bank. Jego działalność zdominowała podstawowy cel działalności stowarzyszenia. W roku 1911 postanowiono jednak o jego rozwiązaniu. W ten sposób ujawniono liczne problemy finansowe, które szczególnie wyraźnie uwidoczniły się w chwili wypłacania zgromadzonych środków poszczególnym członkom stowarzyszenia, jak i klientom banku. Głównym problemem okazało się określenie kategorii upoważnionych do uzyskania zgromadzonych w ramach Benefit Building Society środków. Spór ten obejmował zewnętrznych wierzycieli stowarzyszenia, udziałowców podzielonych na dwie grupy (A i B), oraz klientów banku, którzy posiadali w nim zarówno rachunki stałe, jak i depozytowe. Środki zgromadzone przez syndyka stowarzyszenia wystarczyły, ażeby spłacić wierzycieli oraz udziałowców. Trudności związane $z$ odzyskaniem środków finansowych spowodowały konieczność odwołania się do autorytetu wymiaru sprawiedliwości. W trakcie toczącego się postępowania ujawnił się jednak kolejny problem, jakim było stwierdzenie, czy w zaistniałej sytuacji pierwszeństwo zaspokojenia roszczeń przysługuje udziałowcom z kategorii $\mathrm{B}$, czy raczej depozytariuszom posiadajacym rachunki w banku. Prawnicy reprezentujacy depozytariuszy podnosili, że posiadając rachunek w banku stowarzyszenia, stali się oni jego wierzycielami, a zatem ich roszczenia powinny być zaspokojone wcześniej. Jednocześnie jednak zauważono, iż należy się zastanowić, czy działania stowarzyszenia w zakresie

Future. Essays in Honour of Gareth Jones, Oxford 1998, s. 37-56; J. Halberda, Historia zobowiązań..., passim. 
działalności bankowej, czy też parabankowej, nie stanowiły wykroczenia poza zwykłe cele stowarzyszenia budowlanego, a zatem - czy nie należy zastosować znanej prawu angielskiemu doktryny ultra vires, oznaczającej dokonanie przez organ publiczny, spółkę, bądź inny podmiot prawa czynności, która wykraczała poza jego uprawnienia ${ }^{714}$. W ten sposób wskazano, iż sprawa powinna być rozstrzygana na podstawie dawnej skargi indebitatus assumpsit.

Orzekający w sprawie Viscount Haldane, L.C., stwierdził, że zgodnie $z$ postanowieniami Building Society Act $1836^{715}$, na podstawie której działało stowarzyszenie, czynności przez nie podejmowane $\mathrm{w}$ sferze bankowej przekraczały dopuszczalne cele stowarzyszenia tego typu. W ten sposób działania te odpowiadały konstrukcji ultra vires i jednocześnie uznać należy, że wszystkie zawarte przez stowarzyszenie umowy bankowe były nieważne ${ }^{716}$. Kontynuujacc swoje rozważania Lord Kanclerz uznał, iż w przedmiotowej sprawie nie można w ogóle mówić o roszczeniach typu in personam, gdyż uznając, że stowarzyszenie nie posiadało uprawnień do zawierania kontraktów w sprawach bankowych, nie zawarło ono nigdy żadnej uznanej przez prawo umowy. W ten sposób pokrzywdzeni depozytariusze nie mogli skorzystać ze skargi in personam, nigdy nie stali się bowiem wierzycielami stowarzyszenia, a jedynie mogli domagać się zwrotu swojej własności na podstawie skargi $z$ kategorii in rem ${ }^{717}$. Lord Kanclerz zwrócił uwagę, że podział skarg na in personam oraz in rem wywodzi się $z$ prawa rzymskiego, lecz jego konsekwencje dla systemu prawa angielskiego sa odmienne ${ }^{718}$. Trzeba wyjaśnić, że wskazany podział został przeszczepiony na grunt common law już w czasach średniowiecza przez Glanvilla i Bractona. Przedmiotem recepcji stał się jednak sam podział w oderwaniu od

${ }^{714}$ E.A. Martin, Oxford Dictionary..., s. 513, s.v. ultra vires.

${ }^{715}$ Building Society Act 1836 (6 \& 7 Will. 4, c. 32).

${ }_{716}$ Sinclair v. Brougham [1914] A.C. 398, 411.

${ }^{117}$ Sinclair v. Brougham [1914] A.C. 398, 414.

718 Sinclair v. Brougham [1914] A.C. 398, 415. Por. J. Halberda, Historia zobowiazań..., s. 17. 
instytucji prawa rzymskiego. Jak wcześniej wskazano, prawo angielskie aż do XVIII wieku nie wykształciło samodzielnej kategorii zobowiąań quasi ex contractu. W ten sposób kategoria skarg in personam została ściśle powiąana jedynie $z$ umowami oraz $z$ deliktami. Pamiętać należy również, ìz omawiana sprawa rozstrzygana była przez Izbę Lordów przed wydaniem orzeczenia w sprawie Fibrosa $v$. Fairbairn, a zatem niemożliwe było powołanie się jeszcze na kondykcje, tak jak uczyniono to w roku 1943 w ślad za prawem szkockim. Źródłem zaskarżalności zobowiąań quasi ex contractu była zatem w momencie zaistnienia powyższego stanu faktycznego fikcja prawna zakładająca, że umowa naprawdę mogłaby istnieć. Jednocześnie jednak powszechnie wiadome być powinno, że umowa nie istniała, a zaskarżenie przysługuje ipso iure. Dlatego Viscount Haldane zauważył, iż wszelkie analogie do innych systemów prawnych, a w szczególności do prawa rzymskiego, powinny być dokonywane $z$ uwzględnieniem dwóch zastrzeżeń. Po pierwsze, należy liczyć się z odmienna ewolucja podziału na skargi in personam i in rem $\mathrm{w}$ tradycji romanistycznej i w prawie angielskim oraz po drugie, wszelkie ograniczenia dotyczące zdolności do wniesienia skargi na gruncie angielskiego systemu prawnego obowiąuja jednocześnie, tak w perspektywie prawa (tj. common law), jak i zasad słuszności (equity) ${ }^{719}$. W następstwie tych uwag lord prawa przeszedł do omówienia orzeczenia Lorda Mansfield w sprawie Moses v. Macferlan oraz dziejów skargi indebitatus assumpsit ${ }^{720}$.

Sędzia zadecydował, iż depozytariusze maja prawo domagać się odzyskania złożonych przez siebie środków na zasadzie pari passu, proporcjonalnie do kwot złożonych i zaksięgowanych uprzednio w księgach rozliczeniowych stowarzyszenia $^{721}$.

719 Sinclair v. Brougham [1914] A.C. 398, 415.

${ }^{720}$ Angielski sędzia powołał się na ustalenia dokonane przez amerykańskiego historyka prawa Jamesa Barra Amesa, w jego artykule uwzględnionym w pracy J.B. Ames, Lectures on Legal History and Miscellaneus Legal Essays, Cambridge, Mass. 1913, s. 149-166.

${ }^{721}$ Sinclair v. Brougham [1914] A.C. 398, 427. 
Jako drugi swoje orzeczenie w sprawie wydał Lord Dunedin. Szkocki prawnik odwołał się do prawa rzymskiego ${ }^{722}$ po raz pierwszy w odniesieniu do kwestii zwrotu rzeczy, która została w niewłaściwy sposób komuś wydana.

Sędzia wskazał, iż w sytuacji, w której sprzedawca dostarczył określona rzecz do domu nabywcy B, a miał ja dostarczyć do domu nabywcy A, wówczas nabywcy A przysługuje w stosunku do nabywcy B skarga restytucyjna o zwrot rzeczy. Lord prawa podsumował swój przykład stwierdzając: „to use Roman phraseology, there would be a jus in re”. Jego zdaniem, nie byłoby w takim przypadku trudno odnaleźć na gruncie common law skargi, która odpowiadałaby powyższej sytuacji. Jednakże moment, w którym - jak stwierdził sędzia - wykorzystuje się rzymska frazeologię, można nazwać „wymiennym”, a w szczególności wówczas, gdy dana sprawa dotyczy pieniędzy. Lord prawa zwrócił uwagę, że podobna byłaby sytuacja omyłkowej spłaty długu, wówczas gdy dłużnik byłby przekonany, że dług jest wymagalny. Prawo angielskie wykorzystałoby wówczas action for money had and received, zaś nie znalazłyby zastosowania środki o charakterze prawnorzeczowym. Wypowiedź sędziego nie jest całkowicie jasna ${ }^{723}$. Wydaje się wszakże, iż jego intencją było wykazanie różnicy między skargami in rem oraz in personam.

Trzeba zauważyć, że wskazany podział skarg jest klasyczna wręcz ilustracja zjawiska wybiórczej recepcji charakteryzującej działania angielskich prawników i sędziów. Zaadaptowano rzymska terminologię, lecz zaniechano przyjęcia do systemu prawnego instytucji $z$ nia zwiazanych. Stąd należy po raz kolejny zwrócić uwagę na fakt, że wszelkie stanowiska na temat potencjalnej recepcji prawa rzymskiego w Anglii powinny być formułowane $z$ dużą ostrożnością.

O ewolucji rzymskich konstrukcji w oderwaniu od rzymskiej tradycji prawnej zaświadcza zresztą sam Lord Dunedin,

${ }^{722} \mathrm{Na}$ temat odwołań Lorda Dunedin zob. J. Mackintosh, Roman Law in..., s. 201-202.

${ }^{723}$ Sinclair v. Brougham [1914] A.C. 398, 431. 
który podsumowując dotychczas przedstawiony wątek swego orzeczenia stwierdził, iż współcześnie, gdy ludzie zaprzestali chowania pieniędzy do skrzyń czy skarpet, nie będzie można już mówić o ius in re, a co najwyżej o ius ad rem. W jego przekonaniu zatem, postęp cywilizacyjny doprowadził do wytworzenia w miejsce dotychczasowego prawa rzeczowego uprawnienia do pewnej rzeczy ${ }^{724}$.

W dalszej części swego orzeczenia szkocki sędzia odwołał się jeszcze do pojęcia słuszności. Wskazał jednak, iż jego rozważania nie będa odwoływały się do systemu equity, lecz do słuszności będącej zasadnicza koncepcją sprawiedliwości ${ }^{725}$. W celu przeprowadzenia stosownej analizy lord prawa odwołał się do tradycji prawa rzymskiego. Ciekawy jest sposób, w jaki wprowadził on cywilistyczna interpretację do treści swego orzeczenia.

Sędzia wskazał, że nie ma zamiaru przepraszać za dokonane odwołania do prawa rzymskiego. Dodał jednocześnie, iż nie uważa, aby miało ono jakąś moc obowiąująca w Anglii, lecz służyć może jako pomoc w rozstrzyganiu stanów faktycznych takich jak w przedmiotowej sprawie ${ }^{726}$.

Lord Dunedin wyjaśnił, iż różnorodne skargi występujące na gruncie prawa angielskiego moga być klasyfikowane jako skargi z tytułu umów (contracts) bądź z tytułu deliktów (torts). W przypadku zaś prawa rzymskiego możliwe jest wymienienie czterech kategorii skarg powiazanych $z$ ta problematyka - ex contractu, quasi ex contractu, ex delicto oraz quasi ex delicto. Wreszcie, zauważył sędzia, odnośnie do omawianego zagadnienia zastosowanie znalazłaby któraś ze skarg $z$ rodzaju quasi ex contractu. Law lord wykazał jednak, iż system prawa rzymskiego był dużo bardziej skomplikowany. Zestawił ze soba dwa odmienne stany faktyczne. $Z$ jednej strony wskazał, że w sprawach dotyczących ruchomości można było wykorzystać actio commodati - służąca ochronie praw wynikajacych

${ }^{724}$ Sinclair v. Brougham [1914] A.C. 398, 431.

${ }^{725}$ Sinclair v. Brougham [1914] A.C. 398, 432.

${ }^{726}$ Sinclair v. Brougham [1914] A.C. 398, 432. 
z umowy użyczenia. Gdy zaś nie było umowy, można było skorzystać ze skargi utilis. Z drugiej zaś strony lord prawa podniósł, że istniała w prawie rzymskim umowa mutuum będąca właściwą pożyczką, obok niej występować miało w obrocie prawnym także pro-mutuum, a więc omyłkowa pożyczka. W tym ostatnim przypadku wykorzystywano by do ochrony praw pokrzywdzonej strony condictio indebiti ${ }^{727}$. Przykłady dane przez sędziego wydają się być nieporadnie dobrane, szczególnie odwołanie do umowy użyczenia, które pojawia się dosyć niespodziewanie, lecz ostatecznie lord prawa ujawnia swój zamysł dotyczący powyższych przykładów zestawiając je $z$ rozwiąaniami common law. Lord Dunedin zauważył bowiem, iż prawo angielskie nie zna quasi-kontraktów, zaś w sytuacjach chronionych action for money had and received stosuje fikcję prawna polegajaca na dorozumianym istnieniu umowy. W ten sposób Lord Dunedin rozszerzył analogiczne refleksje poczynione uprzednio przez Lorda Kanclerza.

Co ciekawe jednak, w kolejnym zdaniu szkocki lord prawa, odmiennie niż Viscount Haldane, ocenił charakter prawny omawianej angielskiej konstrukcji. Lord Kanclerz podkreślał bowiem, iż jedynymi środkami procesowymi, jakie przysługiwały depozytariuszom „banku”, były środki o charakterze in rem. Lord Dunedin natomiast podkreślił, że różnica między rzymskimi quasi-kontraktami a angielska fikcją prawna

${ }^{727}$ Sinclair v. Brougham [1914] A.C. 398, 432. Termin pro-mutuum nie występował $\mathrm{w}$ tekstach prawników rzymskich epoki klasycznej. Został stworzony przez prawników ius commune i stosowany był zamiennie $z$ pojęciem quasi mutuum. Oba pojęcia oznaczały sytuację, w której doszło do omyłkowej spłaty nieistniejącego długu bądź spłaty długu z nadwyżką. Prawnicy średniowieczni i nowożytni uznali zatem, iż we wskazanych przypadkach doszło do powstania omyłkowej pożyczki, która nie została zawarta w przepisanej prawem formie. Stąd możliwe było wykorzystanie condictio indebiti. Zdaniem R. Zimmermanna termin pro mutuum był wykorzystany przez Cujaciusa i następnie chętnie przywoływany w pracach francuskich prawników. Na grunt brytyjski omawiany termin dotarł za pośrednictwem szkockich instytucjonalistów. Por. J. Trayner, Latin Phrases and Maxims: Collected from the Institutional and Other Writers on Scotch Law, Edinburgh 1861, s. 261; R. Zimmermann, The Law of Obligations..., ed. 2, s. 899-900. 
uznajaca istnienie umowy jest „wielce metafizyczna”. Zdaniem sędziego bowiem oba systemy prawne w przypadkach mylnego zapłacenia określonej sumy pieniędzy i domagania się jej zwrotu odrzuciły możliwość posługiwania się środkami in rem. Tym samym lord prawa uznał względnie obowiązujacy charakter czynności quasi-kontraktowych na gruncie prawa angielskiego $^{728}$. Niezależnie bowiem od przyjętej formy realizacji roszczenia, wyjaśnia sędzia, u podstaw właściwego rozstrzygnięcia leży zasada słuszności ${ }^{729}$.

Trzeba zauważyć, iż wszystkie poczynione przez Lorda Dunedin uwagi dotyczyły sytuacji, w której przesunięcie majątkowe nastapiło przy braku umowy. W analizowanej sprawie nie można było mówić o takiej sytuacji. Jak podkreślił sędzia, nie ulega wątpliwości, że stowarzyszenie zawierało umowy bankowe, choć nie miało do tego umocowania prawnego. W takiej sytuacji stosowanie skargi for money had and received byłoby bezpodstawne, skoro można byłoby ja wykorzystać jedynie wówczas, gdy dana umowa nie została zawarta, lecz potencjalnie mogłaby być zawarta. W omawianej sprawie okoliczności były zgoła inne. Umowy zostały zawarte, mimo iż było to niedozwolone. Powstała wątpliwość dotyczacca restytucji środków pieniężnych w kontekście doktryny ultra vires.

Lord Dunedin wskazał, że istnieje możliwość wskazania pewnych środków słusznościowych, które mogłyby zostać wykorzystane w przedmiotowym postępowaniu. W jego przekonaniu problemy podobne do powyższych występowały także w rzymskim obrocie prawnym, choć, co zrozumiałe ze względu na niewystępowanie w Rzymie doktryny ultra vires, w odniesieniu do zupełnie innych stanów faktycznych. Upraszczając nieco złożoność problemu, sędzia wskazał, iż

${ }^{728}$ Szeroko na temat źródeł tzw. implied contract theory (teorii dorozumianych umów) zob. J. Halberda, Historia zobowiazań..., s. 291-296. $\mathrm{Na}$ temat dyskusji naukowej toczacej się na ten temat pośród cywilistów i prawników common law zob. P. Birks, G. McLeod, The Implied Contract Theory of Quasi-Contract: Civilian Opinion Current in the Century Before Blackstone, Oxford Journal of Legal Studies 6 (1986), s. 46-85.

${ }^{729}$ Sinclair v. Brougham [1914] A.C. 398, 433. 
wspomniana doktryna prowadzi ostatecznie do stwierdzenia nieważności umowy. Tego rodzaju przypadki znane były zaś prawu rzymskiemu. Przykładem tego rodzaju umów były takie, które zostały zawarte przez pupila bez zgody jego opiekuna. Nieważność takich umów została zwięźle podsumowana brokarda nemo debet locupletari iactura aliena, oparta na wypowiedzi Pomponiusa pochodzacej z Digestów, który w dwudziestej pierwszej księdze swojego komentarza do pism Sabinusa stwierdził: "nam hoc natura aequum est neminem cum alterius detrimento fieri locupletiorem"730. Trzeba podnieść jednak, iż stanowcza opinia sędziego, jakoby pupil w prawie rzymskim był zupełnie pozbawiony możliwości zawierania umów, nie jest trafna. Sam Lord Dunedin przywołał fragmenty autorstwa Ulpiana, w których jurysta wskazał, że skarga $z$ tytułu commodatum nie przysługiwała przeciwko pupilowi, który działał bez zgody opiekuna ${ }^{731}$, lecz jeśli zawarta umowa przyniosła mu jakieś korzyści, możliwe było wytoczenie skargi utilis, co zostało potwierdzone reskryptem Antoninusa Piusa ${ }^{732}$. Nieważna była natomiast umowa, w której pupil zobowiązywał się wobec swojego opiekuna ${ }^{733}$. Po przedstawieniu rzymskich źródeł, sędzia odwołał się jeszcze do autorytetu R.J. Pothiera i jego dzieła Traité des obligations. Lord prawa wskazał, że francuski prawnik obrał ten sam sposób myślenia co rzymscy juryści. Ponownie jednak wydaje się, że sędzia zbyt pochopnie ocenił powoływane przez siebie źródło. Wprawdzie R.J. Pothier istotnie stwierdził, że dzieci, podobnie jak osoby chore psychicznie, nie sa zdolne złożyć oświadczeń woli, lecz zobowiązania $z$ quasi-kontraktów powstaja nie na skutek oświadczenia woli, ale na podstawie działania jednej ze stron stosunku prawnego ${ }^{734}$.

Pomijając nieporadność Lorda Dunedin w posługiwaniu się obcymi źródłami, należy podkreślić, iż udało mu się udo-

\footnotetext{
${ }^{730}$ D. 12, 6, 14 (Pomponius libro 21 ad Sabinum).

${ }^{731}$ D. 13, 6, 1, 2 (Ulpianus libro 28 ad edictum).

732 D. 13, 6, 3, pr. (Ulpianus libro 28 ad edictum).

${ }^{733}$ D. 26, 8, 5, pr. (Ulpianus libro 40 ad Sabinum).

${ }^{734}$ R.J. Pothier, Traité des obligations, § 114 i 115.
} 
wodnić, że nieważność umowy - mniej bąź bardziej podobna do doktryny ultra vires - nie przekreśla podstawy prawnej uzasadniającej domaganie się zwrotu utraconych pieniędzy. Różnice w przyjętych środkach prawnych nie odgrywaja kluczowej roli, gdyż podstawą dla ich wnoszenia jest ogólnie pojęta słuszność.

Dotychczas lord prawa posługiwał się pojęciem słuszności w znaczeniu ogólnym, nie zaś technicznym, występujacym na gruncie prawa angielskiego. Sędzia zdecydował się wreszcie pokazać, iż opisywany dotychczas przez niego sposób myślenia odcisnął piętno także na systemie equity. W tym celu powołał się na sprawę Walton $v$. Edge rozpatrywana przez Izbę Lordów w roku $1884^{735}$.

Ostatecznie lord prawa orzekł w ten sam sposób, w jaki uprzednio uczynił to Lord Kanclerz. Warto jednak podkreślić, że zdaniem szkockiego sędziego uzasadnienie rozdziału środków według zasady pari passu leżało w naturalnej słuszności takiego rozwiązania, nie zaś w środku procesowym o charakterze in rem.

Do rozwiązań prawa rzymskiego odwołał się również marginalnie Lord Sumner ${ }^{736}$. Jego krótkie cywilistyczne rozważania powiąane zostały jednak $z$ precedensem Spence $v$. Union Marine Insurance Co. ${ }^{737}$, który dotyczył zmieszania się ładunku przewożonej na statku transportowym bawełny. Rozważania te nie odnosiły się zatem do przedmiotu badanej sprawy i nie wpłynęły bezpośrednio na jej rozstrzygnięcie.

Ostatecznie lordowie prawa zadecydowali o rozdysponowaniu pozostajacych w gestii syndyka środków pari passuodpowiednio do poczynionych wkładów - między udziałowców z grupy B i depozytariuszy, którzy posiadali konta bankowe oraz depozytowe w banku prowadzonym przez stowarzyszenie budowlane. Prawo rzymskie powołane zostało w sprawie wie-

${ }^{735}$ Walton v. Edge (1884) 10 App. Cas. 33.

${ }^{736} \mathrm{~W}$ sprawie orzekał także Lord Parker of Waddington, który jednak nie powołal autorytetu prawa rzymskiego.

${ }^{737}$ Spence v. Union Marine Insurance Co. (1867-68) L.R. 3 C.P. 427. 
lokrotnie. Jego wpływ na ostateczna decyzję składu orzekajacego był jednak pośredni. Nie doszło bowiem do recypowania konkretnej instytucji prawa Rzymian, lecz wykorzystano podobieństwo systemów i wspólną wszystkim społeczeństwom naturalna potrzebę działania zgodnie $z$ zasadami słuszności. Wart podkreślenia wydaje się także fakt, iż powyższe rozstrzygnięcie możliwe było dzięki połączeniu (merger) common law oraz equity w okresie reformy lat 1873-1875. Przed tym połączeniem sędziowie sądów królewskich nie byliby w stanie wyrokować opierając się na zasadach słuszności, jak uczynili to law lords w powyższej sprawie.

Do sprawy Sinclair v. Brougham lordowie nawiązali i częściowo zmienili wyrażona $\mathrm{w}$ niej regułę prawa w orzeczeniu $z$ roku 1996 w sprawie Westdeutsche Landesbank Girozentrale v. Council of the London City Borough of Islington ${ }^{738}$, ktorra dotyczyła transakcji finansowych określanych mianem swapu stopy procentowej (interest rate swap) ${ }^{739}$. Jest to rodzaj

${ }^{738}$ Westdeutsche Landesbank Girozentrale v. Council of the London City Borough of Islington [1996] A.C. 669. Nie była to zreszta jedyna sprawa, w której lordowie oceniali ponownie doktrynę ultra vires. W roku 1993 orzekali oni w sprawie Woolwich Equitable Builiding Society v. IRC [1993] A.C. 70. Sprawa dotyczyła naliczenia podatku, którego zasadność została podważona przez pozywające stowarzyszenie budowlane. W celu uniknięcia kar, stowarzyszenie uregulowało należności i oczekiwało wydania wyroku. Sprawę rozstrzygnęła ostatecznie Izba Lordów w roku 1990. Podtrzymała ona wyrok pierwszej instancji wydany w roku 1987 (R. v. IRC. Ex parte Woolwich Equitable Building Society [1990] 1 W.L.R. 1400). Organ podatkowy uznał, że zobowiązany jest w związku z tym zwrócić stowarzyszeniu jedynie tę część kwot, które wpłacone zostały po wydaniu pierwszego wyroku, a więc w latach 1987-1990. Stowarzyszenie zażądało jednak zwrotu także wcześniejszych wpłat. Sprawa trafiła do sądu, gdzie stowarzyszenie ponownie wygrało. Lord Goff of Chieveley wspomniał w swym orzeczeniu o Lordzie Mansfield i jego „rozległej kulturze, znajomości i zrozumieniu prawa rzymskiego, jego nadzwyczajnym darze przedzierania się przez szczegóły w celu dostrzeżenia i zdefiniowania reguły prawnej”.

${ }^{739}$ Była to jedna $z$ wielu podobnych spraw, które w tym czasie rozpatrywały angielskie sady. Zagadnienie to stało się przedmiotem zainteresowania J. Halberdy w jego artykule Zasada bezpodstawnego wzbogacenia w prawie angielskim, Studia Prawa Prywatnego 2/33 (2014), s. 97-99. 
umowy, która dotyczy wymiany płatności odsetkowych od określonej sumy kapitałowej w określonym czasie ${ }^{740}$. Umowy takie zawierane były przez jednostki samorzadu terytorialnego ${ }^{741}$. Sądownictwo angielskie uznało jednak, iż zawieranie umów tego rodzaju stanowiło przekroczenie posiadanych przez nie uprawnień. Stąd możliwe było domaganie się odzyskania zainwestowanych środków uzasadniając to doktryna ultra vires. W przedmiotowej sprawie spór toczył bank oraz władze londyńskiej dzielnicy Islington. Władze dzielnicy podnosiły, iż przeniosły na rzecz banku własność określonej sumy pieniędzy pozostajac w mylnym przekonaniu o ważności zawartej umowy, która była nieważna $a b$ initio.

Chociaż w analizowanej sprawie wielokrotnie odwołano się do precedensu Sinclair $v$. Brougham, to jednak sędziowie konsekwentnie unikali powołania rzymskich rozwiąań prawnych. Jedynie Lord Goff of Chieveley enigmatycznie zauważył, że w swej argumentacji Lord Dunedin oparł się na prawie rzymskim i francuskim ${ }^{742}$.

Większa część lordów prawa orzekających w omawianej sprawie odrzuciła pogląd wyrażony w roku 1914 przez ich poprzedników i negatywnie wypowiedziała się na temat podziału spornych środków według zasady pari passu. W jej miejsce zaproponowali zastosowanie zwykłych zasad niesłusznego wzbogacenia.

Rozwinięcie zaproponowanych zmian nastąpiło dwa lata później, w roku 1998, w sprawie Kleinwort Benson Ltd. v. Lincoln City Council ${ }^{743}$. W rzeczywistości były to wspólnie rozpatrywane cztery apelacje złożone przez bank Klienwort

${ }^{740} \mathrm{Na}$ temat swapu stopy procentowej zob. M. Kwaśnik, Z. Kwaśnik, Sekurytyzacja, [w:] Z. Kwaśnik, W. Żukow (red.), Współczesne problemy ekonomiczne jako wyzwanie dla zmieniajacej się gospodarki, Radom 2010, s. 127 .

${ }^{741}$ Kilka lat wcześniej Izba Lordów orzekała w podobnej sprawie Hazell v. Hammersmith and Fulham London Borough Council [1992] 2 AC 1.

${ }^{742}$ Westdeutsche Landesbank Girozentrale $v$. Council of the London City Borough of Islington [1996] A.C. 669, 688.

${ }^{743}$ Kleinwort Benson Ltd. v. Lincoln City Council [1999] 2 A.C. 349. 
Benson Ltd. przeciwko władzom czterech gmin - Birmingham City Council, Southwark London City Council, Kensington and Chelsea City Council oraz Lincoln City Council. W porównaniu $z$ poprzednia sprawa, akcenty $\mathrm{w}$ sporze zostały tym razem odmiennie rozłożone. Po ogłoszeniu pierwszych wyroków $\mathrm{w}$ sprawach dotyczacych wykorzystania interest rate swap przez organa władz samorzadowych, bank wystapił do czterech gmin o wypłacenie niesłusznie uzyskanych pieniędzy. Ich łączna kwota oceniona została na ponad 800 tysięcy funtów. Zdaniem prawników reprezentujacych poszczególne gminy, sprawa nie powinna obejmować całej kwoty, lecz jedynie drobna jej część. Ich zdaniem znaczna część kwoty stanowiacej przedmiot roszczenia wypłacona została na rzecz gmin ponad sześć lat wcześniej, co oznaczało, iż zgodnie z postanowieniami Limitation Act $1980^{744}$ doszło do przedawnienia roszczeń w tym zakresie. Powołanie się na to przedawnienie możliwe było jednak wówczas, gdy błąd, który spowodował wypłacenie przedmiotowej kwoty, był błędem co do prawa. W trakcie prowadzonej przez sędziów analizy postawiono pytanie, czy w ten sam sposób, jak błąd co do prawa, należy traktować również nieznajomość prawa.

$Z$ tego względu lordowie prawa odwołali się do łacińskiej paremii ignorantia iuris non excusat ${ }^{745}$. Brokarda ta stanowi zmodyfikowana w okresie średniowiecza wersję rzymskiej maksymy ignorantia iuris nocet. Refleksja jurystów rzymskich nad szkodliwymi skutkami nieznajomości prawa zebrana została w obszernym tytule 6 (De iuris et facti ignorantia) umieszczonym w dwudziestej drugiej księdze Digestów ${ }^{746}$. Średniowieczna wersja zasady przejęta została następnie przez prawo angielskie, w którym poddano ją dalszej interpretacji ${ }^{747}$.

${ }^{744}$ Limitation Act 1980 (c. 58).

${ }^{745}$ Liber Sextus 5, 12, 13.

746 Por. na przykład D. 22, 6, 9, pr. (Papinianus libro singulari de iuris et facti ignorantia).

${ }^{747}$ Izba Lordów powołała się na tę samą zasadę w orzeczeniu Sweet v. Parsley [1970] A.C. 132 czy CIN Properties Ltd. v. Dollar Land (Cumbernauld) Ltd. 1992 S.C. (H.L.) 104; por. także W. Wołodkiewicz, Nieznajo- 
Lord Goff of Chieveley omawiajac w swym orzeczeniu angielskie mistake of law, zauważył, że początkowo prawo nie różnicowało konsekwencji związanych $z$ błędem co do prawa i błędem co do faktów ${ }^{748}$. Dopiero wykorzystanie łacińskiej maksymy ignorantia iuris non excusat - w orzeczeniu Lowry v. Bourideu $\mathrm{z} 1780$ roku $^{749}$ - spowodowało zmianę sposobu patrzenia na kwestię nieznajomości prawa. Angielski sędzia odwołał się do wydanej w roku 1802 pracy autorstwa Sir Williama Evansa zatytułowanej Action for Money Had and Recei$v_{e d}{ }^{750}$. Zwrócił także uwage, iż autor podążając za przykładem Vinniusa stwierdził, że pieniądze wypłacone przez pomyłkę zawsze powinny być zwrócone niezależnie od tego, czy nastąpiło to wskutek błędu co do prawa czy co do faktów ${ }^{751}$. Opinia Vinniusa stanowiła krytykę odmiennej koncepcji prezentowanej przez R.J. Pothiera, który odmawiał uznania nieznajomości prawa za podstawę wnoszenia kondykcji z tytułu niesłusznego wzbogacenia. Ku tej ostatniej zaczął skłaniać się wspomniany już wcześniej W. Evans, który w roku 1806 opublikował tłumaczenie dzieła R.J. Pothiera poświęconego zobowiąaniom wraz $z$ własnym komentarzem ${ }^{752}$. Odstapienie od uprzednio prezentowanej opinii musiało być zatem pochodna dostrzegalnej już w tym okresie zmiany angielskiego orzecznictwa, które zaczęło podążać za przykładem wspomnianego orzeczenia w sprawie Lowry $v$. Bourdieu.

Lord prawa wskazał, iż zastosowanie powyższej zasady dla sprawy z zakresu niesłusznego wzbogacenia nie jest jednak oczywiste i od dawna budziło liczne kontrowersje. Dotyczyły one zasadniczo faktu, iż zasada ignorantia iuris non

mość prawa szkodzi. U źródeł zasady 'ignorantia iuris nocet', [w:] W. Wołodkiewicz, J. Krzynówek (red.), Łacińskie paremie w europejskiej kulturze prawnej i orzecznictwie sadów polskich, Warszawa 2001, s. 109-126.

${ }^{748}$ Kleinwort Benson Ltd v. Lincoln City Council [1999] 2 A.C. 349, 369.

${ }_{749}$ Lowry v. Bourdieu (1780) 2 Dougl. 469; 99 Eng. Rep. 299.

${ }^{750}$ W. Evans, Action for Money Had and Received, Liverpool 1802.

${ }^{751}$ Ibidem, s. 7.

${ }^{752}$ R.J. Pothier, A Treatise on the Law of Obligations, or Contracts, vol. 2, London 1806, s. 394-395. 
excusat wykorzystywana była na gruncie innych, aniżeli niesłuszne wzbogacenie, gałęzi prawa. Argumenty te, w opinii sędziego, nie były jednak przekonujące. Zauważył, że w starożytnym Rzymie prowadzone były podobne rozważania, które spowodowały częściową akceptację „nieznajomości prawa” jako okoliczności uzasadniającej skorzystanie $z$ kondykcji ${ }^{753}$. Sędzia nie wskazał źródła swej romanistycznej wiedzy, ze względu jednak na specyfikę rozważań można przypuszczać, iż skorzystał $z$ ustaleń poczynionych przez R. Zimmermanna w pracy The Law of Obligations ${ }^{754}$.

Do zasady ignorantia iuris non excusat nawiazał również szkocki sędzia - Lord Hope of Craighead. Wskazał on, że w roku 1802 Lord Ellenborough w sprawie Bilbie v. Lumley ${ }^{755}$ powołał się na zasadę ignorantia iuris non excusat. Lord Hope podniósł jednak, że ta od dawna (także na gruncie Scots law) była przedmiotem analizy i ścierania się poglądów tych cywilistów, którzy twierdzili, że można ją stosować jedynie na gruncie prawa deliktów oraz tych, którzy widzieli możliwość rozciągnięcia jej stosowania także na inne gałęzie prawa. W tym ostatnim przypadku wskazywano na możliwość posługiwania się zasadą w odniesieniu do indebiti solutio ${ }^{756}$. Sędzia nie powołał stanowisk konkretnych przedstawicieli cywilistyki ${ }^{757}$. Ograniczył się do przedstawienia opinii J. Erskine'a, który w swych Institutes stwierdził jedynie, iż między cywilistami toczony jest spór o to, czy ignorantia iuris non excusat odnosi się do przypadku omyłkowego wypłacenia pieniędzy na skutek błędu co do prawa ${ }^{758}$. Lord Hope wskazał, że we współczesnym orzecznictwie dostrzega się tendencje do jednoznacznego odmawiania moż-

${ }^{753}$ Kleinwort Benson Ltd. v. Lincoln City Council [1999] 2 A.C. 349, 370.

${ }^{754}$ R. Zimmermann, The Law of Obligations..., s. 850-851.

755 Bilbie v. Lumley (1802) 2 East 469, 102 Eng. Rep. 448.

${ }^{756}$ Kleinwort Benson Ltd. v. Lincoln City Council [1999] 2 A.C. 349, 405.

${ }^{757}$ Poszczególnych autorów i ich stanowiska przedstawia R. Zimmermann w swojej pracy The Law of Obligations..., s. 869, przyp. 211.

758 J. Erskine, An Institute..., 3, 3, 54. 
liwości domagania się zwrotu środków, które zostały wypłacone w okolicznościach błędu co do prawa ${ }^{759}$.

W dalszej części swego orzeczenia Lord Hope starał się wykazać, iż dokonywanie podziału na mistake of law oraz mistake of fact nie ma znaczenia na gruncie niesłusznego wzbogacenia, gdyż jego istota polega na niesłuszności przysporzenia, niezależnie od jego źródła. Podstaw takiego sposobu myślenia sędzia poszukiwał m.in. w sprawie Fibrosa Spolka Akcyjna v. Fairbairn Lawson Combe Barbour Ltd.

Podobna argumentacja wykorzystana została także w orzeczeniach pozostałych orzekających w sprawie sędziów ${ }^{760}$. Komitet Apelacyjny ostatecznie zadecydował, że skarga o zwrot pieniędzy przysługiwała apelującemu bankowi i wynikała $z$ popełnionego błędu co do prawa. Pamiętać należy jednak, że określenie rodzaju błędu służyło jedynie potwierdzeniu stosowania zasady wynikającej z Limitation Act i nieuwzględnieniu sześcioletniego okresu przedawnienia. Wyrok nie przesądzał zaś o uznaniu uprawnienia do zwrotu ${ }^{761}$.

Warto dodatkowo jeszcze podnieść, że w doktrynie prawa angielskiego zastanawiano się nad tym, czy wyroki zapadłe w Izbie Lordów w powyższych sprawach przekreśliły stosowanie zasady wypracowanej na kanwie sprawy Sinclair v. Brougham. Stosunkowo długo wskazywano, iż począwszy od sprawy Westdeutsche Landesbank Girozentrale v. Council of the London City Borough of Islington doszło do ograniczenia stosowania zasady jedynie w sprawach dotyczacych swapu stopy procentowej. Począwszy jednak od roku 2010, gdy Sąd

${ }^{759}$ Kleinwort Benson Ltd. v. Lincoln City Council [1999] 2 A.C. 349, 405.

${ }^{760}$ Zapadły w ten sposób wyrok stanowił odpowiedź judykatury na krytykę podnoszona od dawna przez naukę prawa angielskiego. Więcej na temat zniesienia podziału na mistake of law oraz mistake of facts zob. J. Halberda, Mistake of law and mistake of fact in English law of restitution, TR 82/3-4 (2014), s. 261-283.

${ }^{761}$ Wyrok w sprawie Kleinwort Benson Ltd. v. Lincoln City Council stanowi jedną $z$ najważniejszych decyzji dotyczących niesłusznego wzbogacenia ostatnich kilkudziesięciu lat. $Z$ tego względu jest on obszernie komentowany w literaturze angielskiej, por. np. A. Burrows, The Law of Restitution, ed. 3, Oxford 2002, s. 222-229. 
Apelacyjny orzekł wbrew Sinclair v. Brougham w sprawie dotyczącej pożyczki, można zastanawiać się, czy sprawa $z$ roku 1914 posiada jeszcze jakiekolwiek praktyczne znaczenie na gruncie prawa angielskiego ${ }^{762}$.

\subsection{Volenti non fit iniuria}

Uznanie, że każdy dobrowolnie może wyzbyć się przysługujacej mu ochrony prawnej, znane było prawu rzymskie$\mathrm{mu}$, lecz nigdy nie zostało sformułowane w postaci zwięzłej maksymy prawnej ${ }^{763}$. Taka, w brzmieniu volenti non fit iniuria, stanowi dopiero dzieło średniowiecznego prawa kanonicznego. Zdaniem P. Steina występowała ona początkowo $\mathrm{w}$ postaci scienti et consentienti non fit iniuria neque dolus jako reguła 27 w Liber Sextus Bonifacego VIII $z$ roku $1298^{764}$, a $z$ czasem zredukowana została do swej obecnej formy ${ }^{765}$. W rzeczywistości jednak fraza volenti non fit iniuria znana była już w pierwszej połowie XIII wieku, gdy posługiwał się nią w De legibus H. Bracton ${ }^{766}$, najprawdopodobniej za przykładem angielskiego kanonisty W. Drogheada ${ }^{767}$. Niezależnie jednak od okoliczności powstania, sama zasada odniosła znaczacy sukces i śmiało może być uznana za jedna $z$ najpopularniejszych łacińskich maksym obecnie powoływanych przez prawników $z$ całego świata. Jej rzymskie pochodzenie

${ }^{762}$ Haugesund Kommune v. Depfa ACS Bank [2012] Q.B. 549. Więcej na ten temat zob. G. Virgo, Restitution of Void Loans, CLJ 69/3 (2010), s. $447-449$.

${ }^{763} \mathrm{Na}$ temat rozumienia zasady w prawie rzymskim zob. J. Krzynówek, 'Volenti non fit iniuria'. Powstanie i historia reguły, [w:] W. Wołodkiewicz, J. Krzynówek (red.), Łacinskie paremie w europejskiej kulturze prawnej i orzecznictwie sądów polskich, Warszawa 2001, s. 267-287.

${ }^{764}$ Liber Sextus 5, 12, 27.

${ }^{765}$ P. Stein, Regulae Iuris..., s. 149.

${ }^{766}$ H. Bracton, Tractatus de Legibus..., f. 18 i f. 169b.

${ }^{767}$ Por. S.E. Thorne, Bracton On the Laws and Customs of England, vol. 1, Cambridge, Mass., 1968, s. xxxvii. 
nie budzi wątpliwości. Peter Stein wskazał, iż współczesna wersja maksymy stanowić musi kompilację reguły autorstwa Ulpiana nemo videtur fraudare eos, qui sciunt et consentiunt zamieszczonej w pięćdziesiątej księdze Digestów ${ }^{768}$ oraz passusu pochodzacego $z$ Kodeksu justyniańskiego nec umquam volenti dolus infertur ${ }^{769}$.

W prawie angielskim zasada volenti non fit iniuria obecna była, jak wspomniano wcześniej, co najmniej od początków XIII wieku. Kwerenda orzecznictwa sądów angielskich sprzed 1875 roku, zawartego w serii English Reports, ujawnia ponad sto przypadków powołania tej zasady, przede wszystkim (pięćdziesiąt osiem przypadków) przez Sąd Ławy Królewskiej. Prawdziwa popularność zasady jest jednak trudna do jednoznacznej oceny, skoro English Reports stanowia wyciag jedynie najważniejszych precedensów prawa angielskiego. Dodatkowo dla spraw starszych, co do zasady pochodzących sprzed roku 1800, zbiór zawiera ledwie krótkie streszczenia wyroków, nie zaś rozbudowana treść całych orzeczeń, co oznacza, iż w niektórych wypadkach można zaledwie domyślać się, jak wyglądały formułowane przez sędziów uzasadnienia.

Powyższa analiza wykorzystania zasady volenti non fit iniuria wskazuje na jej dużą popularność. Nie może dziwić zatem fakt, że omawiana brokarda stała się także częścia orzecznictwa Izby Lordów w latach 1876-2009. Pierwsze istotne odwołanie się law lords do tej maksymy odnaleźć można w roku $1891 \mathrm{w}$ sprawie Smith $v$. Baker \& Sons ${ }^{770}$. Sprawa dotyczyła odszkodowania $z$ tytułu szkody poniesionej przez stronę apelująca w trakcie pracy dla przedsiębiorstwa kolejowego, którego właścicielem była strona pozwana. Joseph Smith wykonywał prace związane $z$ wykuwaniem i usuwaniem kamieni na trasie budowy Halifax High Level Railway. W trakcie jednej $z$ takich prac urzadzenie uległo

${ }^{768}$ D. 50, 17, 145 (Ulpianus libro 66 ad edictum).

${ }^{769}$ C. $2,4,34$.

${ }^{770}$ Smith v. Baker \& Sons [1891] A.C. 325. 
awarii, która sprawiła, że nagromadzone skalne odpadki wysypały się na robotników. W trakcie toczącego się postępowania dowodowego powód przyznał, iż zdawał sobie sprawę $z$ niebezpieczeństwa poruszania się pod załadowanym kamieniami dźwigiem. $Z$ tego względu prawnicy pozwanego zażądali oddalenia powództwa uznając, że ich mocodawca nie może ponosić odpowiedzialności, skoro sam powód wiedział o niebezpieczeństwie i godził się $z$ następstwami ewentualnego wypadku. W trakcie kolejnych faz postępowania powód podnosił, iż wprawdzie zdawał sobie sprawę $z$ niebezpieczeństwa, lecz jednocześnie poniesiona przez niego szkoda wynikała bezpośrednio $z$ niedbalstwa, jakiego dopuściło się zatrudniające go przedsiębiorstwo.

Na temat możliwości zastosowania w przedmiotowej sprawie zasady volenti non fit iniuria wypowiedzieli się wszyscy lordowie prawa. Najbardziej reprezentatywna dla zrozumienia sposobu stosowania maksymy jest jednak wypowiedź zawarta w orzeczeniu Lorda Watsona który podniósł, iż „the maxim, 'Volenti non fit injuria,' originally borrowed from the civil law, has lost much of its literal significance. A free citizen of Rome who, in concert with another, permitted himself to be sold as a slave, in order that he might share in the price, suffered a serious injury; but he was in the strictest sense of the term volens"771.

Sędzia przedstawił przykładowy kazus dotyczacy wykorzystania omawianej zasady na płaszczyźnie ius Romanum. Kazus dotyczył obywatela rzymskiego, który w porozumieniu $z$ innym zgodził się oddać siebie samego w niewolę, tak aby tym samym uczestniczyć w zyskach płynących ze sprzedaży. Chociaż obywatelowi takiemu wyrządzona została znaczaca szkoda, to jednak działał on volens. Lord Watson nie wskazał wprawdzie źródła, na podstawie którego zaprezentował

${ }^{771}$ Smith v. Baker \& Sons [1891] A.C. 325, 356. Zob. również D.J. Seipp, The Reception of Canon Law..., s. 412. Na temat współczesnych rozwiazań dotyczacych zastosowania tzw. defence of volenti non fit iniuria zob. A.J.E. Jaffey, Volenti non fit injuria, CLJ 44 (1985), s. 87-110. 
powyższy kazus, jednak w Digestach justyniańskich można wskazać co najmniej dwa passusy traktujące o tego rodzaju przypadkach $^{772}$. W dalszej części swego wywodu szkocki lord zauważył, iż współcześnie prawo angielskie zasadę volenti non fit iniuria postrzega odmiennie. Nie oczekuje ono bowiem wyraźnej zgody poszkodowanego na negatywne dla niego konsekwencje, które mogą nastąpić, lecz bada, czy w przypadku zaistniałej szkody ryzyko jej wystąpienia ponosił sam poszkodowany ${ }^{773}$.

Paremii, $z$ powołaniem się na różnice prawa rzymskiego i angielskiego, dotyczy również orzeczenie $z$ roku 1999 w sprawie Commissioners of Police for the Metropolis $v$. Reeves $^{774}$. W 1990 roku w policyjnym areszcie powiesił się Martin Lynch, który już wcześniej podjął dwie nieudane próby samobójcze. Lekarz, który badał przestępcę, orzekł, że istnieje ryzyko podjeccia przez niego kolejnych prób tego rodzaju. Mimo to policjanci nie dopilnowali aresztanta, któremu udało się ostatecznie zrealizować trzecią próbę. Powódką w sprawie była konkubina zmarłego. Na podstawie Fatal Accidents Act $1976^{775}$ kobieta wystapiła $z$ powództwem odszkodowawczym, powołując się na niedbalstwo policjantów, które doprowadziło do śmierci Lyncha ${ }^{776}$. W postępowaniu pierwszoinstancyjnym sędzia wydajaca zaskarżony wyrok uznała, iż nie doszło do naruszenia obowiązków służbowych przez policjantów, a bezpośrednią przyczyna śmierci Lyncha był akt samobójczy. W jej przekonaniu działanie samobójcy może zostać scharakteryzowane przy pomocy brokardy volenti non fit iniuria, gdyż brał on pod uwagę skutki własnego czynu, ewentualnie

772 D. 1, 5, 5, 1 (Marcianus libro primo institutionum); D. 40, 12, 7, pr. (Ulpianus libro 54 ad edictum). Ponadto zob. także I. 1, 3, 4.

773 Smith v. Baker \& Sons [1891] A.C. 325, 357.

${ }^{774}$ Commissionaires of Police for the Metropolis V. Reeves [2000] 1 A.C. 360.

${ }^{775}$ Fatal Accidents Act 1976 (c. 30).

${ }^{776}$ Należy zwrócić uwagę, iż problematyka niedbalstwa (negligence) stanowi immanentny element rozstrzygania w sadach angielskich o zastosowaniu zasady volenti non fit iniuria. 
czyn ten może zostać uznany za przypadek tzw. novus actus interveniens - rodzaju konstrukcji prawnej stanowiacy przerwanie zwiazku przyczynowego ${ }^{777}$.

W Izbie Lordów powołanie się przez sąd pierwszej instancji na maksymę volenti non fit iniuria doprowadziło do jej skomentowania przez law lords. Lord Jauncey of Tullichettle uznał, iż zastosowanie reguły jako podstawy zwolnienia policjantów $z$ odpowiedzialności należy uznać za właściwe. W jego przekonaniu wiedza, jaka dysponowali policjanci na temat możliwości popełnienia przez aresztanta samobójstwa, wyłączała ich obowiązek strzeżenia ${ }^{778}$.

$Z$ takim stanowiskiem nie zgodził się jednak Lord Hope of Craighead, który stwierdził, że groźba popełnienia samobójstwa powinna przede wszystkim wzmóc czujność policjantów, nie zaś zwolnić ich od ponoszenia odpowiedzialności ${ }^{779}$. Spór, który toczyli sędziowie, najtrafniej podsumował Lord Hobhouse of Woodborough, który zauważył, iż zasada volenti non fit iniuria zapożyczona została $z$ prawa rzymskiego, w którym stosowana była w zupełnie innym kontekście, aniżeli czyni się to współcześnie w prawie angielskim. Sędzia zauważył, iż volenti non fit iniuria odnosić się może po pierwsze do tzw. intentional torts, gdzie oznacza wolę powoda do działania w sposób, który w innym przypadku uznany byłby za delikt. Prócz tego zasada ta może być również rozpatrywana w perspektywie niedbalstwa. W tym przypadku oznacza ona zgodę na spowodowanie sytuacji ryzykownej, bąź jest zwiazana $z$ wystapieniem ryzyka niedbałego zachowania ${ }^{780}$.

Tak w argumentacji sędziów w sprawie Smith $v$. Baker, jak i w sprawie Commissionaires of Police for the Metropolis

${ }^{777}$ Zob. więcej E.A. Martin, Oxford Dictionary..., s. 334, s.v. novus actus interveniens (nova causa interveniens).

${ }^{778}$ Commissionaires of Police for the Metropolis v. Reeves [2000] 1 A.C. $360,375-376$.

${ }^{779}$ Commissionaires of Police for the Metropolis v. Reeves [2000] 1 A.C. $360,379$.

${ }^{780}$ Commissionaires of Police for the Metropolis v. Reeves [2000] 1 A.C. $360,395-396$. 
v. Reeves, dostrzec można pewną cechę wspólną. Sędziowie orzekajacy w obu precedensach dostrzegli odmienność rzymskiej oraz angielskiej interpretacji zasady volenti non fit iniuria. Takie potraktowanie tego zagadnienia wydaje się być szczególne, gdyż lordowie prawa nie zanegowali rzymskiego rodowodu paremii, lecz jedynie wskazali na ewolucję jej rozumienia. Biorac pod uwagę fakt powtarzającego się odmawiania istnienia jakichkolwiek rzymskich wpływów na prawo angielskie taka postawa warta jest podkreślenia.

\subsection{Rzymskie domicilium i angielski domicile}

Prawo prywatne międzynarodowe stanowi ważną część brytyjskiego porządku prawnego. Służy bowiem nie tylko rozstrzyganiu problemów związanych $z$ zastosowaniem przepisów prawnych obowiazujących w dwóch różnych krajach, lecz także - gdy ujmowane jest jako conflict of laws - wykorzystywane jest przez prawników do określania wzajemnych relacji między prawami wchodzącymi w skład wewnętrznego, brytyjskiego porzadku prawnego. Analiza orzeczeń sądowych dostarcza licznych przykładów spraw, w których podnoszona była kwestia chociażby domicylu Szkota zamieszkujacego przez wiele lat na terytorium Anglii czy Irlandii Północnej. $Z$ tego względu conflict of laws stanowi bardzo ważny składnik orzecznictwa brytyjskich sądów, w tym także Izby Lordów ${ }^{781}$. Wprawdzie rzymscy prawnicy nie znali pojęcia prawa prywatnego międzynarodowego, to jednak rozbudowane regulacje prawne dotyczace chociażby statusu prawnego mieszkańców Cesarstwa, czy istnienie ius gentium, moga być uznane za zwiastun teorii prawa prywatnego międzynarodowego ${ }^{782}$,

${ }^{781} \mathrm{Na}$ temat historii conflicts of law w Anglii zob. J.G. Collier, Conflict..., s. 8-10.

${ }^{782}$ Ostatnio na ten temat zob. G. Hamza, ¿Existió el derecho internacional privado en el Imperio Romano?, Revista Internacional de Derecho Romano 3 (2009), s. 78-90. 
które zaczęło rozwijać się w środowisku średniowiecznych legistów ${ }^{783}$.

Analizując orzecznictwo Izby Lordów dostrzec można, iż rzymskie rozstrzygnięcia prawne stanowiły przedmiot sędziowskich odwołan w sprawach $z$ zakresu domicylu. Trudno również nie zauważyć, że zagadnienie to wydaje się być kluczowe w rozważaniach dotyczących prawa prywatnego międzynarodowego ${ }^{784}$.

Rzymskie odniesienie odnaleźć można po raz pierwszy $\mathrm{w}$ orzeczeniach lordów w sprawie Cooper $v$. Cooper ${ }^{785} \mathrm{z}$ roku 1888. Jej stan faktyczny dotyczył treści umowy przedmałżeńskiej zawartej w roku 1846 przez mieszkańca Szkocji z jego ówczesną narzeczona, która pochodziła $z$ Irlandii. Po śmierci mężczyzny w roku 1882 owdowiała kobieta wystapiła do sądu o rozstrzygnięcie jej praw do spadku, które w istotnej części regulowane były postanowieniami umowy przedmałżeńskiej. $\mathrm{W}$ trakcie postępowania podniesiono, że kobieta w chwili za-

${ }^{783}$ Por. P. Stein, Bartolus, the Conflict of Laws and the Roman Law, [w:] idem, The Character..., s. 83-90.

${ }^{784}$ Obok spraw dotyczacych domicylu, prawo rzymskie wykorzystane zostało w innej sprawie $z$ zakresu conflict of laws, znanej jako British South Africa Company v. Companhia de Moçambique [1893] A.C. 602. Spór toczyły dwie spółki handlowe - Brytyjska Kompania Południowoafrykańska oraz Kompania Mozambiku nadzorowana przez Królestwo Portugalii. Przedmiotem sporu było bezprawne wejście przez Kompanię Mozambiku w posiadanie terytoriów, które stanowiły własność brytyjskiej spółki, jak również usunięcie jej pracowników z placówek do niej należących, zajęcie tych placówek, a nawet uwięzienie niektórych z nich. Zdaniem pozywającej kompanii celem podjętych przez Kompanię Mozambiku działań było celowe wyrzadzenie szkody, uniemożliwienie prowadzenia transakcji handlowych, jak również zajęcie nienależących do niej obszarów. Działania podjęte zatem przez portugalska spółkę miały znamiona klasycznego angielskiego deliktu określanego jako trespass. Podniesiony został jednak problem forum właściwego dla prowadzenia tego rodzaju sprawy. Do tradycji prawa rzymskiego odwołali się lordowie prawa, pośrednio korzystając z pracy poświęconej prawu międzynarodowemu prywatnemu autorstwa J. Story'ego. Przedmiot odwołania dotyczył właściwości wytoczenia skargi. Rzymskie odwołania nie miały jednak wpływu na ostateczne rozstrzygnięcie sprawy.

${ }^{785}$ Cooper v. Cooper (1888) 15 R. (H.L.) 21. 
wierania wspomnianej umowy nie posiadała wymaganej zdolności do czynności prawnych (nie miała ukończonych dziewiętnastu lat) oraz nie działała za pośrednictwem prawnego opiekuna. W ten sposób zawarta przez nią czynność prawna była nieważna.

Oceniając sprawę Lord Kanclerz Halsbury wskazał, iż brak orzeczeń sądów angielskich, które mogłyby pomóc $\mathrm{w}$ rozstrzygnięciu przedmiotowej sprawy, gdyż nigdy $z$ perspektywy conflict of laws nie poddana została prawniczej analizie kwestia niezdolności do zawarcia czynności prawnej ze względu na niepełnoletniość jednej z kontraktujących stron $^{786}$. Z tego względu Lord Kanclerz odwołał się do klasycznej w XIX w. pracy J. Story'ego na temat conflict of laws, w której amerykański prawnik wskazał, że jeśli osoba jest niezdolna do dokonania określonej czynności prawnej według prawa własnego, jej niezdolność rozciaga się także na obce systemy prawne ${ }^{787}$. Cytat z pracy J. Story'ego law lord zakończył passusem pochodzacym, o czym jednak nie wspomniał, $z$ dzieła niemieckiego romanisty $z$ przełomu XVII i XVIII w. Johanna Nikolausa Herta (Heratiusa). Następnie angielski sędzia wskazał, że reguła przywołana przez amerykańskiego prawnika znalazła w dziejach prawa prywatnego międzynarodowego liczne grono zwolenników. Wśród nich w swym orzeczeniu Lord Halsbury wymienił i jednocześnie zacytował następujących autorów: Burgundusa, Boullenoisa, Bertanda d'Argentré oraz J. Voeta. Nie wspomniał wszakże, iż wszystkie cytaty zaczerpnał ze wspomnianej już uprzednio pracy J. Story'ego ${ }^{788}$.

Nieco bardziej skonkretyzowane odwołanie do prawa rzymskiego poczynił w swym orzeczeniu Lord Wilberforce w roku 1969 w sprawie Indyka $v$. Indyka ${ }^{789}$. Sprawa dotyczyła oceny ważności wyroku rozwodowego wydanego w Czechosło-

${ }^{786}$ Cooper v. Cooper [1888] 15 R. (H.L.) 21, 25.

787 J. Story, Commentaries on the Conflict of Laws, Boston 1834, s. 6364, § 64 .

788 Por. ibidem, s. 64, przyp. 2.

${ }^{789}$ Indyka $v$. Indyka [1969] 1 A.C. 33. 
wacji w roku 1949, w czasie gdy mąż uzyskał już prawo domicylu na terytorium Anglii. Analizujacc przypadki stosowania domicylu w kontekście spraw małżeńskich, Lord Wilberforce zacytowa ${ }^{790}$ fragment orzeczenia autorstwa Lorda Westbury w sprawie Udny $v$. Udny ${ }^{791}$ z roku 1869: "The civil status [of each individual] is governed universally by one single principle, namely, that of domicile [...] it is on this basis that the personal rights of the party, that is to say, the law which determines his majority or minority, his marriage, succession, testacy, or intestacy, must depend. International law depends on rules which, being in great measure derived from the Roman law, are common to the jurisprudence of all civilised nations"792.

Wprawdzie angielski lord prawa nie wskazał konkretnie, jakie rzymskie regulacje prawne wpłynąć miałyby na ukształtowanie się analizowanej przez niego zasady domicylu, to jednak odwołał się do dobrze utrwalonego w tradycji prawa angielskiego przekonania (znajdującego zreszta swoje potwierdzenie w badaniach naukowych ${ }^{793}$ ) o kształtowaniu się prawa prywatnego międzynarodowego w kręgu doktorów prawa rzymskiego i kanonicznego w epoce średniowiecza.

Raz jeszcze sędziowie Izby Lordów odwołali się do prawa rzymskiego w kontekście domicylu w roku 2005 w sprawie Mark v. Mark ${ }^{794}$. Pozew rozwodowy wniesiony został przez żonę opozycjonisty nigeryjskiego Davida A.B. Marka, przeciwnika politycznego rządzącego od roku 1993 generała Sani Abacha. Rodzina poczatkowo otrzymała pozwolenie na czasowy pobyt na terytorium Zjednoczonego Królestwa do dnia

${ }^{790}$ Indyka v. Indyka [1969] 1 A.C. 33, 97.

${ }^{791}$ Udny v. Udny (1866-69) L.R. 1 Sc. 441.

${ }^{792}$ Udny v. Udny (1866-69) L.R. 1 Sc. 441, 457; Indyka v. Indyka [1969] 1 A.C. 33, 97.

${ }^{793}$ Por. np. H.E. Yntema, The Historical Bases of Private International Law, American Journal of Comparative Law 2 (1953), s. 297-317.

${ }^{794}$ Mark v. Mark [2005] 3 W.L.R. 111. Zob. szczegółowo na temat tego orzeczenia Ł.J. Korporowicz, Prawo rzymskie w wybranych orzeczeniach..., s. 292-293. 
30 kwietnia 1998 roku. Przed upływem tego terminu mężczyzna złożył wniosek o przedłużenie pobytu na czas nieokreślony. Jego żona powróciła zaś do Zjednoczonego Królestwa w dniu 29 kwietnia 1998 roku z podróży do Stanów Zjednoczonych, ale wniosku o przedłużenie prawa do pobytu na Wyspach Brytyjskich w wymaganym terminie nie złożyła. W lipcu 2000 roku kobieta wystapiła $z$ pozwem rozwodowym. Wskazała w nim, że prawo do wniesienia powództwa w sadzie angielskim uzależnione jest od co najmniej dwunastomiesięcznego pobytu osoby skarżącej na terytorium Zjednoczonego Królestwa. Sąd pierwszej instancji zgodził się z tym argumentem, odrzucając tym samym wątpliwości podnoszone przez prawników męża powódki, którzy przypominali, że większość wspomnianego okresu kobieta spędziła w Anglii nielegalnie. Sąd doszedł do wniosku, iż możliwość wyboru domicylu uzależniona od dwumiesięcznego okresu pobytu na terenie Zjednoczonego Królestwa jest niezależna od jego podstawy prawnej.

$\mathrm{Na}$ rozwiązania prawa rzymskiego powołał się szkocki sędzia Lord Hope of Craighead. Wskazał on, iż jeden $z$ występujących $\mathrm{w}$ sprawie prawników zwrócił uwage na rzymskie pochodzenie prawa umożliwiającego wybór domicylu: „As Mr Nicholls for the Queen's Proctor observed in his written case, the proposition that to acquire a domicile of choice a person must be lawfully present in the country with the intention of remaining indefinitely can be traced back to the Roman jurists"795. Sędzia nawiązał następnie do orzeczenia wydanego przez południowoafrykański sąd w 1915 roku w sprawie Ex parte Donelly ${ }^{796}$. Orzekający wówczas sędzia zauważył, że każdy podmiot prawa może samodzielnie wybrać miejsce swojego domicylu. Wskazał ponadto, iż potwierdzenie tej zasady odnaleźć można w pięćdziesiątej księdze Digestów justyniańskich. Marcellus orzekł, że nie istnieja żadne ogra-

${ }^{795}$ Mark v. Mark [2005] 3 W.L.R. 111, 114.

${ }^{796}$ Ex parte Donelly 1915 W.L.D. 29. 
niczenia wyboru domicylu („ubi velit habeat domicilium”), pod warunkiem, że ten wybór nie jest zabroniony ${ }^{797}$.

Lord Hope zauważył ${ }^{798}$, iż łaciński termin domicilium nie odpowiada pojęciu domicylu, które współcześnie znane jest na gruncie prawa prywatnego. Zaznaczył, że powołany passus pochodzi $z$ tytułu Ad municipalem et de incolis. Wyjaśnił również, iż termin municipium wykorzystywany był w prawie rzymskim na określenie miasta, zazwyczaj położonego w Italii, którego mieszkańcy posiadali obywatelstwo rzymskie, jednak pozwalano im zachować własne lokalne prawo.

Dalej szkocki law lord podją próbę wyjaśnienia, w jaki sposób Rzymianie rozumieli termin incola. Zacytował on kolejny passus pochodzący z Digestów: "Incola' est, qui aliqua regione domicilium suum contulit: quem Graeci nópo1kov appellant"799. Dodatkowo Lord Hope zaznaczył, iż osoby określane w języku greckim jako rápolkos Justynian traktował w ten sam sposób jak kolonów ${ }^{800}$. Reasumując swoje dotychczasowe rozważania, lord prawa odwołał sie jeszcze do ustaleń zawartych w podręczniku autorstwa W.W. Bucklanda na temat statusu prawnego peregrynów oraz latynów kolonialnych ${ }^{801}$.

Trzeba przyznać, iż rozważania lorda prawa dotyczące rzymskiego pojmowania domicilium sa dosyć zawiłe i trudno nabrać przekonania, aby miały one jakieś dalsze konsekwencje dla rozpatrywanej przez sędziego sprawy. $Z$ pewnością jednak warto je odnotować, $z$ tego chociażby względu, iż wpisuja się w praktykę odnoszenia się do regulacji prawa rzymskiego w sprawach dotyczących określenia domicylu.

Kończąc swoje romanistyczne rozważania, szkocki sędzia wskazał, że w jego przekonaniu prawo rzymskie wymagało od mieszkańca municipium jego zgodnej z prawem obecności $\mathrm{w}$ danym miejscu, zanim uzyskałby on domicilium. Jednocześnie jednak lord prawa podniósł, że tak rozumiane poję-

${ }^{797}$ D. 50, 1, 31 (Marcellus libro primo digestorum).

${ }^{798}$ Mark v. Mark [2005] 3 W.L.R. 111, 115.

${ }^{799}$ D. 50, 16, 239, 2 (Pomponius libro singulari enchiridit).

${ }^{800}$ C. $1,34,1$.

${ }^{801}$ W.W. Buckland, A Text-book..., s. 86, przyp. 14 i s. 92-93. 
cie rzymskiego domicylu odpowiadałoby raczej współczesnemu pojęciu „miejsca zamieszkania” (home bądź residence), nie zaś „domicylu”, który uzależnia posiadanie konkretnych uprawnień od statusu prawnego danej osoby ${ }^{802}$.

Ostatecznie apelacja została oddalona, a Izba Lordów uznała, iż sądy Zjednoczonego Królestwa posiadały jurysdykcję do rozpatrzenia pozwu rozwodowego kobiety.

\subsection{Inne przypadki odwołania się do tradycji orzeczniczej}

Oprócz spraw, które przedstawione zostały powyżej, do tej samej kategorii spraw należy także grupa kilku innych, których jednak nie da się w przeciwieństwie do poprzednich zakwalifikować według jednego spójnego klucza. Styku zagadnień prawnego charakteru własności oraz prawa umów dotyczyła sprawa United States of America and Republic of France $v$. Dollfus Mieg et Cie S.A. and Bank of England ${ }^{803}$. Rządy trzech krajów - Stanów Zjednoczonych, Francji oraz Wielkiej Brytanii zdeponowały w Banku Anglii pod koniec II wojny światowej 64 sztabki złota odebrane Niemcom. Złoto oryginalnie należało do francuskiej spółki i w trakcie wojny zostało zrabowane przez okupanta. Gdy spółka chciała odzyskać sztabki, okazało się, że w okresie między grudniem 1948 roku a styczniem roku następnego, trzynaście $z$ nich zostało przez Bank Anglii omyłkowo sprzedanych. Ponieważ jedna $z$ rozstrzyganych przez sędziów kwestii było zagadnienie posiadania sztabek, prawnicy reprezentujacy rządy Stanów Zjednoczonych oraz Francji wspomnieli m.in. o rzymskich rozwiazaniach odnoszacych się do tej problematyki. Wskazali oni, iż prawo rzymskie w znaczący sposób wpłynęło na an-

${ }^{802}$ Mark v. Mark [2005] 3 W.L.R. 111, 115.

${ }^{803}$ United States of America and Republic of France v. Dollfus Mieg et Cie. S.A. and Bank of England [1952] A.C. 582. 
gielskie law of bailment ${ }^{804}$, w ramach którego mieści się umowa depozytu ${ }^{805}$. W tym zakresie możliwe było, w przekonaniu prawników, powołanie się na zasady prawa rzymskiego. Przenoszac jego rozwiąania na grunt angielski można było powiedzieć, iż bailee (w przedmiotowej sprawie depozytariusz) nie zyskiwał animus, a jedynie corpus, przez co trudno mówić w tym przypadku o jakimkolwiek posiadaniu. Na potwierdzenie swej tezy prawnicy odwołali się do drugiego wydania podręcznika W.W. Bucklanda ${ }^{806}$. Przedstawiona przez nich argumentacja nie stała sie jednak przedmiotem analizy law lords. Warto zauważyć, iż poczyniona przez prawników uwaga nie była kompletna. Wprawdzie w opisanym przez nich przypadku nie doszło do przeniesienia posiadania, to jednak, jak wskazał cytowany przez nich W.W. Buckland, w przypadku depozytu nie zachodziło przeniesienie legal 'possessio'. Tym terminem angielski romanista określił possessio civilis. $\mathrm{Pa}-$ miętać trzeba zaś, iż prawo rzymskie dopuszczało także przeniesienie samego fizycznego władztwa. Wówczas taki rodzaj posiadania określano jako possessio naturalis.

Odwołanie się do innej utartej praktyki powoływania rzymskich rozwiązań prawnych miało miejsce w roku $1935 \mathrm{w}$ spra-

${ }^{804}$ Law of bailment oznacza wszystkie przypadki, w których dochodzi do przeniesienia posiadania rzeczy przez jej właściciela na osobę trzecia z zamiarem osiagnięcia pewnego określonego wcześniej celu (zob. E.A. Martin, Oxford Dictionary..., s. 43, s.v. bailment). W znacznym stopniu umowy mieszczace się w kategorii bailments zostały ukształtowane pod wpływem rzymskich kontraktów realnych. Więcej na ten temat zob. komentarz D.J. Ibbetsona do pracy osiemnastowiecznego prawnika Sir Williama Jonesa, An Essay on the Law of Bailments, Bangor 2004, s. 74-103. Kluczowe, w znacznej mierze definiujące, jakiego rodzaju czynności prawne stanowia element law of bailment, było wydane w roku 1703 orzeczenie w sprawie Coggs v. Bernard (1703) 2 Ld. Raym. 909; 92 Eng. Rep. 107. Orzekający wówczas Lord Holt odwołał się kilkakrotnie do autorytetu prawa rzymskiego. Lordowie prawa dostrzegli ten fakt w roku $2003 \mathrm{w}$ sprawie Tomlinson $v$. Congleton Borough Council [2004] A.C. 46.

${ }^{805}$ United States of American and Republic of France v. Dollfus Mieg et Cie. S.A and Bank of England [1952] A.C. 582, 596.

${ }^{806}$ W.W. Buckland, A Textbook of Roman Law, ed. 2, Cambridge 1932, s. $196,467,500$. 
wie Elliot $v$. Lord Joicey ${ }^{807}$. Problem prawny dotyczył możliwości stania się beneficjentem trustu przez dziecko poczęte, lecz nienarodzone. Trust ustanowiony został w testamencie zmarłej 12 stycznia 1912 roku Rose Elliot. Beneficjentami trustu zostali jej synowie. W roku 1931 jeden $z$ nich - Thomas William Henry Elliot - zawarł zwiazek małżeński, jednak już 11 maja 1932 roku zmarł, nie pozostawiając żadnego żywego potomka. Jego syn urodził się dopiero miesiąc później, 12 czerwca. Jeśli przyjąć, iż w chwili śmierci T.W.H. Elliot nie posiadał żadnego potomka, wówczas jego prawa jako beneficjenta trustu przeniesione miały zostać na żyjących jeszcze braci. Narodziny potomka skomplikowały jednak tę sytuację. Kluczowa była zatem fraza zawarta w klauzuli piątej testamentu, która stanowiła, iż przejście na pozostałe rodzeństwo praw do trustu mogło nastąpić wówczas, gdy jeden $z$ braci zmarł leaving any issue him surviving - nie pozostawiajac żadnego potomka, który by go przeżył. Lord Macmillan, oceniając stan faktyczny, stwierdził patetycznie, iz „from the earliest times the posthumous child has caused a certain embarrassment to the logic of the law, which is naturally disposed to insist that at any given moment of time a child must either be born or not born, living or not living"808. Sędzia zauważył jednak, że już Rzymianie dokonali przełamania tak sformułowanej zasady, co doprowadziło ich do stworzenia fikcji prawnej uznającej, że dziecko nienarodzone (in utero), w sytuacji gdy w przyszłości ma czerpać jakieś korzyści, powinno być traktowane jako już narodzone. W przekonaniu szkockiego prawnika sens tej fikcji prawnej najlepiej obrazuje wypowiedź Paulusa wyrażona w pierwszej księdze Digestów: „Qui in utero est, perinde ac si in rebus humanis esset custoditur, quotiens de commodis ipsius partus quaeritur: quamquam alii antequam nascatur nequaquam prosit"809. Lord prawa przytoczył passus w wersji oryginalnej, jak również jego

${ }^{807}$ Elliot v. Lord Joicey 1935 S.C. (H.L.) 57.

${ }^{808}$ Elliot v. Lord Joicey 1935 S.C. (H.L.) 57, 70.

${ }^{809}$ D. 1, 5, 7 (Paulus libro singulari de portionibus, quae liberis damnatorum conceduntur). 
angielskie tłumaczenie ${ }^{810}$. Prawnik dopełnił swoją opinię odwołując się do właściwego fragmentu Jus Feudale autorstwa T. Craiga ${ }^{811}$, a następnie podkreślił, że zasada wyrażona przez Paulusa została przejęta zarówno przez prawo szkockie, jak też angielskie ${ }^{812}$.

Chociaż sądy kościelne w Anglii utraciły swoje kompetencje w zakresie spraw małżeńskich jeszcze przed powierzeniem Izbie Lordów uprawnień sądowniczych w roku 1876, to jednak ich wielowiekowa tradycja wyraźnie wpłynęła na angielski system prawny. $Z$ tego też względu Izba Lordów korzystała $z$ dorobku sądów kościelnych, a tym samym także prawa kanonicznego. Zjawisko takie zaobserwować można na kanwie lordowskich rozstrzygnięć w sprawie rozwodowej C.B. v. A.B., która była przedmiotem ich analizy w roku $1885^{813}$. Poczatkowo, przez pierwszych dwadzieścia miesięcy pozostawania w związku małżeńskim, para regularnie ze sobą współżła. $Z$ czasem kontakty te stały się rzadsze, a pod koniec wskazanego okresu zupełnie zaniknęły. Mimo to, po dwóch latach od zawarcia związku małżeńskiego kobieta zaszła w ciążę. Mężczyzna wniósł pozew rozwodowy, wskazując zdrade jako jego podstawę. Jednocześnie kobieta wniosła oddzielny pozew podnosząc, że rozwiązanie małżeństwa nastapić powinno ze względu na impotencję jej męża. W związku z brakiem właściwych precedensów zarówno w prawie szkockim, jak i angielskim, Lord Kanclerz Selborne uznał, iż w przedmiotowej sprawie konieczne jest odwołanie się do prawa rzymskiego ${ }^{814}$.

${ }^{810}$ „An unborn child is taken care of just as much as if it were in existence, in any case in which the child's own advantage comes in question; though no one else can derive any benefit through the child before its birth" (Digest of Justinian, trans. C.H. Monro, The Digest of Justinian, vol. 1, Cambridge 1904, s. 25).

${ }^{811}$ Th. Craig, Jus Feudale, 2, 13, 15.

${ }^{812}$ Elliot v. Lord Joicey 1935 S.C. (H.L.) 57, 70. Na temat przytoczonego fragmentu oraz innych dotyczacych dziecka poczętego w prawie rzymskim por. P. Niczyporuk, Prywatnoprawna ochrona dziecka poczętego $w$ prawie rzymskim, Białystok 2009, s. 55-64.

${ }^{813}$ C.B. v. A.B. (1885) 12 R. (H.L.) 36.

${ }^{814}$ C.B. v. A.B. (1885) 12 R. (H.L.) 36, 40. 
Wskazał on, że już wczesne prawo rzymskie znało zasadę, wedle której okres dwóch lat był niezbędny, aby małżonkowie podjęli spoczywające na nich obowiązki małżeńskie. Następnie Justynian zmienił tę zasadę i przedłużył ten okres do lat trzech ${ }^{815}$.W tej postaci, jak wskazał Lord Kanclerz, zasada trafiła do prawa kanonicznego, którego autorzy uznali, iż oddalenie małżonka mogło nastąpić, ale nie prius probari non potest. Tak brzmiacca zasada została zaakceptowana również przez angielskie sądy kościelne i poddana dalszym ograniczeniom, na które wskazywał w swej pracy przywołany przez Lorda Kanclerza angielski kanonista Stephen Lushington ${ }^{816}$. Sędzia zauważył ponadto, że już od czasów średniowiecza nauka prawa kanonicznego uznawała wskazany powyżej trzyletni okres jako czas próby, który miał pozwolić na ocenę potencjalnej frigiditas - tzn. oziębłości seksualnej małżonków ${ }^{817}$.

Ostatecznie sędziowie zadecydowali, że w przypadku impotencji, która w przedmiotowej sprawie została udowodniona, nie istnieje prawny obowiązek odczekania trzech lat, które miałyby udowodnić oziębłość małżonków. Dlatego uznali, że w powyższej sprawie żona miała prawo ubiegać się o stwierdzenie nieważności małżeństwa. Tym samym Izba Lordów odrzuciła kanoniczna zasadę triennium, sięgającą czasów prawa justyniańskiego.

Na koniec warto przywołać jeszcze jeden przykład powołania się na rzymskie rozwiązania prawne, które dokonane zostało w roku 1974 przez pełnomocników w sprawie Scott v. Metropolitan Police Commissioner ${ }^{818}$. Przedmiotem lordow-

${ }^{815}$ Początkowo zasada repudiacji męża przez żonę ze względu na jego impotencję została potwierdzona przez Justyniana w konstytucji $z$ roku 528 (C. $5,17,10)$, następnie jednak została ona zmieniona w kolejnej konstytucji z roku 536 (Nov. 22, 6).

${ }^{816}$ G.F.R. Baker, Lushington, Stephan, [w:] DNB, vol. 12, s. 291-293.

${ }^{817}$ Zob. Liber Extra 4, 15, 5. Na temat praktyki dowodowej w sprawach $z$ zakresu impotencji w średniowiecznym prawie kanonicznym zob. R.H. Helmholz, Marriage Litigation in Medieval England, Cambridge 1974, s. 87-90.

${ }^{818}$ Scott v. Metropolitan Police Commissioner [1975] A.C. 819. 
skiej oceny było przestępstwo określane jako conspiracy to defraud. Oskarżony w sprawie zawarł porozumienie $z$ pracownikami pewnego kina dotyczące udostępniania mu wyswietlanych tam filmów, ich kopiowania oraz rozpowszechniania $z$ naruszeniem praw autorskich twórców. Mężczyzna twierdził, iż niemożliwe jest udowodnienie, że działał w sposób podstępny.

Prawnicy reprezentujący interesy Korony wskazali, iż konstrukcja przestępstwa kradzieży w prawie angielskim odpowiada konstrukcji rzymskiego furtum $^{819}$. W celu potwierdzenia stawianej przez siebie tezy odwołali się do dwóch fragmentów pochodzacych z Corpus Iuris Civilis - definicji kradzieży zawartej w Instytucjach Justyniana: „Furtum est contrectatio rei fraudulosa vel ipsius rei vel etiam usus eius possessionisve, quod lege naturali prohibitum est admittere" ${ }^{20}$ oraz definicji autorstwa Paulusa zachowanej w Digestach: „Furtum a furvo, id est nigro dictum Labeo ait, quod clam et obscuro fiat et plerumque nocte: vel a fraude, ut Sabinus ait: vel a ferendo et auferendo: vel a Graeco sermone, qui $\varphi \tilde{\rho} \rho a_{S}$ appellant fures:

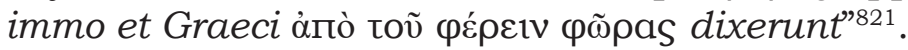

Pełnomocnicy Korony zauważyli następnie, że elementy konstytutywne zawarte w rzymskiej definicji kradzieży zostały przeszczepione na grunt angielski przez Bractona ${ }^{822}$, a następnie przez późniejszych autorów zajmujących się tematyka prawa karnego. Sędziowie Izby Lordów nie odnieśli się jednak do tych argumentów stawianych przez prawników. Wydaje się, że w ten sposób zaprzepaszczony został jeden $z$ potencjalnie ciekawszych przypadków wykorzystania prawa rzymskiego przez Komitet Apelacyjny, zaś samo odwołanie stało się jedynie popisem erudycji prawników.

${ }^{819}$ Scott v. Metropolitan Police Commissioner [1975] A.C. 819, 830.

${ }^{820}$ I. $4,1,1$.

${ }^{821}$ D. 47, 2, 1, pr. (Paulus libro 39 ad edictum).

${ }^{822}$ H. Bracton, Tractatus de Legibus..., f. 150b. S.E. Thorne (Bracton On the Laws..., vol. 2, s. 425, przyp. 2) wskazał, iż defnicja ta oparta jest na Summae Azona. 



\section{Rozdział 5}

\section{RECEPCJA PRAWA RZYMSKIEGO A SCOTS LAW}

\subsection{Lacińskie reguły prawne jako przykład pośredniej recepcji prawa rzymskiego}

Paremie prawnicze odgrywały zawsze dużą rolę w kształtowaniu świadomości prawników i służyły jako narzędzie rozwoju kultury prawnej ${ }^{823}$. Zjawiskiem bardzo częstym było utożsamianie użycia języka łacińskiego przy formułowaniu konkretnej maksymy $z$ jej rzymskim pochodzeniem. Bywa to jednak często uproszczenie, gdyż dana reguła czy brokarda pochodzi zazwyczaj z okresu średniowiecza. Prawda jest jednak, że znacząca część łacińskich maksym została opracowana na podstawie źródeł prawa rzymskiego.

Wyspiarska tradycja prawna - o ile można o takiej w ogóle mówić - wytworzyła cały szereg paremii, które nie były znane prawnikom kontynentalnym ${ }^{824}$. Znaczna ich część powstała $\mathrm{w}$ środowisku prawników szkockich, skąd przeniesiona została następnie na grunt prawa angielskiego. W procesie tym uczestniczyła także Izba Lordów.

${ }^{823}$ Por. np. H. Kupiszewski, Prawo rzymskie a współczesność, wyd. 2, opr. i uzup. T. Giaro, F. Longchamps de Bérier, Kraków 2013, s. 155-177. ${ }^{824}$ Zob. A. Stępkowski, Maksymy prawne na Wyspach Brytyjskich, [w:] W. Wołodkiewicz, J. Krzynówek (red.), Eacinskie paremie w europejskiej kulturze prawnej i orzecznictwie sądów polskich, Warszawa 2001, s. 71-107. 
W roku 1883 w sprawie Studd $v$. Cock ${ }^{825}$ przedmiotem oceny sędziów była - jak podkreślał Lord Watson - szkocka maksyma falsa demonstratio non nocet, si satis constet et relato. Wypada zauważyć jednak, iż oparta ona została na źródłach prawa rzymskiego. Początkowa fraza zdaje się być bezpośrednim nawiazaniem do passusu autorstwa Marcianusa - falsa demonstratio neque legatario neque fideicommissario nocet neque heredi instituto ${ }^{826}$. Podobne sformułowanie odnaleźć można także w Instytucjach Justyniana ${ }^{827}$. Mimo rzymskiej proweniencji, sama zasada wyraźnie opisywana jest przez law lord jako szkocka ${ }^{828}$.

Wiele szkockich paremii powstało w obrębie prawa spadkowego, przede wszystkim zaś w odniesieniu do prawa trustów $^{829}$. W szkockich apelacjach rozpatrywanych przez Izbę

${ }^{825}$ Studd v. Cock (1883) 10 R. (H.L.) 53.

${ }^{826}$ D. $35,1,33$, pr. (Marcianus libro sexto institutionum).

${ }^{827}$ I. $2,20,30$.

${ }^{828}$ Warto zwrócić także uwagę na starsze o dziewięćdziesiąt lat orzeczenie również wydane przez Izbę Lordów, w którym stan faktyczny dotyczył podobnej kwestii. Pewien mężczyzna pochodzacy ze Szkocji zmarł pozostawiajacc nieruchomości tak w Szkocji, jak i w Anglii. Lordowie musieli orzec, według jakich zasad jego najbliżsi powinni dziedziczyć pozostawiony przez zmarłego majatek (dodatkowo problemem był fakt, iż zmarły nie pozostawił po sobie testamentu). Tam Izba Lordów powołała się bezpośrednio na rozwiązania pochodzace $z$ prawa rzymskiego, zob. Balfour $v$. Scott (1793) 6 Bro. 549, 2 Eng. Rep. 1259.

829 Trust stanowi specyficzna konstrukcje prawna, w której występuja trzy podmioty - właściciel powierniczy (trustee), rozporządzający trustem (settlor) oraz beneficjent trustu (beneficiary). Settlor ustanawia trust na rzecz beneficjenta, lecz jego przedmiot przekazywany jest trustee, który ma nim zarządzać. Korzyści uzyskiwane $z$ przedmiotu trustu przekazywane mają być na określonych zasadach beneficjentowi. Prawo angielskie, podobnie jak szkockie, zna liczne przykłady zastosowania trustu - tak w stosunkach między żyjącymi, jak i na wypadek śmierci. Mimo to zabezpieczenie stosunków mortis causa stanowiło oryginalny cel wykorzystania instytucji powiernictwa $\mathrm{w}$ prawie angielskim. W polskiej literaturze na temat konstrukcji trustu zob. K. Michałowska, Trust $i$ stosunki powiernicze $w$ prawie angielskim, Kwartalnik Prawa Prywatnego 5/2 (1996), s. 293341. Na temat trustu w prawie szkockim: A. Stępkowski, L'institution du trust dans le système mixte du droit privé écossais, Warszawa 2005. 
Lordów można wskazać przykłady dwóch szkockich maksym odnoszacych się do omawianej problematyki. W roku 1911 lordowie prawa orzekali w sprawie Crum Ewing's Trustees $v$. Bayly's Trustees ${ }^{830}$. Problem prawny dotyczył kolidujacych umów dwóch trustów. W trakcie przedstawiania argumentów prawnicy Bayly's Treustees przywołali zasadę res aliena scienter legata. Zasada ta, jak wiele innych, często określana była w doktrynie prawa szkockiego jako rzymska. W rzeczywistości stanowi ona rodzimy wytwór szkockiej tradycji prawnej. Źródeł sentencji należy doszukiwać się prawdopodobnie w zamieszczonej w pracy J. Erskine'a uwadze marginesowej brzmiacej legatum rei alienae ${ }^{831}$. Warto w tym miejscu zwrócić dodatkowo uwagę, że orzekajacy w sprawie Lord Shaw wytknął pełnomocnikom bezzasadność powoływania się na powyższą maksymę. Zauważył jednak, iż jeśli strony chciały powołać się na jakiś passus pochodzacy z Corpus Iuris Civilis, to radziłby odnieść się do treści trzydziestej bądź trzydziestej pierwszej księgi Digestów, które noszą wspólny tytuł De legatis et fideicommissis. Sędzia wskazał tytułem przykładu fragment komentarza Pomponiusa do pism Sabiniana („legatarius pro parte adquirere, pro parte repudiare legatum non potest' ${ }^{332}$ ), który Lord Eldon wykorzystał w swoim orzeczeniu w sprawie Ker $v$. Wauchope w roku $1819^{833}$. Na uwage zasługuje ponadto fakt, iż szkocki prawnik, analizując pojęcie res aliena przywołał w swych rozważaniach nazwisko francuskiego humanisty Cujaciusa ${ }^{834}$.

Kilka lat później pełnomocnicy reprezentujący Margaret Heinemann - powódkę w innej szkockiej sprawie dotyczącej trustu (M'Dougal's Trustee v. Heinemann ${ }^{835}$ ) - starali się wykazać, że konieczne jest interpretowanie rozporządzeń testamentowych w sposób, który wskazywałby, iż testator nie

${ }^{830}$ Crum Ewing's Trustees v. Bayly's Trustees 1911 S.C. (H.L.) 18.

${ }^{831}$ J. Erskine, An Institute..., 3, 9, 10.

${ }^{832}$ D. 30, 38, pr. (Pomponius libro sexto ad Sabinum).

${ }^{833}$ Ker v. Wauchope (1819) 1 Bligh 1, 4 Eng. Rep. 1.

${ }^{834}$ J. Cujacius, Opera omnia, Lutetiae Parisiorum 1658, kol. 126.

${ }^{835}$ M'Dougal's Trustee $v$. Heinemann 1918 S.C. (H.L.) 6. 
chciał żadnego ze swoich dziedziców pominąć. Powyższy sposób interpretowania trustów w prawie szkockim określany jest przy pomocy paremii conditio si institutus sine liberis decesserit. Wprawdzie sędziowie orzekajacy w sprawie przychylili się do argumentacji pełnomocników i rozstrzygnęli sprawę na korzyść powódki, to jednak trzeba zauważyć, iż część ich argumentacji dotyczącej stosowania paremii spotkała się $z$ uzasadniona krytyka Lorda Dunedin. Wytknał on prawnikom, że ci nie wskazali źródeł, na podstawie których mogliby przedstawić zakres obowiazywania zasady conditio si institutus sine liberis decesserit ${ }^{336}$. Sędzia stwierdził zaś, iż zasada wywodzi się $z$ prawa rzymskiego i w jego przekonaniu została wprowadzona do szkockiego systemu prawnego treścia orzeczenia $z$ roku $1738 \mathrm{w}$ sprawie The Magistrates of Montrose v. Robertson ${ }^{837}$. Sam sędzia poprzestał jedynie na powyższym stwierdzeniu. Jednak J. Mackintosh, który kilkanaście lat po wydaniu wyroku omawiał jego treść, wskazał, że genezy zasady należy dopatrywać się w prawie rzymskim. Szkocki prawnik wskazał na fragment autorstwa Papiniana umieszczony w trzydziestej piątej księdze Digestów justyniańskich ${ }^{838}$.

Nieco innym zjawiskiem było przenoszenie na grunt angielski szkockich reguł prawnych opartych na źródłach ius Romanum. Przykład takiego działania odnaleźć można w orzeczeniu w sprawie Greenock Corporation $v$. Caledonian Railway Company ${ }^{839}$. Przedmiotem rozważań była stara szkocka paremia sic utere tuo ut alienum non laedas. Maksyma ta dotyczy spokojnego władania rzecza, tak aby nie naruszać uprawnień innych właścicieli w stosunku do przedmiotu ich własności ${ }^{840}$. Ciekawy wydaje się fakt, iż reguła określona zo-

${ }^{836}$ M’Dougal's Trustee $v$. Heinemann 1918 S.C. (H.L.) 6, 13.

837 The Magistrates of Montrose $v$. Robertson (1738) Mor. 6398.

${ }^{838}$ D. 35, 1, 102. Por. szerzej J. Mackintosh, Roman Law..., s. 163165.

${ }^{839}$ Greenock Corporation v. Caledonian Railway Company [1917] A.C. 556.

${ }^{840}$ Greenock Corporation v. Caledonian Railway Company [1917] A.C. 556,561 . 
stała $\mathrm{w}$ raporcie sadowym jako principle of the Roman law. Sformułowania takiego próżno jednak szukać w źródłach klasycznego prawa rzymskiego. Dostrzec można wszakże pewne podobieństwo cytowanej zasady $z$ maksyma qui suo iure utitur neminem laedit ${ }^{841}$, czy zasada male enim nostro iure uti non debemus ${ }^{842}$.

Inna łacińską paremia, która powołana została przez sędziów, była maksyma traditionibus non nudis pactis transferuntur rerum dominia. W przeciwieństwie do wcześniej powoływanych reguł, ta znajduje się w Kodeksie justyniańskim ${ }^{843}$. Okazja do jej interpretacji była sprawa Burnett's Trustee v. Grainger ${ }^{844}$ - szkocka apelacja rozstrzygana przez lordów w marcu 2004 roku. Pewna kobieta (określana jako „A") sprzedała swoje mieszkanie dwóm osobom - „B” i „C”. Uiścili oni ustaloną cenę, zaś kobieta dokonała stosownych rozporządzeń mających na celu wydanie kupujacym przedmiotu sprzedaży. „B” i „C” objęli w posiadanie mieszkanie, jednak nie zarejestrowali faktu nabycia nieruchomości w Register of Sasines. Po pewnym czasie, w związku z niespłaconymi długami, kobieta wniosła o ogłoszenie upadłości. W chwili podjęcia pracy przez wyznaczonego sądownie syndyka (trustee in sequestration) „A” nadal figurowała jako właścicielka mieszkania, które uprzednio sprzedała. Gdy „B” i „C” dowiedzieli się o toczacym się postępowaniu, zarejestrowali transakcję

${ }^{841}$ Takiego sformułowania nie można również odnaleźć bezpośrednio w źródłach prawa rzymskiego, jednak należy uznać, że wzorowana ona była na co najmniej dwóch passusach pochodzacych $\mathrm{z}$ tytułu De diversis regulis iuris antiqui. W D. 50, 17, 151 (Paulus libro 64 ad edictum) wyraźnie wskazuje się, iż nikt nie czyni szkody, jeśli wykonuje prawa, które mu przysługują. $Z$ kolei w D. 50, 17, 155, 2 (Paulus libro 65 ad edictum) nie nadużywa siły ten, kto wykonuje swoje prawa i dochodzi ich za pomoca skargi.

${ }^{842}$ G. 1, 53. Na temat rozwoju i zastosowania zasady male nostro iure uti non debemus zob. F. Longchamps de Bérier, Zakaz nadużywania własnego prawa - male nostro iure uti non debemus, [w:] W. Wołodkiewicz, J. Krzynówek (red.), Łacińskie paremie w europejskiej kulturze prawnej i orzecznictwie sadów polskich, Warszawa 2001, s. 127-151.

${ }^{843}$ C. 2, 3, 20.

${ }^{844}$ Burnett's Trustee v. Grainger 2004 S.C. (H.L.) 19. 
sprzedaży mieszkania w Register of Sasines. Mimo to powiernik sekwestrowy stał na stanowisku, które następnie zostało potwierdzone przez sąd szeryfa, a później także przez Court of Session, iż kobieta w chwili rozpoczęcia oszacowywania majątku nadal pozostawała właścicielka mieszkania.

Zasadę traditionibus non nudis pactis transferuntur rerum dominium powołał szkocki sędzia Lord Hope of Craighead. Podjął on próbę określenia charakteru prawnego przeniesienia własności w prawie szkockim. Powołując się na autorytet szkockiego profesora prawa Johna Burnsa wskazał, iż Scots law przejęło w ślad za prawem rzymskim zasadę traditionibus non nudis pactis transferuntur rerum dominium ${ }^{845}$. W przekonaniu sędziego powyższa zasada pojawiła się w tamtejszym systemie prawnym co najmniej w czasach Lorda Stair ${ }^{846}$ i powtórzona została później przez J. Erskine'a ${ }^{847}$. W obu przypadkach na potwierdzenie swoich słów sędzia wskazał odpowiednie fragmenty dzieł autorów, którzy podkreślali konieczność zagwarantowania pewności obrotu prawnego ${ }^{848}$.

W innym orzeczeniu, $\mathrm{z}$ roku 1881 , w sprawie M'Bain v. Wallace \& Co. ${ }^{849}$ lordowie również odnieśli się do relacji szkockiego i angielskiego prawa w zakresie nabywania własności. Rozstrzygając to zagadnienie, powołali wyżej wspomniana paremię $\mathrm{w}$ innym nieco brzmieniu: traditionibus et usucapionibus non nudis pactis transferuntur rerum dominia. Lord Blackburn potwierdził, iż zagadnienie momentu nabycia własności rzeczy stanowiącej przedmiot sprzedaży różni się w obu brytyjskich systemach prawnych. W Anglii mówi się bowiem o bargain and sale, które cywiliści nazywali emptio perfecta. W Szkocji zaś obowiązuje zasada rozdzielenia czynności prawnej zobowiązującej i rozporządzającejes0.

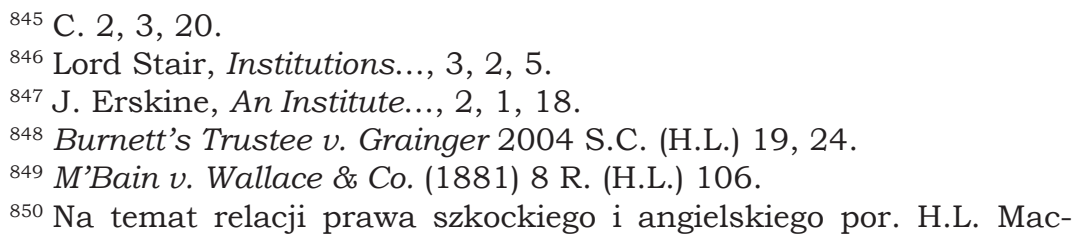
Queen, Scots Law and English Law: The Case of Contract, Current Legal 
Także w roku 1881 Lord Blackburn przywołał inną rzymska paremię - si aes pro auro veneat non valet ${ }^{851}$. Pochodzi ona $z$ fragmentu autorstwa Ulpiana $z$ tytułu Digestów De contrahenda emptione et de pactis inter emptorem et venditorem compositis et quae res venire non possunt. Szkocki sędzia przywołał powyższa paremię w swym orzeczeniu wydanym w sprawie Mackay $v$. Dick \& Stevenson ${ }^{852}$, która dotyczyła sprzedaży warunkowej. Kupujący chciał nabyć maszynę umożliwiająca wydobycie m.in. gliny. Sprzedaż miała dojść do skutku po spełnieniu kilku warunków. Po pierwsze, maszyna musiała w ciagu jednego dnia roboczego wydobyć co najmniej 350 jardów sześciennych gliny. Po drugie, test ukazujący jej możliwości wydobywcze miał być przeprowadzony na bocznicy kolejowej przygotowanej uprzednio przez sprzedającego, co nie nastapiło ani w pierwotnym, ani w nowo wyznaczonym terminie. Ponadto maszyna, nim została przetransportowana na miejsce testu, uległa uszkodzeniu. Świadomy tego kupujący odmówił nabycia urządzenia. Sprzedawca uważał, że kupujacy nie miał prawa powoływać się na okoliczność wadliwości maszyny, skoro nie przystąpił nawet do przeprowadzenia umówionych wcześniej testów. Argumenty stawiane przez sprzedawcę stały się jednak przedmiotem surowej krytyki sędziów. Lord Blackburn uznał, że prawo szkockie umożliwia nabywcy zwrot rzeczy, która została mu już wydana w celu wykonania zobowiązania i nabywca może żądać zwrotu zapłaconej ceny, bądź może odmówić zapłacenia ceny, jeśli nie została ona jeszcze uiszczona, a rzecz wydana nie jest w swej istocie taka, co do jakiej strony się umówiły. Za źródło tak rozumianej kon-

Problems 54 (2001), s. 205-229. Obszernie na temat sprzedaży i przeniesienia własności rzeczy w prawie szkockim zob. natomiast D. Johnston, Sale and transfer of title in Roman and Scots law, [w:] A.D.E. Lewis, D.J. Ibbetson (eds.), The Roman Law Tradition, Cambridge 1994, s. 182-198.

${ }^{851}$ D. 18, 1, 14 (Ulpianus libro 28 ad Sabinum).

${ }^{852}$ Mackay v. Dick \& Stevenson (1881) 8 R. (H.L.) 37. 
strukcji sprzedaży w prawie rzymskim sędzia uznał powołaną powyżej paremię ${ }^{853}$.

Pośrednie odwołanie do maksymy si aes pro auro veneat non valet odnaleźć można również w orzeczeniu Izby Lordów w sprawie Mitchey $v$. Finney ${ }^{854}$ z roku 1983. Sprawa dotyczyła mylnego dostarczenia przez producenta ziaren spółce rolniczej. Relacjonując ustalenia sędziego Parkera orzekającego w sacdzie pierwszej instancji wskazano, iż porównał on błąd „grochu i fasoli” do „błędu miedzi i złota” odwołując się pośrednio do omawianej rzymskiej paremii.

Kończąc problematykę szkockich maksym opartych pośrednio na źródłach prawa rzymskiego, jak i na rodzimej tradycji prawnej, warto zwrócić uwagę na ciekawe zjawisko ich formułowania. Nawet pobieżne porównanie kontynentalnych oraz szkockich brokard prawniczych wskazuje na ich różnice konstrukcyjne. Paremie znane prawnikom europejskim charakteryzują się zazwyczaj zwięzłością. Pośród paremii znanych na Wyspach Brytyjskich jedynie nieliczne zdradzają taka cechę. Wyjaśnienia tego zjawiska należy poszukiwać w fakcie, iż maksymy powstałe w środowisku prawników szkockich, ale także angielskich, sa zaczerpnięte wprost $z$ traktatów prawniczych. Proces ich powstawania polegał zazwyczaj na zacytowaniu przez jednego sędziego fragmentu pochodzącego $z$ pracy któregoś ze szkockich instytucjonalistów. Passus ten zaś, powoływany przez kolejnych sędziów, stawał się nowa maksymą prawniczą, która bardzo często rozwijała się w oderwaniu od oryginalnego źródła swego pochodzenia.

${ }^{853}$ Lord Blackburn błędnie wskazał, iż cytowana przez niego maksyma pochodzi z czwartego tytułu osiemnastej księgi Digestów.

${ }^{854}$ Mitchey $v$. Finney [1983] 2 A.C. 803. 


\subsection{Pośrednie wykorzystanie prawa rzymskiego poprzez prawo szkockie}

W wielu sprawach, które Izba Lordów rozpatrywała w drodze apelacji od szkockiego Court of Session, zarówno sędziowie, jak i pełnomocnicy stron, powoływali argumenty pochodzące z dzieł prawniczych klasycznych autorów szkockich - przede wszystkim Lorda Stair oraz J. Erskine'a. Charakterystyczny jest brak interpretacji rzymskich źródeł prawa cytowanych przez instytucjonalistów. W zamian za to sędziowie milcząco przyjmowali fakt rzymskiego pochodzenia danego rozwiazania. Jednym $z$ pierwszych przykładów takiego traktowania prawa rzymskiego przez law lords jest sprawa Mann $v$. Brodie $z$ roku $1885^{855}$. Dotyczyła ona określenia czasu niezbędnego do zasiedzenia drogi, która w przeszłości miała status drogi publicznej. Droge tego rodzaju definiowano jako taka, która jest powszechnie używana przez mieszkańców danej okolicy. W swoim orzeczeniu Lord Watson ${ }^{856}$ przywołał autorytet wspomnianych powyżej prawników - Lorda Stair ${ }^{857}$ oraz J. Erskine'a. W cytacie pochodzącym $z$ dzieła tego drugiego znalazło się następujące stwierdzenie: „positive prescription is generally defined by our lawyers as the Romans did usucapion, the acquisition of property by the continued possession of the acquirer for such a time as is described by the law to be sufficient for that purpose" 858 .

Lord Watson użył cytatu $z$ pracy J. Erskine'a jedynie dla potwierdzenia faktu powszechnie znanego prawnikom szkockim. Powszechność tego przekonania sprawiła, że sędzia nawet nie ustosunkował się do powołanej przez siebie wypowiedzi.

Mniej więcej $z$ tego samego okresu pochodzi inne powołanie prawa rzymskiego. W angielskiej sprawie Dalton v. An-

${ }^{855}$ Mann v. Brodie (1885) 12 R. (H.L.) 52.

${ }^{856}$ Mann v. Brodie (1885) 12 R. (H.L.) 52, 57.

${ }^{857}$ Lord Stair, Institutions..., 2, 12, 9.

858 J. Erskine, An Institute...3, 7, 2. 
gus \& Co. ${ }^{859}$ rozstrzygany był problem charakteru prawnego angielskiej służebności określanej jako right of support. Lord Kanclerz Selborne dokonujacc wykładni obowiązujacych zasad prawa angielskiego wskazal, iż right of support posiada dwie odmiany: lateral - odnoszaca się do prac podejmowanych przy granicy sąsiadującego gruntu oraz vertical - oznaczajaca zakaz dokonywania w warunkach sąsiedzkich takich czynności, w których sąsiad mieszkający na niższym piętrze doznać miałby jakiegoś uszczerbku na swoim majątku ${ }^{860}$. W tym przypadku Lord Selborn dostrzegł podobieństwo do szkockiej, lecz wywodzącej się z prawa rzymskiego, służebności oneris ferendi. Wskazał jednocześnie, że rzymscy juryści przypisywali ja do kategorii służebności miejskich, jednak nie był to podział sztywny i możliwe było, w zależności od zaistniałej sytuacji, uznanie istnienia służebności miejskiej na gruntach wiejskich i na odwrót. W tym miejscu Lord Kanclerz wskazał kilka fragmentów pochodzacych z Instytucji oraz Digestów justyniańskich, które dotyczyły omawianego zagadnienia $^{861}$. Warto zauważyć jednak, że Lord Kanclerz nie zacytował wskazanych przez siebie źródeł, lecz ograniczył się jedynie do podania ich oznaczenia. Nieco dalej angielski prawnik wspomniał także o the law of ancient light, nie podając wszakże łacińskiej nazwy tej służebności. Przyznał jednak, iż była ona, podobnie jak oneris ferendi, znana prawu rzymskiemu.

Nieco inny przykład recypowania prawa rzymskiego za pośrednictwem prawa szkockiego dostarcza analiza sprawy Winter $v . I R C^{862} z$ roku 1963. Sprawa stanowiła wprawdzie apelację od wyroku angielskiego Court of Appeal, jednakże jej przedmiotem była analiza charakteru prawnego tzw. contingent liability, czyli odpowiedzialności potencjalnej, której wystapienie zależy od zaistnienia pewnych późniejszych okoliczności. Konstruk-

${ }^{859}$ Dalton v. Angus \& Co. (1881) 6 App. Cas. 740.

860 Dalton $v$. Angus \& Co. (1881) 6 App. Cas. 740, 794.

${ }^{861}$ I. 3, 2; D. 8, 2, 24-25, 33; D. 8, 5, 6, 8.

${ }^{862}$ Winter $v . \operatorname{IRC}[1963]$ A.C. 235. 
cja ta swymi korzeniami sięga prawa szkockiego, z którego następnie przeniesiona została do prawa angielskiego. Jej właściwa interpretacja wymaga wszakże - na co zwrócili uwagę także sędziowie - odwołania się do szkockiej literatury prawniczej. Stan faktyczny sprawy dotyczył spółki, której główny zarządca zmarł w marcu 1953 roku. W zwiazku z obowiazujacymi wówczas przepisami prawnymi udziały zmarłego udziałowca zostały poddane oszacowaniu (na potrzeby uiszczenia podatku spadkowego - estate duty), a ich własność przeniesiona na samą spółkę. Wniesiony w ten sposób majątek obejmował m.in. pięć statków. Ze względu na fakt, iż statki te miały służyć spółce, administracja podatkowa zwolniła ja z obowiazku uiszczania daniny publicznej od nabytych obiektów. Kilka miesięcy później spółka sprzedała wszystkie statki, co spowodowało naliczenie podatku od dokonanej transakcji.

Lord Reid podją w swym orzeczeniu zagadnienie właściwego rozumienia terminu contingent liability. Sędzia odwołał sie do passusu pochodzacego z Institute J. Erskine'a, gdzie szkocki prawnik wyjaśnił, iż zobowiąania moga być podzielone na takie, które określa się mianem czystych (pure), wymagalnych w określonym dniu (in diem) oraz takie, do których dołączany jest jakiś warunek. Mówiąc o zobowiązaniach warunkowych zauważył on, iż zobowiązanie takie nie wywołuje skutku dopóki warunek się nie spełni. Tym samym wierzytelność powstaje wraz $\mathrm{z}$ chwila ziszczenia się warunku. Zawieszeniu podlega nie tylko wykonanie zobowiąania, lecz nawet jego powstanie ${ }^{863}$. W przekonaniu J. Erskine'a także prawo rzymskie znało zobowiazania tego rodzaju, które tworzyć miały hope of a debt, tj. „nadzieję wierzytelności”864. Lektura tekstu szkockiego prawnika wskazuje, że oparł on swój pogląd na fragmencie pochodzacym $z$ Instytucji Justyniana, gdzie w tytule De verborum obligatione wskazano, iż „ex condicionali stipulatione tantum spes est debitum iri" ${ }^{865}$. Wbrew

${ }^{863}$ Winter v. IRC [1963] A.C. 235, 248.

${ }^{864} \mathrm{~J}$. Erskine, An Institute..., 3, 1, 6.

${ }^{865}$ I. 3, 15, 4. 
jednak jednoznacznej wypowiedzi J. Erskine'a warto podkreślić, że rzymscy juryści dostrzegali problemy związane $z$ dołaczaniem do oświadczeń woli warunków. Gaius wspomina na przykład na kanwie rozważań o kontraktach konsensualnych o problemach zwiazanych $z$ precyzyjnym określeniem, jakiego rodzaju kontrakt został zawarty, jeśli dołaczony został do niego warunek ${ }^{866}$.

W następnym roku sędziowie Izby Lordów rozpatrywali niecodzienna sprawę Burmah Oil Company v. Lord Advocate $^{867}$. Jej specyfika polegała na żądaniu wypłacenia przez rząd Zjednoczonego Królestwa odszkodowania za wyrządzone w czasie II wojny światowej powodowi szkody. Wydarzenia, które doprowadziły do wytoczenia powództwa, a z czasem złożenia apelacji do Izby Lordów, miały miejsce w roku 1942 podczas wojny na Dalekim Wschodzie. W przededniu wkroczenia wojsk japońskich na terytorium Birmy, która w tym czasie była brytyjska kolonia, rząd w Londynie zadecydował o zniszczeniu, w razie bezpośredniego zagrożenia atakiem, rurociagów roponośnych, które należały do Burmah Oil Company. W dniu 7 marca 1942 roku rurociagi zostały zniszczone, zaś następnego dnia japońska armia cesarska wkroczyła do stolicy kolonii - Rangunu. W roku 1961 spółka wniosła powództwo przeciwko Koronie o wypłacenie odszkodowania za zniszczone mienie.

Do rozwiązań prawa rzymskiego lordowie odnieśli się dwukrotnie. Jako pierwszy uczynił to Lord Reid. Wskazał on, że w przypadku braku szkockich rozwiazań prawnych (powództwo zostało złożone przez Burmah Oil Company w Szkocji) tamtejsi prawnicy bardzo często odwoływali się w przeszłości do autorytetu prawa rzymskiego ${ }^{868}$. Lord prawa przypomniał, iż nieco miejsca temu zagadnieniu w swoim orzeczeniu w spra-

${ }^{866}$ Więcej na temat tych kontrowersji zob. W.W. Buckland, A Textbook..., ed. 3, s. 422-426. Na temat G. 3, 146 zob. ostatnio P. du Plessis, Letting and Hiring in Roman Legal Thought: 27 BCE - 284 CE, Leiden 2012, s. $106-110$.

867 Burmah Oil Company v. Lord Advocate 1964 S.C. (H.L.) 117.

${ }^{868}$ Burmah Oil Company v. Lord Advocate 1964 S.C. (H.L.) 117, 127. 
wie Stewart v. London, Midland and Scottish Railway Co. poświęcił Lord Macmillan. Wstęp ten pozwolił sędziemu płynnie przejść do omówienia terminu dominium eminens oznaczającego własność zwierzchnia pana feudalnego ${ }^{869}$. Dalsze rozważania angielskiego prawnika odnosiły się do próby sformułowania odpowiedzi na pytanie, czy monarcha działając w interesie swoich poddanych, ma prawo w pewnych szczególnych i wyjatkowych okolicznościach naruszać ich własność prywatną. Przy pozytywnej odpowiedzi na tak postawione pytanie, kolejna sporna kwestią było pytanie o to, czy monarcha jest zmuszony wypłacić poszkodowanym poddanym stosowne odszkodowanie $^{870}$. Lord Reid wyjaśnił, że średniowieczna zasada dominium eminens odnosząca się do zasad sprawowania władzy przez monarchów oznaczała m.in., iż władca podlega prawu naturalnemu, prawu narodów oraz prawu boskiemu. Nieco dalej sędzia odwołał się do pism dwóch szkockich pisarzy - Jus Feudale autorstwa Th. Craiga oraz Practicks J. Balfoura (Lorda Pittendreich). Obaj szesnastowieczni prawnicy wskazali, że prawo, które obowiazuje w Szkocji, obejmuje kilka płaszczyzn. Dla Th. Craiga sa to prawo natury, prawo narodów oraz prawo cywilne ${ }^{871}$. Dla J. Balfoura $z$ kolei sa to prawo natury, prawo boskie oraz prawo pozytywne ${ }^{872}$. W obu przypadkach dostrzec można silne cywilistyczne wpływy na tezy formułowane przez szkockich autorów ${ }^{873}$.

Starając się ustosunkować do wcześniej postawionego pytania o prerogatywy królewskie, Lord Reid odwołał się także do pracy H. Grocjusza De Jure Belli ac Pacis, gdzie holenderski myśliciel wprost uznał, iż monarcha ma prawo posługiwać się rzeczami należącymi do jego poddanych, lecz jest

${ }^{869}$ J. Sondel, Słownik łacińsko-polski dla prawników i historyków, Kraków 2006, s. 309, s.v. dominus -i.

${ }^{870}$ Burmah Oil Company v. Lord Advocate 1964 S.C. (H.L.) 117, 127.

${ }^{871}$ Th. Craig, Jus Feudale, 1, 8, 6 (Quo jure hodie Scoti regantur. De jure natuali, et duplicate ejus significatione).

${ }^{872}$ J. Balfour, The Prackticks of Sir James Balfour of Pittendreich, Edinburgh ed. 1754, process. P.G.B McNeill, Stair Society 21-22 (1963), s. 1. ${ }^{873}$ Więcej na ten temat zob. P. Stein, Roman Law..., s. 94-97. 
on jednocześnie zobowiazany do pokrycia szkód związanych $z$ ich utrata ${ }^{874}$. Przychylnie stwierdzenie H. Grocjusza ocenił kolejny autor, którego pracę przywołał lord prawa - inny holenderski prawnik Cornelius van Bynkershoek w swojej pracy Quaestiones Iuris Publici ${ }^{875}$. Na koniec Lord Reid przywołał dodatkowo passus pochodzacy z pracy autorstwa Emericha de Vattela. Szwajcarski prawnik i myśliciel wskazał, że istnieją dwa rodzaje zniszczeń, które moga być spowodowane przez państwo bądź przez jego władcę. Do pierwszej kategorii należą zniszczenia w majątku prywatnym, które związane sa np. $z$ polepszeniem obronności kraju. W takim przypadku stosowne odszkodowanie powinno być przyznane. Drugim rodzajem zniszczeń sa te spowodowane $\mathrm{w}$ trakcie prowadzenia działań zbrojnych. Traktowane są one wówczas w taki sam sposób, jak by zostały uczynione przez wrogów ${ }^{876}$.

Drugim $z$ sędziów, który odniósł się do tradycji prawa rzymskiego, był Viscount Radcliffe. Jego postawa zwiazana $z$ wykorzystaniem powyższych autorytetów diametralnie różniła się jednak od tej, która prezentował Lord Reid. Viscount Radcliffe zauważył, że w sytuacji, w której konieczne jest odwołanie się do obcych instytucji prawnych, najlepszym rozwiązaniem jest przywołanie rozwiązań amerykańskich, a nie, jak sugerowali niektórzy prawnicy bioracy udział w postępowaniu, nawiazanie do tradycji prawa rzymsko-holenderskiego. Stwierdził on bowiem, iż choć w wiekach XVII i XVIII prawo rzymskie oddziaływało na prawo szkockie, to jednak w przedmiotowej sprawie nie ma ono żadnego zastosowania ${ }^{877}$.

Ostatecznie lordowie prawa uznali, iż odszkodowanie powinno być przez Koronę wypłacone ze względu na fakt, że zniszczenia zostały dokonane nie w trakcie bezpośrednich działań wojennych, lecz w związku z wykonywaniem królewskiej prerogatywy. Nastapiło bowiem w ten sposób zawłasz-

${ }^{874}$ H. Grotius, De Jure Belli ac Pacis 3, 20, 7, 1.

${ }^{875}$ C. von Bynkershoek, Quaestiones Iuris Publici 2, 15.

876 E. de Vattel, Le Droit de Gens, 3, 15, 232.

${ }^{877}$ Burmah Oil Company v. Lord Advocate 1964 S.C. (H.L.) 117, 144. 
czenie rurociagu w celu jego zniszczenia. W takich okolicznościach obowiąkiem Korony jest wypłacenie stosownego odszkodowania. W ten sposób sędziowie nawiązali do cywilistycznej i prawnonaturalnej tradycji prerogatyw królewskich omawianych przez Lorda Reida w jego orzeczeniu.

Ostatnie pośrednie powołanie prawa rzymskiego przez lordów prawa dokonane zostało w roku 2007 w sprawie Moncrieff v. Jamieson ${ }^{878}$. Jej przedmiotem był spór dwóch właścicieli nieruchomości położonych w Sandsound na Szetlandach. Nieruchomość należąca do skarżącego była pozbawiona bezpośredniego dostępu do drogi publicznej. Zgodnie $z$ wcześniejszymi ustaleniami właścicieli, mieszkańcy nieruchomości pozbawionej dostępu do drogi mogli korzystać ze służebności przejścia (ze względu na dużą stromość terenu podjazd samochodem był niemożliwy), a jednocześnie od lat korzystali także z możliwości zatrzymywania pojazdu tuż przy nieruchomości służebnej, bądź na jej terenie. W 1998 roku doszło jednak do sporu między stronami, w którym pozwani uznali, że skarżący nie może korzystać $z$ ich nieruchomości w celu dotarcia do własnego domu. Romanistyczny aspekt sprawy został poruszony przez Lorda Rodgera of Earlsferry ${ }^{879}$. Zwrócił on uwage na fakt, że choć w prawie rzymskim nie występowała służebność zatrzymywania pojazdu mechanicznego, to problem ten mógł w starożytnym Rzymie dotyczyć powozów lub innych pojazdów, brak zaś wiadomości na ten temat jest wynikiem selekcji dokonanej przez komisję Tryboniana w trakcie prac nad Digestami ${ }^{880}$. Wskazał on, że wiele służebności gruntowych znanych prawu szkockiemu nie występowało w prawie rzymskim. Lord Rodger porównał służebność zatrzymania pojazdu mechanicznego $z$ rzymskim kazusem dotyczacym udzielenia odrębnej służebności wybudowania szałasu pasterzowi, który

${ }^{878}$ Moncrieff $v$. Jamieson [2007] 1 W.L.R. 2620.

${ }^{879}$ Moncrieff $v$. Jamieson [2007] 1 W.L.R. 2620, 2646.

${ }^{880} \mathrm{Na}$ temat wpływu rzymskich rozwiazań prawnych na szkockie służebności zob. W.M. Gordon, Servitutes. Scots Law and Roman Law, [w:] W.M. Gordon, Roman Law, Scots Law and Legal History. Selected Essays, Edinburgh 2007, s. 141-147. 
posiadał służebność wypasu zwierząt na czyimś pastwisku ${ }^{881}$. Choć Lord Rodger zwrócił uwagę na uciążliwość służebności zatrzymania pojazdu na czyimś gruncie, to jednak zauważył jednocześnie, iż wiele służebności do takich ograniczeń władania rzecza prowadziło $z$ samej swej istoty, np. servitus aquaehaustus czy servitus aquaeductus ${ }^{882}$. Podobne utrudnienia wynikały ze służebności dotyczacej prowadzenia kamieniołomu oraz zrzucania kamieni na sąsiedni grunt i pozostawania ich tam do czasu rozkruszenia. Przykład tej służebności znany jest dzięki przekazowi Neratiusa zachowanemu w pismach Ulpiana: „Eodem libro ait vicino, cuius lapidicinae fundo tuo immineant, posse te cedere ius ei esse terram rudus saxa iacere posita habere, et ut in tuum lapides provolvantur ibique positi habeantur indeque exportentur" 883 .

\subsection{Bezpośrednie wykorzystanie prawa rzymskiego w orzeczeniach pochodzących $z$ apelacji szkockiej}

Listę bezpośrednich powołań prawa rzymskiego i recepcji jego zasad przez Izbę Lordów otwiera sprawa z roku 1974 Barclay's Trustee v. IRC ${ }^{884}$. W roku 1962 zamieszkały w Szkocji James Barclay, powołujac się na postanowienia ustawy Married Women's Policies of Assurance (Scotland) Act 1880885, ustanowił na rzecz swoich dwóch synów oraz żony polisy ubezpieczeniowe, każdą wartości 15 tysięcy funtów. Pod koniec stycznia 1963 roku J. Barclay zmarł. Zgodnie z postanowieniami Finance Act $1894^{886}$, po śmierci mężczyzny naliczony został estate duty. Pojawiła się jednak w związku $z$ tym

${ }^{881}$ D. 8, 3, 6, 1 (Paulus libro 15 ad Plautium).

${ }^{882}$ Moncrieff $v$. Jamieson [2007] 1 W.L.R. 2620, 2647.

${ }^{883}$ D. 8, 3, 3, 2 (Ulpianus libro 17 ad edictum).

${ }^{884}$ Barclay's Trustee v. IRC [1975] 1 W.L.R. 106.

${ }^{885}$ Married Women's Policies of Assurance (Scotland) Act 1880 (43\& 44 Vict., c. 26).

${ }^{886}$ Finance Act 1894 (57 \& 58 Vict., c. 30). 
kontrowersja, jak ocenić $z$ perspektywy prawa podatkowego ustanowione na rzecz żony i synów polisy. Izba Lordów uznała, że J. Barclay zawarł polisy na rzecz członków swojej rodziny w celu zapewnienia im określonych korzyści majątkowych i nie moga być one traktowane jako pożytki uzyskane przez zmarłego, jak chciały tego organa podatkowe.

Na rozwiązania prawa rzymskiego powołał się Lord Kilbrandon ${ }^{887}$, który badając historyczne tło uregulowan zawartych w ustawie $z$ roku 1880, zacytował m.in. pracę J. Erskine'a, w której prawnik wskazał, iż „all deeds, whether granted by the wife to the husband or by him to the wife, importing a donation, are indeed valid; but may, both by the Roman law and ours, be revoked or voided by the donor, at any time of his or her life" 888 . Zasada, o której wspomniał w odniesieniu do prawa rzymskiego J. Erskine, nie jest jednak tak oczywista, jak mogłoby się wydawać. Teza osiemnastowiecznego autora nie jest poprawna. Co do zasady bowiem prawo rzymskie zakazywało darowizn między małżonkami. Od tej ogólnej reguły istniały jednak wyjątki - dozwolone były na przykład darowizny mortis causa ${ }^{889}$, czy z okazji pewnych wyjattkowych wydarzeń, jak urodziny, czy ubieganie się o wysokie funkcje publiczne ${ }^{890}$. Wynika $z$ tego zatem, iż w rzeczywistości teza postawiona przez J. Erskine'a na temat podobieństwa prawa rzymskiego i szkockiego w zakresie donatio inter virum et uxorem była nieścisła i oparta jedynie na wyjatkach od zasady. Powyższy kazus jest zatem interesującym przykładem recepcji błędnie interpretowanych regulacji prawa rzymskiego. Warto jeszcze dodać, że w powyższym kazusie dostrzec można wykorzystanie przez law lords argumentacji per analogiam, gdyż sprawa dotyczyła ustanowienia polisy ubezpie-

${ }^{887}$ Barclay's Trustee v. IRC [1975] 1 W.L.R. 106, 119.

${ }^{888}$ J. Erskine, An Institute..., 1, 6, 29.

${ }^{889}$ D. 24, 1, 9, 2 (Ulpianus libro 32 ad Sabinum); PS 2, 23, 6.

${ }^{890}$ D. 24, 1, 31, 8 (Pomponius libro 14 ad Sabinum); D. 24, 1, 40 (Ulpianus libro secundo responsorum); D. 24, 1, 42 (Gaius libro 11 ad edictum provinciale). 
czeniowej, zaś rzymskie odwołania odnosiły się do problemu darowizny między małżonkami.

Pośród orzeczeń Izby Lordów, w których uzasadnienie oparte zostało bezpośrednio na rzymskiej tradycji prawnej, na szczególna uwagę zasługują orzeczenia lordów prawa wydane w roku $1976 \mathrm{w}$ sprawie Wills'Trustees $v$. Cairngorm Canoeing and Sailing School Ltd. ${ }^{891}$ Sprawa ta stanowi prawdopodobnie najcenniejszy przykład powołania się przez sędziów Izby Lordów na prawo rzymskie w analizowanym w niniejszej pracy okresie. Strony spierały się na temat statusu prawnego odcinka rzeki Spey w północnej Szkocji. Powodem był właściciel nieruchomości znajdujących się na dwóch przeciwległych brzegach rzeki. Pozwanym była zaś szkoła kajakarstwa i żeglarstwa. Instruktorzy szkoły często pływali po rzece Spey na odcinku, który zdaniem strony powodowej miał status rzeki prywatnej, wykorzystywanej jednocześnie jako prywatne łowisko łososi.

$\mathrm{Na}$ rozwiązania prawa rzymskiego powołali się niemal wszyscy sędziowie orzekający w przedmiotowej sprawie. Jako pierwszy uczynił to Lord Wilberforce, który zwrócił uwagę na fakt, iż bardzo podobny stan faktyczny był już przedmiotem analizy lordów w roku 1782 w sprawie Grant $v$. Duke of Gordon ${ }^{892}$, która także dotyczyła rzeki Spey.

W pierwszej części swego orzeczenia sędzia skupił się na problematyce autorytetu rzymskich rozwiązań prawnych dotyczacych ocenianej przez niego sprawy. Stwierdził między innymi, iż powszechnie uważa się, że prawo szkockie bardzo wiele zawdzięcza prawu rzymskiemu, m.in. w zakresie regulacji dotyczacych prawa morskiego, portów i nabrzė̇y ${ }^{893}$, czy wreszcie prawa rzecznego. Następnie wskazał, że problema-

${ }^{891}$ Wills' Trustees v. Cairngorm Canoeing and Sailing School Ltd 1976 S.C. (H.L.) 30.

${ }^{892}$ Grant v. Duke of Gordon (1782) 2 Pat. App. 582 (H.L.).

${ }^{893}$ Izba Lordów także wypowiadała się w tym zakresie. Prawa właściciela gruntu do brzegu morskiego były przedmiotem wyrokowania Izby Lordów w końcu XVIII w. w sprawie Smart v. Magistrates of Dundee (1797) 8 Bro. 119; 3 Eng. Rep. 481. 
tyka statusu prawnego rzek umieszczona została w księdze 43, tytule 12 Digestów justyniańskich, zaś autorem większości zamieszczonych tam fragmentów jest Ulpian. Na podkreślenie zasługuje przekonanie lorda prawa o wpływie rzymskich rozwiązań prawnych na rozwój prawa szkockiego. Ciekawy wydaje się być również pogląd prawnika dotyczący przyczyn akceptacji wskazanych przez niego fragmentów Digestów przez kolejne pokolenia prawników i wtłoczenia ich w ramy ius gentium, które lord prawa utożsamia $z$ prawem międzynarodowym. Lord Wilberforce stwierdził, że $z$ jednej strony wynika to $z$ ogólnego prestiżu i autorytetu, jakim cieszyły się Digesta, $z$ drugiej zaś $z$ przejrzystego połączenia norm prawnych $z$ prawami natury i doświadczeniem życiowym.

Po tych uwagach sędzia przedstawił obszernie rzymskie zasady dotyczące prawa rzecznego. Wskazał, iż zdaniem rzymskich jurystów rzeka odróżniana była od zwykłych strumieni bądź ze względu na swój rozmiar, bądź ze względu na powszechne mniemanie okolicznych mieszkańców ${ }^{894}$. Rzymianie dokonali podziału rzek na publiczne i prywatne ${ }^{895}$, jak również zakazali praktyk utrudniających żeglowanie po nich $^{896}$. Na koniec tej części swych rozważań sędzia przywołał jeszcze dwie inne zasady, które zawarte zostały w Digestach. Zgodnie $z$ nimi kanał stanowiący część rzeki publicznej należy do ogółu ${ }^{897}$, zaś pod pojęciem navigium, oprócz statków, Rzymianie rozumieli także tratwy ${ }^{898}$. Wszystkie powyższe reguły $^{899}$ - jak zaznaczył lord prawa - znane były w XVIII w. szkockim instytucjonalistom. Sędzia omawiając powyższe rozstrzygnięcia, nie wskazał ich konkretnego pochodzenia,

${ }^{894}$ D. 43, 12, 1, 1 (Ulpianus libro 68 ad edictum).

${ }^{895}$ D. 43, 12, 1, 3 (Ulpianus libro 68 ad edictum).

${ }^{896}$ D. 43, 12, 1, 12 (Ulpianus libro 68 ad edictum).

${ }^{897}$ D. 43, 12, 1, 8 (Ulpianus libro 68 ad edictum).

${ }^{898}$ D. 43, 12, 1, 14 (Ulpianus libro 68 ad edictum).

${ }^{899} \mathrm{Na}$ temat definicji prawnej rzeki i jej rodzajów w prawie rzymskim zob. ostatnio R. Kamińska, Ochrona dróg i rzek publicznych $w$ prawie rzymskim $w$ okresie republiki i pryncypatu, Warszawa 2010, s. 42-54. 
lecz tylko ogólnie określił, że zaczerpnięte zostały z prawa rzymskiego ${ }^{900}$.

W dalszej części swego orzeczenia sędzia podją temat szkockich regulacji rzecznych, z których - jak wskazał - najstarsze odnaleźć można już w pochodzącym z XI w. zbiorze Books of Feus, w którym wskazano, iż rzeczy publiczne, w tym rzeki, należały do kategorii inter regalia bądz in patrimonio principis. Zdaniem lorda prawa oczywiste jest, że podział ten skonstruowany został za rzymskim przykładem, nie wykluczył jednak także istnienia innych jego korzeni. Niezależnie od pochodzenia wskazanej kategoryzacji, przyjęta została ona przez późniejszych prawników szkockich, w tym przez Lorda Stair ${ }^{901}$ oraz J. Erskine'a ${ }^{902}$.

Powyższe rozważania pozwoliły sędziemu odnieść się przychylnie do rozstrzygnięcia Izby Lordów $\mathrm{z}$ roku $1782 \mathrm{w}$ powoływanej uprzednio sprawie Grant $v$. Duke of Gordon. Lordowie orzekli bowiem, iż rzeka, stanowiąc res publica, powinna być udostępniona wszystkim do swobodnego korzystania. Lord prawa zauważył wszakże, iż w jego przekonaniu użycie terminu „żeglować” ograniczało zastosowanie przyjętych w XVIII w. rozwiązań. Uznał on, że stosowniejsze byłoby używanie terminu „możliwość korzystania z rzeki”, który by wskazywał także na inne formy jej wykorzystania. Swoja opinię sędzia poparł jeszcze jednym odwołaniem do prawa rzymskiego: „Ait praetor: 'iterque navigii deterius fiat'. Hoc pro navigatione positum est: immo navigium solemus dicere etiam ipsam navem, iter ergo navigio potest et sic accipi 'iter navi deterius fiat'. $\mathrm{Na}$ vigii appellatione etiam rates continentur, quia plerumque et

${ }^{900}$ Lord Wilberforce zacytował wprawdzie trzykrotnie wyjatki $z$ omawianego tytułu Digestów (D. 43, 12, 1, 1 „existimatione circum scolentium"; D. $43,12,1,12$ „ea interdictema tantum flumina publica pertinet, quae sunt navigabilia”; D. 43, 12, 1, 14 „Navigii appellatione etiam rates continentur, quia plerum-que et ratium usus necessarius est"), jednak $\mathrm{w}$ żadnym $z$ tych przypadków nie oznaczył źródła, $z$ którego zaczerpnął swoją wiedzę. Ponadto angielski sędzia modyfikował treść cytowanych passusów.

${ }^{901}$ Lord Stair, Institutions..., 2, 1, 5.

902 J. Erskine, An Institute..., 2, 6, 17. 
ratum usus necessarius est. Si pedestre iter impediatur, non ideo minus iter navigio deterius fit'903.

W zacytowanym passusie pretor wskazał, że czasownika navigo używać można było nie tylko w odniesieniu do statków, lecz także w odniesieniu do tratw, do których Lord Wilberforce zaliczył tym samym kajaki. O słuszności swojej opinii lord starał się przekonać także przez odwołanie do podobnych wyroków wydanych w sprawach kanadyjskich (rozpatrywanych przez Tajna Radę) ${ }^{904}$ oraz w nowojorskim sądzie stanowym ${ }^{905}$, a także odwołując się do regulacji zawartych w kodeksach cywilnych Dolnej Kanady ${ }^{906}$ oraz Francji ${ }^{907}$.

Interesujące, ze względu na powołanie rzymskich źródeł, rozważania przedstawił w swym orzeczeniu kolejny angielski sędzia Lord Hailsham of St. Marylebone ${ }^{908}$. Na wstępie wskazał on, że podstawowym podziałem wód na gruncie prawa rzymskiego był podział na rivi oraz flumina (strumienie i rzeki) ${ }^{909}$. Następnie sędzia stwierdził, iż kwestią rodzącą najwięcej trudności było jednak rozróżnienie rzek na publiczne i prywatne ${ }^{910}$. W starożytnym Rzymie podział ten możliwy był na podstawie obserwacji zmian poziomu rzek, co w skrajnych przypadkach oznaczało badanie faktu wysychania rzeki w okresie letnim ${ }^{911}$. Angielski prawnik zauważył jednak, że dla Brytyjczyków mieszkających w wilgotnym klimacie rzymska przesłanka klasyfikacji rzek nie znajduje praktycznego zastosowania. Na potwierdzenie swej tezy lord prawa zacytował fragment pochodzacy ze szkockiego podręcznika prawa

${ }_{903}$ D. 43, 12, 1, 14 (Ulpianus libro 68 ad edictum).

${ }^{904}$ Bell v. The Corporation of Quebec (1879) 5 App. Cas. 84; MacLaren v. Attorney General for the Province of Quebec [1914] A.C. 258.

${ }_{905}$ Morgan v. King 35 N.Y. 454 (1866).

${ }^{906}$ Sek. 400 k.c. Dolnej Kanady.

907 Art. 538 Code civil.

${ }^{908} \mathrm{Na}$ temat działalności sądowniczej Lorda Hailshama zob. G. Lewis, Lord Hailsham. A Life, London 1998, s. 254-281, 303-317.

${ }_{909}$ D. 43, 12, 1, 1 (Ulpianus libro 68 ad edictum).

${ }^{910} \mathrm{~W}$ tym miejscu prawnik odwołał się ogólnie do tytułów od 12 do 14 księgi 43 Digestów justyniańskich.

${ }^{911}$ Por. np. D. 43, 12, 1, 3 (Ulpianus libro 68 ad edictum). 
własności autorstwa Johna Rankine’a, w którym zwrócono uwagę na fakt, że podążając za rzymska przesłanka podziału rzek na prywatne i publiczne, należałoby uznać, iż niemal wszystkie szkockie rzeki maja status publicznych ${ }^{912}$. Pomijając jednak te watpliwości, Lord Hailsham stwierdził, że za przykładem prawa rzymskiego w ramach kategorii rzek publicznych wyróżnić można tzw. rzeki żeglowne, które stanowia species w stosunku do rzek publicznych będących genus.

Nawiązując do swojej wcześniejszej wypowiedzi, lord prawa wskazał także, iż współcześnie szkockie prawo rzeczne różni się od swojego rzymskiego pierwowzoru. Po pierwsze, prawo rzymskie nie znało problemu pływów morskich oddziałujacych na poziom rzek. Po drugie, uznawało ono koryto rzeki za rzecz publiczna, podczas gdy prawo szkockie uznawało je za należące do Korony. Ponadto, zdaniem sędziego, czym innym jest własność koryta rzeki, a czym innym uprawnienie do korzystania $z$ samej rzeki. Potwierdzenia swej opinii angielski prawnik poszukiwał w Instytucjach Justyniana ${ }^{913}$, podręczniku W.W. Bucklanda ${ }^{914}$ oraz we francuskim podręczniku prawa rzymskiego P.F. Girarda ${ }^{915}$. Trzecim szkockim odstępstwem od zasad prawa rzymskiego jest $z$ kolei, zdaniem sędziego, odrzucenie zasady wyrażonej w Instytucjach Justyniana, zgodnie $z$ która wszystkie rzeki (flumina) sa publiczne, przez co każdy ma prawo łowić w nich ryby ${ }^{916}$. W roku 1894 w sprawie Grant $v$. Henry zadecydowano bowiem o ograniczeniu tego prawa jedynie do tych obszarów rzek, na których występuja pływy morskie ${ }^{917}$. Podsumowujac swoje rozważania

912 J. Rankine, Law of Landownership in Scotland, ed. 4, Edinburgh 1909, s. 533.

${ }_{913}$ I. 2, 1, 23-24.

914 W.W. Buckland, A Text-book..., s. 185.

${ }_{915}$ P.F. Girard, Manuel élémentaire de droit romain, Paris 1898, s. 233.

${ }^{916}$ I. 2, 1, 2.

917 Grant v. Henry (1894) 21 R. 358. Zmiany w prawie szkockim w tym zakresie zwiazane były $z$ wpływami prawa angielskiego na prawo szkockie. Niall Whitty mówi wręcz o zanglicyzowanej rewolucji pływów morskich, zob. N. Whitty, Water Law Regimes, [w:] HPLS, vol. 1, s. 448-449. 
lord prawa nie zawahał się stwierdzić, iż mimo wyraźnych odstępstw od prawa rzymskiego we współczesnym prawie szkockim, idea przewodnia nadal pozostaje romanistyczna w swej zasadniczej treści.

Apelacja została ostatecznie odrzucona większościa czterech głosów do jednego. Lordowie uznali, że możliwość korzystania $z$ rzeki jest uprawnieniem powszechnym, dostępnym wszystkim i nie może być w żaden sposób ograniczana ${ }^{918}$.

Nietypowe powołanie rzymskich rozwiazań prawnych odnaleźć można z kolei w orzeczeniu Lorda Rodgera of Earlsferry we wspomnianej już sprawie Burnett's Trustee $v$. Grainger. W sprawie tej do rzymskiej tradycji prawnej odniosło się dwóch sędziów. Jak to już wcześniej wskazano, Lord Hope powołał rzymska paremię traditionibus non nudis pactis transferuntur rerum dominium. Drugi ze szkockich sędziów odniósł się zaś do wywodzącego się $z$ prawa rzymskiego i znanego również prawu szkockiemu - podziału uprawnień na rzeczowe (in rem) oraz osobowe (in personam). Lord Rodger zauważył: „drawing on Roman law, Scots law distinguishes between real rights, rights in rem, and personal rights, rights in personam"919. Sędzia wyraził jednocześnie przekonanie, że podział ten najlepiej w nowoczesnej literaturze romanistycznej wyjaśnił w swoim podręczniku prawa rzymskiego oksfordczyk Barry Nicholas. Lord Rodger przywołał obszerny fragment wspomnianego opracowania: „Any claim is either in rem or in personam, and there is an unbridgeable division between them. An action in rem asserts a relationship between a person and a thing, an action in personam a relationship between persons [...]. The Romans think in terms of actions not of rights, but in substance one action asserts a right over a thing, the other a right against a person, and hence comes the modern dichotomy between rights in rem and rights in

${ }^{918}$ Do reguł prawa rzymskiego odniósł się także pobieżnie Lord Fraser of Tullybelton, który jednak w znacznej części swojego orzeczenia powtórzył wcześniejsze ustalenia poczynione przez Lordów Wilberforce'a oraz Hailshama.

${ }^{919}$ Burnett's Trustee v. Grainger 2004 S.C. (H.L.) 19, 46. 
personam. Obviously there cannot be a dispute between a person and a thing, and therefore even in an action in rem there must be a defendant, but he is there not because he is alleged to be under any duty to the plaintiff but because by some act he is denying the alleged right of the plaintiff. In a rei vindicatio he is denying the plaintiff's ownership by being in possession of the thing claimed"920.

Powołanie przez Lorda Rodgera fragmentu pochodzacego $z$ opracowania B. Nicholasa jest szczególnym rodzajem odniesienia się do prawa rzymskiego. Sędzia skorzystał z klasycznego podręcznika stosowanego w kręgu angielskojęzycznych romanistów. Poniechał zaś powołania się na oryginalne źródła, co w przypadku pracy naukowej mogłoby być uznane za błąd warsztatowy. W przypadku orzeczenia natomiast dostrzec można w takim zabiegu próbę odsunięcia niebezpieczeństwa zarzutu powoływania się na źródła obce brytyjskiej kulturze prawnej. Należy także zauważyć, iż cytat z pracy B. Nicholasa posłużył sędziemu do doprecyzowania terminów używanych przez niego w dalszej części orzeczenia zarówno w odniesieniu do analizy recepcji prawa rzymskiego w Szkocji, jak i w przedmiotowej sprawie. Przyjać zatem można, iż poczyniony przez Lorda Rodgera wybieg ostatecznie wpłyną pośrednio na końcowe negatywne rozstrzygnięcie w przedmiotowej sprawie.

Podobne marginalne powołanie prawa rzymskiego odnaleźć można także w innym orzeczeniu Lorda Rodgera wydanym w tym samym czasie. Sprawa Davidson $v$. Scottish Ministers $^{921}$ była przedmiotem zainteresowania Komitetu Apelacyjnego w listopadzie i grudniu 2005 roku. Jej przedmiotem była skarga więźnia przebywającego w Barlinnie Prison w Glasgow. Podnosił on, że warunki tam panujące (w tym przepełnienie zakładu karnego oraz złe warunki sanitarne) stanowiły naruszenie art. 3 EKPC dotyczącego nieludzkiego traktowania i zażądał przeniesienia go do innego więzienia. Skarga została skierowana przeciwko Scottish Ministers - lo-

${ }^{920}$ B. Nicholas, Introduction to Roman Law, Oxford 1962, s. 100.

${ }^{921}$ Davidson v. Scottish Ministers 2006 S.C. (H.L.) 41. 
kalnemu rzadowi. Orzekajacy w Court of Session Lord Johnston odrzucił skargę Scotta Davidsona podnosząc, iż zgodnie $z$ dotychczasowym orzecznictwem sąd nie może nakazać organowi rządowemu wydania określonej decyzji administracyjnej ${ }^{222}$. Decyzja ta została podtrzymana także przez Extra Division Court of Session ${ }^{923}$.

Rzymskie odwołanie odnaleźć można jedynie we wspomnianym uprzednio wystapieniu Lorda Rodgera of Earlsferry. Chociaż sprawa dotyczyła problematyki publicznoprawnej, sędzia przywołał kilkakrotnie termin „prawo prywatne”. W związku $z$ tym uznał on za stosowne wyjaśnienie sposobu, w jaki jego zdaniem należy rozumieć to pojęcie. Powołując się na wcześniejsza wypowiedź Lorda Hope’a, sędzia zauważył, iż do niedawna tak szkoccy, jak i angielscy praktycy prawa jedynie incydentalnie posługiwali się terminami „prawo publiczne” i „prawo prywatne” ${ }^{24}$. Kategorie te znane były natomiast autorom rozpraw naukowych. Geneza wspomnianego podziału sięga zaś - jak wskazał Lord Rodger - czasów rzymskich, gdy w swym podręczniku prawa Ulpian przedstawił dychotomiczny podział na ius publicum i ius privatum ${ }^{925}$. Ten sam podział został następnie zaadaptowany przez Justyniana na potrzeby jego podręcznika ${ }^{926}$. Wprawdzie zakresy obu pojęć sa trudne do jednoznacznego określenia ${ }^{927}$, to jednak zyskały one duże znaczenie i przez wieki były wykorzystywane przez autorów wielu traktatów prawniczych $^{928}$.

\footnotetext{
922 Davidson v. Scottish Ministers 2002 S.C.L.R. 166.

${ }^{923}$ Davidson v. Scottish Ministers 2002 S.C. 205.

${ }_{924}$ Davidson v. Scottish Ministers 2006 S.C. (H.L.) 41, 51-52.

${ }_{925}$ D. 1, 1, 1, 2 (Ulpianus libro primo institutionum).

${ }^{926}$ I. $1,1,4$.
}

${ }^{927} \mathrm{Na}$ dowód swojego twierdzenia Lord Rodger przywołał passus ze wstępu do English Private Law - kompendium wiedzy przygotowanego w roku 2000 pod redakcja oksfordzkiego romanisty P. Birksa, zob. P.H. Birks (ed.), English Private Law, vol. 1, Oxford 2000, s. xxxvi.

${ }^{928}$ Jako wyjątek Lord Rodger podaje Komentarze Blackstone'a, w których nie został wykorzystany podział na prawo publiczne i prywatne. Niemniej sam W. Blackstone znał oba terminy, a nawet wspomniał o ich 


\subsection{Recepcja rzymskich rozwiązań dotyczących odpowiedzialności deliktowej}

Powołane dotychczas przykłady wykorzystania prawa rzymskiego $\mathrm{w}$ orzeczeniach wydawanych $\mathrm{z}$ apelacji szkockiej miały charakter jednostkowy. Analizując jednak historię rzymskich odwołan dokonywanych przez sędziów Izby Lordów można zauważyć, że w odniesieniu do niektórych zagadnień cywilistyczne wpływy i powołania miały charakter trwały. Trudno w takiej sytuacji uznać je za przypadkowa inspirację, konieczne jest mówienie wówczas o prawdziwej recepcji rzymskich rozwiazań prawnych.

Taka ciagłość myśli orzeczniczej dostrzec można badając wyroki lordów pod katem wykorzystania w nich cywilistycznych rozważań dotyczących deliktów iniuria oraz damnum iniuria datum.

Pierwsze poważne zastosowanie rzymskich rozwiązań prawnych dotyczących deliktu zniewagi dostrzec można w wyroku Izby Lordów z roku $1943 \mathrm{w}$ sprawie Stewart $v$. London, Midland and Scottish Railway Co. ${ }^{929}$ Sprawa wszczęta została z powództwa Margaret Elizabeth Stewart, będącej następca prawnym swojej zmarłej siostry Mary Hellen Stewart. Obie siostry w dniu 20 września 1940 roku podróżowały pociagiem należacym do London, Midland and Scottish Railway Co. Na skutek błędu pracownika spółki doszło do wypadku, w którym powódka została ranna, zaś jej siostra odniosła na tyle poważne ranny, iż jeszcze tego samego dnia zmarła w szpitalu nie odzyskując przytomności. W marcu 1941 roku Margaret Elizabeth Stewart wniosła do sądu powództwo, w którym domagała się wypłacenia przez spółkę kolejową odszkodowania za poniesiony przez siebie uszczerbek na zdrowiu oraz, działając jako następca prawny swej zmarłej siostry, odszkodowa-

dychotomii we wstępie do swojego życiowego dzieła, zob. W. Blackstone, Commentaries on the Laws of England, vol. 1, Oxford 1765, s. 13.

${ }^{929}$ Stewart v. London, Midland and Scottish Railway Co. 1943 S.C. (H.L.) 19. 
nia za krzywdy jej wyrządzone. Spółka przyznała się do błędu popełnionego przez jej pracownika i uznała żądania powódki odnoszace się do niej samej. Prawnicy spółki konsekwentnie jednak odmawiali możliwości wypłacenia pozostałej przy życiu siostrze odszkodowania za uszczerbek na zdrowiu poniesiony przez zmarła. Ostatecznie sprawa, w drodze apelacji złożonej od wyroku Court of Session, trafiła do Izby Lordów. Odniesienia do prawa rzymskiego znalazły się w orzeczeniach czterech law lords ${ }^{930}$.

Jako pierwszy decyzję ogłosił Viscount Simonds, pełniący wówczas funkcję Lorda Kanclerza. Sędzia rozpoczął od stwierdzenia, iż zasadą obowiązująca, tak w prawie szkockim jak i rzymskim, jest niewygasanie roszczenia wraz ze śmiercią którejś ze stron toczących spór. Następcy prawni stron moga wystąpić w miejsce zmarłych w celu wniesienia powództwa, jego kontynuacji, jak również w celu podjęcia obrony. Od tej ogólnej zasady istnieja jednak wyjątki. Na przykład w sytuacji, gdy ktoś poniósł szkodę na osobie, istnieje możliwość kontynuowania obrony przez następców prawnych sprawcy, lecz następcy prawni pokrzywdzonego nie maja już prawa wytoczenia czy też kontynuowania postępowania. Viscount Simonds wskazał, że ten sposób postępowania jest bezpośrednio związany ze ściśle osobistym charakterem actio iniuriarum. Personalność skargi $z$ tyłu zniewagi mogła być jednak przełamana wówczas, gdy postępowanie zostało wszczęte za życia powoda, a jego śmierć nastąpiła później ${ }^{931}$. Jak zauważył Lord Kanclerz, w tym zakresie prawa rzymskie i szkockie jedynie nieznacznie różniły się od siebie. Prawo rzymskie uznawało bowiem za kluczowy dla utrzymania wniesionego powództwa moment litis contestatio, który z kolei nieznany jest prawu szkockiemu. Na poparcie swych tez odnoszących się do konsumpcji procesowej

930 Lord Clauson ograniczył się jedynie do poparcia argumentacji przedstawionej przez Lorda Kanclerza, sam jednak nie sporządził orzeczenia.

931 Stewart $v$. London, Midland and Scottish Railway Co. 1943 S.C. (H.L.) 19, 25. 
Viscount Simonds zacytował passus pochodzacych $z$ dzieła Paulusa: "litis contestatione et poenales actiones transmittuntur ab utraque parte, et temporales perpetuantur" ${ }^{332}$, jak również wskazał dla porównania fragment podobnej treści zamieszczony w Instytucjach Justyniana ${ }^{933}$. Następnie sędzia zauważył, iż co do zasady stwierdzenie litis contestatio powodowało wygaśnięcie zobowiązania i jego ponowne zawiązanie już między powodem i pozwanym (specyficzny przykład nowacji). Tym razem Lord Kanclerz odwołał się do autorytetu Gaiusa ${ }^{934}$. Niemniej prawnik zaznaczył, iż w prawie rzymskim, na różnych etapach jego rozwoju, litis contestatio następowała $\mathrm{w}$ innych momentach toczacego się postępowania ${ }^{935}$. Prawo szkockie nie znało wprawdzie pojęcia litis contestatio, ale według sędziego kontynuowanie powództwa możliwe było wówczas, gdy postępowanie zostało faktycznie wszczęte (actually raised) ${ }^{936}$. Należy przyznać, że powyżej przedstawione rozważania lorda prawa wydaja się być rudymentarne, choć trudno odmówić im rzetelności oraz przydatności dla dalej podejmowanych zagadnień.

W kolejnych punktach swojego orzeczenia Lord Kanclerz odniósł się do stosowania w prawie szkockim i angielskim maksymy actio personalis moritur cum persona. Sędzia zauważył, iż w przeciwieństwie do tego, jak się zwykło uważać, zasada ta nie pochodzi ani $z$ prawa rzymskiego, ani $z$ prawa kanonicznego ${ }^{937}$. Udowodnione zostało to, w jego przekonaniu, w dwóch pracach naukowych. Sędzia przywołał artykuł autorstwa Henry'ego Goudy'ego pochodzacy ze zbioru wyda-

${ }_{932}$ D. 27, 7, 8, 1 (Paulus libro nono responsorum).

${ }_{933}^{93}$ I. $4,12,1$.

934 G. 3, 180.

${ }^{935} \mathrm{Na}$ temat litis contestation w prawie rzymskim zob. H. Kupiszewski, Litis contestatio, Czasopismo Prawno-Historyczne 15/1 (1963), s. 243-265.

${ }_{936}$ Stewart $v$. London, Midland and Scottish Railway Co. 1943 S.C. (H.L.) 19, 25.

${ }^{937}$ Stewart v. London, Midland and Scottish Railway Co. 1943 S.C. (H.L.) 19, 26. 
nego w roku 1913 pod redakcją P. Vinogradoffa ${ }^{938}$ oraz podręcznik prawa deliktowego autorstwa znanego angielskiego prawnika i historyka prawa P.H. Winfielda ${ }^{939}$. W swym podręczniku Winfield wskazał, że najwcześniejsze użycie powyższej zasady prawa datowane może być dopiero na rok $1479^{940}$.

Drugim $z$ lordów, który wydał orzeczenie w przedmiotowej sprawie, był Lord Thankerton. Przedstawiajac argumenty utwierdzające go w przekonaniu o konieczności odrzucenia apelacji panny Stewart, szkocki lord wykorzystał przede wszystkim przykład wcześniejszych orzeczeń, które posłużyły ustaleniu linii orzeczniczej, niekorzystnej dla apelującej kobiety. Odwołania do prawa rzymskiego w orzeczeniu szkockiego lorda stanowiły jedynie zapożyczenia $z$ cytowanych przez niego precedensów ${ }^{941}$.

Trzecie orzeczenie w sprawie wydał Lord Macmillan. Na początek lord prawa zdecydował się przedstawić w zarysie dzieje odpowiedzialności odszkodowawczej z tytułu deliktów w prawie szkockim. Wskazał, iż przybrała ona ostateczny kształt nie wcześniej niż w roku 1795. To właśnie w XVIII w., zdaniem Lorda Macmillana, doszło w prawie szkockim do ostatecznego rozdzielania odpowiedzialności $z$ tytułu przestępstw karnych i deliktów. Ponadto sędzia zauważył, iż w tym okresie prawo szkockie nadal podlegało rozwojowi i podatne było na wpływy rzymskiej tradycji prawnej ${ }^{942}$. Ich przyczynę szkocki prawnik dostrzega w konieczności odbywania przez studentów prawa w XVII i XVIII w. podróży naukowych na uniwersytety kontynentalne, szczególnie do Holandii, gdzie nauka prawa rzymskiego święciła wówczas tryumfy. Lord Macmillan wymienił nazwiska kilku znanych prawników szkockich, którzy odbyli

${ }^{938}$ H. Goudy, Two Ancient Brocards, [w:] P. Vinogradoff (ed.), Essays in Legal History, Oxford 1913, s. 215-232.

939 P.H. Winfield, A Textbook of the Law of Tort, ed. 2, London 1943.

940 Ibidem, s. 201.

${ }^{941}$ Stewart $v$. London, Midland and Scottish Railway Co. 1943 S.C. (H.L.) 19, 32.

942 Stewart $v$. London, Midland and Scottish Railway Co. 1943 S.C. (H.L.) 19, 38. 
tego rodzaju peregrynacje naukowe. Wskazał: Lorda Stair, który przebywał w Leyden w latach 1682-1688, w tym samym mieście studia odbywał także Lord President Forbes, zaś Lord President Dundas studiował w Utrechcie ${ }^{943}$. Lord Macmillan zauważył wreszcie, iż żadna szanująca się biblioteka prawnicza w Szkocji nie była w tym okresie kompletna, jeśli nie zawierała prac Grotiusa, Vinniusa, prawników z rodziny Voetów, Heinecciusa, czy innych znanych cywilistów ${ }^{944}$.

$\mathrm{Z}$ tych względów szkocki sędzia uznał, że nie powinno być zaskakujące przejęcie rozwiązań dotyczacych stosowania rzymskiej actio iniuriarum przez prawo szkockie. Analizujac pierwotne przeznaczenie rzymskiej skargi, Lord Macmillan wskazał za Vinniusem (,in ea non principaliter de damno sarciendo sed de contumelia vindicanda agitur"945), iż miała ona służyć naprawieniu szkody na rzecz osoby, która sama tę szkodę poniosła ${ }^{946}$. Law lord zauważył, że być może lepsze byłoby przeprowadzenie analogii szkockich rozwiązan do rzymskiej utilis actio legis Aquiliae, lecz to właśnie na actio iniuriarum powoływali się wielcy prawnicy szkoccy. Na koniec wreszcie lord stwierdził, iż dzięki przejęciu tych rozwiązań prawnych przez jurysprudencje szkocka do jej rodzimego systemu prawnego, pojęcie iniuria zdaje się mieć szersze zastosowanie aniżeli to samo pojęcie stosowane w prawie angielskim, a przeszczepione do niego przez H. Bractona ${ }^{947}$.

Po tych rozważaniach Lord Macmillan odniósł się do meritum sprawy. Wskazał, podobnie jak uczynił to wcześniej Lord

${ }^{943}$ Więcej na temat Szkotów studiujących prawo w Holandii w XVII i XVIII w. zob. R. Feenstra, Scottish-Dutch Legal Relations in the Seventeenth and Eighteenth Centuries, [w:] T.C. Smout (ed.), Scotland and Europe 1200-1850, Edinburgh 1986, s. 128-142.

${ }^{944}$ Stewart v. London, Midland and Scottish Railway Co. 1943 S.C. (H.L.) 19, 39.

${ }_{945}$ A. Vinnius, Institutionum Imperialium Commentarius 4, 12.

${ }^{946}$ Stewart v. London, Midland and Scottish Railway Co. 1943 S.C. (H.L.) 19, 39.

${ }^{947}$ Lord Macmillan powołał się w tym miejscu na komentarz autorstwa F.W. Maitlanda do dzieła Bractona, zob. F.W. Maitland, Select Passages..., s. 218. 
Kanclerz, iż w prawie rzymskim obowiązywała powszechnie zasada, zgodnie $z$ która następcy prawni mogli wytaczać powództwa „w imieniu” swoich zmarłych, których w ten sposób zastępowali. Od tej zasady jednak obowiazywał wyjątek w postaci skargi z tytułu zniewagi. Szkocki prawnik wskazał, że powodem tego wyłączenia był cel, dla którego występowano $z$ actio iniuriarum; zdaniem Vinniusa było to contumeliam vindicare, zaś zdaniem Heinecciusa quia ad vindictam tendit. Rzymska myśl prawnicza $\mathrm{w}$ tym względzie została przejęta do prawa szkockiego ${ }^{948}$. W dalszej części swego orzeczenia Lord Macmillan odniósł się także do wyjątku, zgodnie z którym skarga z tytułu zniewagi mogła być „dziedziczona”, o ile postępowanie już zostało wszczęte. Tym razem szkocki law lord odniósł się do autorytetu Heinecciusa (,una est exceptio si lis ante mortem contestata sit. Per litis contestationem enim fit novatio et quod antea ex delicto debebatur jam debetur ex quasi contractu" ${ }^{49}$ ) oraz uzupełnił jego pogląd o krótkie odwołanie do komentarza Vinniusa („quia judicio accipiendo nova contrahitur obligatio judicati”950). Odmiennie jednak, aniżeli Lord Kanclerz, Lord Macmillan przede wszystkim zwrócił uwagę na nowacyjny charakter litis contestatio ${ }^{951}$. Zacytował $\mathrm{m}$.in. fragment dzieła J. Erskine'a, w którym osiemnastowieczny prawnik stwierdził, iż w trakcie postępowania dochodzi do zawarcia pewnego rodzaju umowy sądowej. Postępowanie sądowe stanowi zatem, używając słów J. Erskine’a, nova causa obligationis ${ }^{952}$.

Ze względu na fakt, iż strony podnosiły także możliwość zastosowania $\mathrm{w}$ przedmiotowej sprawie skargi $z$ tytułu solatium, szkockiego odpowiednika zadośćuczynienia, Lord Macmillan wskazał, że skarga taka nie istniała w prawie rzym-

${ }^{948}$ Stewart v. London, Midland and Scottish Railway Co. 1943 S.C. (H.L.) 19, 39.

949 J.H. Heineccius, Recitationes in Elementa Iuris Civilis Secundum Ordinem Institutionum, 4, 4, 1111.

950 A. Vinnius, Institutionum..., 4, 12.

${ }^{951}$ Stewart v. London, Midland and Scottish Railway Co. 1943 S.C. (H.L.) 19, 40.

952 J. Erskine, An Institute..., 4, 1, 69. 
skim $^{953}$. Zauważył ponadto, iż prawo rzymskie nie dopuszczało możliwości wytoczenia skargi w związku ze śmiercią wolnego człowieka quia liberum corpus nullam recipit aestimationem ${ }^{954}$, podobnie zreszta jak prawo angielskie ${ }^{955}$.

Jako ostatni orzeczenie w sprawie Stewart v. London, Midland and Scottish Railway Co. wydał Lord Wright. Jego orzeczenie stanowi w zasadzie uzupełnienie pewnych kwestii, które jego zdaniem nie zostały w wystarczający sposób wyjaśnione przez pozostałych sędziów. Pośród nich znalazło się również zagadnienie skutków litis contestatio w przypadku skargi $z$ tytułu zniewagi. Lord prawa $z$ niespotykaną wręcz szczerościa przyznał, że trudno mu zrozumieć, na czym polegała konsumpcja procesowa w prawie rzymskim ${ }^{956}$.

$Z$ pewnym zaskoczeniem przyjąć należy także dalsze rozważania lorda prawa dotyczące obowiązywania maksymy actio personalis moritur cum persona na płaszczyźnie prawa szkockiego. Sędzia uznał, iż zasada ta nigdy w Szkocji nie była stosowana. Ponadto, w przekonaniu Lorda Wright, na gruncie prawa angielskiego stosowanie zasady możliwe jest do wyśledzenia najwcześniej od czasów Lorda E. Coke’a. Przekonanie sędziego trudno uzasadnić przy pomocy jakichkolwiek argumentów, biorąc pod uwage fakt, iż od dawna historycy prawa angielskiego wykazywali dużo wcześniejsze pojawienie się powyższej reguły w common law ${ }^{957}$. Trudno także podażać za dalszymi rozważaniami Lorda Wright, który odmówił rzymskiego pochodzenia maksymie actio personalis moritur cum persona. Sędzia stwierdził, iż prawo rzymskie nie wykorzystałoby [terminu] personalis na określenie skargi $z$ tytułu deliktu. Zauważył, że określenie poenalis byłoby właściwsze, zaś

${ }_{953}^{95}$ Stewart $v$. London, Midland and Scottish Railway Co. 1943 S.C. (H.L.) 19, 41.

${ }^{954}$ D. 9, 3, 7 (Gaius libro sexto ad edictum provinciale).

${ }^{955}$ Lord Macmillan odwołał się do wypowiedzi Lorda Ellenborough w sprawie Baker v. Bolton (1808) 1 Camp. 493; 170 Eng. Rep. 1033.

${ }^{956}$ Stewart v. London, Midland and Scottish Railway Co. 1943 S.C. (H.L.) 19, 44.

957 J. Halberda, Dzieje doktryny..., s. 36-48. 
personalis mogłoby co najwyżej odnosić się do skarg typu in personam ${ }^{958}$. Takie rozumienie pojęć personalis oraz poenalis na gruncie prawa rzymskiego nie znajduje żadnego potwierdzenia w źródłach. Przypuszczać można jednak, iż inspiracja dla lorda prawa mogły być informacje przekazane przez Sir W.S. Holdswortha w jego History of English Law. Angielski historyk wykazal bowiem w swojej pracy penalny charakter skarg związanych $z$ długami spadkowymi ${ }^{959}$.

Ostatecznie wszyscy lordowie potwierdzili fakt recypowania do prawa szkockiego rzymskich rozwiązan dotyczacych actio iniuriarum, choć różnili się w ocenie zakresu tego wpływu.

Należy wyjaśnić, iż orzeczenie w sprawie Stewart $v$. London, Midland and Scottish Railway Co. nieprzypadkowo uznawane jest za jeden $\mathrm{z}$ kluczowych precedensów prawa szkockiego dotyczących odpowiedzialności deliktowej. Decyzja Izby Lordów stanowiła sądowe potwierdzenie przekonań doktryny dotyczacych znaczenia rzymskiego deliktu zniewagi na gruncie Scots law. Jak zauważa bowiem Niall R. Whitty, mimo że omawiany delikt przeszczepiono do szkockiego systemu prawnego w XVIII stuleciu, to jednak dopiero tzw. neo-Civilian reaction, obserwowana $\mathrm{w} \mathrm{XX}$ wieku, w trwały sposób pozwoliła na jego pełne wykorzystanie ${ }^{960}$.

$Z$ tej samej perspektywy konieczne jest spoglądanie na kolejne wyroki Komitetu Apelacyjnego Izby Lordów wydawane po zakończeniu II wojny światowej. Choć dotyczyły one również szkockiego odpowiednika zadośćuczynienia, czyli solatium, nieznanego prawu rzymskiemu, to jednak ich analiza oparta była również w głównej mierze na rzymskiej iniurii. Do tej kategorii należy z pewnością sprawa Cole-Hamilton $v$. Boyd $^{961} \mathrm{z}$ roku 1963.

958 Stewart v. London, Midland and Scottish Railway Co. 1943 S.C. (H.L.) 19, 46.

${ }^{959}$ W.S. Holdsworth, History of English Law, vol. 3, London 1923, s. $577-580$.

960 N.R. Whitty, Rights of Personality, Property Rights and the Human Body in Scots Law, ELR 9 (2004-2005), s. 200.

961 Cole-Hamilton v. Boyd 1963 S.C. (H.L.) 1. 
Stan faktyczny sprawy dotyczył wypadku drogowego, w którym uczestniczyły trzy pojazdy - jeden samochód oraz dwa motocykle. Jednym $z$ nich podróżowała w charakterze pasażera młoda kobieta, która odniosła poważne obrażenia. Kierowca samochodu zapłacił na rzecz poszkodowanej określona sumę pieniędzy. Na skutek tego przedstawiciel kobiety postanowił o przelaniu na rzecz kierowcy samochodu uprawnienia do wytoczenia skargi przeciwko trzeciemu uczestnikowi wypadku ${ }^{962}$. Mimo to ostatecznie skarga $z$ tytułu solatium została wytoczona przez przedstawiciela kobiety, co spowodowało powstanie kontrowersji dotyczących zasadności takiego działania.

Prawnicy reprezentujacy pokrzywdzona odwołali się do zasady personalności skargi wypowiedzianej przez law lords w orzeczeniu Stewart $v$. London, Midland and Scottish Railway Co. Wskazali, iż kluczowym zagadnieniem przy ocenie stanu faktycznego dotyczacego solatium nie jest intencja towarzyszaca osobie pokrzywdzonej, lecz osobisty charakter przysługujacej jej skargi. Wprawdzie, w przekonaniu pełnomocników, było to ważne dla rzymskich jurystów, jednak nie zdecydowali się oni poprzeć swojej tezy stosownym odwołaniem do rzymskich źródeł prawa bąź literatury romanistycznej. Nawiązanie do antycznej tradycji prawnej odnaleźć można jednak w dalszych uwagach pełnomocników. Odwołując się do wypowiedzi Lorda Prezydenta Court of Session na temat braku możliwości dziedziczenia skarg $z$ tytułu zniewagi, prawnicy odwołali się do angielskiego tłumaczenia popularnego podręcznika prawa rzymskiego autorstwa R. Sohma. Mimo różnic dzielących prawo rzymskie, szkockie oraz angielskie, pełnomocnicy powódki wskazali wreszcie, że na gruncie trzech wskazanych systemów prawnych niemożliwe

${ }^{962}$ Dokonane zostało tzw. assignment. Jest to konstrukcja początkowo nieznana common law, lecz akceptowana na gruncie systemu equity. Polega ona na dokonaniu cesji prawa do skargi na rzecz osoby trzeciej. Współcześnie prawo angielskie zna różne rodzaje assignment of claim, ale poddane sa one różnym ograniczeniom, zob. E.A. Martin, Oxford Dictionary..., s. 35-36, s.v. assignment. 
było przenoszenie uprawnień do korzystania ze skargi odszkodowawczej na osoby trzecie ${ }^{963}$.

W dalszej części swego wystapienia prawnicy odnieśli się do argumentów przeciwników procesowych, którzy odwołali się m.in. do fragmentu pracy J. Erskine'a dotyczacego cesji ${ }^{964}$. W odpowiedzi na te argumenty i powołane źródło, prawnicy powódki stwierdzili, iż szkocki autor zaledwie jeden paragraf wcześniej w swym dziele wyjaśnił, że cesja odnosi się tylko do długów i ruchomości, nie zaś do omawianych w przedmiotowej sprawie skarg deliktowych ${ }^{965}$. Zbijając kolejne argumenty oponentów procesowych, prawnicy reprezentujący kobietę wytknęli przeciwnikom bezzasadne powołanie się na konstytucje pochodzaca $z$ Kodeksu Justyniana, a dotycząca wytoczenia skargi przeciwko dziedzicom nabywcy przedmiotu, na którym ustanowione było prawo zastawu. W swojej konstytucji Dioklecjan i Maksymian wyrazili pogląd, że w razie śmierci wierzyciela, jak i działającego w dobrej wierze nabywcy rzeczy, skarga o jej wydanie powinna być wniesiona przeciwko następcom prawnym wierzyciela ${ }^{966}$. Prawnicy stwierdzili, iż zacytowany przez ich przeciwników kazus nie ma żadnego zastosowania w przedmiotowej sprawie i należy wiązać go raczej z dwoma innymi przykładami pochodzacymi od rzymskich jurystów - skarga wytaczana przeciwko następcom prawnym opiekuna ${ }^{967}$ oraz o dziedziczność skargi $z$ tytułu zniewagi pod warunkiem wcześniejszej litis contestatio ${ }^{968}$.

Lordowie prawa nie odnieśli się w swych orzeczeniach bezpośrednio do zagadnień prawa rzymskiego. Uznali jednak

${ }_{963}$ Cole-Hamilton v. Boyd 1963 S.C. (H.L.) 1, 3-4.

${ }^{964} \mathrm{~J}$. Erskine, An Institute..., 3, 5, 2. Prawnicy pozwanego przywołali także fragment pochodzący $z$ Instytucji Justyniana $(4,12,1)$ dotyczący nieprzysługiwania prawa do wszystkich skarg następcom prawnym osoby poszkodowanej.

${ }^{965} \mathrm{Na}$ temat assignation u J. Erskine'a zob. K. Luig, Assignation, [w:] HPLS, vol. 2, s. 416-417.

${ }_{966}$ Cole-Hamilton v. Boyd 1963 S.C. (H.L.) 1, 7. C. 8, 29, 5 (w law report błędnie wskazano tytuł księgi jako trzydziesty).

${ }^{967}$ D. 27, 7, 8, 1 (Paulus libro nono responsorum).

${ }_{968}$ D. 47, 10, 28 (Ulpianus libro 34 ad Sabinum). 
(potwierdzając tym samym w części wyrok wydany przez sąd pierwszej instancji), iż na gruncie prawa szkockiego dopuszcza się możliwość cesji skargi dotyczącej zadośćuczynienia między żyjącymi (inter vivos).

Do problematyki szkody na osobie odnosiła się również sprawa $z$ roku 1972 M'Kendrick $v$. Sinclair ${ }^{969}$. Jej stan faktyczny dotyczył wypadku, w trakcie którego zginął porażony pradem elektrycznym pracownik fabryki. Rodzeństwo zmarłego wystapiło do sacdu $z$ tzw. action of assythment. Był to rodzaj skargi znanej prawu szkockiemu, która wywodziła się $z$ prawa feudalnego i w zasadzie odpowiadała średniowiecznej konstrukcji główszczyzny. W szkockich traktatach prawniczych porównywana była ona do anglosaskiego wergeld ${ }^{970}$. Podkreślano także jej cel w postaci zapobiegnięcia rodzinnej wendecie ${ }^{971}$. Zdaniem skarżacych, zarzadca fabryki - pozwany w sprawie - zdawał sobie sprawę $z$ faktu, iż wózek, którym posługiwał się w fabryce pracownik, był wadliwy. Wskazywano, że już wcześniej inni pracownicy fabryki, korzystając $z$ niesprawnego urządzenia, byli wielokrotnie rażeni prądem elektrycznym. Mimo to w sposób zawiniony i nieodpowiedzialny (culpably and recklessly) nadzorca nie zadbał o to, aby wózek został naprawiony. Strona pozwana w odpowiedzi na stawiane jej zarzuty starała się wykazać, że skarga $z$ tytułu assythment uległa desuetudo i przestała obowiązywać w prawie szkockim.

Z grona orzekających w sprawie law lords, dwóch odwołało się wprost do autorytetu prawa rzymskiego. Jako pierwszy uczynił to Lord Reid. Sędzia wskazał, iż wykorzystana przez rodzeństwo zmarłego skarga była istotnie nietypowym i rzadko używanym we współczesnym obrocie prawnym środkiem

${ }^{969}$ M'Kendrick v. Sinclair 1972 S.C. (H.L.) 25.

${ }^{970}$ B. Griffith, Early..., s. 31.

${ }^{971}$ Zob. K. McK. Norrie, Intentional Delicts, [w:] HPLS, vol. 2, s. 484. Szeroko na temat historii action of assythment zob. R. Black, A historical survey of delictual liability in Scotland for personal injuries and death, Comparative and International Law Journal of Southern Africa 8 (1975), s. 52-70. 
ochrony procesowej. Prawnik przedstawił w swoim orzeczeniu jej historię, pomijając jednak jej średniowieczne początki ${ }^{972}$. Zauważył, iż opierając się na przekazach pozostawionych przez J. Balfoura, można wykazać dużą popularność skargi z tytułu "główszczyzny” w XVI w. i jej regularne wykorzystywanie w szkockich sadach ${ }^{973}$. Następnie Lord Reid przywołał krótkie fragmenty autorstwa późniejszych autorów - Lorda Stair ${ }^{974}$ oraz Lorda Bankton ${ }^{975}$ odnoszace się do sposobu rozumienia action of assythment w czasach im współczesnych.

Sędzia zauważył wreszcie, że omawiana skarga w przeszłości była często łączona $z$ problematyką odpowiedzialności karnej. Tę tezę lord prawa uzasadnił odwołujac się do obszernego passusu zaczerpniętego $z$ dzieła innego szkockiego instytucjonalisty - J. Erskine'a ${ }^{976}$. Na koniec sędzia przywołał kilka precedensowych orzeczeń sądów szkockich, w których problematyka assythment była rozstrzygana ${ }^{977}$. Zauważył równocześnie, iż po raz ostatni miało to miejsce w roku 1768, gdy Court of Session orzekał w sprawie Lady Leith-Hall v. Earl of Fife ${ }^{978}$.

Obszerne omówienie dziejów przedmiotowej skargi związane było $z$ faktem jej późniejszego zastapienia przez wywodzace się $z$ prawa rzymskiego zasady odpowiedzialności quasi-deliktowej $z$ tytułu niedbalstwa ${ }^{979}$. Sędzia wskazał, że zjawisko to zapoczątkowane zostało u schyłku XVIII stulecia. Lord Reid przeciwstawił się jednak twierdzeniom strony pozwanej, zakładającym zniknięcie ze szkockiego systemu prawnego action of assythment. Wskazał on, że zjawisku wypierania rodzimej szkockiej skargi w niektórych przypadkach towarzyszyło jednak umiejętne łączenie obu tytułów odpowie-

${ }^{972}$ M'Kendrick v. Sinclair 1972 S.C. (H.L.) 25, 50.

973 The Prackticks of Sir James Balfour..., s. 516. Por. także A.M. Godfrey, Civil Justice..., s. 256-257.

${ }^{974}$ Lord Stair, Institutions..., 1, 9, 7.

${ }^{975}$ Lord Bankton, An Institute..., 1, 10, 15.

976 J. Erskine, An Institute..., 4, 4, 105.

${ }_{977}$ M'Kendrick v. Sinclair 1972 S.C. (H.L.) 25, 50-51.

${ }^{978}$ Lady Leith-Hall v. Earl of Fife (1768) Mor. 13904.

${ }^{979}$ M'Kendrick v. Sinclair 1972 S.C. (H.L.) 25, 53. 
dzialności. Sędzia przywołał sprawę Black v. Caddell ${ }^{980}$ rozpatrywana przez szkockie sądy, jak również przez Izbę Lordów na początku XIX wieku. Za ciekawy należy uznać fakt, iż we wskazanej przez lorda sprawie strona powodowa na etapie postępowania pierwszoinstancyjnego oparła swoje żądania jedynie na doktrynie assythment, podczas gdy przed Izba Lordów podniosła dodatkowo zarzut $z$ tytułu rzymskiej obligatio quasi ex delicto.

Powołany przez sędziego przykład stanowi ważny dowód przemawiający za recepcja prawa rzymskiego na gruncie szkockim. Podkreślić należy również, że prócz zwyczajnej recepcji, polegajaccej na przejęciu obcych rozwiązań prawnych, szkoccy prawnicy umieli połączyć dwa odmienne porządki prawne tak, aby stworzyć pewna nową wartość.

Drugim z lordów, który odniósł się do zagadnień cywilistycznych, był Szkot - Lord Kilbrandon. Z aprobata wypowiedział się on o ustaleniach dotyczących dziejów szkockiego assythment, które przedstawione zostały w orzeczeniach sędziów Court of Session ${ }^{981}$. Za szczególnie godny uwagi uznał fakt, iż action of assythment spełniała funkcje nie tylko typowej główszczyzny, lecz nawiązywała w swej istocie także do późniejszej cywilistycznej konstrukcji reparatio damnorum ${ }^{982}$. Dalej Lord Kilbrandon wskazał na wyraźna tendencję, cechująca tak instytucjonalistów, jak i sędziów szkockich sądów, do stopniowego rozdzielania prywatno- i publicznoprawnej formy assythment, gdzie ta pierwsza coraz wyraźniej zaczęła zbliżać się do konstrukcji cywilistycznego naprawienia szko$\mathrm{dy}^{983}$. Sędzia przywołał $\mathrm{w}$ tym miejscu passus pochodzący $z$ pracy J. Erskine'a, w którym wspomina się o konieczności poniesienia odpowiedzialności przez sprawcę szkody ${ }^{984}$. Lord

980 Black v. Caddell (1804) Mor. 13905.

${ }^{981}$ M'Kendrick $v$. Sinclair 1972 S.C. (H.L.) 25, 63-64.

${ }^{982} \mathrm{Na}$ temat odpowiedzialności za wyrządzona szkodę w tradycji cywilistycznej zob. R. Zimmermann, Usus Modernus Legis Aquiliae and Delictual Liability Today, Stellenbosch Law Review 1 (1990), s. 67-93.

${ }_{983}$ M'Kendrick $v$. Sinclair 1972 S.C. (H.L.) 25, 65.

984 J. Erskine, An Institute..., 3, 1, 12. 
prawa zwrócił uwagę, iż stwierdzenie J. Erskine’a koresponduje $z$ rzymska zasada alterum non laedere ${ }^{985}$.

Kontynuujacc swe rozważania na temat wyodrębnienia się prywatnoprawnej formy assythment, Lord Kilbrandon odwołał się do literatury oraz orzecznictwa ${ }^{986}$. Zacytował obszerny fragment artykułu autorstwa D.M. Walkera, w którym szkocki naukowiec wskazał m.in., że w XIX wieku możliwe było obserwowanie procesu utożsamiania terminu assythment z naprawieniem szkody, odszkodowaniem, czy nawet solatium. Stwierdził jednocześnie, że niemożliwe jest wskazanie, kiedy dokładnie doszło do rozdzielenia karnej i cywilnej emanacji assythment, jednak pewne jest, iż z jej cywilnej formy wykształciła się szkocka actio iniuriarum ${ }^{987}$. W ten sposób Lord Kilbrandon nawiazał do omawianego powyżej orzeczenia Lorda Macmillana w sprawie Stewart v. London, Midland and Scottish Railway Co., gdzie sędzia omówił okoliczności powstawania szkockiej skargi $z$ tytułu zniewagi na podstawie wzorców rzymskich ${ }^{988}$. Uwagę zwracają utyskiwania sędziego na błędny dobór argumentów w tej sprawie, podczas gdy, jego zdaniem, właściwym przedmiotem odwołań powinna być ustawa akwiliańska ${ }^{989}$.

Ostatecznie law lords odrzucili skargę rodzeństwa, lecz uznali jednocześnie, że samo assythment nie zniknęło $z$ sy-

985 D. 1, 1, 10, 1 (Ulpianus libro secundo regularum).

${ }_{986}$ M'Kendrick $v$. Sinclair 1972 S.C. (H.L.) 25, 66.

987 D.M. Walker, Solatium, JR 62 (1950), s. 156.

988 M'Kendrick $v$. Sinclair 1972 S.C. (H.L.) 25, 66.

${ }^{989} \mathrm{Na}$ potwierdzenie swych sądów Lord Kilbrandon odwołał się do prac T.B. Smitha (Strange Gods: Crisis of Scots law as Civilian System, [w:] T.B. Smith, Studies Critical and Comparative, Edinburgh 1962, s. 78) oraz D.M. Walkera, F.H. Lawson (A Common Lawyer Looks at the Civil Law, Ann Arbor 1953, s. 155, przyp. 121). Sędzia wskazał, że odwołuje się do artykułu D.M. Walkera opublikowanego w „Juridical Review” w roku 1970. Nie podał jednak tytułu publikacji. We wskazanym numerze czasopisma D.M. Walker nie opublikował jednak żadnej pracy dotyczacej problematyki odpowiedzialności deliktowej. Wydaje się, iż w tekście oficjalnym raportu sądowego jest błąd, zaś szkocki sędzia odwołał się do pracy D.M. Walkera dotyczacej solatium $\mathrm{z}$ roku 1950. 
stemu prawa szkockiego, wskazując, iż zasada prawa nie może ulec tak w prawie angielskim, jak i szkockim desuetudo. Co ciekawe, kilka lat po wydaniu wyroku w przedmiotowej sprawie, uchwalona została ustawa dotyczacca zasad odpowiedzialności odszkodowawczej w Szkocji, która formalnie zniosła assythment ${ }^{990}$.

Nieco inny stan faktyczny stanowił przedmiot prawniczej analizy lordów trzy lata później, w roku 1975, w sprawie Dick v. Burgh of Falkirk ${ }^{991}$. Sprawa ponownie dotyczyła wypadku przy pracy, do którego doszło na skutek zaniedbań wynikających $z$ opieszałości pracodawcy (władz okręgu Falkirk). Poszkodowany pracownik wniósł do sądu skargę o wypłacenie mu odszkodowania $z$ tytułu poniesionych szkód. Niecały rok po wniesieniu skargi (w marcu 1973 roku) mężczyzna zmarł. Zarządca majątku zmarłego została jego żona, która jednocześnie stała się jego następca procesowym. Niezależnie od tego kobieta wystapiła $z$ indywidualna skarga $z$ tytułu solatium. Strona pozwana uznała, że w zaistniałych okolicznościach kobieta nie jest uprawniona do wytaczania tego rodzaju powództwa. W listopadzie 1975 roku w sprawie wypowiedzieli się członkowie Komitetu Apelacyjnego. Dwóch $z$ nich odniosło się do zasad prawa rzymskiego. Jako pierwszy uczynił to Lord Wilberforce. W końcowej części swego orzeczenia lord prawa zauważył, iż prawnicy strony pozwanej odnieśli się do konstrukcji litis contestatio, rozumianej jako przeistoczenie skargi odszkodowawczej ( $z$ deliktu), wraz $z$ jej wniesieniem do sądu, w konstrukcje prawna o charakterze jak gdyby kontraktu łączącego powoda i pozwanego. W ten sposób zniknąć miała możliwość prowadzenia postępowania $z$ tytułu deliktu przez rodzinę zmarłego. Lord Wilberforce stwierdził wszakże, iż choć dostrzega oryginalność tego argumentu, to jednak nie jest on w pełni dla niego przekonujacy. Uznał także, że szkockie rozumienie terminu litis contestatio różni się od

990 Sec. 8 Damages (Scotland) Act 1976 (c. 13). Zob. także K. McK. Norrie, Intentional Delicts..., s. 488.

${ }^{991}$ Dick $v$. Burgh of Falkirk 1976 S.C. (H.L.) 1. 
oryginalnego rzymskiego sposobu patrzenia na to zagadnienie i jedynie „łacińskość” (Latinity) terminu pozwala dostrzec podobieństwo obu rozwiązań prawnych ${ }^{992}$.

Drugim $z$ lordów, który wypowiedział się w przedmiotowej sprawie, odnosząc się jednocześnie do prawa rzymskiego, był znany już ze sprawy M'Kendrick $v$. Sinclair Lord Kilbrandon. Wskazał on, iż śmierć poszkodowanego powoduje w prawie szkockim wyłączenie możliwości dochodzenia roszczeń $z$ tytułu solatium, co zdaniem lorda prawa odpowiada zakazowi przewidzianemu $\mathrm{w}$ prawie rzymskim dla skargi $\mathrm{z}$ tytułu zniewagi ( $z$ wyjątkiem sytuacji, gdy powództwo zostało wniesione za życia poszkodowanego). Nie dotyczy to jednak roszczeń odszkodowawczych za utracone korzyści (patrimonial loss) ${ }^{993}$.

Odnosząc się do problematyki litis contestatio, Lord Kilbrandon przywołał passus pochodzacy z pracy Heinecciusa ${ }^{994}$, cytowany uprzednio przez Lorda Macmillana w sprawie Stewart v. London, Midland and Scottish Railway Co ${ }^{995}$. Niemiecki prawnik wyjaśniał $\mathrm{w}$ swym dziele, że skutkiem konsumpcji procesowej było powstanie między stronami więzi prawnej mającej cechy jak gdyby kontraktu ${ }^{996}$. Sędzia wskazał, że takie rozwiazanie istniało w prawie rzymskim, jednak nie koresponduje ono ze szkockim postępowaniem prywatnym. Wyjaśnił, iż litis contestatio $\mathrm{w}$ rzymskim postępowaniu formułkowym wy-

${ }_{992}$ Dick v. Burgh of Falkirk 1976 S.C. (H.L.) 1, 20.

${ }_{993}$ Dick $v$. Burgh of Falkirk 1976 S.C. (H.L.) 1, 25.

994 Dick v. Burgh of Falkirk 1976 S.C. (H.L.) 1, 26.

995 J.H. Heineccius, Recitationes..., 4, 4, 1111.

${ }_{996}$ Zagadnienie kontraktowego charakteru litis contestatio wiązać należy $z$ koncepcjami zaproponowanymi przez $\mathrm{M}$. Wlassaka na przełomie XIX i XX w. Zostały one jednak poddane krytyce i już w pracach $z$ połowy stulecia dostrzega się wyraźne zanegowanie popularnej wcześniej koncepcji niemieckiego romanisty. Należy zatem dziwić się, że Lord Kilbrandon odwoływał się do kontraktowej koncepcji litis contestatio jeszcze w latach 70. XX w., szczególnie że na brytyjskim rynku wydawniczym opublikowane były już dwie popularne prace, w których zanegowano tezę M. Wlassaka - podręcznik W.W. Bucklanda (A Textbook..., s. 695-696) oraz praca H.F. Jolowicza w opracowaniu B. Nicholasa zatytułowana Historical Introduction to the Study of Roman Law (Cambridge 1972, s. 177). 
znaczona była ostatnia czynnościa procesowa dokonana przez pretora $\mathrm{w}$ postępowaniu in iure. Było to wyznaczenie sędziego i skierowanie do niego sprawy, jeśli zaistniały wątpliwości natury faktycznej. Gdy kontrowersje dotyczyły jedynie zagadnień prawnych, wówczas pretor sam miał rozstrzygać spór ${ }^{997}$. Ostatnia wypowiedź Lorda Kilbrandon rodzi wątpliwości dotyczące jego znajomości prawa rzymskiego. Proces formułkowy dopuszczał zakończenie postępowania $\mathrm{w}$ fazie in iure jedynie $\mathrm{w}$ kilku przypadkach, $\mathrm{np}$. w zwiazku $\mathrm{z}$ odmowa przyznania skargi przez pretora (denegatio actionis), uznania roszczenia przez pozwanego (confessio in iure), złożenia przysięgi (iusiurandum), czy zawarcia ugody przez strony (transactio).

Pomijając te wątpliwości, trzeba stwierdzić, że sędzia odmówił zastosowania rzymskiej litis contestatio $\mathrm{w}$ prawie szkockim oraz przywołał fragment pochodzacy z podręcznika prawa rzymskiego autorstwa W.A. Huntera, w którym angielski romanista stwierdził, iż skutki wywoływane przez ogłoszenie litis contestatio były "niesprawiedliwe i kapryśne"998, oraz passus J. Erskine'a, w którym autor jasno stwierdza, iż Szkotom sa „obce rzymskie formulae”999. Sędzia wyjaśnił, że $\mathrm{w}$ prawie szkockim momentem wygaśnięcia uprawnienia przysługującego $z$ tytułu skargi jest orzeczenie sądu, porozumienie stron, bądź jednostronna decyzja o odstapieniu od dochodzenia roszczeńn ${ }^{1000}$.

Kierując się uwagami poczynionymi przez szkockiego sędziego, lordowie prawa orzekli ostatecznie o dopuszczalności żądania kobiety i nakazali ponowne rozpatrzenie jej sprawy przez Court of Session.

Podobnej problematyki dotyczyła sprawa rozpatrywana przez Komitet Apelacyjny w roku 1981 - Robertson v. Turnbull ${ }^{1001}$. Ze względu na podobieństwo stanów faktycznych obie

${ }^{997}$ Dick v. Burgh of Falkirk 1976 S.C. (H.L.) 1, 27.

${ }^{998}$ W.A. Hunter, A Systematic and Historical Exposition of Roman Law in the Order of a Code, ed. 4, London 1903, s. 984.

999 J. Erskine, An Institute..., 4, 1, 65.

1000 Dick v. Burgh of Falkirk 1976 S.C. (H.L.) 1, 27.

${ }^{1001}$ Robertson v. Turnbull 1982 S.C. (H.L.) 1. 
sprawy sa ze soba często zestawiane. Badanym zagadnieniem był zakres podmiotowy żądania zadośćuczynienia. Powód wystapił bowiem $z$ żądaniem solatium w związku $z$ wypadkiem, jakiemu uległa jego żona. Stan zdrowia kobiety uniemożliwił jej kontynuowanie dotychczasowych obowiązków, w tym także uniemożliwił jej podjęcie pracy. Mężczyzna uznał zatem, że jest on uprawniony do wystąpienia przed sądem $z$ żądaniem solatium. Lordowie prawa jednogłośnie uznali jednak, iż roszczenie tego rodzaju jest bezpodstawne. Dopuszczalność wystapienia ze skarga, o jakiej zadecydowano w sprawie Dick v. Burgh of Falkirk, została ograniczona bowiem jedynie do członków rodziny osoby zmarłej.

Problematyka prawa rzymskiego została podniesiona w sprawie przez prawników powoda ${ }^{1002}$. Do argumentów tych nawiazał w swym orzeczeniu Lord Fraser of Tullybelton. Po omówieniu dotychczasowej linii orzeczniczej sądów szkockich i Izby Lordów, lord prawa wyraził pogląd, iż nie istnieja przesłanki umożliwiające rozszerzenie stosowania roszczenia z tytułu solatium na członków rodziny osoby nadal żyjącej. Wskazał jednocześnie orzeczenie $z$ roku $1870 \mathrm{w}$ sprawie Eisten v. National British Railway Co. ${ }^{1003}$, zawierajace podobna argumentację. Orzekający wówczas Lord President Inglis miał stwierdzić, iż podstawą wydanego przez niego orzeczenia sa m.in. rzymskie rozwiazania dotyczace actio iniuriarum. W przekonaniu Lorda Frasera w rzeczywistości szkockiej rozwiązania dotyczące odpowiedzialności deliktowej wywodzą się z ustawy akwiliańskiej. Tezę tę lord prawa uzasadnił odwołując się do literatury oraz orzecznictwa ${ }^{1004}$. W ten sposób powtórzył wcześniejszą opinię wygłoszoną w roku 1943 przez Lorda Macmillana w sprawie Stewart $v$. London, Midland and Scottish Railway Co. Pamiętać należy jednak, że zasadność wykorzystania powyższych rozważań została skrytykowana w roku 1972 przez Lorda Kilbrandon.

1002 Robertson v. Turnbull 1982 S.C. (H.L.) 1, 2.

1003 Eisten v. National British Railway Co. (1870) 8 M. 980.

${ }^{1004}$ Robertson v. Turnbull 1982 S.C. (H.L.) 1, 8. 
Kontynuujac swoje rozważania, Lord Fraser stwierdził również, iż na rozwój szkockiego solatium wpływ miała także skarga assythment. Ostatecznie sędzia, chcąc udowodnić wspólną wszystkim lordom prawa tezę o braku możliwości zastosowania skargi $\mathrm{z}$ tytułu solatium $\mathrm{w}$ przedmiotowej sprawie, postanowił odwołać się do obcych precedensów, które wyraźnie oparte zostały na zasadach odpowiedzialności deliktowej. W tym celu przywołał południowoafrykańskie orzeczenia, za pośrednictwem których wykazał wspólny prawu szkockiemu i rzymsko-holenderskiemu trzon tkwiący w klasycznym prawie rzymskim ${ }^{1005}$.

Jak zostało to wcześniej wykazane, jednym $z$ podstawowych zarzutów stawianych, tak przez sędziów, jak i naukę prawa szkockiego, rodzimym rozwiązaniom prawnym dotyczącym solatium, było zbyt pochopne ograniczenie się do rzymskiego deliktu zniewagi. Podkreślano, że właściwsze byłoby oparcie rozważań na odpowiedzialności akwiliańskiej. Trzeba zauważyć, iż ta ostatnia została recypowana do Scots law, lecz w odniesieniu do innych stanów faktycznych. Sędziowie Komitetu Apelacyjnego Izby Lordów kilkakrotnie powoływali się na actio legis Aquiliae.

Należy jednak pamiętać, że ocena wpływu prawa rzymskiego na szkockie rozwiąania prawne musi być rozpatrywana w sposób wyważony, szczególnie gdy przedmiotem analizy sędziów jest instytucja, której recypowana obecność na gruncie Scots law jest poświadczona przynajmniej trzystuletnia praktyką. Dobrą ilustracja wskazanego problemu może być sprawa Kolbin \& Sons $v$. Kinnear \& Co. ${ }^{1006}$ rozpatrywana w roku 1931. Dotyczyła ona transportu towarów z Archangielska do Dundee w czasie I wojny światowej. Uwagę romanisty zwróci $z$ pewnością odwołanie się przez Lorda Atkina do pojęcia negotiorum gestor oraz do pojęcia winy w jej trzech postaciach - culpa lata, culpa levis oraz culpa levissima ${ }^{1007}$.

1005 Robertson v. Turnbull 1982 S.C. (H.L.) 1, 9.

1006 Kolbin \& Sons $v$. Kinnear \& Co 1931 S.C. (H.L.) 128.

1007 Kolbin \& Sons v. Kinnear \& Co 1931 S.C. (H.L.) 128, 138. 
Pojęcia te znane były jednak tradycji prawa szkockiego od dawna i nie może być w tym kontekście mowy o ich recepcji w przywołanym orzeczeniu, zwłaszcza że sędzia nie poddał ich dalszej analizie ${ }^{1008}$.

Szczególnym przypadkiem, który łączy się z podjętą tu tematyka odpowiedzialności akwiliańskiej, jest sprawa Donoghue $v$. Stevenson ${ }^{1009}$ - kluczowy precedens szkockiego, jak również angielskiego prawa deliktowego. Tym razem brak jednoznacznego odwołania się do rzymskich źródeł nie wyklucza cywilistycznego fundamentu, na którym spoczęła argumentacja Lorda Macmillana.

Sprawa dotyczyła odpowiedzialności wytwórcy piwa imbirowego. W trakcie procesu fermentacji dopuścił się on niedbalstwa, które doprowadziło do zamknięcia w jednej z butelek ślimaka. W sierpniu 1928 roku powódka napiła się trunku, co spowodowało u niej problemy gastryczne oraz szok będący następstwem dostrzeżenia na dnie butelki ślimaka w stanie rozkładu. Po tych wydarzeniach kobieta starała się na drodze sądowej uzyskać od wytwórcy alkoholu odszkodowanie $z$ tytułu poniesionej szkody. W roku 1931 sprawa trafiła przed oblicze law lords. Ostatecznie większościa głosów trzy do dwóch sprawę rozstrzygnięto na korzyść kobiety, zaś sama sprawa stała się jednym $z$ najbardziej znanych precedensów prawa angielskiego. Czytając treść poszczególnych orzeczeń, nie odnajduje się żadnego odwołania do prawa rzymskiego, czy też tradycji cywilistycznej. Mimo to konstrukcja ogólnych zasad odpowiedzialności, jaka została sformułowana na gruncie powyższego kazusu przez szkockiego sędziego Lorda Macmillana, wyraźnie przywodzi na myśl ogólne zasady odpowiedzialności deliktowej wypracowane przez rzymskich jurystów na gruncie lex Aquilia. Do niedawna brakowało dowodów, które potwierdzałyby powyższe przypuszczenie. W roku 1992 na

${ }^{1008} \mathrm{Na}$ temat pojęcia culpa w prawie szkockim i możliwości przejęcia całej konstrukcji szkockiej odpowiedzialności opartej na zasadach winy z prawa rzymskiego sceptycznie wypowiedział się jednak G. MacCormak, Culpa in the Scots Law of Reparation, JR 1974, s. 13-29.

${ }^{1009}$ Donoghue v. Stevenson [1932] A.C. 562. 
łamach „Law Quarterly Review” opublikowana została przez Alana Rodgera oryginalna wersja orzeczenia autorstwa Lorda Macmillana ${ }^{1010}$, która zawierała m.in. odwołania do prac szkockich autorów tworzacych w duchu ius commune.

Zmiana wynikała najprawdopodobniej ze starań podjętych przez Lorda Atkina, który zgadzajac się co do toku rozumowania zaprezentowanego przez Lorda Macmillana, prosił go o zuniwersalizowanie rozważań, tak aby szkockie cytaty nie spowodowały wyłączenia stosowania precedensu $\mathrm{w}$ sferze angielskiego common law ${ }^{1011}$. Orzeczenie zmodyfikowane zostało przede wszystkim w jego pierwszej części. Po wstępie, który pozostał niezmieniony, Lord Macmillan starał się zarysować zasady odpowiedzialności deliktowej w prawie angielskim i szkockim. Wskazał m.in., iż geneza angielskich torts i szkockich delicts jest różna, lecz w odniesieniu do sprawy Donoghue $v$. Stevenson nie ma to znaczenia ${ }^{1012}$. W przypadku zaś codziennych problemów, przed jakimi stanęła również powódka, oba systemy prawne kieruja się podobnymi zasadami. Następnie szkocki sędzia ocenił dopuszczalność złożonego pozwu (a w konsekwencji także apelacji) ${ }^{1013}$. Na poczatku przywołał fragmenty pochodzace $z$ pracy Lorda Stair odnoszące się do problematyki istoty deliktu ${ }^{1014}$, następnie zaś zacytował obszerny passus autorstwa J. Erskine'a, w którym osiemnastowieczny pisarz zdefiniował model odpowiedzialności deliktowej - „every fraudulent contrivance or unwarrantable act by which another suffers damage [...] subjects the delinquent to reparation. [...] Wrong may arise not only from positive acts of trespass or injury, but from blameable omis-

${ }^{1010}$ A. Rodger, Lord Macmillan's Speech in Donoghue v. Stevenson, LQR 108 (1992), s. 236-259. Por. także idem, Mrs. Donaghue and Alfenus Varus, Current Legal Problems 41 (1988), s. 1-22; D.J. Ibbetson, A Historical..., s. 190-195; R. Evans-Jones, Roman Law..., s. 97-108.

${ }^{1011}$ Zob. R. Evans-Jones, Roman Law..., s. 102-103.

1012 A. Rodger, Lord Macmillan's..., s. 248-249.

1013 Ibidem, s. 249.

${ }^{1014}$ Lord Stair, Institutions..., 1, 8, 9; 1, 9, 1; 1, 9, 6. 
sion or neglect of duty"1015. Na koniec Lord Macmillan zacytował jeszcze fragment pochodzacy z Principles G.J. Bella ${ }^{1016}$. Nieco dalej przywołana została przez sędziego paremia alterum non laedere ${ }^{1017}$, uznana przez niego za rozpoznawalna we wszystkich cywilizowanych systemach prawa ${ }^{1018}$.

Lord Macmillan w swym nieogłoszonym orzeczeniu nie odwołał się wprawdzie wprost do zasad prawa rzymskiego, ale do konstrukcji prawnych sformułowanych przez szkockich autorów traktatów prawniczych. Niemniej wszystkie przywolane przez lorda prawa fragmenty pochodzace $z$ prac Lorda Stair, J. Erskine'a oraz G.J. Bella, oparte zostały na rzymskiej tradycji prawnej. Co ważne, ostateczna wersja orzeczenia pozbawiona była odwołań do powyższych prac, jednak jego idea pozostała niezmieniona ${ }^{1019}$.

Chociaż żadne $z$ orzeczeń w sprawie Donoghue $v$. Stevenson nie zawierało odwołania do prawa rzymskiego, to jednak angielscy prawnicy świadomi byli podobieństwa rodzimych i rzymskich rozwiazań prawnych. Nie zawsze jednak dostrzegali geneze zasad sformułowanych przez Lorda Macmillana i pozostałych lordów w ich orzeczeniach. Potwierdza to wypowiedź Lorda Denninga z roku 1960 w sprawie Watson v. Fram Reinforced Concrete Co. ${ }^{1020}$ dotyczącej biegu terminu do wniesienia przez pokrzywdzonego skargi $z$ tytułu poniesionej szkody. Jako że w sprawie wystapił także element obowiązku dołożenia należytej staranności, angielski sędzia w sposób naturalny odwołał się do wcześniej analizowanej sprawy $z$ roku 1932, stanowiącej już dobrze utrwalony w tym czasie w doktrynie prawa angielskiego leading case. Stwierdził on, iż zasada wypowiedziana w Donoghue $v$. Stevenson dotyczy wszelkich spraw, w których przyczyna wniesienia

1015 J. Erskine, An Institute..., 3, 1, 13.

1016 G.J. Bell, Principles..., sec. 553.

${ }^{1017}$ D. 1, 1, 10, 1 (Ulpianus libro secundo regularum).

1018 A. Rodger, Lord Macmillan's..., s. 250.

${ }^{1019} \mathrm{Na}$ temat tła prawnego, które poprzedziło wydanie orzeczenia zob.

D.J. Ibbetson, A Historical..., s. 188-189.

1020 Watson v. Fram Reinforced Concrete Co. 1960 S.C. (H.L.) 92. 
skargi jest zaistnienie szkody. Będąc przekonanym o słuszności zasady, Lord Denning wskazał, że nie tylko występuje ona w prawie angielskim, lecz także w innych systemach prawa, w tym w prawie rzymskim ${ }^{1021}$. Na potwierdzenie swych słów zacytował fragment pracy W.W. Bucklanda zamieszczonej w zbiorze Some Reflections on Jurisprudence: „so too the careless conduct without damage, or the damage without anything making it imputable, would have no import at civil law. The breach of duty is the wrongful infliction on damage. And so the Romans put it - damnum iniuria datum"1022. Przechodząc do zagadnień prawa szkockiego Lord Denning uznał, iż skoro zasada odpowiedzialności z tytułu niedochowania należytej staranności jest identyczna w prawie angielskim i rzymskim, to także musi ona obowiazywać w prawie szkockim $^{1023}$.

Celem przyświecającym Lordowi Atkinowi w roku 1932 było dyskretne przeniesienie, opartej na rzymskich wzorach, szkockiej odpowiedzialności deliktowej na grunt prawa angielskiego. Pomysł ten udało się zrealizować, czego dobrym przykładem jest bardzo ważne orzeczenie w precedensowej sprawie Fairchild $v$. Glenhaven Funeral Services Ltd. ${ }^{1024}$ rozpatrywanej przez Komitet Apelacyjny w roku 2002. Trzej mężczyźni - Arthur Eric Fairchild, Thomas Fox oraz Edwin Matthews, w związku $z$ wykonywanymi przez siebie zawodami, przez długi czas narażeni byli na kontakt $z$ włóknami azbestu. Dwaj pierwsi zmarli w roku 1996 po wykryciu u nich międzybłonniaka opłucnej. U trzeciego mężczyzny tę samą chorobę wykryto w roku 2000. Rodziny dwóch pierwszych mężczyzn oraz sam Matthews zdecydowali się wytoczyć powództwo o naprawienie powstałej szkody. Problemem, który ujawnił się w trakcie toczącego się postępowania, było wska-

1021 Watson v. Fram Reinforced Concrete Co. 1960 S.C. (H.L.) 92, 116. ${ }^{1022}$ W.W. Buckland, Some Reflections on Jurisprudence, Cambridge 1945, s. 113.

${ }^{1023}$ Watson v. Fram Reinforced Concrete Co. 1960 S.C. (H.L.) 92, 116. ${ }^{1024}$ Fairchild v. Glenhaven Funeral Services Ltd. [2003] 1 A.C. 32. 
zanie podmiotu bezpośrednio odpowiadającego za wyrządzone szkody.

We wskazanej sprawie kluczowe orzeczenie ogłoszone zostało przez Lorda Rodgera of Earlsferry. Szkocki sędzia zwrócił uwage na fakt, iż zagadnieniem przypisania odpowiedzialności konkretnej osobie zajmowali się już w swych pracach rzymscy juryści na kanwie rozważan dotyczących legis Aquiliae $^{1025}$. Prawnik przywołał w tym miejscu artykuł autorstwa J.S. Kortmanna ${ }^{1026}$ dotyczacy przedmiotowego zagadnienia, następnie zaś przedstawił swoją interpretację dwóch passusów z Digestów justyniańskich ${ }^{1027}$. Najpierw przywołał fragment autorstwa Juliana ${ }^{1028}$, w którym rzymski prawnik przedstawił kazus niewolnika pobitego przez dwie osoby działające niezależnie od siebie. Powstał wówczas problem, który $z$ napastników powinien odpowiadać na podstawie przepisów legis Aquiliae za spowodowanie śmierci niewolnika. Zdaniem Juliana, obu napastnikom należałoby przypisać odpowiedzialność z tytułu zabójstwa niewolnika. W celu potwierdzenia swej tezy Julian przywołał autorytet veteres $^{1029}$, a za nim uczynił to również Lord Rodger przytaczając tak oryginalna łacińska wersję fragmentu, jak i jej angielskie tłumaczenie autorstwa C.H. Monro'a ${ }^{1030}$. W dalszej części swych rozważań law lord przywołał korespondujący $z$ powyższym fragment autorstwa Ulpiana $z$ tytułu poświęconego odpowiedzialności akwiliańskiej ${ }^{1031}$. Swe rozważania na temat legis Aquiliae

${ }^{1025}$ Fairchild v. Glenhaven Funeral Services Ltd. [2003] 1 A.C. 32, 113. 1026 J.S. Kortmann, 'Ab alio ictu(s)': Misconceptions about Julian's View on Causation, JLH 20/2 (1999), s. 95-103.

${ }^{1027}$ Fairchild v. Glenhaven Funeral Services Ltd. [2003] 1 A.C. 32, 113-114.

${ }_{1028}$ D. 9, 2, 51, pr. (Iulianus libro 86 digestorum).

1029 D. 9, 2, 51, 1 (Iulianus libro 86 digestorum).

1030 „This is in keeping with the view handed down from the old lawyers, who, where the same slave was wounded by several persons under such circumstances that it did not appear by whose hand it was that he died, came to the conclusion that they were all liable [under the lex Aquilia]", C.H. Monro, The Digest of Justinian, vol. 2, Cambridge 1909, s. 140-141. ${ }^{1031}$ D. 9, 2, 11, 2 (Ulpianus libro 18 ad edictum). 
sędzia zakończył następująca konstatacją: „the exact scope of these decisions can, of course, no longer be ascertained and it is likely that different jurists held differing views: the sixth-century compilers of the Digest may well have altered the texts to some extent, if only by abbreviation, cutting out the cut and thrust of debate"1032.

Ostatecznie Izba Lordów przychyliła się do argumentacji Lorda Rodgera i orzekła podobnie, jak niemal dwa tysiace lat wcześniej uczynił to Ulpian. Uznano bowiem, że w nadzwyczajnych okolicznościach, gdy niemożliwe jest ustalenie podmiotu bezpośrednio odpowiedzialnego za wyrządzenie szkody, poszkodowany ma możliwość dochodzenia swych roszczeń od wszystkich podmiotów, które do tej szkody mogły się przyczynić. Trzeba jednocześnie zaznaczyć, iż powyższe rozstrzygnięcie nie byłoby możliwe, gdyby nie fakt recepcji szkockiej odpowiedzialności deliktowej na grunt prawa angielskiego w sprawie Donoghue $v$. Stevenson w roku $1932^{1033}$.

$\mathrm{Na}$ koniec warto wskazać jeszcze jeden angielski kazus mieszczacy się w tej samej linii orzeczniczej, co omawiana powyżej sprawa Fairchild $v$. Glenhaven Funeral Services Ltd. Jednym $z$ głównych problemów, przed jakim stanęli w roku 2002 lordowie prawa, było określenie osoby bezpośrednio odpowiedzialnej $z$ tytułu deliktu. Rozwiązanie przyjęte przez sędziów uznano za w pełni satysfakcjonujące i oparte na tradycji romanistycznej. Było ono jednak właściwe dla tej konkretnej sprawy, natomiast sam problem wystapienia kilku odpowiedzialnych za wspólnie wyrządzona szkodę stał się przedmiotem analizy Komitetu Apelacyjnego raz jeszcze w sprawie Heaton v. Axa Equity \& Law Assurance Society Plc. ${ }^{1034}$ Stan

${ }^{1032}$ Fairchild v. Glenhaven Funeral Services Ltd. [2003] 1 A.C. 32, 114 115.

${ }^{1033} \mathrm{Na}$ kanwie orzeczenia Lorda Rodgera w sprawie Fairchild v. Glenhaven Funeral Services Ltd. swoje uwagi dotyczace następstw prawnych spowodowania śmierci według prawa rzymskiego przedstawiła H. Scott w artykule Killing and Causing Death in Roman Law, LQR 123 (2013), s. 101-122. ${ }^{1034}$ Heaton v. Axa Equity \& Law Assurance Society Plc. [2002] 2 A.C. 329. 
faktyczny sprawy dotyczył możliwości wytoczenia powództwa przeciwko jednemu $z$ dwóch odpowiedzialnych za spowodowanie szkody podmiotów. Wątpliwość prawna związana była jednak $z$ faktem, że drugi $z$ podmiotów zdążył wypłacić należne skarżącemu odszkodowanie ${ }^{1035}$. Ciężar postępowania skupiał się zatem na nieco innym zagadnieniu, aniżeli miało to miejsce w sprawie Fairchild $v$. Glenhaven Funeral Services Ltd., szczególnie że spór dotyczył zawartych uprzednio umów. Wszyscy law lords wskazali jednak zgodnie, iż podstawa odpowiedzialności w tym wypadku nie miała znaczenia i przedstawione przez nich rozstrzygnięcie może znaleźć aplikację również $\mathrm{w}$ odniesieniu do odpowiedzialności $\mathrm{z}$ tytułu deliktów.

Trudności zwiazane $z$ ocena przedmiotowego stanu faktycznego podkreślił Lord Rodger of Earlsferry. Wskazał on jednak, iż nie są one zjawiskiem nowym. Przypomniał, że również rzymscy prawnicy musieli rozwiązywać podobne problemy ${ }^{1036}$. Jako przykład sędzia przedstawił pochodzący z końca II wieku kazus zachowany w komentarzu Paulusa do pism Plautiusa, w którym stronami byli wierzyciel, dłużnik oraz poręczyciel stypulacyjny. Pytanie prawne dotyczyło możliwości pozwania poręczyciela w sytuacji, w której wierzyciel zgodził się nie pozywać dłużnika ${ }^{1037}$.

Powyższe odwołanie Lorda Rodgera nie miało wprawdzie bezpośredniego przełożenia na ostateczny wyrok, jednak ponownie trzeba stwierdzić, iż powołanie to możliwe było dzięki recepcji prawa rzymskiego przez angielski system prawny za pośrednictwem prawa szkockiego.

${ }^{1035}$ Strony i lordowie prawa powoływali się na podobny kazus, który był przedmiotem orzekania Izby Lordów w roku 1998 - Jameson v. Central Electricity Generating Board [2000] 1 A.C. 455.

1036 Heaton v. Axa Equity \& Law Assurance Society Plc. [2002] 2 A.C. $329,356$.

${ }^{1037}$ D. 2, 14, 32 (Paulus libro tertio ad Plautium). 



\section{ZAKOŃCZENIE}

Izba Lordów, jako najwyższy sąd Anglii, następnie Wielkiej Brytanii i wreszcie Zjednoczonego Królestwa, pełniła swoja funkcje nieprzerwanie przez ponad czterysta lat. Doliczając wcześniejsza działalność z czasów średniowiecza, lordowie wykonywali zadania sądownicze już od wieku XIII. W książce ocenie poddany został jednak stosunkowo krótki okres stu trzydziestu trzech lat aktywności Izby, który zakreślony został wydaniem Appellate Jurisdiction Act w roku 1876 oraz wejściem w życie Constitutional Reform Act w dniu 1 października 2009 roku.

Pod wieloma względami wskazany okres był szczególnie ważny dla rozwoju prawa angielskiego oraz szkockiego. Nie ulega wattpliwości, że cecha charakteryzująca oba wskazane systemy prawne jest ich nieprzerwany rozwój. Bardzo często prawnicy kontynentalni postrzegaja dzieło ruchu kodyfikacyjnego jako wielkie osiągnięcie europejskiej myśli prawnej. Trzeba jednak stwierdzić, iż mimo licznych dobrych skutków, jakie niosło ze soba promulgowanie kodeksów, przyniosło ono również zmierzch wielowiekowej tradycji prawnej poszczególnych krajów. Ich porządki prawne, pod względem strukturalnym, niewiele różniły się od przeciwstawianego im dziś common law. Idea powoływania się na rozstrzygnięcia precedensowe nie była tylko dziełem Anglików. Dziś tamto przedkodeksowe prawo jest domena badań historyków prawa. Dogmatycy zaś jedynie w nielicznych przypadkach odwołuja się do dawnych rozwiazań prawnych.

Mimo podejmowania licznych zabiegów, zjawisko kodyfikacji nie dotarło do Wielkiej Brytanii. Dzięki temu badania 
nad historia prawa w Anglii czy Szkocji prowadzone sa w zupełnie innej perspektywie, aniżeli ma to miejsce na kontynencie. Refleksja historycznoprawna służy lepszemu zrozumieniu tych regulacji prawnych, które wciąż obowiąują. Co ważne, refleksja taka nie ogranicza się tylko do dysputy akademickiej, lecz przenoszona jest także w realia sal sądowych. Wymiernych skutków takich rozważań należy poszukiwać w rozbudowanych orzeczeniach wydawanych przez brytyjskie sady i trybunały.

Argumenty natury historycznej służyć mogą licznym celom przyświecającym ferującym wyroki sędziom. W większości będą one oczywiście powołaniami źródeł i tradycji prawnej Wysp Brytyjskich. Nie ulega jednak wątpliwości, że dobrze utrwalona jest także praktyka odwoływania się przez angielskie oraz szkockie sądy do obcych systemów prawnych. Poczesne zaś miejsce pośród tych ostatnich zajmuje prawo rzymskie. Stosowne odwołania czynione były również przez sędziów Izby Lordów w czasie jej funkcjonowania na podstawie przepisów Appellate Jurisdiction Act.

W trakcie sprawowania sądowych obowiązków w latach 1876-2009 Izba Lordów rozpatrzyła około stu spraw, w których instytucje prawa rzymskiego, albo przynajmniej jego duch, zostały powołane przez pełnomocników reprezentujących strony bądź przez samych sędziów. Jest to zatem liczba niewielka, gdy porówna się ją do liczby wszystkich wyroków, jakie wydane były przez law lords. Dla przykładu warto chociażby wskazać, iż tylko w 2009 roku, kończącym prace Komitetu Apelacyjnego, ostateczne rozwiązanie znalazło ponad czterdzieści postępowań. Proste porównywanie liczb jest jednak w odniesieniu do omawianej problematyki zwodnicze i prowadzić może do błędnych wniosków. Znaczenie precedensu w systemie common law oceniane musi być bowiem $z$ perspektywy jego dalszego oddziaływania i częstotliwości odwoływania się do niego w przyszłości. Gdy weźmie się to pod uwagę, warto podkreślić, że rzymskie powołania prawne znalazły się w wielu orzeczeniach, które $z$ biegiem lat stały się tzw. leading cases. Do tej kategorii warto zaliczyć chociażby 
takie sprawy, jak: Keighley, Maxsted \& Co. v. Durant, National Bank of Greece and Athens S.A. v. Metliss, Sandeman and Sons $v$. Tyzack, Cantiere San Rocco v. Clyde Shipbuilding and Engineering Co., Sinclair v. Brougham, Stewart v. London, Midland and Scottish Railway Co. czy Donoghue v. Stevenson. Posługujący się tymi orzeczeniami prawnicy musza, czy chca tego czy też nie, zapoznać się z romanistycznymi uzasadnieniami lordów prawa. Taka recepcja starożytnych rozwiązań prawnych jest zatem trudna do jednoznacznej oceny, gdyż nie ma ona charakteru zrównoważonego. Jest za to dynamiczna, co rozumieć należy jako możliwość powołania się na konkretne orzeczenie i jego ratio decidendi kiedykolwiek, przez kogokolwiek i przed jakimkolwiek angielskim sadem.

Fakt pojawienia się romanistycznych odwołań przed sadem Izby Lordów rodzić musi pytanie o jego przyczyny. Nie ulega wątpliwości, iż argumentacja opierająca się na zupełnie obcej podstawie prawnej stosowana przez sadownictwo angielskie może początkowo dziwić. Trzeba jednak zauważyć, że dziwi ona przede wszystkim prawników kontynentalnych, których wyobrażenie o sposobie ferowania wyroków i ich uzasadnianiu znacząco różni się od tego, jakie istnieje na Wyspach Brytyjskich. Sędziowie działający w środowisku romańskiej czy germańskiej tradycji prawa przyzwyczajeni sa do skrupulatnej egzegezy użytych przez ustawodawcę bądź wypracowanych przez doktrynę pojęć. W uzasadnieniach sędziów angielskich dużo częściej napotkać można natomiast odwołania do praktyki codziennego życia czy wypływającej z zasad logiki sprawiedliwości społecznej. Osiagnięciu takiego celu służyć $z$ kolei moga odwołania do innych systemów prawnych, co pozwala uchwycić brytyjskim sędziom sposób kształtowania się linii orzeczniczych $\mathrm{w}$ sprawach analogicznych. Stąd prawo rzymskie w orzecznictwie Izby Lordów nie może w żaden sposób zaskakiwać. Pozostaje jednak pytanie, w jakich okolicznościach jego rozwiązania były przez law lords wykorzystywane.

Analiza „rzymskich” orzeczeń Izby Lordów pozwala wskazać ich cztery źródła. Po pierwsze ius Romanum było trakto- 
wane jako autorytet. Służyło budowaniu przekonania o doniosłości, jak również o podobieństwie starożytnych oraz współczesnych - angielskich oraz szkockich - rozwiązań prawnych. W znaczacym odsetku przypadków posłużenie się argumentem ex auctoritate nie niosło ze soba jednoznacznego wykorzystania konkretnej konstrukcji prawnej. Otwierało jednak pole do różnych interpretacji pojęcia prawa rzymskiego i tym samym wpisywało się w wieloznaczność terminu romanesimo. Nie ulega wattpliwości, że różnorodność powołań była bezpośrednim skutkiem prób okazania przez pełnomocników oraz sędziów ich erudycji, choć warto zwrócić uwagę, iż trafność doboru poszczególnych odniesień może być czasami przedmiotem krytyki.

Drugim źródłem stosowania rzymskich odwołań - bardzo silnie związanym $z$ poprzednim - jest konieczność uzupełniania luk prawnych. W badanym okresie działalności Izby Lordów próba taka podjęta została jedynie trzykrotnie. Pożądany skutek osiagnięty został natomiast dwukrotnie - w sprawach National Bank of Greece and Athens S.A. v. Metliss oraz DPP v. Jones.

Warto wskazać, iż powołania prawa rzymskiego dokonane w dwóch powyższych przypadkach cechowały się pewna „wstydliwościa”. Lordowie prawa, którzy posługiwali się autorytetem ius Romanum, czynili to w sposób możliwie utajony i dalecy byli od ostentacyjności. Charakterystyczne sa także liczne wypowiedzi sędziów, którzy uzasadniali fakt przywoływania przez siebie rozwiązań prawnych pochodzacych od starożytnych Rzymian.

Kolejnym źródłem romanistycznych nawiązań są przypadki kontynuowania przez sąd Izby Lordów dotychczasowej linii orzeczniczej. Tak jak już wcześniej wskazano, rzymskie nawiazania i analogie umieszczane w uzasadnieniach powinno się traktować jako stały element praktyki orzeczniczej sądów angielskich. W wielu rodzajach spraw wielowiekowe nawarstwienie takich działań sprawiło, że opis cywilistycznych instytucji bądź cytowanie starożytnych źródeł uważane było za powszechnie przyjętą normę. Znacząca część roma- 
nistycznych odwołań, jakie odnaleźć można w orzeczeniach Izby Lordów, miała taka właśnie naturę. Raz przybierały one charakter bardziej, kiedy indziej mniej bezpośredni. Wbrew jednak możliwemu przypuszczeniu, odwołania tego rodzaju nie zawsze były czysto mechaniczne.

Ostatnim motywem pojawienia się prawa rzymskiego w lordowskich orzeczeniach było rozpatrywanie apelacji pochodzacych ze Szkocji. Odwołanie się do rzymskich źródeł czy traktatów naukowych pochodzacych z okresu Oświecenia było naturalnym nastepstwem specyfiki Scots law. Warto jednak zauważyć, że obok orzeczeń, w których sędziowie powołali się na autorytet jednego ze szkockich instytucjonalistów nieco na marginesie głównych rozważań, można wskazać wiele innych decyzji, za pośrednictwem których cywilistyczne rozwiązania prawne weszły do użytku na gruncie prawa angielskiego. Jest to zatem drugie istotne źródło uzupełniania angielskich lacunae iuris. Tym samym można powiedzieć, że prawo szkockie było istotnym nośnikiem cywilistycznej myśli, która następnie recypowano w obręb common law.

Analiza orzeczeń pozwala również wskazać gałęzie prawa, w odniesieniu do których prawo rzymskie było najczęściej wykorzystywane. Szczególną rolę odgrywało ono w lordowskich wyrokach odnoszących się do zagadnień odpowiedzialności deliktowej zarówno na płaszczyźnie prawa szkockiego, jak i angielskiego. Należy podkreślić, iż współczesne określenie niektórych przynajmniej zasad odpowiedzialności $z$ tytułu torts bardzo wiele zawdzięcza recepcji rzymskich rozstrzygnięć dokonanych za pośrednictwem prawa szkockiego. Duże znaczenie ius Romanum zaobserwować można również w odniesieniu do problematyki niesłusznego wzbogacenia. $Z$ pewnością zaważył na tym fakt, że unjust enrichment jako samodzielna gałąz prawa angielskiego rozwinęła się dopiero pod wpływem orzecznictwa sądów w XX wieku. W nauce historii prawa angielskiego często wskazuje się, że liczne przykłady recepcji odnaleźć można w obrębie property, czyli prawa rzeczowego rozumianego podobnie jak gajańskie res. Orzeczenia Izby Lordów będące przedmiotem powyższych rozważań nie dostar- 
czaja jednak wielu przykładów bezpośredniego zastosowania cywilistycznych reguł w odniesieniu do wskazanej problematyki. Większość powołań prawa rzymskiego w zakresie property miała jedynie walor ozdobny i erudycyjny. Zaledwie w kilku sprawach można mówić o recepcji tradycji romanistycznej. Oprócz powyższych przykładów prawo rzymskie powoływane było czasami również na kanwie bardziej wyspecjalizowanych dziedzin prawa, jak na przykład prawo ubezpieczeniowe, prawo prywatne międzynarodowe, prawo karne.

Dalszym ważnym następstwem analizy „romanistycznego" orzecznictwa Izby Lordów jest możliwość przyjrzenia się formalnym źródłom dokonywanych przez sędziów odwołań. Jednoznacznie trzeba stwierdzić, iż spośród starożytnych źródeł prawa najczęściej cytowane były fragmenty pochodzące $z$ Digestów. Jako drugie pod względem popularności znajdowały się Instytucje Justyniana, zaś na trzecim miejscu znalazł się Kodeks. Odnaleźć można również nieliczne cytacje fragmentów Ustawy XII tablic, Instytucji Gaiusa oraz tekstów nieprawniczych (Noctes Atticae Aulusa Geliusa oraz $A b$ Urbe condita Liwiusza). Zdarzyły się również odwołania do Corpus Iuris Canonici. Uwagę zwraca wszakże fakt, iż kilkanaście razy sędziowie oraz pełnomocnicy odwoływali się do instytucji i rozwiązań prawa rzymskiego w ogóle nie wskazując źródła swoich refleksji.

Gdy chodzi o powoływaną literaturę, różnorodność cytowanych autorów jest bardzo duża. Spośród romanistów w ścisłym tego słowa znaczeniu lordowie prawa powołali: W.W. Bucklanda, R. Zimmermanna, W.A. Huntera, P.F. Girarda, H. Bonda, H.J. Roby'ego oraz B. Nicholasa. Duża rozpiętość czasowa, jak i zróżnicowane wykształcenie i przynależność do szkół naukowych dotyczą również twórców kontynentalnych. Spośród nich najczęściej powoływany był R.J. Pothier. Prócz tego cytowani byli między innymi: B. de Saxoferrato, J. Cujacius, J. Domat, S. von Puffendorf, H. Grocjusz, S. van Leeuwen i inni. Oddzielnie należy jeszcze wymienić prawników szkockich, pośród których największą grupę stanowili instytucjonaliści. Cytowani byli: T. Craig, J. Balfour, Lord Stair, 
Lord Bankton, J. Erskine oraz G.J. Bell. Kilkakrotnie sędziowie odwołali się również do pism prawników angielskich: H. Bractona oraz E. Coke'a oraz kanonisty S. Lushingtona. Ze względu na historyczna oraz teoretycznoprawna specyfikę badań powołano również wypowiedzi Kanclerza Kenta oraz J. Story'ego - autorów amerykańskich.

Powyższy przegląd źródeł oraz cytowanych prac wskazuje na stosunkowo dobrą formację intelektualna sędziów oraz prawników, jak również na cechującą ich zapobiegliwość badawcza w zakresie argumentacji stawianych przez siebie tez.

Ostatnim istotnym następstwem przeprowadzonych badań jest możliwość udzielenia odpowiedzi na pytanie, kto odwoływał się do romanistycznej tradycji prawnej najczęściej. Pierwszoplanową rolę $\mathrm{w}$ tym zakresie odegrało dwóch sędziów - Lord Hope of Craighead oraz Lord Rodger of Earlsferry. Szczególnie postać drugiego nie może zaskakiwać, gdyż był on jednym $z$ najbardziej znanych brytyjskich romanistów drugiej połowy XX i początków XXI wieku. Pod względem częstotliwości rzymskich odwołań kolejnymi sędziami byli Lord Watson, Lord Hoffmann oraz Lord Macmillan. Wiele mówiąca wydaje się być zbieżność życiorysów wskazanych pięciu sędziów. Czterech z nich pochodziło ze Szkocji, jeden zaś (Lord Hoffmann) $z$ Republiki Południowej Afryki. Nie ulega wattpliwości, że dokonywane przez nich w sądzie Izby Lordów romanistyczne odwołania były konsekwencją odebranego przez nich wykształcenia uniwersyteckiego na terenach, na których prawo rzymskie było recypowane. Ten sam klucz pochodzenia obserwować można w stosunku do dalszych sędziów. Spośród ośmiu, którzy w swoich orzeczeniach przywołali autorytet prawa rzymskiego przynajmniej trzykrotnie, czterech pochodziło i odebrało prawnicze wykształcenie w Szkocji: Lord Dunedin, Lord Kilbrandon, Lord Reid oraz Lord Shaw.

Na koniec wypada zastanowić się jeszcze nad przyszłościa prawa rzymskiego w orzecznictwie sądów angielskich, w szczególności zaś w orzecznictwie Sądu Najwyższego Zjednoczonego Królestwa, który zastapił Komitet Apelacyjny Izby Lordów. Podejmowane przed rokiem 2009 działania lordów 
prawa na styku prawa angielskiego i szkockiego pozwalaja sądzić, że pośrednia recepcja prawa rzymskiego nie może być traktowana w Anglii jako zjawisko minione. To, co udało się już wypracować na płaszczyźnie odpowiedzialności deliktowej, $z$ pewnościa może być traktowane jako zapowiedź podejmowania podobnych prób na gruncie innych gałęzi prawa. Bardzo wiele zależy tu jednak od dwóch okoliczności - jednej obiektywnej, drugiej zaś subiektywnej. W systemie prawa precedensowego rozwój bądź modyfikacja określonej doktryny zawsze uzależniona jest od pojawienia się konkretnego spornego stanu faktycznego. To zatem, co stanowi o doniosłości systemu prawnego opartego na działalności sądów, może być czasami również źródłem zahamowania niektórych tendencji zmierzających do jego ewolucji. Nieco więcej kłopotu może przynieść przesłanka natury subiektywnej. Prawo rzymskie stanowić będzie przedmiot sądowej analizy tak długo, jak istnieć będa sędziowie, którzy posiadaja co najmniej elementarna wiedzę na temat prawa starożytnych Rzymian. W odniesieniu do Wielkiej Brytanii jest to zatem zasadniczy problem. Współcześnie prawo rzymskie wykładane jest w Anglii na trzech uniwersytetach - w Cambridge, Oxfordzie oraz na University College London. Przy liczbie istniejacych wydziałów prawa oznacza to, że jedynie wąskie grono praktyków odebrało stosowne romanistyczne wykształcenie. W przypadku Szkocji, wykład z ius Romanum nadal pozostaje jednym z najważniejszych podczas akademickich studiów, jednak spadek liczby apelacji kierowanych dawniej do Komitetu Apelacyjnego, dziś zaś do Sądu Najwyższego, sprawia, że coraz rzadziej sędziowie najwyższego organu brytyjskiej judykatury będa mieli okazję zmierzyć się z instytucjami prawnymi, których korzenie sięgaja starożytności.

Mijajace siedem lat działalności Supreme Court of the United Kingdom pozwala jednak zauważyć, iż powyższe pesymistyczne wizje być może jeszcze przez pewien czas się nie ziszcza. W omawianym okresie autorytet prawa rzymskiego powołany został dziesięciokrotnie (R. v. Redcar and Cleveland Borough Council [2010] UKSC 11, Inveresk plc v. Tullis Russell 
Papermakers Ltd. [2010] UKSC 19, Star Energy Weald Basin Ltd. v. Bocardo SA [2010] UKSC 35, Anderson v. Shetland Islands Council [2012] UKSC 7, Morris v. Rae [2012] UKSC 50, R. v. Waya [2012] UKSC 51, Futter $v$. The Commissioners for HM Revenue and Customs [2013] UKSC 26, R. v. East Sussex CC [2015] UKSC 7, Makdessi v. Cavendish Square Holdings $B V$ [2015] UKSC 67, Mohamud $v$. Wm Morrison Supermarkets $P l c$ [2016] UKSC 11). W żadnym ze wskazanych wyroków nie przeprowadzono wprawdzie dogłębnej analizy rzymskich źródeł prawa, lecz wydaje się, że nie było to konieczne. Uwagę zwraca natomiast fakt, że siedem ze wskazanych decyzji podjęte zostało po śmierci piewcy prawa rzymskiego Lorda Rodgera of Earlsferry, z którego osoba w logiczny sposób należałoby łączyć romanistyczne odwołania.

Wprawdzie trudno przekonująco argumentować, iż prawo rzymskie bezpośrednio i nieustannie wpływa na prawo angielskie, lecz istnieje nieodparta pokusa, by stwierdzić, że autorytet ius Romanum w jego licznych wcieleniach określanych pojęciem romanesimo jeszcze nie raz będzie przedmiotem interpretacji brytyjskich sędziów. 



\section{WYKAZ ORZECZEŃ}

Admiralty Commissioners v. Owners of the S.S. Amerika [1917] A.C. 38 Albacruz v. Albazero [1977] A.C. 774

Armsworth v. South Eastern Railway Company (1847) 11 Jur. 758

Arthur J.S. Hall and Co. v. Simon [2002] 1 A.C. 615

Attorney-General v. Antrobus [1905] 2 Ch. 188

Baker v. Bolton (1808) 1 Camp. 493; 170 Eng. Rep. 1033

Balfour v. Scott (1793) 6 Bro. 549, 2 Eng. Rep. 1259

Banque Financière De La Cité v. Parc (Battersea) Limited and Others [1999] 1 A.C. 221

Barclay's Trustee v. IRC [1975] 1 W.L.R. 106

Bell $v$. The Corporation of Quebec (1879) 5 App. Cas. 84

Bilbie v. Lumley (1802) 2 East 469, 102 Eng. Rep. 448

Black v. Caddell (1804) Mor. 13905

Blisset v Daniel (1853) 10 Hare. 493; 68 Eng. Rep. 1022

Bradford v. Pickles [1895] A.C. 587

Bradlaugh v. Clarke (1883) 8 App. Cas. 354

British Railways Board v. Pickin [1974] A.C. 765

British South Africa Company v. Companhia de Moçambique [1893] A.C. 602

Buckley v. Gross (1863) 3 B. \& S. 566; 122 Eng. Rep. 213

Burmah Oil Company v. Lord Advocate 1964 S.C. (H.L.) 117

Burnett's Trustee v. Grainger 2004 S.C. (H.L.) 19

Burton \& Co. v. English \& Co. (1883) 12 Q.B.D. 218

Bywater v. Lord Advocate (1781) 2 Patton's App. 564

Campbell v. MGN Ltd. [2005] 1 W.L.R. 3394

Cantiere San Rocco v. Clyde Shipbuilding and Engineering Co. 1923 S.C. (H.L.) 105

C.B. v. A.B. (1885) 12 R. (H.L.) 36

Chandler v. Webster [1904] 1 K.B. 493

Chasemore $v$. Richards (1859) VII H.L.C. 349; 11 Eng. Rep. 140

CIN Properties Ltd. v. Dollar Land (Cumbernauld) Ltd. 1992 S.C. (H.L.) 104

Coggs v. Bernard (1703) 2 Ld. Raym. 909; 92 Eng. Rep. 107

Cole-Hamilton v. Boyd 1963 S.C. (H.L.) 1

Commissionaires of Police for the Metropolis v. Reeves [2000] 1 A.C. 360 
Cooper v. Cooper (1888) 15 R. (H.L.) 21

Corporation of Bradford $v$. Pickles [1894] 3 Ch. 53

Coy v. Iowa 487 U.S. 1012 (1988)

Crawford v. Washington 541 U.S. 36 (2004)

Crum Ewing's Trustees v. Bayly's Trustees 1911 S.C. (H.L.) 18

Dalton v. Angus \& Co. (1881) 6 App. Cas. 740

Davidson v. Scottish Ministers 2002 S.C.L.R. 166

Davidson v. Scottish Ministers 2002 S.C. 205

Davidson v. Scottish Ministers 2006 S.C. (H.L.) 41

Dick v. Burgh of Falkirk 1976 S.C. (H.L.) 1

Dickson v. National Bank of Scotland 1917 S.C. (H.L.) 50

Donoghue v. Stevenson [1932] A.C. 562

$D P P$ v. Jones [1999] 2 A.C. 240

DPP for Northern Ireland v. Lynch [1975] A.C. 653

Duff Development Co. Ltd. v. Government of Kelantan [1924] A.C. 797

Durant \& Co. v. Roberts and Keighley, Maxsted and Co. [1900] 1 Q.B. 629

Eisten v. National British Railway Co. (1870) 8 M. 980

Elliot v. Lord Joicey 1935 S.C. (H.L.) 57

Elwes $v$ Maw (1802) 3 East. 37; 102 Eng. Rep. 510

Ex parte Donelly 1915 W.L.D. 29

Fairchild $v$. Glenhaven Funeral Services Ltd. [2003] 1 A.C. 32

Fibrosa Spolka Akcyjna v. Fairbairn Lawson Combe Barbour Ltd. [1943]

A.C. 32

Fitzpatrick v. Sterling Housing Association Ltd. [2001] 1 A.C. 27

Foskett v. McKeown [2001] 1 A.C. 102

Grant v. Duke of Gordon (1782) 2 Pat. App. 582 (H.L.)

Grant v. Henry (1894) 21 R. 358

Gray v. Thames Trains Ltd. [2009] 3 W.L.R. 167

Greenock Corporation v. Caledonian Railway Company [1917] A.C. 556

Hall v. Warren (1804) 9 Ves. Jun. 605; 32 Eng. Rep. 738

Hammerton \& Co. v. Earl of Dysart [1916] 1 A.C. 57

Haugesund Kommune v. Depfa ACS Bank [2012] Q.B. 549

Heaton v. Axa Equity \& Law Assurance Society Plc. [2002] 2 A.C. 329

Hickman v. Peacey [1945] A.C. 304

Horlock v. Beal [1916] 1 A.C. 486

Indyka $v$. Indyka [1969] 1 A.C. 33

In re Ellenborough Park [1956] Ch. 131

In re F. (Mental patient: sterilisation) [1990] 2 A.C. 1

Jameson v. Central Electricity Generating Board [2000] 1 A.C. 455

J.A. Pye (Oxford) Ltd. v. Graham [2003] 1 A.C. 419

Keeble v. Hickeringill (1707) Holt, K.B. 16; 90 Eng. Rep. 906

Keighley, Maxsted \& Co. v. Durant [1901] A.C. 240

Ker v. Wauchope (1819) 1 Bligh 1, 4 Eng. Rep. 1

Kirkness v. John Hudson \& Co. [1955] A.C. 696 
Kleinwort Benson Ltd v. Lincoln City Council [1999] 2 A.C. 349

Kolbin \& Sons $v$. Kinnear \& Co 1931 S.C. (H.L.) 128

Krell v. Henry [1903] 2 K.B. 740

Lady Leith-Hall v. Earl of Fife (1768) Mor. 13904

Lickbarrow v. Mason (1787) 2 T.R. 63; 100 Eng. Rep. 35

London Street Tramways Co. Ltd. v. London County Council [1898] A.C. 375

Lowry v. Bourdieu (1780) 2 Dougl. 469; 99 Eng. Rep. 299

Mackay v. Dick \& Stevenson (1881) 8 R. (H.L.) 37

MacLaren v. Attorney General for the Province of Quebec [1914] A.C. 258

Magistrates of Elgin v. Ministers of Elgin (1713) Robertson 69

Manchester Corporation v. Manchester Palace of Varieties Ltd. [1955] 2 W.L.R. 440

Manifest Shipping Co. Ltd. v. Uni-Polaris Insurance Co. Ltd. [2003] 1 A.C. 469 Mann v. Brodie (1885) 12 R. (H.L.) 52

Mark v. Mark [2005] 3 W.L.R. 111

M'Bain v. Wallace \& Co. (1881) 8 R. (H.L.) 106

McMonagle v. Westminster City Council [1990] 2 A.C. 716

M'Dougal's Trustee $v$. Heinemann 1918 S.C. (H.L.) 6

Milnes v. Gery (1807) 14 Ves. Jun. 399; 33 Eng. Rep. 574

Mitchel $v$. Reynolds (1711) P. Wms. 181; 24 Eng. Rep. 347

Mitchey $v$. Finney [1983] 2 A.C. 803

M'Kendrick $v$. Sinclair 1972 S.C. (H.L.) 25

Morgan v. King 35 N.Y. 454 (1866)

Moses v. Macferlan (1760) 2 Burr. 1005; 97 Eng. Rep. 676

National Carriers Ltd. v. Panalpina (Northern) Ltd. [1981] A.C. 675

Nicolsoun v. Watsoun (1560) Stair Society 2/1937

Nordenfelt v. Maxim Nordenfelt Guns and Ammunition Co.[1894] A.C. 535

North Wales Training and Enterprise Council Ltd v. Astley [2006] 1 W.L.R. 2420

OBG Ltd. v. Allen [2007] 2 W.L.R. 920

O'Connell v. R. (1844) 11 Cl. \& Fin. 155; 8 Eng. Rep. 1061

O’Neill v. Phillips [1999] 1 W.L.R. 1092

Pelham v. Pickersgill (1787) 1 T.R. 659; 99 Eng. Rep. 1306

Pierson v. Post 3 Cai. R. 175 (1805)

Pilk v. Venere (1350) SS 46/1929

Practice Statement (Judicial Precedent) [1966] 1 W.L.R. 1234

R. v. Bentham [2005] 1 W.L.R. 1057

$R$ v. Cambridge University (1723) 1 Strange 557; 93 Eng. Rep. 698

R. v. City of Sunderland, [2004] 1 A.C. 889

R. v. Davies [2008] 1 A.C. 1128

R. v. Hove [1987] A.C. 417

R. v. Immigration Office at Prague Airport [2005] 2 W.L.R. 1

R. v. Oxfordshire County Council. Ex parte Sunningwell Parish Council [2000] 1 A.C. 335 
R. v. Secretary of State for Home Department. Ex parte Uttley [2004] UKHL 38

R. v. IRC. Ex parte Woolwich Equitable Building Society [1990] 1 W.L.R. 1400

Rex v. Marsden (1765) 3 Burr 1812; 97 Eng. Rep. 1113

Rhone-Poulenc Rorer International Holdings Inc. v. Yeda Research and Development Co. Ltd. [2007] Bus. L.R. 1797

Ridge v. Baldwin [1964] A.C. 40

Ruabon Steamship Co. Ltd. v. London Assurance [1900] A.C. 6

S. v. Goliath 1972 (3) SA 1 (A)

Salmon v. Duncombe (1886) 11 App.Cas. 627

Sandeman and Sons $v$. Tyzack [1913] A.C. 680

Scholfield v. Earl of Londesborough [1896] A.C. 514

Scott v. Metropolitan Police Commissioner [1975] A.C. 819

Sempra Metals Ltd. v. Her Majesty's Commissioners of Inland Revenue

Sempra Metals Ltd. v. Her Majesty's Commissioners of Inland Revenue [2007] 3 W.L.R. 354

Sinclair v. Brougham [1914] A.C. 398

Skinner v. East India Company (1669) T.B. Howell, State Trials, t. 6, col. 709-770

Smart v. Magistrates of Dundee (1797) 8 Bro. 119; 3 Eng. Rep. 481

Smith v. Baker \& Sons [1891] A.C. 325

Snell v. Beadle [2001] 2 A.C. 304

Spence v. Union Marine Insurance Co. (1867-68) L.R. 3 C.P. 427

Stewart v. London, Midland and Scottish Railway Co. 1943 S.C. (H.L.) 19

Stirling v. Forrester (1821) 3 Bligh 575; 4 Eng. Rep. 712

Strange, Steel \& Co. v. Scott (1889) 14 App. Cas. 601

Studd v. Cock (1883) 10 R. (H.L.) 53

Sudbrook Trading Estate Ltd. v. Eggleton [1983] 1 A.C. 444

Sweet $v$. Parsley [1970] A.C. 132

Taylor v. Caldwell (1863) 3 B. \& S. 826; 122 Eng. Rep. 309

The Amerika [1914] P. 167

The Magistrates of Montrose v. Robertson (1738) Mor. 6398

Tomlinson v. Congleton Borough Council [2004] A.C. 46

TRM Copy Centres (UK) Ltd. v. Lanwall Services Ltd.[2009] 1 W.L.R. 1375

Udny $v$. Udny (1866-69) L.R. 1 Sc. 441

United States of America and Republic of France v. Dollfus Mieg et Cie. S.A.

and Bank of England [1952] A.C. 582

Vickers $v$. Vickers (1867) L.R. 4 Eq. 529

Wake v. Hall (1883) 8 App. Cas. 195

Walton v. Edge (1884) 10 App. Cas. 33

Watson v. Fram Reinforced Concrete Co. 1960 S.C. (H.L.) 92

Watson $v$. Shankland (1871) 10 M. 142

Welham v. DPP [1961] A.C. 103 
Westdeutsche Landesbank Girozentrale v. Council of the London City Borough of Islington [1996] A.C. 669

Wills' Trustees v. Cairngorm Canoeing and Sailing School Ltd 1976 S.C. (H.L.) 30

Winter v. IRC [1963] A.C. 235

Woolwich Equitable Builiding Society v. IRC [1993] A.C. 70

Wright v. Marwood (1881) 7 Q.B.D. 62

Wyndham v. Chetwynd (1757) 1 Black. W. 96; 96 Eng. Rep. 53

Young v. Grote (1827) 4 Bing 253; 130 Eng. Rep. 764 



\section{WYKAZ ŹRÓDEE}

\section{Źródla prawa rzymskiego}

Codex Iustinianus

$1,34,1$

$2,3,20$

$2,4,34$

4, 7,5

$4,37,3$

4, 38, 15, 2

$5,9,6, \mathrm{pr}$.

$5,17,10$

$8,29,5$

Codex Theodosianus

$9,36,1$

$11,7,2$

Digesta

$1,1,1,2$

$1,1,1,3$

$1,1,10,1$

$1,5,5,1$

$1,5,7$

$2,14,32$

3,5

$3,5,3,10$

$3,5,5,12(10)$

$3,5,20,2$

4, 2, 21, 5

$6,1,23,3$

$8,1,8, \mathrm{pr}$.

$8,2,24-25$

$8,3,3,2$

$8,3,6,1$

$8,5,6$

$8,5,8$
9, 2, 11, 2

9, 2, 13, pr.

9, 2, 51, pr.

9, 2, 51, 1

$9,3,1,5$

$9,3,7$

$12,1,40$

124,5 , pr.

$12,4,5,2$

$12,4,5,4$

$12,5,6$

$12,6,14$

$12,6,64$

$12,7,1,2-3$

$12,7,4$

$13,6,1,2$

$13,6,3$, pr.

$14,2,1$

$17,1,26,7$

$17,153-59$

$18,1,4$

22, 6, 9, pr.

24, 1, 9, 2

$24,1,31,8$

$24,1,40$

24, 1, 42

$26,8,5, \mathrm{pr}$.

$27,7,8,1$

$28,1,22,1$

$28,3,6,7$

28, 6, 2, 4

29, 1, 34, pr.

30, 38, pr.

$34,2,19,13$

$34,5,8(9)$

$34,5,9(10), 4$

$34,5,16(17)$ 


\begin{tabular}{|c|c|}
\hline $34,5,17(18)$ & 3,146 \\
\hline $34,5,18(19), 1$ & 3,180 \\
\hline \multicolumn{2}{|l|}{$34,5,22(23)$} \\
\hline $35,1,33$, pr. & Institutiones Iustiniani \\
\hline $35,1,102$ & $1,1,4$ \\
\hline $36,1,48$ & $1,3,4$ \\
\hline $39,3,1,12$ & $2,1,2$ \\
\hline $40,12,7, \mathrm{pr}$ & $2,1,23-24$ \\
\hline $41,1,7,7$ & $2,1,27-28$ \\
\hline $41,1,7,10$ & $2,1,30$ \\
\hline $41,1,7,12$ & $2,1,45$ \\
\hline $41,1,9,2$ & $2,10,10$ \\
\hline $41,1,24$ & $2,20,30$ \\
\hline $41,3,3$ & 3,2 \\
\hline $43,12,1,1$ & $3,15,4$ \\
\hline $43,12,1,3$ & 3,23 , pr. \\
\hline $43,12,1,8$ & $3,23,1$ \\
\hline $43,12,1,12$ & $3,25,4$ \\
\hline $43,12,1,14$ & $4,1,1$ \\
\hline \multicolumn{2}{|l|}{$43,16,1,14$} \\
\hline 43,17 & Lex XII tabularum \\
\hline $43,17,1, \mathrm{pr}$. & 5,2 \\
\hline $43,17,1,5$ & 6,3 \\
\hline $43,18,1, \mathrm{pr}$ & 8,17 \\
\hline $\begin{array}{l}43,24,1 \\
43,26,1, \text { pr. }\end{array}$ & $43,26,1$, pr. \\
\hline $43,26,2$ & Novellae Iustiniani \\
\hline $44,7,1,4$ & 22,6 \\
\hline \multicolumn{2}{|l|}{$45,1,23$} \\
\hline $45,1,33$ & Pauli Sententiae \\
\hline $45,1,91,1$ & $2,14,1$ \\
\hline $47,2,1, \mathrm{pr}$ & $2,23,6$ \\
\hline \multicolumn{2}{|l|}{$\begin{array}{l}47,10,28 \\
49,15,6\end{array}$} \\
\hline \\
\hline $50,1,31$ & \\
\hline $50,16,195$ & Zródla prawa \\
\hline $50,16,239,2$ & kanonicznego \\
\hline \multicolumn{2}{|l|}{$50,17,145$} \\
\hline \multicolumn{2}{|l|}{$50,17,151$} \\
\hline $50,17,152$ & Decretum \\
\hline $50,17,155,2$ & C. 1 , q. 1 , post dictum c. 39 \\
\hline \multicolumn{2}{|l|}{$50,17,160$} \\
\hline & Liber Extra \\
\hline Gai Institutiones & $4,15,5$ \\
\hline 1,53 & Liber Sextus \\
\hline 2,73 & $5,12,13$ \\
\hline 3,139 & $5,12,27$ \\
\hline 3,140 & $5,12,65$ \\
\hline
\end{tabular}




\section{Źródla biblijne i literackie}

Actus Apostolorum

25,16

Aulus Gellius, Noctes Atticae

20, 1, 13

Beda, Historia ecclesiastica gentis An-

2, 5 glorum

Cicero, De Inventione

2, 161

Cicero, Pro Milone

18,48

Livius, $A b$ Urbe condita

$39,15,11$

\section{Źródla prawnicze \\ z okresu średniowiecza \\ i traktaty naukowe \\ (do pol. XIX w.) ${ }^{1}$}

Bacon F., Maxims of the Law, [w:] idem, The Works of Francis Bacon, vol. 2, London 1753

Balfour J., The Prackticks of Sir James Balfour of Pittendreich, Edinburgh ed. 1754, process. P.G.B McNeill, Stair Society 21-22 (1963)

Bartolus de Saxoferrato, Commentaria ad digestum vetus, ed. Givuta, Venezia 1570

Bell G.J., Principles of the Law of Scotland, Edinburgh 1829

Blackstone W., Commentaries on the Laws of England, Oxford 17651769

${ }^{1}$ Jeśli nie wskazano inaczej, podano rok pierwszego wydania pracy.
Bracton H., Tractatus de Legibus et Consuetudinibus Regni Angliae tempore Regni Henrici Secundo, ok. 1235; tłumaczenie angielskie: S.E. Thorne, Bracton On the Laws and Customs of England, Cambridge, Mass., 1968

Burge W., Commentaries on Colonial and Foreign Laws, vol. 4, London 1838

Bynkershoek von C., Quaestiones Iuris Publici, Leyden 1737; tłumaczenie angielskie: T. Frank, Quaestiones Iuris Publici Libri Duo, Oxford 1930

Coke E., Commentary upon Littleton, London 1628

Craig Th., Jus Feudale, Edinburgh 1603; tłumaczenie angielskie: Lord Clyde, The Jus Feudale, Edinburgh-London 1934

Cujacius J., Opera omnia, Lutetiae Parisiorum 1658

Domat J., The Civil Law in Its Natural Order, ed. W. Straham, London 1722

East E.H., A Treatise of the Plesas of the Crown, London 1803

Erskine J., An Institute of the Law of Scotland, Edinburgh 1773

Evans W., Action for Money Had and Received, Liverpool 1802

Fortescue J., De laudibus legume Angliae. The Translation into English and The Original Latin Text with Notes, ed. A. Amos, Cambridge 1825

Grotius H., De Jure Belli ac Pacis, Amsterdam 1631; thumaczenie angielskie: F.W. Kelsey, De Jure Belli ac Pacis Libri Tres, Oxford 1913-1925

Hale M., Historia Placitorum Coronae. The History of the Pleases of the Crown, vol. 1, London 1736

Heineccius J.H., Recitationes in Elementa Iuris Civilis Secundum 
Ordinem Institutionum, Amsterdam 1725

Jones W., An Essay on the Law of Bailments, ed. D.J. Ibbetson, Bangor 2004

Kent J., Commentaries on American Law, vol. 2, ed. 10, Boston 1860

Kent J., Commentaries on American Law, vol. 2, ed. 14, Boston 1896

Leeuven van S., Het Rooms-Hollands-regt, Leiden 1664

Lord Bankton, An Institute of the Laws of Scotland, Edinburgh 1752

Lord Stair, Institutions of the Laws of Scotland, Edinburgh 1681

Mackeldey F., Systema Juris Romani Hodie Usitati, Latine interpretatus: E.E. Hindenburg, Lipsiae 1847

Ortolan M.J.L.E., Explication Historique des Institutes de Justinien, Paris 1827

Pothier R.J., Pandectae Justinianeae, vol. 2, ed. 4, Pariisis 1821

Pothier R.J., Traité de la possession; traité de la prescription, Paris 1807

Pothier R.J., Traité des obligations, Orléans 1761; wydanie angielskie: Pothier R.J., A Treatise on the Law of Obligations, or Contracts, vol. 2, London 1806

Pothier R.J., Traité du Contrat de Change, Paris 1809

Pufendorf von S., De iure naturae et gentium, Londini Scanorum [Lund] 1672

Scaccia S., Tractatus de comerciis et cambio, Roma 1619

Story J., Commentaries on the Conflict of Laws, Boston 1834

Vattel de E., Le Droit de Gens, Londres 1758; tłumaczenie angielskie: J. Chitty, The Law of Nations, London 1834.

Vinnius A., Institutionum Imperialium Commentarius, Amsterdam 1665

\section{Ustawodawstwo brytyjskie}

Magna Charta Libertatum 1215

$5 \& 6$ Ann., c. 11, Act of Union with Scotland 1707

6 Ann., c. 53, Exchequer Court (Scotland) Act 1707

6 Geo. I, c. 12, Declaratory Act 1719

$39 \& 40$ Geo. III, c. 67, Act of Union with Ireland 1800

11 Geo 4 \& 1 Will 4, c. 70, Law Terms Act 1830

$3 \& 4$ Will. 4, c. 41, Judicial Committee Act 1833

$4 \& 5$ Will 4, c. 36, Central Criminal Court Act 1834

$6 \& 7$ Will. 4, c. 32, Building Society Act 1836

9 \& 10 Vict., c. 95, County Courts Act 1846

$11 \& 12$ Vict., c. 78, Crown Cases Act 1848

$14 \& 15$ Vict., c. 83, Court of Chancery Act 1851

$14 \& 15$ Vict., c. 94, High Peak Mining Customs and Mineral Courts Act 1851

$17 \& 18$ Vict., c. 47, Ecclesiastical Courts Act 1855

$20 \& 21$ Vict., c. 77, The Court of Probate Act 1857

$20 \& 21$ Vict., c. 85, The Divorce and Matrimonial Causes Act 1857

$36 \& 37$ Vict., c. 66, Judicature Act 1873

38 \& 39 Vict., c. 77, Judicature Act 1875

$43 \& 44$ Vict., c. 26, Married Women's Policies of Assurance (Scotland) Act 1880

$53 \& 54$ Vict., c. 39, Partnership Act 1890

$57 \& 58$ Vict., c. 30, Finance Act 1894

7 Edw. 7, c. 23, Criminal Appeal Act 1907 
$15 \& 16$ Geo. 5, c. 20, Law of Property Act 1925

$24 \& 25$ Geo. 5, c. 40, Administration of Justice (Appeals) Act 1934

$8 \& 9$ Eliz. 2, c. 65, Administration of Justice Act 1960

Commons Registration Act 1965 (c. 64)

Constitutional Reform Act 2005 (c. 4)

Criminal Justice and Public Order Act 1994 (c. 33)

Damages (Scotland) Act 1976 (c. 13)

Fatal Accidents Act 1976 (c. 30)

Firearms Act 1968 (c. 27)

House of Lords Act 1999 (c. 34)

Human Rights Act 1998 (c. 42)

Limitation Act 1980 (c. 58)

Public Order Act 1986 (c. 64)

\section{Wewnętrzne źródła}

\section{prawa}

Practice Directions and Standings Orders Applicable to Civil Appeals

The Supreme Court of the United Kingdom Practice Directions

\section{Źródla prawa innych krajów}

Code Civil de Français

Kodeks cywilny Dolnej Kanady

\section{Źródla prawa międzynarodowego}

Dyrektywa 1977/187/EEC

Dyrektywa 2001/23/EC

Europejska Konwencja Praw Człowieka $z 3$ września 1953 roku 



\section{BIBLIOGRAFIA}

Ames J.B., Lectures on Legal History and Miscellaneus Legal Essays, Cambridge, Mass. 1913, s. 149-166

Amielańczyk K., Rzymskie prawo karne $w$ reskryptach cesarza Hadriana, Lublin 2006

Anderson O., The Wensleydale peerage case and the position of the house of lords in the mid-nineteenth century, EHR 82 (1967), s. 486-502

Baker G.F.R., Lushington, Stephan, [w:] DNB, vol. 12, s. 291-293

Baker J.H., The Law Merchant and the Common Law Before 1700, CLJ 38 (1979), s. 295-322

Baker J.H., English Law and the Renaissance, CLJ 44 (1985), s. 46-61

Baker J.H., The History of Quasi-Contract in English Law, [w:] W.R. Cornish, R. Nolan, J. O'Sullivan, G. Virgo (eds.), Restitution. Past, Present and Future. Essays in Honour of Gareth Jones, Oxford 1998, s. 37-56

Baker J.H., An Introduction to English Legal History, ed. 4, Oxford 2002

Baker J.H., Roman Law at the Third University of England, Current Legal Problems 55 (2002), s. 123-150

Baran K., Impeachment a poczatki odpowiedzialności politycznej ministrów $w$ Anglii, Zeszyty Naukowe UJ. Prace Prawnicze 51 (1971), s. 7-30

Baran K., King versus Parliament. Rediscussion of constitutional cases illustrative of the Stuart reign till 1642, Zeszyty Naukowe UJ. Prace Prawnicze 86 (1980), s. 7-32

Baran K., $Z$ dziejów prawa karnego Anglii. Między renesansem a oświeceniem XVI-XVIII $w$., Kraków 1996

Baran K., Małek M., Szczurek K., Z dziejów angielskich defences: obrona konieczna i stan wyższej konieczności, [w:] A. Lityński, M. Mikołajczyk (red.), Przez tysiaclecia: państwo - prawo - jednostka, Katowice 2001, s. $53-59$

Baran K., Past performance jako reminiscencja aequitas $w$ prawie angielskim, [w:] W. Uruszczak, P. Święcicka, A. Kremer (red.), Leges sapere. Studia $i$ prace dedykowane Profesorowi Januszowi Sondlowi $w$ pięćdziesiata rocznice pracy naukowej, Kraków 2008, s. 103-106

Barrett M., The Law Lords. An Account of the Workings of Britain's Highest Judicial Body and the Men who Preside Over It, Basingstoke 2001

Barton J.L., Bracton as a Civilian, TLR 42 (1968), s. 555-583 
Barton J.L., Roman Law in England, Mediolani 1971

Barton J.L., The Faculty of Law, [w:] HUO, vol. 3, Oxford 1986, s. 257-293

Barton J.L., The Mystery of Bracton, JLH 14/3 (1993), s. 1-142

Barton J.L., The Authorship of Bracton, JLH 30/2 (2009), s. 117-174

Baston K., Charles Areskine's Library. Lawyers and Their Books at the Dawn of the Scottish Enlightenment, Leiden 2016

Beatson J., Zimmermann R., Jurists Uprooted. German-speaking Émigré Lawyers in Twentieth-Century Britain, Oxford 2004

Behrends O., Knütel R., Kupisch B., Seiler H.H., Corpus Iuris Civilis. Text und Übersetzung, Bd. 3, Digesten 11-20, Heidelberg 1999

Beloff M., The End of the Twentieth Century: The House of Lords 19822000, [w:] Jud.HL, s. 232-254

Berger A., Encyclopaedic Dictionary of Roman Law, Philadelphia 1953

Beven T., The Appellate Jurisdiction of the House of Lords, LQR 17 (1901), s. $155-170$

Birks P., McLeod G., The Implied Contract Theory of Quasi-Contract: Civilian Opinion Current in the Century Before Blackstone, Oxford Journal of Legal Studies 6 (1986), s. 46-85

Birks P.H. (ed.), English Private Law, vol. 1, Oxford 2000

Birley E., Law in Roman Britain, [w:] Aufstieg und Niedergang der römischen Welt, II.13, Berlin-New York 1980, s. 609-625

Black R., A historical survey of delictual liability in Scotland for personal injuries and death, Comparative and International Law Journal of Southern Africa 8 (1975), s. 52-70

Blom-Cooper L., Drewry G., Final Appeal. A Study on the House of Lords in Its Judicial Capacity, Oxford 1972

Blom-Cooper L., 1966 and All That: The Story of the Practice Statement, [w:] Jud.HL, s. 128-143

Boase G.C., Geldart, James William, [w:] DNB, vol. 7, s. 991-992

Boase G.C., Edward Gordon, Baron Gordon of Drumearn, [w:] DNB, vol. 8, s. 177

Bond H., Possession in the Roman Law, LQR 6 (1890), s. 259-279

Boyle L.E., The Beginnings of Legal Studies at Oxford, Viator 13 (1983), s. $107-131$

Brand P., The Beginning of the Law Reporting, [w:] Ch. Stebbings (ed.), Law Reporting in Britain. Proceedings of the Eleventh British Legal History Conference, London-Rio Grande, OH 1995, s. 1-14

Brand P., The Age of Bracton, [w:] J. Hudson (ed.), The History of English Law. Centenary Essays on 'Pollock and Maitland', Oxford 1996

Brand P., The Date and Authorship of Bracton, JLH 31/3 (2010), s. 217-244 Brodie P.H., From Scotland to Ireland (a) Scotland after 1707, [w:] Jud.HL, s. $279-293$

Buckland W.W., Casus and Frustration in Roman and Common Law, HLR $46 / 8$ (1933), s. $1281-1300$ 
Buckland W.W., Praetor and Chancellor, TLR 13 (1939), s. 163-177

Buckland W.W., Some Reflections on Jurisprudence, Cambridge 1945

Buckland W.W., McNair A.D., Roman Law and Common Law, rev. F.H. Lawson, Cambridge 1952

Buckland W.W., A Text-book of Roman Law: From Augustus to Justinian, ed. 2, Cambridge 1932; ed. 3, rev. P. Stein, Cambridge 1963

Burrows A., The Law of Restitution, ed. 3, Oxford 2002

Caillemer E., Le droit civil dans les provinces Anglo-Normandes au XIIe siècle, Mémoires de l'Académie des Science de Caen 1883, s. 157-226

Cairns J.W., Institutional Writings in Scotland Reconsidered, [w:] A. Kiralfy, H.L. MacQueen (eds.), New Perspectives in Scottish Legal History, London 1984, s. 76-117

Cairns J.W., The Breve Testamentum and Craig's Jus Feudale, TR 56 (1988), s. 311-332

Cairns J.W., Rhetoric, Language, and Roman Law: Legal Education and Improvement in Eighteenth-Century Scotland, LHR 9 (1991), s. 31-58

Cairns J.W., The Origins of the Glasgow Law School: The Professors of Civil Law, 1714-61, [w:] P. Birks (ed.), The Life of the Law. Proceedings of the Tenth British Legal History Conference, Oxford 1991, London-Rio Grande, OH 1993, s. 152-183

Cairns J.W., Advocates' Hats, Roman Law and Admission to the Scots Bar, 1580-1812, JLH 20/2 (1999), s. 24-61

Cairns J.W., Historical Introduction, [w:] HPLS, vol. 1, Oxford 2000

Cairns J.W., 'Ius civile' in Scotland, ca. 1600, Roman Legal Tradition 2 (2004), s. 136-170

Cairns J.W., MacQueen H.L., Learning and Law. A Short History of the Edinburgh Law School, Edinburgh 2013 (www.law.ed.ac.uk/history/)

Cobban A.B., The Medieval Universities. Their Development and Organization, London-Chatham 1975

Collier J.G., Conflict of Laws, ed. 3, Cambridge 2001

Coquillette D.R., Legal Ideology and Incorporation 1. The English Civilian Writers, 1523-1607, Boston University Law Review 61 (1981), s. 1-89

Constitutional Reform: a Supreme Court for the United Kingdom, London 2003

Cornioley P., De l'origine de la longi temporis praescriptio, TR 41 (1973), s. $119-130$

Conway R.S., Roby, Henry John, [w:] DNB 1912-1921, s. 473-475

Coote H.C., A Neglected Fact in English History, London 1864

Cooper Th., Men of the Time: A Dictionary of Contemporaries containing Bibliographical Notices of Eminent Characters of Both Sexes, ed. 11, London 1884

Courtney W.P., Halifax, Samuel, [w:] DNB, vol. 8, s. 996-998

Cumming Ch.S., The English High Court of Admiralty, Tulane Maritime Law Review 17 (1993), s. 209-255 
Daily Hansard Vol. 507 Part 55 - Written Ministerial Statements for 11 March 2010, http://www.publications.parliament.uk/pa/cm200910/ cmhansrd/cm100311/wmstext/100311m0002.htm

Dębiński A., Kościół i prawo rzymskie, Lublin 2007

Dębiński A., Prawo rzymskie a systematyka prawa kanonicznego, [w:] W. Uruszczak, P. Święcicka, A. Kremer (red.), Leges Sapere. Studia $i$ prace dedykowane Profesorowi Januszowi Sondlowi $w$ pięćdziesiata rocznice pracy naukowej, Kraków 2008, s. 135-142

Dias R.W.M., Precedents in the House of Lords - Much Needed Reform, CLJ 1966, s. 153-156

Dickens Ch., Klub Pickwicka, t. 2, tłum. W. Górski, uzup. Z. i W. Popławscy, Warszawa 1987

Diósdi G., Contract in Roman Law. From the Twelve Tables to the Glossators, Budapest 1981

Donahue Jr. Ch., 'Ius Commune', Canon Law, and Common Law in England, TLR 66 (1992), s. 1745-1780

Donohoe FitzGerald J., Fitzgerald, John David, Lord Fitzgerald, [w:] DNB, vol. 22, Supp., s. 640-641

Drewry G., Towards a System of Administrative Law: The Reid and Wilberforce Era 1945-82, [w:] Jud.HL, s. 209-231

Dunlop R., O'Connel, Daniel, [w:] DNB, vol. 14, s. 816-864

du Plessis P., Letting and Hiring in Roman Legal Thought: 27 BCE - 284 CE, Leiden 2012

Dworkin G., Stare Decisis in the House of Lords, MLR 25 (1962), s. 166-174

Elsyng H., Judicature in Parliament, ed. E.R. Foster, London-Rio Grande, OH 1991

Evans-Jones R., Roman Law in Britain, [w:] U. Manthe and C. Krampe (eds.), Quaestiones Iuris. Festschrift für Joseph Georg Wolf zum 70. Geburtstag, Berlin 2000, s. 83-110

Feenstra R., Scottish-Dutch Legal Relations in the Seventeenth and Eighteenth Centuries, [w:] T.C. Smout (ed.), Scotland and Europe 12001850, Edinburgh 1986, s. 128-142

Foster E.R., The House of Lords 1603-1649. Structure, Procedure, and The Nature of Its Business, Chapel Hill-London 1983

Foster J., Men-at-the-Bar, London-Aylesbury 1885

Franklin M., Bracton, Para-Bracton(s) and the Vicarage of the Roman Law, TLR 42 (1968), s. 455-518

Gardiner G., Martin A. (eds.), Law Reform Now, London 1963

Gibb A.D., The Inter-Relation of the Legal Systems of Scotland and England, LQR 53 (1937), s. 61-79

Girard P.F., Manuel élémentaire de droit romain, Paris 1898

Godfrey A.M., Ius Commune, Pracktick and Civil Procedure in the SixteenthCentury Court of Session, TR 72 (2004), s. 283-295 
Godfrey A.M., Civil Justice in Renaissance Scotland. The Origins of a Central Court, Leiden 2009

Gordon W.M., Roman Law in Scotland, [w:] R. Evans-Jones (ed.), The Civil Law Tradition in Scotland, Edinburgh 1995, s. 13-40

Gordon W.M., The Acts of the Scottish Lord of Council in the Late Fifteenth and Early Sixteenth Centuries: Records and Reports, [w:] Ch. Stebbings (ed.), Law Reporting in Britain. Proceedings of the Eleventh British Legal History Conference, London-Rio Grande, OH 1995, s. 55-71

Gordon W.M., Servitutes. Scots Law and Roman Law, [w:] W.M. Gordon, Roman Law, Scots Law and Legal History. Selected Essays, Edinburgh 2007, s. $141-147$

Goudy H., Two Ancient Brocards, [w:] P. Vinogradoff (ed.), Essays in Legal History, Oxford 1913, s. 215-232

Griffith G., Early English Law. An Introduction, Norfolk 2006

Grodecki J.K., The Greek Bond Cases, MLR 24/6 (1961), s. 701-714

Güterbock C., Bracton and His Relation to the Roman Law, trans. B. Coxe, Philadelphia 1866

Hackett M.B., The University as a Corporate Body, [w:] HUO, vol. 1, Oxford 1984 , s. 39-75

Hadfield B., Constitutional Law, [w:] Jud.HL, s. 502-505

Halberda J., Dzieje doktryny actio personalis cum persona moritur $w$ angielskim common law, [w:] W. Uruszczak, D. Malec, M. Mikuła (red.), Krakowskie studia $z$ historii państwa i prawa, t. 3, Kraków 2010, s. 37-49

Halberda J., Doktryna consideration $w$ angielskim prawie zobowiazan kontraktowych (XVI-XX w.), Czasopismo Prawno-Historyczne 63 (2011), s. $261-281$

Halberda J., Impossibility as the Factor in the Total Failure of Consideration, [w:] V. Knool (ed.), Naděje právní vědy. Bykov 2010, Plzeň 2011, s. $46-57$

Halberda J., Środki odwoławcze $w$ średniowiecznym $i$ nowożytnym common law, [w:] S. Grodziski, A. Dziadzio (red.), Regnare - Gubernare - Administrare. Prawo i władza na przestrzeni wieków. Prace dedykowane profesorowi Jerzemu Malcowi z okazji 40-lecia pracy naukowej, Kraków 2012, s. 41-50

Halberda J., Historia zobowiazan quasi-kontraktowych $w$ common law, Kraków 2012

Halberda J., Zasada bezpodstawnego wzbogacenia $w$ prawie angielskim, Studia Prawa Prywatnego 2/33 (2014), s. 91-104

Halberda J., Mistake of law and mistake of fact in English law of restitution, TR 82/3-4 (2014), s. 261-283

Halberda J., Fibrosa S.A. v. Fairbairn Lawson Combe Barbour Ltd (1942). Spółka z Kresów przed Izba Lordów, Miscellanea Historico-Iuridica $14 / 1$ (2015), s. 197-217 
Hall J.G., Martin D.F., Haldane. Statesman, Lawyer, Philosopher, Chichester 1996

Halson R., Contract Law, Harlow 2001

Hamilton J.A., MacDowall, Andrew, Lord Bankton, [w:] DNB, vol. 12, s. 508

Hamza G., ¿Existió el derecho internacional privado en el Imperio Romano?, Revista Internacional de Derecho Romano 3 (2009), s. 78-90

Hanbury H.G., The Vinerian Chair and Legal Education, Oxford 1958

Handford P., Lord Campbell and the Fatal Accidents Act, LQR 129 (2013), s. $420-448$

Handler P., The Court for Crown Cases Reserved, 1848-1908, LHR 29/1 (2011), s. 261-271

Hart Jr. J.S., Judicial Review in the House of Lords (1640-43), [w:] A. Kiralfy, M. Flatter, R. Virgoe (eds.), Custom, Courts and Counsel. Selected Papers of the 6th British Legal History Conference, Norwich 1983, London 1985 , s. $65-78$

Hart J.S., Justice upon Petition. The House of Lords and the Reformation of Justice 1621-1675, London 1991

Helmholz R.H., Marriage Litigation in Medieval England, Cambridge 1974

Helmholz R.H., The Roman Law of Guardianship in England, 1300-1600, TLR 52 (1978), s. 223-257

Helmholz R.H., Canon Law and English Common Law, SS Lecture, London 1983

Helmholz R.H., Continental Law and Common Law: Historical Strangers or Companions?, Duke Law Journal 1990, s. 1207-1228

Helmholz R.H., Roman Canon Law in Reformation England, Cambridge 1990

Helmholz R.H., The Canon Law and Ecclesiastical Jurisdiction from 597 to 1640s, OHLE, vol. 1, Oxford-New York 2004

Helmholz R.H., Three Civilian Notebooks 1580-1640, SS 127, London 2010

Helmholz R.H., University Education and English Ecclesiastical Lawyers 1400-1650, Ecclesiastical Law Journal 13 (2011), s. 132-145

Helmholz R., Richard Zouche (1590-1661), Ecclesiastical Law Journal 15 (2013), s. 204-207

Hoeflich M.H., Roman and Civil Law and the Development of Anglo-American Jurisprudence in the Nineteenth Century, Athens-London 1997

Hogg T.J., An introductory lecture on the study of the Civil Law, intended to have been read at the University of London, London 1831

Holdsworth W.S, The Development of the Law of Merchants and its Court, [w:] Selected Essays in Anglo-American Legal History, vol. 1, Boston, 1907, s. 289-331

Holdsworth W.S., The Reception of Roman Law in the Sixteenth Century, 1, LQR 27 (1911), s. 387-398 
Holdsworth W.S., The Reception of Roman Law in the Sixteenth Century, 4, LQR 28 (1912), s. 236-254

Holdsworth W.S., The Origin of the Rule in Baker v. Bolton, LQR 32 (1916), s. $431-437$

Holdsworth W.S., History of English Law, vol. 3, London 1923

Holdsworth W.S., Charles Dickens as a Legal Historian, New Haven 1928

Hope D., Voices from the Past - The Law Lords' Contributions to the Legislative Process, LQR 123 (2007), s. 547-570

House of Lords Judicial Business Statistics 2002

Howell P.A., The Judicial Committee of the Privy Council, 1833-1876, Cambridge 1979

Hunter W.A., A Systematic and Historical Exposition of Roman Law in Order of a Code, ed. 3, London 1897, ed. 4, London 1903

Ibbetson D.J., A Historical Introduction to the Law of Obligations, Oxford 1999

Ibbetson D., Common Law and 'Ius Commune', SS Lecture, London 2001

Ibbetson D., English Law and the European 'Ius Commune' 1450-1650, Cambridge Year Book of European Legal Studies 8 (2005-2006), s. $115-132$

Jackson R.M., The Machinery of Justice in England, Cambridge 1972

Jaffey A.J.E., Volenti non fit injuria, CLJ 44 (1985), s. 87-110

Jenks E., Edward Plantagenet (Edward I). The English Justinian or Making of the Common Law, London 1901

Johnston D., Sale and transfer of title in Roman and Scots law, [w:] A.D.E. Lewis, D.J. Ibbetson (eds.), The Roman Law Tradition, Cambridge 1994 , s. $182-198$

Jolowicz H.F., Nicholas B., Historical Introduction to the Study of Roman Law, ed. 3, Cambridge 1972

Jones D.L., The Judicial Role of the House of Lords before 1870, [w:] Jud. HL, s. 3-12

Judicial and Court Statistics 2008, Ministry of Justice 2009

Jurewicz A.R., Problem domniemania $w$ rzymskim ius quod ad personas pertinet', Olsztyn 2009

Kacprzak A., La Ratihabitio nel diritto romano classico, Napoli 2002

Kaczmarczyk A., Wojciechowski R., Robert-Joseph Pothier (1699-1772), Kwartalnik Prawa Prywatnego 21/1 (2012), s. 5-49

Kamińska R., Ochrona dróg i rzek publicznych $w$ prawie rzymskim $w$ okresie republiki i pryncypatu, Warszawa 2010

Kantorowicz H., Bractonian Problems, Glasgow 1941

Keane R., From Scotland to Ireland (b) Ireland, [w:] Jud.HL, s. 295-303

Kennedy A.G., Disputes about bocland: the forum for their adjudication, Anglo-Saxon England 14 (1985), s. 175-196

Kitchin S.B., The Cambridge School of Law, South African Law Journal 43 (1926), s. 129-139 
Korporowicz Ł.J., Działalność 'legati iuridici’ $w$ rzymskiej Brytanii, SPE 82 (2010), s. 69-80

Korporowicz Ł.J., Nieskuteczność prowincjonalnego wymiaru sprawiedliwości na przykładzie rzymskiej Brytanii, [w:] K. Amielańczyk, A. Dębiński, D. Słapek, Ochrona bezpieczeństwa i porzadku publicznego w prawie rzymskim, Lublin 2010, s. 129-137

Korporowicz Ł.J., Prawo rzymskie w wybranych orzeczeniach Izby Lordów w latach 1999-2009, Z Dziejów Prawa 4/12 (2011), s. 283-296

Korporowicz Ł.J., Spółka akcyjna w prawie angielskim - rozwój konstrukcji,

[w:] K. Brzeziński, Prywatnoprawne aspekty działalności gospodarczej $w$ prawie polskim i europejskim, Kraków 2011, s. 99-108

Korporowicz Ł.J., Roman Law in Roman Britain. An Introductory Survey, JLH 33/2 (2012), s. 133-150

Korporowicz Ł.J., Buying a Slave in Roman Britain. The Evidence from the Tabulae, Revue Internationale des Droits de l'Antiquite 58 (2011), s. $211-224$

Korporowicz Ł.J., William Blackstone a prawo rzymskie. Uwagi na temat prawa rzymskiego $w$ 'On the study of law', [w:] E. Kozerska, P. Sadowski, A. Szymański (red.), Ze studiów nad tradycja prawa, Warszawa 2012 , s. $39-57$

Korporowicz Ł.J., Roman Tax Law in Roman Britain, Revue Internationale des Droits de l'Antiquite 61 (2014), s. 229-251

Korporowicz Ł.J., Pacta sunt servanda w prawie kanonicznym, [w:] E. Kozerska, P. Sadowski, A. Szymański (red.), Pacta sunt servanda-nierealny projekt czy gwarancja ładu społecznego i prawnego?, Kraków 2015, s. $113-125$

Kortmann J.S., 'Ab alio ictu(s)': Misconceptions about Julian's View on Causation, JLH 20/2 (1999), s. 95-103

Krzynówek J., 'Volenti non fit iniuria'. Powstanie i historia reguły, [w:] W. Wołodkiewicz, J. Krzynówek (red.), Łacińskie paremie w europejskiej kulturze prawnej i orzecznictwie sądów polskich, Warszawa 2001, s. $267-287$

Kwaśnik M., Kwaśnik Z., Sekurytyzacja, [w:] Z. Kwaśnik, W. Żukow (red.), Współczesne problemy ekonomiczne jako wyzwanie dla zmieniajacej sie gospodarki, Radom 2010, s. 113-133

Kunkel W., Römische Rechtsgeschichte, Weimar 1964

Kupiszewski H., Litis contestatio, Czasopismo Prawno-Historyczne 15/1 (1963), s. 243-265

Kupiszewski H., Prawo rzymskie a współczesność, wyd. 2, opr. i uzup.

T. Giaro, F. Longchamps de Bérier, Kraków 2013

Lambrick G., The Impeachment of the Abbot of Abingdon 1368, EHR 82 (1967), s. 250-276

Langbein J.H., Modern Jurisprudence in the House of Lords: The Passing of London Tramways, CLR 53 (1967-1968), s. 807-813 
Langbein J., Trinity Hall and the Relations of European and English Law from the Fourteenth to the Twenty-First Century, [w:] H. Felter (ed.), Trinity Hall Cambridge. The Milestones Lectures. In celebration of 650 years of education and learning, Cambridge 2001, s. 75-86

Lawson F.H., A Common Lawyer Looks at the Civil Law, Ann Arbor 1953

Leach W.B., Revisionism in the House of Lords: The Bastion of Rigid Stare Decisis Falls, HLR 80 (1966-1967), s. 797-803

Lee J., Confusio: Reference to Roman Law in the House of Lords and the Development of English Private Law, Roman Legal Tradition 5 (2009), s. 24-66

Lee S., Budden, John, [w:] DNB, vol. 3, s. 221-222

Lentin A., The Last Political Law Lord: Lord Sumner (1859-1934), Newcastle upon Tyne 2008

Le Sueur A., From Appellate Committee to the Supreme Court: A Narrative, [w:] Jud.HL s. 64-94

Lewis G., Lord Hailsham. A Life, London 1998

Lobban M., Preparing for Fusion: Reforming the Nineteenth-Century Court of Chancery, Part I, LHR 22 (2004), s. 389-427

Leader D.R., HUC, vol. 1, Cambridge 1988

Levack B.P., The Civil Lawyers in England 1603-1641. A Political Study, Oxford 1973

Levack B.P., Law, [w:] HUO, vol. 4, Oxford 1997, s. 559-568

Liere F. van, The Study of Canon Law and the Eclipse of the Lincoln Schools, 1175-1225, [w:] M. Feingold (ed.), History of Universities, Oxford 2003, s. $1-10$

Longchamps de Bérier F., Zakaz nadużywania własnego prawa-male nostro iure uti non debemus, [w:] W. Wołodkiewicz, J. Krzynówek (red.), Łacińskie paremie $w$ europejskiej kulturze prawnej $i$ orzecznictwie sadów polskich, Warszawa 2001, s. 127-151

Lord Bingham, A New Supreme Court for the United Kingdom, London 2002 Lord Cooper, The Dark Age of Scottish Legal History 1350-1650, Glasgow 1952

Lord Hope of Craighead, Taking the Case to London - Is It All Over?, JR 1998, s. 135-149

Luig K., Assignation, [w:] HPLS, vol. 2, s. 399-419

Lyall A., The Irish House of Lords as a Judicial Body, 1783-1800, Irish Jurist 28-30 (1993-1995), s. 314-360

MacCormak G., Culpa in the Scots Law of Reparation, JR 1974, s. 13-29

Macgregor L.J., Pacta Illicita, [w:] HPLS, vol. 2, s.129-156

Mackay A.J.G., Craig, Thomas, [w:] DNB, vol. 4, s. 1373-1376

Mackintosh J., Roman Law in Modern Practice, Edinburgh 1934

MacLean A.J, The 1707 Union: Scots Law and the House of Lords, JLH 4/3 (1984), s. 50-75 
MacLean A.J., The House of Lords and Appeals from the Court of Justiciary, 1707-1887, JR 30 (1985), s. 192-226

MacMullen Rigg J., Bell, George Joseph, [w:] DNB, vol. 2, s. 158-159

MacMullen Rigg J., Lee, Sir William, [w:] DNB, vol. 11, s. 824-826

MacMullen Rigg J., Blackburn, Colin, Baron Blackburn, [w:] DNB, vol. 22, Supp., s. 203-204

MacQueen H.L., Scots Law and English Law: The Case of Contract, Current Legal Problems 54 (2001), s. 205-229

MacQueen H., Delict, Contract, and the Bill of Rights: A Perspective from the United Kingdom, South African Law Journal 121 (2004), s. 359-394

Maddicott J.R., The Origins of the English Parliament, Oxford 2010

Maitland F.W., Selected Passages from the Works of Bracton and Azo, SS 8, 1894, London 1895

Maitland F.W., Magistri Vacari Summa de Matrimonio, LQR 13 (1897), s. 133-143, 270-287

Maitland F.W., Pollock F., History of English Law Before the Time of Edward I, vol. 1, Cambridge 1898

Maitland F.W., English Law and the Renaissance, Cambridge 1901

Manchester A.H., The Reform of the Ecclesiastical Courts, AJLH 10 (1966), s. $51-75$

Manchester A.H., Law Reform in England and Wales 1840-80, [w:] W. de Vos, W.H.B. Dean, I. Leeman (eds.), Essays in Honour of Ben Beinart, vol. 2, Cape Town-Wetton-Johannesburg 1979, s. 189-202

Martin E.A., Oxford Dictionary of Law, Oxford 2003

Marzec Ł., Kilka uwag o sadownictwie admiralicji w Anglii, ZP UKSW 4/1 (2004), s. 75-89

Marzec Ł., Kilka uwag o Sadzie kanclerskim $i$ systemie Equity $w$ Anglii, ZP UKSW 5/ 1 (2005), s. 195-212

Marzec Ł., Artur Duck, De Usu et Authoritate Iuris Civilis Romanorum - podrzędna rozprawa czy dzieło światowej romanistyki?, ZP UKSW 6/1 (2006), s. 145-157

Marzec Ł., Prawo rzymskie $w$ dawnej Anglii $w$ świetle pogladów Artura Ducka (wybrane zagadnienia), ZP UKSW 6/2 (2006), s. 117-136

Marzec Ł., Fibrosa przeciwko Fairbairn. Polska spółka, Izba Lordów i prawo rzymskie, ZP UKSW $7 / 1$ (2007), s. 113-121

Marzec Ł., Wizja powszechnego prawa europejskiego według Arthura Ducka, Studia Prawnoustrojowe 7 (2007), s. 255-261

Marzec Ł., Artur Duck, De Usu Authoritate Iuris Civilis Romanorum in Regno Galliarum. Przeglad bazy bibliograficznej, ZP UKSW 8/1 (2008), s. $141-150$

May A.N., The Bar and the Old Bailey, 1750-1850, Chapel Hill-London 2003 McElroy R.G., Williams G., Coronation Cases - I, MLR 4/4 (1941), s. $241-260$

McElroy R.G., Williams G., Coronation Cases - II, MLR 5/ 1 (1941), s. 1-20 
McK. Norrie K., Intentional Delicts, [w:] HPLS, vol. 2, s. 477-516

McSweeney T., English Judges and Roman Jurists: The Civilian Learning behind England's First Case Law, Temple Law Review 84 (2012), s. $827-862$

McSweeney T.J., Creating a Literature for the King's Courts in the Later Thirteenth Century: Hengham Magna, Fet Asaver, and Bracton, JLH 37/1 (2016), s. 41-71

Michałowska K., Trust $i$ stosunki powiernicze $w$ prawie angielskim, Kwartalnik Prawa Prywatnego 5/2 (1996), s. 293-341

Miller T., Judge-Admiral James Graham of Airth (1702-1746) with Special Reference to His Civil Law Library, JR 49 (1937), s. 390-413

Milsom S.F.C., Historical Foundations of the Common Law, ed. 2, Oxford 1981

Mommsen T., Krueger P., Watson A., The Digest of Justinian, vol. 1, Philadelphia 1985

Monro C.H., Digest of Justinian, Cambridge 1904-1909

Morgan J.H., Murison, Alexander Falconer, [w:] DNB, 1931-1940, s. 636637

Moyle J.B., The Institutes of Justinian, Oxford 1883

Moyle J.B., Imperatoris Iustiniani Institutionum Libri Quattor with Introductions, Commentary and Excurses, Oxford 1883

Nicholas B., Introduction to Roman Law, Oxford 1962

Niczyporuk P., Prywatnoprawna ochrona dziecka poczętego $w$ prawie rzymskim, Białystok 2009

Nys M.E., Les Manuscripts de Sir Julius Caesar, Revue de droit international et de légistlation comparée 19 (1887), s. 461-471

O'Day R., The Professions in Early Modern England, 1450-1800. Servants of the Commonwealth, Harlow 2000

Oldham J., English Common Law in the Age of Mansfield, Chapel Hill-London 2004

Oldham J., Lord Mansfield, 'Stare Decisis', and the 'Ratio Decidendi' 1756 to 1788, [w:] W.H. Bryson, S. Dauchy (eds.), 'Ratio decidendi'. Guiding Principles of Judicial Decisions, Berlin 2006, s. 137-150

Otto C., Schilling B., Sintenis C., Das Corpus Juris Civilis in's Deutche übersetzt, Bd. 2, Leipzig 1831

Outhwaite R.B., The Rise and Fall of the English Ecclesiastical Courts, 1500-1860, Cambridge 2006

Owen D.M., The Medieval Canon Law. Teaching, Literature and Transmission, Cambridge 1990

Palmirski T., Obligationes quasi ex delicto. Ze studiów nad źródłami zobowiąań $w$ prawie rzymskim, Kraków 2004

Paterson A.A., Scottish Lords of Appeal, 1876-1988, JR 33 (1988), s. $235-254$ 
Plucknett T.F.T., The Harvard Manuscript of Thornton's Summa, HLR 51 (1938), s. $1038-1056$

Plucknett T.F.T., The Relations Between Roman Law and English Common Law Down to the Sixteenth Century: A General Survey, University of Toronto Law Journal 3 (1939-1940), s. 24-50

Plucknett T.F.T, The Origin of Impeachment, Transactions of the Royal Historical Society (fourth series) 24 (1942), s. 47-71

Plucknett T.F.T., The Impeachment of 1376, Transactions of the Royal Historical Society (fifth series) 1 (1951), s. 153-164

Plucknett T.F.T., A Concise History of the Common Law, ed. 5, Boston-London 1956

Plucknett T.F.T., Early English Legal Literature, Cambridge 1958

Plucknett T.F.T., Barton J.L., St. German's Doctor and Student, SS 91, London 1974

Płodzień S., 'Lex Rhodia de Iactu'. Studium historycznoprawne z zakresu rzymskiego prawa handlowomorskiego, Lublin 2010

Polden P., History of the County Court, 1846-1971, Cambridge 1999

Polden P., The Judicial Roles of the House of Lords and Privy Council, 18201914, Oxford History of the Laws of England, vol. 11, Oxford 2010, s. $528-568$

Polden P., The Judicature Acts, OHLE, vol. 11, Oxford 2010, s. 757-784

Polden P., The Early Years of the House of Lords, 1876-1914, [w:] Jud.HL, s. $181-197$

Pollitt D.H., The Right of Confrontation: Its History and Modern Dress, Journal of Public Law 8 (1959), s. 381-413

Pollock F., The History of the Law of Nature: A Preliminary Study, Journal of the Society of Comparative Law 2 (1900), s. 418-433

Powell R., Roman Law in Common Law Courts, Current Legal Problems 1958, s. $19-36$

Precz I., Iustitia Romanorum in Foederibus, Studia Prawnicze KUL 49 (2012), s. 129-137

Pugsley D., On the Style of Paul's and Ulpian's Commentaries on the Edict, Acta Juridica 1973, s. 185-200

Pugsley D., London Tramways (1898), JLH 17/2 (1996), s. 172-184

Rankine J., Law of Landownership in Scotland, ed. 4, Edinburgh 1909

Rathbone E., Roman Law in the Anglo-Norman Realm, Studia Gratiana 11 (1967), s. 255-271

Re E.D., The Roman Contribution to the Common Law, Fordham Law Review 29 (1961), s. 447-449

Richardson H.G., Azo, Drogheda and Bracton, EHR 59 (1944), s. 22-47

Richardson H.G., Sayles G.O., Fleta. Prologue, Books 1 and 2, SS 72 (1953), London 1955

Richardson H.G., Bracton. The Problem of His Text, SS Sup.Ser. 2, London 1965 
Richardson H.G., Sayles G.O., Fleta, Book 3 and 4, SS 89 (1972), London 1972

Richter T., Did Stair Know Pufendorf?, ELR 7 (2003), s. 367-378

Robinson R.B., The Two Institutes of Thomas Wood: A Study in Eighteenth Century Legal Scholarship, AJLH 35 (1991), s. 432-458

Roby H.J., Private Roman Law in the Times of Cicero and of the Antonines, vol. 2, Cambridge 1902

Rodger A., Molina, Stair and the Jus Quaesitum Tertio, JR 1969, s. 35-44, $128-151$

Rodger A., Mrs. Donaghue and Alfenus Varus, Current Legal Problems 41 (1988), s. 1-22

Rodger A., Lord Macmillan's Speech in Donoghue v. Stevenson, LQR 108 (1992), s. 236-259

Rodgers J.S., The Early History of the Law of Bills and Notes, Cambridge 1995

Rumble W.E., Doing Austin Justice. The Reception of John Austin's Philosophy of Law in Nineteenth-Century England, London-New York 2005

Runyan T.J., The Rolls of Oleron and the Admiralty Court in Fourteenth Century England, AJLH 19 (1975), s. 95-111

Ruszkiewicz B., 'Longi termporis praescriptio' jako zarzut długiego okresu posiadania, ZP UKSW 11/1 (2011), s. 235-248

Sarnecki P., Ustroje konstytucyjne państw współczesnych, wyd. 5, Warszawa 2013

Sayles G.O., Fleta. Book 5 and 6, SS 99 (1983), London 1984

Scott H., Killing and Causing Death in Roman Law, LQR 123 (2013), s. 101-122

Scrutton T.E., The Influence of the Roman Law on the Law of England, Cambridge 1885

Seipp D.J., Bracton, the Year Books, and the "Transformation of Elementary Legal Ideas" in the Early Common Law, LHR 7 (1989), s. 179-183

Seipp D.J., Roman Legal Categories in the Early Common Law, [w:] T.G. Watkin (ed.), Legal Record and Historical Reality. Proceedings of the Eighth British Legal History Conference, Cardiff 1987, London-Ronceverte 1989, s. 9-36

Seipp D.J., The Reception of Canon and Civil Law in the Common Law Courts before 1600, Oxford Journal of Legal Studies 13 (1993), s. 388-420

Seipp D.J., The Concept of Property in the Early Common Law, LHR 12 (1994), s. 29-91

Seller W.D.H., Scots Law: Mixed from the Very Beginning? A Tale of Two Receptions, ELR 4 (2000), s. 3-18

Senior W., Roman Law in England before Vacarius, LQR 46 (1930), s. 191206

Senior W., Peter della Vigna, LQR 48 (1932), s. 324-327

Senior W., Accursius and his son Franciscus, LQR 51 (1935), s. 513-516

Searby P., HUC, vol. 3, Cambridge 1997 
Shepard A., Legal Learning and the Cambridge University Courts, c. 15601640, JLH 19/1 (1998), s. 62-74

Shephard J.W., The Rôles d'Oléron: A 'lex mercatoria' of the Sea?, [w:]

V. Piergiovanni (ed.), From lex mercatoria to commericial law, Berlin 2005, s. 207-217

Sherman Ch.P., The Romanization of English Law, Yale Law Journal 23 (1914), s. 318-329

Simon J., Dr. Cowell, CLJ 26 (1968), s. 260-272

Simmonds K.R., The Gentili Manuscripts, Zeitschrift der Savigny-Stiftung für Rechtsgeschichte, Die Romanistische Abteilung 76 (1959), s. 545550

Simmonds N.E., Reason, History, and Privilege: Blackstone's Debt to Natural Law, Zeitschrift der Savigny-Stiftung für Rechtsgeschichte, Die Germanistische Abteilung 105 (1988), s. 200-213

Simpson A.W.B., Leading Cases in the Common Law, Oxford 1995

Skeel C.A.J., The Influence of the Writtings of Sir John Fortescue, Transactions of the Royal Historical Society (Third Series) 10 (1916), s. 77114

Skrzywanek-Jaworska D., Nieważne zobowiazanie ex stipulation. Znaczenie 'Impossibilium nulla obligation est' Celsusa (D. 50,17,185) w prawie rzymskim, SPE 83 (2011), s. 205-235

Skrzywanek-Jaworska D., Nieważne zobowiazania ex venditione. Nec emptio nec venditio sine re quae veneat potest intellegi (D. 18,1,8, pr.) Pomponiusa a Impossibilium nulla obligation est Celsusa (D. 50,17,185), SPE 84 (2011), s. 209-238

Smith T.B., Strange Gods: Crisis of Scots law as Civilian System, [w:] T.B. Smith, Studies Critical and Comparative, Edinburgh 1962, s. 72-88

Sobczyk M., Siła wyższa $w$ rzymskim prawie prywatnym, Toruń 2005

Sokala A., Zasada superficies solo cedit $w$ prawie rzymskim, Acta Universitatis Nicolai Copernici. Prawo XXV. Nauki Humanistyczno-Społeczne 172 (1987), s. 143-160

Sondel J., Artur Duck - niedoceniony poprzednik Savigny'ego i jego poglady na role prawa rzymskiego $w$ Polsce, Zeszyty Naukowe Uniwersytetu Jagiellońskiego DCXXV. Prace Prawnicze 97 (1982), s. 69-86

Sondel J., Sadownictwo nad scholarami Akademii Krakowskiej, [w:] D. Janicka, R. Łaszewska (red.), Historia Integra. Ksiega pamiatkowa ofiarowana Prof. Stanisławowi Salmonowiczowi $w$ siedemdziesiecciolecie urodzin, Toruń 2001, s. 249-272

Sondel J., Słownik łacińsko-polski dla prawników i historyków, Kraków 2006

Spencer J.R., Criminal Law, [w:] Jud.HL, s. 594-612

Squibb G.D., The High Court of Chivalry. A Study of the Civil Law in England, Oxford 1959 
Squibb G.D., Doctors' Commons. A History of the College of Advocates and Doctors of Law, Oxford 1977

Steele D., The Judicial House of Lords: Abolition and Restoration 1873-6, [w:] Jud.HL, s. 13-29

Stein P., Regulae Iuris. From Juristic Rules to Legal Maxims, Edinburgh 1966

Stein P., Roman Law in Scotland, Mediolani 1968

Stein P., The source of Romano-canonical part of Regiam Maiestatem, Scottish Historical Review 48 (1969), s. 107-123

Stein P., Logic and Experience in Roman and Common Law, Boston University Law Review 59 (1979), s. 433-451

Stein P., The Character and Influence of the Roman Law. Historical Essays, London-Ronceverte 1988

Stein P., Bartolus, the Conflict of Laws and the Roman Law, [w:] idem, The Character and Influence of the Roman Law. Historical Essays, LondonRonceverte 1988, s. 83-90

Stein P., Roman Law and English Jurisprudence. Yesterday and Today, [w:] idem, The Character and Influence of the Roman Law. Historical Essays, London-Ronceverte 1988, s. 151-165

Stein P., Vacarius and the Civil Law, [w:] idem, The Character and Influence of the Roman Law. Historical Essays, London-Ronceverte 1988, s. $167-185$

Stein P., Sir Thomas Smith: Renaissance Civilian, [w:] idem, The Character and Influence of the Roman Law. Historical Essays, London-Ronceverte 1988, s. 186-196

Stein P., Thomas Legge, a Sixteenth Century English Civilian and his Books, [w:] idem, The Character and Influence of the Roman Law. Historical Essays, London-Ronceverte 1988, s. 197-208

Stein P., Continental Influences on English Legal Thought, 1600-1900, [w:] idem, The Character and Influence of the Roman Law. Historical Essays, London-Ronceverte 1988, s. 209-230

Stein P., Roman Law in European History, Cambridge 1999

Stevens R, The Final Appeal: Reform of the House of Lords and Privy Council, 1867-1876, LQR 80 (1964), s. 343-369

Stevens R., Law and Politics. The House of Lords as a Judicial Body, 18001976, Chapel Hill 1978

Steyn J., The Case for a Supreme Court, LQR 118 (2002), s. 382-396

Stępkowski A., Maksymy prawne na Wyspach Brytyjskich, [w:] W. Wołodkiewicz, J. Krzynówek (red.), Łacińskie paremie w europejskiej kulturze prawnej i orzecznictwie sadów polskich, Warszawa 2001, s. 71-107

Stępkowski A., Kształtowanie sie szkockiego systemu prawa prywatnego do końca XVIII wieku, Studia Iuridica 40 (2002), s. 209-230

Stępkowski A., Kształtowanie się mieszanego systemu szkockiego prawa prywatnego w XIX i XX wieku, ZP UKSW 2/ 1 (2002), s. 57-92 
Stępkowski A., L'institution du trust dans le système mixte du droit privé écossais, Warszawa 2005

Stone R., Modern Law of Contract, Abingdon-New York 2009

Supreme court 'could cost $£ 32 m$ ', http://news.bbc.co.uk/2/hi/uk_news/ politics/3519083.stm

Swadling W., Property. General Principles, [w:] P.H. Birks (ed.), English Private Law, Oxford 2000, s. 203-384

Swatland A., The Role of Privy Council in the House of Lords, 1660-1681, [w:] C. Jones (ed.), A Pillar of the Constitution: The House of Lords in British Politics, 1640-1784, London-Ronceverte 1989, s. 51-77

Swatland A., The House of Lords in the Reign of Charles II, Cambridge 1996 Taggart M., Private Property and Abuse of Rights in Victorian England. The Story of Edward Pickles and the Bradford Water Supply, Oxford 2002

Tate J.C., Ownership and Possession in the Early Common Law, AJLH 48 (2006), s. 280-313

The Black Book of the Admiralty with the Appendix, ed. T. Twiss, vol. 1-4, London 1871-1876

The Cambridge University Calendar for the year 1804, Cambridge 1804

The Cambridge University Calendar for the year 1833, Cambridge 1833

The Cambridge University Calendar for the year 1837, Cambridge 1837

The Cambridge University Calendar for the Year 1850, Cambridge 1850

The Cambridge University Calendar for the Year 1886, Cambridge 1886

The Cambridge University Calendar for the Year 1900-1901, Cambridge 1900

Thomas D.A., Origins of the Common Law. Part 1: The Disappearance of Roman Law from Dark Age Britain, Brigham Young University Law Review 1984 , s. 563-598

Thorne S.E., Gilbert de Thornton's Summa de Legibus, University of Toronto Law Journal 7 (1947), s. 1-26

Tompson R.S., James Greenhields and the House of Lords: A Reappraisal, [w:] W.M. Gordon, T.D. Fergus (eds.), Legal History in the Making. Proceedings of the Ninth British Legal History Conference Glasgow 1989, London-Rio Grande, OH 1991, s. 109-124

Trayner J., Latin Phrases and Maxims: Collected from the Institutional and Other Writers on Scotch Law, Edinburgh 1861

Tulejski T., Od zasady użyteczności do demokracji. Filozofia polityczna Jeremy Benthama, Łódź 2004

Turberville A.S., The House of Lords in the Age of Reform, 1784-1837, London 1958

Turner R.V., Roman Law in England Before the Time of Bracton, Journal of British Studies 15 (1975), s. 1-25

Turner R.V., Who was the Author of 'Glanvill'? Reflections on the Education of Henry II's Common Lawyers, LHR 8 (1990), s. 97-127 
Twining W.L., Laws, [w:] F.M.L. Thompson (ed.), The University of London and the World of Learning, 1836-1986, London 1990, s. 81-114

Underwood M., The structure and operation of the Oxford Chancellor's court, from the sixteenth to the early eighteenth century, Journal of the Society of Archivists 6 (1978), s. 18-27

Vallance White J., The Judicial Office, [w:] Jud.HL, s. 30-47

Virgo G., Vindicating vindication: Foskett v. McKeown reviewed, [w:] A. Hudson (ed.), New Perspectives on Property Law, Obligations and Restitution, London 2004, s. 203-222

Virgo G., Restitution of Void Loans, CLJ 69/3 (2010), s. 447-449

Walker D.M., Solatium, JR 62 (1950), s. 144-168

Walker D.M., Viscount Stair, Denning Law Journal 6 (1991), s. 143-156

Walton F.P., Actio personalis and the French Law, Journal of Comparative Legislation and International Law 18 (1936), s. 40-59

Watkin T.G., Saints, Seaways and Dispute Settlements, [w:] W.M. Gordon, T.D. Fergus (eds.), Legal History in the Making. Proceedings of the Ninth British Legal History Conference Glasgow 1989, London 1991, s. 1-9

Watkin T.G., The Death and Later Life of Legal Symbols. Welsh Legal Symbols after the Union with England, [w:] R. Schulze (ed.), Symbolische Kommunikation vor Gericht in der Frühen Neuzeit, Berlin 2006, s. 213-224

Watson A., Some Notes on Mackenzie's 'Institutions' and the European Legal Tradition, Ius Commune 16 (1989), s. 303-313

Watt F., Erskine, John, [w:] DNB, vol. 6, s. 849-850

Watt G., Equity and Trusts Law, ed. 3, Oxford 2012

Weglarz M., Specyfika prawa angielskiego - doktryna precedensu, Studenckie Zeszyty Prawnicze TBSP 4 (2000), s. 55-72

Whitty N., Water Law Regimes, [w:] HPLS, vol. 1, s. 420-479

Whitty N.R., Rights of Personality, Property Rights and the Human Body in Scots Law, ELR 9 (2004-2005), s. 395-400

Wijffels A., Law Books at Cambridge, 1500-1640, [w:] P. Birks (ed.), The Life of the Law. Proceedings of the Tenth British Legal History Conference, Oxford 1991, London-Ohio 1993, s. 59-87

Wijffels A., The civil law, [w:] L. Hellinga, J.B. Trapp (eds.), The Cambridge History of the Book in Britain. Volume III, 1400-1557, Cambridge 1999, s. 399-410

Williams D.G.T., A Developing Jurisdiction, 1914-1945, [w:] Jud.HL, s. $198-208$

Williams G.L., Criminal Law. The General Part, London 1961

Willis Clark J., Jowett, Joseph, [w:] DNB, vol. 10, s. 1103

Wilson A.L.M., Stair and the Inleydinge of Grotius, ELR 14 (2010), s. 259268

Winfield P.H., The Chief Sources of English Legal History, Cambridge, MA, 1925 (reprint z 2000)

Winfield P.H., A Textbook of the Law of Tort, ed. 2, London 1943 
Winkler J.F., Roman Law in Anglo-Saxon England, JLH 13/2 (1992), s. $101-127$

Wołodkiewicz W., Nieznajomość prawa szkodzi. U źródeł zasady 'ignoratia iuris nocet', [w:] W. Wołodkiewicz, J. Krzynówek (red.), Łacińskie paremie $w$ europejskiej kulturze prawnej i orzecznictwie sadów polskich, Warszawa 2001, s. 109-126

Wonnacott M., Possession of Land, Cambridge 2006

Woodbine G.E., The Roman Element in Bracton's De Adquirendo rerum dominio, Yale Law Journal 31/8 (1922), s. 827-847

Wormald P., 'Quadripartitus', [w:] G. Garnett, J. Hudson (eds.), Law and Government in Medieval England and Normandy. Essays in honour of Sir James Holt, Cambridge 1994, s. 111-172

Wormald P., The First Code of English Law, Canterbury 2005

Yntema H.E., The Historical Bases of Private International Law, American Journal of Comparative Law 2 (1953), s. 297-317

Zabieglik S., Historia Szkocji, Gdańsk 2000

Zabłocki J., Rozważania o procesie rzymskim w 'Noctes Atticae' Aulusa Gelliusa, Warszawa 1999

Zabłocki J., Najstarsze formy testamentu rzymskiego, [w:] M. Mikołajczyk (et al.), O prawie i jego dziejach ksiegi dwie. Studia ofiarowane Profesorowi Adamowi Lityńskiemu w czterdziestopięciolecie pracy naukowej $i$ siedemdziesięciolecie urodzin, Białystok-Katowice 2010, s. 137-145

Zimmermann R., Usus Modernus Legis Aquiliae and Delictual Liability Today, Stellenbosch Law Review 1 (1990), s. 67-93

Zimmermann R., The Law of Obligations. Roman Foundation of the Civilian Tradition, Deventer 1992; ed. 2, Oxford 1996

Zulueta F. de, William of Drogheda, [w:] Mélanges de droit romain dédiés a Georges Cornil, vol. 2, Gand-Paris 1926, s. 641-657

Zulueta F. de, The Liber Pauperum of Vacarius, SS 44, London 1927

Zulueta F. de, Stein P., The Teaching of Roman Law in England around 1200, SS Sup.Ser. 8, London 1990

Zwalve W.J., 'Snell v. Beadle' - The Privy Council on Roman Law, Norman Customary and the 'Ius Commune', [w:] L. de Ligt, 'Viva Vox Iuris Romani'. Essays in Honour of Johannes Emil Spruit, Amsterdam 2002, s. 379-386

Żak E., Niedziedziczność pasywna skarg wynikajacych $z$ deliktów w rzymskim prawie klasycznym, [w:] A. Dębiński, M. Wójcik, Współczesna romanistyka prawnicza $w$ Polsce, Lublin 2004, s. 353-365 